MARTIM DELLA VALLE

\title{
DA DECISÃO POR EQÜIDADE NA ARBITRAGEM COMERCIAL INTERNACIONAL
}

Faculdade de Direito da Universidade de São Paulo 


\title{
DA DECISÃO POR EQÜIDADE NA ARBITRAGEM COMERCIAL INTERNACIONAL
}

\author{
Tese de Doutorado
}

Orientador: Prof. Dr. Luiz Olavo Baptista

Tese apresentada à Comissão de Pós-Graduação da Faculdade de Direito da Universidade de São Paulo, para a obtenção do título de doutor.

Área de concentração: Direito Internacional

Faculdade de Direito da Universidade de São Paulo 
À memória de meu pai, Odécio Della Valle, que, agricultor, ensinou-me o que é universal.

A minha mãe, Maria de Jesus Gibertoni Della Valle, pela inspiração ao caminho dos estudos. 


\section{Agradecimentos}

Agradeço ao Prof. Luiz Olavo BAPTISTA pela honra de ter me orientado neste projeto, cuja realização não seria possível sem sua generosa confiança. Seu exemplo pessoal tem sido uma orientação para a vida.

Ao amigo Adelino Arantes Neto pelos valiosos comentários e a perene disposição em contribuir. Sobretudo, pela amizade. Ao amigo Maurício de Almeida Prado, pelos conselhos e pela inspiração.

A Michael Timmins e Rotem Giladi pela importante ajuda na elaboração da pesquisa de campo e pela amizade. A Christian Patelmo, Martin Eckner, Sebastian Lovera, Sonia Rolland e BARRY DE CicCo pelas valiosas contribuições.

Agradeço à Universidade de Michigan (Ann Arbor) pela oportunidade de estudos e de convivência em um ambiente acadêmico instigante.

À CÂmara de ComérCio Internacional por franquear o mais importante acervo de sentenças arbitrais no mundo, sem o qual este trabalho não teria o mesmo alcance.

Aos meus colegas da Companhia de Bebidas das AmÉRICAs (AmBev) pelo apoio à iniciativa deste trabalho.

A todos os noventa e dois profissionais que gentilmente cederam parte de seu tempo para participar da pesquisa de campo. Sem eles, uma parte importante deste trabalho não seria realizada. Deles, os seguintes autorizaram a revelação do nome para o merecido agradecimento: Aboubacar Fall, Alain Viandier, Alejandro Garro, Alexandre Palermo Simões, Alvaro Castellanos Howell, Andreas Bucher, Anton Baier, Antonio Crivellaro, Arnoldo Wald, Bernard Hanotiau, Carlos Nehring, Charles Jarrosson, Christophe Imhoos, C. Ryan Reetz, Denis Bensaude, Diego Corapi, Edoardo Ricci, Edouard Bertrand, Eduardo Silva Romero, Eugen Salpius, Fernando Aguilar, Gabrielle Kaufmann-Kohle, Giorgio Bernini, Guido Santiago Tawil, Guy Keutgen, Henry Peter, Hilmar Raeschke-Kessler, Jacques Malherbe, Jan Dalhuisen, Jean-Jacques Daigre, José Emílio Nunes Pinto, Juan Antonio Cremades SanzPastor, Juan Fernández Armesto, Klaus Sachs, loukas Mistelis, Luc Demeyere, Marcos Paulo de Almeida Salles, Mauro Rubino-Sammartano, Michael Pryles, Michel Soumrani, Otto Sandrock, Paolo Michele Patocchi, Patrick Bernard, Pedro Baptista Martins, Philippe Merle, Pierre Bienvenu, Pierre Raoul Duval, Pierre-Yves Gunter, Pierre Mayer, Piero Bernardini, Piotr Nowaczyk, Selma Lemes, Serge Lazareff Sigvard Jarvin, Stefano Azzali, Thomas Clay, Tibor Várady, Werner Mellis, Xavier Favre-Bulle.

E à AlESSANDRA, por toda a ajuda, proteção e paciência. Sobretudo, pela prova de que nada vale a pena sem amor. A ela, todo o meu amor e gratidão. 
Mostrar-se eqüitativo é [...] recorrer a uma arbitragem mais do que a um processo, porque o árbitro considera a eqüidade e o juiz a lei. Os árbitros foram instituídos justamente para permitir o exercício da eqüidade. ArISTóteles. Arte retórica.

Equity is a roguish thing. For Law we have a measure, know what to trust to; Equity is according to the conscience of him that is Chancellor, and as that is larger or narrower, so is Equity. 'Tis all one as if they should make the standard for the measure we call a "foot" a Chancellor's foot; what an uncertain measure would this be! One Chancellor has a long foot, another a short foot, a third an indifferent foot. 'Tis the same thing in the Chancellor's conscience. JoHn SELDEN.

Bananas, ananás! Pencas felizes.

Vinho nas vasilhas seladas...

Mas eis que de repente como praga

No Peru imperam os juízes.

Encerram num círculo de incisos

Os pássaros, as mulheres e o riso.

Boiões de lata, os olhos dos juízes

São faíscas num monte de lixo.

Vladimir MaIAKóvski, Hino ao juiz 


\section{SUMÁRIO}

INTRODUÇÃO

\section{PARTE I \\ CONCEITO DA ARBITRAGEM POR EQÜIDADE}

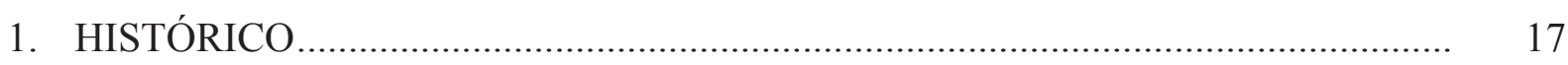

1.1 Problemas de história do direito na arbitragem ............................................ 17

1.2 Histórico da arbitragem............................................................................. 20

1.2.1 Da antiguidade ............................................................................ 20

1.2.2 Grécia ..................................................................................... 22

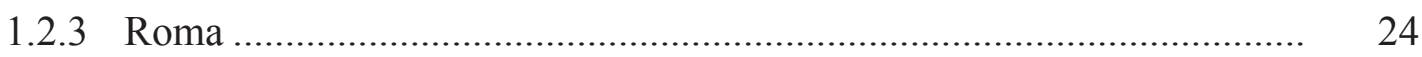

1.2.4 Idade Média.................................................................................. 26

1.2.5 Movimento de codificação ............................................................... 27

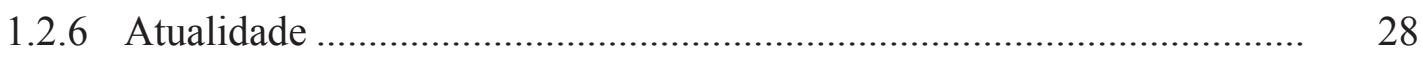

1.3 Histórico da eqüidade na arbitragem ....................................................... 28

1.3.1 Grécia ....................................................................................... 29

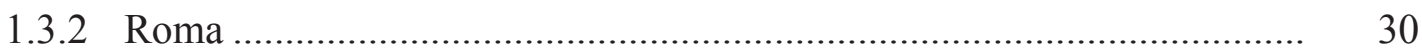

1.3.3 Idade Média ...................................................................................... 34

1.3.4 Movimento de Codificação ................................................................... 40

1.3.5 A Lei Modelo da CNUDCI ................................................................ 41

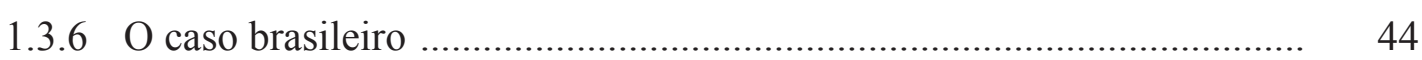

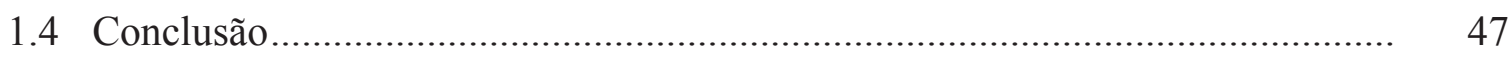

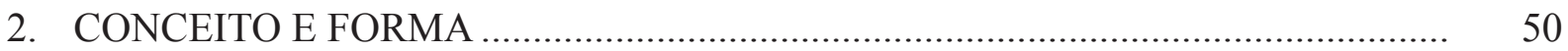

2.1 Natureza jurídica da arbitragem por eqüidade ............................................. 50

2.1.1 O problema da natureza jurídica da arbitragem ................................... 51

2.1.2 Da natureza jurídica da arbitragem por eqüidade ................................ 54

2.1.2.1 Da arbitragem por eqüidade como arbitragem ........................ 54

2.1.2.2 Dos juízos de eqüidade como renúncia .................................. 57

2.1.2.3 Posição da renúncia no direito.................................................. 58

2.1.2.4 Crítica à posição da renúncia...................................................... 62

2.1.2.5 Da arbitragem por eqüidade como negócio jurídico com elemento de renúncia 
2.2 Denominações.................................................................................. $\quad 70$

2.2.1 Arbitragem por eqüidade e amiable composition.................................. 71

2.2.2 Arbitragem de por eqüidade e ex aequo et bono .................................... 86

2.2.3 Outras expressões ............................................................................. 88

2.3 A arbitragem por eqüidade e institutos próximos ............................................ 89

2.3.1 Arbitragem por eqüidade e transação..................................................... 90

2.3.2 Arbitragem por eqüidade e mandato .................................................. 92

2.3.3 Arbitragem por eqüidade e arbitramento.............................................. 93

2.3.4 Arbitragem por eqüidade e conciliação .................................................. 95

2.3.5 Arbitragem por eqüidade e lex mercatoria ............................................ 95

2.3.6 Arbitragem por eqüidade e equity ...................................................... 100

2.3.7 Arbitragem por eqüidade e ausência de escolha de lei.......................... 102

2.3.8 Arbitragem por eqüidade e decisão sem recurso................................... 103

2.4 Da contratação da arbitragem por eqüidade....................................................... 104

2.4.1 Da Lei aplicável à escolha da arbitragem por eqüidade ........................ 104

2.4.2 Forma da e poderes para contratação ................................................... 115

2.4.3 Do tempo para a contratação da arbitragem por eqüidade ..................... 119

2.4.4 Dos poderes para a contratação da arbitragem por eqüidade ................. 123

2.4.5 O Estado e a arbitragem por eqüidade .............................................. 125

3. EFEITOS DA ESCOLHA DA EQÜIDADE …......................................................... 129

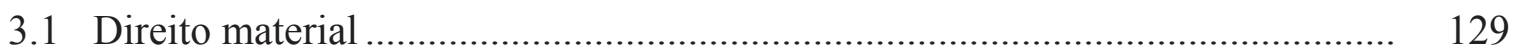

3.1.1 Estrutura do juízo de eqüidade ...................................................... 129

3.1.1.1 Juízo de eqüidade como entimema aristotélico ou juízo de fato 130

3.1.1.2 Juízo de eqüidade como descarte de soluções injustas.............. 132

3.1.1.3 Juízo de eqüidade como juízo jurídico .................................... 136

3.1.1.4 Juízo de eqüidade como busca de uma solução mutuamente

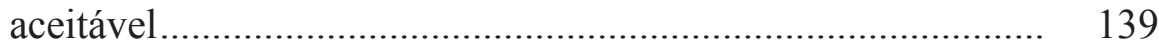

3.1.1.5 Apreciação crítica das posições: da liberdade para escolha do método

3.1.2 Efeito principal: derrogação do direito positivo..................................... 143

3.1.3 Obrigação ou faculdade de utilização da eqüidade ............................... 144

3.1.4 O problema da escolha simultânea de direito ....................................... 149

3.1.5 Eqüidade e questões não ligadas ao mérito ........................................... 152

3.1.6 Decisão por eqüidade e costume ....................................................... 158

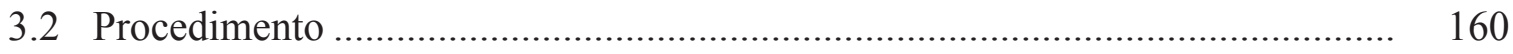


3.2.1 Procedimento estatal ............................................................................ 160

3.2.2 Procedimento convencional .................................................................. 169

3.2.3 Motivação ..................................................................................... 172

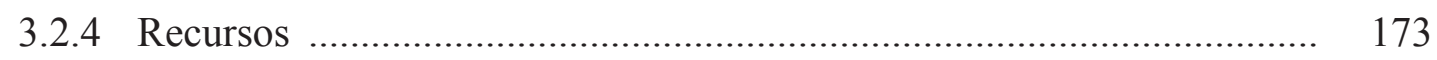

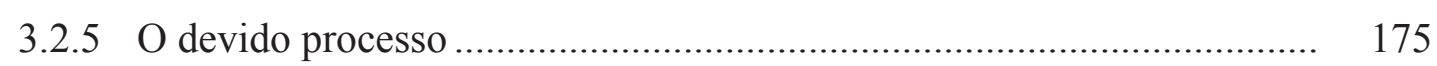

3.2.6 Correlação entre pedido e provimento ............................................... 178

4. ARBITRAGEM POR EQÜIDADE E SEUS LIMITES ........................................... 180

4.1 Ordem pública........................................................................................... 180

4.1.1 Os níveis de atuação da ordem pública ............................................... 180

4.1.2 Atuação da ordem pública na arbitragem por eqüidade .......................... 183

4.2 Contrato ................................................................................................... 187

\section{PARTE II \\ DA PRESENÇA DA ARBITRAGEM POR EQÜIDADE \\ NO DIREITO INTERNACIONAL}

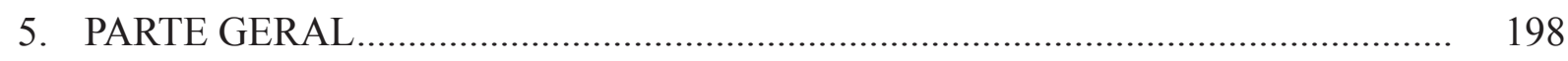

5.1 A presença da arbitragem por eqüidade nos sistemas jurídicos nacionais ......... 201

5.1.1 A obra da CNUDCI ........................................................................ 203

5.1.2 A presunção de arbitragem de direito..................................................... 206

5.1.3 O sistema hispano-americano............................................................. 210

5.1.4 O sistema de vedação ....................................................................... 212

5.2 Dos Tratados Internacionais...................................................................... 215

5.3 Regras de Arbitragem............................................................................... 216

5.3.1 Contornos da Arbitragem por Eqüidade nos Regulamentos ................... 217

5.3.2 Presunção de arbitragem de direito ........................................................ 223

5.3.3 Presunção de arbitragem por eqüidade..................................................... 229

5.3.4 Proibição ………………………………………………………………... 233

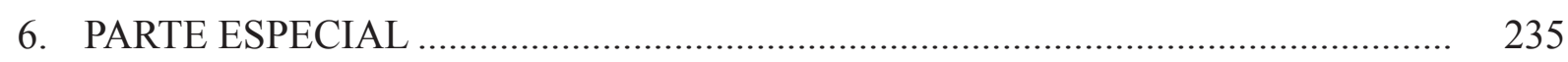

6.1 Tratados Internacionais .............................................................................. 235

6.1.1 Da Convenção de Nova Iorque ............................................................ 235

6.1.2 Código Bustamante .............................................................................. 237

6.1.3 Convenção de Genebra......................................................................... 238

6.1.4 Convenção de Washington ................................................................. 240

6.1.5 Acordo sobre Arbitragem Comercial Internacional do Mercosul ........... 241 
6.1.6 Convenção de Amã sobre Arbitragem Comercial .....

6.1.7 Organização para Harmonização do Direito Empresarial na África (OHADA)

6.1.8 Convenção do Panamá ......................................................................... 245

6.1.9 Agência Multilateral de Garantia de Investimentos (MIGA)................. 246

6.1.10 Acordos de Argel ............................................................................. 246

6.1.11 Convenção de Estrasburgo ................................................................. 247

6.1.12 Convenção Estabelecendo a Sociedade Inter-Árabe para Garantia de Investimentos

6.1.13 Convenção de Moscou ........................................................................ 248

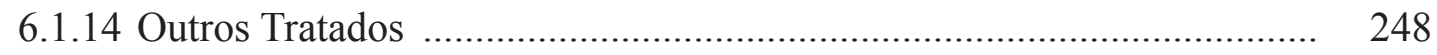

6.2 Legislações Nacionais............................................................................... 249

6.2.1 África do Sul .............................................................................. 249

6.2.2 Alemanha .................................................................................. 249

6.2.3 Arábia Saudita .............................................................................. 251

6.2.4 Argélia ..................................................................................... 251

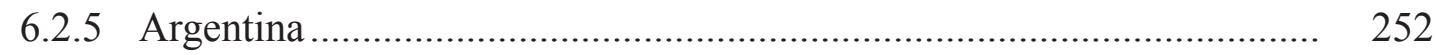

6.2.6 Austrália ...................................................................................... 255

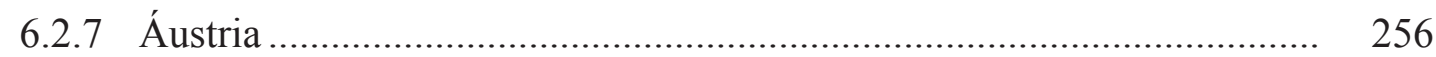

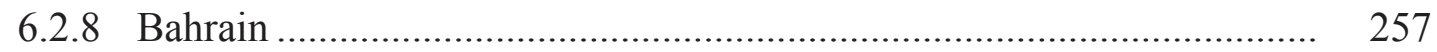

6.2.9 Bangladesh ............................................................................ 257

6.2.10 Bélgica ................................................................................. 258

6.2.11 Bermudas................................................................................ 260

6.2.12 Bielo-Rússia _............................................................................... 260

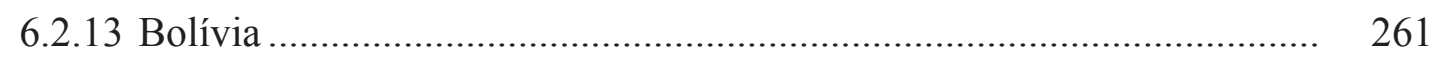

6.2.14 Bulgária ............................................................................................ 262

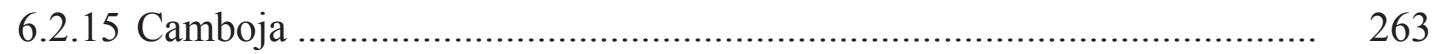

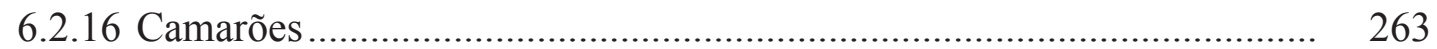

6.2.17 Canadá ................................................................................................ 263

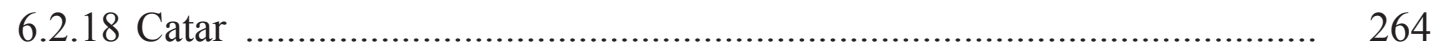

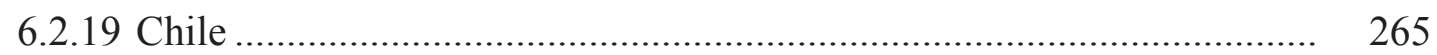

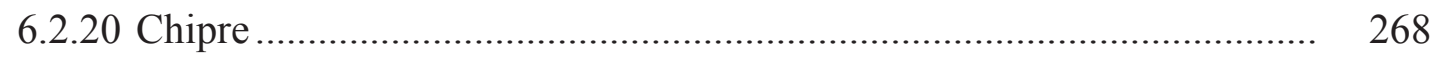

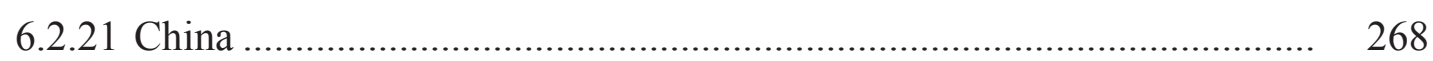

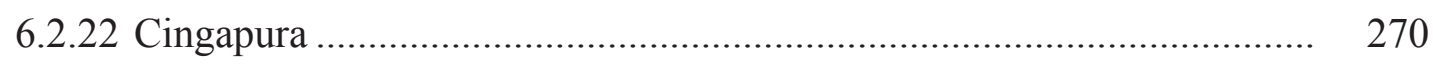

6.2.23 Colômbia .............................................................................. 270 


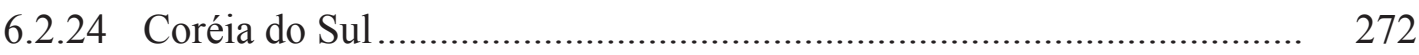

6.2.25 Costa do Marfim ............................................................................ 272

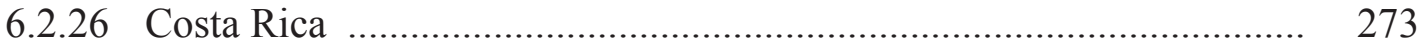

6.2.27 Croácia ........................................................................................... 273

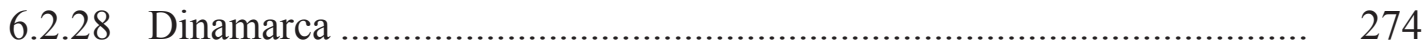

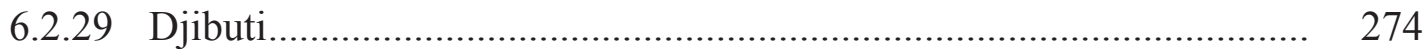

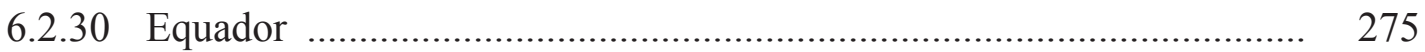

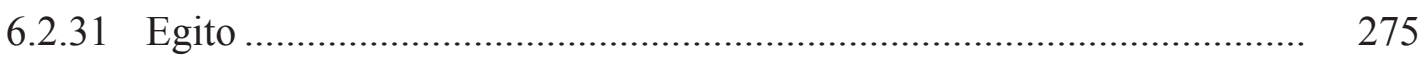

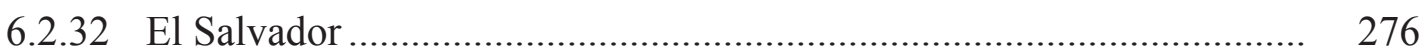

6.2.33 Emirados Árabes Unidos................................................................ 276

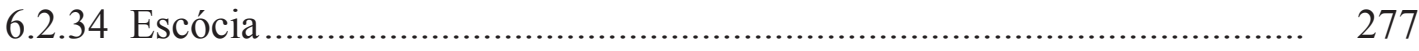

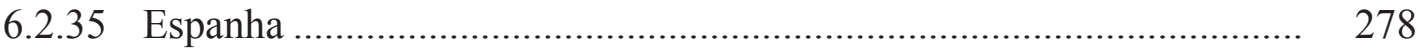

6.2.36 Estados Unidos da América............................................................... 279

6.2.37 Finlândia ................................................................................... 280

6.2.38 França ....................................................................................... 280

6.2.39 Grécia....................................................................... 281

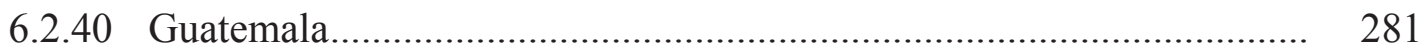

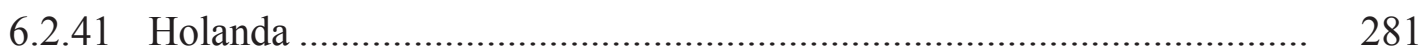

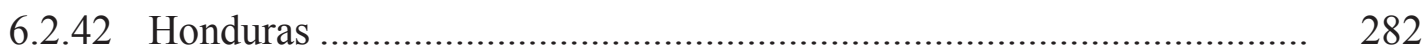

6.2.43 Hong Kong ............................................................................... 283

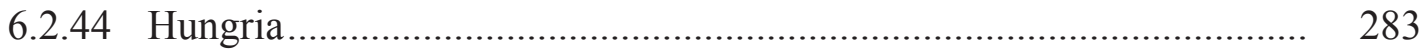

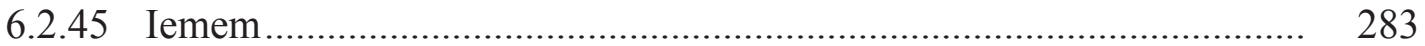

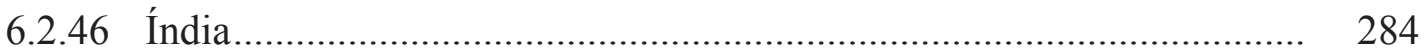

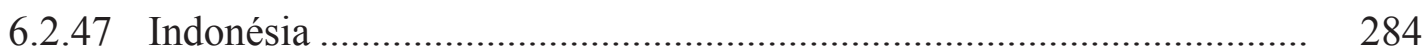

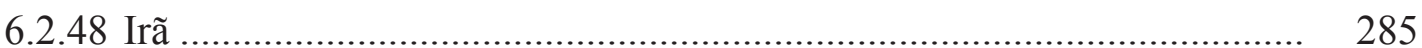

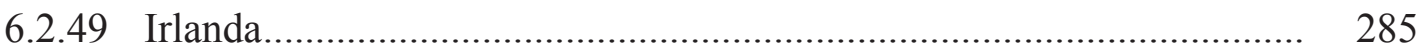

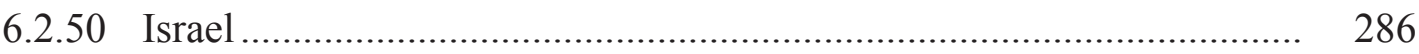

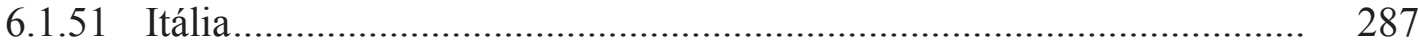

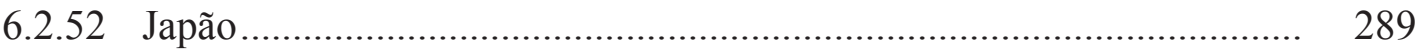

6.2.53 Jordânia …..................................................................................... 289

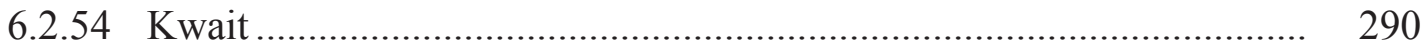

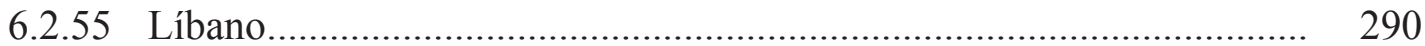

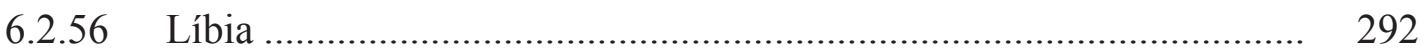

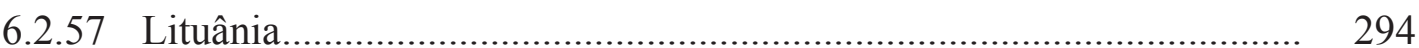


6.2.58 Luxemburgo ........................................................................... 294

6.2.59 Madagascar............................................................................. 294

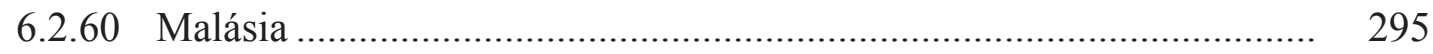

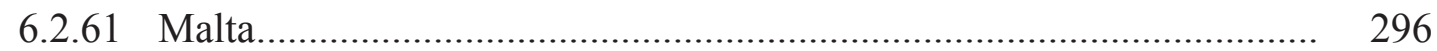

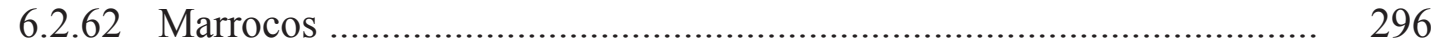

6.2.63 Mauritânia ....................................................................................... 296

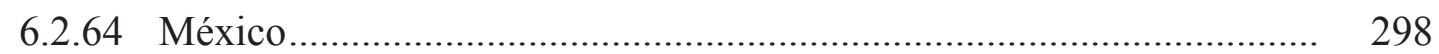

6.2.65 Mongólia ..................................................................................... 298

6.2.66 Nepal ...................................................................................... 299

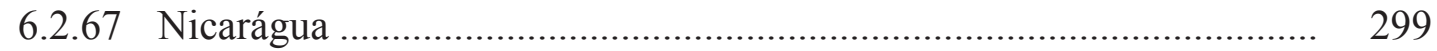

6.2.68 Nigéria .......................................................................................... 301

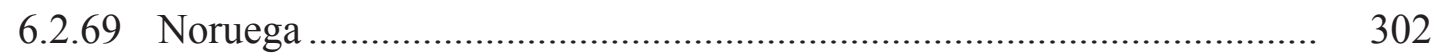

6.2.70 Nova Zelândia .............................................................................. 302

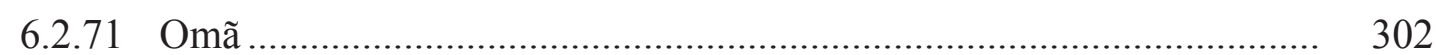

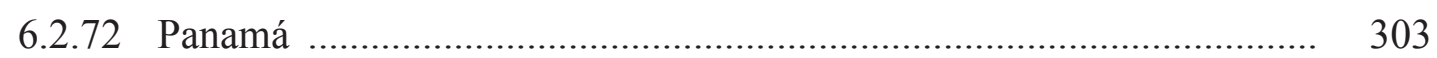

6.2.73 Paquistão ................................................................................... 304

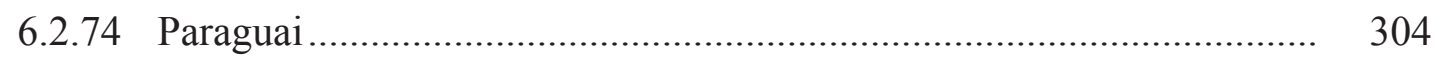

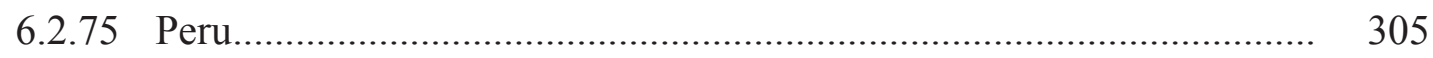

6.2.76 Polônia.......................................................................................... 306

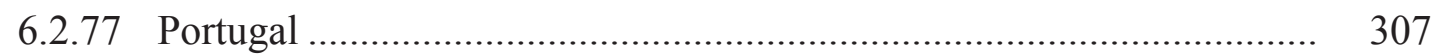

6.2.78 Quênia ....................................................................................... 309

6.2.79 Reino Unido (Inglaterra, Gales e Irlanda do Norte) .......................... 309

6.2.80 República Dominicana ................................................................... 310

6.2.81 República Tcheca.......................................................................... 310

6.2.82 Romênia ................................................................................. 311

6.2.83 Rússia ........................................................................... 312

6.2.84 Síria .................................................................................... 313

6.2.85 Sri Lanka ........................................................................... 314

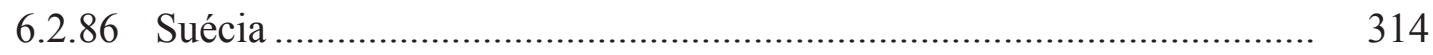

6.2.87 Suíça ........................................................................................ 315

6.2.88 Tailândia .................................................................................... 316

6.2.89 Taiwan (Formosa) ............................................................................ 316

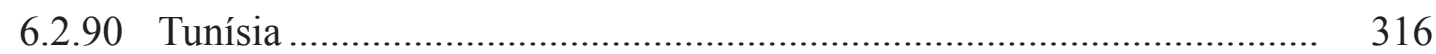

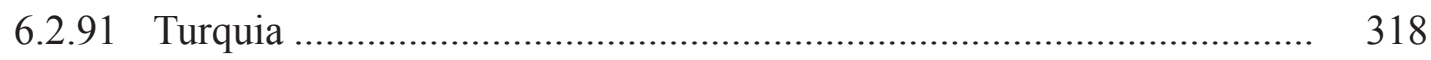


6.2.92 Ucrânia ....................................................................................... 318

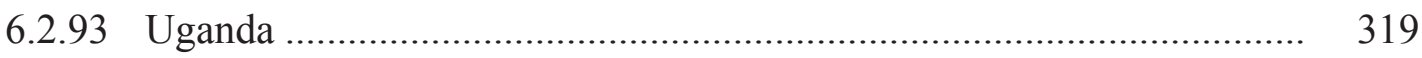

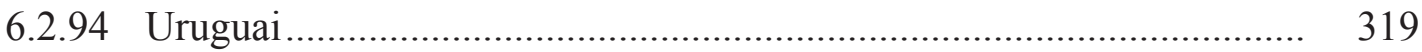

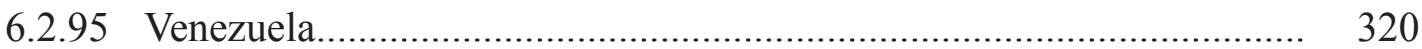

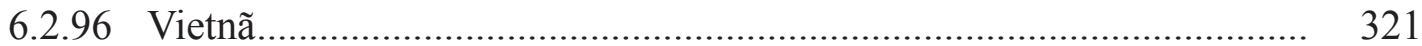

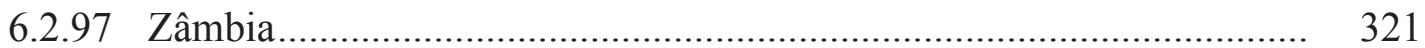

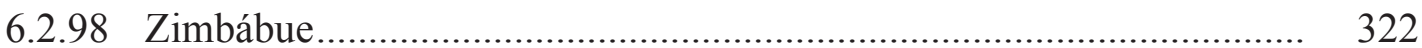

\section{PARTE III \\ ELEMENTOS DE EQÜIDADE \\ NO COMÉRCIO INTERNACIONAL}

7. ELEMENTOS DE EQÜIDADE NA JURISPRUDÊNCIA ARBITRAL..................... 324

7.1 Estatísticas da arbitragem por eqüidade.......................................................... 326

$7.2 \quad \mathrm{O}$ caso dos contratos de publicidade ............................................................. 329

7.3 Elementos de Eqüidade na Jurisprudência ............................................................. 333

7.3.1 Prescrição ..................................................................................... 333

7.3.2 Aplicação do contrato........................................................................ 335

7.3.3 Diferença entre amiable compositeur e decisão por eqüidade ................. 347

7.3.4 Aplicação da lei ................................................................................ 348

7.3.5 Aplicação da lex mercatoria e princípios do comércio ............................. 350

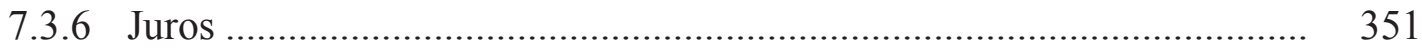

7.3.7 Fixação de danos .............................................................................. 353

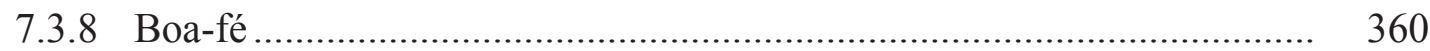

7.3.9 Temas processuais ....................................................................... 363

7.3.10 Corrupção ………………………………………......................... 367

7.3.11 Determinação de lei aplicável ................................................................ 367

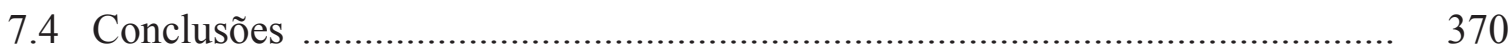

8. PESQUISA DE CAMPO_............................................................................. 372

8.1 Da necessidade de pesquisa empírica na arbitragem ......................................... 372

8.2 Dos objetivos da pesquisa ......................................................................... 373

8.3 Do desenho do questionário ......................................................................... 375

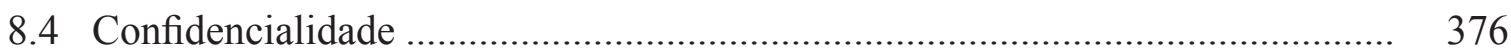

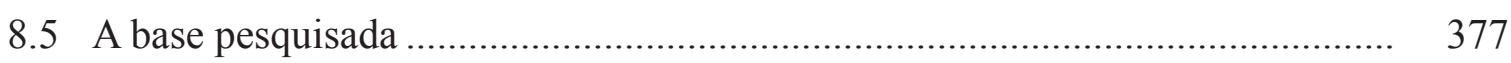

8.6 Limitações da pesquisa ................................................................................ 378

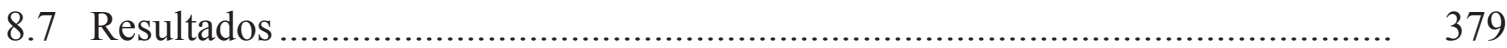


8.7.1 Utilização prática da arbitragem por eqüidade em relação à arbitragem de direito

8.7.2 Recomendação de utilização ................................................................... 383

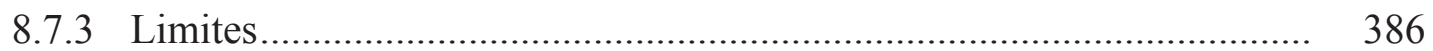

8.7.4 Princípios de eqüidade na arbitragem comercial internacional.............. 390

8.7.5 Principal área de atuação dos participantes ........................................ 403

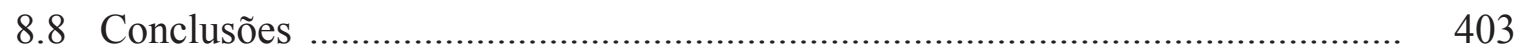

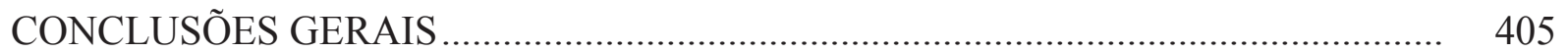

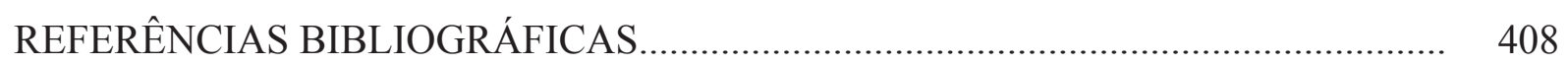

ANEXO - QUESTIONÁRIO ...................................................................... 421

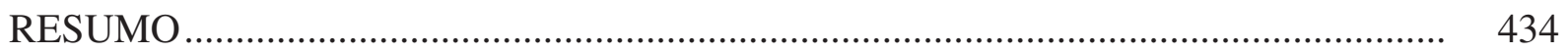

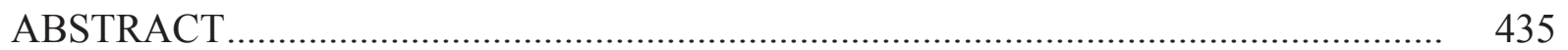

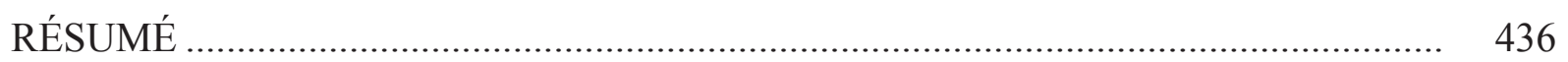




\section{INTRODUÇÃO}

A eqüidade é um termo polissêmico e comporta diversas definições, que variam conforme o momento histórico e a escola doutrinária. Em suas várias acepções, pode tanto ser um sinônimo de direito positivo (aequitas scripta), ou o fim último do ordenamento jurídico, como um antônimo do mesmo direito positivo. ${ }^{1}$

A discussão sobre a posição da justiça dentro do fenômeno jurídico é um dos debates mais profícuos e complexos da teoria do direito. Por esse debate passaram os nomes mais destacados da ciência jurídica e da filosofia, desde a Grécia antiga. Retomar uma discussão que acompanha o pensamento ocidental desde os corredores da Academia não é objeto deste trabalho.

O propósito deste trabalho é menos abrangente, como seu nome indica: trata-se do estudo de decisões por eqüidade e não da eqüidade em todos os seus aspectos. Cuida-se de uma espécie de decisão em um âmbito específico: por eqüidade na arbitragem comercial internacional. Essa espécie de decisão é estatisticamente minoritária e, embora razoavelmente debatida, ainda pouco conhecida.

Não é função desta obra buscar uma definição de eqüidade ou mesmo discutir em profundidade seu estatuto na ciência jurídica atual. Ao contrário, o objetivo deste trabalho, muito mais modesto, é estudar um particular uso da eqüidade.

1 Há extensa bibliografia sobre a matéria. Além das obras diretamente citadas nesta introdução, podem-se mencionar Alvim, Agostinho. Da equiidade. Revista dos Tribunais, São Paulo, v. 82, p. 3 e ss., 1941. Maximiliano, Carlos. Hermenêutica e aplicação do direito. 19. ed. Rio de Janeiro: Forense, 2006. p. 140 e ss. CARvalHo Filho, Milton Paulo. Indenização por eqüidade no novo Código Civil. São Paulo: Atlas, 2003. p. 15 e ss. Dinız, Maria Helena. As lacunas no direito. 7. ed. São Paulo: Saraiva, 2006. Limongi FrançA, R. Formas e aplicação do direito positivo. São Paulo: RT, 1980. p. 72 e ss. MoTA DE SouZA, Carlos Aurélio. Evolução do conceito de eqüidade e sua influência na jurisprudência. 1989. Tese (Doutorado) - Faculdade de Direito da Universidade de São Paulo, São Paulo, mimeografado. Perelman, Chaïm. Ética e direito. São Paulo: Martins Fontes, 2005. p. 33 e ss., 162 e ss. Ráo, Vicente. O direito e a vida dos direitos. 5. ed. São Paulo: RT, 1997. p. 88 e ss. Reale, Miguel. A eqüidade no direito do trabalho. Estudos de filosofia e ciência do direito. São Paulo: Saraiva, 1978. p. 93 e ss. SiLVEIRA, Alípio. Hermenêutica no direito brasileiro. São Paulo: RT, 1980. p. 370. Vários autores. L'Équité ou les Équités: Confrontation Occident et Monde Arabe. Paris: Societé de Législation Comparée, 2003. NEwman, Ralph (Ed.). Equity in the World's Legal Systems: a Comparative Study. Brussels: Établissements Émile Bruylant, 1973. Goldstein, Stephen (Ed.). Equity and Contemporary Legal Develpment. Jerusalém: The Hebrew University of Jerusalem, 1992. Rabelo MoRdeChaI, Alfredo. Aequitas and Equity: Equity in Civil Law and Mixed Jurisdictions. Jerusalém: The Hebrew University of Jerusalem, 1997. Para um prisma diferenciado, veja-se Rawls, John. Uma teoria da justiça. São Paulo: Martins Fontes, 2002. Também Justiça como eqüidade: uma reformulação. São Paulo: Martins Fontes, 2003. FleISCHACKER, Samuel. Uma breve história da justiça distributiva. São Paulo: Martins Fontes, 2006. Kolm, Serge-Christophe. Teorias modernas da justiça. São Paulo: Martins Fontes, 2000. PRODI, Paolo. Uma história da justiça. Lisboa: Editorial Estampa, 2002. 
O exame dessa forma de decisão trata de um aspecto da eqüidade, que é a chamada função substitutiva. Portanto, não tem a dimensão teórica do problema das fontes do direito ou da relação entre direito e justiça.

A despeito desse enquadramento, pode-se fazer um modesto comentário introdutório sobre a eqüidade dentro do fenômeno jurídico, pelo qual chegar-se-á à função substitutiva da eqüidade.

Alípio Silveira ${ }^{2}$ elenca 19 diferentes conceituações de eqüidade, e quase todas englobam o conceito de "justo", "justiça", "ideal de justiça", "justiça absoluta" e "ideal de direito". Entretanto, a despeito de apresentar-se como uma noção mais ou menos intuitiva para os operadores do direito, o termo encerra uma quantidade considerável de significados e de funções.

A polissemia e a pluralidade de conceitos e funções parecem ser uma decorrência de sua longeva história. Ao menos desde a Grécia antiga discute-se e conceitua-se a eqüidade. A evolução do direito ocidental é permeada pela referência, em algum grau, à eqüidade. Nesse aspecto, a discussão da eqüidade é intimamente ligada à questão da justiça no direito.

A fluidez e a polissemia parecem refletir também a dificuldade da ciência do direito em encontrar o estatuto da eqüidade dentro do fenômeno jurídico. De um sinônimo dos mais altos valores morais a uma forma específica de decisão circunscrita a poucas hipóteses, a eqüidade oscila. Ou, conforme Biscardi, oscila entre a essência do direito e a total antítese do direito positivo. ${ }^{3}$ Como aponta Frosini, a ambigüidade do conceito de eqüidade reflete uma crise maior do pensamento jurídico, que é escolher entre o formalismo e o antiformalismo. ${ }^{4}$ Dito de forma mais direta, o relacionamento entre direito e eqüidade nos tempos modernos nunca foi claramente estabelecido. ${ }^{5}$

Embora Aristóteles seja normalmente o ponto de partida obrigatório de qualquer referência sobre eqüidade, o conceito era conhecido e usado anteriormente. Ainda que tenha sido o primeiro a delinear uma doutrina, Aristóteles não foi seu "inventor". ${ }^{6}$ Encontra-se o termo epi-

2 Conceito e funções da eqüidade em face do direito positivo, cit., p. 52-53.

3 Biscardi, Arnaldo. On Aequitas and Epikeia in Aequitas and Equity: Equity in Civil Law and Mixed Jurisdictions. Anais da Second International Conference on Aequitas and Equity. Jerusalém: The Hebrew University of Jerusalém, 1997. p. 1-22.

4 Frosini, Vittorio. La Struttura Giuridica del Giudizion di Equita. Teoremi e Problemi di Scienza Giuridica. Milano: Giuffrè, 1971. p. 197-212.

5 Newman, Ralph (Ed.). Equity in the World's Legal Systems... cit., p. 15.

6 D'Agostino, Francesco. Epikeia: Il Tema dell'Equita nell'Antichita Greca. Milano: Giuffrè, 1973. p. 1. 
keia na forma adjetiva, nos sentidos moral e lógico, já nos tempos de Hipócrates, para afirmar a correção formal e moral de um discurso. ${ }^{7}$ Também o termo, com suas variações, é amplamente citado na Ilíada e na Odisséia. Em todos eles, pode-se traduzi-lo eficazmente como "apropriado" ou "conveniente". ${ }^{8}$ As grandes obras de Aristóteles sobre o tema são Ética a Nicômaco e Arte retórica.

Em Platão, o termo epikeia costuma ser usado de forma genérica, mas nele se encontra uma definição: eqüidade seria a "disposição de ceder os próprios direitos e interesses; moderação nas relações; correta atitude do espírito racional quanto ao bem e ao mal". ${ }^{9}$

$\mathrm{Na}$ obra de Aristóteles, as virtudes éticas têm origem no hábito. A virtude encontra-se no justo meio entre dois extremos opostos. Entretanto, a forma de determinar esta justa medida não é rígida e deve adaptar-se a cada indivíduo e a cada situação. Trata-se de uma medida variável que se alcança por meio da sabedoria. A virtude encontra-se em comedir-se nas paixões e nos excessos (e, portanto, nos defeitos) e encontrar o justo centro. Ou seja, estar no justo centro é uma virtude, um comportamento a ser mantido. Portanto, ser justo é manter essa virtude. $\mathrm{O}$ prazer que decorre da virtude tem epikeia, o prazer que decorre do vício é perverso. ${ }^{10}$

Num sentido, justiça é a observância das leis. Nisso ela se confunde com a virtude em geral, porque o objetivo das leis é prever as condutas que devem ser seguidas pelos cidadãos. Ou seja, são os atos que devem ser praticados ou evitados pelos cidadãos que cultivam a virtude. Há, porém, outro sentido de justiça, que é o de respeitar a igualdade na distribuição dos bens públicos ou na retificação a ser feita na esfera privada. A primeira equivale à justiça distributiva e a segunda, à justiça retificadora. ${ }^{11}$

Aristóteles reconhece duas espécies de justo, que fariam parte de um gênero da justiça. O justo legal, que é o decorrente da aplicação da lei. O eqüitativo é o justo que retifica a lei, para aplicá-la ao caso em sua especificidade. O eqüitativo busca, no caso concreto, qual seria a solução legislada. ${ }^{12} \mathrm{O}$ eqüitativo seria superior ao justo legal.

D’agostino, Francesco. Epikeia... cit., p. 3.

8 "Appropriato", em italiano, cf. D’Agostino (Idem, p. 4). Entendemos que se pode utilizar o equivalente em português. Ou "expediency" em inglês, conforme citado por Biscardi (On Aequitas... cit., p. 2).

9 D'agostino, Francesco. Epikeia... cit., p. 19. Para um apanhado sobre a idéia de justiça em Platão, veja-se Kelsen, Hans. A justiça platônica. O que é Justiça? A justiça, o direito e a política no espelho da ciência. São Paulo: Martins Fontes, 2001. p. 81 e ss.

10 Biscardi, Arnaldo. On Aequitas... cit., p. 3.

11 Ética a Nicômaco. Bauru: Edipro, 2002. v. 2, p. 139. BisCARDI, Arnaldo. On Aequitas... cit., p. 4.

12 Arte retórica. Rio de Janeiro: Ediouro, [s.d.]. Capítulo XIII, II. p. 81-82. 
De Aristóteles, pode-se dessumir que há um gênero, que é o justo. Lei e eqüidade são espécies. Quanto ao gênero, justiça conforme a lei e eqüidade são iguais; porém, quanto à espécie, a eqüidade é melhor. Isso porque o legislador pode incorrer em lacunas. Ou porque um fato passou-lhe despercebido ou porque, por não prever tudo, prevê princípios gerais. Caso surja um caso particular, vendo-se que o legislador foi omisso ou enganou-se por expressar-se em termos muito gerais, é imprescindível suprir o silêncio ou corrigir o equívoco, da mesma forma que ele faria se tivesse ciência dos fatos. Assim, conforme Ferraz Jr., o "eqüitativo é o justo independente da lei escrita, é uma retificação do justo legal". ${ }^{13}$

Alguns autores sustentam que o conceito de eqüidade não era exatamente o de "justiça do caso concreto", mas sim uma espécie de superação do direito positivo no caso concreto. Conforme postula Frosini, tratava-se de criar o direito para o caso, como nos chamados "juízos salomônicos", em que a regra nasce do fato. Algo parecido com a referência àquilo que alguns chamam de "natureza das coisas". ${ }^{14}$ Ou seja, uma atuação que excede a operação de subsunção à norma positiva, envolvendo também uma forma de criação do direito para o caso.

Tampouco deve-se confundir a eqüidade grega com um sentimento geral de bondade. A epikeia possui uma "sede” racional: “"'Loin d'être un comportement vague ou sentimental au sens général de la bonté et de l'indulgence, l'Epikeia exprime une delicatesse raisonable, non depourvue de rigueur". ${ }^{15}$ Esta "sede" é o exercício da virtude da justiça.

A virtude é fruto do desenvolvimento histórico da sociedade. A passagem de uma justiça que seria um atributo divino para uma justiça que é uma qualidade humana mostra uma mudança considerável de concepções, o que concede grande importância à epikeia, como expressão da individualização e da proporção. Um paralelo pode ser visto na passagem da legislação draconiana para a de Sólon, que individualizava as penas conforme os delitos. ${ }^{16}$

Como tentativa de examinar um conteúdo da epikeia, Biscardi ${ }^{17}$ faz um interessante inventário das utilizações do termo. Na forma adjetiva, no uso comum, os exemplos correspondem a "razoável”, "moderado", “oportuno", “apropriado", “plausível”, “adaptado", mas também “suave”, “dócil” e, algumas vezes, “indulgente”. Na forma substantiva, "razão” ou "ra-

13 Ferraz Jr., Tércio Sampaio. Estudos de filosofia do direito. São Paulo: Atlas, 2002. p. 141 e ss.

14 Frosini, Vittorio. La Struttura Giuridica... cit., p. 202. Sobre a "natureza das coisas", ver BobBio, Norberto. Il positivismo giuridico. Torino: Cooperativa Libraria Universitária Torinese, 1961. p. 264 .e ss.

15 JAEGER, H. Justinien et l'episcopalis audientia. Revue Historique du Droit Francais et Etranger, n. 37, p. 241, 1960 apud D'Agostino, Francesco. Epikeia... cit., p. 9.

16 D’agostino, Francesco. Epikeia... cit., p. 11. Ousamos afirmar que a trilogia Oréstia (especialmente Eumênides), de Ésquilo, apresenta uma alegoria desta mudança.

17 Biscardi, Arnaldo. On Aequitas... cit., p. 5-6. 
zoabilidade", "justo equilíbrio", "justa medida", "moderação" e, às vezes, "indulgência”. Num sentido mais "técnico", a epikeia é aplicada como "eqüidade", "eqüitativo", com referências específicas a "respeito à igualdade", "justiça no caso específico", "retificação da justiça legal formal" e "tratamento igualitário em casos iguais". O mesmo autor defende que em todas elas pode-se ver um denominador comum de "adequação", "adequado". ${ }^{18}$

Embora com pontos comuns, a aequitas romana não coincide com a epikeia grega. Nesse aspecto, é interessante notar que o termo aequitas era traduzido ao grego pelos comentadores bizantinos como isotis (igualdade) e não como epikeia. ${ }^{19}$ De qualquer forma, ambas apontam para uma visão prática por parte de quem aplica o direito. ${ }^{20}$

Também ambas contrapõem-se, em alguma medida, ao direito positivo. No entanto, em Roma pode-se dizer que a aequitas, tanto quanto a eqüidade atual, oscila entre ser compreendida como a essência do direito romano quanto a antítese do direito positivo. ${ }^{21}$

No mundo romano, destaca-se o efeito criador da eqüidade na evolução do direito. Especialmente a obra dos pretores e sua função de renovação do ius civile no período clássico. A distinção entre ius e aequitas representa, em larga medida, a oposição entre direito positivo e a justiça como "ideal ético".

Conforme Bonfante, ${ }^{22}$ o caráter concreto, determinado e estável da regra jurídica pode fazer com que a lei não satisfaça o caso particular. Essas imperfeições da norma nascem da falibilidade do legislador e geram oposição entre direito como lei positiva e direito como ideal ético. Os termos romanos para essa oposição são ius e aequitas ou bonum et aequum. Não se deve traduzir aequitas pela atual eqüidade ${ }^{23}$ ou mesmo a epikeia grega, de significado mais restrito, segundo ele. Ainda conforme aquele autor, Aequitas vem do tema *aikwo-, "uno, igual" e significa justiça. ${ }^{24}$

Aequum visum est, aequissimum est, Pretor aequitatem secutus, são frases repetidas no Digesto para significar a obra ativa do pretor para dar "sanção jurídica aos postulados da justiça

\footnotetext{
18 No original, expediency e expedient.

19 Frosini, Vittorio. La Struttura Giuridica... cit., p. 203. Também citado pelo mesmo autor no verbete Equita (nozione) da Enciclopédia del diritto. Milano: Giuffrè, 1966. v. 15, p. 72.

20 Idem, ibidem, p. 73.

21 Biscardi, Arnaldo. On Aequitas... cit., p. 7.

22 Bonfante, Pietro. Diritto romano. Milano: Giuffrè, 1976. p. 91.

23 Aqui o autor refere-se a "equità" em italiano, mas pode ser usada com a mesma função em português.

24 Essa discussão será retomada na parte histórica da tese.
} 
social". Aequum est, aequissimum est usam-se para qualificar as variadíssimas soluções de casos práticos, entre os quais não ocorre outro ponto de contato que a aplicação ou a combinação de normas jurídicas para um resultado conforme os ditames da justiça distributiva ou comutativa: proporção de danos e vantagens, lucros e perdas, prêmios e penas, responsabilidade dos próprios atos, dedução lógica com base nos relacionamentos intercorrentes, cálculo completo dos prós e contras, etc.

Por outro lado, os termos iustitia, iustus exprimem qualidades relativas a ius. Equivalem a legal, jurídico, legítimo. A palavra legitimus não podia substituir iustus. Legitimus pode descrever o que vem do ius civile, mas não o que vem do ius honorarium ou das fontes extraordinárias do direito. Assim, legitimae hereditates em oposição a bonorum possessiones do ius honorarius, iudicium legitimus em oposição aos julgamentos com base no imperium do pretor. $^{25}$

Apenas num momento posterior, já no período cristão, o termo iustus tomou o posto da aequitas. Assim, acabou assimilado também a dikaion. A época de Justiniano já se chama de iusta leges, o que antigamente dizia-se aequae leges. ${ }^{26}$

Em tempos posteriores, a eqüidade aparece como algo piedoso. Bonfante afirma que os romanos, em casos similares, fariam uso da utilitas, benignitas ou humanitas. A eqüidade moderna é um conceito individual, a aequitas romana era uma idéia social da justiça. ${ }^{27}$

Biscardi vê como denominador comum nas noções gregas e romanas de eqüidade a correspondência ao "espírito da lei". ${ }^{28}$ Talvez mais do que o espírito da lei, o espírito do legislador, como já apontado por Aristóteles: a decisão que seria tomada caso o legislador estivesse presente.

A eqüidade foi o motor da criação de um novo direito romano, paralelo ao ius civile. Ao tempo de Cícero, o édito do pretor continha não apenas fórmulas das ações, mas também regras sobre as normas que os magistrados iriam aplicar. Os éditos de um pretor eram freqüentemente repetidos pelos pretores posteriores. Assim, surgiram dois tipos de regra: um previsto pela lei e outro previsto pelos éditos. A repetição dos éditos translatícios conferiu-lhes a fixidez e a estabilidade análogas às das disposições legislativas. Ao prometer de modo constante

25 Bonfante, Pietro. Diritto romano, cit., p. 91. Somente depois o termo legitimus tornou-se de uso mais amplo, especificamente quando, no direito imperial, a fonte do direito passou a ter o titulo de leges.

26 Idem, ibidem, p. 93.

27 Idem, p. 93.

28 BisCARDi, Arnaldo. On Aequitas... cit., p. 10. 
proteger alguém que estivesse em determinada situação, o pretor criou "uma situação de fato equivalente a um estado de direito". Cícero apresenta o édito dos magistrados como uma das principais fontes do direito costumeiro. ${ }^{29}$ As inovações foram normalmente bem acolhidas porque tratavam de questões de utilidade pública ou de eqüidade. O pretor jamais criou inovações que não estivessem apoiadas na opinião e secundadas pela prática. ${ }^{30}$

A criação do ius honorarium foi feita com base em decisões eqüitativas dos pretores, no momento em que a legislação antiga (especialmente a legis actiones) não mais correspondia às necessidades da vida quotidiana. ${ }^{31}$

Conforme Sohm, o ius gentium era comum a todos os homens, existente entre todos os povos em razão da natureza das coisas e graças ao sentimento do eqüitativo que todos têm. ${ }^{32}$ Não se considerava o direito natural no sentido idealizado dos filósofos, mas sim como uma parte do direito positivo, elaborado e concretizado pelos costumes comerciais e por outras fontes jurídicas (especialmente os éditos do pretor). Os poderes do pretor eram praticamente ilimitados, razão pela qual converteu-se em órgão de elaboração do direito, do ius gentium. Embora não pudesse editar leis, podia dar e recusar ações. ${ }^{33}$ Tendo em vista a lógica do direito romano, de tipicidade das ações, retirar uma ação tinha o efeito de retirar um direito.

O curso da história do direito romano foi colocar este ius aequum de nova criação no lugar que ocupava o ius strictum, substituir o antigo ius civile pelo ius gentium. Entretanto, essa substituição é fruto de um constante e ininterrupto trabalho de mais de 500 anos, em que o "direito eqüitativo" foi-se formando e ganhando espaço ao lado direito antigo. Três forças contribuíram para essa formação de um direito eqüitativo: o édito do pretor, a ciência jurídica e a legislação imperial.

De qualquer modo, o estatuto da eqüidade no direito romano basicamente varia entre duas posições. De um lado, é a fonte ou justificativa filosófica para as normas. Trata-se aqui da justiça das leis. Por outro, é um objetivo a ser alcançado na aplicação do direito. Logo, quando houver descompasso entre a lei, mais especificamente o vetusto ius civile, e os imperativos de justiça da consciência social, há a atuação da aequitas, seja para criar novas normas para atender novas situações, seja para modificar a aplicação das normas antigas.

\footnotetext{
29 CuQ, Edouard. Les Institutions Juridiques des Romains. 2. ed. Paris: Librairie Plon, 1904. t. II, p. 31.

30 Idem, ibidem, p. 32.

31 Essa discussão será retomada na obra, especificamente na parte histórica.

32 SoHm, Rudolf. Historia e instituciones del derecho privado romano. Madrid: La Espana Moderna, 1898(?). p. 102.

33 Idem, ibidem, p. 112. Também BetTi, Emilio. Diritto romano - parte generale. Padova: Cedam, 1935. p. 42.
} 
Entretanto, a despeito deste imenso poder da aequitas dentro do direito romano, a força de norma positiva continuava com o ius. ${ }^{34}$

Posteriormente ao período romano clássico, a eqüidade recebe a influência de valores cristãos, como a caritas, benignitas e humanitas. Ela recebe uma forte influência da idéia de direito natural do cristianismo. Seu efeito passa a ser o de derrogação da lei positiva todas as vezes em que esta estiver em desacordo com um direito superior, emanado do divino. Já nesta época pode-se falar em eqüidade como uma forma benigna de temperar o rigor da lei.

A eqüidade deixa de conter uma espécie de "equação" que balança os diversos interesses sociais e adquire um caráter pessoal. O antigo eixo de proporcionalidade e retribuição da idéia de justiça cede espaço a uma doutrina fundamentada no conceito cristão de amor. Um caráter de derrogação das normas em vista de especiais circunstâncias pessoais do caso, com um "viés" de "bondade", de caridade cristã. A fonte maior desta mudança de eixo na concepção de eqüidade parece vir do conceito cristão de amor: não mais um amor individual, mas um amor por todos, pela humanidade. Um amor baseado em perdão (oferecer a outra face) e em caridade. Assim, aparentemente há uma perda do caráter de retribuição e compensação. A preocupação com a justiça deixa de ser apenas a expressão de uma consciência jurídica objetiva social, mas também um ato de amor e caridade pelo qual se derroga a lei escrita. ${ }^{35}$

Essa concepção parece ter permeado o desenvolvimento da eqüidade durante a Idade Média. Uma análise mais aprofundada desse desenvolvimento alargaria demasiadamente esta introdução. No entanto, cumpre notar que seu principal produto parece ser assimilação da eqüidade ao conceito de direito natural. Ou seja, a eqüidade passa a ser a ratio naturalis, em última instância, razão pela qual passa-se a diferenciar a chamada aequitas rudis et primaeva (não escrita) e a aequitas scripta. ${ }^{36}$

Posteriormente, o Estado assume o monopólio da jurisdição e da elaboração do direito. Com o primado do direito positivo, houve outro deslocamento do conceito de eqüidade. $O$ posterior movimento de codificação trará consigo o positivismo jurídico e sua centralização das fontes do direito. Neste momento histórico, a eqüidade passa a ter uma posição subsidiária no fenômeno jurídico, subordinada ao direito positivo. Essa modificação do status da eqüidade deve-se ao fato

34 Biscardi, Arnaldo. On Aequitas... cit., p. 8-9.

35 Paralelamente, no renascimento do comércio no período medieval, os tribunais de mercadores que decidiam ex aequo et bono foram os vetores da criação de um direito de mercadores.

36 Frosini, Vittorio. La Struttura Giuridica... cit., p. 203. Também Broggini, Gerardo. Aspetti Storici e Comparativisti in L'Equita. Atos da Convenção sobre Eqüidade realizada pelo Centro Nazionale di Prevenzione e Difesa Sociale. Milano: Giuffrè, 1975. p. 29. 
de que o juiz perde a faculdade de derrogar qualquer lei por meio de sentença. ${ }^{37}$ Embora perca algum espaço na elaboração doutrinária, continua a ser matéria de amplo debate.

Nos dias atuais, parece existir uma ausência de consenso na doutrina sobre o papel da eqüidade em face do direito positivo. Um claro índice de falta de consenso parece ser a classificação da eqüidade como "fonte do direito", sobre a qual há grande divergência da doutrina. Essa falta de consenso parece derivar em larga medida das diferentes concepções de ordenamento jurídico que se adotam.

De qualquer modo, por qualquer concepção que se adote, os autores geralmente têm reconhecido ao menos três diferentes funções para a eqüidade: a integrativa, a substitutiva e a interpretativa. ${ }^{38}$

A chamada eqüidade integrativa, como o nome indica, tem a função de integração do sistema jurídico. Serve para, de certo modo, corrigir a generalidade da lei e definir os elementos do suporte fático. Serve, para os que aceitam a existência de lacunas no ordenamento, como uma das formas de colmatá-las.

A chamada eqüidade substitutiva é aquela que substitui a norma positiva, quer por permissão legal, quer por vontade das partes. Nesta espécie, o julgador é chamado a decidir não conforme a norma estabelecida, pelo clássico esquema de silogismo, mas sim por meio de recurso, conforme definido por Ferraz Jr., "a uma espécie de intuição, no concreto, das exigências de justiça enquanto igualdade proporcional". ${ }^{39}$

Por fim, a eqüidade interpretativa, em que o julgador define com base na eqüidade o conteúdo da norma. Esta terceira posição pode ser considerada como uma forma de derrogação da norma positiva e portanto é vista com certa desconfiança pelos defensores do positivismo jurídico. ${ }^{40}$

Essas três definições de funções da eqüidade não são as únicas possíveis. Diversos autores apresentam enumerações distintas, que vão desde apenas as duas primeiras acima descritas até um desdobramento detalhado de atuações sobre contratos. Alípio Silveira, seguramente

37 Bоввіо, Norberto. Il positivismo giuridico, cit., p. 258.

38 Idem, ibidem, p. 261.

39 Introdução ao estudo do direito. São Paulo: Atlas, 1990. p. 277. Todavia, como será visto no decorrer da obra, há opiniões distintas sobre a forma de decisão por eqüidade.

40 Boвbio, Norberto. Il positivismo giuridico, cit., p. 261. 
o autor nacional que mais se dedicou ao tema, esboça cinco funções da eqüidade "no direito positivo":41 (i) compreensão de disposições contratuais e costumeiras; (ii) interpretação das fontes do direito; (iii) adaptação das normas ao caso concreto; (iv) integração de lacunas da norma; e (v) decisão ex bono et aequo. O mesmo autor ainda apresenta três acepções do termo eqüidade: (i) latíssima, pela qual a eqüidade seria um princípio universal da ordem normativa; (ii) lata, pela qual a eqüidade é sinônima à idéia de justiça absoluta ou ideal, com o direito natural em suas acepções; e (iii) estrita, que seria o ideal de justiça aplicado no caso concreto (por interpretação, integração ou adaptação). ${ }^{42}$

José de Oliveira Ascenção enumera seis possíveis formas de atuação da eqüidade: (i) aplicação da regra; (ii) complemento de cláusulas gerais; (iii) medida de conseqüência jurídica (especialmente na quantificação de danos); (iv) permissão legal ou negocial; (v) colmatação de lacuna da lei; (vi) substituição da lei. ${ }^{43}$

Há outra classificação de eqüidade, proposta no âmbito do processo civil. Trata-se da classificação de eqüidade entre formativa, supletiva e substitutiva. ${ }^{44}$ Formativa seria aquela destinada a preencher lacunas do ordenamento; a supletiva, aquela que opera quando as disposições legais deixam margem para aplicação de critério eqüitativo pelo juiz (fixação de alimentos, honorários advocatícios, certos valores de indenização ou multa); a substitutiva é a que se coloca em lugar do direito positivo.

Embora haja outras classificações possíveis, o desdobramento das funções da eqüidade, em maior ou menor medida, pode ser sintetizado nas três funções acima mencionadas, tal como propostas por Norberto Bobbio. De qualquer modo, todas as classificações apresentadas reconhecem a função substitutiva da eqüidade.

Não parece haver dúvida de que a autorização para decisão por eqüidade em sede de arbitragem é uma expressão da eqüidade substitutiva. Toda a doutrina consultada, quer nacional, quer estrangeira, quando se dedica a tal sorte de classificação, coloca a decisão por eqüidade como um exemplo de eqüidade substitutiva.

41 BobBio, Norberto. Il positivismo giuridico, cit., p. 261.

42 O mesmo autor ainda divide as funções da eqüidade em dois campos: (i) na elaboração legislativa e (ii) na atividade puramente judiciária. Na elaboração legislativa, e eqüidade apareceria como informadora ou inspiradora da norma e como elemento ativo de normas elásticas ou de equiidade (essas são aquelas que deixam espaço para uma apreciação eqüitativa de circunstâncias não definíveis a priori). Na atividade puramente judiciária, as funções da eqüidade seriam (a) a escolha da norma; (b) interpretação da lei; (c) integração da lei; (d) função corretiva (eqüidade contra legem).

43 Enciclopédia Saraiva do Direito, verbete Eqüidade.

44 Carmona, Carlos Alberto. Arbitragem e processo. 2. ed. São Paulo: Atlas, 2004. p. 77, referindo-se a Giovanni Verde. 
O objeto deste trabalho, como já mencionado, é apenas a eqüidade substitutiva, enquanto método de decisão na arbitragem comercial internacional. Apenas nesta função a eqüidade será estudada. Embora o estudo das demais funções seja tentador, ele teria por efeito diluir o núcleo da tese em discussões que, embora de altíssimo valor teórico, não atenderiam aos propósitos de um estudo de arbitragem internacional.

A decisão por eqüidade na arbitragem apresenta-se sobretudo como uma técnica. Tratase de uma forma de decidir sem que haja remissão necessária ao direito positivo. Uma forma de decidir que pode (e apenas pode) prescindir do clássico silogismo jurídico que tem por premissa a norma. Esta forma de decisão, tanto na sua estrutura lógica como em seus limites de atuação, é o objeto primordial deste trabalho. O conteúdo material de tal decisão é também propósito deste trabalho, com o objetivo de aferir tendências de um "senso de justiça" da comunidade da arbitragem.

O foco em uma das funções não impede a discussão do que seja a eqüidade. Na presente obra, ela ocorre na busca de alguns de seus elementos atuais, na comunidade do comércio internacional. Como será desenvolvido na terceira parte desta tese, buscaram-se elementos empíricos do que seja o eqüitativo no âmbito do comércio internacional. Portanto, a indagação sobre o que é a eqüidade faz parte do trabalho, ainda que com uma perspectiva um pouco distinta.

A perspectiva escolhida é eminentemente empírica. Embora o conteúdo da arbitragem seja objeto de considerações teóricas da mais alta importância, escolheu-se para este trabalho uma via indutiva, a partir de dados concretos e exemplos. A opção por essa linha se deve a uma característica encontrada no desenvolvimento teórico da eqüidade em geral. Ainda que tenha servido para a cristalização de regras concretas em diversos períodos históricos, a definição de seu conteúdo geralmente encerra proposições bastante gerais.

Essas proposições apresentam um grau elevado de incerteza, quando de sua concreção no nível decisório, do mesmo modo que os princípios gerais do direito. Assim, o autor fez a opção de adotar o método indutivo: a partir da aplicação concreta da eqüidade e da opinião dos operadores da arbitragem comercial internacional, tentou identificar algumas tendências a respeito do que seria eqüitativo nesse campo específico.

Para o desenvolvimento do trabalho, o autor decidiu dividi-lo em três partes.

Na primeira, busca-se o conceito da decisão por eqüidade, em seu conteúdo, forma, efeitos e limites. 
Essa parte inicia-se por um estudo histórico das decisões por eqüidade na arbitragem. Em primeiro lugar, faz-se uma breve recapitulação histórica do papel da arbitragem no direito. Esboçada a evolução histórica da arbitragem, passa-se a um estudo da decisão por eqüidade dentro dela. Ou seja, a evolução histórica da possibilidade de decisão por eqüidade, desde quando se pode diferenciá-la da aplicação do direito. Essa diferença nem sempre é verificável em todas as épocas, da mesma forma que nem sempre é clara a divisão entre jurisdição estatal e arbitragem. Em épocas mais remotas, há pouca diferença (se alguma) entre órgãos estatais, jurisdição e a aplicação da justiça por árbitros. Tampouco a diferença entre decisão por eqüidade e direito positivo é nítida, pois nem sempre o caráter positivo do direito pode ser afirmado de modo claro: juízos de forma cádi ou com a aplicação de costumes são comuns. A existência de normas claramente preexistentes, mesmo que consuetudinárias, nem sempre é aferível com facilidade. O objetivo da parte histórica é demonstrar a presença da arbitragem por eqüidade na tradição histórica do Ocidente.

À discussão histórica segue-se o exame do conceito e da forma da arbitragem por eqüidade no presente. Inicia-se o capítulo com um breve exame da natureza jurídica da arbitragem, para contextualizar a questão e verificar se a arbitragem por eqüidade efetivamente pertence aos domínios da arbitragem. Não obstante essa questão não se coloque no direito brasileiro, existem diferenças e opiniões no direito estrangeiro que colocaram a arbitragem por eqüidade como uma instituição paralela à arbitragem, embora similar.

Após situar a arbitragem por eqüidade no âmbito da arbitragem, passa-se ao exame de sua natureza jurídica. Depois, pela principal qualificação da arbitragem por eqüidade na doutrina internacional, que é a de renúncia à proteção do direito positivo. Após a análise desta posição, que, como será visto, privilegia um aspecto negativo da eqüidade (a derrogação do direito positivo), propõe-se que ela seja qualificada também por seu critério positivo: um critério de julgamento. Para melhor delinear o alcance e a unicidade do instituto, o autor efetuou também um exame das diferentes denominações da arbitragem por eqüidade no mundo. Os diversos nomes pelos quais essa instituição é conhecida no mundo, especialmente ex aequo et bono e amiable composition, mais do que uma questão de tradução, encerram questões conceituais. Parte da doutrina e da jurisprudência tem proposto a diferenciação entre eqüidade e amiable composition (e suas traduções), ora para que a primeira seja mais ampla que a segunda, ora para afirmar que esta tem natureza contratual. Nessa seção, o autor tentou demonstrar que se trata, essencialmente, do mesmo instituto. À discussão sobre a denominação segue-se uma comparação da arbitragem por eqüidade com institutos, figuras, situações de fato e sistemas que tenham pontos de contato. Nesta comparação, pretende-se situar de modo mais claro as fronteiras do instituto. 
Ainda no mesmo capítulo, discutem-se os aspectos formais da contratação da arbitragem por eqüidade no direito comparado. Essas questões envolvem problemas de direito internacional privado não desprezíveis. Entre elas, a qualificação da cláusula de arbitragem por eqüidade nos domínios do procedimento, da convenção de arbitragem ou do mérito. A questão da lei aplicável à cláusula, de difícil resposta, obteve uma solução de cunho eminentemente pragmático na doutrina do passado: em vista de ordenamentos jurídicos hostis à arbitragem, buscou-se a aplicação da lei do local da arbitragem. O autor debate se essa solução ainda é adequada no atual estágio do desenvolvimento legislativo mundial. $\mathrm{O}$ autor trata, ainda, da existência de regras materiais transnacionais que possam ser depreendidas do exame do direito comparado e jurisprudência arbitral, especificamente para a arbitragem por eqüidade. Neste capítulo, trata-se ainda da possibilidade de o Estado participar de arbitragens por eqüidade.

No terceiro capítulo, discutem-se os efeitos da escolha da arbitragem por eqüidade em relação ao direito material e ao procedimento. O estudo inicia-se pela "mecânica" da decisão por eqüidade, abrangendo as diversas proposições doutrinárias existentes. Após apresentar uma valoração de cada uma delas, conclui que a característica principal da arbitragem por eqüidade é a liberdade no uso dos diversos métodos, à falta de orientação legislativa, posição dominante em doutrina e jurisprudência e sanção a qualquer escolha. Conclui, também, que o principal efeito dessa escolha é a possibilidade de derrogação do direito positivo.

Quanto ao procedimento, estudam-se as diversas modificações que essa escolha pode implicar, seja em relação ao procedimento legal ou ao convencional. Analisa-se, também, um tema polêmico do instituto: a possibilidade de sua aplicação a questões não relacionadas ao mérito, como a validade da cláusula arbitral e outras questões "preliminares" da arbitragem.

No quarto capítulo, discutem-se os limites da arbitragem por eqüidade. O primeiro deles é a ordem pública. Essa questão, além das difíceis discussões de conceito, ainda apresenta alguns aspectos de direito internacional privado, que são discutidas. $\mathrm{O}$ segundo limite é dado pelo procedimento. Todavia, como a questão é discutida no capítulo anterior, por brevidade, prefere-se apenas fazer referência à discussão já feita. Outro limite da atuação da arbitragem por eqüidade é o contrato. Nesta seção, discutem-se os efeitos deste tipo de arbitragem sobre o contrato, uma questão que, embora ainda provoque polêmica, parece apresentar uma unificação de entendimento. Definir limites é como definir o alcance. Assim, a seção sobre contratos poderia ser tratada diretamente no capítulo anterior. Entretanto, por questão de conveniência e simetria, preferiu-se abordar o tema no capítulo relativo aos limites.

A segunda parte trata da presença da arbitragem por eqüidade no direito internacional. Ela é dividida entre parte geral e parte especial. Seu escopo principal é analisar a existência, a 
aceitação e o alcance do instituto no mundo atual. São três eixos de verificação: nas legislações nacionais, nas regras de arbitragem e nos tratados internacionais. Na parte geral, são apresentados os três sistemas principais da arbitragem por eqüidade no mundo: o sistema de permissão mediante autorização (presunção de arbitragem de direito); o sistema de presunção de arbitragem por eqüidade; e o sistema da vedação. Um idêntico exame é feito em relação aos diferentes regulamentos de arbitragem no mundo. Também é realizado um exame de como a matéria é abordada nos tratados internacionais.

Na parte especial, apresentam-se, em primeiro lugar, os diversos tratados pesquisados, com suas disposições específicas sobre a arbitragem por eqüidade, ou a ausência de menção. Em segundo lugar, apresenta-se, de forma mais ou menos resumida, a legislação de 98 países (excluído o Brasil, que é objeto de seção específica no corpo da tese). Embora possa parecer exagerado, a presente obra optou por pesquisar o maior número possível de legislações nacionais. Foram incluídos todos os países em que o autor pôde obter dados suficientes sobre a legislação de arbitragem. A opção por uma base expandida decorre da proposta de verificar um regime verdadeiramente internacional da arbitragem por eqüidade. A forma mais eficaz e completa de estabelecer caracteres efetivamente internacionais é a máxima expansão possível da base pesquisada. Evidentemente, a contrapartida do aumento da base é o menor aprofundamento nos respectivos direitos nacionais. $\mathrm{O}$ autor tentou compensar o menor aprofundamento geral com um tratamento mais detalhado de determinados países que apresentam maior complexidade em seu regime ou oportunidade de maior número de fontes para pesquisa. Entendemos que os efeitos positivos da ampliação de base compensam suas deficiências, sobretudo por permitir a dedução de princípios verdadeiramente internacionais e um panorama efetivamente global do instituto. $\mathrm{O}$ autor preferiu situar a pesquisa de legislação comparada no corpo da tese e não em um anexo, por recomendação de sua banca de qualificação.

$\mathrm{Na}$ terceira parte, a presente obra dedica-se à identificação de elementos de eqüidade na arbitragem comercial internacional. Seu propósito é a identificação de elementos empíricos que possam delinear algum conteúdo material da eqüidade na arbitragem comercial internacional. Em outras palavras, elementos que possam desvendar o "justo do comércio internacional": elementos comuns a uma comunidade tão diversa como a do comércio internacional e seus árbitros. Essa parte é inteiramente dedicada a duas pesquisas empíricas realizadas.

No primeiro capítulo, cuida-se de pesquisa de jurisprudência arbitral. Ela abrange tanto sentenças publicadas de diversas instituições como sentenças inéditas obtidas junto à Corte de Arbitragem da Câmara de Comércio Internacional (“CCI”). O acesso a essas sentenças inéditas deu-se mediante autorização especial concedida por aquela instituição. Ela permitiu o exame de um material único, que possibilitou uma visão mais completa do conjunto de decisões por 
eqüidade feitas recentemente e não apenas daquelas selecionadas para publicação. Conquanto as sentenças publicadas sejam as que despertam maior interesse, quer pela matéria de fundo, quer pela matéria processual, nem sempre retratam determinadas questões de modo integral. Nesse capítulo, são apresentadas determinadas questões relativas ao mérito e ao procedimento que desvendam alguns contornos da prática da arbitragem por eqüidade, certos modos recorrentes de decidir. A pesquisa não pode reivindicar a existência de um retrato completo da prática da arbitragem por eqüidade, todavia fornece elementos para sua percepção.

No segundo capítulo, o autor expõe os resultados de uma pesquisa de campo feita com 92 profissionais ligados à prática da arbitragem no mundo. Esses profissionais são sobretudo advogados e acadêmicos que atuam como árbitros no âmbito internacional. Eles foram convidados a responder questões relativas a aspectos formais e materiais da arbitragem por eqüidade, por meio de questionário que lhes foi encaminhado pelo autor.

Com essa pesquisa, o autor pretende demonstrar qual é a percepção atual da arbitragem por eqüidade no ambiente internacional, tanto no que diz respeito a seus limites e formas como no que concerne ao que possa parecer eqüitativo. Para esta última análise, o autor preparou 14 hipóteses retiradas da jurisprudência em que houve derrogação do direito positivo em favor de considerações de eqüidade. Além das hipóteses selecionadas, os participantes puderam indicar outras hipóteses em que entendiam que solução idêntica deveria ocorrer.

O autor espera que a obra elaborada possa ser uma pequena contribuição para o estudo da arbitragem por eqüidade. 


\section{Parte I \\ CONCEITO DA ARBITRAGEM POR EQÜIDADE}

Nesta parte, serão apresentadas as principais características da arbitragem por eqüidade. Começa por um esboço histórico de sua existência (1), passando por seu conceito, qualificação e formalidades (2). Em seguida, são examinados seus efeitos concernentes ao direito material e processual (3) e seus limites (4), especialmente a ordem pública e a vontade das partes expressa no contrato. 


\section{CAPÍTULO 1}

\section{HISTÓRICO}

\subsection{Problemas de história do direito na arbitragem}

A arbitragem é uma instituição que se perde no tempo. Pode-se afirmar que ela corresponde a uma primeira forma de julgamento, anterior a qualquer tribunal estatal. ${ }^{45}$

Em regra, a evolução da solução de controvérsias é apresentada da seguinte forma: vingança privada indiscriminada, vingança privada regulada, uso facultativo da arbitragem, uso obrigatório da arbitragem e finalmente o uso da justiça estatal. Entretanto, essa visão não é unânime. ${ }^{46}$

Qualquer histórico da arbitragem apresenta um problema de ordem metodológica: a partir de que momento no desenvolvimento da humanidade pode-se claramente divisar uma linha entre jurisdição estatal e um meio privado de solução de controvérsias?

Essa questão não é de fácil resposta. O desacordo entre autores parece indicar que talvez não haja uma resposta única no presente momento. Ao contrário, sempre dependerá do grau de separação que cada autor haverá de conferir entre a função jurisdicional estatal e outras formas de solução de controvérsias.

Também a escassez de fontes históricas conduz à tal divergência de interpretações. Especialmente no que diz respeito aos primórdios da civilização, muitas fontes são literárias, como os estudos da Grécia. Nem sempre tais passagens são interpretadas da mesma forma, por

45 JAKUBOwSKI, Jerzy. Reflections on the philosophy of international commercial arbitration and conciliation. The Art of Arbitration - Essays on International Arbitration. Liber Amicorum, Pieter Sanders, Deventer: Kluwer, p. 175, 1982.

46 Jarrosson, Charles. La notion d'arbitrage. Paris: LGDJ, 1987. p. 3. Pasukanis situa a origem do direito penal no costume de vingança de sangue, que precede a lei do talião. Originalmente, a vingança de sangue tornava o ofendido e/ou sua família ofensores, fazendo com que o ciclo continuasse nas gerações seguintes. Somente em épocas tardias é que teria havido a assimilação da vingança de sangue com o jus talionis, em que o princípio da reparação equivalente exclui uma vingança posterior desde que o ofendido (e/ou sua família) tenha sido vingado. PAsukanis, Eugeny B. A teoria geral do direito e o marxismo. Rio de Janeiro: Renovar, 1989. p. 145. 
exemplo, o caso da célebre passagem do escudo de Aquiles na Ilíada, que ora serve para demonstrar a existência da arbitragem, ora para demonstrar um caso de jurisdição estatal. ${ }^{47}$

Em última instância, uma análise histórica do instituto da arbitragem passa pelo exame das funções do estado. No entanto, a formação do estado é um processo milenar e não homogêneo. Nesse processo, encontram-se variados tipos em coexistência.

Também deve-se ter em mente que a centralização do Estado e a assunção, por parte deste, do monopólio da jurisdição são um passo relativamente recente na história da humanidade. Sem adentrar em polêmicas históricas, pode-se definir, com razoável grau de acerto, que a criação do Estado como hoje se conhece é uma obra da Idade Moderna. ${ }^{48}$

Na maioria dos Estados modernos, a jurisdição estatal é exercida em caráter permanente, por funcionários públicos com dedicação exclusiva, em estruturas preexistentes ao litígio. De outra parte, a arbitragem moderna caracteriza-se pela escolha de pessoas (normalmente não investidas de qualquer magistratura) para a decisão de um caso específico, fora do procedimento judicial estatal. Todavia, tais categorias nem sempre podem ser encontradas com clareza na evolução histórica.

A solução de controvérsias é uma função muito mais antiga que o estado moderno. Desde tempos imemoriais o soberano tomou para si a função de administrar a justiça ou ao menos o modo em que a solução de controvérsias deveria se desenrolar.

Entretanto, em tais primórdios, nem sempre houve um grau de institucionalização da administração que permitisse ver com clareza a diferença entre jurisdição estatal e arbitragem privada, tampouco a inter-relação entre tais esferas, ou seja, o modo com que formas privadas de solução de controvérsias eram aceitas como o julgamento final de uma matéria, sem que se passasse pela jurisdição estatal.

47 Jarrosson, Charles. La notion d'arbitrage, cit., p. 3. Em favor do caráter arbitral, veja-se RuBELLIN-DEVICHI, Jaqueline. L'arbitrage, nature juridique. Paris: LGDJ, 1965. Também Declareuil parece ver caráter arbitral no episódio, afirmando que o caráter público do julgamento não o torna estatal. Ao contrário, justamente pelo baixo grau de exeqüibilidade da decisão arbitral na antiguidade é que ela deveria ser feita em público, de modo a impor sanção social. Nisso a arbitragem antiga se difere da atual (fins do século XIX), segundo aquele autor, na medida em que a atual tem por função maior desembaraço procedimental (DeCLAREuIL, Joseph. Du Compromis en Droit Romain et en Droit Français. Paris: Imprimerie Moquet, 1887. p. 11-12).

48 Dallari, Dalmo de Abreu. Elementos de teoria geral do Estado. 15. ed. São Paulo: Saraiva, 1991. p. 51 e ss. 
Por exemplo, o Código Hamurabi menciona tanto a figura dos "anciãos" como a do “juiz" para a solução de controvérsias. Por outro lado, no preâmbulo "bombástico" do Código, ${ }^{49}$ o próprio Hamurabi é descrito como "o árbitro perfeito, que designa pastos e água para Lagash e Girsu". ${ }^{0}$

Em diversos momentos históricos, a jurisdição estatal era exercida por particulares, nomeados por determinado mandato, como na Grécia clássica. ${ }^{51}$

O fato de cidadãos privados exercerem funções públicas ad hoc ou por mandato torna incerta a configuração de determinado meio de solução de controvérsia como puramente jurisdicional ou de arbitragem. Especialmente em casos em que a coerção, como na antiguidade, pode ter caráter religioso ou místico, nem sempre dependendo de atuação estatal direta, tal como hoje se conhece.

Mesmo em estágios mais recentes do desenvolvimento humano, há interpenetração entre jurisdição estatal e arbitragem, como no caso dos tribunais das corporações de ofícios da Idade Média. Embora possuíssem um grau elevado de jurisdicionalização e institucionalização, ainda eram paralelos à jurisdição estatal e à aplicação do direito comum. Também a fase apud iudicem do processo civil romano, em que, uma vez concedida a ação (e a respectiva fórmula) pelo pretor, a decisão de mérito era feita por um cidadão comum, muitas vezes escolhido pelas partes. Embora haja autores que vejam algum caráter arbitral na fase apud iudicem, ela conviveu com o arbitrium de cunho exclusivamente privado.

Já no século XX os tribunais arbitrais constituídos no âmbito das câmaras de comércio exterior dos países socialistas também foram objeto de questionamento acerca de seu caráter "arbitral", ${ }^{52}$ pois eram essencialmente órgãos criados pelo Estado, que normalmente trabalhavam com listas fechadas de árbitros e que detinham competência, por legislação e/ou tratado, para conhecer de controvérsias relativas ao comércio internacional.

49 Roebuck, Derek. Ancient Greek arbitration. Oxford: Holo Books, 2001. p. 6.

50 Versão inglesa: "the perfect arbitrator, who designates pastures and the watering-places for Lagash and Girsu [...]". Richardson, Mej. Hammurabi's laws: text, translation and glossary, 2000, p. 35, apud RoEBuck, Derek, Ancient Greek arbitration, cit., p. 6. Neste caso, o equivalente mais preciso parece ser o da moderna arbitragem de direito internacional privado.

51 Roebuck, Derek. Ancient Greek arbitration, cit., p. 36 e ss. Também o comentário de Aristóteles sobre a Constituição de Atenas. Tradução de Sir Frederic Kenyon, disponível em: <http://www.constitution.org/ari/ athen_00.htm>. Acesso em: 13 mar. 2008).

52 Fouchard, Philippe; Gaillard, Emmanuel; Goldman, Berthold. Traité de l'Arbitrage Commercial International. Paris: Litec, 1996. p. 164. 
Iguais considerações podem ser feitas no tocante ao direito aplicável ao mérito da disputa. A centralização do Estado contribuiu para o monopólio da lei positiva como fonte de direito. Entretanto, tal centralismo jurídico (oposto a um anterior pluralismo de fontes) é um fruto da cultura jurídica do século XIX. ${ }^{53}$ Portanto, nem sempre é segura ou correta a contraposição entre direito positivo e eqüidade no plano histórico.

Por um lado, a aplicação da justiça, com a qual a eqüidade se identifica em algum grau, parece ser um pressuposto (ao menos ideológico) de todos os sistemas de solução de controvérsias. Por outro, considerações de eqüidade foram fonte importante para a criação ou adaptação do direito positivo, sem que houvesse uma separação clara de ambos, como no caso do ius honorarium romano.

A despeito de tais problemas, afirma-se aqui o interesse de uma breve visão histórica tanto da arbitragem em si como da arbitragem por eqüidade. $\mathrm{Na}$ opinião do autor, a análise histórica de um instituto auxilia a delinear sua posição atual. Embora a configuração atual da arbitragem por eqüidade seja obra sobretudo da onda de renovação das leis nacionais ocorrida a partir da década de 1980, essa verificação histórica permitirá sua melhor compreensão como fenômeno jurídico.

\subsection{Histórico da arbitragem}

\subsubsection{Da antiguidade}

Embora a anterioridade da arbitragem sobre a jurisdição estatal seja contestada por alguns, ${ }^{54}$ parece ser ainda a hipótese mais plausível. O fato de se encontrarem tribunais estatais ainda em estágios muito primitivos da evolução humana não altera tal conclusão. Um eventual paralelismo de jurisdições desde muito cedo não infirma a hipótese de "ancestralidade" da arbitragem em relação à jurisdição estatal.

Uma hipótese de evolução direta da vingança de sangue para a jurisdição estatal, embora possa ser verdadeira em algumas sociedades, parece deixar de considerar formas iniciais de tentativa de intermediação de conflitos fora dos quadros estatais, especialmente de cunho religioso ou com o recurso aos sábios ou anciãos.

53 Ferraz JR., Tercio Sampaio. Introdução ao estudo do direito. 4. ed. São Paulo: Atlas, 2003. p. $72-81$.

54 Jarrosson, Charles. La notion d'arbitrage, cit., p. 3 (com notas remetendo a outras fontes). 
Autores como Domke ${ }^{55}$ afirmam que o uso de arbitragem já era mencionado em escritos cuneiformes de Ur datados de 2.500 AC. O mesmo autor ainda refere-se ao Código de Hamurabi como uma fonte de várias menções ao uso da arbitragem. Entretanto, as traduções do Código normalmente utilizam-se da palavra "juiz" para aquele que julga, prevendo formas públicas de sua destituição em caso de erro (inclusive com a imposição de multa). Em outras passagens, o Código refere-se aos anciãos como julgadores. Aquele próprio autor ressalva que, naquele momento histórico, é difícil fazer uma clara separação entre o que seja arbitragem e o que seja julgamento estatal. Entretanto, considera razoável assumir que diversas disputas fossem resolvidas fora dos tribunais do rei. ${ }^{56}$ Outros autores, em estudos mais detalhados, apontam que, conquanto seja aceitável a postulação da existência de arbitragem privada na Mesopotâmia, a sua comprovação documental ainda resta a ser feita. ${ }^{57}$

Domke ainda refere-se ao uso comum da arbitragem no antigo Egito, ressalvando, porém, o fato de que sobreviveram poucos registros escritos de tais arbitragens, possivelmente por se desenrolarem fora do sistema oficial de solução de controvérsias. ${ }^{58}$

No entanto, aponta pelo menos dois casos em que há previsão do uso de arbitragem, em oposição ao sistema de solução de controvérsias do Estado. Por volta de 2.700 a.C., o chefe de Nekheb criou um fundo para as oferendas fúnebres após sua morte. O fundo seria administrado por sacerdotes e as disputas entre os sacerdotes e os leigos seriam resolvidas pela jurisdição normal. Entretanto, caso houvesse disputas entre os sacerdotes, elas seriam dirimidas pelos demais sacerdotes administradores do fundo, que decidiriam como árbitros. ${ }^{59}$ Outro exemplo, datado de 2.300 a.C., também envolve a criação e administração de um fundo para homenagens fúnebres de uma pessoa chamada Senu-Ankh. Há, ainda, referências aos sacerdotes e chefes de comunidades menores que agiram como juízes durante diversos períodos da história do Egito.

Todavia, esses exemplos são esparsos e não permitem afirmar que exista um corpo de evidência histórica suficiente para um estudo aprofundado da arbitragem na antiguidade. Somente nos estágios posteriores da evolução humana é permitido um estudo mais aprofundado da arbitragem, ainda assim sujeito a limitações.

55 Domke, Martin. Domke on commercial arbitration: the law and practice of commercial arbitration. 3. ed. [s.l.]: Thompson West, 1997. p. 2-2 e ss.

56 Idem, ibidem, p. 2-2 e ss.

57 Lafont, Sofie. L'Arbitrage en Mésopotamie. Revue de l'Arbitrage, Paris, Comité Français de l'Arbitrage, n. 4, p. 557 e ss., 2000.

58 Domke, Martin. Domke on commercial arbitration... cit., p. 2-2.

59 Idem, bidem. 


\subsubsection{Grécia}

A arbitragem era uma instituição conhecida na Grécia tanto para a solução de disputas entre suas cidades ${ }^{60}$ como entre seus cidadãos. ${ }^{61} \mathrm{~A}$ arbitragem entre cidades assemelha-se à atual arbitragem de direito internacional público. Contudo, há registros antigos de arbitragem também no plano de conflitos interindividuais.

Autores referem-se à arbitragem como um modo comum de solução de controvérsia já à época de Homero, permanecendo uma constante desde então. Mais ainda, afirma-se que arbitragem seria uma parte da vida quotidiana dos gregos e, ao tempo de Demóstenes, haveria considerável sofisticação sobre o procedimento de arbitragem compulsória. ${ }^{62} \mathrm{O}$ comentário de Aristóteles sobre a constituição de Atenas não parece deixar dúvidas sobre o uso do termo arbitragem e sua forma de organização.

Entretanto, para uma exata compreensão da arbitragem no sistema jurídico da Grécia antiga, deve-se considerar que havia dois tipos de arbitragem paralelos.

A arbitragem pública, mais referida pelos diversos autores, era um procedimento formal que servia como uma espécie de primeira instância civil, para casos acima de determinada alçada (dez dracmas). Funcionavam como árbitros os cidadãos que estivessem em seu $600^{\circ}$ ano de vida (fim do serviço militar). A atuação como árbitro era um serviço público, cuja desobedi-

60 RaEder, Anton Henrik. L'Arbitrage International chez les Hellenes. Kristiania: H. Aschehoug \& Co. (W. Nygaard); New York: G. P. Putnam's Sons, 1912. Esta obra apresenta um interessante apanhado sobre o uso da arbitragem na Grécia antiga, sobretudo entre cidades. O relato mais antigo de oferta de arbitragem data de 740 a.C., feita pelos habitantes de Messenia a Esparta (p. 14). Todavia, não foi aceita. A primeira oferta aceita data de 650 a.C., em disputa entre Calcis e Andros (p. 16).

61 Vide, por exemplo, o comentário de Aristóteles sobre a Constituição de Sólon: Livro 7, Parte 53:

"The Forty are also elected by lot, four from each tribe, before whom suitors bring all other cases. Formerly they were thirty in number, and they went on circuit through the demes to hear causes; but after the oligarchy of the Thirty they were increased to forty. They have full powers to decide cases in which the amount at issue does not exceed ten drachmas, but anything beyond that value they hand over to the Arbitrators. The Arbitrators take up the case, and, if they cannot bring the parties to an agreement, they give a decision. If their decision satisfies both parties, and they abide by it, the case is at an end; but if either of the parties appeals to the law-courts, the Arbitrators enclose the evidence, the pleadings, and the laws quoted in the case in two urns, those of the plaintiff in the one, and those of the defendant in the other. These they seal up and, having attached to them the decision of the arbitrator, written out on a tablet, place them in the custody of the four justices whose function it is to introduce cases on behalf of the tribe of the defendant. These officers take them and bring up the case before the law-court, to a jury of two hundred and one members in cases up to the value of a thousand drachmas, or to one of four hundred and one in cases above that value. No laws or pleadings or evidence may be used except those which were adduced before the Arbitrator, and have been enclosed in the urns".

Fonte: Tradução de Sir Frederic Kenyon. Disponível em: <http://www.constitution.org/ari/athen_00.htm>. Acesso em: 13 mar. 2008).

62 Domke, Martin. Domke on commercial arbitration... cit., p. 2-4 e 2-5. 
ência acarretava a sansão de perda dos direitos civis, sendo escusados aqueles que estivessem no exterior ou exercendo outro cargo no período. Partes prejudicadas por árbitros poderiam apresentar queixas que, se procedentes, acarretariam a perda dos direitos civis do árbitro.

As partes tinham pouca ingerência na escolha dos árbitros ou no procedimento. Em primeiro lugar, o dever dos árbitros era buscar a conciliação entre as partes. Se esta não fosse possível, então a matéria era decidida. As decisões dos árbitros eram sujeitas a recurso ao dikasterion, que era uma espécie de versão reduzida da assembléia geral dos cidadãos de Atenas. O número de cidadãos necessários para a decisão do recurso dependia do valor da causa. Caso envolvesse valor superior a 1.000 dracmas, seriam 401. Em valores inferiores, 201. Assim, a arbitragem pública era um procedimento bastante institucionalizado e integrante do sistema judiciário grego. ${ }^{63}$

Ao lado dessa arbitragem pública, existiu também uma arbitragem privada, desenvolvida por comum acordo entre as partes, sem envolvimento direto das instituições judiciárias (na medida em que se pode referir a tais instituições na Grécia antiga), e cuja decisão era final para as partes. Desde, pelo menos, o período clássico parece haver convivência entre os dois tipos de arbitragem, encontrando-se a arbitragem privada, embora reconhecida pelo sistema legal, em certa medida fora dele. A partir do quarto século antes de Cristo, há provas de que aqueles que contrataram a arbitragem privada não poderiam levar o caso para o sistema judicial. ${ }^{64}$ Há referência a arbitragens privadas na obra de Menandro (Os árbitros), e Demóstenes (Contra Mídias), embora este último seja muito provavelmente uma interpolação. ${ }^{65}$ Não obstante não se conheça uma regulação específica sobre a arbitragem privada (salvo textos possivelmente interpolados), há autores que defendem sua existência. Os principais argumentos para tanto são: (i) a prática da arbitragem privada era por demais difundida para não ser objeto de alguma espécie de regulação; (ii) interconexão entre arbitragem pública e privada; e (iii) referências, ainda que indiretas, em documentos e fragmentos. ${ }^{66}$ Assim, é provável que tenha existido ao menos uma determinação de que as sentenças arbitrais privadas fossem consideradas como finais.

Em alguns autores, as arbitragens pública e privada são tratadas dentro das leis de Sólon: os cidadãos eram livres para escolher um árbitro para dirimir suas controvérsias privadas e sua decisão seria final. ${ }^{67}$ Além dos árbitros escolhidos pelas partes, havia os árbitros escolhidos

\footnotetext{
63 Roebuck, Derek. Ancient Greek arbitration, cit., p. 42 e ss.

64 Idem, ibidem, p. 45.

65 Idem, p. 46.

66 Para uma visão completa da discussão, veja-se RoEBuck, Derek. Ibidem, p. 352-353.

67 Dalloz, M.D. Repertoire de Legislation de Doctrine et de Jurisprudence. Verbete "Arbitrage”. Paris: Bureau de la Jurisprudence Generale, 1846. p. 367.
} 
por sorteio, em número de quarenta e quatro por tribo. No entanto, havia diferença em razão da matéria e no sistema recursal. Os árbitros de caráter público conheciam causas de direito público, criminal, capacidade das pessoas. Os árbitros escolhidos pelas partes apenas tratavam de matérias contratuais. As sentenças dos árbitros "públicos" poderiam ser objeto de recurso. As sentenças dos árbitros escolhidos pelas partes decidiam de definitivo. ${ }^{68}$

Também em Esparta havia o uso da arbitragem, cujos procedimento eram julgados nos templos após juramento das partes de se submeter à sentença. ${ }^{69}$

Em suma, conclui-se que a arbitragem era utilizada na Grécia Antiga, pelo menos em Atenas, de modo paralelo à jurisdição estatal.

\subsubsection{Roma}

Em Roma, a arbitragem era bastante conhecida e praticada, paralelamente à jurisdição estatal. Desde o ano de 446 a.C., com a arbitragem entre cidades, ${ }^{70}$ até o Código Justiniano quase um milênio após, ${ }^{71}$ Roma conheceu e praticou a arbitragem em mais de uma forma. Alguns autores apontam na Lei das Doze Tábuas uma determinação para o uso da arbitragem, ao prescrever que as famílias interviessem na impossibilidade de resolução de uma controvérsia entre as partes interessadas. ${ }^{72}$

No período clássico, o processo civil romano era bifásico, começando perante o pretor que, se concedesse a ação (por meio de uma fórmula), encaminhava o caso para julgamento de um cidadão, que decidia o mérito (o iudex) ${ }^{73}$ Esta segunda fase era chamada de apud iudicem. Um cidadão comum era indicado para a decisão do caso. Não era um magistrado fixo ou investido de qualquer outro poder que não para o caso específico. Embora o pretor o nomeasse, era admitido que as partes pudessem indicar pessoa de sua confiança. Assim, a decisão final de mérito era feita por um cidadão, que poderia ser indicado pelas partes. Há, portanto, alguma

68 Dalloz, M.D. Repertoire de Legislation de Doctrine et de Jurisprudence, cit., p. 367.

69 Idem, p. 368.

70 Domke, Martin. Domke on commercial arbitration... cit., p. 2-5.

71 Digesto, Livro IV, Título VIII; Código, Livro II, título LVI[LV]. Edição consultada: Garcia Del Corral, Ildefonso L. Cuerpo del derecho civil romano. Barcelona: Jaime Molinas Editor, 1889.

72 Dalloz, M.D. Repertoire... cit., p. 368.

73 Moreira Alves, José Carlos. Direito romano. 13. ed. Rio de Janeiro: Forense, 2005. p. 205 e ss. 
aproximação entre a fase apud iudicem do processo romano com o conceito atual de arbitragem, conforme afirmam diversos autores. ${ }^{74}$

Entretanto, também existiu no direito romano a figura da arbitragem, à parte do procedimento estatal. Nela, o arbiter era chamado pelas partes a decidir uma controvérsia nos moldes por elas posto. Assim, poderia ser chamado tanto a decidir um litígio como também poderia apenas declarar ou integrar determinado aspecto do negócio, vir bonus. ${ }^{75} \mathrm{~A}$ fonte da investidura do arbiter era a vontade das partes e não a fórmula do pretor: advinha de um negócio jurídico, denominado compromisso.

A etimologia da palavra compromisso (cum promissum) indicaria a existência de uma promessa dupla, destinada a dar ao pacto a força que lhe faltaria. ${ }^{76}$ A mera referência a um terceiro para decidir não tinha efetividade no direito romano, originalmente. Seria um pacto nu, uma obrigação natural e não uma obrigação civil. Inicialmente, o direito romano conheceu o arbitrium boni viri feito por um arbitrator, no quadro da boa-fé (ou seja, sem execução própria). ${ }^{77}$

Posteriormente, de mera obrigação natural, foi-se criando a possibilidade de conjugar uma pena para garantir o pactuado. Assim, mesmo que a parte não cumprisse a sentença, poderia ser aplicada uma multa. Fala-se aqui dos árbitros ex compromisso. Ou seja, aqueles que são investidos conforme o compromisso.

Conforme Declareuil, ${ }^{78}$ os poderes do árbitro eram fixados no compromisso, que servia como a fórmula do pretor ao juiz. O árbitro devia conservar a liberdade de julgar conforme sua consciência. As partes não podiam impor que decidisse em um sentido determinado (ut certam sententiam dicat). Pode-se dizer, assim, que o compromisso regulava toda a parte externa da arbitragem, mas deve deixar livre seu lado interno, ou seja, o conteúdo da sentença.

74 Declareule, Joseph. Du Compromis... cit., p. 25. Nesta passagem, o autor cita Cícero (Pro Cluentio, n. 120) ao afirmar que o juiz escolhido pelas partes ou nomeado pelo pretor agia como árbitro. Também indaga se a litis contestatio não seria um verdadeiro compromisso. Também CRIFO, Giuliano. Enciclopedia del diritto. Verbete "arbitrato - diritto romano". Milano: Giuffrè, 1958. p. 893 e ss. RoEBuck, Derek; De Fumichon, Bruno L. Roman arbitration. Oxford: Holo Books, 2004. p. 67 e ss. Nesta obra, os autores sugerem uma correlação entre a decisão do iudex e a arbitragem pública de Atenas.

75 CRIFo, Giuliano. Enciclopedia del diritto, cit., p. 893.

76 Declareuil, Joseph. Du Compromis... cit., p. 36.

77 Loquin, Eric. L'Amiable composition en Droit Comparé et International. Paris: Librairies Techniques, 1980. p. 10 .

78 Declareuil, Joseph. Du Compromis... cit., p. 102. 
A sentença arbitral escapa do controle do pretor, que não pode sentenciar nem verificar o conteúdo da sentença. Esta vedação decorria de duas razões principais: (i) o compromisso era feito sem intervenção do pretor e (ii) o árbitro não tinha o dever de observar as regras de direito. Ao julgar, o árbitro obedecia ao compromisso e sua consciência.

O aparecimento da arbitragem ex compromisso é bastante posterior ao surgimento da arbitragem do bonus vir. Entretanto, deitou raízes fundas na tradição romana e, embora conhecendo algum declínio no tocante às formas de execução, ${ }^{79} \mathrm{com}$ ela chegou até o direito justinianeu, a Idade Média e mesmo os tempos modernos.

\subsubsection{Idade Média}

Além da sobrevivência por meio do direito romano, a arbitragem também era encontrada, durante a Idade Média, nas compilações “bárbaras", como no caso da Lex Visigothorum. ${ }^{80}$ Alguns autores chegam mesmo a afirmar que as sentenças arbitrais eram mais freqüentes que as sentenças judiciais, em razão da perda de credibilidade do sistema judicial feudal. ${ }^{81}$

Com o renascimento do direito romano, todas as disposições do Corpus Iuris relativas à arbitragem voltaram a ser estudadas, com contribuições do direito canônico. ${ }^{82}$ Vários estatutos das cidades previram a existência da arbitragem, que foi objeto de vários estudos dos comentadores, que vieram a modificar o instituto com o passar do tempo.

Com o renascimento do comércio, tribunais de comerciantes, normalmente ligados às respectivas corporações de ofícios, foram criados e tinham jurisdição inicialmente sobre os comerciantes (posteriormente alargada para os atos de comércio). Tratava-se de uma jurisdição paralela à das cortes estatais que aplicavam o direito civil comum. Os tribunais dos comerciantes em geral atuavam ex aequo et bono, sem grandes formalidades processuais, aplicando o costume dos comerciantes. Diversos autores reconhecem nesses tribunais de mercadores uma arbitragem..$^{83}$

\footnotetext{
79 Declareuil, Joseph. Du Compromis... cit., p. 60 e ss.

80 Mortari, Vincenzo Piano. Enciclopedia del diritto. Verbete "arbitrato - diritto intermedio". Milano: Giuffrè, 1958. p. 895 e ss.

81 Idem, ibidem, p. 896.

82 Mortari, Vincenzo Piano. Enciclopedia del diritto, cit., p. 896.

83 Por todos, Domke, Martin. Domke on commercial arbitration... cit., p. 2-7.
} 
Embora possam ser considerados "arbitrais", esses tribunais de mercadores apontam algumas dificuldades de definição da arbitragem em um contexto de pluralismo jurídico. Uma vez que o Estado aceita a existência de órgãos institucionalizados e permanentes, onde traçar a linha entre arbitragem e jurisdição?

Para os fins desta obra, podemos considerar tais órgãos como tribunais arbitrais por constituírem uma atividade judicante não estatal, composta por particulares e, embora fosse praticamente compulsória a todos os que comerciavam, pressupunha um grau volitivo mínimo das partes.

\subsubsection{Movimento de codificação}

O desenvolvimento histórico que levou à unificação do Estado e das fontes de direito produziu o fenômeno da codificação dentro da tradição jurídica romano-germânica. A edição do Código Civil francês no início do século XIX marca o início de tal era, ${ }^{84}$ caracterizada pela unificação das fontes e a abordagem sistemática da regulação da vida social.

Os Códigos não deixaram de seguir o substrato jurídico existente na sociedade. Dessa forma, diversos deles recepcionaram o compromisso romano, já na forma elaborada na Idade Média. Com efeito, desde o Código de Processo Civil francês ao Código Civil brasileiro de 1916, houve ampla adoção da figura do compromisso. ${ }^{85}$ Diga-se que o direito de base européia continental foi adotado, em medidas diversas, em toda a América Latina, nas ex-colônias africanas e asiáticas, de independência mais recente, e por países que pretendiam realizar esforços de modernização (ou "ocidentalização") de seus sistemas jurídicos, como foi o caso do Japão e da Turquia.

De outra parte, os países de direito consuetudinário (common law), embora não tenham aderido ao movimento de codificação, também conheceram a arbitragem como instituto. ${ }^{86}$

84 Embora houvesse códigos editados anteriormente, como o da Prússia, o francês detém a primazia de uma abordagem sistemática da matéria, razão pela qual o autor também o considera o marco inicial do movimento de codificação.

85 Por ora, considera-se indiferente o fato de a arbitragem estar prevista em códigos de processo ou de direito material.

86 A posição da arbitragem na Inglaterra tem diversas peculiaridades que serão vistas nesta obra. Entretanto, pode-se afirmar desde logo que a instituição da arbitragem foi desde muito cedo reconhecida e praticada naquele país. Para uma interessante visão histórica da arbitragem na Inglaterra, veja-se DAvid, René. Conception Française et Conception Anglaise de l'Arbitrage. Miscellanea W. J. Ganshof van der Meersch. Bruxelles: Etablissements Emile Bruylant, 1972. t. II, p. 765 e ss. Nessa obra, o autor coloca a arbitragem na Inglaterra 


\subsubsection{Atualidade}

No atual momento, passados alguns milênios desde o início de seu uso, a arbitragem parece estar consolidada como uma forma de solução de controvérsias amplamente aceita. Mais que continuar sua existência, a arbitragem parece ter ganhado reconhecimento unânime em todos os sistemas de direito atuais. Em alguns campos, como no caso do comércio internacional, a arbitragem afigura-se o modo de solução de controvérsias por excelência.

Apenas a Convenção de Nova Iorque de 1958 sobre o reconhecimento e execução de sentenças arbitrais estrangeiras conta com 143 países signatários em janeiro de $2009 .{ }^{87}$

Assim, pode-se afirmar que a arbitragem é uma instituição jurídica ${ }^{88}$ amplamente reconhecida em todo o mundo. Em perspectiva diacrônica, existe desde tempos imemoriais. Em perspectiva sincrônica, a arbitragem é reconhecida no mundo atual em praticamente todos os sistemas de direito contemporâneos.

\subsection{Histórico da eqüidade na arbitragem}

O histórico da arbitragem como instituição é permeado, ao menos a partir da experiência grega, pela questão do direito aplicável. Devem os árbitros aplicar o direito e o procedimento tal como um tribunal estatal ou aplicar um direito que lhes é próprio?

como uma parte integrante do sistema judicial, razão que explicaria a resistência histórica daquele país em aceitar a decisão por eqüidade.

87 Disponível em: <www.uncitral.org>. Acesso em: 11 jan. 2009. Alguns países podem não aderir à Convenção por outras razões que não o desconhecimento do instituto. Um exemplo típico é o do próprio Brasil, que somente a ratificou no ano de 2002, muito embora reconheça a arbitragem desde as Ordenações de Portugal e da Constituição do Império.

88 SAvigny, Friedrich Karl von. Ciencia del derecho. Buenos Aires: Losada, 1949. v. 1: Sistema de direito romano, p. 31:

"Pero de idéntica manera que la sentencia en una controversia particular solo posee una naturaleza limitada y dependiente y no encuentra sino en el enjuiciamiento de la relación jurídica su raíz viva y su fuerza convincente, radica la regla jurídica y su acuñación legal en el enfoque de la institución jurídica como en su fundamento mas profundo, cuya naturaleza orgánica tanto se evidencia en el contexto vivo de los elementos como en su desenvolvimiento progresivo. Si por tanto no nos paramos ante el fenómeno inmediato, sino que nos adentramos en la esencia misma del asunto, conocemos que en efecto cada relación jurídica se halla debajo de una institución jurídica correspondiente que es su tipo y que la domina de idéntica manera en que la sentencia particular es dominada por la regla jurídica". É certo que a obra de Savigny corresponde a um estágio específico da ciência do direito, chamado Escola Histórica. Segundo aquela escola, as instituições jurídicas tinham extrema importância como categoria de elaboração do direito. Embora desde há muito não seja a escola predominante no pensamento jurídico, entendemos válida para esta obra a definição de instituição ali apresentada. 
À primeira vista, a questão deveria se colocar com maior força a partir da centralização do Estado e do monopólio da lei como fonte de direito. Entretanto, como será visto adiante, essa questão se apresenta desde os tempos de Aristóteles.

\subsubsection{Grécia}

As relações entre direito e eqüidade foram um objeto de estudo dos filósofos gregos. Especialmente Aristóteles dedicou-se à matéria em duas de suas obras mais importantes. Embora Ética a Nicômaco seja a obra mais estudada de Aristóteles sobre o problema do direito, da justiça e da eqüidade, Arte Retórica também se ocupa da eqüidade, com especial interesse para os que estudam a arbitragem, principalmente a arbitragem por eqüidade.

Em Ética a Nicômaco, Aristóteles dedica-se ao problema da justiça e da relação desta com o direito positivo. Em síntese bastante apertada, ele conclui que o eqüitativo e o justo legal são ambos espécies da justiça. Entretanto, o eqüitativo é superior ao justo legal porque, em sua generalidade, a lei pode não dar a melhor solução ao caso, por ser impossível ao legislador prever todas as situações de fato. Por permitir essa correção do justo legal, o eqüitativo é-lhe superior.

Na célebre passagem da Arte retórica, Aristóteles dá exemplos de uma conduta eqüitativa. ${ }^{89}$ Nesses exemplos, coloca o modo de solução de controvérsias como parte desta conduta, afirmando ser eqüitativa a preferência pela arbitragem, que seria o modo criado para a aplicação da eqüidade, em oposição ao recurso aos juízes, que aplicam a lei:

Mostrar-se eqüitativo é ser indulgente com as fraquezas humanas; é também ter menos consideração pela lei do que pelo legislador; ter em conta não a letra da lei, mas a intenção do legislador, não a ação em si, mas a ação premeditada; não a parte, mas o todo; não o estado atual do acusado, mas sua conduta constante, ou sua conduta na maioria das circunstâncias. É também lembrar-nos do bem, mais do que o mal que nos foi feito, dos benefícios recebidos mais do que dos concedidos. É ainda suportar uma injustiça que nos fere, preferir resolver uma desavença amigavelmente a apresentar uma ação no tribunal; recorrer a uma arbitragem mais do que a um processo, porque o árbitro considera a eqüidade e o juiz a lei. Os árbitros foram instituídos justamente para permitir o exercício da eqüidade. ${ }^{90}$

89 Deve-se lembrar que, no mundo grego, a justiça apresenta-se sobretudo como uma virtude, um proceder.

90 Aristóteles. Arte retórica e arte poética. 16. ed. Rio de Janeiro: Ediouro, [s.d.]. p. 82. 
Esta passagem de Aristóteles é possivelmente a melhor evidência de que havia a possibilidade de decisão por eqüidade na arbitragem, em oposição às decisões baseadas apenas no direito positivo. Ou, como preferem outros autores, trata-se do melhor registro possível do sentimento dos cidadãos atenienses sobre a arbitragem em sua época. ${ }^{91}$

De qualquer modo, essa passagem parece ser uma demonstração cabal da possibilidade de decisão por eqüidade na arbitragem. Em verdade, ela parece indicar que a decisão por eqüidade era, se não a regra, pelo menos uma das finalidades da arbitragem. Essa percepção é confirmada por outras fontes, ${ }^{92}$ que afirmam a existência de árbitros que, julgando por eqüidade e sujeitos a formas mais rigorosas, tinham poderes para exigir que as partes abandonassem suas pretensões.

Portanto, desde a Grécia antiga, pode-se dizer que existe decisão por eqüidade na arbitragem. Aristóteles, em Arte retórica, parece indicar que a arbitragem está umbilicalmente ligada à eqüidade. Embora o texto não permita afirmar que todas as decisões arbitrais eram feitas apenas por eqüidade, pode-se inferir que esta era uma função central: "o árbitro não foi, aliás, inventado senão para dar força à eqüidade".

Embora não se possa afirmar que a decisão por eqüidade era a regra de todas as arbitragens, vê-se nesta passagem uma característica que acompanhará, em maior ou menor grau, a percepção da arbitragem em sua evolução histórica: uma instituição dotada de maior flexibilidade no que diz respeito às soluções finais, quer no procedimento, quer no mérito.

Mais ainda, vê-se uma instituição permeada pela conciliação, quer pelo próprio espírito de conciliação e moderação peculiar ao eqüitativo, como descrito por Aristóteles em Arte retórica, quer como uma etapa prévia do procedimento ou durante o desenrolar deste, como sustentado por estudiosos da arbitragem na Grécia antiga. ${ }^{93}$

\subsubsection{Roma}

Em Roma, a eqüidade teve um papel importante na própria criação do direito. O ius honorarium foi elaborado com base em decisões eqüitativas dos pretores, no momento em que

\footnotetext{
91 Roebuck, Derek. Ancient Greek arbitration, cit., p. 178.

92 Dalloz, M.D. Repertoire... cit., p. 367. A opinião aqui mencionada é atribuída a Samuel Petit.

93 Roebuck, Derek. Ancient Greek arbitration, cit., p. 358.
} 
a legislação antiga (especialmente a legis actiones) não mais correspondia às necessidades da vida quotidiana.

Conforme Sohm, o ius civile era o direito que se aplicava aos cidadãos, ${ }^{94}$ ao passo que o ius gentium era comum a todos os homens, existente entre todos os povos em razão da natureza das coisas e graças ao sentimento do eqüitativo que todos têm (jus gentium, quod apud omnes gentes peraeque custoditur). ${ }^{95}$ Segundo aquele autor, três forças contribuíram para essa formação de um direito eqüitativo: o edito do pretor, a ciência jurídica e a legislação imperial.

Os pretores possuíam autoridade jurisdicional acompanhada de uma faculdade de resolver conflitos, de modo soberano e discricionário (imperium). Ao contrário do juiz atual, um funcionário estatal, o pretor era um soberano, um magistrado supremo no que dizia respeito à aplicação da justiça. ${ }^{96}$

Os éditos dos pretores eram disposições tornadas públicas para fazerem conhecer os preceitos e normas a que pretendiam ater-se no exercício de sua magistratura (especialmente fórmulas para ações). Os éditos seriam renovados a cada pretor, anualmente. Entretanto, com o tempo e a sofisticação dos éditos, boa parte passou a ser repetida pelo pretor posterior, apenas com algumas modificações ou acréscimos.

Tendo em vista os poderes praticamente ilimitados do pretor, os éditos tornaram-se formas de elaboração do direito. Não obstante o pretor não pudesse editar leis, podia dar e recusar ações. ${ }^{97}$ Tendo em vista a lógica do direito romano, de tipicidade das ações, retirar ou conceder uma ação tinha efeito próximo de conceder ou retirar um direito. Portanto, houve uma evolução do direito romano, com criação de novos direitos e figuras jurídicas, com base eqüitativa, a partir da obra dos pretores.

Assim, a atuação em eqüidade das jurisdições estatais não apenas ocorria, como foi também um motor do desenvolvimento do direito positivo. Em Roma, pode-se dizer que a eqüidade era considerada parte do direito.

94 Neste caso, o termo civile refere-se aos cidadãos e não ao conceito atual de direito civil.

95 Soнm, Rudolf. Historia e instituciones del derecho privado romano. Madrid: La España Moderna, 1898(?). p. 102.

96 Idem, ibidem, p. 107.

97 Idem, p. 112. 
Segundo Bonfante, ${ }^{98}$ os termos romanos para a contraposição entre direito positivo e justiça são ius e aequitas ou bonum et aequum. A aequitas romana não seria exatamente o equivalente atual de eqüidade, que teria um sentido mais estrito. As definições de Cícero (quae paribus in causis paria iura desiderat, que adapta pari iuri os superiores e os inferiores) seriam definições da própria justiça. Quando dizia que o direito civil era a aequitas constituta ad res suas obtinendas ou quando a lei era tida como fons aequitatis e fundamentum libertatis, colocava a eqüidade como justiça. Também a eqüidade era usada como justiça nas legendas das moedas imperiais (Aequitas Antonini, Aequitas Severi). Já os termos iustitia e iustus não exprimiam o que se entende hoje por justiça e justo. Exprimiam antes qualidades derivadas de ius. Assim, devem ser traduzidas como legal, jurídico, legítimo.

A possibilidade de os árbitros julgarem apenas com recurso a eqüidade, sem aplicação do direito, parece ser admita pela maioria dos autores. ${ }^{99}$ Isso tanto na decisão do bonus vir como na arbitragem ex compromisso.

No caso da arbitragem por bonus vir, como já mencionado, tratava-se de um procedimento inteiramente privado, sujeito inteiramente à vontade das partes que a instituíam. Não havia nenhum grau de ingerência estatal na condução da arbitragem, tampouco na execução da decisão. Como apontado por Roebuck, ${ }^{100}$ tratava-se de uma versão de mediação-arbitragem informal, encontrada em diversas outras sociedades, com a diferença de que os romanos atribuíram-lhe nome. Dado o seu caráter de extrema informalidade, não se pode falar em obrigação de aplicação de qualquer lei.

De qualquer modo, a arbitragem do bonus vir estava ligada à idéia de boa-fé, de fides, que permeava o ideal romano de direito, relacionada com justiça e eqüidade. O bonus vir, embora não tivesse sua decisão sujeita à revisão por parte do pretor ou de qualquer iudex, deveria atuar em boa-fé, como um bom cidadão. Como tal, esperava-se um homem que agisse com senso de justiça, mas que também respeitasse, como todos os demais, as leis de Roma. Conforme autores como Horácio, esperava-se que o bonus vir observasse as leis, mas que estas estariam mais bem servidas se ele exercitasse sua discrição eqüitativa ao aplicá-las. ${ }^{101}$ Em todo caso, mesmo com uma possível penalidade por não agir de acordo com a boa-fé, ${ }^{102}$ o bonus vir estava liberado para uma decisão baseada em seu senso de justiça.

98 Bonfante, Pietro. Diritto romano. Milano: Giuffrè, 1976. p. 91 e ss.

99 Entre outros: Declareuil, Joseph. Du Compromis... cit., p. 103, Também Dalloz (Repertoire... cit., p. 368), que menciona a existência em Roma de vários tipos de árbitros, inclusive o equivalente ao amiable compositeur francês. Punzi, Carmine. Disegno sistematico dell'arbitrato. Padova: Cedam, 2000. p. 6 e ss.

100 Roebuck, Derek; De Fumichon, Bruno L. Roman arbitration, cit., p. 46.

101 Idem, ibidem, p. 57.

102 Idem. 
No caso da arbitragem ex compromisso, a liberdade de procedimento era uma das mais notáveis características. Especialmente em oposição ao processo formalista então em vigor. A famosa passagem de Cícero em Pro Roscio Comoedo, embora fosse um arrazoado para um caso, deixa clara a diferença entre arbitragem e procedimento judicial:

vai-se a juízo com a expectativa de receber ou a soma toda ou nada; vai-se a arbitragem com a expectativa nem de receber nada, nem de receber tudo que se pediu [...] o que é o juízo (ou a fórmula): direto, áspero, simples. [...] O que é a arbitragem? Suave, moderada: deve-se dar o que é mais justo e moderado. ${ }^{103}$

Neste famoso texto, Cícero descreve a diferença entre uma cobrança de dívidas em sede de arbitragem e em sede de ação civil.

Nesta passagem, há uma diferenciação de direito material e processual ${ }^{104}$ entre procedimento "judicial" e arbitragem, bem como uma espécie de diferença de "atitude" ou postura entre eles. $\mathrm{Na}$ arbitragem, atenua-se o rigor da lei e busca-se alguma espécie de composição entre as posições antagônicas. Assim, parece resultar clara a possibilidade de decisão por eqüidade, com base nos critérios de justiça do julgador, em detrimento do direito estrito.

Também é famosa passagem de Sêneca, bastante citada por autores que postulam a existência de decisão por eqüidade em sede de arbitragem:

meliorem esse conditionem causae bonae si ad judicem quam ad arbitrum mittatur; quia illum formula includit, et certos quos non excedat terminos ponit: at hujus libera nullis adstricta vinculis religio, et detrahere aliquid potest, et adjicere et sententiam suam non prout lex, vel justitia suadet, sed prout humanitas, aut misericórdia impellit et regit (Sêneca, De benef., III). ${ }^{105}$

103 "Pecunia tibi debebatur certa, quae nunc petitur per iudicem, in qua legitimae partis sponsio facta est. Hic tu si amplius HS. nummo petisti, quam tibi debitum est, causam perdidisti, propterea quod aliud est iudicium, aliud est arbitrium. Iudicium est pecuniae certae, arbitrium incertae; ad iudicium hoc modo venimus, ut totam litem aut obtineamus aut amittamus; ad arbitrium hoc animo adimus, ut neque nihil neque tantum, quantum postulavimus, consequamur. Ei rei ipsa verba formulae testimonio sunt. Quid est in iudicio? Derectum, asperum, simplex: SI PARET HS. ICCC DARI --. Hic nisi planum facit HS. ICCC ad libellam sibi deberi, causam perdit. Quid est in arbitrio? Mite, moderatum: QUANTUM AEQUIUS ET MELIUS SIT DARI.” Disponível em: <http://www.uah.edu/student_life/organizations/SAL/texts/latin/classical/cicero/procomoedo1.html> (sítio de internet da Universidade do Alabama). Acesso em: 17 mar. 2008. Tradução livre inglesa de Derek Roebuck e outro (Roman arbitration, cit., p. 161).

104 Embora de um modo geral essa diferenciação não seja tão nítida no direito romano como nos dias atuais. Ainda que a obra de Oskar von Bülow, o pioneiro da postulação da autonomia da relação processual, seja inspirada no processo bifásico romano, a distinção marcada da relação processual tal como hoje se conhece é obra do pensamento jurídico dos séculos XIX e XX.

105 Declareuil, Joseph. Du Compromis... cit., p. 103. 
Além disso, a possibilidade de pessoas não habituadas ao uso do direito poderem funcionar como árbitros, sem o limite da fórmula, mas apenas do compromisso das partes, demonstra uma maior flexibilidade no tocante ao direito estrito. Tal fato aliado, à impossibilidade de recurso, serve como índice de uma maior liberdade.

De qualquer modo, parece haver poucas dúvidas sobre a possibilidade de decisão sem recurso ao direito estrito na arbitragem em Roma. Ou seja, arbitragem em que se observava a consciência de justo dos árbitros, tanto na arbitragem por bonus vir quanto na arbitragem ex compromisso. No que diz respeito ao iudex, este também gozava de ampla liberdade de julgamento. Todavia, conceituá-lo como um árbitro ainda não é questão pacífica. Ao menos, não como árbitro privado.

\subsubsection{Idade Média}

A Idade Média tem dois eixos de desenvolvimento da arbitragem por eqüidade. De um lado, as corporações que, embora decidindo como árbitros em eqüidade, possuíam algum caráter jurisdicional e aplicavam os estatutos das corporações. De outro, o reconhecimento da arbitragem por eqüidade na obra de canonistas e romanistas, especialmente com a figura do arbitrator ou do amicabilis compositor.

a) Obra dos glosadores e desenvolvimentos legislativos

Um dos desenvolvimentos da obra dos comentadores foi a diferenciação entre dois tipos de árbitros: os que decidem em direito e os que decidem conforme a eqüidade.

Cuidava-se da diferenciação entre arbiter e arbitrator. O primeiro era aquele que decidia as questões segundo o direito positivo e seguia, no procedimento, as formas do juízo estatal. Dizia-se que decidiam de iure e seguiam o procedimento secundum iudiciorum ordinem. Já o arbitrator deveria decidir conforme a eqüidade, ex aequo et bono. Ou seja, sem a aplicação das normas de direito estrito. Sua principal função era compor amigavelmente uma lide sem se empenhar demasiadamente no exame do direito e dos fatos. Esse tipo de arbitragem era também chamado de compositio amicabilis e era freqüentemente ressaltada sua semelhança de natureza com a transação.

O amicabilis compositor já era comentado em textos de Baldo, Bartolo, Durand e Boutellier. ${ }^{106}$ Num primeiro momento histórico, a função do amicabilis compositor era efetiva-

106 Loquin, Eric. L'Amiable composition ... cit., p. 12. Rubino-Sammartano, Mauro. Il diritto dell'arbitrato. Padova: Cedam, 2005. p. 564-565. 
mente a de promover a concórdia entre as partes, favorecendo uma solução negociada. Daí sua aproximação com a transação ou mesmo com a atual conciliação. ${ }^{107}$

Originalmente, o amicabilis compositor não era investido da função de julgar um litígio, como o era o árbitro, mas sim de promover a pacificação. Alguns autores ${ }^{108}$ vêem nesta figura a redescoberta do arbitrium boni viri e distinta da arbitragem, assimilada ao arbitrium ex compromissum. Em alguns autores, houve mesmo distinção entre as figuras do amicabilis compositor, agindo estritamente como conciliador, e a do arbitrator, que decidiria a questão. Entretanto, essa distinção desaparece em autores posteriores. ${ }^{109}$

Assim, embora seja inicialmente um conciliador, com o decorrer do tempo a figura do amicabilis compositor passa novamente a se associar à função de árbitro, tão cedo quanto os séculos XIII e XIV.

No século XVI, houve no direito francês a unificação de recursos tirados de decisões de arbitragem de direito e da arbitragem de amicabilis compositor ou de arbitrator. ${ }^{110}$

No direito medieval francês, a assimilação do amicabilis compositor ao árbitro tornou marcada a existência paralela de duas espécies de arbitragem: uma de direito e uma liberada da aplicação deste. Não há mais uma diferença de figuras, mas sim de poderes: o árbitro deve julgar conforme o direito e o amiable compositeur está liberado desta aplicação. Alguns autores vêem na assimilação da amiable composition à arbitragem uma quebra de sua unidade e propósitos iniciais, essencialmente destinada a trazer concórdia entre os que terão relacionamentos em toda a vida. ${ }^{111}$

Essa figura do direito medieval é o antecedente histórico direto do instituto da arbitragem de eqüidade no direito francês, que conservou sua denominação, traduzida, como amiable composition e amiable compositeur.

No direito português medieval, verifica-se a presença da arbitragem (decisão por "alvidros") desde o século XII. ${ }^{112}$ Segundo Nogueira, à tal arbitragem aplicavam-se tanto direito

107 LoQuin, Eric. L'Amiable composition... cit., p. 14.

108 Idem, ibidem, p. 14.

109 Idem.

110 Loquin, Eric. L’Amiable composition... cit., p. 16.

111 DAvid, René. Conception... cit., p. 767-768.

112 Nogueira, José Duarte. A arbitragem na história do direito português, apud Lemes, Selma Ferreira. Arbitragem e a decisão por eqüidade no direito brasileiro e comparado. In: Lemes, Selma F.; CARMONA, Carlos Alberto; 
quanto eqüidade. Posteriormente, as Ordenações Afonsinas, ${ }^{113}$ Manuelinas ${ }^{114}$ e Filipinas ${ }^{115}$ adotaram disposições bastante semelhantes no que diz respeito ao juízo arbitral. Essencialmente, os julgadores eram divididos entre juízes árbitros e arbitradores, devendo os primeiros julgar segundo fato e direito e os segundos, somente segundo os fatos. Entretanto, no caso dos arbitradores, caso surgisse questão de direito, eles deveriam encaminhar as partes aos tribunais estatais para resolvê-la.

b) As corporações

Em um desenvolvimento paralelo, o arbitrium ex compromisso jurisdicionaliza-se na Idade Média também por obra das corporações. ${ }^{116}$

$\mathrm{Na}$ instabilidade daqueles tempos, a população livre das cidades procurou defesa em vínculos de associação, que vieram a se tornar, em períodos posteriores, as poderosas corporações de ofícios. Tais corporações desenvolveram em seu seio sistemas para a solução de controvérsia entre seus membros (em alguns casos, abrangeram também não-membros).

As corporações existiram durante séculos em boa parte da Europa, embora o território da Itália e, em menor escala, o da França sejam normalmente tidos como representativos dessa nova realidade econômica. Não obstante haja variações de organização nas diferentes cidades ou épocas estudadas, as considerações feitas a seguir referem-se a elementos centrais e representativos do fenômeno das corporações.

A forma das corporações era altamente institucionalizada e seu ordenamento, em alguma medida, imitou o ordenamento das cidades. ${ }^{117}$ Entretanto, a despeito da forte institucionali-

Martins, Pedro B. Arbitragem: estudos em homenagem ao Professor Guido F. Soares. São Paulo: Atlas, 2007.

113 Livro III, Título CXIII: Dos Juizes Alvidros; Livro III, Título CXIIII: Dos Alvidradores, que quer tanto dizer como Valiadores, ou Estimadores.

114 Livro III, Título LXXX: Dos Juizos Aluidros; Livro III, Título LXXXII: Dos Aluidradores, que quer tanto dezer como Aualiadores, ou Estimadores.

115 Livro III, Título XVI: Dos Juizes árbitros; Livro III, Título XVII: Dos Arbitradores.

116 Datam ao menos do século XI registros de corporações de ofícios e sua respectiva forma de resolução de controvérsias, como da associação de hortelões (ortolani) de Roma, de 1032, na qual as controvérsias de seus membros seriam "dirimidas por uma pessoa grada”, conforme TAVAres Guerreiro, José Alexandre. Fundamentos da arbitragem do comércio internacional. São Paulo: Saraiva, 1993. p. 81.

117 Vivante, Cesare. Trattato di diritto commerciale. 5. ed. Milano: Francesco Vallardi, 1922. v. 1, p. 3. 
zação do procedimento de solução de controvérsias, a maioria dos autores continua a ver nele a natureza de arbitragem. ${ }^{118}$

Ainda que a maioria dos autores que se dedicam à arbitragem tenda a defender a existência do instituto em situações dúbias, entendemos que é correto associar os tribunais das corporações à arbitragem porque (i) neles havia alguma liberdade das partes para escolher os julgadores e (ii) eles opunham-se à justiça comum dos senhores locais. Todavia, deve-se admitir que tais características podem ser encontradas em outros tribunais antes da centralização do Estado Moderno.

Diga-se, porém, a despeito do caráter de arbitragem dos tribunais das corporações, que houve casos de previsão de arbitragem paralelamente ao procedimento corporativo. Conforme Lattes, alguns estatutos previam arbitragem compulsória ou da faculdade de os juízes corporativos determinarem que as partes dela se valessem, como foi o caso de Gênova, Milão e Bérgamo. Outras facultam o método de "amichevole componimento". ${ }^{119}$

Conquanto alguns autores vejam na jurisdição das corporações sobretudo uma aplicação do direito positivo, ${ }^{120}$ é certo que os julgamentos ali mantidos eram feitos em larga medida por eqüidade e contribuíram decisivamente para a criação do direito comercial, como hoje se conhece.

Em geral, a justiça das corporações era administrada, em primeira instância, pelos cônsules, por vezes com intervenção de um jurisconsulto e dois comerciantes. Esse procedimento era guiado pelos estatutos e pelos usos. O procedimento era sumário (sine strepitu et figura iudicii), com prazos curtíssimos, e a decisão era por eqüidade (ex bono et aequo, sola veritate rei inspecta). ${ }^{121}$ Os litigantes compareciam sem auxílio de advogados e o tribunal julgava quando estimava a causa bem instruída. Os recursos eram normalmente excluídos, mas certos casos permitiam revisão por outros comerciantes.

No uso das fontes e na interpretação procedia-se conforme eqüidade e consciência em boa-fé. Não são muito grandes os traços de direito romano ou canônico nos estatutos. Alguns excluíam sua aplicação às causas mercantis (como Milão, Ferrara e Pisa). Outros remetiam à lei

\footnotetext{
118 Loquin, Eric. L'Amiable composition... cit., p. 13. Domke, Martin. Domke on commercial arbitration... cit., p. 2-7.

11 LATtes, Alessandro. Il diritto commerciale nella legislazione statutaria delle città italiane. Milano: Ulrico Hoepli, 1884. p. 244.

120 Loquin, Eric. L’Amiable composition... cit., p. 13.

121 Vivante, Cesare. Trattato di diritto commerciale, cit., p. 3.
} 
romana em caso de lacuna. O direito romano, porém, teve influência na elaboração do direito mercantil por obra dos jurisconsultos chamados para tomar parte na formação dos estatutos ou para decidir como juízes/árbitros. Além disso, a escassez de normas de direito privado nos estatutos tornava freqüente as ocasiões de aplicar os princípios gerais do direito comum por analogia. $^{122}$

Assim, a despeito de o julgamento se dar por eqüidade, havia a aplicação de regras corporativas. De qualquer modo, ainda que se referindo a um corpo de regras mais ou menos desenvolvido, as decisões das corporações se davam fora do direito estatal inicialmente aplicável. ${ }^{123}$

Em verdade, tal aplicação foi um vetor importantíssimo na criação do direito comercial: os comerciantes eram os cônsules que aplicavam as regras conforme sua experiência quotidiana, os comerciantes eram os redatores dos estatutos e os comerciantes compunham a assembléia que os aprovava. Poucas vezes na história a vida prática e o direito se comunicaram tão rapidamente.

Neste momento do desenvolvimento histórico, pode-se vislumbrar uma das possíveis atuações da arbitragem por eqüidade até os dias de hoje: o afastamento de regras estatais em favor de regras corporativas. Naquela época, o direito estatal era essencialmente o direito romano "redescoberto" e o direito canônico, com algum aporte do chamado "direito comum". Tal moldura jurídica não se mostrava completamente adaptada ao surgimento do comércio que conduziu à criação da burguesia. Ademais, havia vedações canônicas à usura. Assim, o uso da eqüidade tanto no fundo quanto no procedimento proporcionou a aplicação não exatamente de um senso de justiça comum, mas sim um certo senso comum de uma classe de profissionais.

Em outras palavras, serviu para a criação do que se veio chamar de ius mercatorum, convivendo, na sociedade medieval, com o direito civil retomado especialmente pela via do Corpus Iuris de Justiniano "redescoberto" e com o direito canônico. ${ }^{124}$

Sendo o contrato a forma jurídica do comércio por excelência, é natural que o ius mercatorum atuasse de forma acentuada sobre tal matéria (e das obrigações, de modo mais

122 LATtes, Alessandro. Il diritto commerciale... cit., p. 72.

123 Situação semelhante pode ser encontrada quando da criação da doutrina da nova lex mercatoria, em que, ao menos nos primeiros momentos, a arbitragem por eqüidade foi recomendada como veículo para a aplicação do direito dos mercadores. Em verdade, um dos postulados desta teoria é uma constante reivindicação de analogias históricas com o direito forjado pelos mercadores medievais.

124 Galgano, Francesco. Lex Mercatoria. Bologna: Il Mulino, 2001, p. 38. 
geral). O sistema do direito romano era voltado sobretudo à conservação e ao gozo da propriedade e não à acumulação e ao lucro. Assim, da mesma forma que o direito romano foi um direito destinado à questão da propriedade, o ius mercatorum voltou-se ao contrato e aos relacionamentos contratuais, buscando maior liberdade de formas, abandonando-se as solenidades consagradas no direito romano. Sendo a compra e venda o contrato mercantil por excelência, buscou-se em grande medida a proteção do mercador, especialmente enquanto credor de preço de coisa vendida. ${ }^{125}$

O ius mercatorum apresentou desde cedo caráter de superação do âmbito comunal e passou a uniformizar-se nas várias praças de comércio. Logo tornou-se um direito mais ou menos uniforme no âmbito europeu: as várias praças de comércio, embora sujeitas a diferentes soberanos, apresentavam um direito mercantil uniforme. Havia também um direito mercantil próprio das feiras. Assim, o direito mercantil passa a abranger um raio geográfico muito maior que as normas editadas nas cidades.

As normas relativas à produção e compra de insumos poderiam ser reguladas localmente. Entretanto, o mercado de circulação dos bens abrangia um universo muito maior que o da cidade, exigindo-se normas de aplicação para além de seus limites. Havendo preponderância econômica de determinadas cidades, era natural que conseguissem impor seu direito a outros mercados, por força de seu poderio econômico. Portanto, o direito mercantil da Idade Média foi o direito mercantil das cidades-estado italianas (especialmente Gênova, Florença, Milão e Veneza), que detinham a primazia no comércio. O raio de ação da lex mercatoria ia de Gênova a Londres. ${ }^{126}$

Um outro centro operoso deste direito profissional, cada vez mais uniforme, eram as feiras, dos séculos XII ao XVI, especialmente na França. O senhor da terra tinha prepostos (maîtres des foires, custodes nundinarum) aos quais era concedida plena jurisdição sobre as controvérsias lá ocorridas. Os costumes estabelecidos para as feiras foram especialmente importantes para o desenvolvimento de direitos de compensação, o direito cambiário e certas formas de execução mais rigorosas.

\footnotetext{
125 Um exemplo citado por Galgano mostra a evolução do direito dos mercadores em relação ao direito romano: a compra de coisa furtada. Enquanto em Roma o proprietário tinha ação para reivindicar a res furtiva, no direito dos mercadores tal reivindicação não era possível se a coisa houvesse sido adquirida de um comerciante registrado. Protege-se, assim, o comerciante (mais que o adquirente ou o proprietário furtado): quem compra dele, compra bem. A mesma proteção não era concedida se a coisa furtada fosse adquirida de um não-comerciante (Galgano, Francesco. Lex Mercatoria, cit., p. 43).

126 Idem, ibidem, p. 57.
} 
Ascarelli ${ }^{127}$ afirma que, observando-se a história do direito, descobre-se com freqüência que o direito privado se encontra dividido em um sistema tradicional e um sistema eqüitativo, às vezes regulando-se exclusivamente, às vezes de forma concorrente. Neste caso, o sentido de eqüidade não é exatamente o de "justiça no caso concreto", mas a emersão de novos valores e novos princípios, invocados inicialmente vel suplendi vel corrigendi gratia do direito tradicional e depois tornam-se regras de direito positivo como direito especial. A contraposição entre ius honorarium e ius civile em Roma e entre common law e equity no direito anglo-saxão também o demonstrariam.

O fim da Idade Média é marcado pela ascensão das monarquias absolutistas, em que surge a centralização do Estado e das fontes do direito. A burguesia comercial, classe cosmopolita largamente ajudada pela descentralização do Estado, perde seu poder político (embora não o econômico). Assim, o direito dos mercadores deixa de ser um direito ditado pela própria classe e passa a ser um direito ditado pelo monarca. Deixa de ser um direito universal para se tornar um direito nacional. Mesmo as jurisdições mercantis perdem seu caráter autônomo (ainda que continuem a existir tribunais do comércio, com eleição de juízes pelos comerciantes, há a confirmação do soberano). A condição de comerciante passa a ser, em grande medida, um favor concedido pelo soberano. Alguns juristas da época absolutista colocam o direito comercial como um direito público. ${ }^{128}$ Desse modo, as fontes do direito mercantil são alteradas, passando a prevalecer o direito editado pelo soberano (como a Ordonnance du Commerce francesa de 1673) sobre as fontes tradicionais.

\subsubsection{Movimento de Codificação}

As duas vertentes da arbitragem de eqüidade na Idade Média resultaram, quando do surgimento do movimento de codificação, em dois campos distintos.

Por um lado, o direito desenvolvido ao longo dos séculos pelas corporações de ofícios foi assimilado pelo Estado, como acima dito. Essa assimilação, juntamente com a visão de um caráter de especificidade, passou a compor um ramo separado do direito privado, a que veio se chamar direito comercial. O seu espaço natural deixou de ser a sociedade multicêntrica da Idade Média para se dar no plano do Estado nacional.

127 Ascarelli, Tulio. Lezioni di diritto commerciale. Introduzione. 2. ed. Milano: Giuffrè, 1955. p. 1.

128 Domat, apud Galgano, Francesco. Lex Mercatoria, cit., p. 76. 
Outro fruto do desenvolvimento da arbitragem de eqüidade foi justamente a recepção, por parte de diversos ordenamentos jurídicos, da possibilidade de tal tipo de arbitragem. Certamente, tais disposições são herdeiras diretas da tradição medieval de arbitragem por eqüidade, tanto quanto a recepção da própria arbitragem como instituto o foi. Tal possibilidade de decisão foi prevista tanto em Códigos de Processo Civil (como o caso emblemático do Código francês de 1806) quanto em Códigos Civis (por exemplo, o Código Civil brasileiro de 1916).

Embora prevista em boa parte das legislações, a arbitragem por eqüidade não foi aceita da mesma forma que a arbitragem em geral. Diversos países não a permitiam ou a ignoravam, como a Inglaterra até pouco antes da edição do Arbitration Act de 1996, ou os países socialistas em geral. De um modo bastante geral, pode-se dizer que a tradição jurídica francesa permitia a arbitragem por eqüidade. A tradição luso-brasileira igualmente a permitia, bem como a hispanoamericana. Por outro lado, os países de tradição de common law, com exceção dos EUA, mostraram-se refratários à arbitragem por eqüidade, como igualmente o foram os países socialistas do século XX. Os países árabes parecem em geral admiti-la, seja por herança do colonialismo francês, seja pela tradição otomana, embora com uma concepção distinta.

Entretanto, a partir dos anos 1970, houve uma onda de renovação de legislações locais de arbitragem, que continua até a presente data.

Tal renovação inspirou-se fortemente na Comissão das Nações Unidas para o Direito Comercial Internacional (CNUDCI ou UNCITRAL). Como veremos, seu trabalho foi decisivo para o reconhecimento da arbitragem por eqüidade.

\subsubsection{A Lei Modelo da CNUDCI}

A CNUDCI foi criada por decisão da Assembléia Geral das Nações Unidas em 1966, em reconhecimento de que a falta de harmonia entre as legislações nacionais dificultava o fluxo do comércio internacional. Seu mandato prescreve a promoção da harmonização e unificação do direito do comércio internacional.

Em 1976, a CNUDCI aprovou suas regras de arbitragem, especificamente desenhadas para arbitragens $a d$ hoc. Tais regras são bastante usadas no âmbito da arbitragem internacional e foram recomendadas pela Assembléia Geral das Nações Unidas. ${ }^{129}$

129 Resolução 31/1998, de 15.12.1976. 
As regras de arbitragem da CNUDCI são amplamente utilizadas na arbitragem internacional, servindo de referência para outras instituições, como foi o caso do Tribunal Irã-Estados Unidos, criado pelos Acordos de Argel.

Talvez parte dessa aceitação das regras da CNUDCI deva-se ao fato de terem sido elaboradas sob a égide de uma instituição multilateral com participação de países de todos os graus de desenvolvimento. O prestígio da Organização das Nações Unidas e uma distribuição geográfica mais ou menos eqüitativa dos membros da CNUDCI parecem outorgar ao trabalho desta Comissão uma percepção de "neutralidade" e/ou de "representatividade" de seus trabalhos. Tal fato parece ter sido especialmente importante quando da existência de dois blocos político-econômicos rivais na configuração mundial. As regras da CNUDCI puderam se colocar como um "terreno comum" entre interesses opostos.

As regras da CNUDCI de 1976 previram, em seu art. 33, o uso de arbitragem por eqüidade, se as partes expressamente o consentirem. ${ }^{130}$

Posteriormente, em 21.06.1985, a CNUDCI adotou uma "Lei-Modelo sobre Arbitragem Comercial Internacional”, ${ }^{131-132}$ que foi objeto da Resolução 40/1972 da Assembléia Geral das Nações Unidas, de 11.12.1985. Naquela Resolução, a Assembléia Geral recomendou que os Estados considerassem "devidamente" a Lei-Modelo, em vista do objetivo da uniformidade da regulação da arbitragem e das necessidades específicas da arbitragem internacional.

Baseada em grande medida nas próprias regras de arbitragem da CNUDCI, ${ }^{133}$ a Lei Modelo cobre todas as fases do procedimento arbitral, de sua constituição até a execução do laudo. De certa forma, pode-se dizer que ela representa um "consenso" quanto a certos pontos principais da arbitragem. Naturalmente, trata-se de um modelo que pode ser adaptado a particu-

130 Article 33.

1. The arbitral tribunal shall apply the law designated by the parties as applicable to the substance of the dispute. Failing such designation by the parties, the arbitral tribunal shall apply the law determined by the conflict of laws rules which it considers applicable.

2. The arbitral tribunal shall decide as amiable compositeur or ex aequo et bono only if the parties have expressly authorized the arbitral tribunal to do so and if the law applicable to the arbitral procedure permits such arbitration.

3. In all cases, the arbitral tribunal shall decide in accordance with the terms of the contract and shall take into account the usages of the trade applicable to the transaction.

131 A Lei Modelo sofreu pequenas alterações em 2006. Entretanto, nenhuma delas modifica o conteúdo relativo à arbitragem por eqüidade.

132 Doravante, tal ato será referido como "Lei Modelo" nesta obra.

133 SAnders, Pieter. The Work of Uncitral on Arbitration and Conciliation. The Hague (Den Haag), Kluwer Law International, p. 22, 2001. 
laridades locais, embora grandes mudanças do texto original não sejam encorajadas. ${ }^{134}$ Por outro lado, mesmo que os Estados não adotem a Lei Modelo em sua integralidade, as disposições desta continuam sendo uma referência para o legislador nacional, como foi o caso brasileiro e o inglês.

A adoção da Lei Modelo derivou essencialmente da consideração de que as leis domésticas de até então apresentavam estágios variados de evolução, em que muitas delas ainda colocavam a arbitragem em igualdade ao processo judicial. Mesmo as mais modernas tratavam essencialmente da arbitragem interna, o que acarretava certo aporte de particularidades internas no âmbito internacional, em prejuízo da previsibilidade. ${ }^{135}$

Após sua aprovação, a Lei Modelo foi rapidamente adotada por vários países, a começar pelo Canadá, no ano de 1986. Em outubro de 2007, a Lei Modelo contava com a adoção direta de mais de 48 países. ${ }^{136}$ Entretanto, além desses 48 países, vários outros inspiraram-se na Lei Modelo.

Em seu art. 28 (3), a Lei Modelo prevê a possibilidade de decisão por eqüidade, nos termos previstos nas regras da CNUDCI:

Article 28. Rules applicable to substance of dispute

(1) The arbitral tribunal shall decide the dispute in accordance with such rules of law as are chosen by the parties as applicable to the substance of the dispute. Any designation of the law or legal system of a given State shall be construed, unless otherwise expressed, as directly referring to the substantive law of that State and not to its conflict of laws rules.

(2) Failing any designation by the parties, the arbitral tribunal shall apply the law determined by the conflict of laws rules which it considers applicable.

(3) The arbitral tribunal shall decide ex aequo et bono or as amiable compositeur only if the parties have expressly authorized it to do so.

(4) In all cases, the arbitral tribunal shall decide in accordance with the terms of the contract and shall take into account the usages of the trade applicable to the transaction.

134 Veja-se nota explicativa do Secretariado da CNUDCI disponível em: <http://www.uncitral.org/pdf/english/ texts/arbitration/ml-arb/MLARB_explanatory_note.pdf>. Acesso em: 15 ago. 2007.

135 Idem.

136 Alemanha, Austrália, Áustria, Azerbaijão, Bahrain, Bangladesh, Bielo-Rússia, Bulgária, Cambodja, Canadá, Chile, Chipre, Cingapura, Coréia do Sul, Croácia, Dinamarca, Egito, Espanha, Filipinas, Grécia, Guatemala, Hungria, Índia, Irã, Irlanda, Japão, Jordânia, Lituânia, Madagascar, Malta, México, Nicarágua, Nigéria, Noruega, Nova Zelândia, Omã, Paraguai, Peru, Polônia, Quênia, Rússia, Sri Lanka, Tailândia, Tunísia, Turquia, Ucrânia, Zâmbia e Zimbábue. Alem disso, adotaram a Lei Modelo as regiões administrativas especiais de Hong-Kong e Macau (República Popular da China), a Escócia e Bermuda dentro do Reino Unido e os Estados da Califórnia, Connecticut, Illinois, Louisiana, Oregon e Texa, nos Estados Unidos da América (Disponível em: <www.uncitral.org>. Acesso em: 17 out. 2007. 
Portanto, a Lei Modelo reconhece a arbitragem por eqüidade. No entanto, não a presume. Ela somente poderá ser utilizada quando houver expressa permissão das partes.

Além da maciça adesão à Lei Modelo, talvez seu efeito mais perceptível para o tema seja o de introduzir a arbitragem por eqüidade nos países de common law e os que adotavam o regime socialista.

A Lei Modelo foi adotada diretamente por Austrália, Nova Zelândia, Cingapura e Índia e inspirou partes do Arbitration Act inglês de 1996, que, embora com outro texto, finalmente permitiu que decisões arbitrais sejam tomadas com base em eqüidade, desde que as partes assim concordem.

Também os países do antigo bloco socialista passaram a permitir a arbitragem por eqüidade, como a Polônia, a República Tcheca, a Ucrânia e a Hungria. Restam, porém, as aparentes exceções da Rússia e da Bulgária, ainda que tenha havido adoção de quase todo o resto da Lei Modelo.

O processo de adoção da Lei Modelo, embora avançado, continua em curso. Em anos muito recentes, países como a Áustria e a Dinamarca a adotaram. Assim, a obra da CNUDCI vem forjando um novo panorama da arbitragem comercial no mundo. Ao fazê-lo, criou uma espécie de sistema comum que, com poucas adaptações, pode ser encontrado por quase todo o globo. Há, assim, uma "língua comum" da arbitragem internacional e a arbitragem por eqüidade faz parte dela.

\subsubsection{O caso brasileiro}

No Brasil, o primeiro diploma legal a mencionar a possibilidade de decisão por eqüidade foi a Lei 1.350, de 14.09.1866. ${ }^{137}$ Essa lei, que terminou com a arbitragem compulsória, previu, em seu art. 1. $.^{\circ} \S 2 .^{\circ}$, que "podem as partes autorizar seus árbitros para julgarem por eqüidade independentemente das regras e formas do direito".

No Decreto 3.900, de 1867, continha idêntica disposição:

Art. 10. Além dos requisitos essenciais do art. $8 .^{\circ}$ podem as partes acrescentar no compromisso as seguintes declarações:

137 O famoso Regulamento 737 , de 1850 , não trata da arbitragem por eqüidade. 
$[\ldots]$

$\S 4 .^{\circ}$ Autorização para os árbitros julgarem por eqüidade, independentemente das regras e formas do direito.

Aquele decreto, ao contrário da lacônica Lei 1.350, ainda possuía duas disposições que mencionavam a eqüidade:

Art. 46. Os árbitros julgarão de fato e de direito conforme a lei, e as cláusulas do compromisso; salvo se no compromisso (art. 10, $\S 4 .^{\circ}$ ) as partes os autorizarem para julgar por eqüidade, independentemente das regras e formas do direito.

Art. 47. Quando os árbitros tiverem poderes para julgar por eqüidade, independentemente das regras formais do direito, poderão prescindir do processo estabelecido nos artigos antecedentes, e darão a sua decisão ouvindo verbal e sumariamente as partes e testemunhas; reduzindo a termo os depoimentos das testemunhas, e admitindo os memoriais que as partes oferecerem.

Assim, o Decreto 3.900 possui uma particularidade na história do direito brasileiro: pela única vez um texto legislativo cuidou do procedimento da arbitragem por eqüidade de modo distinto da arbitragem de direito.

Ambos os textos legais obtiveram um breve comentário de Teixeira de Freitas sobre a natureza e o alcance da arbitragem por eqüidade, colocada em nota de rodapé na famosa Consolidação das Leis Civis:

O julgamento arbitral por eqüidade, como autorisa o art. $1 .^{\circ}, \S 2 .^{\circ}$, do cit. Regul. de 1867, é julgamento fundado na razão absoluta, que não se deve confundir com a recta razão - direita razão, que é a nossa boa razão da Lei de 18 de agosto de 1769, a essas duas normas de julgar, pertencentes ao direito do futuro, allude a definição romana - Jus est ars bonis et cequi-, antes o bom e depois finalmente o igual. Diz Merlin Repert. De Jurispr. Vb. Équité, que não há maior eqüidade que a da lei. Se fala da lei positiva, alcançou pouco; porque o Direito positivo é transitório, progressivo, até que afinal, pelo bem relativo, attinge o bem absoluto da eqüidade (destaques do original; grafia original mantida). ${ }^{138}$

Posteriormente, o Código Civil de 1916 manteve disposição semelhante sobre a possibilidade de julgamento por eqüidade:

Art. 1.040. O compromisso poderá também declarar:

$[\ldots]$

138 Teixeira de Freitas, Augusto. Consolidação das Leis Civis. Edição fac-símile. Brasília: Senado Federal, 2003. p. 273. 
IV - A autorização, dada aos árbitros para julgarem por eqüidade, fora das regras e formas do direito.

O Código de Processo Civil de 1939 mencionava a decisão por eqüidade apenas para excepcionar uma causa de nulidade da sentença arbitral:

Art. 1.045 . Será nula a decisão arbitral:

$[\ldots]$

IV - Quando infringente de direito expresso, salvo se, autorizado no compromisso, o julgamento tenha sido por eqüidade.

Já o Código de Processo Civil de 1973 dispôs sobre a arbitragem por eqüidade em termos idênticos aos do Código Civil de 1916:

Art. 1.075. O compromisso poderá ainda conter:

$[\ldots]$

IV - a autorização para os árbitros julgarem por eqüidade, fora das regras e formas do direito.

A nova Lei de Arbitragem (Lei 9.307, de 23.09.1996) reformulou e modernizou o regime da arbitragem no Brasil. Em linha com a tradição jurídica nacional, admite expressamente a decisão por eqüidade, em seu art. 2. ${ }^{\circ}$. Neste particular, divide as arbitragens em arbitragem de direito e de eqüidade:

Art. 2. ${ }^{\circ}$ A arbitragem poderá ser de direito ou de eqüidade, a critério das partes.

$\S 1 .^{\circ}$ Poderão as partes escolher, livremente, as regras de direito que serão aplicadas na arbitragem, desde que não haja violação aos bons costumes e à ordem pública.

$\S 2{ }^{\circ}$ Poderão, também, as partes convencionar que a arbitragem se realize com base nos princípios gerais de direito, nos usos e costumes e nas regras internacionais de comércio.

Caso tenha havido autorização das partes pela eqüidade, esse fato deve constar do compromisso: ${ }^{139}$

Art. 11. Poderá, ainda, o compromisso arbitral conter:

$[\ldots]$

II - a autorização para que o árbitro ou os árbitros julguem por eqüidade, se assim for convencionado pelas partes.

Também há obrigação de expressa menção ao fato de a sentença ser proferida por arbitragem, quando for o caso:

139 Embora se trate de matéria facultativa, a falta de menção a uma tal autorização provavelmente acarretará uma decisão conforme o direito, caso as partes não tenham deixado sua vontade clara de outra forma. 
Art. 26. São requisitos obrigatórios da sentença arbitral:

$[\ldots]$

II - os fundamentos da decisão, onde serão analisadas as questões de fato e de direito, mencionando-se, expressamente, se os árbitros julgaram por eqüidade.

O legislador brasileiro houve por bem dividir de forma marcada a arbitragem em duas espécies, o que não ocorre na maioria dos países do mundo (embora a arbitragem por eqüidade tenha, também na maioria desses países, valor idêntico).

Portanto, a possibilidade de decisão por eqüidade em arbitragem tem raízes profundas na tradição jurídica brasileira, desde as Ordenações Filipinas, passando por praticamente todos os períodos subseqüentes. ${ }^{140}$ Todavia, essa tradição não se converteu necessariamente em utilização prática, que de resto não existiu com a própria arbitragem.

Há poucas referências a decisões por eqüidade na literatura brasileira. Algumas envolvem arbitragens entre o Governo de Império e herdeiros do Lord Cochrane e disputas de limites entre Estados da federação, que tinham um caráter iminentemente não comercial. ${ }^{141} \mathrm{~A}$ primeira referência encontrada a uma arbitragem por eqüidade de caráter mais comercial (embora envolvesse concessão de serviço público) encontra-se na obra de Alípio Silveira. ${ }^{142}$

Pode-se afirmar, porém, que a arbitragem por eqüidade acompanha a história da arbitragem no Brasil, tendo existido durante praticamente durante toda a sua história.

\subsection{Conclusão}

Concluindo a parte histórica, pode-se afirmar que, em perspectiva diacrônica, o uso da arbitragem fora das regras de direito positivo é conhecida desde a Grécia antiga. Todavia, nem sempre a oposição entre direito positivo e sentimento de justiça pode ser claramente definida historicamente.

140 Uma possível exceção pode ser o período entre a edição do Regulamento 737, de 1850, que regulou o procedimento comercial, sem mencionar a arbitragem por eqüidade, e 1866.

141 LEMES, Selma Ferreira. Arbitragem e decisão por eqüidade... cit., p. 12.

142 Silveira, Alípio. Conceito e funções da eqüidade em face do direito positivo. [s.l.]: [s.n.], 1943. p. 240. A sentença foi publicada no Diário da Justiça da União em 30.09.1943. 
Em sua evolução histórica, a arbitragem por eqüidade ${ }^{143}$ apresenta certos elementos que, de forma mais ou menos difusa, a permearam e podem ser encontrados ainda hoje. Na opinião do autor, tais elementos compreendem: (i) uma disposição de promover conciliação das partes; (ii) uma tendência para soluções de cunho transacional, que busca alguma espécie de proporção entre as posições das partes (ao contrário de uma posição mais favorável ao "winner takes all” da solução em direito); (iii) maior liberdade de formas e de procedimento; (iv) uma possibilidade de julgamento leigo, mais baseado em fatos do que em regras; (v) declarada busca da boa-fé (embora ela também faça parte do direito positivo e, muitas vezes, não passe de um topos argumentativo sem conteúdo material); e (vi) maior liberdade para uma solução do caso concreto. ${ }^{144}$

De qualquer modo, pode-se pensar que sempre permeou a história da humanidade desde (ao menos) a Grécia um desejo de prevalência da justiça quando esta confronta a norma. Além disso, um desejo por uma decisão com base no "justo" ou no senso comum. Em qualquer dos casos, uma decisão sem grande tecnicismos ou procedimentos cuja utilidade escapa ao cidadão comum. ${ }^{145}$

A principal forma de prevenir o arbítrio ainda parece ser a lei positiva, tanto no tocante ao mérito quanto ao procedimento. A lei positiva é a principal garantia de previsibilidade para a conduta humana, assim como o procedimento serve para impedir parcialidade e garantir a defesa.

Entretanto, a maior complexidade e institucionalização da sociedade afastou os processos legislativo e judiciário do cidadão comum. Também passaram a constituir uma técnica específica, nem sempre compreensível aos não-iniciados. Some-se a isso a condição inerente a toda norma positiva de, por sua generalidade, não ser capaz de prever todas as situações concretas, situação já apontada por Aristóteles há mais de dois milênios.

Tal distanciamento e generalidade podem criar uma espécie de um sentimento de alteridade em relação ao sistema legal. Um sentimento de que talvez a lei e o processo são demasiado complexos e genéricos, nem sempre conduzindo ao "justo", conforme compreendido no senso comum.

\footnotetext{
143 E, em grau maior ou menor, a própria arbitragem.

144 Embora alguns dos itens mencionados possam ser absorvidos em outros, o autor preferiu colocá-los de modo separado, para melhor demonstrar alguns elementos que, no decorrer da história, apareceram de modo significativo para a descrição da arbitragem por eqüidade.

145 É absolutamente desnecessário reafirmar que a função dos procedimentos é justamente garantir o resultado final. Todavia, tal finalidade nem sempre é percebida pelo cidadão comum, que por vezes entende o emaranhado de leis processuais como uma cabala para iniciados, que não raro serve à impunidade ou a resultados "não naturais", fora do senso comum de justiça.
} 
Aqui se tem um "justo" que é mais "sentido" do que fruto de uma técnica. Um "justo" mais ligado à experiência quotidiana do que criado em volumes de autos. Esse "justo" continua sendo uma preocupação dos cidadãos. Seja pelo seu próprio patrimônio, seja pela configuração da sociedade. Na vida quotidiana, faz-se ou deixa-se de fazer algo com o simples argumento de que "não é correto" e se espera que os demais ajam de forma mais ou menos parecida. Esse "correto", porém, não é necessariamente o correto da lei, mas sim do mero senso comum, se não geral da sociedade, ao menos comum a um determinado grupo ou segmento.

Assim, um desejo de resolução com base no que é "correto" e não em uma técnica para iniciados parece ser uma aspiração que acompanha o homem a longo tempo.

O Estado, de sua parte, quer por impossibilidade material de impor seu ordenamento ou jurisdição, quer por mera opção de facultar a resolução fora de suas regras, parece ter permitido que os cidadãos, ao menos em alguns domínios, façam uso de soluções fora das leis e do procedimento. Mesmo após ter tomado o monopólio da jurisdição e elaboração normativa, o Estado ainda conservou áreas em que as partes podem recorrer a esse meio de solução.

Ousamos aqui tomar de empréstimo a parábola de Mário de Andrade para explicar a poesia. ${ }^{146}$ Nela, o autor conta que Adão resolve imitar Deus e criar. Não sabendo alcançar uma costela, tira de sua língua um outro ser, uma mulher "humana, cósmica e bela" e a coloca no monte Ararat. Envergonhado da nudez, coloca-lhe uma folha; Caim coloca-lhe um velocino alvíssimo e todas as gerações seguintes colocam algo a cobrir-lhe, até que não mais se lhe veja. $\mathrm{E}$ continua coberta até que um "vagabundo" que por ali perambulava (Rimbaud) chuta a rouparia e descobre, soterrada, a mulher, falando por sons musicais, selvagem, áspera, sincera e livre. A escrava do Ararat, como se sabe, era a poesia.

Talvez possamos ver na decisão por eqüidade a mesma busca de uma justiça original, algo intuitiva e áspera, mas sobretudo mais livre, mais próxima do senso comum do justo. Enfim, talvez se busque uma mesma "escrava", um sentido original coberto sob os mantos que cada geração colocou.

Esse desejo de resolver problemas de forma "simples e justa" parece ser um sentimento que liga, em maior ou menor grau, o cidadão ateniense aos cidadãos de hoje.

A arbitragem por eqüidade, historicamente, pode ser vista como um instrumento de concretização de tal desejo, mesmo que apenas em espaços controlados pelo poder soberano.

146 Andrade, Mário de. A escrava que não é Isaura. Obra imatura. 3. ed. São Paulo: Martins; Belo Horizonte: Itatiaia, 1980. p. 201. 


\section{CAPÍTULO 2}

\section{CONCEITO E FORMA}

\subsection{Natureza jurídica da arbitragem por eqüidade}

Uma questão recorrente em obras acadêmicas sobre arbitragem é a sua natureza jurídica. Ou, em outra vertente, sua qualificação. Praticamente todas abordam com maior ou menor profundidade a matéria.

O mesmo não ocorre com a arbitragem por eqüidade: poucas obras dedicam atenção à sua natureza jurídica ou qualificação. Encontramos duas possíveis explicações para o fato: a pouca atenção que esse tipo de arbitragem recebe de um modo geral ou a ausência de autonomia que justifique uma discussão apartada da arbitragem em geral.

De outra parte, a própria utilização da categoria "natureza jurídica" não é isenta de críticas, se for reduzida apenas a um exercício classificatório. Todavia, afirma-se aqui o interesse no exame da "natureza jurídica" da arbitragem por eqüidade. Não como um exercício de "taxonomia", mas como uma análise de seus efeitos e usos concretos para melhor situá-la dentro do fenômeno jurídico, nos moldes da qualificação do Direito Internacional Privado. ${ }^{147}$

O interesse justifica-se porque a arbitragem por eqüidade, embora espécie do gênero arbitragem, tem suficiente particularidade para ser referida como um instituto próprio, conforme se espera demonstrar adiante. Postula-se aqui que dentro do gênero arbitragem há um instituto de suficiente densidade para qualificação autônoma. Essa densidade pode ser verificada tanto no exame histórico como no de direito comparado. Em sua evolução, a arbitragem por eqüidade ora foi sinônimo de arbitragem, ora distinguiu-se dela com nitidez (aproximando-se da conciliação). No direito comparado, há disciplinas particulares à arbitragem por eqüidade, tornando-a específica em relação à arbitragem de direito.

Para o exame da natureza jurídica da arbitragem por eqüidade, é indispensável uma prévia remissão à qualificação da própria arbitragem. Entendendo-se que a arbitragem por eqüidade está contida nos domínios da arbitragem (o que se pretende demonstrar adiante), devem-

147 Dolinger, Jacob. Direito internacional privado (parte geral). 2. ed. Rio de Janeiro: Renovar, 1993. p. 301 e ss. 
se delimitar as fronteiras de uma para melhor situar a outra. Somente com a caracterização da instituição maior é que se coloca a qualificação da arbitragem por eqüidade.

\subsubsection{O problema da natureza jurídica da arbitragem}

A discussão sobre a natureza jurídica da arbitragem é um dos temas mais recorrentes neste domínio e pouco resta a ser dito sobre o assunto. Praticamente todas as obras editadas desde a década de 1960 mencionam três diferentes posições sobre a natureza jurídica da arbitragem. Elas são a posição contratualista, a posição jurisdicional e a posição mista. ${ }^{148}$

Em princípio, a qualificação da arbitragem tem um papel importante para a definição de seu regime. Todavia, a utilidade prática dessas teorias tem sido questionada, na medida em que aparentemente nenhum direito nacional ou convenção internacional tratou a arbitragem expressamente à luz de alguma das teorias. Portanto, a disciplina da arbitragem tem sido, de um modo geral, mais empírica do que pautada por divergências doutrinárias. ${ }^{149}$ Assim, os efeitos contratuais e/ou jurisdicionais da arbitragem são decorrentes de disposições mais elaboradas empiricamente e sujeitas a questões de política legislativa do que propriamente de uma filiação sistemática a doutrinas.

De um ponto de vista processualista, classifica-se a arbitragem como um meio de heterocomposição da lide. Conforme o conceito de Carnelutti, a heterocomposição é o modo de solução de conflitos que envolve alguma espécie de intervenção de um terceiro entre as partes. Opõe-se à chamada autocomposição da lide, que são formas pelas quais as partes resolvem sua divergência entre si, sem intervenção de terceiros. Os meios de autocomposição normalmente adotados são a transação (na qual há recíprocas concessões), a renúncia (ato pela qual alguém abdica de um direito) e o reconhecimento (ato pelo qual uma parte reconhece a pretensão da outra parte, abrindo mão de sua própria). São métodos de heterocomposição tanto o juízo estatal quanto a decisão arbitral. ${ }^{150}$

148 Para um exame da questão da natureza jurídica da arbitragem, veja-se: Fouchard, Gaillard e Goldman. Traité de l'Arbitragem Commercial International, cit., p. 11 e ss.; STREnger, Irineu. Arbitragem comercial internacional. São Paulo: LTr, 1996. p. 32 e ss.; Baptista, Luiz Olavo; Magalhães, José Carlos de. Arbitragem comercial. Rio de Janeiro: Freitas Bastos, 1986. p. 21; Jarronsson, Charles. La notion d'arbitrage, cit., passim; Rubellin-Devichi, Jaqueline. L'arbitrage, nature juridique, cit., passim; Dolinger, Jacob; TibúRCio, Carmen. Direito internacional privado: arbitragem comercial internacional. Rio de Janeiro: Renovar, 2003. p. 96; Oppetit, Bruno. Théorie de l'Arbitrage. Paris: PUF, 1998. p. 41 e ss. Praticamente todos os manuais de arbitragem contêm menções a essa discussão.

149 SAnders, Pieter. International Encyclopedia of Comparative Law. Capítulo "Arbitration". Tübigen: J. C. B. Mohr (Paul Siebeck), 1996. p. 5-6, 12-13.

150 Entre outros, veja-se Leães, Luiz Gastão Paes de Barros. Ensaio sobre arbitragens comerciais. São Paulo, [n.d], 1966. p. 10 e ss. Também Carmona, Carlos Alberto. Arbitragem e processo. 2. ed. São Paulo: Atlas, 2004. p. 52. 
De um modo geral, a doutrina especializada em arbitragem adota três posições quanto à natureza jurídica da arbitragem: (i) a posição contratualista, segundo a qual a arbitragem tem natureza de um contrato; (ii) a posição jurisdicionalista, conforme a qual a arbitragem tem natureza de ato jurisdicional e (iii) posição mista, segundo a qual a arbitragem possui características tanto jurisdicionais quanto contratuais. ${ }^{151}$

A posição contratualista, como o nome sugere, postula a natureza jurídica contratual da arbitragem. Seu principal argumento é o de que a origem da arbitragem é contratual: ela somente existe em razão da celebração da cláusula e/ou do compromisso. Sua existência decorre da vontade das partes, tanto em sua criação como em sua condução. Assim, seu regime jurídico seria assemelhado ao de um contrato. Os efeitos dessa doutrina impactam diretamente a forma de execução e anulação da sentença arbitral: em ambos os casos receberiam o tratamento de negócio jurídico.

Assim, em vez de uma execução semelhante a uma sentença judicial, haveria execução nos moldes de um contrato ou transação. Igualmente, as causas de nulidade da decisão arbitral são as que atingem os negócios jurídicos em geral e não aquelas destinadas às sentenças judiciais. Também o desenrolar do procedimento arbitral pode ser afetado, na medida em que os poderes instrutórios dos árbitros serão distintos daqueles de um juiz estatal. Embora a grande maioria dessas questões seja tratada nas legislações nacionais de modo específico, uma adoção da teoria em seus inteiros termos traz conseqüências relevantes para o regime da arbitragem.

Interessante notar que, mesmo nos países em que as sentenças arbitrais estão sujeitas a recursos perante tribunais estatais, alguns autores sustentam o caráter contratual da arbitragem, afirmando que o recurso seria uma expressão de um direito de revogação da convenção de arbitragem. No tocante à autoridade de coisa julgada da sentença arbitral, ela seria expressão de uma irrevogabilidade contratual. ${ }^{152}$

No outro pólo, a teoria jurisdicional caracteriza a arbitragem por seu caráter equivalente ao da prestação jurisdicional. O ponto característico da arbitragem é o da decisão final de uma lide, nos moldes de uma decisão judicial. Sendo essa a função primordial da arbitragem,

151 Alguns autores ainda apontam uma quarta posição, segundo a qual a arbitragem internacional seria autônoma. Essa posição decorre da tendência atual de considerar aquele tipo de arbitragem desvinculado de qualquer ordem jurídica estatal (Dolinger, Jacob; TibúRCio, Carmen. Direito internacional privado... cit., p. 96.). Todavia, com todo o respeito devido à posição, entendemos que a autonomia da arbitragem internacional não altera o posicionamento quanto à sua origem contratual ou jurisdicional. Com todas as vênias, entendemos que mesmo uma arbitragem internacional considerada autônoma em relação a quaisquer ordenamentos jurídicos estatais ainda assim poderá apresentar caráter contratual, jurisdicional ou misto.

152 MотULSKy, Henri. Écrits: études et notes sur l'arbitrage. Paris: Dalloz, 1974. p. 8-9. 
ela a caracteriza e qualifica: é função do árbitro dizer o direito (juris dictio) de modo definitivo entre as partes.

A doutrina internacional ${ }^{153}$ acentua a "missão jurisdicional" do árbitro: resolver um litígio segundo a lei ou a consciência, de maneira final e sujeita à execução nos moldes de uma sentença. ${ }^{154}$ À objeção de que a jurisdição é função exclusiva do Estado, os defensores dessa teoria distinguem o conceito de jurisdição de jurisdição pública, sustentando que o caráter privado da arbitragem não impede o reconhecimento de sua natureza jurisdicional. ${ }^{155}$ De um modo geral, as disposições legais que conferem efeitos de coisa julgada e execução forçada à sentença arbitral são argumentos utilizados pelos defensores da teoria jurisdicional. Igualmente os regimes recursais de alguns países, que permitem recursos de mérito contra sentenças arbitrais perante tribunais estatais.

Como um ponto intermediário entre as duas principais teorias, surgiu a chamada teoria mista, que conjuga elementos das duas anteriores. Essa teoria reconhece o fundamento contratual da arbitragem, em sua origem, mas também reconhece sua função jurisdicional, especialmente na decisão e seus efeitos. Assim, a arbitragem nasce de um acordo de vontades entre as partes (e somente da vontade das partes), sendo nesse aspecto inegavelmente contratual; todavia, decide a lide de modo definitivo, gerando efeitos inequivocamente jurisdicionais, ainda que não seja um órgão da jurisdição estatal.

A teoria mista parece ter a preferência da atual doutrina, ${ }^{156}$ o que se compreende por duas razões. Em primeiro lugar, porque parece se adaptar melhor ao já mencionado "empirismo" das legislações nacionais ao disciplinar a arbitragem. Em segundo lugar, porque aproveita aspectos de inegável valor científico das outras teorias. Dessa conjunção de teorias extraem-se duas características fundamentais da arbitragem: trata-se de um modo de solução de controvérsias (i) de caráter privado, (ii) com efeitos jurisdicionais.

Cumpre mencionar ainda os métodos de solução de controvérsias de cunho contratual. Nesses institutos, encontrados, por exemplo, nos direitos italiano, holandês, alemão e colombiano, a controvérsia é dirimida por terceiros nomeados pelas partes. Todavia, a decisão é executada na forma de negócio jurídico privado, tal como a transação ou contrato. Em geral, tais

153 Fouchard, Gaillard e Goldman. Traité de l'Arbitrage Commercial International, cit., p. 14.

154 Em alguns países, a sentença arbitral é sujeita também a recursos de mérito junto à jurisdição estatal, nos moldes de uma apelação civil.

155 Motulsky, Henri. Écrits... cit., p. 10.

156 SANDERs, Pieter. International Encyclopedia of Comparative Law... cit., p. 5. Fouchard, Gaillard e Goldman. Traité de l'Arbitrage Commercial International, cit., p. 14; Baptista, Luiz Olavo; Magalhães, José Carlos de. Arbitragem comercial, cit., p. 21. 
institutos convivem com a arbitragem tradicional, que tem sua decisão executada em modelos mais próximos de uma sentença judicial. Embora haja evidentes pontos de contato entre tais institutos e a arbitragem "clássica", a forma de impugnação e execução das decisões é distinta. Nesses institutos, tanto execução como impugnação se dão do mesmo modo do que com contratos. Advirta-se, apenas, que existe uma corrente importante de opinião que propõe uma noção de arbitragem mais ampla que compreenda também as figuras contratuais. ${ }^{157}$

\subsubsection{Da natureza jurídica da arbitragem por eqüidade}

Tanto os direitos nacionais quanto os atos internacionais dedicam poucas disposições à arbitragem por eqüidade. Em geral, as menções não vão além da autorização para essa espécie de decisão. Mesmo em direitos nacionais que dedicam mais disposições à arbitragem por eqüidade, pouco existe sobre seu alcance. Portanto, a qualificação, bem como o delineamento da arbitragem por eqüidade, é uma obra da doutrina e da jurisprudência. Assim, existe inegável valor prático nesse estudo, talvez em um grau maior do que o da própria arbitragem.

\subsubsection{Da arbitragem por eqüidade como arbitragem}

Embora pareça desnecessário no caso brasileiro, deve-se verificar se a arbitragem por eqüidade é uma espécie de arbitragem ou é um instituto paralelo e afim à arbitragem. A opção do legislador brasileiro é claramente disposta no texto do art. 2.o da Lei de Arbitragem: a arbitragem pode ser de direito ou de eqüidade.

A Lei Modelo da Comissão das Nações Unidas para o Direito Comercial Internacional (CNUDCI) igualmente apresenta a arbitragem por eqüidade como uma possibilidade de decisão dentro da arbitragem em geral, prevendo-a em seu artigo relativo às regras aplicáveis ao mérito da decisão.

Nem todas as legislações nacionais, contudo, apresentam caracterização tão clara dessa espécie de arbitragem. Em algumas delas, a arbitragem por eqüidade encontra-se em previsões paralelas às da arbitragem de direito e algumas vezes sob denominação diferente (em geral, variações do termo "composição amigável”). Poderia este fato indicar a existência de uma instituição paralela à arbitragem?

157 DAVID, René. Arbitration in international trade. Deventer: Kluwer Law International, 1985. p. 409. JARROSSON, Charles. La notion d'arbitrage, cit., p. 364. 
A nosso ver, os elementos essenciais da arbitragem são (i) a submissão contratual de um litígio (ii) a terceiros (iii) para solução definitiva, com efeito de sentença.

A vontade das partes para a criação de uma instância decisória parece comum a todas as legislações pesquisadas e característica inerente tanto à arbitragem de direito quanto à arbitragem por eqüidade. ${ }^{158}$ Assim, em ambos os casos existe a origem contratual do instituto.

A atuação de terceiros para dirimir o litígio é igualmente comum a ambos. Na totalidade das legislações pesquisadas, as partes são livres para indicá-los, embora possa haver delegação da nomeação a instituições de arbitragem. Essa constatação é óbvia: a atuação de tais terceiros é da essência da abitragem. Sem eles, sequer se pode falar em arbitragem. Ou heterocomposição da lide, para utilizar a classificação de Carnelutti sobre as possíveis formas de solução de controvérsias. Sem essa intervenção, resta apenas a autocomposição das partes. Igualmente óbvia é a constatação de que os terceiros não podem ser juízes no exercício de função jurisdicional. ${ }^{159}$

Em relação à arbitragem por eqüidade, por vezes existem requisitos distintos para os terceiros. Em alguns sistemas, sobretudo na América Latina, exige-se que árbitros de direito sejam profissionais habilitados para o exercício de profissões jurídicas (bacharéis em direito ou advogados). No caso dos terceiros que decidem por eqüidade, essa qualificação é dispensada. Em alguns países de tradição muçulmana exige-se que os terceiros que decidem por eqüidade sejam indicados por nome no ato da escolha deste critério de julgamento, o que não ocorre em caso de arbitragem de direito. Todavia, essas pequenas particularidades, previstas em poucos ordenamentos, não são suficientes para caracterizar institutos diversos. Tanto pelo fato de não alterarem a essência da atuação dos terceiros quanto pela sua pouca difusão em termos internacionais.

De outra parte, em todos os direitos pesquisados os efeitos da decisão por eqüidade são idênticos aos da sentença conforme o direito: vinculam as partes de forma definitiva, da mesma maneira que uma sentença judicial. Existem alguns poucos direitos nacionais que prevêem métodos de decisão baseados em eqüidade que não produzem efeitos idênticos aos de uma sentença estatal. Trata-se do caso do arbitrato irrituale ou libero, da Itália, e a amigable composi-

158 Os casos de arbitragem obrigatória parecem em virtual extinção. Anteriormente, existiram em países socialistas para determinadas causas ligadas ao comércio exterior. No direito brasileiro, para causas comerciais em algumas décadas do século XIX.

159 Caso contrário, tratar-se-ia de exercício da jurisdição estatal. No Brasil, existe impedimento para que juízes atuem como árbitros. 
ción colombiana. ${ }^{160}$ Nestes casos, o resultado da decisão dos árbitros é de natureza contratual e executa-se nos moldes de um negócio jurídico. No entanto, em ambos os países esses institutos coexistem com a arbitragem por eqüidade, prevista em dispositivos legais distintos. No dois casos, a arbitragem por eqüidade produz o mesmo resultado de uma sentença estatal ou arbitral de direito: uma solução definitiva de um litígio. Assim, a existência desses procedimentos paralelos não modifica o regime da arbitragem por eqüidade. São, antes, representantes dos procedimentos afins à arbitragem, de natureza contratual, encontrados em diversos ordenamentos jurídicos. Como já visto na seção antecedente, existem posições que defendem a incorporação de tais figuras contratuais no conceito de arbitragem. Contudo, esse posicionamento ainda não parece ser majoritário.

Em países que permitem recursos contra decisões arbitrais, por vezes encontram-se regimes diferenciados, caso a decisão seja de direito ou de eqüidade. ${ }^{161}$ Essas disposições podem ser desde a vedação de recurso até a autorização para que o tribunal estatal julgue por eqüidade. Embora a diferença de regime recursal possa ser um indicativo de natureza distinta das sentenças, esse não é o caso da arbitragem por eqüidade. A razão para as diferentes regras afigura-se mais como uma questão de política legislativa do que um reflexo de natureza distinta. Com efeito, o fato de serem vedados recursos contra a arbitragem por eqüidade parece demonstrar que o legislador local reservou para si apenas o papel de guardião da aplicação do direito em seu território, desinteressando-se da revisão de critérios de justiça aplicados pelos árbitros. Assim, revisam apenas as sentenças arbitrais decididas conforme o direito. No caso do julgamento do recurso estatal por eqüidade, o legislador quis preservar o critério de julgamento escolhido pelas partes, mesmo fora do âmbito da arbitragem. No caso de escolha do direito pelas partes, os tribunais julgam conforme o direito. Nenhum dos critérios encontrados apresenta uma natureza ou eficácia distinta da arbitragem por eqüidade. Ao contrário, confirmam seu caráter de decisão terminativa da questão de mérito.

Portanto, os árbitros que decidem por eqüidade desenvolvem a mesma tarefa dos que decidem conforme o direito. Em ambos os casos, põem fim a uma controvérsia levada ao seu conhecimento pelas partes. Dirimem o mérito do litígio ou, para utilizar linguagem processual, põem fim à "crise de direito material" existente, ainda que não pela aplicação do direito. A arbitragem por eqüidade é uma arbitragem, cujo resultado se executa como sentença arbitral. Tanto quanto o árbitro de direito, o árbitro de eqüidade exerce uma função jurisdicional. ${ }^{162}$

160 Para um exame mais detelhado de ambos os sistemas, vejam-se as respectivas seções no capítulo dedicado ao exame das legislações nacionais.

161 Para uma descrição dos diferentes regimes, veja-se a seção específica dedicada aos efeitos da eqüidade no procedimento.

162 Entre outros, Motulsky, Henri. Écrits... cit., p. 33. Loquin, Eric. L'Amiable composition... cit., p. 17 e 67 e ss. 
Mesmo a dualidade de tratamento legislativo, que vem diminuindo conforme os países reformam sua disciplina de arbitragem, não cria suficiente distinção. Existem duas espécies do gênero arbitragem: arbitragem de direito e arbitragem de eqüidade. Não há classificação da arbitragem por eqüidade fora da categoria arbitragem. ${ }^{163}$

Portanto, a identidade de elementos essenciais entre a arbitragem de direito e por eqüidade, confirmada por exame de direito comparado, permite afirmar que se trata de espécies do gênero arbitragem.

\subsubsection{Dos juízos de eqüidade como renúncia}

Segundo Eric Loquin, ${ }^{164}$ a arbitragem por eqüidade pode ser qualificada como uma renúncia das partes a eventuais direitos oriundos da aplicação da lei ao litígio. Como parte da doutrina afirma que o compromisso arbitral constitui uma renúncia à utilização do Judiciário, a arbitragem por eqüidade também pode ser entendida como uma renúncia ao direito de ser julgado conforme o direito positivo.

Loquin reconhece que não se trata de uma renúncia pura nos termos da doutrina civil. Em primeiro lugar, porque a cláusula de arbitragem é bilateral. A maioria da doutrina classifica a renúncia como ato unilateral, embora exista divergência. Em segundo lugar, porque pode ser revogada por convenção das partes, ao passo que quase todos os doutrinadores entendem que a renúncia é irrevogável.

Aquele autor ainda afirma que nada se opõe à qualificação da cláusula de arbitragem por eqüidade como uma renúncia ao benefício da aplicação da lei. Utilizando o direito interno francês como paradigma, equipara a cláusula à renúncia a recurso ou à aplicação das regras de procedimento, possíveis de acordo com o processo civil daquele país.

Em seu favor, cita as opiniões de Carbonnier, ${ }^{165}$ segundo o qual a cláusula de arbitragem por eqüidade representa uma renúncia global às regras de direito positivo, sob reserva de

163 Para um apanhado sobre a dualidade de regimes e suas consequiências, veja-se Nestor, Ion. L'Amiable Composition e l'Arbitrage selon les Règles du Droit in Arbitrage Commercial/Commercial Arbitration: essays in memoriam Eugenio Minoli. Torino: UTET, 1974. p. 341 e ss. Também SANDERs, Pieter. International Encyclopedia of Comparative Law... cit., p. 137 e ss.

164 L'amiable Composition em Droit Comparé et International. Paris: Librairies Techniques, 1980. p. 37-39.

165 Carbonnier, Jean. Les Renontiations au Bénéfice de la Loi en Droit Privé. Travaux de l'Association Henri Capitant. Paris: Dalloz, 1963. t. XIII (1959-1960), p. 283 e ss. Nesse interessantíssimo artigo, Carbonnier defende a retomada do conceito justinianeu de renúncia, que se referia à lei (direito objetivo) e depois foi 
ordem pública. Entretanto, ao contrário de Carbonnier, afirma que a renúncia abrange apenas os direitos subjetivos. Invocando a autoridade de Rigaux, sustenta ser impossível a renúncia a direito objetivo. Neste caso, haveria renúncia ao direito de ser julgado conforme o direito positivo.

Como a obrigação dos árbitros de julgar conforme a lei seria um direito conferido às partes, a escolha de eqüidade seria uma renúncia a tal direito. Em outra parte da mesma obra, Loquin situa a renúncia não apenas a um direito de ter o direito positivo aplicado à solução da controvérsia, mas também aos próprios direitos subjetivos conferidos pelo ordenamento. ${ }^{166}$

A qualificação da arbitragem por eqüidade como renúncia, oriunda sobretudo da doutrina francesa (e vista em grande medida no contexto do direito interno daquele país), parece ser predominante. Embora contenha em si elementos anteriores, que remontam ao século XIX, a formulação elaborada por Eric Loquin parece ter sido o catalisador de tal posição.

\subsubsection{Posição da renúncia no direito}

Embora renúncia seja um termo utilizado quotidianamente, a busca de sua posição como instituto ainda está em curso, e as tentativas de sistematização ainda não parecem ter tomado a forma final. Esse caráter de instituto em desenvolvimento parece ocorrer também em países de common law. ${ }^{167}$

No caso da tradição do direito romano, as tentativas de sistematização tornaram o conceito da renúncia mais restrito que o seu uso quotidiano parece indicar. Isso porque o termo renúncia é polissêmico e comporta duas ordens de compreensão.

substituído pela renúncia ao direito subjetivo. Embora reconheça que não exista muita diferença prática entre a renúncia ao direito objetivo e aos direitos subjetivos que aquele confere, defende a utilidade da distinção pela possibilidade de uma operação global, tal como no caso da cessão de contrato (da mesma forma que a cessão de um contrato é o conjunto de cessões de todos os créditos e débitos deste, a renúncia ao direito objetivo, como uma lei qualquer, será o somatório da renúncia de todos os direitos conferidos pelo ato legislativo). Para confirmar sua postulação, aquele autor afirma que a arbitragem por eqüidade equivale a uma renúncia global de todo o direito positivo.

166 Loquin, Eric. L’Amiable composition... cit., p. 274 e ss. Também JurisClasseur de processo civil, verbete Amiable Composition, fascículo 1038, item 91 e ss. Disponível em: <www.lexisnexis.com/fr/droit/frame. do?tokenKey=rsh-23>. Acesso em: 30 mar. 2008. No mesmo sentido, veja-se JARrosson, Charles. Comentário ao julgado da Cour de Cassation de 18.10.2001. Revue de l'Arbitrage, n. 2, p. 363, 2002.

167 WiLKen, Sean e Villiers. The Law of Waiver, Variation, and Estoppel. 2. ed. Oxford: Oxford University Press, 2002. Bowers, Renzo D. A Treatise on the Law of Waiver. Denver: The W. H. Courtright Publishing Co., 1914. p. 24. 
Em qualquer dos usos, contém um elemento central abdicativo (abdica-se de algo, deixa-se algo, desfaz-se de algo, deixa-se de aceitar algo), que é seu núcleo principal. Esse núcleo central de abdicação é encontrado tanto na renúncia propriamente dita como em diversos outros atos jurídicos quotidianamente ocorridos. Em ambos os casos, utiliza-se normalmente o termo "renunciar". No entanto, nem todos podem ser classificados como renúncia. A simples presença do elemento abdicativo não configura a renúncia em seu sentido estrito no direito civil.

Em seu sentido comum, renúncia é ato pelo qual o titular de um direito abdica deste. Já em sentido estrito renúncia é um ato pelo qual "o titular de um direito dele se desfaz ou deixa de aceitá-1o". 168

Em regra, a renúncia "estrita" é tida como ato jurídico unilateral, bastando para sua existência a declaração da vontade de quem renuncia. Embora seja a posição dominante e aparentemente pacífica da doutrina no que diz respeito a direitos reais, existe alguma controvérsia a respeito de direitos de crédito, porque há ordenamentos em que a remissão depende de anuência do devedor.

Em geral, a renúncia não contém caráter translativo. Ainda que alguém se beneficie dos efeitos de uma renúncia, ela em si nada transmite. Caso contrário, cuidar-se-ia de uma alienação. Somente indiretamente existe o efeito translativo da renúncia. Alguém pode adquirir algo em razão de uma renúncia do primeiro titular do direito; porém, quem renuncia nada transmite. Ela não depende da aceitação de outra parte para operar. ${ }^{169}$

168 Carvalho Santos, J.M. Repertório enciclopédico do direito brasileiro. Rio de Janeiro: Borsoi, [s.d.]. v. 48, p. 316. Entretanto, esta definição está longe de ser pacífica. A renúncia é matéria controvertida em direito civil e não cabe alongar a discussão nos estreitos limites deste trabalho. Para um panorama geral da discussão: BEVILÁqua, Clóvis. Theoria geral do direito civil. Rio de Janeiro: Francisco Alves, 1929. p. 362 e ss. CAvalCANTI, José Paulo. Da renúncia no direito civil. Rio de Janeiro: Forense, 1958. Serpa Lopes, Miguel Maria de. Curso de direito civil. Rio de Janeiro: Freitas Bastos, 2000. v. 1, p. 364. PereIra, Caio Mário da Silva. Instituições de direito civil. Rio de Janeiro: Forense, 2004. v. 1, p. 468. Venosa, Silvio de Salvo. Direito civil. São Paulo: Atlas, 2001. v. 1, p. 387 e ss. Pontes de Miranda, Francisco Cavalcanti. Tratado de direito privado. São Paulo: RT, 1983. t. III, p. 140 e ss. Limongi FrançA. Manual de direito civil. São Paulo: RT, 1980. v. 1, p. 283 e ss. Rigaux, François. Les Renontiations au Bénéfice de la Loi en Droit Civil Belge. Travaux de l'Association Henri Capitant. Paris: Dalloz, 1963. t. XIII (1959-1960), p. 385 e ss.

169 Pontes de Miranda, Francisco Cavalcanti. Tratado de direito privado, cit., t. III, p. 152. No entanto, há autores que defendem a existência da renúncia translativa, como Serpa Lopes (Curso de direito civil, cit., p. 417). No caso dos EUA, a doutrina aceita a renúncia em troca de sinalagma (Bowers, Renzo D. A Treatise on the Law of Waiver, cit., p. 24.). Nos casos de remissão, pode haver dependência de aceitação, dependendo do ordenamento envolvido. 
A renúncia também tem caráter abstrato, não sendo um negócio jurídico causal. Assim, não importa a causa para que a renúncia tenha existido, ou mesmo em favor de quem ela possa operar. ${ }^{170}$

Outra característica importante da renúncia é sua irrevogabilidade: uma vez efetuada, não se pode mais retratar. Essa parece ser a posição amplamente dominante na doutrina. ${ }^{171}$ Mesmo nos casos de erro ou dolo, admite-se a anulação, nos moldes dos demais atos jurídicos, mas não a retratação.

Colocada a renúncia nos seus estritos termos do direito civil, a qualificação da arbitragem por eqüidade como tal somente pode existir com algumas considerações adicionais. Em verdade, mesmo os autores que propõem essa qualificação admitem que arbitragem por eqüidade não seria uma espécie "pura” de renúncia, tal como conhecida na doutrina de direito civil. Mesmo porque a arbitragem por eqüidade (ou melhor, sua contratação) é ato bilateral, revogável e possivelmente causal.

De qualquer forma, pode-se fazer um exercício de amoldamento da arbitragem por eqüidade na categoria da renúncia, antes de prosseguir com a crítica da posição. Como primeiro aspecto, pode-se destacar que a renúncia é tema suficientemente controverso para permitir largas divergências doutrinárias sobre seus aspectos essenciais (inclusive a unilateralidade). Portanto, uma posição mais ou menos seletiva de doutrina pode tornar a arbitragem por eqüidade mais ou menos enquadrada na renúncia. $\mathrm{O}$ autor tentou utilizar nesta obra o conceito dominante sobre o instituto.

Negócios jurídicos unilaterais podem estar inseridos dentro de negócios bilaterais. ${ }^{172}$ Podem ser utilizados ao lado de outras disposições que produzam um outro negócio jurídico. Neste caso, ocorre o ato unilateral junto das demais disposições acordadas pelas partes. A eficácia do ato bilateral é a mesma que tem o ato unilateral. ${ }^{173}$

Assim, a renúncia pode ser "bilateralizada" quando integrar negócio jurídico bilateral. Neste caso, será renúncia acrescida de negócio jurídico bilateral. Ela em si manterá suas propriedades (unilateral, incondicional e irrevogável). Entretanto, será colocada no contexto de um negócio.

\footnotetext{
170 Pontes de Miranda, Francisco Cavalcanti. Tratado de direito privado, cit., t. III, p. 153.

171 Carvalho Santos, J.M. Repertório... cit., p. 317.

172 Pontes de Miranda, Francisco Cavalcanti. Tratado de direito privado, cit., t. III, p. 138.

173 Idem, ibidem, p. 138.
} 
Por outro lado, há diversas espécies de renúncia estrita (repúdio, remissão de dívida, renúncia ao imóvel, etc.). Cada uma delas pode ter disciplina específica, em que pode haver elementos adicionais à expressão (ou recepção, para os que a conceituam como receptícia) da vontade, como o registro no cartório de imóveis.

Assentadas essas premissas, verifica-se que a autorização para decisão por eqüidade parece ser mais que um ato puro de renúncia. Afigura-se uma espécie de "renúncia bilateral" na medida em que ambas as partes renunciam à proteção do direito positivo e só o fizeram porque a outra parte também o fez. Mais ainda, trata-se de uma espécie de "renúncia condicionada", pois a parte apenas renuncia à proteção do direito positivo porque outra proteção (a do senso de eqüidade dos árbitros) lhe é assegurada: renuncia-se na expectativa de receber outra coisa. A rigor, isso a afastaria do conceito clássico de renúncia, que pressupõe unilateralidade, abstração, ausência de sinalágma. O mesmo no tocante à revogação: a renúncia é irrevogável em regra.

Assim, poderá haver duas soluções para a questão da cláusula de decisão por eqüidade. Pode-se considerar que a sua inserção dentro de negócio jurídico bilateral complexo (como o contrato que contém a cláusula), bem como o fato de versar apenas sobre direitos futuros que podem ou não se materializar, lhe confere certas características especiais não encontráveis nas demais formas de renúncia (e tais características permitiriam a revogação).

Em outras palavras, sua inserção em negócio jurídico bilateral seria tão grande e imbricada que se lhe imporia um grau de bilateralização em que se reconhecem características especiais, tal como a aplicação de certas regras afetas ao negócio jurídico bilateral (como sua revogabilidade por comum acordo entre as partes). Assim, criar-se-ia uma espécie de renúncia com características especiais que vão além do conceito clássico de renúncia no direito civil atual.

Caso não se deseje alargar o espectro do instituto da renúncia em seus estritos termos da doutrina civil, deve-se entender então que se está diante de um negócio jurídico em que há o elemento abdicativo, mas que não se confunde com a renúncia estritamente considerada.

Assim, a menção à renúncia na doutrina deve ser entendida no contexto amplo do termo e não no seu significado técnico de direito civil. Não haverá novidade nenhuma em tal entendimento, na medida em que há diversos outros negócios abdicativos que não se confundem com renúncia em sentido estrito (como para alguns é o caso do abandono ou derrelição). Tratarse-ia, pois, pura e simplesmente de um ato de disposição do patrimônio, abdicativo, ainda que não revestido do caráter de renúncia em seu sentido estrito da dogmática civilista. 
Em outras palavras, ou se considera a autorização para julgamento por eqüidade uma forma especial de renúncia ou a entende como um ato abdicativo de direitos, sem caráter de renúncia em sentido estrito. Ou se considera que a renúncia da cláusula de decisão por eqüidade é uma forma especial de renúncia prevista na lei específica, ou se entende que está fora do âmbito estreito da categoria "renúncia". Afigura-se-nos que a segunda opção é mais correta, pois não parece haver necessidade de modificar o entendimento de um instituto apenas para abarcar ato que se atinge seu fim independentemente da classificação.

De outra parte, mantendo-se o enfoque dos direitos romano-germânicos, não há dúvida de que a cláusula arbitral (como o próprio contrato que a contém) é um negócio jurídico bilateral que abarca outros elementos além do abdicativo. Assim, parece-nos que o elemento abdicativo é condição necessária, mas não suficiente, para explicar a natureza jurídica da autorização para decisão por eqüidade.

\subsubsection{Crítica à posição da renúncia}

Como visto acima, existem percalços para a classificação da arbitragem por eqüidade como uma renúncia, nos estritos termos do conceito de direito civil. Todavia, pode-se vislumbrar um elemento de abdicação, que é próprio da renúncia, mas não exclusivo desta. Portanto, deve-se verificar qual o papel do elemento abdicativo na qualificação da arbitragem por eqüidade.

Para os autores que defendem a qualificação da arbitragem por eqüidade como renúncia, essa espécie de arbitragem se define em relação à arbitragem de direito. Assim, sua qualificação caracteriza-se por sua oposição a esta última. Em vista da arbitragem de direito, a arbitragem por eqüidade equivale à dispensa da aplicação do direito positivo. Desse modo, renuncia-se ao direito de ser julgado conforme o ordenamento.

a) A dicotomia entre arbitragem de eqüidade e arbitragem de direito

Cumpre indagar, porém, em primeiro lugar, se existe uma dicotomia absoluta entre arbitragem de direito e eqüidade na arbitragem internacional. Ou seja, pode-se afirmar que existem duas espécies do gênero arbitragem, a de direito e a de eqüidade? A resposta necessariamente passa pela conceituação de direito, para os fins de aplicação ao mérito da disputa.

Se por direito considerar-se apenas o ordenamento jurídico de algum país, a resposta é evidentemente não, pois a maioria da doutrina internacional aceita decisões baseadas em nor- 
mas transnacionais, sejam elas princípios gerais do direito internacional ou normas oriundas da prática dos operadores do comércio internacional (cuja expressão mais célebre é a doutrina da chamada lex mercatoria).

Além da doutrina da lex mercatoria propriamente dita, a prática da arbitragem internacional mostra diversos exemplos de cláusulas em que as partes determinam a aplicação de princípios gerais, de princípios comuns aos países de origem das partes, de princípios comuns a mais países, etc.

Sendo esses princípios internacionais considerados prevalentemente como direito, restam duas soluções classificatórias: ou se entende a aplicação de tais regras transnacionais como uma subespécie da espécie "arbitragem de direito" ou se considera que tal aplicação constitui um tertium genus, ao lado da arbitragem de direito e a arbitragem de eqüidade.

Tal discussão, todavia, parece servir mais a propósitos classificatórios. Concretamente, a aplicação de princípios transnacionais parece ter sobretudo um método próprio, distinto do método utilizado na aplicação dos direitos nacionais. ${ }^{174}$ Esse método parece diferenciar-se da aplicação do direito nacional positivo pela obrigatoriedade de os árbitros buscarem, em fontes múltiplas e esparsas (direito comparado, jurisprudência arbitral, tratados internacionais, documentos de organizações internacionais representativas, etc.), os princípios aplicáveis e depois efetuarem a subsunção aos fatos. Há, assim, uma atividade prévia "reveladora" dos princípios a serem aplicados e que não obedece ao monopólio de fontes normalmente encontrado nos direitos nacionais. A prática mostra, ademais, que os princípios encontrados são bastante mais amplos e genéricos do que as normas estatais. Desse modo, mesmo sua aplicação aos fatos da causa permite maior espaço para uma atividade construtiva do intérprete do que a aplicação de normas mais individualizadas dos direitos nacionais. ${ }^{175}$

Portanto, pode-se falar que existe uma diferença substancial de método entre a aplicação do direito positivo nacional e a aplicação de regras transnacionais.

De sua parte, a arbitragem por eqüidade possui um método próprio, que não se confunde com o da decisão segundo o direito nacional ou segundo regras transnacionais. ${ }^{176}$

174 Fouchard, Gaillard e Goldman. Traité de l'Arbitrage Commercial International, cit., p. 826 e ss.

175 Em verdade, a vagueza dos enunciados de tais princípios é uma das principais críticas de cunho prático à doutrina da lex mercatoria. Diversos autores vêem na aplicação de princípios vagos um pretexto para os árbitros decidirem o que quiserem, de modo arbitrário.

176 Embora possa significar a aplicação do direito nacional ou de regras internacionais, caso os árbitros entendam justo. 
Esse método e as divergências doutrinárias que o envolvem serão objeto de capítulo específico. Todavia, pode-se afirmar que o elemento central da decisão por eqüidade é a possibilidade de derrogação do direito positivo (nacional ou transnacional) caso este não se conforme com o sentimento de justiça dos árbitros. Essa possibilidade não é dada aos árbitros que decidem conforme o direito nacional ou mesmo conforme princípios do direito internacional. ${ }^{177}$

Logo, há três métodos distintos de decisão na arbitragem internacional. Deles, apenas um envolve a aplicação exclusiva do direito positivo. Um deles pressupõe uma espécie de "revelação" do direito antes de aplicá-lo. O terceiro contém a liberdade de derrogar o direito positivo, sob reserva de ordem pública. Dessa forma, parece ao autor que a divisão entre arbitragem de direito e de eqüidade é menos marcada na arbitragem internacional.

Essa atenuação da dicotomia se dá pelo fato de que, mesmo fora da arbitragem por eqüidade, existe a possibilidade de não-aplicação de regras de direito positivo entendidas em seu sentido clássico de normas emanadas de um poder estatal. Há outras formas de decisão que não sejam a aplicação do direito positivo estatal e a eqüidade, como princípios gerais do comércio internacional, usos e costumes, etc. Portanto, não apenas a decisão por eqüidade implica derrogação do direito positivo estatal.

b) Da renúncia na arbitragem internacional

Como visto, a posição da renúncia implica dizer que as partes são livres para renunciar a proteção que o direito positivo lhes outorga.

Esse caráter de abdicação parece mais claro no âmbito nacional, em que há, em princípio, um direito positivo aplicável desde logo. Caso a controvérsia esteja sujeita à jurisdição estatal, há um direito aplicável determinado: ou o do próprio país ou aquele que sua lei de conflito estabelecer. $\mathrm{Na}$ arbitragem interna, aplica-se também em princípio o direito do país. Embora seja possível que as partes escolham um direito estrangeiro, esses casos devem ser vistos como excepcionais. ${ }^{178}$ Portanto, no âmbito nacional, as partes possuem uma espécie de "ordenamento de base", em que seus direitos subjetivos estão previstos.

177 Não obstante seja muito difícil, na prática, verificar se os árbitros de direito não se valeram de expedientes de hermenêutica para desviar-se da norma positiva.

178 Conforme o ordenamento nacional, admite-se ou não a aplicação de direito estrangeiro em arbitragens internas, conforme opção legislativa. Como exemplos, o Brasil a permite; a Índia, não. 
O que ocorre se as partes, em vez de seguirem esse direito "de base", escolhem um outro direito positivo para reger sua relação? Terão renunciado aos direitos que o "ordenamento de base" lhes conferia? Mantendo-se a perspectiva proposta, parece-nos que sim: as partes abdicam dos direitos que aquele ordenamento lhes conferiria. Imagine-se que um "ordenamento de base" exija anuência do devedor para a cessão de crédito. Caso as partes escolham um direito que dispense a anuência, parece ao autor que o devedor renunciou a um direito conferido pelo "ordenamento de base". O único limite a tal renúncia parece ser a ordem pública. O mesmo pode ser afirmado nos casos em que, em vez da escolha de um direito positivo, as partes escolhem outros critérios de decisão, como regras corporativas ou deontológicas.

Seguindo-se pela ótica da renúncia, conclui-se que ela ocorre também, em algum grau, com a escolha de lei. O "ordenamento de base" pode ser "derrogado" pela escolha de um outro ordenamento. Talvez nesse aspecto possa-se invocar a citada opinião de Carbonnier em favor da renúncia ao direito objetivo, ${ }^{179}$ embora se possa igualmente afirmar que houve renúncia aos direitos subjetivos conferidos pelo "ordenamento de base".

No tocante à arbitragem internacional, parece haver uma posição dominante sobre sua autonomia em relação aos ordenamentos estatais, ao menos no que diz respeito ao direito de fundo. ${ }^{180-181}$ Portanto, todos os ordenamentos estatais lhes são indiferentes em um primeiro momento. As leis de conflito do local da arbitragem não são obrigatoriamente aplicáveis na arbitragem internacional. Assim, não servem para determinar desde logo um "ordenamento de base".

A ampla autonomia da vontade das partes para a escolha do direito aplicável é um princípio consagrado na arbitragem internacional. Em caso de ausência de escolha, normalmente cabe ao tribunal arbitral determinar o direito aplicável. Portanto, na ausência de escolha das partes, a determinação do "ordenamento de base" será feita no curso da arbitragem. Esse "ordenamento" não será necessariamente estatal: os árbitros podem escolher regras transnacionais para aplicação ao mérito.

Ausente um "ordenamento de base" que seja imediatamente aplicável, a que, exatamente, as partes renunciam ao escolher a arbitragem por eqüidade? Em um contato internacional, há ao menos dois ordenamentos jurídicos envolvidos. Pode-se argumentar que as partes renunciaram a todos os eventuais direitos que lhe seriam conferidos pelos ordenamentos? $\mathrm{Ou}$ ainda pode-se argumentar que as partes renunciam a um julgamento de direito, qualquer que

179 CARbonnier, Jean. Les Renontiations... cit., p. 283 e ss.

180 Fouchard, Gaillard e Goldman. Traité de l'Arbitrage Commercial International, cit., p. 797 e ss.

181 Conclusão idêntica se aplica também nos casos em que se permite a escolha de lei estrangeira para a arbitragem interna. 
seja o direito positivo que pudesse ser escolhido por elas ou pelos árbitros? O mesmo se aplica considerando-se que as partes e os árbitros podem escolher regras não estatais para dirimir o litígio? Pode-se responder afirmativamente a todas as questões. Entretanto, as respostas acarretam um grau maior de abstração à renúncia.

Sem dúvida, pode-se argumentar que a renúncia ocorre em relação a qualquer direito que pudesse ser escolhido pelas partes, inclusive regras internacionais. Entretanto, trata-se de uma elaboração teórica. Ela implica aceitar que a aplicação de qualquer direito tem efeitos próximos.

Do ponto de vista da arbitragem interna, ${ }^{182}$ a dicotomia entre arbitragem de direito e de eqüidade é forte: ou se decide conforme o direito (na imensa maioria das vezes o direito do país) ou se decide conforme eqüidade. Contudo, do ponto de vista da arbitragem internacional, a dicotomia perde força, embora ainda exista.

Dada a ampla liberdade de escolha das partes, estas têm a faculdade de escolher: (i) um direito nacional; ${ }^{183}$ (ii) que os árbitros decidam por eqüidade; (iii) a aplicação de princípios gerais do direito, usos e costumes ou regras transnacionais, como é o caso da lex mercatoria, ou mesmo corporativas.

A opção de um direito nacional tem uma dimensão diferente na arbitragem internacional: enquanto na arbitragem interna o direito interno será o escolhido ou aplicado naturalmente na maioria dos casos, ${ }^{184}$ na arbitragem internacional existe ampla liberdade de escolha. Não existe nesta um direito de referência obrigatória. Qualquer que seja a escolha, haverá uma decisão conforme algum direito. No entanto, a possibilidade de aplicação de um direito alheio à relação contratual torna mais tênue o caráter de renúncia. A escolha de um direito em vez de outro significa renúncia aos direitos não escolhidos?

A possibilidade da escolha de critérios outros que não sejam nem o direito positivo nem a eqüidade mostra que a dicotomia direito estrito e eqüidade não é suficiente para resolver a questão dos critérios de julgamento na arbitragem internacional. Caso as partes escolham a

\footnotetext{
182 Ao menos nas legislações que determinam a aplicação da lei nacional.

183 Essa escolha de lei pode ser qualificada ou acrescida de outras exigências, como era o caso das cláusulas de "congelamento de lei". As partes podem, também, incluir ou excluir determinados elementos no direito nacional (como é o clássico caso em que as partes determinam a aplicação de uma lei nacional, com a exclusão da Convenção de Viena sobre Compra e Venda Internacional).

184 Embora em princípio exista a possibilidade de escolha de um direito estrangeiro também em arbitragens internas, alguns autores colocam limites a tal liberdade, especialmente em casos que o direito estrangeiro não apresenta conexão com a relação jurídica.
} 
aplicação da lex mercatoria, estarão também renunciando ao direito de serem julgadas conforme o direito positivo? Hoje, a doutrina da lex mercatoria parece ter grande aceitação na arbitragem internacional, e suas normas podem ser consideradas como direito positivo, ao menos como normas consuetudinárias. Todavia, por mais "positiva" que a chamada lex mercatoria possa ser, ela não pode ser reputada como parte do ordenamento jurídico nacional. Desse modo, apresenta-se como a escolha paralela ao direito nacional, com método e conteúdo próprios. ${ }^{185} \mathrm{O}$ mesmo se diga de regras corporativas ou setoriais que as partes porventura apliquem.

Portanto, a oposição entre decisão por eqüidade e decisão conforme o direito estrito é mais tênue na arbitragem internacional. Em verdade, do exame das opções de julgamento na arbitragem internacional, verifica-se que existe uma multiplicidade de critérios, à escolha das partes. Esse parece ser o eixo da arbitragem internacional: critérios de decisão, que incluem o direito positivo e a eqüidade (havendo, porém, outras alternativas).

Do ponto de vista da aplicação do direito positivo, a eqüidade pode ser considerada uma renúncia. Contudo, para essa conclusão deve-se estender o conceito de renúncia aos outros direitos positivos não escolhidos, no caso da escolha de uma lei. Deve-se, igualmente, estender tal renúncia ao próprio direito escolhido, nos casos de exclusão de partes do ordenamento ou cláusulas de "congelamento" de legislação.

c) Elementos negativo e positivo na escolha da eqüidade

De qualquer modo que se encare a autorização para julgamento fora do direito positivo, existe um elemento de abandono. Esse abandono do direito positivo é um dos elementos para o julgamento por eqüidade, sendo ou não considerado renúncia. Entretanto, deve-se indagar se ele é condição suficiente para caracterizar a arbitragem por eqüidade.

A escolha da arbitragem por eqüidade, em regra, pode se dar de duas formas. Nos países que presumem a arbitragem de direito, a arbitragem por eqüidade pode ser escolhida juntamente com a celebração da cláusula arbitral ou em documento apartado. Nos países em que há presunção de arbitragem por eqüidade (o que será chamado neste trabalho de "sistema hispano-americano"), a mera escolha da arbitragem implica decisão por eqüidade, salvo opção das partes pela aplicação do direito. Portanto, em qualquer um dos sistemas, a arbitragem por eqüidade é um negócio jurídico havido entre as duas partes.

185 Fouchard, Gaillard e Goldman. Traité de l'Arbitrage Commercial International, cit., p. 813 e ss. 
Esse negócio jurídico tem como elemento fundamental a permissão para o julgamento fora das regras de direito. Todavia, a nosso ver, ao escolherem uma decisão fora das regras de direito, as partes não abandonam pura e simplesmente os direitos que lhe são conferidos pelo ordenamento jurídico.

Em primeiro lugar, porque "ontologicamente" elas abandonam um julgamento conforme determinadas regras, em troca de receberem outro julgamento baseado em critérios diferentes. Fazem-no por entender que esses critérios melhor protegerão seus interesses no caso. Seja para receber mais, seja para receber algo mais adequado ao espírito do negócio.

Mesmo na perspectiva dos direitos subjetivos materiais, não se pode dizer que exista um abandono propriamente dito. Há uma busca de sua proteção por outro modo de julgamento, ainda que esse outro modo possa retirar certos pressupostos de validade dos mesmos direitos. ${ }^{186}$

Qualquer que seja a razão para tal escolha, ela tem um caráter evidente de substituição: troca-se um tipo de julgamento por um julgamento baseado em outros critérios.

Desnecessário afirmar que somente o escolhem porque a parte contrária também o deseja. Mesmo nos casos de presunção de arbitragem por eqüidade, essa escolha está implícita na própria decisão de utilizar a arbitragem.

Ao escolherem a decisão por eqüidade, as partes optam por uma espécie de decisão que é baseada na consciência dos árbitros mais do que no direito positivo. Ao julgarem conforme sua consciência, os árbitros poderão chegar a diversas soluções. No entanto, os árbitros poderão conferir a qualquer das partes exatamente os mesmos direitos que o ordenamento jurídico conferiria, se assim entenderem adequado.

Como será visto adiante nesta obra, entre os possíveis critérios de julgamento do árbitro de eqüidade, há a possibilidade de que ele venha a julgar de acordo com o direito positivo, caso essa solução lhe pareça a mais justa. Em verdade, há parte da doutrina, em parte corroborada pela pesquisa de campo efetuada para esta tese, que considera ser dever dos árbitros de eqüidade aplicar em primeiro lugar o direito positivo e, apenas se esta solução lhe parecer injusta, descartá-lo. Assim, para essa parte da doutrina, a aplicação do direito positivo é o primeiro passo de uma decisão por eqüidade.

186 Esses pressupostos (a proteção legal) são trocados por outros (o senso de justiça dos árbitros). 
Os árbitros podem concluir que o direito positivo apresenta uma solução justa, o que não é de surpreender. As leis são, em princípio, expressão da vontade geral e incorporam valores que compõem, com maior ou menor precisão, uma espécie de "sentimento médio de justiça" na sociedade. Portanto, as partes "renunciam" a um direito, com a possibilidade de que o mesmo direito seja conferido sob outra fundamentação.

Assim, quer parecer ao autor que o critério da renúncia explica apenas um ângulo do fenômeno da decisão por eqüidade. Ela tem um caráter de renúncia (rectius, abandono) do direito positivo. No entanto, a par do elemento negativo (derrogação do direito positivo), há também um elemento positivo, que é a escolha de um outro critério para a decisão, o do senso de justiça dos árbitros. Esse elemento positivo é afirmado simultaneamente entre as partes, mostrando seu caráter bilateral.

A rigor, ao escolherem uma arbitragem por eqüidade, as partes abdicam de uma proteção legal em favor de outra proteção. Essa outra proteção é a do senso de eqüidade dos árbitros.

Do ponto de vista da finalidade, as partes não abdicam de suas pretensões. Elas apenas preferem uma outra espécie de proteção aos seus direitos, quer porque essa outra proteção lhes parece mais vantajosa (ao menos em potencial), quer por entenderem que esse tipo de decisão é mais adequado aos litígios relativos à relação contratual de base. Existe uma opção de critério de julgamento.

Portanto, há um conteúdo positivo na escolha da arbitragem por eqüidade, que é a escolha de um critério de julgamento.

Assim, postula-se neste trabalho que a arbitragem por eqüidade tem o caráter principal de método de julgamento. No tocante ao direito positivo, ela pode ser considerada uma abdicação. Todavia, apenas o caráter abdicativo não é suficiente para caracterizar o instituto. Uma vez abdicada a proteção do direito positivo, as partes devem ser julgadas de um modo específico, que será visto adiante nesta obra.

A qualificação de critério de julgamento parece ter amparo nos ordenamentos jurídicos inspirados na Lei Modelo da CNUDCI. Neles, a escolha da arbitragem por eqüidade situa-se dentro do artigo dedicado à escolha do direito aplicável à arbitragem. Ela é uma rubrica de esco- 
lha do direito aplicável, disposta no mesmo patamar da escolha das regras aplicáveis ao mérito. Parece-nos, portanto, que está colocada como mais um critério de julgamento.

\subsubsection{Da arbitragem por eqüidade como negócio jurídico com elemento de renúncia}

Do exame da matéria, percebe-se que há dois elementos essenciais da arbitragem por eqüidade. O primeiro deles é a derrogação do direito positivo, quando ela é analisada sob o prisma da aplicação deste. Com efeito, excetuada a ordem pública, os árbitros investidos da missão de julgar por eqüidade possuem a faculdade de fazê-lo sem recurso ao direito positivo. Portanto, trata-se aqui da derrogação do direito positivo, sob reserva de ordem pública.

Ao mesmo tempo, as partes fazem a escolha de serem julgadas de outro modo, conforme o critério de justiça dos árbitros. Esse julgamento pode obedecer mecânicas próprias, que não necessariamente serão as mesmas para a decisão conforme o direito positivo. Esse é, a nosso ver, o elemento mais marcante da arbitragem por eqüidade: a possibilidade de julgamento baseado apenas no critério de justiça dos árbitros. Conquanto implique um poder de derrogar o direito positivo, ela acrescenta um elemento positivo, que é a forma de julgamento. Essa forma, como será vista adiante, é bastante ampla e admite diversas mecânicas. Todavia, os árbitros devem usá-las para atingir a finalidade desse tipo de arbitragem: uma solução justa, conforme seja a opinão dos árbitros sobre justiça.

Assim, o autor propõe a qualificação da autorização para decisão por eqüidade como negócio jurídico complexo, pelo qual as partes abdicam da proteção conferida pelo direito positivo em favor de uma solução eqüitativa, segundo o entendimento dos árbitros.

\subsection{Denominações}

Nem sempre questões de semântica despertam o interesse no estudo de um instituto jurídico. Entretanto, no caso da arbitragem por eqüidade, há especial interesse no estudo de suas diferentes denominações. Elas refletem, em alguma medida, diferentes. Seja o uso das expressões consagradas de eqüidade, amiable composition e ex aequo et bono, sejam as formas perifrásticas utilizadas em alguns ordenamentos de língua inglesa, há interesse num estudo mais aprofundado das diferentes denominações deste tipo de arbitragem, pois podem implicar diferença de conceitos. 


\subsubsection{Arbitragem por eqüidade e amiable composition ${ }^{187}$}

a) Do uso da expressão em direito comparado

Uma das clássicas denominações da arbitragem por eqüidade é a amiable composition. Embora utilizada sobretudo nos países de língua francesa, ela também é usada em língua inglesa. Suas traduções são empregadas em alguma medida em espanhol, italiano e português. Sua origem, como já mencionado na parte histórica desta obra, é o instituto medieval da amicabilis compositio, ${ }^{188}$ às vezes referida diretamente pela qualidade do árbitro, chamado de amicabilis compositor. ${ }^{189}$

Na língua francesa, a expressão amiable composition ganhou uso normativo a partir da edição do Código de Processo Civil francês de 1806 e tal emprego se estende até os dias atuais. A utilização dessa expressão tanto pode se dar para qualificar o instituto como para indicar os árbitros como amiables compositeurs. Nos direitos de ex-colônias francesas, ela é frequentemente adotada. ${ }^{190}$

Em outros países francófonos, existem variações. No caso da legislação suíça, o termo empregado é équité e não amiable composition ou amiable compositeur. Essa utilização diferenciada de termos causou alguma divergência, sobretudo na doutrina suíça, sobre a eventual diferenciação entre a arbitragem por eqüidade e amiable composition, que será abordada mais adiante.

Na legislação belga, não há menção direta à eqüidade, e sim uma autorização para decidir de outra forma que não o direito. No direito de Luxemburgo, existe a alusão à decisão "en amiable compositeur", com a explicação seguinte de que se trata de decisão por eqüidade: "Le tribunal arbitral statue en amiable compositeur, c'est-à-dire selon les règles de l'équité, uniquement si les parties l'y ont expressément autorisé" (art. 461, 3, do Código de Processo Civil).

\footnotetext{
187 Embora existam registros da expressão “composição amigável” em português, preferimos utilizar a versão francesa amiable composition. A expressão em português é pouco usada em doutrina e legislação. No âmbito legislativo, salvo em Portugal, existe apenas na tradução brasileira do Código Bustamante. No uso brasileiro, a expressão é sinônima de arbitragem por eqüidade. Como existe, no exterior, divergência doutrinária sobre assimilação de amiable composition e arbitragem por eqüidade, preferimos a versão internacionalmente adotada, sob pena de imprecisão de linguagem.

188 Ou ainda amiabilis compositio (Rubino-Sammartano, Mauro. Il diritto dell'arbitrato, cit., p. 564)

189 Loquin, Eric. L'Amiable composition ... cit., p. 13.

190 Camarões, Costa do Marfim, Djibuti, Líbano, Madagascar, Mauritânia, Tunísia.
} 
Na língua portuguesa, existe menção legislativa à "composição amigável" na legislação portuguesa de arbitragem. ${ }^{191}$ Essa menção legislativa portuguesa afigura-se relevante porque a mesma lei menciona tanto a possibilidade de decisão por eqüidade como a composição amigável. Assim, parece haver alguma indicação de dessemelhança entre os dois institutos. No caso brasileiro, desde o século XIX, o legislador tem sido constante em utilizar apenas o termo decisão por eqüidade. A única exceção parece ser a tradução do Código Bustamante. ${ }^{192}$ Todavia, encontram-se algumas alusões esparsas à composição amigável na doutrina, ${ }^{193}$ ainda que raras. A utilização dessa expressão é condenada por Guido da Silva Soares, por não ser corrente no direito brasileiro e por propiciar entendimentos "bizarros". ${ }^{194}$

$\mathrm{Na}$ língua espanhola, a expressão amigable componedor é bastante difundida nas legislações da América. Argentina, Chile, Colômbia (embora com um sentido diferente), El Salvador, Guatemala, México e Paraguai a mencionam expressamente, seja na qualificação de árbitro (amigable componedor), seja como instituto (amigable composición). A atual lei espanhola refere-se a amigable componedor apenas na exposição de motivos, como uma das formas de contratar arbitragem por eqüidade. Outros países a utilizavam, mas preferiram a fórmula "por eqüidade" em suas reformas legislativas, como é o caso da Bolívia. Em geral, o uso da expressão amigable componedor indica a adoção da arbitragem por eqüidade. A exceção parece ser a legislação colombiana, em que o amigable componedor coloca-se ao lado da arbitragem por eqüidade. Naquele país, o amigable componedor é um terceiro que decide questões relativas ao estado, às partes e à forma de cumprimento do negócio jurídico, com força de transação (ou seja, sem execução como sentença). Trata-se aqui de uma espécie de arbitragem contratual, aparentemente inspirada nos binded advies holandeses ou no arbitrato irrituale italiano.

191 Veja-se a seção sobre o direito português no capítulo dedicado ao direito comparado.

192 Decreto 18.871, de 13 de agosto de 1929:

Art. 432. O processo e os efeitos regulados nos artigos anteriores serão aplicados nos Estados contratantes às sentenças proferidas em qualquer deles por árbitros ou compositores amigáveis, sempre que o assunto que as motiva possa ser objeto de compromisso, nos termos da legislação do país em que a execução se solicite.

193 Beviláqua, Clóvis. Código Civil dos Estados Unidos do Brasil comentado. 6. ed. Rio de Janeiro: Livraria Francisco Alves, 1943. v. 4, p. 194: Os árbitros podem ser autorizados a decidir como compositores amigáveis sem se adstringirem às regras e às formas de direito. Neste caso, terão eles por diretriz as normas da eqüidade. Os seus poderes são mais amplos. Por isso mesmo, só se consideram desprendidos dos rigores da lógica jurídica e da exata aplicação da lei ao caso por ela previsto, se lhe forem concedidos os poderes para julgar segundo lhes parecer eqüitativo (de bono et aequo). Carlos Alberto Carmona (Arbitragem e processo, cit., p. 201) refere-se a "amigável compositor". Também Barros, Hamilton de Moraes. Comentários ao Código de Processo Civil. v. 9, p. 398 apud Pucci, Adriana Noemi. El arbitraje en los países del Mercosur. Buenos Aires: Ad Hoc, 1997. p. 135.

194 SoAREs, Guido Fernando da Silva. Curso de direito internacional público. São Paulo: Atlas, 2002. p. 57. 
Na língua inglesa, é comum o uso da expressão francesa amiable composition para se referir à arbitragem por eqüidade, embora ex aequo et bono seja bastante utilizada. ${ }^{195} \mathrm{O}$ uso de expressões estrangeiras na literatura de língua inglesa parece ser em razão do virtual desconhecimento, por longo período, dessa espécie de arbitragem na common law, especialmente na Inglaterra. ${ }^{196}$ Além disso, a menção a equity, no sistema de common law, refere-se a um sistema jurídico elaborado, que não pode ser igualado ao significado da eqüidade nos países de tradição romana. A despeito disso, as cláusulas de arbitragem por eqüidade são normalmente referidas na literatura inglesa como equity clauses ${ }^{197}$ ou por vezes fala-se em decisão conforme equity. ${ }^{198}$ Em geral, tanto ex aequo et bono e amiable composition são utilizados como sinônimos na literatura inglesa.

$\mathrm{Na}$ língua italiana, adota-se a expressão amichevole componimento, com um sentido que, ao menos no regime anterior à recente reforma, apresentava alguma ambigüidade, ${ }^{199} \mathrm{em}-$ bora tendente a significar arbitragem por eqüidade. ${ }^{200} \mathrm{O}$ regime da arbitragem na Itália é historicamente marcado pela divisão entre a arbitragem de caráter jurisdicional (arbitrato rituale) e arbitragem de cunho contratual (arbitrato irrituale). A referência ao amichevole componimento poderia ser considerada tanto a outorga de um mandato dentro do quadro do arbitrato irrituale ou uma escolha da arbitragem jurisdicional por eqüidade (arbitrato rituale). Assim, a questão não parece definitivamente resolvida; contudo, em qualquer das alternativas a referência ao amichevole componimento implica uma decisão por eqüidade. ${ }^{201}$

b) Existe diferença entre arbitragem por eqüidade e amiable composition?

De acordo com as legislações consultadas, a expressão amiable composition e suas traduções referem-se a uma decisão por eqüidade. Todavia, parte da doutrina entende haver diferenças entre a arbitragem por eqüidade propriamente dita e a amiable composition.

195 O que não impediu a existência de entendimentos anedóticos, como a tradução de amiable compositeur como friendly printer por advogados ingleses (SoARes, Guido Fernando da Silva. Curso de direito internacional público, cit., p. 57).

196 Para uma visão da concepção inglesa e continental da arbitragem, com especial relevo na arbitragem por eqüidade, veja-se DAVID, René. Conception... cit., p. 765 e ss. Sobre a pouca atenção à arbitragem por eqüidade na Inglaterra, veja-se Mustill, Michael J.; Boyd, Stewart. The law and practice of commercial arbitration in England. London: Butterworths, 1982. p. 605.

197 Mustill, Michael J.; Boyd, Stewart. The law and practice... cit., p. 605. RedFern, Alan; Hunter, Martin. Law and practice of international commercial arbitration. 3. ed. London: Sweet \& Maxwell, 1999. p. 127.

198 VÁRAdy, Tibor; BARCEló, John J.; Von MEhren, Arthur T. International commercial arbitration: a transnational perspective. Saint Paul: Thompson West, 2003. p. 558.

199 Rubino-Sammartano, Mauro. Il diritto dell'arbitrato, cit., p. 110 e ss. Também p. 566 e ss., em que se defende a distinção entre o amichevole componimento e o árbitro em eqüidade.

200 Verde, Giovanni. Lineamenti del diritto dell'arbitrato. Torino: G. Giapichelli, 2004. p. 124.

201 Em geral, é considerado que o arbitrato irrituale tenha um componente eqüitativo. Veja-se a respeito a apreciação da legislação italiana no capítulo referente a legislações nacionais desta obra. 
Na tradição suíça (sobretudo da parte francófona), existe divergência acerca da sinonímia entre eqüidade e amiable composition. Parte da doutrina afirma que a amiable composition, tal como concebida na doutrina francesa, apresentaria um grau menor de liberdade do que a decisão por eqüidade: enquanto na arbitragem por eqüidade os árbitros seriam livres para decidir puramente conforme sua consciência, na amiable composition eles devem sempre fazer referência ao ordenamento estatal e derrogar apenas as regras dispositivas. ${ }^{202}$ Os doutrinadores de língua alemã são mencionados como menos afetos à distinção. ${ }^{203}$ De qualquer modo, a jurisprudência suíça, ao menos em seu tribunal federal, parece não distinguir as duas noções. ${ }^{204}$

Por outro lado, Mauro Rubino-Sammartano propõe, em vista das origens dos institutos, uma diferenciação entre decisões ex aequo et bono e amiable composition. ${ }^{205}$ Segundo aquele autor, enquanto a primeira deve ser considerada a decisão conforme eqüidade, a segunda deve ser reputada como um mandato conjunto a transigir. Ou seja, tenta recuperar o sentido mais antigo do amicabilis compositor mencionado pelos glosadores medievais, juntando-o ao conceito do arbitrato irrituale italiano: uma decisão de cunho contratual. Assim, ao contrário do árbitro que decide em eqüidade (de acordo com seu sentido de justiça e mitigando a aplicação da lei positiva quando cabível), o árbitro decidindo como amiable compositeur age na qualidade de mandatário das partes, na busca de um acordo. Naturalmente, suas funções "negociais" darão uma gama maior de ação do que um árbitro de eqüidade. Aquele autor aponta algumas decisões de cortes italianas em suporte de sua opinião, bem como o fato de a Lei Modelo, em sua redação inglesa, utilizar "ou" para separar as expressões ex aequo et bono e amiable compositeur.

No entanto, a maioria da doutrina internacional não diferencia ex aequo et bono e amiable composition. Com efeito, a começar da própria doutrina francesa, a chamada amiable composition é equivalente à arbitragem por eqüidade. Eric Loquin, ao comentar parte da doutrina que pretende diferenciar a arbitragem ex aequo et bono de amiable composition, conclui

202 Para um exame do conjunto da questão, veja-se Jolıdon, Pierre. Commentaire du Concordat Suisse sur l'Arbitrage. Berne: Éditions Stæmpfli \& Cie., 1984. p. 447 e ss.; La Sentence en Équité dans le Concordat Suisse sur l'Arbitrage. Recueil des Travaux Suisses sur l'Arbitrage International, Zürich, Schulthess Polygraphischer Verlag, p. 259 e ss., 1984. Lalive, Pierre; Poudret, Jean-François; Reymond, Claude. Le Droit de l'Arbitrage Interne et International en Suisse. Lausanne: Payot, 1989. p. 172 e 400 (em aparente contradição). Lalive, Pierre; Gaillard, Emmanuel. Le Nouveau Droit de l'Arbitrage International en Suisse. Journal du Droit International (Clunet), Paris, Editions Techniques SA ano 116, n. 4, p. 946 e ss., out.-nov.-dez. 1989. Também instrutivas são as respostas aos questionários submetidos pela Força Tarefa da CCI sobre arbitragem por eqüidade, submetidos por Rocco Bonzanigo e Urs Weber-Stecher, ambos disponíveis em: <http://intranet. iccwbo.org/view_topic.asp?topic $=190 \&$ forum $=10>$. Consulta para membros da Força Tarefa.

203 Relatório de Urs Weber-Stecher.

204 Lalive, Pierre; Gaillard, Emmanuel. Le Nouveau Droit... cit., p. 947.

205 Amiable Compositeur (Joint Mandate to Settle) and Ex Bono et Aequo (Discretional Authority to Mitigate Strict Law): Apparent Synonyms Revisited. Journal of International Arbitration, Geneva, Kluwer, v. 9, n. 1, p. 5 e ss., 1992. Também do mesmo autor: International commercial arbitration: law and practice. 2. ed. The Hague: Kluwer Law International, 2001. p. 471 e ss. 
que todas as tentativas de diferenciação falharam e que ambas as expressões remetem à vontade das partes de uma decisão que escape à aplicação do direito estrito. ${ }^{206}$ Igualmente Fouchard, Gaillard e Goldman afirmam que a diferenciação entre arbitragem de eqüidade, ex aequo et bono e amiable composition, seria artificial e que a jurisprudência francesa não tem distinguido as expressões. ${ }^{207}$ Igualmente, Jean Robert entende pela sinonímia entre as expressões amiable composition, ex aequo et bono e eqüidade. ${ }^{208}$ Matthieu de Boisséson, por seu turno, parece colocar a amiable composition como um sinônimo de decisão por eqüidade. ${ }^{209}$ Por sua vez, Motulsky sustenta que o efeito principal da amiable composition é um julgamento por eqüidade. ${ }^{210}$ Da mesma forma, René Davi ${ }^{211}$ e Sigvard Jarvin. ${ }^{212}$

Aliás, Eric Loquin é apontado por alguns autores suíços como um dos que advogam a diferenciação entre a amiable composition e a arbitragem por eqüidade. Isso se dá em razão da posição de que 'l'assimilation de l'arbitrage d'amiable composition au jugement d'équiteé n'a pas toujours servi l'institution", ${ }^{213}$ Entretanto, como visto, ele não sustenta tal posição.

Com efeito, embora critique em sua obra o uso exclusivo da eqüidade como fonte para as decisões do amiable compositeur, não diferencia dois tipos de arbitragem. Na passagem mencionada, o autor defende que a noção de eqüidade é demasiado filosófica e contestada para inspirar a confiança das partes. Por demasiado filosófica, a mera remissão a eqüidade deve ser vista com cuidado, pois varia conforme o árbitro. Aquele autor vê na amiable composition uma dupla função: a de buscar uma solução que seja eqüitativa e uma solução que seja mutuamente aceitável pelas partes. Essas duas soluções podem auto-excluir-se.

Entretanto, essa posição parece referir-se ao conteúdo material da decisão do amiable compositeur, na qual reitera que os árbitros não devem recorrer apenas e tão-somente à eqüidade (i.e., seu senso particular de justiça) para efetuar a decisão. Defende-se que a função da amiable compositeur é fornecer uma solução eqüitativa, mas também procurar uma solução que

\footnotetext{
206 Loquin, Eric. L'Amiable composition... cit., p. 45 e ss. Note-se, porém, que o mesmo autor, na mesma obra (p. 343 e ss.), afirma que a amiable composition não se restringe à eqüidade. Todavia, essa noção parece ser mais dirigida ao critério de julgamento do que propriamente à natureza do instituto.

209 Boisséson, Matthieu de. Le Droit Français de l'Arbitrage: interne et international. Paris: GLN Joly, 1990. p. 298 e ss.

210 Motulsky, Henri. Écrits... cit., p. 33.

211 DAvid, René. Arbitration... cit., p. 329 e ss.

212 JARvin, Sigvard. The sources and limits of the arbitrator's powers. Arbitration International, v. 2, n. 2, p. 140 e ss., 1986.

213 Loquin, Eric. L'Amiable composition... cit., p. 343.
} 
seja aceitável para as partes, em termos de impedir a ruptura do contrato e favorecer a consecução de suas relações negociais.

Entretanto, ao analisar os contornos gerais da amiable composition, Loquin parece aceitar de modo claro a sinonímia entre amiable composition, decisão por eqüidade e ex aequo et bono. ${ }^{214} \mathrm{~A}$ tentativa de diferenciação entre amiable composition e decisão ex aequo et bono, vinda de autores respeitáveis como Goldman e Amadio, que sugeriram um aporte transacional para a amiable composition (busca do interesse comercial das partes), ao passo que a decisão ex aequo et bono seria puramente um juízo de eqüidade sem maiores considerações negociais, é refutada por Loquin.

Assim, o próprio país de origem da expressão amiable composition parece colocá-la como um sinônimo de arbitragem por eqüidade. Essa sinonímia parece ser seguida pela doutrina de língua inglesa que utiliza os termos amiable composition e ex aequo et bono sem grandes distinções, também se referindo a elas como decisões in equity, ${ }^{215}$ embora boa parte das obras se preocupe com a divergência doutrinária.

Apenas como uma nota da sinonímia em outras culturas, veja-se a discussão da Lei Modelo na Polônia, onde a comissão responsável pelo anteprojeto decidiu retirar a expressão "ou como amiable compositeurs", por entenderem-na redundante e sinônima de ex aequo et bono. ${ }^{216}$

O outro argumento de origem suíça para a diferenciação da arbitragem por eqüidade da amiable composition tampouco parece ser decisivo. Com efeito, sustentam alguns autores que, na amiable composition francesa, os árbitros podem apenas desconsiderar as normas de direito dispositivo, ao passo que na arbitragem por eqüidade esse poder seria mais amplo, po-

214 Loquin, Eric. L'Amiable composition... cit., p. 45.

215 Mustill, Michael J.; Boyd, Stewart. Commercial Arbitration - 2001 Companion. London: Butterworths, 2001. p. 328 (embora mencionando cada uma delas como possibilidade. Na edição de 1982 da obra clássica, o termo amiable composition é preferido). REDFERn, Alan; HunTER, Martin. Law and practice... cit., p. 43 (ressaltando que a denominação latina é mais freqüente em autores de direito internacional público); Coe Jr., Jack J. International Commercial Arbitration: American principles and practice in a global context. Irvington-on-Hudson: Transnational Publishers, 1997. p. 173 (ressaltando que amiable composition vem da tradição francesa e ex aequo et bono é um "paralelo de common law"; de qualquer modo, informa a divergência doutrinária, ressaltando que, seja qual for o resultado, são institutos muito próximos). Lew, Julian D. M. Applicable Law in International Commercial Arbitration. Dobbs Ferry: Oceana Publications, 1978. p. 508.

VÁrady, Tibor; Barceló, John J.; Von Mehren, Arthur T. International commercial arbitration... cit., p. 558.

216 SzURSKI, Tadeusz. Introducing Uncitral Model Law to Poland. Journal of International Arbitration, Deventer, Kluwer Law, 18(2), p. 232, 2001. Posteriormente, a Polônia adotou uma redação diferente, como se pode verificar no capítulo desta obra dedicado às legislações nacionais. 
dendo derrogar as normas de direito imperativo, estando limitada apenas pela ordem pública internacional. Esse argumento parece ser mais tocante à natureza da ordem pública do que da arbitragem por eqüidade propriamente dita. Caso se conceitue a arbitragem por eqüidade como a possibilidade de decisão fora das regras de direito positivo, sob reserva de ordem pública, ela caberia tanto ao caso suíço quanto ao francês. Haveria, apenas, uma diferença de limite da ordem pública, em que uma seria em seu nível nacional (direito dispositivo) e a outra em seu grau de menor intervenção (ordem pública internacional). Ora, se a amiable composition francesa referir-se a uma arbitragem internacional, parece intuitivo que os limites de derrogação serão aqueles da ordem pública internacional francesa, e não do direito interno dispositivo. ${ }^{217}$

Este autor entende que o grau de ordem pública que limita a liberdade de decisão não é o elemento definidor da arbitragem por eqüidade, tampouco pode ser a causa bastante para a criação de uma outra instituição. O elemento central da arbitragem por eqüidade é a possibilidade de derrogação do direito positivo, por árbitros que decidem com autoridade final. Eventual diferenciação entre os limites de tal tarefa (de resto, não especificada nas legislações nacionais) deve ser tida mais na conta de uma variação regional do que uma instituição distinta. Além de faltar um elemento distintivo mais sério, a criação de uma nova instituição parece ter escassa utilidade prática. Está a ciência do direito mais bem servida com a diferenciação doutrinária entre arbitragem por eqüidade e amiable composition? Parece-nos que não. Estão as partes mais seguras ou mais bem protegidas com a existência dessas duas categorias? Parece-nos que não, igualmente.

Cumpre ressaltar a divergência entre os que defendem a diferença entre arbitragem por eqüidade e a amiable compositon. Uma parte da doutrina defende que a amiable composition implica poderes transacionais e portanto mais amplos que os da simples decisão por eqüidade. Outra parte defende que a amiable composition tem efeitos mais restritos (de derrogação do direito positivo) do que a arbitragem por eqüidade.

Assim, além de minoritária, a diferenciação da arbitragem por eqüidade e amiable composition é um campo dividido, o que evidencia um grau alto de incerteza dos que pretendam utilizar essa diferenciação.

A prática arbitral não parece sancionar a diferença entre as duas instituições. Na pesquisa realizada para esta obra, não foi encontrada nenhuma sentença arbitral que utilizasse a expressão amiable composition como um mandato para transigir. De outro lado, poucos jul-

217 A única exceção parece ser os casos de escolha simultânea de lei, que a doutrna francesa considera como uma determinação para derrogação apenas do direito dispositivo do ordenamento escolhido. Para um exame da matéria, veja-se a seção relativa à ordem pública nesta obra. 
gados mencionam a diferença entre decisão por eqüidade e amiable composition, nos termos normalmente postos por parte da doutrina suíça.

No caso CCI n. 12.772, ${ }^{218}$ de Zurique, há referência a uma "vasta" maioria de autores (suíços) que afirmariam que, na amiable composition, os árbitros devem aplicar a lei e corrigir o resultado de modo eqüitativo, ao passo que na arbitragem por eqüidade os árbitros possuem uma "área mais ampla de discricionaridade", limitados pelos princípios de ordem pública.

No caso CCI n. 940.220, ${ }^{219}$ houve escolha simultânea de eqüidade e uma lei nacional. O tribunal decidiu que não haveria decisão pura em eqüidade, mas sim da "eqüidade legal": aquela permitida pela lei, como forma de integração e interpretação. $\mathrm{O}$ tribunal diferenciou decisão por eqüidade e amiable composition, concluindo que a escolha de lei com eqüidade tem efeitos diferentes da simples opção pela eqüidade.

De outra parte, nos casos CCI n. $7.913,{ }^{220} 7.986^{221}$ e $11.409,{ }^{222}$ os tribunais claramente afirmam a identidade entre arbitragem por eqüidade e amiable composition.

No que diz respeito à amiable composition como uma forma transacional ou uma figura mais próxima da arbitragem contratual, faz-se necessário perguntar se interesa ao desenvolvimento do instituto mais uma diferenciação que toque a natureza contratual ou jurisdicional da arbitragem.

Como já visto nesta obra, existem opiniões doutrinárias que buscam a unificação do conceito de arbitragem, aglutinando alguns institutos afins, inclusive os de cunho contratual. A criação de mais uma diferenciação entre arbitragem por eqüidade e mandato conjunto a transigir parece ir em sentido diametralmente oposto.

Além disso, uma das maiores críticas à arbitragem por eqüidade é sua falta de previsibilidade. Parece duvidoso que as partes que receiam a falta de previsibilidade de uma decisão sem recurso ao direito positivo possam olhar com mais favor para uma decisão em que os árbitros substituirão sua tarefa de contratar.

\footnotetext{
218 ICC International Court of Arbitration Bulletin, v. 18, n. 1, p. 112 e ss., 2007.

219 Inédito.

220 ICC International Court of Arbitration Bulletin, v. 18, n. 1, 2007, p. 67 e ss.

221 Idem, p. 72 e ss.

222 Idem, p. 100 e ss.
} 
Em um exame de direito comparado, apenas dois países parecem adotar lineamentos de transação para a "composição amigável": Colômbia ${ }^{223}$ e Portugal. ${ }^{224} \mathrm{Na}$ Itália, a expressão poderá situar-se tanto no domínio do arbitrato rituale (jurisdicional) como irrituale (contratual). Todavia, essas são as únicas diferenciações concretas em direito comparado.

No direito internacional público, a doutrina predominante defende a sinonímia das expressões. Em alentado estudo sobre eqüidade, Degan ${ }^{225}$ afirma que a maioria da doutrina que se dedicou à matéria considera que a amiable composition tem o mesmo alcance do julgamento por eqüidade ou ex aequo et bono. Sustenta, igualmente, que os tratados sobre arbitragem (de direito internacional público) frequentemente utilizam-se da expressão amiable composition como um sinônimo de decisão por eqüidade.

\section{c) Da Lei Modelo}

Considerando a importância da Lei Modelo para a criação de uma "linguagem comum" da arbitragem internacional, uma análise mais detalhada do tratamento dos termos arbitragem por eqüidade e amiable composition é conveniente para verificar a sinonímia ou a diferenciação das expressões.

O exame dos trabalhos legislativos não é o único método de interpretação e possivelmente não é o mais utilizado. Mesmo porque a hipótese do "legislador racional" não se confunde com o falível legislador histórico. A despeito disso, o exame do processo legislativo pode ajudar a compreender o contexto e as aspirações do legislador (histórico) e portanto a sua vontade.

No caso da Lei Modelo, as objeções ao uso do processo "legislativo" poderiam ser ainda maiores, pois ela é apenas um texto de orientação, que será filtrado e emendado no regular processo legislativo dos países e passarão a integrar ordenamentos e culturas jurídicas distintas, que possuem suas regras de interpretação próprias.

223 Na Colômbia, a amigable composición é definida em lei como "um mecanismo de solução de conflitos, pelo qual dois ou mais particulares delegam a um terceiro a faculdade de precisar, com força vinculante, o estado, as partes e a forma de cumprimento de um negócio jurídico particular". Vê-se nela um claro componente negocial, que parece remeter à doutrina do negócio jurídico de accertamento, da doutrina italiana. Ou seja, é um elemento de integração do negócio jurídico.

224 No caso português, a própria doutrina daquele país parece divergir sobre o alcance e a autonomia da figura. Há quem defenda a sinonímia entre a composição amigável e a arbitragem por eqüidade. Caso se entenda pela diferenciação, o conteúdo da norma parece indicar uma sentença arbitral nos moldes clássicos, cuja forma de decisão deve levar em consideração a razão econômica e de proporção ("com base no equilíbrio dos interesses em jogo").

225 Degan, V.D. L'Équité et le Droit International. La Haye (Den Haag): Martinus Nijhoff, 1970. p. 19-20. 
Entretanto, sendo a Lei Modelo uma espécie de reflexo do pensamento preponderante na arbitragem internacional em um momento determinado, seu exame tem o interesse de revelar uma espécie de "pensamento médio" de então no mundo da arbitragem.

Passa-se, então, a seu breve exame.

No relatório do Secretário-Geral da CNUDCI sobre Possible features of a model law on international commercial arbitration, datado de $14.05 .1981,{ }^{226}$ colocou-se a questão da possibilidade de outorga de poderes aos árbitros para decisão como amiables compositeurs (ou ex aequo et bono), bem como seus eventuais limites (no tocante à ordem pública, por exemplo). Neste documento, os termos amiable composition e decisão ex aequo et bono foram tratados como sinônimos.

Na nota do secretariado da CNUDCI, datada de 1. ${ }^{\circ} .12 .1981,{ }^{227}$ sobre possíveis pontos de uma p.sobre arbitragem comercial internacional (questões para discussão pelo Grupo de Trabalho), pergunta-se se a p.deve reconhecer como vinculante o acordo das partes para decisão ex aequo et bono. Em caso positivo, se deveria haver uma definição do mandato para tal espécie de decisão. Ao fornecer um exemplo de questão, pergunta-se se os amiable compositeurs estão limitados pela ordem pública. Novamente aqui, os termos são tratados como sinônimos.

No primeiro relatório do grupo de trabalho em práticas de contratos internacionais (international contract practices), datado de $10.11 .1982,{ }^{228}$ o grupo apresenta uma primeira minuta de artigo sobre a matéria (art. 32): "The arbitral tribunal shall decide ex aequo et bono [or as amiable compositeur] [only] if the parties have expressely authorized it to do so".

O grupo relata que o artigo foi considerado aceitável por todos, embora nem todos os países reconheçam tal tipo de arbitragem. O grupo também julgou importante a menção às duas expressões porque em algumas legislações nacionais pode haver diferenciação no significado delas. $^{229}$

226 Doc. A/CN.9/207, p. 24. Fonte: Kavass, Igor; LivaK, Arno (Compiladores). Uncitral Model Law of International Commercial Arbitration: a documentary history. Buffalo (NY), 1985. v. 1. Trata-se de uma compilação em forma de pasta para o Institute for International Legal Information. A menos que de outra forma indicados, os textos consultados para a parte histórica vêm dessa obra e disponíveis em: <www.uncitral.org >. Documento A/CN.9/WG.II/WP.35, p. 13, questão n. 5-9. In: KAVASS, Igor; LiIVAK, Arno. Uncitral Model Law... cit.

228 Documento A/CN.9/232, p. 31. In: KAVASs, Igor; LivaK, Arno. Uncitral Model Law... cit.

229 "because under some national laws there might be a difference between them." 
No relatório do mesmo grupo de trabalho datado de $22.09 .1983,{ }^{230}$ adotou-se o texto acima citado (agora como parágrafo quarto do art. XXIX e sem colchetes), embora este tipo de arbitragem não fosse reconhecido por todos os países. ${ }^{231}$

Na nota do Secretariado apresentando a minuta da Lei Modelo, o texto aparece como parágrafo terceiro do art. $28 .^{232}$

Nos comentários dos países à minuta, não houve reparos sobre o uso dos termos. Apenas a delegação da Itália sugeriu que fosse adicionado texto determinando que, a despeito da autorização, os árbitros devem procurar, tanto quanto possível, garantir a execução da sentença nos países em que a arbitragem tem conexão significativa. ${ }^{233}$

No relatório do Secretário-Geral, datado de 25.03.1985, ${ }^{234}$ intitulado International Commercial Arbitration: Analytical Commentary on Draft Text of a Model Law, os termos são referidos designando o mesmo tipo de arbitragem, ressaltando que em alguns sistemas esta é denominada de uma forma e em outros, de maneira diversa. Também relata-se que não se tentou definir esse tipo de arbitragem na Lei Modelo, uma vez que ele se apresenta de várias formas, freqüentemente vagas.

O Secretário-Geral também defende a utilização do instituto, mesmo que desconhecido em alguns países, pelas seguintes razões: (i) é correto acomodar práticas conhecidas em apenas alguns países, porque seria contrário a uma p.desconsiderar ou proibir práticas estabelecidas; (ii) a utilização das práticas estabelecidas ajuda a diminuir a importância do local da arbitragem; e (iii) as partes estão preservadas de um resultado não desejado, pois somente pode ser utilizada em caso de escolha expressa.

Na discussão de cada um dos artigos no âmbito da CNUDCI, a questão da denominação da arbitragem por eqüidade e possíveis confusões concernentes ao uso dos dois termos foi levantada pelo representante do Conselho Internacional para Arbitragem Comercial (ICCA), que sugeriu que os termos fossem definidos como equivalentes, por exemplo, usando a expres-

230 Documento A/CN.9/245, p. 22. In: KavAss, Igor; LiIVAK, Arno. Uncitral Model Law... cit.

231 O texto original foi: "The arbitral tribunal shall decide ex aequo et bono or as amiable compositeur only if the parties have expressely authorized it to do so".

232 "composite draft text of a model law on international commercial arbitration", datado de 29.11.1983, documento A/CN.9/WG.II/WP.48, p. 14. In: Kavass, Igor; Livak, Arno. Uncitral Model Law... cit.

233 Relatório do Secretário-Geral compilando os comentários dos governos, datado de 19.03.1985. Documento A/ CN.9/263, p. 42. In: Kavass, Igor; LiIVAK, Arno. Uncitral Model Law... cit.

234 Documento A/CN.9/264, p. 62-63. In: Idem, ibidem. 
são amiable composition seguida por ex aequo et bono entre parênteses, para evitar que eles fossem interpretados como procedimentos diferentes. ${ }^{235}$

O presidente dos trabalhos, Sr. Loewe, da Áustria, disse que lhe parecia um problema de redação. Ainda neste artigo, exprimiu esperança de que a consistência com as regras de arbitragem da CNUDCI de 1976 evitasse maiores discussões sobre redação.

Embora a manifestação do presidente dos trabalhos sobre a consistência com o regulamento de arbitragem da CNUDCI se referisse à observância do contrato e dos usos e costumes do comércio (art. 28(4)), é possível que essa preocupação com consistência na redação tenha sido o motivo para se manter, na Lei Modelo, a mesma redação do Regulamento, também no que diz respeito à arbitragem por eqüidade.

Nos trabalhos de elaboração do regulamento de arbitragem da CNUDCI, por sua vez, a diferenciação surge como uma questão de tradução. Posteriormente, segue como uma forma de contemplar possíveis diferenças regionais. ${ }^{236}$

Posteriormente à adoção da lei modelo, o secretariado da CNUDCI emitiu uma nota informativa em 25.03.1988, ${ }^{237}$ explicitando diversos aspectos da Lei Modelo. Embora tenha caráter informativo e negue o status de comentário oficial, a nota esclarece entendimentos que foram levados em conta na elaboração da Lei Modelo e apresenta algumas recomendações. Em sua página 9, a nota reafirma que a arbitragem por eqüidade ainda não era conhecida ou utilizada em todos os sistemas jurídicos. Também reconhece que não existe entendimento uniforme sobre o conteúdo preciso de tal cláusula e quais os poderes que investe o tribunal arbitral quan-

235 Versão revisada do Summary Records of the 305th to 333rd Meetings, datado de 18.12.1985, p. 180 (documento consolidado A/CN.9/SR.327). A versão original encontra-se na página 4 da minuta sumária da 327.a Reunião, datada de 19.06.1985, com o mesmo número de documento.

236 No documento A/CN.9/9/C.2/SR.14, de 26.04.1976 (http://www.uncitral.org/pdf/english/travaux/ arbitration/1976Arbitration/ACN99C2SR14.pdf), tanscrição sumária da 14.a reunião do "Comittee of the Whole”, p. 4. Acesso em: 15 ago. 2007), discutiu-se a razão de utilizar as duas expressões (amiable composition e ex aequo et bono) em vez de colocar os termos amiable compositeurs entre parênteses, como na versão francesa do documento (A/CN.9/112). Apresentava-se, assim, a diferença em termos de tradução, de lingüística, e amiable composition seria a versão francesa dos termos ex aequo et bono, empregados em inglês. A comprovar tal fato, a sugestão do representante da França de que, na versão francesa, fosse invertida a ordem e colocada a expressão ex aequo et bono entre parênteses.

A explicação da nova proposta (feita pelo representante dos EUA, co-autor da proposta) devia-se ao fato de que diferentes sistemas jurídicos interpretavam os termos de maneiras diferentes. Além disso, havia discordância entre os acadêmicos sobre seu significado exato. Portanto, os autores da proposta preferiram incluir os dois termos, para deixar as partes livres para usar qualquer uma delas, dependendo do sistema jurídico. Também neste caso, o presidente deixou a questão para o comitê de redação. O resultado final foi a prevalência das duas expressões.

237 Documento n. A/CN.9/309. Disponível em: <www.uncitral.org>. 
do de sua celebração. Aconselha as partes que, sempre que houver alguma espécie de incerteza sobre o alcance da cláusula, a questão seja esclarecida na convenção de arbitragem.

Parece-nos que a opção da CNUDCI foi claramente acomodar possíveis interpretações distintas de uma figura, e não efetivamente criar dois institutos diferentes. Sequer pode-se dizer que a utilização das duas expressões reflete uma divisão clara dos direitos mundiais. Ao contrário, prefere-se o uso de duas expressões que são utilizadas em diversas tradições jurídicas para descrever situações idênticas ou, apenas potencialmente, instituições distintas. Nenhum país é mencionado como exemplo de entendimento diverso.

O raciocínio por trás da adoção dos dois termos parece ter sido o de conferir maior flexibilidade ao texto, e não diferenciar institutos. Em outras palavras, usou-se a redação dupla em reconhecimento de possíveis diferenciações, mas não para prescrevê-la.

Como mencionado, há autores importantes que tomaram o uso de termos separados na Lei Modelo como argumento pela existência de dois tipos diferentes de arbitragem. O valor alternativo da conjunção "ou” tem sido uma razão para os que defendem a diferença entre ambos os institutos. ${ }^{238}$ Contudo, o argumento deve ser tomado com as devidas cautelas.

A palavra "ou" nem sempre tem o valor de disjunção, ou seja, exclusão ou diferenciação, mas também alternatividade ou sinonímia para o mesmo objeto (“o Ceilão ou Sri Lanka”, "Mianmar ou Birmânia"). E este uso é da mesma forma reconhecido na língua inglesa ${ }^{239}$ e francesa. $^{240}$ Portanto, não cremos que o texto do art. 28(3) seja determinante para demonstrar uma clara opção de diferenciação entre ex aequo et bono e amiable composition.

O regulamento de arbitragem da CNUDCI, por outro lado, claramente dispõe os termos como sinônimos, ao colocar, por exemplo, na versão francesa a expressão ex aequo et

238 Rubino-Sammartano, Mauro. Amiable Compositeur... cit., p. 5 e ss. Também do mesmo autor: International arbitration law and practice. The Hague; Boston: Kluwer Law International, 2001, p. 471 e ss.; Il diritto dell'arbitrato, cit., p. 112. De certo modo, também parece tomar posição nesse sentido Pieter Sanders (The work of Uncitral... cit., p. 17). Entretanto, aquele autor comenta o artigo do regulamento de arbitragem e não da própria lei e parece seguir uma visão mais comum aos autores suíços, ao diferenciar, em doutrina, arbitragem por eqüidade e amiable composition. Ao comentar o artigo da Lei-Modelo (op. cit., p. 48), aquele autor utiliza apenas os termos amiable composition.

239 Merriam-Webster's Collegiate Dictionnaire. 10. ed. Springfield: Merriam-Webster. 1994. p. 817.

240 Le Robert Micro: Dictionnaire de la Langue Française. Paris: Dictionnaires Le Robert, 1998. p. 920. 
bono entre parênteses após amiable composition. ${ }^{241} \mathrm{O}$ mesmo ocorre na versão espanhola. ${ }^{242} \mathrm{Na}$ versão inglesa, usa-se a mesma terminologia da Lei Modelo. ${ }^{243} \mathrm{Na}$ versão russa, emprega-se a mesma forma da Lei Modelo, utilizando-se a conjunção "ili”, que significa "ou”, com as mesmas propriedades - disjunção e alternatividade. ${ }^{244}$

Assim, a própria tradição da CNUDCI não parece autorizar a conclusão de diferenciação entre os dois tipos de arbitragem. Ao contrário, a mudança de redação conforme a língua que se utiliza para o Regulamento demonstra certa equivalência de termos ou ao menos a falta de uma distinção nítida entre eles.

d) Regulamentos de arbitragem

O regulamento da CCI menciona em seu art. 17 as duas expressões, nos moldes da Lei Modelo. ${ }^{245}$ Os termos normalmente adotados desde a década de 1920 sempre foram amiable composition. Apenas em 1998 a expressão ex aequo et bono foi incluída. A razão para tanto, segundo os comentadores, é mais ou menos a mesma para outras experiências normativas, como a Lei Modelo e o regulamento de arbitragem da CNUDCI: (i) os ordenamentos jurídicos ora se

241 Article 33.

1. Le tribunal arbitral applique la loi désignée par les parties comme étant la loi applicable au fond du litige. À défaut d'une telle indication par les parties, le tribunal arbitral applique la loi désignée par la règle de conflit de lois qu'il juge applicable en l'espèce.

2. Le tribunal arbitral ne statue en qualité d' "amiable compositeur" (ex aequo et bono) que si le tribunal arbitral y a été expressément autorisé par les parties et si ce type d'arbitrage est permis par la loi applicable à la procédure arbitrale.

242 Artículo 33.

1. El tribunal arbitral aplicará la ley que las partes hayan indicado como aplicable al fondo del litigio. Si las partes no indican la ley aplicable, el tribunal arbitral aplicará la ley que determinen las normas de conflicto de leyes que estime aplicables.

2. El tribunal arbitral decidirá como amigable componedor (ex aequo et bono) sólo si las partes lo han autorizado expresamente para ello y si la ley aplicable al procedimiento arbitral permite este tipo de arbitraje.

243 Article 33.

1. The arbitral tribunal shall apply the law designated by the parties as applicable to the substance of the dispute. Failing such designation by the parties, the arbitral tribunal shall apply the law determined by the conflict of laws rules which it considers applicable.

2. The arbitral tribunal shall decide as amiable compositeur or ex aequo et bono only if the parties have expressly authorized the arbitral tribunal to do so and if the law applicable to the arbitral procedure permits such arbitration.

244 O autor agradece a Ivana Mihaleva pela ajuda com a tradução do texto russo.

245 Article 17. Applicable Rules of Law

$[\ldots]$

3. The Arbitral Tribunal shall assume the powers of an amiable compositeur or decide ex aequo et bono only if the parties have agreed to give it such powers. 
referem a uma, ora à outra forma; (ii) ainda existe controvérsia sobre eventuais diferenças entre as duas expressões. ${ }^{246}$

A American Arbitration Association igualmente faz alusão às duas expressões em seu regulamento de arbitragem. ${ }^{247} \mathrm{O}$ mesmo ocorre com a London Court of International Arbitration, que ainda utiliza uma terceira expressão: honorable engagement. ${ }^{248}$ No caso da Câmara de Comércio de Estocolmo, igualmente as duas expressões são empregadas. ${ }^{249}$ Por sua vez, no caso da Câmara Federal Econômica de Viena, a expressão empregada é exclusivamente equity. ${ }^{250}$ No caso da Convenção para a Solução de Controvérsias relativas a Investimentos entre Estados e Nacionais de Outros Estados, a chamada Convenção de Washington de 1965, somente há menção à expressão ex aequo et bono. ${ }^{251}$ No caso do Centro Regional do Cairo para Arbitragem Comercial Internacional, as regras mencionam ambas as expressões. ${ }^{252}$

246 Derains, Yves; Schwartz, Eric. A Guide to the ICC Rules of Arbitration. 2. ed. The Hague: Kluwer Law International, 2005. p. 245.

247 Article 28.

$[\ldots]$

3. The tribunal shall not decide as amiable compositeur or ex aequo et bono unless the parties have expressly authorized it to do so. [...]

248 Article 22. Additional Powers of the Arbitral Tribunal

$[\ldots]$

22.4 The Arbitral Tribunal shall only apply to the merits of the dispute principles deriving from "ex aequo et bono", "amiable composition" or "honourable engagement" where the parties have so agreed expressly in writing.

249 Article 22. Applicable law

$[\ldots]$

(3) The Arbitral Tribunal shall decide the dispute ex aequo et bono or as amiable compositeur only if the parties have expressly authorised it to do so.

250 Applicable Law. Equity

Article 24.

$[\ldots]$

(3) The sole arbitrator (arbitral tribunal) may decide on equity only if the parties have expressly authorized him (it) to do so.

251 Article 42.

$[\ldots]$

(3) The provisions of paragraphs (1) and (2) shall not prejudice the power of the Tribunal to decide a dispute ex aequo et bono if the parties so agree.

As versões francesa e espanhola da Convenção igualmente apenas referem-se a ex aequo et bono.

252 Applicable Law, Amiable Compositeur

Article 33.

1. The arbitral tribunal shall apply the law designated by the parties as applicable to the substance of the dispute. Failing such designation by the parties, the arbitral tribunal shall apply the law determined by the conflict of laws rules, which it considers applicable.

2. The arbitral tribunal shall decide as amiable compositeur or ex aequo et bono only if the parties have expressly authorized the arbitral tribunal to do so and if the law applicable to the arbitral procedure permits such arbitration.

3. In all cases, the arbitral tribunal shall decide in accordance with the terms of the contract and shall take into account the usages of the trade applicable to the transaction. 
No caso brasileiro, a maioria das instituições consultadas refere-se apenas à arbitragem por eqüidade. Todavia, no regulamento da Câmara de Mediação e Arbitragem de São Paulo (com funcionamento junto à Federação das Indústrias do Estado de São Paulo), há expressa menção à atuação dos árbitros como "amigável compositor", juntamente com decisão por eqüidade. 253

\subsubsection{Arbitragem de por eqüidade e ex aequo et bono}

A outra forma normalmente utilizada para se referir à arbitragem por eqüidade é a expressão latina ex aequo et bono. A origem da "elegante" expressão parece ser de Celso, conforme mencionada no Digesto: nam, ut eleganter Celsus definit, ius est ars boni et aequi. ${ }^{254}$

Ex aequo et bono, ex bono et aequo, ${ }^{255}$ de bono et aequo, ${ }^{256}$ pro aequo et bono, ${ }^{257}$ pro bono et aequo ${ }^{258}$ têm sido expressões normalmente usadas para se referir a uma forma de julgar sem alusão direta ao ordenamento jurídico, mas com apelo à eqüidade. De todas elas, a expressão ex aequo et bono tem sido mais empregada e ganhou força na arbitragem internacional tanto pela via do direito internacional público como pelo uso na arbitragem comercial.

No direito internacional público, encontra-se a referência ao julgamento ex aequo et bono igualmente no famoso art. 38 do Estatuto da Corte Internacional de Justiça. ${ }^{259}$ A doutrina

253 17. Das Disposições Finais

17.1 Em arbitragem internacional competirá às partes a escolha da lei aplicável ao mérito da controvérsia e o idioma da arbitragem. Não havendo previsão ou consenso a respeito, competirá ao tribunal arbitral indicar as regras que julguem apropriadas, bem como o idioma, levando-se em consideração as estipulações do contrato, os usos, costumes e regras internacionais de comércio. Os árbitros somente poderão decidir por eqüidade ou atuar como amigável compositor se estiverem autorizados pelas partes.

254 D.1.1.1pr.

255 Institutas, Livro VI, 31.

256 Beviláqua, Clóvis. Código Civil dos Estados Unidos do Brasil comentado, cit., p. 194. Digesto, 45.1.91.3

257 Long, George. The decline of the Roman Republic. London: Bell and Daldy, 1866. v. 2, p. 135 (citando Licínio Crasso, sobre a interpretação de um testamento).

258 Regulamento da Câmara de Arbitragem Marítima de Mônaco. Disponível em: <http://www.arbitragemaritimemonaco.com/pgengl/statutes/statugb.htm>. Acesso em: $31 \mathrm{dez} .2008$.

259 Article 38.

1. The Court, whose function is to decide in accordance with international law such disputes as are submitted to it, shall apply:

a. international conventions, whether general or particular, establishing rules expressly recognized by the contesting states;

b. international custom, as evidence of a general practice accepted as law;

c. the general principles of law recognized by civilized nations; 
por vezes tentou diferenciar a expressão ex aequo et bono do julgamento em eqüidade, especialmente pelos autores oriundos dos sistemas de common law, que aproximavam a noção de eqüidade à de equity e viam no julgamento ex aequo et bono uma amplitude ainda maior para julgamento. Entretanto, essas distinções não encontraram aceitação ampla. ${ }^{260} \mathrm{~A}$ expressão ex aequo et bono tem sido empregada desde o direito romano. A partir do Tratado de Jay, de 1794, as cláusulas compromissórias passaram a adotar, na maioria, a expressão "eqüidade". Alguns textos, porém, têm preferido a expressão latina para significar essencialmente o mesmo. ${ }^{261}$

$\mathrm{Na}$ arbitragem internacional, a locução ex aequo et bono tem sido utilizada sobretudo nos escritos de língua inglesa para denominar a arbitragem em que se decide sem necessidade de aplicação do direito positivo. Naquele idioma, usam-se igualmente os termos amiable composition, de origem francesa. Em outros idiomas, parece haver preferência pelo termo eqüidade, embora seja comum a referência ao termo latino como um equivalente. A sinonímia entre os termos é afirmada pela maioria da doutrina. ${ }^{262}$

Ao contrário da expressão amiable composition e suas respectivas traduções, não parece haver controvérsia, no âmbito da arbitragem comercial, sobre o alcance dos termos ex aequo et bono como sinônimos de arbitragem por eqüidade. Com efeito, mesmo os que defendem a divisão entre arbitragem por eqüidade e amiable composition costumam colocar a decisão ex aequo et bono como sinônimo da decisão por eqüidade. ${ }^{263}$ Alguns autores que discutem uma eventual diferença entre eqüidade e ex aequo et bono parecem fazê-la por conta do sentido de equity na common law, com referências ao direito internacional público, em que efetivamente houve uma discussão longa sobre o lugar da eqüidade nos moldes anglo-saxões e sua relação com as decisões ex aequo et bono. ${ }^{264}$

Compreende-se que a expressão ex aequo et bono tenha sido utilizada na doutrina de língua inglesa, ao lado de amiable composition. A expressão semanticamente mais próxima

d. subject to the provisions of Article 59, judicial decisions and the teachings of the most highly qualified publicists of the various nations, as subsidiary means for the determination of rules of law.

2. This provision shall not prejudice the power of the Court to decide a case ex aequo et bono, if the parties agree thereto.

260 Degan, V.D. L'Équité et le Droit International, cit., p. 17-19.

261 Idem, ibidem, p. 17.

262 Loquin, Eric. L'Amiable composition... cit., p. 45. Fouchard, Gaillard e Goldman. Traité de l'Arbitrage Commercial International, cit., p. 848.

263 Rubino-Sammartano, Mauro. Amiable Compositeur... cit.

264 Weinberg, Karyn. Equity in international arbitration: how fair is "fair"? A study of lex mercatoria and amiable composition. Boston University International Law Journal, 12, p. 227 e ss., primavera de 1994. MANIRUZZAMAN, A. F. M. The arbitrator's prudence in lex mercatoria: amiable composition and ex aequo et bono in decision making. Separata de Mealey's International Arbitration Report, v. 18, n. 12, dez. 2003. 
(equity) tem um significado próprio nos países de common law, que não pode ser identificado diretamente com a decisão por eqüidade, como conhecida na tradição romano-germânica. Não obstante as cláusulas de arbitragem por eqüidade sejam por vezes referidas como equity clauses, e mesmo a arbitragem por eqüidade como equity arbitration, as denominações ex aequo et bono e amiable composition prevalecem.

No caso brasileiro, como já demonstrado, a tradição legislativa é o uso da palavra eqüidade. A expressão ex aequo et bono por vezes aparece na doutrina como sinônimo de arbitragem por eqüidade. ${ }^{265}$ Em textos legislativos, a única referência encontrada nesta pesquisa foi a do art. 73 do Código de Águas. ${ }^{266}$

Logo, não parece haver diferença substancial entre o significado de arbitragem por eqüidade e a expressão ex aequo et bono e suas variações.

\subsubsection{Outras expressões}

Além das expressões mais tradicionais já mencionadas, uma série de países utiliza outras para descrever a arbitragem por eqüidade. Uma boa parte, de língua inglesa, preferiu formas descritivas desse tipo de arbitragem, especialmente quando da adoção da Lei Modelo.

A fórmula mais adotada por esses países é a decisão conforme considerações de justiça e eqüidade (according to considerations of justice and fairness ou justice and equity). Assim são os casos da Indonésia, Nova Zelândia (que utiliza as expressões da Lei Modelo, seguidas de um parêntese explicativo), Quênia, Sri Lanka e Uganda.

Em alguns países árabes, como Arábia Saudita, Kwait e Omã, fala-se em “efetuar um compromisso" (settle by compromise ou effect a compromise, na tradução inglesa). Aqui parece haver remissão à figura do sulh, oriunda da escolha sunita hanafi. Embora tenha um caráter próximo da conciliação, ela resulta em uma decisão irrecorrível. ${ }^{267}$

265 Carmona, Carlos Alberto. Arbitragem e processo, cit., p. 77.

266 Art. 73. Se o prédio é simplesmente banhado pela corrente e as águas não são sobejas, far-se-á a divisão das mesmas entre o dono ou possuidor dele e o do prédio fronteiro, proporcionalmente a extensão dos prédios e as suas necessidades.

Parágrafo único. Devem-se harmonizar, quanto possível, nesta partilha, os interesses da agricultura com os da indústria; e o juiz terá a faculdade de decidir "ex-bono et aequo".

267 Para maiores detalhes sobre a figura do sulh, veja-se a exposição sobre a Arábia Saudita no capítulo referente a legislações nacionais nesta obra. Também SALEH, Samir. Commercial Arbitration in the Arab Middle East: Shari’a, Lebanon, Syria and Egypt. 2. ed. Oxford: Hart Publishing, 2006. p. 45. 
No caso peruano, a legislação chama a arbitragem por eqüidade de arbitragem de consciência (conforme leal saber e entender) ou em consciência e eqüidade.

Nos casos da Bélgica e da Inglaterra, não há menção expressa à eqüidade, e sim uma permissão para decidir "conforme outros critérios" além do direito nacional (caso inglês) ou admitindo convenção em contrário à decisão por direito (caso belga). Essa forma de permissão de decisão em contrário, sobretudo no caso belga, parece inspirada na lei uniforme do Conselho da Europa de $1966 .{ }^{268}$

Essas outras maneiras de se referir à arbitragem por eqüidade parecem revelar elementos da percepção do instituto. Talvez a falta de tradição de arbitragem por eqüidade em alguns países de língua inglesa e o desejo de evitar a utilização de palavras estrangeiras os tenham levado a preferir formas perifrásticas, que acabam por demonstrar a essência de um julgamento por eqüidade: decisão conforme considerações de justiça e eqüidade, em oposição à estrita aplicação da lei nacional.

No caso dos países árabes, parece haver a remissão a um elemento conciliatório transacional que, a despeito de uma origem na conciliação, tem por efeito uma decisão final.

Por outro lado, a expressão adotada no Peru ("em consciência") parece revelar certo critério prudencial: decide-se conforme a boa consciência do árbitro sobre o que é mais justo, em detrimento de uma decisão puramente legal. Essa forma remete à tradicional forma latinoamericana para se referir ao julgamento por eqüidade: segundo o "leal saber e entender".

Portanto, ainda que se utilizando de formas diferentes, menos consagradas no uso internacional, esses países revelam elementos que são característicos da arbitragem por eqüidade: fundamento de justiça e eqüidade, caráter algo transacional e prudencial.

\subsection{A arbitragem por eqüidade e institutos próximos}

Para uma melhor delimitação da arbitragem por eqüidade, deve-se fazer uma breve contraposição com institutos e situações normalmente tidos como confinantes.

268 "Art. 21. Except when otherwise stipulated, arbitrators make their awards in accordance with the rules of law." SANDERs, Pieter. International Encyclopedia of Comparative Law... cit., p. 138. 
Entretanto, convém desde logo asseverar que a principal característica de distinção já foi efetuada nesta obra: a arbitragem por eqüidade é uma arbitragem propriamente dita. Aceitando-se tal classificação, a diferenciação da arbitragem por eqüidade no tocante aos institutos próximos passa a ser mais clara.

\subsubsection{Arbitragem por eqüidade e transação}

De um modo geral, a transação pode ser conceituada como o ato pelo qual as partes colocam fim a uma controvérsia, presente ou futura, mediante concessões mútuas. Embora haja divergências, pode-se afirmar que seus elementos centrais, além daqueles relativos a um ato jurídico em geral, são um litígio existente ou a existir, intenção de lhe pôr fim e concessões recíprocas. ${ }^{269}$ As concessões mútuas são um elemento central da transação: caso apenas uma das partes efetue concessões, haverá reconhecimento ou confissão. O efeito da transação será um negócio jurídico, um acordo de vontades que como tal será regido em sua validade, eficácia, execução e demais efeitos.

No âmbito da doutrina civilista, há alguma aproximação entre a transação e o compromisso. Uma prova disso é o art. 1.048 do Código Civil de 1916, que dispunha que seriam aplicadas ao compromisso as disposições relativas à transação sempre que possível. ${ }^{270}$ Alguns autores, como Carvalho de Mendonça, equiparam a transação ao compromisso, sustentando que aquela é um gênero do qual este é espécie. ${ }^{271}$ Igualmente a doutrina internacionalista equiparaos substancialmente, como Luiz Olavo Baptista. ${ }^{272}$

No que diz respeito à arbitragem por eqüidade, essa aproximação parece ser ainda maior, como mostram os exemplos da doutrina estrangeira. ${ }^{273}$ A principal razão dessa aproximação é a posição segundo a qual os árbitros em eqüidade decidem fora do direito, com uma visão de negócios, buscando por vezes uma decisão mutuamente aceitável para as partes.

Embora haja um potencial componente transacional na arbitragem por eqüidade, ela não pode se confundir com a própria transação. A função do árbitro de eqüidade é a mesma de

269 Serpa Lopes, Miguel Maria de. Curso de direito civil, cit., v. 2, p. 269.

270 Art. 1.048. Ao compromisso se aplicará, quanto possível, o disposto acerca da transação (arts. 1.025 a 1.036).

271 Apud Serpa Lopes, Miguel Maria de. Curso de direito civil, cit., v. 2, p. 295.

272 Baptista, Luiz Olavo; Magalhães, José Carlos de. Arbitragem comercial, cit., p. 34 (referindo-se, todavia, ao regime anterior da arbitragem no Brasil, substancialmente modificado a partir de 1996).

273 Para uma discussão aprofundada, com análise das posições, veja-se LoQuIn, Eric. L'Amiable composition... cit., p. 67 e ss. 
um árbitro em direito: decidir uma controvérsia, de modo final, entre duas ou mais partes. $\mathrm{O}$ fato de as partes dispensarem os árbitros da aplicação do direito positivo não significa mudança da função principal. Eles apenas o farão com um critério diferente; porém, continuarão a dirimir uma controvérsia.

Em outras palavras, a função do árbitro de eqüidade continua a exercer um efeito jurisdicional claro: a pretensão é dirimida de modo final, por sentença. A orientação do direito positivo brasileiro é particularmente incisiva nesse aspecto. Ao diferenciar arbitragem de direito e de eqüidade em seu art. 2.o, não há margem para dúvida sobre os efeitos idênticos entre as duas decisões. Portanto, não se trata de uma transação, mesmo que esta possa ter o efeito final de coisa julgada, tal como uma sentença arbitral. Mesmo que haja efeitos similares, são atos distintos: a transação pertence ao mundo dos contratos ou dos atos jurídicos bilaterais, conforme a classificação que se lhe dê; a sentença arbitral é um ato jurisdicional, com regime de impugnação próprio.

O direito comparado não parece mostrar divergência. No caso da Lei Modelo, a autorização para julgamento por eqüidade apresenta-se como uma forma de julgamento, uma das opções permitidas como critério. Sua escolha não implica mudança do regime da sentença arbitral, quer na sua forma, quer na sua eficácia, quer no modo de homologação, reconhecimento e anulação.

Mesmo nos países que não adotam a Lei Modelo, a solução não parece ser diferente. Na França, a questão já havido sido resolvida majoritariamente na doutrina antes do atual regime de arbitragem. ${ }^{274} \mathrm{O}$ novo regime, por seu turno, não trouxe nenhuma modificação que sugerisse qualquer diferença de tratamento.

Um caso de diferenciação legal parece ser a Colômbia, ${ }^{275}$ com a sua figura da amigable composición, que efetivamente é assemelhada a uma transação, inclusive com remissão expressa: "la decisión del amigable componedor producirá los efectos legales relativos a la transación”. No entanto, ela convive paralelamente com a arbitragem por eqüidade.

No caso dos países em que existem figuras "contratuais" de arbitragem, como o italiano, pode-se constatar algum caráter de transação, delegada a terceiros. No entanto, dentro da disciplina prevalente da arbitragem, essas variações "contratuais" não produzem o mesmo

274 Loquin, Eric. L'Amiable composition... cit., p. 69.

275 Veja-se a seção relativa a esse país no capítulo dedicado ao direito comparado. 
efeito de uma sentença arbitral. Mesmo porque, igualmente em tais países, a arbitragem jurisdicional por eqüidade existe paralelamente às arbitragens "contratuais".

Assim, um certo "ânimo transacional” da arbitragem por eqüidade pode às vezes integrá-la como um critério de decisão. Contudo, não retira o caráter jurisdicional dessa espécie de arbitragem. Ela continua a ser uma arbitragem, produzindo todos os seus efeitos e não os efeitos de uma transação.

\subsubsection{Arbitragem por eqüidade e mandato}

O mandato caracteriza-se pela outorga de poderes a um terceiro para que este, em nome do outorgante, pratique atos ou administre interesses. ${ }^{276}$ Sua característica principal é a representação. ${ }^{277}$

A aproximação da arbitragem por eqüidade de um mandato depende, em princípio, da amplitude que se queira ver no mandato. Partindo-se de uma perspectiva sociológica, até mesmo a jurisdição estatal pode ser considerada uma forma de mandato: no contrato social, os homens abdicaram de seu direito de vingança em favor do Estado, que toma para si o monopólio da força e a função de dirimir conflitos. Evidentemente, somente com licença de imagem figurada é que se haverá de cogitar de mandato neste caso.

Em um nível menos figurado, a arbitragem também pode ser vista como possuidora de elementos de um mandato. Neste caso, com maior propriedade, as partes escolhem diretamente um terceiro que irá solucionar a controvérsia entre elas. Pode-se vislumbrar aqui uma espécie de mandato conjunto para a decisão de uma controvérsia. Por outro lado, as previsões legislativas de arbitragem e de mandato são bastante diferentes. Em outras palavras, existe uma tipologia legal na maioria dos sistemas que não confunde a arbitragem com o mandato.

Ao estudar a diferença entre arbitragem e institutos próximos, inclusive o mandato, Motulsky afirma que a diferenciação, nem sempre clara, deve ser verificada na função exercida pelo terceiro. ${ }^{278}$ Se ele decide a controvérsia como um juiz, trata-se de arbitragem. Caso contrário, deve-se verificar em qual outra figura jurídica a tarefa se encaixa.

276 Código Civil, art. 653.

277 Essa parece ser também a orientação do direito francês. No direito alemão, a gratuidade é o seu elemento distintivo. Para um apanhado da doutrina sobre o mandato, veja-se SERPA LoPes, Miguel Maria de. Curso de direito civil, cit., v. 4, p. 310 e ss.

278 Motulsky, Henri. Écrits... cit., p. 23. 
Como já mencionado, o resultado final da atuação do árbitro em eqüidade é uma sentença arbitral, que como tal é executada. Caso haja uma clara escolha das partes por uma arbitragem, a ser julgada por eqüidade, trata-se de uma arbitragem. As partes não conferem ao terceiro um mandato, se não por uma licença de linguagem figurada. Por outro lado, caso haja na investidura do terceiro uma função de representação, pode-se vislumbrar a existência de um mandato.

Em certos casos em que as partes delegam a um terceiro a integração de algum elemento de um determinado negócio jurídico, pode-se aventar a existência de um mandato. Assim é o caso de fixação de preço ou de qualidade de determinado bem objeto do negócio. Todavia, nesta situação não se pode dizer que exista uma arbitragem propriamente dita.

No caso de determinadas espécies de arbitragens contratuais, como o arbitrato irrituale italiano, pode-se vislumbrar a atuação dos terceiros como de mandatários conjuntos das partes. $^{279}$

De qualquer forma, a principal característica diferenciadora entre a arbitragem propriamente dita e um eventual "mandato conjunto" é a natureza e forma de execução do seu resultado. Enquanto nos casos resultantes de mandato comum a execução de qualquer resultado final se dá na forma de um contrato ou de uma transação, a solução final de uma arbitragem será, em regra, executada como uma sentença.

O fato de haver um componente de eqüidade ou negocial (ambas fora do direito positivo $^{280}$ ) nas formas de integração do contrato aproxima-as, em seu critério de julgamento, da arbitragem por eqüidade. Conquanto a eqüidade aumente a liberdade dos árbitros, trazendo elementos negociais, transacionais ou mesmo conciliatórios, a tarefa do árbitro em eqüidade continua sendo a de decidir a controvérsia por sentença.

\subsubsection{Arbitragem por eqüidade e arbitramento}

Chamamos de arbitramento nesta obra as intervenções de terceiros nos negócios jurídicos de modo geral. ${ }^{281}$ Essa expressão também é utilizada no processo civil para determinar

279 Rubino-Sammartano, Mauro. Il diritto dell'arbitrato, cit., p. 81.

280 Veja-se, a respeito do caráter de eqüidade no arbitrato irrituale, a seção relativa à Itália no capítulo referente a legislações nacionais desta obra.

281 Carmona, Carlos Alberto. Arbitragem e processo, cit., p. 200 (referindo-se à diferença entre árbitros e arbitradores). 
uma forma de liquidação da sentença ${ }^{282}$ e não se confunde com a arbitragem. Como já visto, distinção entre a figura do árbitro e do arbitrador nem sempre é nítida ${ }^{283} \mathrm{e}$ tem relacionamento direto com a concepção de arbitragem que se adote.

Nos casos de arbitramento, os terceiros são chamados a intervir em determinados aspectos do negócio, tais como a qualidade dos bens entregues ou do serviço prestado. Em algumas circunstâncias, as opiniões desses terceiros podem modificar o preço e outros aspectos importantes do contrato. Esse tipo de intervenção, cujo resultado final é uma decisão que vincula as partes, tem sido considerado por alguns como arbitragem propriamente dita. ${ }^{284}$ Outros, porém, como já visto nesta obra, não a qualificam como arbitragem, em razão de sua execução como negócio jurídico e não como sentença. ${ }^{285}$ Mantendo-se a opção feita nesta obra, considera-se arbitragem apenas a solução de controvérsia de cunho jurisdicional.

Embora se tenha entendido que os arbitradores decidem por eqüidade ou de modo negocial, ${ }^{286}$ sua atuação não se confunde com a do árbitro de eqüidade, em vista da diferente natureza de sua função. Todavia, sempre que a função do terceiro puder ser considerada como arbitragem, então estar-se-á diante de uma arbitragem, em que se decide por eqüidade. Neste caso, a eqüidade aparece como um aspecto negocial próximo de um conteúdo transativo.

Assim, as mesmas conclusões das duas seções anteriores podem ser aplicadas às outras formas de integração do contrato. Em verdade, por vezes é difícil diferenciar uma categoria da outra. De qualquer modo, essa aproximação entre a decisão por eqüidade e certas formas de integração do contrato demonstra certo caráter transacional que a decisão por eqüidade pode adquirir em determinados casos, ainda que os institutos não se confundam. Esse caráter quasetransacional da eqüidade é apontado por alguns autores. ${ }^{287}$

${ }^{282}$ CPC, arts. 606 e 607. Determinados peritos são chamados de arbitradores, como na ação de demarcação (arts. 956, 957, 964, 965 e 966).

283 Para um apanhado sobre a questão, veja-se LEÃEs, Luiz Gastão Paes de Barros. Ensaio sobre arbitragens comerciais, cit., p. 19 e ss. Nessa obra, há remissão à questão do arbitrium merum e do arbitrium boni viri. No primeiro caso, haveria arbítrio pleno, segundo parte da doutrina. No segundo, haveria um elemento de eqüidade (ou uma obrigação de agir com eqüidade), o que possibilitaria sua revisão judicial, em caso de desatendimento desse elemento.

${ }^{284}$ DAVID, René. Arbitration... cit., p. 6.

285 Carmona, Carlos Alberto. Arbitragem e processo, cit., p. 200.

286 Para um apanhado sobre a questão, veja-se LeÃEs, Luiz Gastão Paes de Barros. Ensaio sobre arbitragens comerciais, cit., p. 19 e ss.

287 Loquin, Eric. L'Amiable composition... cit., p. 362 e ss. 


\subsubsection{Arbitragem por eqüidade e conciliação}

Alguns autores vêem alguma dificuldade em traçar a linha distintiva entre arbitragem e conciliação, justamente porque os árbitros às vezes são chamados a decidir conforme eqüidade ou outros princípios que não aqueles utilizados pelos juízes estatais. Também porque os árbitros por vezes tentam criar uma solução mutuamente aceitável às partes. ${ }^{288}$

Entretanto, existe um critério claro de distinção entre arbitragem por eqüidade e conciliação. Na conciliação, o conciliador apresenta uma solução que deve ser aceita pelas partes. Ela não tem efeito sem a concordância destas, embora possa haver formas de coação moral que tornem difícil uma parte rejeitar a proposta. A despeito de pressões não jurídicas, o elemento central da conciliação é sem dúvida a aceitação das partes. No caso da arbitragem, a solução dada pelos árbitros é final (eventualmente sujeita a anulação ou recurso, nos países que o permitem) e não depende da aceitação das partes. ${ }^{289}$

\subsubsection{Arbitragem por eqüidade e lex mercatoria}

A doutrina da chamada nova lex mercatoria pode ser definida, em brevíssima síntese, como a postulação da existência de uma ordem jurídica não-estatal, criada pela prática dos comerciantes internacionais, cujas repetição e aceitação no comércio internacional criam regras de direito, com força jurígena. ${ }^{290}$ Tal ordem jurídica nasceria da prática da sociedade internacional dos comerciantes e teria autonomia e especificidade suficientes para se impor como lei aplicável para a regência dos contratos do comércio internacional e solução das controvérsias deles decorrentes.

288 "It is more difficult to draw a clear distinction between arbitration and conciliation. Confusion may arise here from the fact that arbitrators are sometimes given the power to decide according to equity or may be directed to apply rules or legal principles other than the rules or principles which a judge would have to apply. Account must be taken also of the fact that arbitrators may be, in many cases, inclined to work out a decision which will be acceptable to all parties concerned." DavID, René. Arbitration... cit., p. 7. DAvid, René. Idem, ibidem, p. 7.

290 Há ampla bibliografia sobre a matéria. Entre elas, podemos citar, entre muitas outras: GolDMAN, Berthold. Frontières du droit et lex mercatoria. Archives de philosofie du droit, Paris, p. 177, 1964; La lex mercatoria dans les contrats et l'arbitrage internationaux: réalité et perspectives. Journal du Droit International, p. 475, 1979; Fouchard, Gaillard e Goldman. Traité de l'Arbitragem Commercial International, cit., p. 813 e ss.; TAVAres Guerreiro, José Alexandre. Fundamentos da arbitragem do comércio internacional, cit., p. 83 e ss.; Kassis, Antoine. Théorie Generale des Usages du Commerce. Paris: LGDJ, 1984. p. 268 e ss.; Lagarde, Paul. Approche Critique de la Lex Mercatoria. Mèlanges Goldman. Paris: Librairies Techniques, 1982. p. 125-149 e ss.; Mustill, M. The new Lex Mercatoria: the first twenty-five years. Arbitration International, 4(2), p. 86 e ss., 1987; Huck, Hermes Marcelo. Sentença estrangeira e lex mercatoria. São Paulo: Saraiva, 1994. MAGALHÃes, José Carlos de. Direito econômico internacional. Curitiba: Juruá, 2005. p. 283 e ss. 
Seu caráter fortemente consuetudinário, sua criação pela própria classe dos praticantes do comércio internacional (sem maior mediação política dos Estados) e o fato de seu campo primordial de aplicação ser a arbitragem comercial fizeram com que autores renomados a vissem como uma nova versão do ius mercatorum medieval. ${ }^{291}$

291 No que diz respeito especificamente à lex mercatoria, o efeito mais importante do fenômeno da globalização parece ser uma espécie de pluralismo jurídico decorrente da intersecção de fluxos econômicos, de transnacionalização dos mercados e das cadeias produtivas. A cadeia produtiva passa a ter caráter transnacional (fugindo, portanto, do âmbito da regulação de apenas um Estado nacional), passando os organismos multilaterais e os conglomerados transnacionais, as instituições financeiras internacionais a adquirir um certo poder de criação de regras, de algum modo concorrente com aquele do poder soberano estatal.

Essa espécie de erosão do monopólio estatal possibilitou a criação de focos alternativos de regulações jurídicas, que se colocam em posição de concorrência com o direito positivo ditado pelo Estado. Segundo Faria, esse pluralismo se dá na "perspectiva da sobreposição, articulação, intersecção e interpenetração de vários espaços jurídicos misturados" (Faria, José Eduardo. O direito na economia globalizada. São Paulo: Malheiros, 2002. p. 155).

O mesmo autor (p. 158) aponta os seis principais modos de poder na vida social: (i) produção, formado pelas relações industriais, comerciais e financeiras e trabalhistas no âmbito do sistema econômico; (ii) mercado, constituído pelas relações de distribuição e consumo das mercadorias e serviços; (iii) comunitário, formado pelas relações de vizinhança e associativas, reproduzindo identidades étnicas e culturas; (iv) cidadania, constituído pelas relações cidadãos-Estado na esfera pública; (v) mundialidade, formado pelas relações econômicas e políticas no nível internacional, que são determinadas pela posição ocupada por cada sociedade no sistema mundial, com seu peso específico próprio; e (vi) o espaço doméstico, onde se dão as relações de parentesco.

Para os fins do presente estudo, a vertente internacional do poder na vida social interessa mais. Neste espaço "a unidade prática social é o Estado-nação; a forma institucional é o conjunto de organismos multilaterais (como o Banco Mundial, o Fundo Monetário Internacional, o Banco de Compensações Internacionais, a Organização Mundial do Comércio, a Organização para Cooperação e Desenvolvimento Econômico etc.); o mecanismo de poder é expresso pela desigualdade das trocas comerciais e das relações financeiras; a forma jurídica é dada pelas relações entre o Direito Internacional com a Lex Mercatoria, ou seja, o corpo autônomo de usos, costumes, princípios regras e contratos constituído espontânea e pragmaticamente pelas sucessivas gerações da comunidade empresarial para autodisciplinar suas atividades sem interferências dos Estados-nação; dito de outro modo, a forma jurídica deste espaço é um 'direito sistêmico' (no sentido da economia-mundo ou do sistema-mundo), formado tanto pelas convenções e tratados internacionais quanto, principalmente, pelas redes de acordos informais firmados por instituições financeiras e empresas transnacionais; o modo de racionalidade é de natureza eminentemente material, traduzida pela maximização da eficiência; e a forma epistemológica é condicionada pela expansão da ciência e da tecnologia, bem como por valores universalizantes" (Faria, José Eduardo. Op. cit., p. 158).

Embora esta globalização seja normalmente localizada a partir da década de 1980, é importante, para os fins do presente trabalho, mencionar o movimento de descolonização ocorrido a partir do fim da Primeira Guerra Mundial e acelerado após o fim da Segunda, em que houve o surgimento de uma plêiade de novos Estados soberanos, que criaram novos mercados e ordenamentos jurídicos autônomos e receberam investimentos estrangeiros (em grande medida de suas antigas metrópoles). Os grandes investimentos dos países capitalistas centrais nos novos países, que exigiam a submissão dos contratos aos novos direitos nacionais, geraram os conflitos que vieram a desembocar no movimento para a criação de uma nova lex mercatoria e que tornaram a arbitragem internacional o modo solução de controvérsias preferencial em tal espécie de conflitos. Com efeito, as questões relativas às nacionalizações do petróleo nas décadas de 50, 60 e 70 representam a afirmação da arbitragem como meio de solução de controvérsias e a criação prática da doutrina da chamada nova lex mercatoria.

Há autores que apontam que o advento da sociedade da informação (ou sociedade pós-industrial) não ocasionou profundas mudanças legislativas. Isso porque a lei não mais é o instrumento pelo qual as mudanças jurídicas ocorrem, mas sim o contrato (GALGano, Francesco. Lex Mercatoria, cit., p. 232). Assim, a sociedade civil organiza-se nos espaços não ocupados pelo Estado. No âmbito do comércio internacional, o advento de novas figuras contratuais (normalmente advindas de países da common law), a uniformização de contratos e cláusulas (como o caso dos Incoterms da Câmara de Comércio Internacional) e outros contratos-tipo e a jurisprudência arbitral são claros produtos desta atividade. 
Por outro lado, a escolha da decisão por eqüidade tem por efeito liberar os árbitros da aplicação estrita da lei, ressalvada a ordem pública. A obrigação dos árbitros é decidir a controvérsia conforme lhes pareça justo, independentemente das regras de direito positivo. Todavia, podem aplicá-lo caso lhes pareça equitativo. Podem aplicar, também, outras regras não estatais que lhe pareçam justas, como o costume ou regras corporativas.

A quebra da obrigatoriedade do direito estatal proporcionada pela eqüidade foi um dos vetores da criação da lex mercatoria dentro de um contexto de monismo jurídico. Com efeito, alguns autores de renome como Goldman e Kahn defenderam que a escolha da arbitragem por eqüidade deveria ser interpretada como uma remissão direta aos princípios do comércio internacional. ${ }^{292}$ Outros autores reconhecem que a referência à eqüidade foi uma das portas para a aplicação dos usos e costumes do comércio internacional. ${ }^{293}$ Em outra obra, Goldman, embora reconheça que em princípio a eqüidade não indique diretamente a lex mercatoria, defende a aplicação desta:

Prima facie, cette clause dispense l'arbitre de se référer à toute règle de droit,
quelle qu'elle soit; ainsi interprétée, elle ne designe pas la lex mercatoria,
dont on n'entend pas faire du non-droit, mais um ensemble, fût-il incomplet,
de règles de droit. Mais il est legitime d'admettre que la référence à l'équité,
ou sous une autre forme, la mission qui lui est conférée de statuer ex ae-
quo et bono, doi conduire l'arbitre, amiable compositeur, à tenir compte dês
príncipes généraux du droit et des pratiques du commerce international; ainsi
interprétée, la clause d'amiable composition peut être considérée comme dé-
signant implicitement la lex mercatoria.

Em verdade, trata-se em alguma medida de uma deformação do uso da eqüidade, ${ }^{295}$ pois esta implica a busca de regras eqüitativas para a solução da controvérsia, sem remissão necessária ao direito positivo. A aplicação da lex mercatoria, de outra parte, é a referência a regras emanadas de um determinado grupo social e não implica, por si só, que suas regras tragam a solução eqüitativa ao caso concreto. Não há possibilidade de identificar, ontologicamente, a nova lex mercatoria com a "justiça no caso concreto". 296

292 Apud LoQuin, Eric. L'Amiable composition ... cit., p. 319-320.

293

Entre outros, Derains, Yves. Chronique de Jurisprudence de la CCI. Clunet, 1975.

294 Goldman, Berthold. La lex mercatoria... cit., p. 481.

295 Loquin, Eric. L'Amiable composition... cit., p. 319.

296 Lando, Ole. The Lex Mercatoria in International Commercial Arbitration. International Comparative Law Quarterly, n. 34, p. 754, 1985: "some of the authors who oppose the parties' right to choose the lex mercatoria will permit them to agree on amiable composition or decisions based on equity. This is, however, a yet more uncertain basis than the lex mercatoria. In spite of common traits, there is a difference between the lex mercatoria and equity. The lex mercatoria obliges the arbitrator to base his decision on the law merchant even when equity might lead him to another result". 
Para os defensores da nova lex mercatoria, esta afigura-se como uma ordem jurídica ou ao menos um conjunto de regras emanadas de uma dada comunidade. Neste sentido, deve ser considerada como direito positivo, quer na forma de princípios gerais, quer na forma de norma consuetudinária. Um direito anacional, para utilizar a expressão dos autores franceses. Logo, tais normas também são passíveis de derrogação por parte dos árbitros investidos de poderes para decisão por eqüidade: sempre que alguma disposição da lex mercatoria conduza a uma solução iníqua, poderá ser desconsiderada.

Portanto, os árbitros não têm obrigação direta de aplicação da lex mercatoria (ou princípios gerais do comércio internacional) quando as partes de um contrato tenham convencionado que a decisão das controvérsias se dará por eqüidade. No entanto, nada impede que a decidam aplicar, caso essa lhes pareça a solução eqüitativa para a controvérsia.

Na prática, contudo, existe alguma aproximação entre a arbitragem por eqüidade e a aplicação de princípios gerais do comércio internacional. ${ }^{297}$ A prática da arbitragem comercial internacional oferece exemplos de aplicação de princípios gerais do comércio internacional ou da chamada lex mercatoria em casos nos quais os árbitros são autorizados a decidir por eqüidade, mesmo sem nenhuma referência a eles como expressão da solução eqüitativa para o caso concreto.

Podemos citar os casos CCI n. $1.850^{298}$ e $1.337,{ }^{299}$ em que o árbitro se recusou a aplicar a lex mercatoria na ausência de autorização por eqüidade. Nestes casos, houve assimilação dos conceitos. No caso CCI n. 5.616, ${ }^{300}$ as partes atribuíram ao tribunal a determinação da lei aplicável. Embora considerando que não seria estritamente necessário decidir a lei no caso concreto, o tribunal adota os princípios geralmente aceitos do direito das relações contratuais. No caso CCI n. 3.540, ${ }^{301}$ o tribunal resolve aplicar a lex mercatoria, por entender que a eqüidade indicaria "implicitamente" à vontade de submeter o litígio aos princípios do comércio internacional. No caso CCI n. 5.587/ES, ${ }^{302}$ de 1992, o tribunal decide aplicar a lex mercatoria, esclarecendo que ela não se confunde com eqüidade. Na sentença parcial do caso CCI n. $3.267,{ }^{303}$ de 1979 , o tribunal decide que, uma vez investido do poder de decidir por eqüidade, não precisa decidir direito aplicável; todavia, afirma que "will apply the the widely accepted general principle go-

297 Berger, Klaus Peter. International Economic Arbitration, cit., p. 568.

298 LoQuin, Eric. L'Amiable composition... cit., p. 325

299 Idem, ibidem, p. 326.

300 Inédito.

301 ICC Arbitral Awards. Recueil des Sentences Arbitrales de la CCI. Boston: Taxation Publishers, 1990, p. 399.

302 Inédito.

303 Idem, ibidem, p. 76. 
verning commercial international law with no specific reference to a particular system of law". No caso n. 9.679/DK, ${ }^{304}$ o tribunal afirma que, como o contrato é internacional, sua validade é regida pelos princípios gerais do direito internacional.

Um exemplo interessante é citado por Loquin, ${ }^{305}$ sobre a Câmara Arbitral de Estrasburgo, destinada à solução de litígios do comércio de frutas. Pelo regulamento daquela Câmara, os árbitros teriam sempre autorização para decidir por eqüidade, salvo estipulação contrária das partes. Em pesquisa de dez anos de sentenças arbitrais, apenas uma fez referência à eqüidade propriamente dita para a solução do litígio. Todas as outras aplicaram os usos da respectiva cooperativa (COFREUROP). Portanto, verifica-se que o recurso à eqüidade serviu apenas para descartar o direito estatal e a aplicação das normas corporativas, sem maiores preocupações com o "justo no caso concreto".

Assim, dentro de um contexto de monismo jurídico, a arbitragem por eqüidade foi uma primeira "válvula de escape" para a aplicação da lex mercatoria, em oposição aos direitos nacionais. Serviu do mesmo modo para afastar resistências que o meio jurídico pudesse ter contra a aplicação de um direito não estatal, que também sofria resistências de ordem psicológica, conforme apontado por René David. ${ }^{306}$ Ao possibilitar tal aplicação, a decisão por eqüidade foi a forma de forjar um corpus do que se veio a chamar de lex mercatoria, pela via de sua jurisprudência. $^{307}$

No contexto inicial da criação doutrinária da lex mercatoria, esta não possuía a autonomia de "direito positivo" que hoje boa parte da doutrina lhe confere. Posteriormente, a lex mercatoria veio a ganhar aplicação na arbitragem como conjunto de regras autônomas. Essa aplicação passou a se dar quer pela via da escolha direta pelas partes, ou pela ausência de escolha de lei estatal, fazendo com que os árbitros, dentro da chamada "via direta", aplicassem os princípios do comércio internacional em vez de um direito nacional.

À medida que a lex mercatoria ganhou aceitação e conteúdo, a eqüidade deixou de ser necessariamente o veículo de sua criação. Logo, deixou de ter importância como meio de aplicação da lex mercatoria $a^{308}$ e pôde voltar ao seu uso original, qual seja a decisão com base no senso de justiça dos árbitros escolhidos pelas partes, podendo descartar as regras de direito

304 Inédito.

305 LoQuin, Eric. L'Amiable composition... cit., p. 321.

306 Apud Loquin, Eric. L'Amiable composition... cit., p. 331.

307 Fouchard, Gaillard e Goldman. Traité de l'Arbitragem Commercial International, cit., p. 851.

308 Idem, ibidem, p. 851, e LoQuin, Eric. L'Amiable composition... cit., p. 338. 
positivo em prol do eqüitativo, inclusive da própria lex mercatoria, para aqueles que a consideram como regra de direito.

\subsubsection{Arbitragem por eqüidade e equity}

Como visto, na língua inglesa as cláusulas de arbitragem por eqüidade são por vezes referidas como equity clauses. ${ }^{309}$ Em outras vezes, fala-se em decisão conforme equity. ${ }^{310}$ Todavia, as expressões ex aequo et bono e amiable composition parecem ser predominantes. Existe uma diferença entre a eqüidade como se conhece nos países de direito romano-germânico e a equity dos países de common law.

A menção a equity, no sistema de common law, refere-se a um sistema jurídico elaborado, que não pode ser igualado ao significado da eqüidade nos países de tradição romana. Uma breve menção à experiência da common law inglesa (com a respectiva irradiação nas colônias daquele país) justifica-se pelo peculiar desenvolvimento da equity pelas cortes da chancelaria. ${ }^{311}$

As origens do moderno direito inglês remontam à conquista normanda da Inglaterra em 1066. Antes de tal conquista, o sistema jurídico inglês era essencialmente baseado no costume local, aplicado por assembléias locais, depois substituídas por tribunais de senhores feudais (Courts Baron, Manorial Courts, etc.). Embora houvesse alguma legislação escrita no direito anglo-saxão anterior à conquista normanda, ele era essencialmente baseado no costume local e não escrito.

Com o domínio normando, criou-se um poder central, que permitiu a existência de tribunais reais superiores, com jurisdição sobre todo o país. Estes tribunais, que vieram a se fixar em Westminster, serão os órgãos criadores do direito comum, em um processo que durará

309 Mustill, Michael J.; Boyd, Stewart. The law and practice... cit., p. 605. RedFern, Alan; Hunter, Martin. Law and practice... cit., p. 127.

310 VÁrady, Tibor; Barceló, John J.; Von Mehren, Arthur T. International commercial arbitration... cit., p. 558.

311 Para um exame detalhado da equity, veja-se: SOARES, Guido Fernando Silva. Common law: introdução ao direito dos EUA. São Paulo: RT, 2000. p. 32 e ss. DAVID, René. Grandes sistemas de direito contemporâneo. 4. ed. São Paulo: Martins Fontes, 2002; O direito inglês. 2. ed. São Paulo: Martins Fontes, 2006. FriedmanN, Wolfgang. The contribution of English equity to the ideal of an international equity tribunal. London: Constable \& Co., 1935. Davies, J. Derek. Equity in English Law. In: Newman, Ralph (Ed.). Equity in the world's legal systems: a Comparative Study. Brussels, Établissements Émile Bruylant, 1973, p. 159. SEFton-Green, Ruth. Les Genèses de l'Équité dans le Common Law. L'Équité ou les Équités: Confrontation Occident et Monde Arabe. Paris/Beyrouth, Societé de Législation Comparée, 2003, p. 65. 
séculos. Neste desenvolvimento, os demais órgãos de jurisdição foram desaparecendo e as cortes reais, embora tivessem competência mais ou menos restrita, afirmaram-se como os órgãos jurisdicionais por excelência.

Contudo, o desenvolvimento do direito comum derivou de procedimentos excessivamente formalistas, distanciando-o das necessidades sociais surgidas e criando uma espécie de "esclerose" decorrente da rotina de sua prática. Tal descompasso com a realidade social levou a uma percepção generalizada de injustiça de suas decisões.

As partes derrotadas podiam recorrer ao rei que, "fonte de justiça", tinha prerrogativas de sobrepor-se a decisão de suas cortes. O recurso ao rei era geralmente feito por intermédio do chanceler, que o transmitia ao soberano, conforme achasse oportuno. Com o passar do tempo, o uso de tal prerrogativa do rei institucionalizou-se e a função foi delegada diretamente ao chanceler, que passou a ter uma função eminentemente judicial. Criaram-se, assim, os Tribunais da Chancelaria, que tinham por função a decisão com base na eqüidade.

Muitos autores assimilam a função dos tribunais de eqüidade à dos pretores romanos do período republicano, relativamente ao antigo ius civile. Houve uma obra criativa de adaptação de um direito arcaico a novas realidades sociais. Essa criação romana, que operou com base na eqüidade, deu origem ao ius gentium e foi uma forma importante de criação de direito que seria posteriormente reconhecido como positivo.

No desenvolvimento histórico da dualidade entre tribunais de common law e tribunais de eqüidade, havia diferenças de procedimento e de direito material. A jurisdição de eqüidade baseava-se em uma maior liberdade (e discricionariedade) por parte do chanceler. Entretanto, por conta da reação das cortes de common law e da crítica à arbitrariedade das cortes de chancelaria, o sistema das cortes de eqüidade passou a ser, cada vez mais, um sistema baseado em seus precedentes, com menor poder criativo e menor poder de intervenção vis-à-vis a common law.

Essa assimilação da jurisdição de eqüidade a um sistema mais ou menos previsível baseado em precedente é importante para marcar a diferença entre a experiência dos países de direito consuetudinário e o conceito atual de eqüidade. Não obstante a eqüidade possa ter outras funções, uma delas é a de substituição do direito positivo. Embora a equity tenha começado com esta função, pode-se afirmar que hoje ela opera como um sistema elaborado de regras (ainda que pautadas em precedentes e em máximas bastante gerais) e não mais pode ser vista como uma substituição em prol da justiça "no caso concreto", mas sim como um sistema normativo positivo, colocado paralelamente ao direito comum. Atualmente, existe uma divisão de matérias entre common law e equity, variando entre EUA e Inglaterra. Dependendo da matéria 
de fundo ou, em alguns casos, do tipo de provimento que se pede, far-se-á recurso à equity ou à common law.

No final do século XIX, com a edição dos judicature acts, em primeiro lugar foi permitido que os tribunais de common law pudessem conceder remédios originários da equity. Posteriormente, em 1875 foram unificadas as cortes, sendo extintas as cortes exclusivas de equity. Nos Estados Unidos, contudo, alguns Estados ainda mantêm cortes de equity distintas das cortes de common law. É o caso de Montana e Delaware.

\subsubsection{Arbitragem por eqüidade e ausência de escolha de lei}

Uma posição instigante sobre a arbitragem por eqüidade foi apresentada por um autor na doutrina internacional. Antoine Kassis, ${ }^{312}$ ao examinar o direito francês de arbitragem, afirma que a simples ausência de escolha de direito pelas partes, na arbitragem internacional, é suficiente para que os árbitros decidam por eqüidade. Aquele autor fundamenta sua opinião no art. 1.496 do Código de Processo Civil francês que dispõe que, caso as partes não tenham escolhido o direito aplicável, os árbitros aplicam as regras que entenderem convenientes. Ao conferir tal liberdade, o legislador não especificou quais regras devem ser aplicadas: podem ser estatais, transnacionais ou mesmo criadas para o caso concreto.

Assim, em vista de tal liberdade, o árbitro internacional sem escolha de lei seria um árbitro em eqüidade ex natura. Em favor de sua posição, invoca a autoridade de Loussouarn, Lagarde, Perrot e Derains, em discussões do Comitê Francês de Direito Internacional Privado, ao afirmarem que, considerando a tamanha liberdade conferida aos árbitros internacionais no que diz respeito às regras de mérito da controvérsia, a arbitragem por eqüidade perde muito de sua utilidade. ${ }^{313}$

Com todo o respeito à opinião de um autor prolífico e aguerrido, entendemos que ela não pode ser admitida na arbitragem comercial internacional. Por maior liberdade que o árbitro disponha para a escolha do direito aplicável, ele não pode decidir por eqüidade sem autorização das partes (exceto nos poucos casos de presunção de arbitragem por eqüidade). A Lei Modelo é expressa nesse sentido. Ademais, em caso de ausência de escolha das partes, a Lei Modelo

312 L'Autonomie de l'Arbitrage Commercial International: le Droit Français en Question. Paris: L'Harmattan, 2005. p. 361 e ss.

313 Idem, p. 364-365. 
determina que os árbitros apliquem o direito (law) conforme a lei de conflito que entenderem mais conveniente. Essa é a solução de outros direitos, tais como o brasileiro ou o inglês.

Por mais que a liberdade de escolher regras transnacionais reveladas pelo próprio tribunal possa se assemelhar a uma decisão por eqüidade na prática, elas restam ainda como situações diferentes, como já demonstrado na seção relativa à lex mercatoria. No caso da arbitragem por eqüidade, existe a possibilidade de decisão sem nenhuma remissão a regras preexistentes. Ao contrário, pode-se decidir a partir de um juízo de fato. No caso de aplicação de regras preexistentes, qualquer que seja sua origem, existe uma "mecânica decisória" distinta.

Caso se entenda que o direito francês autoriza os árbitros a criar regras específicas que entendam apropriadas, talvez se possa falar em uma aproximação de fato entre a ausência de escolha de direito e a arbitragem por eqüidade. Todavia, ela não pode ser transposta à arbitragem internacional, no atual estágio de elaboração legislativa. A arbitragem por eqüidade, em seu caráter excepcional, continua a exigir autorização específica das partes, ainda que de modo mais ou menos informal. Essa é, ademais, a interpretação mais conforme ao respeito à vontade das partes.

\subsubsection{Arbitragem por eqüidade e decisão sem recurso}

Nos direitos em que se permitem recursos contra decisões arbitrais, houve discussões acerca da assimilação da arbitragem por eqüidade e uma decisão sem recurso. ${ }^{314}$ A idéia existente sob tal assimilação é a de que, ao excluir qualquer revisão da sentença arbitral quanto ao mérito, as partes implicitamente aceitam qualquer decisão dos árbitros. Estes, por sua vez, são colocados fora de qualquer escrutínio judicial, e sua decisão será definitiva independentemente como seja dada.

A despeito de ter havido tal assimilação no passado, ela não prevalece. Com efeito, tal assimilação desconsidera a missão atribuída aos árbitros. Como bem observado por Mezger ${ }^{315}$ e Loquin, ${ }^{316}$ o fato de as partes excluírem recurso significa que elas não desejam que um juiz estatal examine e substitua o que os árbitros decidiram. O risco inerente a esta escolha é o de que eventuais erros do tribunal arbitral na aplicação da lei não serão corrigidos. Todavia, essa

\footnotetext{
314 Mezger, Ernst. La Distinction entre l'Arbitre Dispensé d'Observer la Règle de la Loi et l'Arbitre Statuant sans Appel. Liber Amicorum Martin Domke. The Hague: Martinus Nijhoff, 1967. p. 184.

315 Idem, ibidem.

316 Revue de l'Arbitrage, n. 3, p. 549, 1980.
} 
assunção de risco não significa que decidiram abrir mão da aplicação do direito positivo. Tal vontade deve ser feita de modo expresso e específico.

\subsection{Da contratação da arbitragem por eqüidade}

Tal como a contratação da arbitragem em geral, a contratação da arbitragem por eqüidade possui requisitos específicos. Sua especificidade, porém, acarreta questões particulares, que não necessariamente serão dirimidas da mesma forma que a cláusula de arbitragem em geral. Em verdade, um primeiro passo para essa distinção é qualificar a própria cláusula de escolha de eqüidade em relação à cláusula arbitral. Nesta seção, pretende-se discutir os aspectos envolvidos na contratação da arbitragem por eqüidade: sua qualificação, a lei aplicável, o tempo e a forma. Por fim, pretende-se discutir se o Estado pode participar de arbitragens por eqüidade.

\subsubsection{Da Lei aplicável à escolha da arbitragem por eqüidade}

A questão da lei aplicável à arbitragem é delicada e controversa. Há ao menos quatro momentos em que, no plano internacional, diferentes ordens jurídicas podem intervir: na convenção de arbitragem, no procedimento arbitral, no mérito da disputa e na execução da sentença. Em cada uma delas, poderá existir uma aplicação de lei distinta.

a) Qualificação da cláusula de arbitragem por eqüidade

Uma questão preliminar impõe-se na definição de qual lei rege a escolha da arbitragem por eqüidade: à qual fase da arbitragem essa cláusula está ligada? Embora a cláusula de arbitragem por eqüidade seja, conforme demonstrado acima, uma cláusula de escolha de critério de julgamento, ela tem efeitos no procedimento e no mérito da questão.

Assim, a qual parte do "fenômeno" da arbitragem está relacionada a cláusula de arbitragem por eqüidade? Há três hipóteses possíveis: à convenção de arbitragem, ao procedimento arbitral ou ao fundo da controvérsia. Essa qualificação é fundamental para se decidir qual a lei a ela aplicável.

Os textos legislativos e regulamentos de instituições pouco esclarecem sobre essa natureza, embora haja algumas referências esparsas. Nelas, a questão é remetida ou à lei aplicável 
à arbitragem ou à lei aplicável ao procedimento. ${ }^{317} \mathrm{O}$ único texto legislativo encontrado que apresenta uma regra material de qualificação da cláusula de arbitragem por eqüidade é a Convenção de Genebra, colocando-a no âmbito da "lei aplicável à arbitragem".

A doutrina diverge sobre a questão. Em seu estudo sobre a matéria, Eric Loquin ${ }^{318}$ apresenta tal desacordo, mostrando que parte dos autores coloca a cláusula de arbitragem por eqüidade no domínio do procedimento, outros, no âmbito da lei aplicável ao mérito, ao passo que outros ainda a colocam sob o mesmo regime da convenção de arbitragem. O mesmo autor afirma, com razão, que nenhuma dessas posições pode ser descartada em princípio.

A cláusula de arbitragem por eqüidade tem influência clara no procedimento arbitral. Em algumas legislações nacionais, ela modificará o procedimento a ser seguido. Igualmente, terá influência na forma em que os pedidos serão julgados e no comportamento processual das partes. Além disso, certos poderes que o árbitro em eqüidade pode utilizar na sua decisão afiguram-se eminentemente processuais, como o modo de conduzir a instrução ou eventualmente uma maior liberdade concernente aos prazos.

Também é inegável que a arbitragem por eqüidade relaciona-se com o mérito da questão. Sem nenhuma dúvida, o principal efeito de uma cláusula de arbitragem por eqüidade se dá no nível da solução aplicável ao fundo. No entanto, essa aplicação ao fundo da controvérsia cria, como muito bem notado por Loquin, um paradoxo: a utilização da arbitragem por eqüidade serve, precipuamente, para o fim de liberar a decisão de fundo da aplicação de um direito positivo. Sujeitar a disciplina da cláusula de eqüidade a uma lei que a mesma cláusula tende a derrogar não se mostra uma boa solução.

A própria arbitragem por eqüidade representa um desejo de não-aplicação de uma lei estatal, em favor de outro critério de julgamento. Ora, sujeitar a cláusula de arbitragem por eqüidade a uma lei aplicável ao fundo parece ir contra o desejo das partes, além de impor o inconveniente de obrigar os árbitros a uma tarefa penosa de descobrir a lei aplicável ao mérito, quando as partes não a definiram.

317 No regulamento de arbitragem da CNUDCI, existe previsão expressa de que a arbitragem por eqüidade será permitida desde que a lei aplicável ao procedimento arbitral o permita. No caso da Convenção de Genebra de 1961, fala-se apenas que a arbitragem por eqüidade será possível caso assim permita a "lei aplicável à arbitragem". Dada a evolução legislativa da época em que foi elaborada a Convenção, é possível que ela tenha por escopo a lei do local da arbitragem. No caso das regras relativas à "Additonal Facility" da mesma do CIRDI/ ICSID, há referência decisão por eqüidade caso permita a lei aplicável à arbitragem. A Convenção do Panamá possui uma regra segundo a qual, caso as partes não escolham o regulamento de arbitragem, aplicam-se as regras da Comissão Interamericana de arbitragem comercial. Tais regras permitem a arbitragem por equiidade caso as partes e a lei aplicável ao procedimento permitirem.

318 Loquin, Eric. L'Amiable composition... cit., p. 179 e ss. 
Por outro lado, existe inegavelmente uma relação entre a cláusula de arbitragem por eqüidade e a própria convenção de arbitragem. Embora não possam ser confundidas, não há dúvida de que a cláusula de arbitragem por eqüidade será responsável por definir em boa medida o alcance da convenção arbitral, o "conteúdo dos poderes do árbitro". ${ }^{319}$

Loquin $^{320}$ situa a cláusula no âmbito da convenção de arbitragem porque, a despeito dos efeitos que ela tenha sobre o procedimento, não é uma disposição tendente a organizar o procedimento ou mesmo a determinar as regras aplicáveis ao mérito. Segundo aquele autor, ela é uma renúncia convencional a certas prerrogativas, como de resto a cláusula e o compromisso podem ser interpretados como uma renúncia à competência dos tribunais estatais.

A nosso ver, a colocação da cláusula de arbitragem por eqüidade no âmbito da convenção de arbitragem parece ser a solução mais correta, sem prejuízo de seus efeitos relativos ao procedimento e ao mérito e da influência da legislação do foro.

No entanto, o fazemos por razões distintas daquelas apresentadas por Eric Loquin. A nosso ver, a arbitragem por eqüidade é uma espécie do gênero arbitragem. Não obstante sua qualificação seja a da escolha de um critério de julgamento, parece-nos inegável que ela configure uma espécie de complemento da convenção de arbitragem. Ela completa o alcance da convenção, especificando o sentido desta em uma de suas modalidades. Nas palavras já citadas de Goldman, ela trata do conteúdo dos poderes dos árbitros. ${ }^{321}$

Ou seja, ela é um elemento adicional (e facultativo) da cláusula de arbitragem, especificando seu sentido e sua forma de atuação: define um critério de julgamento, confere certos poderes excepcionais aos árbitros, estabelece certas particularidades de procedimento, etc.

Não cremos que um eventual elemento central de renúncia seja necessário para essa conclusão. Não nos parece que o fato de a própria cláusula de arbitragem poder ser considerada uma renúncia à jurisdição estatal seja a causa essencial de sua aproximação com a escolha da arbitragem de eqüidade.

De outra parte, deve-se considerar a questão dos países do "sistema hispano-americano". De acordo com a legislação desses países, a simples escolha da arbitragem indica a

319 Goldman, Berthold. Encylopedie Dalloz apud Loquin, Eric. L'Amiable composition... cit., p. 178.

320 LoQuin, Eric. L'Amiable composition... cit., p. 178-179.

321 Em sentido idêntico, sentença arbitral romena, que liga a cláusula de arbitragem por eqüidade à cláusula de arbitragem: Journal du Droit International, n. 2, p. 475, 1988. 
escolha de decisão por eqüidade, salvo convenção em contrário. Portanto, não se pode falar propriamente em cláusula de arbitragem por eqüidade, a menos que assim se considere a própria cláusula arbitral. Nestes casos, parece haver uma regra material derivada de lei do local da arbitragem, que incide diretamente sobre o procedimento e a decisão. Portanto, este sistema encontra-se apartado da qualificação aqui apresentada. A escolha de eqüidade decorre de regra material estatal.

b) Critérios para a escolha de lei aplicável

Definida a cláusula de arbitragem por eqüidade como ligada à convenção de arbitragem, resta a difícil questão da legislação a ela aplicável. Existem, essencialmente, dois aspectos nessa discussão: a lei aplicável à validade formal da cláusula arbitral e a lei aplicável à chamada validade substantiva ou substancial da cláusula (também chamada essencial). ${ }^{322}$

No primeiro caso, como a denominação indica, trata-se dos requisitos de forma da cláusula arbitral. Em geral, essa disciplina refere-se à forma (escrita) e à prova da convenção. O principal texto internacional sobre a arbitragem, a Convenção de Nova Iorque, prescreve a forma escrita com a qual ela será aferida. Todavia, mesmo tal previsão tem suscitado várias dúvidas na doutrina: aplicam-se as leis nacionais para a aferição do que seja forma escrita? A cláusula arbitral inserida em contrato aceito tacitamente é válida, ou, por faltar anuência expressa, considera-se-a ineficaz? Além disso, a despeito do regime previsto na Convenção de Nova Iorque, nada impede que regimes nacionais sejam mais favoráveis do que a própria Convenção. ${ }^{323}$

No que diz respeito à chamada validade substancial da cláusula arbitral, discutem-se as questões relativas ao alcance da cláusula, tais como a arbitrabilidade objetiva e subjetiva. Em outras palavras, devem atender às seguintes questões: (i) a cláusula foi validamente concluída? (ii) as partes tinham capacidade para contratar a arbitragem? (iii) A disputa pode ser dirimida por arbitragem?

322 Lew, Julian D. M. The Law Applicable to the Form and Substance of the Arbitration Clause. In: VAn Den Berg, Albert Jan (Ed.). ICCA Congress Series. The Hague: Kluwer Law International, 1999. n. 9, p. 114 e ss.

323 Veja-se Fouchard, Gaillard e Goldman. Traité de l'Arbitragem Commercial International, cit., p. 388. Todavia, convém ressaltar que alguns autores, como Jan van den Berg, estimam que a utilização de um regime mais liberal do que o da Convenção de Nova Iorque pode ter como efeito a impossibilidade de utilização do regime da Convenção para outros aspectos. Assim, caso se proceda a uma arbitragem com base em uma cláusula inválida pelo regime da Convenção de Nova Iorque, não se poderia buscar a execução da sentença com base neste mesmo regime, pois trata-se de situação não coberta pela Convenção (ou seja, trata-se de uma arbitragem fora de seu regime). Essa posição não é unânime, todavia. Para um exame mais detalhado da controvérsia, veja-se Fouchard, Gaillard e Goldman. idem, p. 390. 
Em ambos os aspectos, existem dois enfoques "básicos" que podem variar conforme a questão se coloque perante um tribunal nacional ou um tribunal arbitral. ${ }^{324}$

Em princípio, tribunais estatais tenderão a solucionar as questões de acordo com o direito internacional privado do país. Por outro lado, tribunais arbitrais internacionais, os quais boa parte da doutrina reconhece como sem "foro" no sentido clássico da palavra, podem tanto adotar regras de conflito de sua preferência como decidir diretamente a lei aplicável sem referência a qualquer regra de conflito. Neste caso, temos uma posição "conflitualista" e uma posição chamada de "método de regras materiais", 325 pela qual os árbitros buscam certas "regras materiais transnacionais" para reger a convenção de arbitragem, livre de particularismos regionais. ${ }^{326}$

Essas posições igualmente refletem o debate da chamada teoria da "deslocalização" e do "territorialismo" da arbitragem internacional. Trata-se de um debate longo e profícuo na doutrina internacional da arbitragem, cuja reprodução em maior escala fugiria ao escopo desta obra.

O "territorialismo" parte da visão mais tradicional de que a arbitragem sempre está ligada a um ordenamento jurídico nacional: em apertada síntese, a arbitragem somente existe porque um determinado ordenamento jurídico assim o permite. Na maioria das vezes, trata-se do ordenamento do local onde a arbitragem é conduzida. Dessa forma, o foro e a lex fori são elementos da mais alta importância para o andamento da arbitragem. Essa teoria parece ter permeado a elaboração de boa parte dos tratados mais importantes sobre arbitragem internacional. Com efeito, verificase uma tendência de valorização da lei do local da arbitragem tanto na Convenção de Nova Iorque, na Convenção do Panamá e, em menor grau, na Convenção de Genebra. Na doutrina, uma das mais citadas obras de defesa da posição territorialista é o artigo Lex Facit Arbitrum, de J. F. Mann. ${ }^{327}$ Naquela obra, o autor faz uma defesa da tese anunciada no título: a lei faz o árbitro, e não o contrário. $\mathrm{O}$ artigo coloca os fundamentos de uma posição pela qual sempre deverá haver a ligação entre a arbitragem internacional e uma ordem jurídica estatal.

De outro lado, a teoria da "deslocalização" pode ser definida como a proposição de que a arbitragem internacional não possui um foro, por não estar ligada a nenhum ordenamento

324 Lew, Julian D. M. The Law Applicable... cit., passim.

325 Fouchard, Gaillard e Goldman. Traité de l'Arbitrage Commercial International, cit., p. 252.

326 O método de regras materiais pode igualmente ser aplicado por juízes estatais. Um dos casos mais citados é o chamado Dalico, em que os tribunais franceses reconheceram certos princípios internacionais para aferir a validade da cláusula arbitral, fugindo da aplicação de qualquer direito nacional, inclusive o francês.

327 Liber Amicorum Martin Domke, cit., p. 157. 
jurídico nacional. Dessa forma, ao menos em princípio e durante a instância arbitral, todos os ordenamentos jurídicos lhe são iguais, não estando vinculada diretamente a nenhum deles. Não havendo foro, não há que falar propriamente em uma lei aplicável, mas sim em obediência a certos princípios internacionalmente reconhecidos. Essa doutrina tem sua origem na França, especialmente a partir da obra de Goldman e Fouchard, tendo ganhado reconhecimento mais amplo no âmbito mundial. Ela hoje parece ser a mais aceita no âmbito da arbitragem internacional. A despeito dessa aceitação, existem ainda hoje posições menos "triunfalistas" acerca da teoria. De qualquer modo, mesmo os defensores da teoria da deslocalização reconhecem a influência e a importância da lei do foro sobre a arbitragem.

Situados as diferentes concepções de arbitragem e os respectivos métodos de escolha de leis (tanto os conflitualistas quanto os da chamada "via direta"), tem-se uma plêiade de possíveis critérios para a definição da lei aplicável à convenção de arbitragem: ${ }^{328}$ (i) a lei do local da celebração da cláusula de arbitragem, ou a lei do local onde ela produzirá efeitos (o local da arbitragem) para reger a validade formal da cláusula; (ii) lex arbitri, a lei do local da arbitragem; (iii) a lei de regência da cláusula, na medida em que ela tenha sido escolhida pelas partes ou possa ser estabelecida pelas circunstâncias; (iv) a lei aplicável ao contrato, ou seja, ao mérito da disputa (lex causae); (v) lei pessoal das partes ou de uma delas; (vi) a lei do local onde a questão seria decidida caso não houvesse uma cláusula arbitral; (vii) a lei do local onde a sentença arbitral tem a maior possibilidade de ser executada; (viii) uma combinação dos critérios anteriores; (ix) uma visão desnacionalizada, pela qual seriam aplicáveis princípios gerais dos direito. Qual dos critérios, então, deve ser escolhido?

c) Regras materiais específicas da cláusula de arbitragem por eqüidade?

Antes de prosseguir com a questão de qual lei é aplicável à convenção de arbitragem por eqüidade, cumpre indagar se, também para esta cláusula, pode-se afirmar a existência de regras materiais para sua validade, oriundas da observação de valores, princípios e precedentes verificados na prática da arbitragem internacional. ${ }^{329}$ Nesse aspecto, buscamos apreciação da validade da cláusula pelos próprios árbitros, em um primeiro momento, e não pelos juízes estatais. $^{330}$

328 Blessing, Marc. The Law Applicable to the Arbitration Clause. In: Van Den Berg, Albert Jan (Ed.). ICCA Congress Series, cit., p. 168.

329 Para o conjunto da questão, veja-se Fouchard, Gaillard e Goldman. Traité de l'Arbitragem Commercial International, cit., p. 245 e ss, especialmente 252.

330 Eventualmente, os juízes estatais podem aplicar regras materiais diretamente, deixando de lado o método de conflito. Essas regras materiais podem ser dadas pelo próprio ordenamento local. 
Caso se entenda que os árbitros internacionais, por não pertencerem a nenhuma ordem jurídica local, podem buscar no estudo de direito comparado e na jurisprudência arbitral critérios para examinar a validade da cláusula arbitral, ${ }^{331}$ não há razão para que não procedam da mesma forma para julgar a cláusula de arbitragem por eqüidade. Cremos que isso se dá não apenas pela qualificação da cláusula de arbitragem por eqüidade no âmbito da convenção de arbitragem, mas também pelo postulado de regras materiais próprias da arbitragem internacional.

Admitida essa possibilidade, quais seriam os elementos de tais regras materiais? Certamente, existe menos material para a busca dessas regras em comparação com a validade da convenção de arbitragem em si. Pela simples razão de que existem menos casos de arbitragem por eqüidade do que casos de arbitragem em geral. Por outro lado, o direito comparado oferece uma base sólida para a aferição de regras gerais. Como será visto no capítulo próprio desta obra, existe um alto grau de convergência nas regras dedicadas à arbitragem por eqüidade.

A primeira regra que se destaca é a da possibilidade de arbitragem por eqüidade. Exceto por raríssimas exceções (seis casos em 99 ordenamentos pesquisados), a arbitragem por eqüidade é admitida em praticamente todos os ordenamentos nacionais. Proporção similar pode ser encontrada nos regulamentos de arbitragem pesquisados. Tampouco encontram-se na jurisprudência arbitral ou mesmo estatal vedações a esse tipo de arbitragem. Logo, pode-se afirmar a existência de uma regra geral permissiva desse tipo de arbitragem.

Como segunda regra, tem-se que a arbitragem por eqüidade não se presume. Ela deve advir de uma convenção das partes, que claramente demonstre sua vontade de serem julgadas por esse critério. Essa convenção é adicional à escolha da arbitragem. Salvo raras exceções que devem ser tratadas como tal, a arbitragem por eqüidade não decorre da simples escolha de arbitragem. $\mathrm{O}$ fato de existirem ordenamentos que presumem a arbitragem por eqüidade não infirma a regra geral, como de resto o não-reconhecimento da arbitragem por eqüidade por poucos países não infirma a regra geral de sua validade. Em primeiro lugar, porque não é necessária uma unanimidade de ordenamentos nacionais para que certas regras possam ser consideradas como gerais. Em ambos os casos, trata-se de uma minoria reduzida. Em segundo lugar, porque ambas as posições têm perdido adesões no mundo conforme os direitos de arbitragem são reformados. Em terceiro lugar, porque diversos países vêm relativizando a presunção de arbitragem por eqüidade. ${ }^{332}$

331 Fouchard, Gaillard e Goldman. Traité de l'Arbitragem Commercial International, cit., p. 252.

332 Argentina e Uruguai, ao assinarem o Acordo do Mercosul sobre Arbitragem Comercial Internacional, inverteram a regra geral de seu ordenamento, para certos tipos de arbitragem. 
Derivando da segunda regra, tem-se que a cláusula de arbitragem por eqüidade deve ser expressa. Essa é a orientação da imensa maioria dos países, embora expressa não seja necessariamente por escrito.

Como derivação das duas regras anteriores, tem-se que, em caso de dúvida sobre a intenção das partes, deve-se julgar conforme o direito. Esse princípio, embora não afirmado pelas legislações, foi estabelecido em ao menos um julgamento, ${ }^{333}$ além de ser uma conclusão lógica dos dois anteriores.

Como quarta regra, pode-se sustentar que o efeito principal da arbitragem por eqüidade é a possibilidade de não se aplicar o direito positivo ao mérito da demanda. Essa regra, essência do próprio instituto, é verificada em direito comparado à unanimidade e por quase toda a jurisprudência arbitral. ${ }^{334}$

A quinta regra, ligada à anterior, é a de que a escolha simultânea de arbitragem por eqüidade e direito não invalida a escolha de arbitragem por eqüidade. Essa regra é depreendida sobretudo da jurisprudência arbitral. Essa escolha é bastante comum e não tem impedido os árbitros de julgarem por eqüidade. ${ }^{335}$

A sexta regra é a necessidade do respeito à ordem pública pelos árbitros que decidem por eqüidade. Essa regra advém sobretudo da jurisprudência e da doutrina, embora possa também ser dessumida da sistemática geral da arbitragem internacional, em que nenhum árbitro pode exceder os limites da ordem pública (internacional).

Quanto aos poderes dos árbitros relativamente ao contrato, entendemos que não existe suficiente massa crítica para a depreensão de uma regra geral, embora uma regra pareça estar em formação. Por ela, permite-se a moderação de disposições do contrato, sem que se lhe possa alterar a economia de modo substancial. As regras acima elencadas são feitas sem prejuízo daquelas que ordinariamente se aplicariam à própria cláusula arbitral, tal como o respeito à boa-fé.

333 No caso CCI n. 3.380, de 1980 (JARvin, Sigvard; Derains, Yves. Collection of ICC Arbitral Awards. Recueil des Sentences Arbitrales de la CCI. Boston: Kluwer Law and Taxation Publishers, 1990. p. 96), havia duas clásusulas sobre lei aplicável. Na de arbitragem, afirmava-se que esta seria ex aequo et bono; porém, foram riscadas e substituídas por "princípios gerais de direito e de justiça" (law and justice). Em outra cláusula, escolhia-se o direito sírio. O Tribunal entendeu que não havia segurança suficiente para aplicação de arbitragem por eqüidade. Decidiu aplicar o direito da Síria, "sob reserva” dos princípios gerais, que podem ser encontrados tanto na lei síria como em outras fontes, não excluídos usos comerciais.

334 Veja-se o Capítulo 3 desta obra.

335 Vejam-se os Capítulos 3 e 8 desta obra. 
Sem dúvida, trata-se de poucas regras e que podem decepcionar por seu alcance. No entanto, parecem ser suficientes para demonstrar uma disciplina mínima comum à enorme maioria dos países e uma prática consolidada no âmbito internacional. As próprias regras apontadas para efeitos de validade da cláusula arbitral normalmente são poucas.

Mesmo o conteúdo material da chamada lex mercatoria, naturalmente mais abrangente que a disciplina da arbitragem por eqüidade, quer pela extensão, quer pelo interesse despertado na doutrina, tampouco chega a um número muito extenso de princípios, oscilando entre $20^{336}$ e $43 . .^{337-338}$

d) A lei aplicável à cláusula de arbitragem por eqüidade

Ao examinar a questão da lei aplicável à cláusula de arbitragem por eqüidade, Eric Loquin defende que a lei aplicável à validade de tal cláusula é a da sede do tribunal arbitral. ${ }^{339}$

Para tal conclusão, aquele autor afirma que, estando a cláusula de arbitragem por eqüidade ligada à convenção de arbitragem e sendo a autonomia das partes amplamente reconhecida por doutrina e convenções internacionais, nada impediria que a cláusula fosse regida pela lei escolhida pelas partes. Ao contrário, tudo indicaria que, reconhecida a possibilidade de as partes escolherem a lei aplicável aos diversos momentos da arbitragem, essa autonomia fosse estendida também à cláusula de arbitragem por eqüidade. Mais ainda, à falta de uma escolha diversificada de leis pelas partes (para a cláusula, procedimento e fundo), a lei aplicável a todos esses elementos será freqüentemente a mesma. ${ }^{340} \mathrm{E}$ a necessidade de escolher uma lei para a validade da cláusula de arbitragem por eqüidade levaria os juízes, em vista dos problemas de qualificação, a utilizar uma lei única como competente.

Entretanto, a despeito de entender essa construção como satisfatória de um ponto de vista teórico, ela encontrava barreiras claras nos ordenamentos nacionais que proibiam a arbitragem por eqüidade. Com efeito, havia exemplos em que a eqüidade fora considerada contrária à ordem pública dos locais em que a arbitragem se desenvolvia, mesmo estando sujeitas a leis estrangeiras quanto ao fundo e ao procedimento. Sobretudo no caso inglês, havia uma corrente jurisprudencial segundo a qual qualquer disposição tendente a excluir o escrutínio dos tribu-

\footnotetext{
336 Mustill, M. The new Lex Mercatoria... cit., p. 174.

337 Berger, Klaus Peter. International Economic Arbitration. Boston: Kluwer Law and Taxation Publishers, 1993. p. 544.

338 Para este efeito, não estamos considerando os princípios do Unidroit como compilação de lex mercatoria.

339 Loquin, Eric. L'Amiable composition... cit., p. 182.

340 Idem, ibidem, p. 179.
} 
nais ingleses das arbitragens ocorridas em seu território violava a ordem pública. ${ }^{341}$ Portanto, tratava-se de uma lei de aplicação imediata (ou de polícia) daquele foro. ${ }^{342}$

Em vista de tais limitações práticas, aquele autor conclui que a lei do local da arbitragem era o melhor critério para a validade da cláusula de arbitragem por eqüidade. Embora reconheça que tal proposição pareça ir no sentido contrário ao da tendência de internacionalização da arbitragem, defende-a em virtude da conveniência de tal lei para a obtenção de efeitos jurídicos para a cláusula. Trata-se de uma escolha de cunho pragmático.

Essa opinião apresentava vantagens inegáveis quando de sua elaboração. Contudo, considerando a ampla reforma dos direitos nacionais de arbitragem, pode-se afirmar que sua vantagem pragmática ainda é válida?

Qualquer que seja a linha de pensamento acerca da "desnacionalização" da arbitragem internacional, o papel do foro não pode ser negligenciado.

As Convenções Internacionais sobre arbitragem utilizam de forma clara o critério do foro para definir a lei aplicável à convenção de arbitragem, ao menos como um critério subsidiário à vontade das partes. Com efeito, o art. V da Convenção de Nova Iorque remete duas vezes à lei do local da arbitragem como critério para indeferimento do reconhecimento e execução da sentença arbitral. Aquele artigo dispõe que o reconhecimento e a execução poderão ser negados quando a convenção arbitral não for válida conforme a lei à qual as partes a submeteram ou, à falta desta, conforme a lei do local onde a sentença foi proferida (alínea "a"). De acordo com a alínea "d", a execução igualmente pode ser negada caso a instauração da arbitragem não tenha se dado segundo a vontade das partes ou, à falta de disposição desta, conforme a lei do país onde a arbitragem ocorreu. Além disso, consoante a alínea “e”, a execução igualmente pode ser negada caso a sentença arbitral tenha sido anulada ou suspensa pelos tribunais do país em que tenha sido proferida. ${ }^{343}$

341 Loquin, Eric. L'Amiable composition... cit., p. 180.

342 Nos países socialistas, o controle sobre esse tipo de arbitragem se dava por meio das regras das câmaras arbitrais para o comércio exterior, virtuais monopolistas da arbitragem internacional.

343 Art. V - 1. O reconhecimento e a execução da sentença poderão ser indeferidos, a pedido da parte contra a qual ela é invocada, unicamente se esta parte fornecer à autoridade competente onde se tenciona o reconhecimento e a execução, prova de que: a) as partes do acordo a que se refere o Art. II estavam, em conformidade com a lei a elas aplicável, de algum modo incapacitadas, ou que tal acordo não é válido nos termos da lei à qual as partes submeteram, ou na ausência de indicação sobre a matéria, nos termos da lei do país onde a sentença foi proferida; ou [...]d) a composição da autoridade arbitral ou procedimento arbitral não se deu em conformidade com o acordado pelas partes, ou, na ausência de tal acordo, não se deu em conformidade com a lei do país em que a arbitragem ocorreu; ou e) a sentença ainda não se tornou obrigatória para as partes ou foi anulada ou suspensa por autoridade competente do país em que, ou conforme a lei do qual, a sentença tenha sido proferida. 
A Convenção do Panamá segue critérios idênticos aos da Convenção de Nova Iorque, com subsidiariedade da lei do local da arbitragem. ${ }^{344}$ A Convenção de Genebra de 1961 igualmente prevê que a sentença arbitral pode deixar de ser executada caso a cláusula arbitral seja considerada nula de acordo com a lei escolhida pelas partes ou, à falta desta, segundo a lei do local da arbitragem. ${ }^{345}$

Portanto, a lei do local da arbitragem tem um valor inegável para a definição da validade da cláusula de arbitragem. Entretanto, ela é subsidiária da vontade das partes. De outra parte, no atual estágio da arbitragem internacional, apenas seis países apresentam restrições mais sérias à arbitragem por eqüidade. ${ }^{346}$ Mesmo assim, não se encontrou doutrina que afirmasse que a arbitragem por eqüidade implicaria violação da ordem pública do país, de modo a invalidar o procedimento. Ou seja, que haveria leis de aplicação imediata a impedir esse tipo de arbitragem no território. Continuaria a lei do foro o melhor critério para a afirmação da validade da cláusula?

Sem dúvida, trata-se ainda do critério mais seguro. No entanto, o benefício prático parece muito menor do que era no final da década de 1970. Logo, não divisamos maiores impedimentos para que a lei aplicável seja aquela escolhida pelas partes. A se adotar posição favorável ao método de regras materiais transnacionais aplicáveis pelos árbitros internacionais, pode-se mesmo chegar a ponto de vislumbrar alguns princípios gerais inerentes à arbitragem por eqüidade, como acima exposto. Esses princípios poderiam ser aplicados sobretudo pelos árbitros, desengajados de qualquer sistema nacional. Eventualmente, poderiam ser aplicados por tribunais nacionais, caso

344 Art. 5 - 1. Somente poderão ser denegados o reconhecimento e a execução da sentença por solicitação da parte contra a qual for invocada, se esta provar perante a autoridade competente do Estado em que forem pedidos o reconhecimento e a execução:

a) que as partes no acordo estavam sujeitas a alguma incapacidade em virtude da lei que lhes é aplicável, ou que tal acordo não é válido perante a lei a que as partes o tenham submetido, ou se nada tiver sido indicado a esse respeito, em virtude da lei do país em que tenha sido proferida a sentença; ou [...]

d) que a constituição do tribunal arbitral ou o processo arbitral não se ajustaram ao acordo celebrado entre as partes ou, na falta de tal acordo, que a constituição do tribunal arbitral ou o processo arbitral não se ajustaram à lei do Estado onde se efetuou a arbitragem; ou

e) que a sentença não é ainda obrigatória para as partes ou foi anulada ou suspensa por uma autoridade competente do Estado em que, ou de conformidade com cuja lei, foi proferida essa sentença.

345 Article IX - Setting aside of the arbitral award.

- The setting aside in a Contracting State of an arbitral award covered by this Convention shall only constitute a ground for the refusal of recognition or enforcement in another Contracting State where such setting aside took place in a State in which, or under the law of which, the award has been made and for one of the following reasons:

(a) the parties to the arbitration agreement were under the law applicable to them, under some incapacity or the said agreement is not valid under the law to which the parties have subjected it or, failing any indication thereon, under the law of the country where the award was made, or [...]

346 Bulgária, Malásia, Mongólia, Paquistão, Rússia e Vietnã. Bermudas e Cingapura permitem-na para os casos de arbitragens internacionais e aparentemente não a admitem em arbitragens internas. 
prefiram a adoção de regras materiais transnacionais. Autores como Berger vêem na autorização de decisão por eqüidade nos direitos da Suíça, França e Holanda uma regra substantiva de direito internacional privado, que dispensa a utilização do direito aplicável ao procedimento ou ao mérito para aferir sua permissão. ${ }^{347}$ Ao se estender essa análise aos demais países, têm-se uma regra material de direito internacional privado quase que unânime no mundo atual.

De qualquer modo, como princípio de cautela, pode-se proceder a um exame da ordem pública do local da arbitragem como critério para garantir que a sentença arbitral seja válida.

\subsubsection{Forma da e poderes para contratação}

a) Da forma expressa

A grande maioria das legislações nacionais pesquisadas exige que a autorização para decisão em eqüidade deve ser "expressa". A fórmula utilizada pela Lei Modelo (“o tribunal arbitral somente decidirá em eqüidade se as partes expressamente o autorizarem”) encontra-se na maioria das legislações nacionais consultadas. Essa preocupação com a qualificação "expressa" ou "expressamente" parece ser a emanação do regime de exceção que a arbitragem por eqüidade tem na arbitragem internacional, salvo poucos casos em contrário.

Com efeito, uma vez que a maioria dos ordenamentos jurídicos prescreve que a arbitragem é de direito, natural que as partes devam acordar sobre a utilização da arbitragem por eqüidade. Assim, dependendo de uma manifestação de vontade, pede-se que esta seja "expressa", de modo a não restarem dúvidas sobre a real intenção das partes.

A arbitragem de direito é normalmente presumida pelas legislações nacionais, pelo fato de que essa é normalmente a intenção das partes. Além disso, a aplicação do direito positivo tende a ser mais previsível e de acordo com o comportamento geral das partes (atuação conforme o direito positivo). A aplicação da eqüidade, de outra parte, implica um grau maior de incerteza no tocante ao resultado final. Além disso, no atual estágio histórico, a prevalência da lei positiva como fonte do direito demonstra que um julgamento por eqüidade tem caráter de exceção em relação a um julgamento de direito. Como a arbitragem necessita de convenção para derrogar a norma geral da jurisdição estatal, o mesmo ocorre para a faculdade de não aplicar a lei.

347 Berger, Klaus Peter. International Economic Arbitration, cit., p. 564. 
Por "expressa" ou "expressamente" deve-se entender que a arbitragem por eqüidade deve ser contratada por escrito? Não obstante "expressamente" não seja um sinônimo de "por escrito", parece pouco provável o uso de qualquer outra forma para deixar expressa a vontade. Todavia, pode-se imaginar que um registro verbal de uma vontade "expressa" possa valer como uma autorização para julgamento em eqüidade.

A forma "expressa" leva à questão de que se pode haver uma contratação de arbitragem por eqüidade tacitamente. Pode-se imaginar situação semelhante à interpretação da expressão "por escrito" da Convenção de Nova Iorque. Enquanto alguns países consideraram que certos documentos sem a assinatura de ambas as partes não configuravam uma cláusula de arbitragem válida, outros reputaram que sim. ${ }^{348}$ Existem ordenamentos que permitem a contratação tácita da arbitragem por eqüidade, como é o caso da Holanda e da Suíça. ${ }^{349}$ Contudo, mesmo que admitida a possibilidade de escolha tácita, ela deve defluir de modo claro da vontade das partes. Em caso de dúvida, deve-se entender que a arbitragem é de direito. ${ }^{350}$

Outras legislações determinam de modo claro que a escolha da arbitragem por eqüidade seja feita por escrito. A maioria deles prescreve que seja realizada na convenção de arbitragem ou no compromisso. ${ }^{351}$

348 "The critical factor is the requirement of a written agreement between the parties. It does not directly affect the substantive validity of the arbitration agreement. This view is ascertained by the extensive conception of an actually 'written' agreement, as confirmed by subsequent New York Convention case law, more recent international instruments such as the Uncitral Model Law and national statutes.

National courts generally apply the New York Convention over national law when deciding on the formal validity of arbitration agreements. The Convention requirement that a valid agreement must result from a document signed by the parties or from an 'exchange of letters or telegrams' has been variously interpreted by courts. The Italian Supreme Cour has declared inoperative for lack of compliance with the New York Convention's formal requirements a clause that had only been included in orders coming from the plaintiff, without any explicit acceptance by the defendant of a letter or telegram. Relying on both the New York Convention and the Swiss Private International Law Act (Art. 7), the Swiss Tribunal Fédéral recognized the formal validity of an arbitration agreement (in a bill of lading) that had only been signed by one of the parties.

How formal validity is reviewed, in the first place, is well illustrated by the practice of the ICC International Court of Arbitration. Where a party challenges the existence, validity or scope of the arbitration agreement, the ICC will generally decide that the arbitration shall proceed and refer this specific issue to be determined by the arbitration tribunal if it is prima facie satisfied that a written arbitration agreement exists. Thus, the written arbitration clause meets the prima facie requirement of formal validity for the purpose of establishing the jurisdiction of the arbitration tribunal. Lew, Julian D. M. The Law Applicable... cit., p. 118.

349 Berger, Klaus Peter. International Economic Arbitration, cit., p. 565. LALIVE, Pierre; Poudret, Jean-François; Reymond, Claude. Le Droit de l'Arbitrage Interne... cit., p. 402, com advertência de que pode ser uma regra perigosa.

350 Sobre a Alemanha, veja-se Berger, Klaus Peter. International Economic Arbitration, cit., nota 453.

351 Catar (na convenção arbitral ou em acordo separado); Costa do Marfim (convenção de arbitragem); França (na convenção de arbitragem); Honduras (convenção); Líbano (na cláusula, no compromisso ou em documento apartado); Líbia (indica-se inclusive o nome dos árbitros na convenção ou documento anterior); Luxemburgo (no compromisso); Mauritânia (na convenção); Panamá (na convenção ou posteriormente); Portugal (na convenção ou em outro documento); República Dominicana (no compromisso); Tunísia (na convenção); Turquia (aparentemente, no compromisso). 
No caso brasileiro, autorização para decisão por eqüidade é matéria para o compromisso arbitral. Todavia, como o compromisso não é obrigatório, ${ }^{352}$ pode-se convencionar a arbitragem em outro documento, como na própria cláusula. Em outras palavras, se houver compromisso (como normalmente é o caso), a autorização para decisão por eqüidade dele constará; se não houver compromisso, a autorização pode constar em outro documento.

b) Da escolha da arbitragem como escolha de eqüidade

Abre-se este item apenas para uma observação sobre o chamado sistema hispanoamericano. Em determinados países da América espanhola, vigora a regra de que, no silêncio das partes sobre a espécie de arbitragem, ela será por eqüidade.

Portanto, nesses países, a mera contratação da arbitragem, sem qualquer outro qualificativo, implica contratação de uma decisão por eqüidade. Trata-se aqui apenas da inversão da tradicional presunção de arbitragem de direito. A rigor, trata-se de questão de política legislativa. Essa escolha do legislador dos países hispano-americanos é passível de críticas, como será demonstrado nesta obra.

Todavia, para os fins do presente capítulo, deve-se advertir que, sendo alguma lei desses países aplicável à arbitragem, é possível que um eventual silêncio das partes pode ser tomado com um significado diferente do normalmente obtido em outros países.

c) Fórmulas específicas

Embora as legislações nacionais refiram-se à arbitragem por eqüidade com uma designação própria, ${ }^{353}$ elas não prescrevem qualquer espécie de expressão ou fórmula obrigatória. $\mathrm{Ou}$ seja, não há fórmulas sacramentais para contratar a arbitragem por eqüidade.

Nesse particular, a legislação italiana é especialmente explícita ao dizer que os árbitros decidem segundo as normas de direito, "salvo se as partes tenham disposto, com qualquer expressão, que os árbitros decidem conforme eqüidade".

352 Carmona, Carlos Alberto. Arbitragem e processo, cit., p. 105.

353 Seja por menção à eqüidade, seja por menção à amiable composition e suas traduções, seja pela expressão latina ex aequo et Bono. 
A despeito dessa liberdade, é necessário que haja uma manifestação suficientemente clara da vontade das partes de submeter a controvérsia a uma decisão por eqüidade. Naturalmente, a escolha das expressões "por eqüidade", "em eqüidade", amiable composition ou ex aequo et bono, remeterá a esse tipo de arbitragem.

Outras expressões como "de acordo com os princípios de justiça", "conforme a justiça", "acordo com os princípios gerais de justiça" também podem ser consideradas demonstrações inequívocas de vontade, desde que não associadas a outras expressões que indiquem a aplicação de direito positivo.

Algumas expressões, porém, como "decidir livremente", "transigir sobre o direito das partes", encontradas na jurisprudência francesa, ${ }^{354}$ podem transparecer menos claras. Em verdade, há crítica a uma certa liberalidade excessiva da jurisprudência francesa em considerar expressões ambíguas como autorização para arbitragem por eqüidade. ${ }^{355}$

No caso italiano, como já afirmado, existiu controvérsia sobre a denominação amichevole compositore como uma referência à arbitragem rituale por eqüidade, ou uma arbitragem irrituale. Na Itália, igualmente foi considerado que uma cláusula arbitral que se dizia respeito a uma decisão "de modo (in via) amigável e segundo eqüidade" referia-se à arbitragem por eqüidade.. ${ }^{356}$ Por outro lado, naquele mesmo país, decidiu-se que a designação para que os árbitros emanassem um "justo juízo" (giusto giudizio) foi reputada uma determinação para decidir conforme o direito. ${ }^{357}$

Uma questão mais difícil será a menção de que os árbitros devem decidir “conforme o direito e a justiça", ou "conforme o direito e os ditames da eqüidade", ou fórmulas equivalentes. Não se trata aqui do problema da escolha simultânea de direito e eqüidade, que será discutida nesta obra. Trata-se aqui de saber se a mera menção a princípios de justiça ou eqüidade, juntamente com alusão genérica ao direito, autoriza a uma decisão por eqüidade. Não obstante seja possível a autorização para decisão por eqüidade simultânea à indicação de direito aplicável, os exemplos acima podem não exprimir a mesma situação.

354 Loquin, Eric. L'Amiable composition... cit., p. 46

355 Como entender que a expressão "convidados a liquidar definitivamente os créditos entre as partes" designava uma arbitragem por eqüidade (cf. Loquin, Eric. L'Amiable composition... cit., p. 46-47).

356 Laudo arbitral publicado na Rivista dell'Arbitrato, Milano, Giuffrè, ano XIV, n. 1, p. 133, 2004 (comentário de Giuseppe Ruffini).

357 Idem, p. 854. 
Como já debatido na introdução desta obra, a eqüidade, em algumas de suas acepções, é instrumento do direito positivo, seja para integrá-lo, seja como modo de interpretação. Falamos aqui da utilização da eqüidade infra legem ou secundum legem. Como também já debatido nesta obra, a decisão por eqüidade na arbitragem implica a possibilidade de decisão contra legem.

Portanto, como se deve entender a menção ao uso da eqüidade nos casos descritos? A qual função da eqüidade apela às partes? Em uma visão estritamente textual, pode-se aventar a hipótese de que, sendo as funções infra ou secundum legem mais ou menos implícitas no uso do direito positivo, uma menção apartada seria a indicação de um outro uso, não subentendido no primeiro. Ou seja, a função contra legem. Em favor desta interpretação milita o princípio de hermenêutica, segundo o qual, quando duas interpretações forem possíveis, deve-se preferir aquela que dá efeito à expressão interpretada. Logo, a interpretação que confere maior valor à expressão eqüidade é aquela que admite a autorização para o julgamento contra legem.

No entanto, é mais razoável entender que as partes não sejam dadas a sutilezas de teoria do direito. Tanto mais em um domínio em que os próprios juristas não se encontram de acordo sobre o real alcance da expressão eqüidade. Portanto, uma interpretação excessivamente voltada para a teoria pode falsear a vontade das partes. Assim, cremos que o principal critério deva ser perquirir a real intenção das partes, em qualquer circunstância. Em caso de dúvida razoável, como no presente caso, deve-se seguir a arbitragem de direito.

A interpretação da arbitragem por eqüidade deve ser sempre restritiva, por se tratar de um caso excepcional. Além de excepcional, trata-se de escolha que acarreta grau maior de imprevisibilidade. Assim sendo, somente quando a vontade das partes resultar clara é que se deve decidir pela arbitragem por eqüidade. Para os autores que classificam a arbitragem como uma renúncia, existe ainda um argumento adicional: em geral, a renúncia, como de resto vários outros negócios jurídicos benéficos, deve ser interpretada restritivamente. ${ }^{358}$

\subsubsection{Do tempo para a contratação da arbitragem por eqüidade}

Poucas são as legislações que se dedicam ao tempo para a contratação da arbitragem por eqüidade. Na Alemanha, o Código de Processo Civil autoriza a escolha da arbitragem por eqüidade até o momento da decisão pelo tribunal. A legislação de Portugal o faz até a aceitação do primeiro árbitro. ${ }^{359}$

358 Confira-se, a respeito, Loquin, Eric. L'Amiable composition ... cit., p. 45.

359 Art 22, arbitragem interna. 
Em princípio, a escolha de um critério de julgamento pode se dar até o momento do próprio julgamento. Todavia, existem duas questões que decorrem dessa interpretação.

A escolha de arbitragem por eqüidade é, sobretudo, uma escolha de método de decisão. O comportamento das partes pode variar conforme o método de decisão que será utilizado pelos árbitros. Caso a decisão seja de direito, as partes deverão demonstrar seu caso de acordo com as regras aplicáveis. Produzirão as provas que entenderem necessárias para demonstrar que determinado fato ocorreu em detrimento de outros que não sejam tão relevantes conforme a lei aplicável. Por exemplo, caso o direito aplicável seja de um país que exige a anuência do devedor para a cessão de crédito, a parte interessada tentará demonstrar que houve anuência. Caso não seja necessária, a parte não se ocupará de tal fato.

Caso a disputa se dê com aplicação de princípios gerais ou normas costumeiras, as partes procurarão demonstrar a existência do princípio ou da prática que alegarem em defesa de seus interesses.

O mesmo ocorre com a arbitragem por eqüidade. Em princípio, as partes tentarão convencer os árbitros da justiça de suas pretensões. Portanto, o critério de julgamento é determinante para o comportamento das partes no procedimento.

Se as partes não souberem de antemão o critério de julgamento, podem atuar de modo errôneo ou que não seja o mais adequado para a defesa de seus interesses. Assim, a previsibilidade parece ser um elemento da maior importância para a disciplina do procedimento e mesmo para o devido processo e o princípio do contraditório. Do contrário, as partes estariam condenadas a um vôo cego ao entrarem em uma arbitragem.

Essa questão foi analisada por autores oriundos da prática processual. O professor italiano Edoardo Ricci, em artigo sobre a lei brasileira, mas de todo aplicável à arbitragem internacional, chega a um grau ainda mais amplo: afirma que os árbitros julgando em eqüidade devem informar às partes, antes do julgamento, quais são os critérios de justiça que pretendem utilizar. Caso não o façam, deixam as partes às cegas e portanto prejudicam sua atuação em contraditório. ${ }^{360}$ Embora o autor não concorde com o alcance dado por aquele professor aos imperativos de previsibilidade, ${ }^{361}$ a questão apresenta o problema da previsibilidade e o respeito

360 Ricci, Edoardo Flavio. O contraditório na arbitragem de eqüidade. Lei de Arbitragem brasileira. São Paulo: RT, 2004. p. 149 e ss.

361 Essencialmente, porque o critério de julgamento dos árbitros de eqüidade é seu sentimento de justiça em sentido amplo (que pode abranger vários métodos, inclusive a estrita aplicação do direito positivo). Ao escolherem essa espécie de arbitragem, as partes sabem que existe algum grau de indeterminação, que é ínsita ao juízo 
ao contraditório. Logo, a escolha da decisão por eqüidade apenas no momento do julgamento poderá, em princípio, afetar o princípio do contraditório.

Entretanto, a arbitragem por eqüidade somente pode ser contratada de comum acordo entre as partes. As partes são livres para pactuar o procedimento de arbitragem. Elas possuem a faculdade de restringir o conteúdo probatório que será objeto da arbitragem, como as oportunidades que poderão falar no procedimento. Nada impede, portanto, que resolvam adotar um critério diferenciado de julgamento, mesmo no curso do processo. Trata-se apenas do exercício de sua liberdade de contratar.

Sem dúvida, essa liberdade não é absoluta. Possivelmente, uma escolha de procedimento em que uma das partes seja substancialmente favorecida em oportunidades de prova será considerada violadora do contraditório. A escolha de um critério de julgamento, porém, após a produção das provas, feita de comum acordo, não parece violar tal princípio. Se as partes a escolhem é porque lhes pareceu que tal critério era conveniente à luz das provas e das postulações produzidas. Não existe, por si só, uma violação ao contraditório.

Nenhuma legislação impede, hoje em dia, que a contratação da arbitragem por eqüidade se dê na cláusula arbitral. No caso de países em que o compromisso é essencial à instauração da arbitragem, pode restar dúvida se a mera menção na cláusula arbitral é suficiente para que a eqüidade seja contratada ou se é necessário que haja sua reafirmação no compromisso. A resposta, naturalmente, dependerá do regime nacional sobre a relação entre cláusula e compromisso.

No direito brasileiro anterior à reforma de 1996, entendia-se que somente o compromisso era o ato pelo qual as partes retiravam a controvérsia do âmbito do Poder Judiciário e a remetiam à arbitragem. Embora bastante criticável, a doutrina prevalente no direito anterior privava a cláusula arbitral de maiores efeitos, não the reconhecendo execução específica. Tratavase de um mero pacto de contrahendo, cuja inexecução levava, no máximo, ao pagamento de uma indenização. Um dos argumentos em favor do entendimento era o de que as partes somente poderiam contratar a arbitragem quando houvesse efetivamente um litígio entre elas. ${ }^{362}$

de eqüidade. Se não o quiserem, podem simplesmente utilizar a arbitragem de direito (possivelmente, é essa a principal razão para a preferência geral pela arbitragem de direito). Nenhuma legislação estudada para este trabalho exige qualquer antecipação de critérios. Além disso, um inventário de critérios de justiça de cada árbitro parece algo pouco factível.

362 CARmona, Carlos Alberto. Arbitragem e processo. cit., p. 23. 
O mesmo raciocínio parece ser a base da restrição da antiga lei belga, relativamente à eqüidade. Ali previa-se que, salvo estipulação em contrário, a escolha de eqüidade não seria eficaz antes da notificação início da arbitragem. ${ }^{363}$

Conforme a exposição de motivos daquela lei, a contratação de arbitragem por eqüidade, por implicar um poder de grandes dimensões aos árbitros, somente pode ser devidamente apreciada quando um litígio já existir, de modo que as partes possam examinar a conveniência à luz de todos os elementos, podendo pesar as vantagens e as desvantagens da escolha. Além disso, mencionava-se que, com a expansão da arbitragem, evita-se que a cláusula de arbitragem se torne uma "cláusula de estilo", porque suas conseqüências não são conhecidas pelas partes pouco familiarizadas com o procedimento de arbitragem ${ }^{364}-.365$

Essa questão se coloca de modo um pouco distinto aos que consideram a arbitragem por eqüidade como renúncia. Em boa parte dos ordenamentos jurídicos, existem restrições à renúncia de determinados direitos antecipadamente. Tal é o caso brasileiro da renúncia à prescrição. Assim, somente se pode renunciar a determinados direitos uma vez que eles se integraram ao patrimônio da parte, sendo vetada a renúncia prévia.

A doutrina francesa insere essa espécie de direitos na chamada "ordem pública de proteção", em oposição à ordem pública de direção. ${ }^{366}$ Uma vez que esse direito passa a integrar o patrimônio, ele pode ser disposto.

Caso se considere a estipulação da cláusula de arbitragem por eqüidade uma renúncia, anterior à aquisição do direito, ela pode ser reputada válida? Ou implicaria renúncia antecipada? Após discutir jurisprudência e casos legislativos, Eric Loquin afirma que a questão assim posta não se encontra correta e parece confundir arbitrabilidade do litígio e poderes dos árbitros. ${ }^{367}$

\footnotetext{
${ }^{363}$ Matray, Lambert; Lefevre, Françoise; Lemaitre, Henri-Paul; Verbist, Herman. Questionário sobre a arbitragem por eqüidade submetido a Força Tarefa da CCI sobre Arbitragem por Eqüidade, 2006. Mimeografado. Disponível em: <www.iccwbo.org>. Também LoQuin, Eric. L'Amiable composition... cit., p. 48.

364 Apud Loquin, Eric. L'Amiable composition... cit., p. 48.

365 Essa mesma opinião, em um nível diferente, parece orientar alguns países árabes a permitir que a arbitragem por eqüidade somente ocorra quando as partes indicarem os árbitros pelos nomes. Conforme apontado pela doutrina, a razão para tal exigência é a de que a arbitragem por eqüidade é tão importante e implica tamanha liberdade para os árbitros que ela somente pode ser admitida quando as partes conheçam exatamente as pessoas que atuarão como árbitros.

366 Loquin, Eric. L'Amiable composition ... cit., p. 50.

367 Idem, ibidem, p. 50.
} 
Se a matéria do litígio não for arbitrável, então tanto cláusula como compromisso não terão efeito. Caso haja direitos aos quais as partes não podem renunciar, a cláusula de arbitragem por eqüidade, ou melhor, os efeitos de tal cláusula não se estendem aos direitos aos quais não se podem renunciar. Ou seja, os direitos aos quais não se renunciam não são atingidos pelos efeitos da cláusula. Todavia, isso não implica nulidade da cláusula. Caso os árbitros decidam pela derrogação de direitos aos quais não se podia renunciar, certamente a decisão sofrerá sanções. Logo, o objeto da anulação será a sentença, e não a cláusula. ${ }^{368}$

Essa interpretação deve ser aprovada por melhor evidenciar os efeitos da cláusula de arbitragem por eqüidade. Caso a arbitragem por eqüidade seja confirmada no compromisso (e já então se considere que o direito tenha sido incorporado ao patrimônio da parte), então haverá uma extensão dos efeitos da cláusula também àqueles direitos. Portanto, esta demonstra claramente os inconvenientes de qualificar a arbitragem por eqüidade como uma renúncia.

\subsubsection{Dos poderes para a contratação da arbitragem por eqüidade}

Outra questão suscitada pela doutrina estrangeira ${ }^{369}$ é a dos poderes específicos para a contratação da arbitragem por eqüidade. A razão principal para possível exigência de poderes especiais é a posição de que a contratação da arbitragem por eqüidade, ao contrário da arbitragem de direito, envolve uma renúncia e portanto requer poderes específicos. Essa questão se coloca tanto na necessidade de poderes específicos no mandato como alguma investidura especial dos órgãos das pessoas jurídicas.

No caso brasileiro, a disciplina do mandato é dada pelos Códigos Civil e de Processo Civil. No Código Civil, determina-se que o mandato em termos gerais somente concede poderes de administração e quaisquer atos que fujam da administração ordinária dependem de poderes especiais expressos, especialmente para os casos de alienação, hipoteca ou transação. No mesmo artigo (661), determina-se que o mandato para transigir não implica poderes para firmar compromisso. Portanto, há necessidade de poderes distintos e expressos para que se firme compromisso.

No art. 38 do Código de Processo Civil, que cuida da procuração ad judicia, determina-se que esta confere poderes para o foro em geral, exceto, entre outros, para confissão, reconhecimento do pedido, transação, renúncia ao direito em que se funda a ação, dar ou re-

\footnotetext{
LoQuin, Eric. L'Amiable composition... cit., p. 51.
}

369 Idem, ibidem, p. 51-52. 
ceber quitação e firmar compromisso. Portanto, no regime brasileiro, os poderes para renúncia ou para firmar compromisso devem ser expressos. Ao menos na lei processual, os poderes não se confundem. Não existe, de outra parte, qualquer exigência legal de poderes especiais para a arbitragem por eqüidade.

Pode-se vislumbrar, nesse aspecto, mais um dos inconvenientes práticos da assimilação da arbitragem por eqüidade a uma renúncia pura. Como já afirmado nesta obra, a arbitragem por eqüidade é uma espécie do gênero arbitragem e tem como caráter principal a utilização de um critério de julgamento.

Se o direito positivo em geral admite a arbitragem de direito e de eqüidade, os poderes para a contratação de quaisquer dessas espécies deve ser presumido como o mesmo, salvo regra em contrário. E nos países pesquisados não foi encontrada nenhuma menção a poderes especiais para a arbitragem por eqüidade.

No âmbito internacional, embora a questão seja naturalmente sujeita às leis locais, não há razão para definir de modo contrário: sendo a decisão por eqüidade uma possibilidade da arbitragem, não são necessários poderes maiores do que os de celebrar a convenção de arbitragem.

Em verdade, com todas as vênias, a defesa de poderes especiais para a arbitragem por eqüidade, mesmo para os que defendem sua natureza de renúncia, parece ser exagerada. Com efeito, parece levar às últimas conseqüências a qualificação efetuada, mesmo contrariamente à disciplina específica. Se existe uma disciplina legal para a arbitragem por eqüidade, ela deve ser seguida, mesmo que se lhe considere renúncia. Caso contrário, impõe-se o regime geral das renúncias sobre uma disciplina específica. Em outras palavras, mesmo que a arbitragem por eqüidade seja uma renúncia, ela é uma renúncia especificamente regulada, que segue seu regime particular e não o regime geral das renúncias.

A nosso ver, a mesma conclusão aplica-se à representação das pessoas jurídicas: quem tem poderes para celebrar convenção de arbitragem (ou outorgar a competente procuração) tem poderes para celebrar (ou outorgar a competente procuração) a convenção de arbitragem por eqüidade. Por conseguinte, não é necessária autorização especial, ou mesmo a mesma autoridade para a renúncia ou outros atos benéficos. 


\subsubsection{O Estado e a arbitragem por eqüidade}

A participação do Estado na arbitragem internacional é tema de amplos debates na doutrina internacional e nacional. As arbitragens das décadas de 1950, 1960 e 1970, especialmente aquelas referentes à nacionalização das empresas de petróleo, ocupam um lugar quase mítico na arbitragem internacional. ${ }^{370} \mathrm{E}$ não apenas pelos montantes de dinheiro envolvidos nas disputas, mas também por atingirem empresas de países desenvolvidos em geral contra países em desenvolvimento, boa parte deles apenas recém-saídos da independência.

Uma das principais questões que surgiram de tais arbitragens é a possibilidade de o Estado ou entidades estatais participarem de arbitragens com particulares. Esse ponto levou a diversas posições doutrinárias que renderam extensas discussões, não raro acaloradas. Não é objeto da presente obra repassar essa discussão. Ao contrário, importa examinar a possibilidade de que, em arbitragens que envolvam o Estado, possa haver decisão por eqüidade. Para tanto, parte-se da premissa de que a posição dominante nos dias de hoje é a de que o Estado pode participar de arbitragens comerciais e que as eventuais restrições das legislações nacionais não devem ser admitidas no âmbito internacional como forma de se furtar a uma arbitragem livremente consentida. ${ }^{371}$

No direito comparado, encontram-se algumas restrições concernentes à utilização da arbitragem em matérias que envolvam o Estado. O art. 2.060 do Código Civil francês expressamente veda o compromisso sobre litígios que incluam as "coletividades públicas e os estabelecimentos públicos”. Também o art. 1.676 do Código Judiciário belga e a constituição líbia possuem restrições à participação de entes estatais ${ }^{372}$ e a constituição iraniana prevê formas diferenciadas para a expressão do consentimento com a arbitragem. ${ }^{373}$

Essas questões, porém, são relativas à própria presença do Estado na arbitragem. Não obstante algumas delas possam parecer à primeira vista questões relativas à capacidade para

\footnotetext{
370 Garth, Bryant; Dezalay, Yves. Dealing in virtue: International Commercial Arbitration and the Construction of a Transnational Legal Order. Chigado; London: The University of Chigago Press, 1996, p. 74.

371 Fouchard, Gaillard e Goldman. Traité de l'Arbitragem Commercial International, cit., p. 43 e ss. e 330 e ss. Para uma visão brasileira, veja-se MagalHães, José Carlos de. Direito econômico internacional... cit., p. 306 e ss.; Do Estado na arbitragem privada. São Paulo: Max Limonad, 1988. CARmona, Carlos Alberto. Arbitragem e processo, cit., p. 62 e ss. Huck, Hermes Marcelo. Contratos com o Estado: aspectos de direito internacional. São Paulo: Aquarela, 1989. p. 121 e ss. Lemes, Selma. Arbitragem na Administração Pública: fundamentos jurídicos e eficiência econômica. São Paulo: Quartier Latin, 2007. passim.

372 Magalhães, José Carlos de. Direito econômico internacional, cit., p. 307.

373 Fouchard, Gaillard e Goldman. Traité de l'Arbitragem Commercial International, cit., p. 331.
} 
contratar, a doutrina mais moderna tende a ver essa questão como ligada à arbitrabilidade: são matérias eventualmente colocadas fora do espectro da arbitragem. ${ }^{374}$

No entanto, uma vez admitida a participação do Estado na arbitragem, a decisão pode ser tomada por eqüidade? No direito comparado, encontram-se poucas disposições em legislações de arbitragem com alguma especificação sobre a matéria.

De fato, apenas o direito belga dispõe especificamente sobre o assunto. Em seu art. 1.700, o Código Judiciário daquele país dispõe que, "sendo uma pessoa jurídica de direito público parte da convenção de arbitragem, os árbitros decidem sempre conforme as regras de direito, sem prejuízo de leis particulares”. Assim, existe vedação em princípio para decisões por eqüidade quando for parte pessoa jurídica de direito público. Aparentemente, somente uma autorização legal poderá excepcionar tal regra. Alguns outros países prevêem, na legislação esparsa, que determinada espécie de litígios envolvendo administração pública deva ser decidida por arbitragem de direito, como é o caso da Colômbia.

Entretanto, essas restrições locais não parecem apresentar um óbice genérico à utilização da eqüidade em arbitragens que envolvam o Estado. Ou seja, delas não se pode inferir a existência de uma regra internacional que vede a utilização de arbitragens por eqüidade.

Ao contrário, a prática internacional parece demonstrar a existência de uma predisposição para que se aceite essa espécie de arbitragem. A Convenção de Washington expressamente admite a possibilidade de decisão por eqüidade. ${ }^{375}$ Dada a maciça adesão à referida Convenção, não se pode entender pela existência de qualquer vedação no direito internacional. Em verdade, se alguma ilação pode ser feita do referido texto, deve ser exatamente no sentido contrário: admite-se a utilização de arbitragem por eqüidade. Eric Loquin, ao examinar a utilização da arbitragem de eqüidade em certos tipos de contratos de investimento, menciona a utilização dessa espécie de arbitragem na legislação de vários países africanos sobre investimentos estrangeiros, bem como em diversos contratos. ${ }^{376}$

374 Fouchard, Gaillard e Goldman. Traité de l'Arbitragem Commercial International, cit., p. 333. Magalhães, José Carlos de. Direito econômico internacional, cit., p. 309.

375 Article 42.

(1) The Tribunal shall decide a dispute in accordance with such rules of law as may be agreed by the parties. In the absence of such agreement, the Tribunal shall apply the law of the Contracting State party to the dispute (including its rules on the conflict of laws) and such rules of international law as may be applicable.

(2) The Tribunal may not bring in a finding of non liquet on the ground of silence or obscurity of the law.

(3) The provisions of paragraphs (1) and (2) shall not prejudice the power of the Tribunal to decide a dispute ex aequo et bono if the parties so agree.

${ }^{376}$ Loquin, Eric. L'Amiable composition... cit., p. 153. 
No caso brasileiro, existem precedentes de utilização da eqüidade em arbitragem envolvendo o Estado. Conforme narra Alípio Silveira em sua obra Conceito e funções da eqüidade em face do direito positivo, ${ }^{377}$ uma arbitragem julgada em 27.09.1943 envolveu a The Rio de Janeiro City Improvements Comp. Ltd. e a União, tendo como árbitro único o Ministro Eduardo Espínola, decidindo por eqüidade. Naquele caso, as partes litigavam sobre certos pagamentos de garantias que teriam sido efetuados, embora anteriormente suprimidos em um aditivo contratual. Logo, pagamentos feitos em erro. O árbitro decidiu que os pagamentos não eram devidos, mas que, tendo as partes agido conforme um entendimento comum de que o eram, determinou que a autora conservasse os pagamentos recebidos, por entender eqüitativo. Portanto, o Estado brasileiro, em um contrato de concessão com um particular, aceitou que a decisão se desse por eqüidade.

Outro caso citado por Luiz Olavo Baptista e José Carlos Magalhães ${ }^{378}$ é o Acordo de Comunhão de Interesses celebrado entre a Fiat e o Governo de Minas Gerais. Na cláusula arbitral, previa-se recurso a um tribunal arbitral com sede em Paris, que decidiria ex aequo et bono. A disposição é mencionada como um exemplo de "cláusulas que não se referem a nenhum sistema jurídico, mas à boa-fé - 'good will and good faith' - das partes, à interpretação razoável do contrato, que se reduzem, na realidade, à cláusula 'ex aequo et bono' na arbitragem”.

Como já mencionado, no atual desenvolvimento da arbitragem comercial, a participação dos Estados, ao menos quando se tratar de atos de gestão, tende a ser considerada na mesma condição de um particular. Ou seja, sem a possibilidade de invocar suas imunidades ou mesmo normas internas para esquivar-se da aplicação de algo pactuado livremente.

Considerando-se que existe a possibilidade de o Estado contratar e ser parte de uma arbitragem e que a arbitragem por eqüidade é uma espécie de arbitragem, parece-nos difícil, ao menos no âmbito internacional, defender a impossibilidade de utilização da arbitragem por eqüidade.

Eventuais restrições de legislações legais poderão ser admitidas na medida em que a lei nacional for aplicável. Todavia, não se vislumbra um impedimento genérico no âmbito internacional. Ao contrário, tudo indica que eventuais proibições de leis nacionais terão o mesmo destino das proibições para contratar a arbitragem de modo geral.

377 Conceito e funções da eqüidade... cit., p. 240-241.

378 Arbitragem comercial, cit., p. 49. 
Mesmo porque a proteção aos interesses públicos continuará a se dar na forma da arbitrabilidade objetiva: somente serão objeto de arbitragem aqueles direitos que forem disponíveis, o que tende a excluir os atos de império inerentes à soberania estatal. Se determinados direitos podem ser objeto de arbitragem, nada impede que um certo critério de julgamento facultado por esse meio de solução de controvérsias seja utilizado. Ou seja, se pode haver arbitragem, pode existir sua espécie, a arbitragem por eqüidade.

De resto, diga-se que a possibilidade de decisões por eqüidade em direito internacional público está longe de ser proibida, como bem atestam o Estatuto da Corte Internacional de Justiça e os inúmeros tratados que a prevêem.

A título complementar, pode-se dizer também que existem outras formas de mitigação da aplicação das leis nacionais, que são comumente aceitas em arbitragens internacionais comerciais, como é o caso das chamadas cláusulas de estabilização de legislação, pelas quais se pactua que a controvérsia será julgada de acordo com o ordenamento jurídico tal como vigente em determinada data, sendo desconsideradas mudanças posteriores.

Dessa forma, salvo estipulação especial, comparecendo o Estado como um igual e, conforme já demonstrado, sendo a arbitragem por eqüidade uma espécie de arbitragem, não se devem ver maiores impedimentos ao Estado de contratar arbitragem por eqüidade.

Existe o possível impedimento dos contratos administrativos, ou regras de que o Estado não pode ser julgado senão por suas leis. Todavia, se é considerada válida a contratação no âmbito internacional, as normas internas terão pouco efeito, embora possam causar um problema para homologação naquele Estado. 379

379 Já em 1976 Luiz Olavo Baptista advertia que a lei de um Estado não é necessariamente a aplicável em casos a que o Estado se submeta (como exemplo, cita o caso dos empréstimos sérvio-brasileiros). Dentro da autonomia da vontade, podem as partes escolher outra lei e que a escolha de princípios gerais do direito e do Direito Internacional é a melhor solução teórica para os contratos internacionais. Contrato de risco. São Paulo: Bushatsky, 1976. p. 46-48. 


\section{CAPÍTULO 3}

\section{EFEITOS DA ESCOLHA DA EQÜIDADE}

Neste capítulo, serão estudados os efeitos da escolha da eqüidade no direito material e no direito processual. Quanto ao direito material, estudam-se em primeiro lugar a "estrutura" da decisão por eqüidade e suas diferentes formas de atuação. Assentadas suas características principais, passa-se ao estudo dos efeitos concernentes aos procedimentos estatal e convencional, com especial enfoque no devido processo.

\subsection{Direito material}

\subsubsection{Estrutura do juízo de eqüidade}

Juízos jurídicos obedecem ao famoso silogismo segundo o qual a norma é a premissa maior e os fatos são a premissa menor. ${ }^{380}$ Normalmente, descreve-se tal silogismo como: "se A é, B deve ser", na qual “A” representa um fato e "B”, a conseqüência jurídica prevista pela norma. Em regra, a norma é um prius em relação ao fato. ${ }^{381}$

No juízo de eqüidade, pode-se não utilizar a norma positiva. O julgador tem a faculdade de não recorrer à norma positiva para decidir. ${ }^{382}$ Portanto, o clássico silogismo não corresponde (ou ao menos pode não corresponder) à forma da decisão.

Vários autores dedicaram-se ao estudo da estrutura do juízo de eqüidade e não são unânimes em suas conclusões. Esta seção capítulo pretende apresentar as diferentes visões acerca da estrutura lógica do juízo de eqüidade (ou sua "mecânica decisória"), bem como algumas tentativas lhe de imputar um conteúdo valorativo que transcenda apenas a vaga referência ao

380 Veja-se, entre vários outros, LAREnZ, Karl. Metodologia da ciência do direito. 3. ed. Lisboa: Fundação Calouste Gulbekian, 1997. p. 380. Também Reale, Miguel. Lições preliminares de direito. 19. ed. São Paulo: Saraiva, 1991. p. 93 e ss.

381 Ou, conforme a formulação da Larenz (ibidem, p. 381): "Denomino esta figura lógica de 'silogismo de determinação da conseqüência jurídica'. Nele, a premissa maior é constituída por uma proposição jurídica completa e a premissa menor pela subordinação de uma situação de fato concreta, como um 'caso', à previsão da proposição jurídica. A conclusão afirma que para esta situação de fato vale a conseqüência jurídica mencionada nesta proposição jurídica".

382 Entre outros, Ascensão, José de Oliveira. Verbete "Eqüidade". Enciclopédia Saraiva do Direito. São Paulo: Saraiva, 1977. 
"sentimento de justiça” de quem julga. Após a exposição crítica de tais posições, pretende-se demonstrar que o elemento essencial do juízo de eqüidade é a liberdade em relação a métodos preestabelecidos.

\subsubsection{Juizo de eqüidade como entimema aristotélico ou juízo de fato}

Alguns autores, como Vittorio Frosini, definem o juízo de eqüidade, do ponto de vista de sua estrutura, como um silogismo retórico, ou um entimema, conforme a definição de Aristóteles. ${ }^{383} \mathrm{Na}$ retórica (cujo objetivo é o convencimento e se opõe à dialética), pode-se afirmar, em linhas gerais, que o entimema é o equivalente do silogismo.

Todavia, o entimema diferencia-se do silogismo pelo menos em três aspectos. Em primeiro lugar, pelo campo de atuação. Enquanto a dialética aplica-se para o exame crítico de questões morais amplas, a retórica tende a buscar o convencimento e a escolha de opções. Em segundo lugar, enquanto o silogismo busca conclusões acerca de questões gerais (como a natureza do bem, a quem seguir em caso de divergência entre leis e autoridade dos pais, etc.), o entimema procura conclusões a questões específicas (se uma política é boa ou não, se havia um caso de legítima defesa, etc.). Em terceiro lugar, o entimema, em geral, é baseado em um conhecimento tácito da audiência. Ou seja, possui partes que são subentendidas e não necessitam de exposição específica. Um exemplo de entimema é o argumento de que um homem rico está qualificado para cuidar do dinheiro público. Embora não haja menção, está subentendido em tal argumento que um homem que já possui suficiente fortuna não tem necessidade de valer-se do dinheiro público para fins privados. ${ }^{384}$

Assim, a premissa maior do entimema é subentendida, tomada como de conhecimento geral da audiência ou simplesmente suprimida. Neste aspecto, Frosini propõe que a decisão de eqüidade opera com lógica aberta, em que a intuição cognoscitiva (noética) supera o esquema discursivo do silogismo, porque quem decide faz uma associação direta entre fato e a norma

383 FrosinI, Vittorio. Teoremi e problemi di scienza giuridica. Milano: Giuffrè, 1971. p. 206 e ss. Do mesmo autor, veja-se também o mais recente Il Giudizio di Equità e il Giudice di Pace, Rivista di Diritto Civile, Padova, Cedam, ano XLII, parte primeira, p. 143 e ss., 1996. Este último artigo é uma resposta a um artigo de Francesco Galgano, chamado Diritto ed Equità nel Giudizio Arbitrale, Contratto ed Impresa, Padova, Cedam, ano 7, v. 2, p. 461 e ss., 1991. O mesmo Galgano publicou uma resposta ao artigo de Frosini na mesma Diritto e Impresa, ano 12, v. 2, p. 401 e ss., 1996.

Para uma discussão do entimema do ponto de vista da retórica, veja-se o verbete Enthymeme, Encyclopedia of Rhetoric. Oxford: Oxford University Press, 2001. Também ARISTóTELES. Arte retórica e arte poética, cit., p. 150 e ss., e CAfFÉ Alves, Alaôr. Lógica: pensamento formal e argumentação. 3. ed. São Paulo: Quartier Latin, 2003. p. 281.

384 Verbete Enthymeme. Encyclopedia of Rhetoric. Oxford: Oxford University Press, 2001. p. 248-249. 
aplicada. Ou seja, a norma é fruto direto da cognição dos fatos, surge ex facto e não o antecede, como no caso da norma jurídica positiva. Desse modo, não existe uma relação propriamente dedutiva do raciocínio jurídico tradicional, mas sim uma relação algo intuitiva, um vínculo funcional direto imediato entre o fato e a norma criada para ele. O juízo de eqüidade, portanto, funcionaria com a afirmação "apenas quando se apresenta um caso X, deve-se decidir Y". Trata-se, portanto, de um juízo oriundo do fato examinado e de um topos particular, e não da norma preexistente. A "força que sustenta" o juízo de eqüidade é a da persuasão moral e não a da demonstração lógica do silogismo. ${ }^{385}$ Para melhor figurar sua posição, Frosini faz menção ao juízo de eqüidade como um "juízo salomônico". ${ }^{386}$ Esta referência à célebre passagem do juízo de Salomão é feita no sentido de criação de uma regra ad hoc para a decisão do caso concreto e não da divisão (no caso bíblico, literal) do objeto da controvérsia. ${ }^{387}$

Outros autores, como Francesco D’Agostino, ${ }^{388}$ discordam do caráter “entimemático" do juízo de eqüidade, definindo-o como um juízo prático, fundado na prudência. Neste caso, uma espécie de "prudência jurídica", que seria consubstanciada em um "sentido natural de ordem nos relacionamentos humanos".

De qualquer modo, mesmo não se aceitando a classificação do juízo de eqüidade como entimema, há, nas opiniões acima mencionadas, um elemento importante desta espécie de decisão: sua caracterização como um juízo de fato, um juízo independente de regras preestabelecidas que se liga diretamente ao fato a ser decidido.

Essa espécie de juízo parece assemelhar-se aos chamados juízos de lege ferenda, em que o tribunal afirma como deveria decidir se pudesse julgar apenas com base no que entende como justo e razoável. ${ }^{389}$ Também guarda semelhanças, talvez maiores, com os chamados juízos cádi, conhecidos na tradição islâmica como juízos de cunho religioso que decidem em larga medida conforme "aspectos de justiça concretos", ex facto. ${ }^{390}$

385 Frosin, Vittorio. Teoremi e problemi di scienza giuridica, cit., p. 212.

386 Idêntica referência é feita por Max Weber, ao tratar da justiça principesca patrimonialista, assemelhando o juízo salomônico à "justiça de cádi" (Economia e sociedade: fundamento da sociologia compreensiva. São Paulo: Editora UnB/Imprensa Oficial do Estado, 2004. v. 2, p. 121.) Frosin, Vittorio. Il Giudizio di Equità e il Giudice di Pace, cit., p. 143 e ss. D'Agostino, Francesco. Dimensioni dell'Equità. Torino: Giapichelli, 1977. p. 41. Do mesmo autor, veja-se igualmente: Epikeia: Il tema dell'equità nell' antichità greca. Milano: Giuffrè, 1973.

389 Perelman, Chaïm. Lógica jurídica. São Paulo: Martins Fontes, 2004. p. 192.

390 WeBER, Max. Economia e sociedade... cit., p. 110-111:

"Para a economia, a influência teocrática na justiça foi e continua sendo [...] de importância considerável, apesar da limitação crescente de sua esfera. Deve-se isso muito menos - tanto aqui quanto por outra parte - às normas positivas de direito sagrado, do que à 'convicção' fundamental da justiça. Esta aspira à justiça "material" e não à regulação formal de uma luta de interesses. Julga por isso também - por exemplo, em processos relativos a bens de raiz, desde que caiam em sua competência - em grande medida sgundo aspectos concretos, 
Uma interessante discussão que toca o tema de sua "mecânica" deu-se entre Carnelutti e Calamandrei, no âmbito do processo civil, sobre a natureza do juízo de eqüidade na Itália. Esta célebre polêmica é relatada por diversos autores. ${ }^{391}$ Essencialmente, Calamandrei postulou que a sentença por eqüidade seria uma sentença declaratória. Sentenças declaratórias são aquelas que se exaurem com a decisão acerca de uma relação jurídica. Em vista da incerteza, a sentença declara a existência ou inexistência de uma relação jurídica. No entanto, apenas declara, não constitui, por si, a relação jurídica. ${ }^{392}$ Opõe-se às sentenças constitutivas (e condenatórias) porque estas constituem, por si, uma nova situação jurídica: modificam a situação anterior e criam uma nova. Calamandrei afirmava o caráter declaratório porque a sentença de eqüidade apenas declararia "o direito da eqüidade", que preeste à sentença. Em outras palavras, a fonte do direito seria a eqüidade, vista como um ordenamento paralelo ao estatal. Haveria, assim, uma concepção ontológica da eqüidade como um domínio de regras paralelo ao do direito positivo. ${ }^{393}$ Carnelutti sustentou tese contrária, segundo a qual tratar-se-ia de sentença constitutiva. O juízo de eqüidade é emitido sem qualquer regra preestente e a decisão cria, por ela própria, a regra para o caso. Assim, a fonte do direito seria o próprio juízo e não uma espécie de "ordenamento de eqüidade". Atualmente, a posição de Carnelutti parece ter ampla aceitação, sendo que Calamandrei posteriormente aderiu a ela. ${ }^{394}$

Alan Redfern e Martin Hunter sustentam que um puro juízo de fato é normalmente rejeitado por comentaristas, que afirmam que se deve seguir algum princípio jurídico geralmente aceito. Todavia, não informam a quais comentaristas se referem. ${ }^{395}$

\subsubsection{Juizo de eqüidade como descarte de soluções injustas}

Outra linha de pensamento propõe que, na decisão por eqüidade, se devem seguir as normas de direito positivo e, a partir do resultado obtido, aferir sua justiça. Conforme o resultado pareça justo, será ou não modificado. De outra forma: a decisão por eqüidade deve seguir um iter pelo qual haverá a aplicação do direito positivo em primeiro lugar, para depois ser efetuada uma revisão sob o prisma da justiça. A decisão por eqüidade deve ser estruturada funcionalmente como uma decisão tal como na aplicação da lei positiva, seguida de uma reflexão sobre

o que é mais feacil onde falta um direito codificado, subtraindo-se desse modo as possibilidades de cálculo ('justiça de cádi')".

391 Entre outros: BobBio. Ordinamento giuridico. cit., p. 262 e ss. D’ Agostino, Francesco. Epikeia... cit., p. 194.

392 Cintra, Antonio Carlos Araújo; Grinover, Ada Pellegrini; Dinamarco, Cândido Rangel. Teoria geral do processo. 8. ed. São Paulo: RT, 1991. p. 270.

393 Vide D’agostino, Francesco. Epikeia... cit., p. 194.

394 Boвbio. Ordinamento giuridico, cit., p. 263.

395 Redfern, Alan; Hunter, Martin. Law and practice... cit., p. 128. 
a justiça do resultado. Caso o resultado não seja justo, devem os árbitros descartar tal solução e decidir conforme sua consciência. Se a solução do direito positivo for justa, deve aplicá-la.

Assim, cuida-se da utilização do clássico silogismo jurídico, seguido de uma segunda premissa, que seria o critério de justiça. Trata-se de um silogismo composto, com uma condição. ${ }^{396}$ Seguindo-se o exemplo do silogismo, deve-se proceder ao seguinte esquema de raciocínio: "se A é, B deve ser, desde que A seja justo". Ou então, "se A é e A é justo, B deve ser".

Esta solução tem sido defendida por diversos autores, de distintas filiações. Tendo em vista sua característica de colocar o juízo de eqüidade como uma espécie de corretivo de uma solução de direito positivo, denomina-se-lhe nesta obra de "descarte de soluções injustas", que é seu caráter principal.

A defesa mais recente desta posição, no âmbito da arbitragem internacional, foi apresentada no artigo de Sigvard Jarvin e Michael Bühler chamado L'amiable compositeur: Peut-il laisser la quesiton du droit applicable au fond indeterminée? ${ }^{397}$ Este artigo influenciou o relatório sobre arbitragem por eqüidade publicado pelo Comitê Francês da Câmara de Comércio Internacional, ${ }^{398}$ que por sua vez mostrou influência nos trabalhos do Grupo de Trabalho internacional sobre o mesmo tema, montado sob os auspícios da mesma CCI. ${ }^{399}$ Outros autores também defendem a utilização deste método. ${ }^{400}$

A pesquisa de campo realizada para esta tese perguntou aos participantes sua posição acerca da matéria. Pelos resultados obtidos, existe uma inclinação considerável para o uso deste método. ${ }^{401}$ Com efeito, $62 \%$ dos participantes entendem que os árbitros devem escolher a lei aplicável e desconsiderar as disposições que considerarem injustas, ao passo que $30 \%$ entendem que os árbitros devem decidir apenas conforme a consciência.

\footnotetext{
396 Sobre formas do silogismo, veja-se Caffé Alves, Alaôr. Lógica... cit., p. 278.

397 Publicado em Mélanges en l'honneur de François Knoepfler. Neuchatel: Helbing \& Lichenhan, 2002. p. 325 e ss.

398 Groupe de travail "Amiable composition et ex æquo et bono". Note aux Comités Nationaux, aux Groupes et aux Membres (Pour information). Paris, 2004. Mimeografado.

399 O relatório final deste grupo de trabalho foi finalizado em setembro de 2008. Ele dedica um grande espaço à discussão sobre os métodos de decisão. Embora não formule recomendação a respeito, existe um grande número de membros que prefere o método do descarte de soluções injustas. Em geral, esse método é visto como um modo para redução de incertezas.

400 Veja-se Broggini, Gerardo. Réflexions sur l'Équité dans l'Arbitrage International. Bulletin de la Association Suisse de l'Arbitrage, n. 2, p. 95 e ss., jun. 1991. São de especial interesse os debates entre o autor e Pierre Lalive e François Poudret, transcritos após o artigo. Também essa parece ser a posição de De Marini, C. M. Il giudizio di equità nel processo civile (premesse teoriche). Padova: Cedam, 1957. p. 215.

401 Veja-se capítulo específico sobre pesquisa de campo.
} 
O objetivo principal desta teoria é reduzir o espaço para uma decisão apenas conforme a consciência, que pode levar ao arbítrio. ${ }^{402}$ Assim, prefere a previsibilidade à liberdade de decidir.

Todavia, a despeito da popularidade que esta teoria parece desfrutar, não tem aceitação unânime ou, aparentemente, mesmo majoritária. Autores do mais alto renome defendem que o árbitro decidindo em eqüidade está dispensado de fazer referência ao direito aplicável ou, no caso da arbitragem internacional, de sequer buscá-lo. ${ }^{403}$

No caso da arbitragem internacional, a teoria coloca um problema prático de alta relevância, que é o da procura de uma lei aplicável quando as partes deixam de fazê-lo. A ausência de escolha de lei é relativamente comum em arbitragens de direito, o que obriga os árbitros a se valer dos métodos de direito internacional privado para definir o direito aplicável. A extensão da bibliografia sobre a aplicação de direito na arbitragem internacional é suficiente para demonstrar o quão dificultosa esta tarefa pode ser. Diversos métodos podem ser escolhidos, entre eles: (i) o das leis de conflito da sede da arbitragem; (ii) a cumulação de diferentes leis de conflito dos países com os quais a disputa possui contatos; (iii) o uso dos princípios gerais do direito internacional privado; (iv) a livre seleção ou elaboração de uma regra de conflito de leis; (v) a chamada "via direta". 404

$\mathrm{Na}$ opinião do autor, parece ser pouco razoável obrigar os árbitros a percorrer todo o intricado caminho de escolha de uma lei aplicável a uma relação contratual internacional sem que haja obrigação expressa. Em verdade, é duvidoso que as próprias partes queiram tal fixação.

Não existe disposição que determine escolha de lei nos 99 ordenamentos jurídicos pesquisados para esta obra, tampouco em qualquer dos tratados internacionais que dedicam disposições à arbitragem. Portanto, não existe uma obrigação legal expressa de assim proceder. A posição é doutrinária.

402 Essa opinião foi confirmada por um dos autores dos artigos aqui citados, em conversas com o autor desta tese.

403 Vide as posições de Pierre Lalive e François Poudret, nos debates contidos no Bulletin de la Association Suisse de l'Arbitrage, n. 2, p. 123 e ss., jun. 1991, bem como Loquin, Eric. L'Amiable composition... cit., passim. Fouchard, Gaillard e Goldman. Traité de l'Arbitrage Commercial International, cit., p. 850. Lalive, Pierre; Poudret, Jean-François; Reymond, Claude. Le Droit de l'Arbitrage Interne... cit., p. 173 (arbitragens domésticas) e 400-401 (arbitragens internacionais).

404 Vide, entre outros, Fouchard, Gaillard e Goldman. Traité de l'Arbitrage Commercial International, cit., p. 879 e ss. 
A ausência de escolha de lei pode ter um significado per se. Se as partes não escolheram um direito, embora pudessem fazê-lo, é razoável entender que assim preferiram. Conforme a pesquisa de campo realizada para esta tese, um dos casos de recomendação da arbitragem por eqüidade é justamente a dificuldade de escolha de uma lei aplicável. ${ }^{405}$

Parece excessivo entender que as partes deveriam ter escolhido o direito aplicável. Ou que, por não o escolherem, deixaram a escolha a cargo dos árbitros. Essa posição implica dizer que deve haver sempre referência a um direito aplicável, mesmo que as partes não o queiram. O silêncio das partes não pode ser entendido como uma delegação da tarefa aos árbitros, pela simples razão de que não existe obrigatoriedade de escolha.

A posição de obrigatoriedade de escolha de lei parece apresentar uma inversão da regra geral. A escolha de eqüidade tem como substrato o desejo de uma decisão menos ligada ao direito positivo e mais baseada no sentimento de justiça dos árbitros. Dada a ocorrência de escolha simultânea, ${ }^{406}$ a doutrina apresentou soluções para essa aparente contradição, harmonizando a escolha de lei e a escolha de eqüidade. No entanto, levar tal harmonização ao status de regra geral não parece correto.

Essa posição pressupõe que as partes não podem escolher julgamento apenas por eqüidade. Ao se afirmar que os árbitros devem sempre escolher um direito positivo, sustenta-se que o sentimento de justiça não pode ser aplicado sem condicionantes. Deve existir apenas em relação a uma solução de direito positivo e não por si só. Essa assertiva parece uma desfiguração do sentido primeiro da decisão por eqüidade.

Não é determinante se, na prática, os árbitros por eqüidade busquem freqüentemente cotejar a justiça de sua decisão com o direito positivo. ${ }^{407}$ Essa busca deve ser vista como uma procura de legitimação da decisão, feita muitas vezes em caráter "superabundante", e não como o exercício de um dever.

405 Veja-se capítulo sobre pesquisa de campo realizada.

406 Yves Derains nota a freqüência de tal ocorrência: "Les clauses d'arbitrage combinant l'élection d'un droit étatique pour le règlement d'eventuels litiges et l'attribution aux arbitres des pouvoirs d'amiables compositeurs ne son pas exceptionnelles". Comentário ao caso n. 2.216, publicado no Recueil des Sentences arbitales de la CCI, Paris: ICC Publishing, 1990, p. 227.

407 E também o contrário, que levou autores como Jean Denis Bredin a afirmar que existe um árbitro de eqüidade dentro de um árbitro de direito e um árbitro de direito dentro de um árbitro de eqüidade: "De telle sorte qu'il y aura chez tout arbitre en droit un amiable compositeur dissimulé. Et chez tout amiable compositeur un arbitre en droit qui chercherait à confondre le droit e l'équité". L'amiable composition et le contrat. Revue de L'Arbitrage, Paris, Comité Français de l'Arbitrage, n. 2, p. 271, 1984. 
Reafirme-se que existe uma corrente majoritária e tradicional que defende que o efeito da arbitragem por eqüidade é afastar a aplicação da lei positiva. Essa derrogação torna desnecessário seguir o direito positivo como "guia" e é respaldada por uma sólida jurisprudência arbitral. $^{408}$

De qualquer modo, caso a solução do direito positivo seja injusta, a decisão que a substituir será baseada no senso de justiça dos árbitros. Mesmo nos casos de precedência da solução do direito positivo, ainda haverá espaço para a solução ex facto.

\subsubsection{Juízo de eqüidade como juízo jurídico}

Uma espécie de desenvolvimento paralelo do descarte de soluções injustas é a consideração de que a decisão por eqüidade é um juízo jurídico. Esta posição baseia-se no entendimento de que há maior porosidade entre direito e eqüidade do que admite a visão positivista.

Segundo Broggini, ${ }^{409}$ a decisão por eqüidade apresenta uma diferença de grau em relação à decisão de direito positivo. Na decisão segundo o direito, haveria o exercício de uma função "ordinária" dos árbitros. Na decisão por eqüidade, uma função especial, com maior liberdade de apreciação dos fatos, das exigências atuais da vida social e de valorar criticamente os resultados da aplicação do direito. Essa posição parece ter eco em parte da doutrina, com algumas nuanças. ${ }^{410}$

Essa teoria defende que o raciocínio por trás de decisão por eqüidade deve ser “jurídico", no sentido de seguir os grandes lineamentos das ordens jurídicas (estatais ou não). Deve seguir um "modo de pensar" jurídico, mesmo sem aplicar a regra positiva. Embora não seja mencionado de modo explícito, essa forma de raciocínio parece ser um julgamento com base em princípios gerais do direito: princípios gerais depreendidos do ordenamento jurídico, em-

408 Vejam-se, entre outros, os casos CCI n. 3.327, 3.267, 5.103, 6.763, 7.986, 8.544/AC, 8.891/CK, 9.653/AC, 10.900/DB e 12.070. Também o caso n. 57, da Associação Italiana para Arbitragem. Todos são mencionados no capítulo relativo à jurisprudência arbitral desta obra.

409 Réflexions sur l'Équité dans l'Arbitrage International, cit., p. 106.

410 Rubino-Sammartano, Mauro. International arbitration: law and practice. The Hague: Kluwer Law International, 2001. p. 461. Do mesmo autor, veja-se também Il diritto dell'arbitrato, cit., p. 562. De modo diferente, defendendo a observância de critérios, ainda que sejam o correspondente de um senso comum econômico de um determinado momento, Francesco Galgano, Diritto ed Equità nel Giudizio Arbitrale, cit., p. 461 e ss. De modo breve e mais radical (negando a possibilidade de decisão contra legem), Clive Schmitthoff parece adotar a mesma posição (Extrajudicial Dispute Settlement. Forum Internationale, Deventer, Kluwer Law and Taxation Publishers, n. 6, p. 14, 1985). Também JAKUbowski, Jerzy. Reflections on the philosophy... cit., p. 179-180. 
bora não necessariamente referidos na legislação positiva, que conferem certos sentidos gerais ao ordenamento. ${ }^{411}$ Tal posição parece, assim, uma aplicação da "razão jurídica" ${ }^{412}$ sobreposta à norma positiva.

Embora haja autores que identifiquem os princípios gerais do direito com a eqüidade, ${ }^{413}$ essa não parece ser a posição dominante no atual estágio do pensamento jurídico.

De qualquer modo, o apelo à "razão jurídica" ou aos princípios gerais do direito parece uma exigência, sobretudo retórica. Como identificar a razão jurídica e aplicá-la ao caso concreto? Qual a sanção pelo descumprimento? Os princípios gerais têm função de unificar e dar sentido ao ordenamento, em caso de antinomias aparentes ou lacunas. São proposições genéricas o suficiente para que alguns autores lhes neguem aplicação imediata. ${ }^{414}$ Afirmar que a razão jurídica deve ser aplicada não conduz necessariamente a uma concreção maior da mecânica da decisão por eqüidade, em comparação com uma decisão livre de referenciais.

Todavia, caso se concretize algum conteúdo da razão jurídica, ${ }^{415}$ haveria sanção por seu descumprimento? Se houver, ela seria forçosamente a nulidade da sentença por descumprimento do mandato outorgado pelas partes. Assim, abrir-se-ia uma via de revisão judicial por violação da "forma de decidir em eqüidade". Entretanto, a violação de enunciados genéricos pode significar um poder de revisão quase que ilimitado. Assim, se se reconhecer sanção, abrese uma causa de revisão judicial da sentença arbitral, o que parece inconveniente, por razões de ordem prática. Se não se reconhecer tal efeito, a postulação tem pouco efeito prático, cingindose ao aspecto de recomendação de conduta aos árbitros.

Além disso, há casos freqüentes em que princípios gerais podem se contrapor, dependendo do alcance que se queira dar a eles. Assim, um credor que tarda para cobrar um crédito pode basear sua pretensão no princípio do pacta sunt servanda, na boa-fé ou mesmo

411 A posição dos chamados princípios gerais do direito na ciência do direito é controversa e, em última análise, depende da filiação doutrinária do autor a que se refira. Conforme Tércio Sampaio Ferraz (Introdução ao estudo do direito, cit., p. 223), eles não são propriamente normas. São regras estruturais e não exatamente elementos do repertório do sistema. Fornecem um elemento de coesão entre as normas e têm caráter tópico. Para Miguel Reale (Lições preliminares de direito, cit., p. 300), os princípios gerais do direito são "enunciações normativas de valor genérico, que condicionam e orientam a compreensão do ordenamento jurídico, quer para sua aplicação e integração, quer para a elaboração de novas normas".

412 Ferraz JR., Tercio Sampaio. Introdução ao estudo do direito, cit., p. 222.

413 Idem, ibidem, p. 223.

414 Veja-se o apanhado da doutrina alemã feita por Karl Larenz. Metodologia da ciência do direito, cit., p. 236 e ss.

415 Para um repertório de tópicos jurídicos, veja-se Perelman, Chaïm. Lógica jurídica, cit., p. 120 e ss. (A lista de tópicos foi elaborada por Gerhard Struck na obra Topische Jurisprudenz.) 
no neminem laedere. O devedor, por outro lado, pode alegar existência do princípio da estabilização das relações sociais ou da vedação do comportamento contraditório ou ainda jura scripta vigilantibus. Nesse caso, qualquer que seja a decisão, ela poderá invocar a aplicação de um princípio geral. ${ }^{416}$

Em sua formulação abstrata, correspondem a uma espécie de "moralidade média" da sociedade. É muito pouco provável que qualquer decisão fuja de alguma das máximas consideradas como princípios gerais do direito, ao menos em sua formulação abstrata. Postular que sejam obrigatoriamente observados critérios jurídicos de formulação ampla, de conteúdo variável e pouco tangível, com função de topos argumentativo e mais ou menos integrante de um sentimento intuitivo de justiça, pouco acrescenta em termos concretos a uma decisão por eqüidade.

Deve-se considerar, ademais, que os chamados princípios gerais do direito não são exatamente predeterminados em um rol fechado. Sua existência é uma obra do julgador e dos doutrinadores, que os depreendem, por um lado, da tradição do sistema e, de outro, do próprio ordenamento. Portanto, existe um grau razoável de flexibilidade em sua aferição.

Portanto, a posição de que um juízo de eqüidade deve seguir a "razão jurídica" ou os princípios gerais do direito, ou ainda seguir o direito, mesmo que sem respeitar a norma positiva, parece uma proposição de pouco alcance prático. Embora tenha em si a busca de uma tradição de longa data no pensamento jurídico (que de certa forma remonta ao direito natural), seus efeitos práticos são escassos, salvo uma perigosa possibilidade de revisão judicial de sentenças arbitrais proferidas em eqüidade.

Em termos formais, a postulação conduz à referência a normas anteriores preestabelecidas, embora não necessariamente na forma de direito positivo. Todavia, do ponto de vista material, as regras preestabelecidas são enunciados de cunho geral, cuja "revelação" depende em parte dos próprios julgadores. Qualquer decisão poderá invocar, em alguma medida, algum princípio geral do direito ou determinado aspecto da "razão jurídica" como fundamento.

Tanto quanto a pesquisa para esta tese revelou, não há no direito comparado nenhum comando legislativo que indique tal orientação. Ao contrário, quase nenhuma indica qualquer critério. Na minoria das legislações que esboçam alguma espécie de conteúdo material para a decisão por eqüidade, colocam-se em geral fora das regras de direito, apelando para a consciência ou o "leal saber e entender".

$\overline{416}$ Sobre a crítica ao uso de tópicos, veja-se Perelman, Chaïm. Lógica jurídica, cit., p. 129-130. 
Em uma variação dessa posição, Galgano ${ }^{417}$ postula que o juízo de eqüidade não é meramente intuitivo e subjetivo e que, de algum modo, obedece a critérios e princípios externos à mera consciência do julgador. Admite que a exigência de fundamentação das sentenças de eqüidade, exigida pela Corte de Cassação italiana, tornaria superadas as posições de exclusiva subjetividade. Invocando a autoridade de Calamandrei, Liebman e Carnelutti, afirma que o julgador por eqüidade deve buscar critérios, quer sejam "concepções econômicas e éticas prevalentes na sociedade", quer sejam "o sentido ético e jurídico difuso na sociedade", ou ainda "regras técnicas ou éticas". Conclui com um esboço de definição: "julgar por eqüidade significa traduzir em regras a cultura econômica e social de um tempo".

Os mesmos argumentos desenvolvidos anteriormente podem aplicar-se à postulação de Galgano. Acrescente-se que a exigência de fundamentação das decisões por eqüidade não significa a exigência de recurso a qualquer critério. A exigência de fundamentação, onde ocorre, representa uma garantia às partes para que saibam as razões da decisão, tanto para seu conhecimento como para eventuais impugnações. A exigência, porém, é de forma, e não de conteúdo.

\subsubsection{Juízo de eqüidade como busca de uma solução mutuamente aceitável}

$\mathrm{Na}$ mais importante monografia escrita sobre o tema da arbitragem por eqüidade, Eric Loquin menciona a existência de um duplo dever dos árbitros que decidem dessa forma. A primeira delas seria a de fornecer uma solução eqüitativa, por ele definida como "une solution qui respecte les objectifs visés par chaque partie dans l'opération litigieuse". ${ }^{418} \mathrm{O}$ segundo dever do árbitro seria o procurar uma solução aceitável a ambas as partes, com o objetivo de impedir tanto o a ruptura do contrato como favorecer a seqüência de suas relações comerciais. ${ }^{419}$

Esse segundo dever propõe uma ótica diferente aos árbitros que decidem por eqüidade. Postula que, especialmente no âmbito internacional, as partes buscam soluções negociadas para a solução de suas controvérsias e tentam, sempre que possível, evitar a solução jurisdicional. Esta última tenderia a criar uma postura de "duelo", em que as partes necessariamente tornam-se mais apegadas a seus direitos. Além disso, sua solução tende a criar um lado vencedor que terá mais vantagens que o outro, o que se dá em prejuízo do prosseguimento de relações entre as partes.

\footnotetext{
417 Galgano, Francesco. Diritto ed Equità nel Giudizio Arbitrale, cit., p. 475.

418 Loquin, Eric. L'Amiable composition... cit., p. 343.

419 Idem, ibidem, p. 343.
} 
Em tal contexto, a função da decisão por eqüidade seria a de apresentar uma espécie de estágio intermediário entre a solução negocial que se tornou impossível e uma decisão jurisdicional "pura", com vencedores e vencidos. O árbitro em eqüidade deve, assim, diminuir as dificuldades inerentes ao um procedimento jurisdicional clássico, procurando uma solução que contemple a expectativa das partes, facilitando a continuação do relacionamento entre as partes e inclusive a execução voluntária da sentença.

Esse tipo de solução terá certo caráter transacional, reconhecido como mais ou menos usual na prática. ${ }^{420}$ Esses poderes "quase-transacionais" dos árbitros de eqüidade podem ser úteis para a preservação dos relacionamentos futuros entre as partes e especialmente para preservar o próprio contrato litigioso, quando a controvérsia surge durante sua execução.

Todavia, embora possa apresentar um caráter transacional, a decisão por eqüidade continua a ter natureza jurisdicional. Apenas o caráter de winner takes all passa a ser atenuado. $\mathrm{O}$ aspecto jurisdicional da decisão não é desnaturado por uma tomada de posição "negocial" por parte do tribunal arbitral.

Esse caráter negocial parece ser adotado em alguma medida na legislação portuguesa, que prevê a composição amigável de modo distinto da arbitragem por eqüidade. ${ }^{421} \mathrm{O}$ "apelo à composição das partes na base do equilíbrio dos interesses em jogo" parece indicar uma solução de cunho mais transacional. As formas de solução de controvérsias de natureza contratual, como o arbitrato irrituale italiano, trazem também, como não poderia deixar de ser, um componente transacional mais acentuado. A sulh prevista em alguns países árabes também parece trazer o mesmo traço.

De outro lado, existe uma corrente firme no estudo da arbitragem internacional que postula que os árbitros devem atender à legítima expectativa das partes. ${ }^{422}$ Embora defendida normalmente em outros contextos, a solução postulada por Loquin pode ser inserida dentro dessa tradição doutrinária. Deve-se, contudo, atentar aos riscos de se interpretar a intenção legítima das partes, quando estas controvertem sobre o que seria tal intenção.

\footnotetext{
${ }^{420}$ Loquin, Eric. L'Amiable composition... cit., p. 362 e ss.

421 Artigo 35.

(Composição amigável)

Se as partes lhe tiverem confiado essa função, o tribunal poderá decidir o litígio por apelo à composição das partes na base do equilíbrio dos interesses em jogo.

422 Especialmente no que diz respeito à lei aplicável ao mérito, conforme se verifica, entre outros, em DERAINS, Yves. Public policy and the law applicable to the dispute in international arbitration. ICCA Congress series, Deventer, Kluwer, n. 3, p. 227-256, 1986.
} 
Nesse último aspecto reside a principal crítica à função proposta. Embora a busca por uma solução mutuamente aceitável pareça uma justa aspiração de qualquer arbitragem, ela não pode desnaturar sua função última, que é exatamente a de dirimir um litígio, na forma em que foi colocado pelas partes.

Não se pode perder de vista o pitoresco exemplo da arbitragem por eqüidade citada por Galgano, em que um árbitro sem formação jurídica decide a questão de modo completamente diverso daquele que é pretendido pelas partes. ${ }^{423}$ É perfeitamente possível que o árbitro em questão acreditasse produzir uma solução mutuamente aceitável. No entanto, certamente foi muito além de qualquer desejo das partes e do objeto do litígio.

A busca de uma solução de cunho transacional pode levar a uma postura de modificação da relação comercial original das partes. Contudo, como será visto, os poderes dos árbitros em eqüidade não chegam à modificação substancial do contrato havido entre as partes. Portanto, tal limite deve ser respeitado, sob pena de violação do mandato conferido.

\subsubsection{Apreciação crítica das posições: da liberdade para escolha do método}

Vistas as diferentes proposições acerca da mecânica da decisão por eqüidade, todas parecem ter um ponto em comum: são proposições doutrinárias feitas por autores proeminentes. Não obstante a proeminência de tais autores, não têm caráter normativo.

A prática arbitral mostra que as diferentes mecânicas de decisão por eqüidade vêm sendo usadas em algum grau, às vezes conjuntamente. Não foi possível divisar a predominância de qualquer uma delas.

Do exame das disposições de legislação comparada, da doutrina e da prática da arbitragem internacional, verifica-se um elemento central na decisão por eqüidade: a liberdade de não aplicar o direito positivo.

\footnotetext{
${ }^{423}$ No caso citado, uma companhia cinematográfica era proprietária de um navio de época, utilizado para filmagens. Contratou sua reparação junto a um armador que, uma vez terminados os trabalhos, notou que os custos haviam sido muito superiores ao valor do contrato. Assim, demandou pagamentos adicionais, recusando-se a devolver o navio. A empresa cinematográfica, por outro lado, reclamava-o para o início de filmagens. As partes decidiram remeter a controvérsia para uma arbitragem por eqüidade, tendo como árbitro único o $\mathrm{Sr}$. Ricamer, um especialista em embarcações, sem formação jurídica. A sentença do Sr. Ricamer determinou que o navio ficasse na propriedade do estaleiro, mas determinou que ele pagasse à companhia cinematográfica o valor equivalente a uma embarcação idêntica nova (Galgano, Francesco. Diritto ed Equità nel Giudizio Arbitrale, cit., p. 472).
} 
Ao julgarem sem observância do direito positivo, os árbitros possuem liberdade quanto à forma de decidir. De outra parte, as leis que fazem alguma menção ao conteúdo da decisão afirmam a liberdade de decidir "em consciência", "de acordo com princípios de eqüidade e justiça", "conforme leal saber e entender", "boa-fé guardada", "sem recurso às leis", etc. Ou seja, não determinam qualquer método de decisão em particular. ${ }^{424}$ Em geral criam um espaço jurídico para que tal forma de decisão seja desenvolvida, sem destinar regras para seu funcionamento.

À falta de determinação legal, podem doutrina e jurisprudência precisar-lhe o método e o conteúdo. Todavia, o elemento central é a liberdade de critério. No exercício da faculdade de julgar fora do direito positivo, o árbitro pode adotar o critério que mais lhe pareça adequado.

O árbitro poderá, caso the convenha, decidir com base apenas nos fatos trazidos pelas partes, resolvendo a disputa do modo que lhe parecer mais justo, sem nenhuma referência a qualquer regra. Neste caso, atuará diretamente sobre o fato e criará uma decisão ex facto. Poderá, igualmente, percorrer o caminho de uma decisão em direito e adotá-la ou substituí-la, conforme mande seu senso de justiça. Poderá, ainda, decidir em consonância com princípios gerais do direito ou com referência à tradição da(s) cultura(s) jurídica(s) envolvida(s). Poderá, também, buscar um sentido econômico, acompanhando a alocação da álea ou dos riscos envolvidos na transação. Além disso, poderá buscar uma solução de caráter transacional, mutuamente aceitável às partes. Qualquer desses critérios pode ser utilizado pelos árbitros, única ou cumulativamente, para sua decisão.

Essa parece ser a opinião, ainda que de modo menos incisivo, de Matthieu de Boisséson, ao afirmar que:

L'arbitre amiable compositeur n'est pas assujetti à une méthode unique pour trancher le litige qui lui est soumis. Au contraire, le propre de l'amiable composition est de permettre à l'arbitre d'examiner et de trancher le litige de manière empirique. Cet empirisme suppose une gamme variée de références. On peut cependant relever certains fils conducteurs qui aident l'arbitre à remplir sa mission: le recours aux usages du commerce (1), la recherche d'un certain équilibre contractuel (2), le souci d'aboutir à un niveau élevé de justice (3). ${ }^{425}$

Alguns dos defensores dos métodos invocam a redução de incertezas como benefício de sua utilização. Embora tal objetivo seja louvável, as formas sugeridas não parecem diminuir as in-

424 Talvez com a exceção de Portugal no que diz respeito à composição amigável.

425 Boisséson, Matthieu. Le Droit Français de l'Arbitrage... cit., p. 315. 
certezas de modo efetivo. A arbitragem internacional possui elementos de indeterminação inerentes. A ausência de um órgão superior aos tribunais arbitrais que dê às sentenças um sentido unificador é um deles. ${ }^{426}$ Outro é a possibilidade de árbitros, mesmo com formação jurídica, decidirem de acordo com leis de outros países. Essa hipótese quotidiana possibilita "desvios" em relação à aplicação da lei na prática doméstica. Como bem lembrado por Luiz Olavo Baptista, na prática os intérpretes de um contrato internacional são mais importantes do que a própria lei aplicável. ${ }^{427}$

Não cremos que os métodos de decisão propostos aumentem substancialmente a previsibilidade dos resultados. Algum grau de imprevisibilidade ou de poder criativo dos árbitros é ínsito à arbitragem em geral e à de eqüidade em particular. A escolha desse tipo de arbitragem somente ocorre por vontade das partes. ${ }^{428}$ Ao escolherem-na, sabem que estão conferindo um grau maior de liberdade aos árbitros. Portanto, embora a previsibilidade seja bem-vinda, não pode ter o preço de normatizar excessivamente o juízo de eqüidade em sua mecânica decisória. Especialmente porque os métodos propostos não parecem trazê-la na prática e ainda podem acarretar o imenso inconveniente de aumento do escrutínio judicial das sentenças.

Em resumo, o autor submete como conclusão deste item que a mecânica da decisão por eqüidade é a liberdade de escolha dos diversos métodos descritos. O cerne da mecânica decisória da eqüidade é o senso de justiça, que pode ser aplicado com a elaboração de regras diretamente aos fatos ou mediante o recurso a outras técnicas decisórias.

\subsubsection{Efeito principal: derrogação do direito positivo}

Estabelecida a mecânica do juízo de eqüidade, verifica-se que, qualquer que seja o método adotado, o efeito final será o da possibilidade de derrogação do direito positivo, respeitado o limite da ordem pública.

Qualquer dos critérios examinados para a mecânica da decisão por eqüidade possibilita a evicção do direito positivo. Mesmo no método de aplicação do direito positivo como paradigma existe uma autorização para derrogação da solução de direito.

426 Fouchard, Gaillard e Goldman. Traité de l'Arbitrage Commercial International, cit., p. 824.

427 Baptista, Luiz Olavo. Arbitragem e contratos internacionais: a proteção da parte mais fraca. In: PuCCI, Adriana (Coord.). Arbitragem comercial internacional. São Paulo: LTr, 1998. p. 77.

428 Mesmo nos casos de presunção de arbitragem por eqüidade, em lei ou regulamento de arbitragem, as partes podem excluí-la. 
No caso da solução conforme critérios jurídicos, embora exista observância de princípios gerais ou mesmo de solução econômica, há liberdade para desconsideração do direito positivo em favor de tais critérios. Igualmente, no caso de uma busca de solução de cunho negocial, com base na legítima expectativa das partes, está implícita a derrogação do direito positivo.

Alguns autores, todavia, afirmam que a liberdade da decisão por eqüidade existe apenas praeter legem e não pode operar contra legem ou mesmo extra legem. Ela poderia, apenas, servir de critério interpretativo, buscando uma solução mais maleável, dentro do espírito de boafé e dos princípios de bom senso e justiça. ${ }^{429}$ Contudo, esta interpretação é minoritária e advém, em grande medida, de uma visão anglo-saxã anterior à reforma de 1996, de franca hostilidade a decisões que não fossem baseadas na lei. ${ }^{430}$ Atualmente, não restam dúvidas de que a arbitragem por eqüidade abrange decisões contra legem. Em verdade, esse é seu elemento caracterizador, porque a eqüidade praeter legem pode ser utilizada em decisões conforme o direito.

Uma vez fixada a possibilidade de derrogação do direito positivo, cumpre verificar qual a medida de sua derrogação. Essa questão será discutida sobretudo no capítulo destinado à ordem pública.

\subsubsection{Obrigação ou faculdade de utilização da eqüidade}

Como visto, a eqüidade concede liberdade para a escolha de critérios de julgamento. Uma vez escolhida a eqüidade, indaga-se se os árbitros podem aplicar a lei, se assim entenderem justo.

A resposta parece intuitiva e de certo modo já antecipada nos capítulos precedentes. A função principal do árbitro decidindo em eqüidade é a de solucionar a controvérsia do modo que entender mais justo. A doutrina é unânime em admitir que o árbitro pode aplicar o direito, se entender que este é expressão de eqüidade. ${ }^{431}$ Essa tem sido também uma linha consistente de jurisprudências nacionais. ${ }^{432}$

429 Schmitthoff, Clive. Extrajudicial Dispute Settlement, cit., p. 14.

430 Embora Clive Schmitthoff seja de origem alemã, sua obra sobre arbitragem é essencialmente inglesa. Note-se também que o direito anglo-saxão, ao incluir a equity dentro de seu sistema, de certa forma permite uma maior maleabilidade em comparação ao direito romano-germânico.

431 Por todos: LoQuin, Eric. L'Amiable composition ... cit., p. 240.

432 Para França, Itália e Bélgica, veja-se Idem, ibidem, p. 240. 
A partir de um ponto de vista legislativo, a questão pode se colocar nos direitos que utilizam formulações como "os árbitros decidirão conforme o direito, salvo disposição em contrário". Embora a eqüidade possa ser uma "disposição em contrário" ao direito positivo, não significa que os árbitros terão uma obrigação de não aplicar o direito. O mesmo ocorre no tocante aos ordenamentos que determinam o julgamento "conforme leal saber e entender" e expressões similares, ou "sem recurso às leis". Não se imagina que excluam a aplicação do direito positivo que, conforme "leal saber" ou "em consciência", seja a solução justa para o caso.

Pode-se dizer, nesse aspecto, que a eqüidade representa o campo da justiça, que inclui também o direito positivo. ${ }^{433}$ Caso contrário, estar-se-ia afirmando que o direito positivo é, por definição, iníquo. Tal posição não se sustentaria do ponto de vista prático ou teórico. As leis são produzidas como vontade geral da sociedade. Em sua elaboração, pelo regular processo legislativo, busca disciplinar, do modo mais correto ao legislador, as relações sociais.

Ainda que o processo legislativo tenha suas vicissitudes, é razoável presumir que em algum grau a vontade geral do que é correto aparecerá nas leis. Mesmo que existam governos e regimes iníquos, não haverão de produzir apenas e tão-somente normas iníquas. Portanto, alguma relação entre justiça e direito positivo existe. No caso do direito privado, boa parte de suas normas é fruto de uma evolução secular, que tem servido a diferentes épocas e regimes de modo mais ou menos uniforme. Existe uma base utilizada e reconhecida como expressão de justiça. ${ }^{434}$

Essas considerações ficam mais evidentes quando se considera, na prática, o que seja o direito positivo. Nos dias atuais, o ordenamento jurídico é um conjunto muito complexo e abrangente, que reflete a complexidade da vida social. Concebido para regular a sociedade conforme uma espécie de "consciência média" elaborada pelo processo legislativo, é impossível imaginar que não reflita soluções adequadas aos olhos do homem médio ou dos árbitros. $\mathrm{O}$ direito positivo constitui um corpo elaborado e extenso de regras de comportamento. Portanto, é inevitável que os árbitros em eqüidade socorram-se do direito positivo para determinadas situações. ${ }^{435}$

${ }_{433}$ Posição afirmada no caso CCI n. 4.467, de 1984. Neste caso, o árbitro afirma que pode aplicar o direito, quando coincide este com a equiidade. Esta é um campo maior, que contém também o direito positivo (JARVIN, Sigvard; Derains, Yves. Collection of ICC Arbitral Awards. Recueil des Sentences Arbitrales de la CCI. Boston: Kluwer Law and Taxation Publishers, 1990. p. 501).

${ }^{434} \mathrm{O}$ direito civil do sistema romano-germânico serve como bom exemplo dessa base renovada ao longo dos tempos.

${ }^{435}$ Loquin, Eric. L'Amiable composition... cit., p. 242. 
Além disso, o árbitro em eqüidade deve respeitar a ordem pública. Portanto, mesmo no exercício de sua função, deverá aplicar certas regras consideradas imperativas, ou ao menos não pronunciar sentença que as contradiga. Portanto, algum grau de aplicação de normas legais haverá na decisão por eqüidade.

Diga-se, por fim, que existe uma consolidada jurisprudência arbitral em que existe a aplicação do direito positivo, mesmo quando os árbitros estão autorizados a decidir por eqüidade. $^{436}$

Verificada a possibilidade de decisão conforme o direito, cumpre examinar essa faculdade em relação à fundamentação da sentença. Podem os árbitros decidir com referência apenas ao direito, sem apresentarem justificativas em eqüidade?

Eric Loquin defende que o árbitro autorizado a julgar por eqüidade tem, mais que uma faculdade, uma missão. Essa missão seria composta de uma faculdade, a possibilidade de julgar contra legem, e um dever de eliminar iniqüidades. ${ }^{437} \mathrm{O}$ árbitro tem o dever de dirimir o litígio da forma que entender mais justa. Ao fazê-lo, tem a faculdade de descartar a lei positiva.

$\mathrm{Na}$ forma como foi inicialmente formulada, existiria obrigatoriedade de justificar a decisão em eqüidade sempre que o árbitro for confrontado com um pedido que não encontra fundamento em lei. Assim, para rejeitar o pedido, não poderia simplesmente afirmar que o direito estrito não permite, mas tecer considerações de eqüidade. Caso contrário, estaria descumprindo sua "missão". ${ }^{438}$

Embora inicialmente pouco difundida, ${ }^{439}$ essa interpretação é hoje prevalente na França e encontra julgados favoráveis na Itália, onde é defendida por parte da doutrina. ${ }^{440}$

Na França, a matéria teve uma evolução consistente, chegando-se ao julgamento da Corte de Cassação de 15.02.2001, em que foi reconhecida a obrigação do árbitro de apresentar

\footnotetext{
436 Nos casos CCI n. 4.467, 6.955, 11.206/JNK e 13.214/RCH, todos mencionados no capítulo relativo à jurisprudência arbitral. Em alguns deles houve escolha de lei aplicável. Veja-se também o caso n. 1.795 da Associação Italiana para a Arbitragem.

437 LoQuin, Eric. L'Amiable composition... cit., p. 245.

438 Idem, ibidem, p. 244.

439 Eric Loquin (Ibidem, p. 244) refere-se, em 1980, a apenas um entendimento da Corte de Cassação italiana à ausência de julgados nesse sentido na França.

440 Rubino-Sammartano, Mauro. Il diritto dell'arbitrato, cit., p. 461.
} 
seus fundamentos em eqüidade, mesmo que esta se traduza na aplicação da lei. ${ }^{441} \mathrm{~A}$ mesma questão havia sido julgada pela Corte de Apelações de Grenoble. Esse princípio foi reafirmado pela Corte de Cassação em julgamento de 28.11.2007. Neste caso, porém, a sentença arbitral não foi anulada porque se pôde inferir de suas razões que o julgamento foi feito por eqüidade, embora sem menção expressa. ${ }^{442}$

Ainda que se verifique nestas soluções a boa intenção de obrigar os árbitros a respeitar a vontade das partes e desempenhar sua tarefa a contento, ela possui limitações.

Em primeiro lugar, como afirmado por Galgano, ${ }^{443}$ ela implica uma presunção de que as leis são iníquas, dependendo de uma confirmação de eqüidade por parte dos árbitros. Em segundo lugar, conforme posições confirmadas por jurisprudência italiana, pode-se também considerar que uma decisão sem referência à eqüidade significa o reconhecimento implícito de

${ }_{441}$ Julgados publicados na Revue de l'Arbitrage, n. 1, 2001, p. 135 e ss.: Cour de cassation (2e Ch. civile) 15 février 2001; Cour d'appel de Grenoble (Ch. com.) 15 décembre 1999. Em nota aos julgados, Eric Loquin afirma que:

"La Cour de cassation comme la Cour d'appel de Grenoble admettent que l'amiable compositeur doit d'office faire usage de ses pouvoirs d'équité et rechercher dans tous les cas si les solutions résultant de la seule application du droit ou du contrat doivent être corrigées par l'appréciation de l'équité. Nous avions conçu de manière moins exigeante la mission de l'amiable compositeur. Celui-ci ne manquerait à sa mission que dans les seuls cas où il refuserait de faire droit à une demande fondée sur l'équité, au seul motif que la loi ou le contrat n'autoriserait pas à la satisfaire, sans vérifier si l'équité ne permettrait pas de corriger cette conséquence (L'amiable composition en droit comparé et international, op. cit., n. 427). A la réflexion, la position des arrêts commentés est plus respectueuse de la mission d'amiable compositeur reçue par les arbitres. Cette jurisprudence radicalise la distinction que nous avons toujours soutenue entre l'arbitrage de droit et l'amiable composition et consacre pleinement la dualité de l'arbitrage."

442 “06-16.835 - Arrêt n. 1363 du 28 novembre 2007 - Cour de cassation - Première chambre civile

$[\ldots]$

Attendu qu'il est fait grief à l' arrêt d'avoir rejeté le recours en annulation alors, selon le moyen, que lorsqu'il est investi par les parties d'une mission de statuer comme amiable compositeur, l'arbitre a l'obligation de trancher le litige qui lui est soumis selon l'équité ; que la circonstance qu'un arbitre ait retenu une solution qui ne correspondait pas à celle résultant de l'exacte application des règles de droit n'implique pas, à elle seule, qu'il ait tranché le litige qui lui était soumis selon l'équité, et non selon les règles de droit, dès lors que l'arbitre a pu commettre une erreur dans l'application des règles de droit; que, dès lors, en se fondant, pour retenir que M. le Bâtonnier Bernard Vatier avait jugé en équité et s'était, en conséquence, conformé à la mission de statuer comme amiable compositeur dont il avait été investi par les parties, sur la seule circonstance que M. le Bâtonnier Bernard Vatier avait retenu une solution qui ne s'imposait pas juridiquement, puisqu'il s'était appuyé sur les clauses du contrat de cession de bail auquel les parties à l'arbitrage étaient tiers, la cour d'appel a violé les articles 1474 et 1484 du nouveau code de procédure civile;

Mais attendu que l'arrêt rappelle d'abord les pouvoirs d'amiable compositeur conférés à l'arbitre tant par la clause d'arbitrage que par le procès verbal d'arbitrage du 23 août 2004 ; qu'il précise ensuite qu'en fondant sa décision sur les clauses de la cession du contrat de bail à laquelle les parties à l'arbitrage sont tiers, l'arbitre avait entendu faire référence à l'équité, malgré l'absence de mention explicite des pouvoirs conférés par les parties ; que la cour d'appel a pu en déduire que l'arbitre s'était ainsi conformé à sa mission ; que le moyen n'est pas fondé ; [...]"

Disponível em: <http://www.courdecassation.fr/jurisprudence_2/premiere_chambre_civile_568/arrets_569/ br_arret_11004.html>. Acesso em: 15 nov. 2008.

443 Diritto ed Equità nel giudizio arbitrale, cit., p. 461. 
que a lei é eqüitativa. ${ }^{44}$ Trata-se de posição aceitável, que contempla os poderes dos árbitros em eqüidade de decidir conforme a lei. Ela apenas dispensa uma menção direta ao uso da eqüidade.

Talvez a principal limitação seja o fato de que se trata de solução formal. Na forma em que foi postulada, uma pequena frase dos árbitros ao final da sentença é suficiente para afastar quaisquer problemas. Por outro lado, a busca de um critério material para aferir a aplicação da eqüidade não parece uma alternativa viável, na medida em que abriria uma nova via de escrutínio da sentença arbitral muito próxima de um reexame de mérito.

Outra desvantagem dessa orientação é a de atentar contra a validade da sentença arbitral. Embora possa estar dentro das causas referidas como excesso ou desvio de mandato por parte dos árbitros, trata-se de mais um item passível de causar nulidade da sentença.

No caso brasileiro, o art. 26, II, da Lei de Arbitragem determina menção expressa ao fato de a sentença ter sido dada por eqüidade. A sanção para o desrespeito é a anulação da sentença, com prolação de outra pelo tribunal arbitral (arts. 32 e 33 da mesma lei). Assim, o Brasil filia-se à orientação prevalente na França, de que os árbitros em eqüidade devem mencionar essa circunstância na sentença. Todavia, o faz, com mais ênfase, no âmbito legislativo.

Portanto, recomenda-se que os árbitros, sempre que decidirem conforme o direito, mencionem a circunstância de entenderem que essa é a solução equitativa para o caso. No Brasil, essa menção deve ser feita em qualquer hipótese.

Parte da doutrina e jurisprudência italianas ${ }^{445}$ defende que a qualificação jurídica dos fatos, no juízo de eqüidade, deve ser feita de acordo com o direito. Desse modo, a eqüidade seria apenas o critério de julgamento para fatos colhidos e classificados conforme o direito. Essa opinião parece sobretudo direcionada a arbitragens internas, em que existe uma ordem jurídica estatal de referência.

No caso da arbitragem internacional, à falta de tal ordem jurídica de referência, a opinião tem pouco alcance. A menos que se pretenda que os árbitros autorizados a julgar por eqüidade tenham o dever de escolher uma ordem jurídica estatal de referência apenas para proceder à qualificação dos fatos.

444 Rubino-Sammartano, Mauro. Il diritto dell'arbitrato, cit., p. 561.

445 Idem, ibidem, p. 560. 
Tal opinião teria como conseqüência a abertura de uma tormentosa questão de direito internacional privado para a definição de lei aplicável. Mesmo feita a escolha de ordenamento, ainda assim haveria o problema da qualificação em si, uma das áreas mais desafiadoras do estudo do direito internacional privado. ${ }^{446} \mathrm{Se}$ as partes resolvem conceder aos árbitros a faculdade de decidir conforme sua consciência, parece pouco provável que queiram que eles qualifiquem direitos conforme a lei para depois decidir de acordo com seu sentimento de justiça.

Erros de direito em geral não são causa de nulidade da sentença arbitral. Como então proceder com erros de qualificação? Caso se coloque a questão no âmbito da simples aplicação do direito, ela tem pouco efeito prático: eventual erro não será mais ou menos sancionado do que a derrogação de uma norma supletiva, ${ }^{447}$ a menos que se considere a qualificação como questão de ordem pública. Caso se coloque como questão autônoma, criar-se-ia uma nova modalidade de escrutínio da sentença arbitral, o que parece de todo inconveniente.

Não parece razoável que árbitros investidos de poderes de julgar conforme seu sentimento de justiça tenham de se ater à qualificação dos fatos conforme o direito. Não se nega que ela possa ter utilidade para a decisão de fato. Por exemplo, a correta qualificação de um direito afeta prazos prescricionais, como de resto qualificar a prescrição como pertencente ao direito material ou processual também produz efeitos práticos. Todavia, se os árbitros possuem a faculdade de derrogar normas positivas, ela afeta os efeitos da qualificação. Assim, a exigência parece ser uma imposição do menos a quem pode o mais.

\subsubsection{O problema da escolha simultânea de direito}

Embora a arbitragem por eqüidade se caracterize pela liberdade de não-aplicação do direito positivo, existem numerosos casos em que as partes estipulam simultaneamente no mesmo contrato uma lei aplicável e arbitragem por eqüidade.

Essa aparente contradição ${ }^{448}$ poderia levar a uma solução segundo a qual uma das duas opções prevaleceria sobre a outra: ou se considera a eqüidade ou o direito positivo. Assim, uma das opções seria reputada sem efeito. Todavia, soluções tendentes a negar efeito a alguma parte do contrato devem ser evitadas, sob pena de infringir um cânone da interpretação dos negócios

\footnotetext{
446 De modo geral, Dolinger, Jacob. Direito internacional privado, cit., p. 301 e ss.

447 A menos que se coloque a qualificação como questão de ordem pública, o que é improvável.

448 BoIssÉson, Matthieu. Le Droit Français de l'Arbitrage... cit., p. 314.
} 
jurídicos, segundo o qual, quando forem possíveis duas interpretações, deve-se buscar a que preserve os efeitos do pacto. ${ }^{449}$

De qualquer modo, não existe incompatibilidade fundamental entre a escolha de lei aplicável simultaneamente à eqüidade. Sendo a eqüidade a faculdade de não-aplicação de um direito positivo, não há empecilhos para que as partes forneçam aos árbitros parâmetros para balizar sua decisão.

Sob o fundamento contratual da arbitragem, as partes gozam de ampla liberdade para escolher critérios e leis para a decisão: podem escolher a lei processual, a lei de fundo, a lei de regência da cláusula compromissória, corpos não estatais de regras (tais como regras corporativas, princípios gerais, lex mercatoria, etc.), ou ainda mesclá-los a seu talante.

Podem, por exemplo, utilizar princípios comuns a dois ou mais ordenamentos, um ordenamento apenas na medida em que não contradisser certos princípios reconhecidos internacionalmente ou outras combinações. Dessa forma, nada impede que decidam escolher eqüidade, com a aplicação de uma lei de referência.

No entanto, a escolha de uma lei de referência tem implicações na "mecânica" da decisão por eqüidade. A escolha de uma lei traduz-se na tarefa dos árbitros de seguirem o método denominado de "descarte de soluções injustas": o tribunal deve aplicar a lei escolhida pelas partes e verificar se a solução encontrada é justa, segundo seu entendimento. Se o for, mantém a decisão. Caso não seja, descarta a solução iníqua.

Essa solução é defendida pela doutrina:

Les parties elles-mêmes fournissent parfois des indications sur la démarche qu'elles attendent des arbitres. Il n'est pas rare en effet qu'elles combinent la clause d'amiable composition avec le choix d'une loi étatique. Dans une telle hypothèse, les arbitres partent de l'application de la loi choisie et s'en écartent lorsqu'ils estiment qu'elle conduirait à des résultats inéquitables. ${ }^{450}$

No mesmo sentido, Eric Loquin. ${ }^{451}$

Contudo, alguns autores vêem na escolha simultânea um efeito importante relativamente à ordem pública. Para eles, a escolha de lei obriga os árbitros a respeitarem as disposi-

449 Serpa Lopes, Miguel Maria de. Curso de direito civil, cit., v. 3, p. 49.

450 Fouchard, Gaillard e Goldman. Traité de l'Arbitrage Commercial International, cit., p. 850.

451 Loquin, Eric. L'Amiable composition... cit., p. 243. 
ções imperativas do direito escolhido. ${ }^{452}$ Essa posição decorre de uma "interpretação razoável" da vontade das partes, que quiseram submeter sua questão àquela lei. Assim, a eqüidade tornase uma renúncia ao direito supletivo da legislação escolhida. No mesmo sentido, em vista da liberdade contratual da arbitragem, Yves Derains. ${ }^{453}$

Essa interpretação deve ser vista com reservas. Na arbitragem internacional, as partes podem fazer inúmeras variações de escolhas de lei, podendo "congelar" as normas em uma determinada data, excluir determinadas disposições que anulariam o contrato ou parte dele e outras combinações. A escolha de lei pode significar apenas a escolha de um método de decisão e não a aplicação de normas imperativas daquele direito.

Para os que defendem a "deslocalização" da arbitragem internacional, a ordem pública "natural" seria a chamada ordem pública verdadeiramente internacional. Isso porque reflete melhor sua desvinculação de qualquer sistema nacional. Sendo a ordem pública um "filtro" para a aplicação de certas normas, os árbitros internacionais não estão ligados a nenhum ordenamento em princípio. Não são guardiões de nenhuma ordem pública estatal. A escolha de um direito de referência não parece modificar essa natureza, já que, como visto, pode apenas significar a utilização de uma "mecânica" de decisão. Sendo critério de decisão, não torna o árbitro internacional "guardião" da ordem pública desse ordenamento.

De outra parte, tratando-se de arbitragens internacionais, os limites são conferidos pela ordem pública internacional. Consiste-se de critério mais amplo do que as regras imperativas de direito interno. Situar a escolha de lei de referência no âmbito do direito imperativo interno teria o efeito de diminuir o espaço de atuação dos árbitros: o direito supletivo interno é mais restrito do que a ordem pública internacional.

452 LoQuin, Eric. L'Amiable composition... cit., p. 268.

453 " 30 . The actual implications of the wording of certain clauses stipulating the applicable law can be more difficult to determine. For example, faced with a clause whereby 'the arbitration shall take place at The Hague and the arbitrators shall apply Swedish law', can the arbitrators set aside a clause in the contract because it is in breach of Swedish public policy? It would seem that they can, because the apparent will of the parties is that any dispute is to be settled by Swedish law; and the validity of a contractual clause is a dispute like any other. However, there are other interpretations. It is up to the arbitrator, whose task is to interpret the contract, to decide. Likewise, the fact that arbitrators have been granted the powers of amiables compositeurs and this is combined with the choice of a particular national law should not be interpreted as authority for excluding the public policy of the lex contractus." Derains, Yves. Public policy ... cit., p. 227 e ss. (grifamos). 
Caso a arbitragem fosse de direito, os limites dos árbitros seriam dados pela ordem pública internacional e não pelas regras imperativas de direito interno. Não parece correto impor ao árbitro de eqüidade um alcance menor do que teria se decidisse em direito. ${ }^{454}$

Assim, o efeito principal da escolha concomitante de lei é a forma com que o tribunal deve tomar sua decisão: partindo-se da aplicação do direito escolhido, descartam-se eventuais soluções injustas. Não havendo escolha, ficam os árbitros liberados para a escolha do método que entenderem mais conveniente.

\subsubsection{Eqüidade e questões não ligadas ao mérito}

Alguns autores ${ }^{455}$ e sentenças ${ }^{456}$ afirmam que a eqüidade somente opera em relação ao mérito. Todavia, tal afirmação merece ser vista com algumas nuanças.

A arbitragem por eqüidade tem efeitos sobre o procedimento, especialmente nos países que o prevêem de modo mais detalhado em sua legislação. Como discutido nesta obra, a escolha da eqüidade pode liberar os árbitros de seguir certos procedimentos, bem como alterar regimes recursais nos países que os adotam. Em alguns casos, pode-se mesmo considerar que a eqüidade autoriza modificações nos procedimentos escolhidos pelas partes. ${ }^{457}$

Para além do procedimento arbitral propriamente dito, existem outras questões não ligadas ao mérito que devem ser resolvidas pelos árbitros. Tomando-se de empréstimo a nomenclatura de processo civil, pode-se referir a tais questões como "pressupostos processuais" da arbitragem: questões prévias que condicionam o desenvolvimento válido de um procedimento para que ele atinja seu fim, que é uma sentença final de mérito. ${ }^{458}$ Essas questões não se confundem com o mérito da questão posta aos árbitros, embora sejam condições para sua obtenção.

${ }_{454}$ Referindo-se a situação um pouco distinta, veja-se BERGER, Klaus Peter. International Economic Arbitration, cit., p. 574. Também Lalive, Pierre; Poudret, Jean-François; Reymond, Claude. Le Droit de l'Arbitrage Interne... cit., p. 173.

${ }^{455}$ Lalive, Pierre; Poudret, Jean-François; Reymond, Claude. Concordat sur l'Arbitrage. Lausanne: Editions Payot, 1989. p. 173. Rubino-SAmmartano, Mauro. Il diritto dell'arbitrato, cit., p. 558.

456 Comentários à decisão da Comissão de Arbitragem de Bucareste, de 26.12.1985. Journal du Droit International, Paris, Editions Techiniques, v. 2, p. 476, 1988.

${ }^{457}$ Sobre o procedimento especificamente, veja-se a o item seguinte.

458 Sobre a matéria, veja-se Della VALLE, Martim. Considerações sobre pressupostos processuais em arbitragem. Revista Brasileira de Arbitragem, v. 12, p. 7 e ss., 2006. 
$\mathrm{Na}$ arbitragem pode-se afirmar que o pressuposto processual por excelência é a validade da cláusula arbitral: sem ela, não pode existir um provimento de mérito. Também podem ser assim considerados a possibilidade de a matéria de fundo ser dirimida por arbitragem (arbitrabilidade objetiva) e a capacidade das partes de contratarem arbitragem (arbitrabilidade subjetiva).

Podem essas questões ser dirimidas por eqüidade? A questão não é simples e encontra divergências na doutrina e na prática. Como conceituado nesta obra, a eqüidade é, sobretudo, um critério de julgamento outorgado pelas partes aos árbitros. Por esse critério, os árbitros podem derrogar normas de direito positivo que seriam aplicáveis ao caso, simplesmente decidindo de acordo com seu sentimento de justiça. Sendo um critério concedido aos árbitros para julgamentos no procedimento arbitral, poderia alcançar outras questões que não aquelas de mérito?

Embora tenha origem contratual, a arbitragem deriva de uma autorização estatal. A lei estatal fornece a moldura jurídica em que a arbitragem por eqüidade pode funcionar. As "regras do jogo" advêm da lei. Certos aspectos dessa moldura não podem ser derrogados por vontade das partes. Elas não podem, por acordo, estender a arbitragem a matérias não arbitráveis. Exceto casos de convalidação, uma cláusula pode ser considerada nula pela lei, a despeito da vontade das partes que a previram.

A sanção ao desrespeito dos limites legais da arbitragem é em geral sua nulidade. Antes do exame dos tribunais estatais, cabe ao próprio tribunal arbitral examinar as mesmas questões: os tribunais estatais agirão após a questão ser decidida na arbitragem, salvo raras exceções.

A Convenção de Nova Iorque dispõe que a sentença arbitral pode ser anulada caso a convenção de arbitragem seja inválida segundo a lei que as partes tenham escolhido ou, à falta dessa, da lei do local da arbitragem. Neste caso, existe o reconhecimento do princípio da autonomia da vontade das partes em fixar a lei de regência da cláusula arbitral.

Por outro lado, uma parte considerável da doutrina vem relativizando a influência das regras nacionais sobre a validade da cláusula arbitral. Como se verifica sobretudo na doutrina francesa ${ }^{459}$ existe um movimento para a adoção de "regras materiais" para a aferição da validade da cláusula arbitral, sem remissão direta a particularismos locais. Essa regra material, quando colocada perante os tribunais franceses, como no caso Dalico, teve por efeito a apreciação da validade da cláusula arbitral sem remissão necessária a nenhuma lei nacional, mas tendo em

459 Fouchard, Gaillard e Goldman. Traité de l'Arbitrage Commercial International, cit., p. 245 e ss. 
consideração a vontade das partes e a ordem pública. ${ }^{460}$ Trata-se aqui de um segundo aspecto da autonomia da cláusula arbitral, além do já conhecido efeito da competência-competência.

Essa autonomia, quando colocada perante os árbitros internacionais, tem um efeito mais profundo. Considerando-se a teoria de que o árbitro internacional não possui um foro propriamente dito, ele está desengajado de qualquer ordenamento nacional. Desse desengajamento segue-se que os árbitros devem apreciar a validade da cláusula arbitral de acordo com certos princípios reconhecidos pela comunidade internacional, sem referência a ordenamentos específicos, ou mesmo da ordem pública internacional de qualquer país em especial:

N'appartenant à aucun ordre juridique étatique, les arbitres n'ont aucune rai-
son institutionnelle de faire prévaloir les règles de conflit de l'un ou de l'autre
des systèmes juridiques en présence, pas plus que des dispositions substan-
tielles de ces droits. Dans le silence des parties sur ce point, l'application de
ce qu'ils estiment être les exigences essentielles de la société internationale
dégagées sur la base d'études de droit comparé et de l'examen de la jurispru-
dence arbitrale internationale, indépendamment des particularismes locaux,
est sans dout ce qui correspond le mieux à leur nature et à leur fonction. ${ }^{461}$

Desse modo, por essa corrente doutrinária, o árbitro internacional aplica regras transnacionais depreendidas do estudo de direito comparado e da jurisprudência. ${ }^{462}$

A mesma conclusão - aplicação de regras transnacionais depreendidas do direito comparado e da jurisprudência pelos árbitros internacionais - é aplicada, pelos defensores de tal teoria, a questões como a arbitrabilidade subjetiva e objetiva. ${ }^{463}$ Portanto, igualmente nessas questões existe uma superação da aplicação da lei nacional. No caso da arbitrabilidade subjetiva, um dos exemplos mais recorrentes é o da capacidade dos Estados de celebrarem convenção de arbitragem. Nesses casos, discute-se acima de tudo a relação entre leis nacionais que restringem a capacidade dos Estados de contratarem arbitragem e sua oponibilidade a terceiros que contratam de boa-fé. No caso da arbitrabilidade objetiva, as questões mais recorrentes são a patrimonialidade do objeto da controvérsia e a aplicação do direito concorrencial.

Verifica-se, assim, que questões não ligadas ao mérito são desengajadas da aplicação de qualquer regra nacional, de acordo com parte relevante da doutrina. Portanto, as "regras do

\footnotetext{
460 Essa posição não ficou isenta de críticas, sendo a principal delas que o efeito final seria a criação de um contrato sem lei, cujas tentativas no passado já foram rejeitadas.

461 Fouchard, Gaillard e Goldman. Traité de l'Arbitrage Commercial International, cit., p. 252.

462 Existem também alguns ordenamentos que determinam uma combinação de leis in favorem validitatis, como é o caso da lei suíça (art. 178 da Lei de Direito Internacional Privado).

463 Fouchard, Gaillard e Goldman. Traité de l'Arbitrage Commercial International, cit., p. 345.
} 
jogo", ao menos enquanto discutidas dentro da instância arbitral, são colocadas fora do âmbito de uma legislação nacional. Segue-se que não existe um princípio geral de que "as regras do jogo" devam ser julgadas de acordo com leis nacionais. Todavia, essas leis estatais, ao menos interessarem à ordem pública, terão efeitos no momento da execução da sentença arbitral.

As partes são livres para a escolha do direito que regerá tanto a cláusula arbitral como o próprio procedimento. Em uma perspectiva internacional, em que praticamente todos os direitos nacionais estão disponíveis para a escolha, sem que nenhum deles possa ser considerado como o do "foro" da arbitragem, existe um enorme espaço para a discricionariedade. As partes podem escolher direitos mais ou menos favoráveis à arbitragem, o que implica dizer critérios distintos para a validade da cláusula ou de arbitrabilidade.

A desnecessidade de aplicação de uma regra nacional aliada à discricionariedade para escolha de critérios mostra uma situação de fato: as partes gozam de liberdade para definir os critérios com os quais certas matérias não ligadas ao mérito serão decididas. A possibilidade de sujeitar tais questões a princípios internacionais depreendidos pelos próprios árbitros representa outorga de considerável liberdade decisória. Igualmente, a possibilidade de as partes escolherem direitos mais favoráveis à validade da cláusula.

Havendo ampla liberdade para escolha de lei e mesmo de critérios não-legais, não se vislumbram razões para impedir que essas questões sejam decididas por eqüidade, quando houver autorização para tanto. Trata-se de utilizar um critério de julgamento desvinculado da aplicação do direito positivo.

Embora a distinção entre decisão por eqüidade e regras transnacionais seja amplamente reconhecida no plano teórico, diversos autores reconhecem que, na prática, essa diferença é muito menos nítida. ${ }^{464}$ Assim, é possível que exista uma aproximação prática entre decisão conforme regras transnacionais e uma decisão por eqüidade.

Na doutrina internacional existem posições, ainda que menos enfáticas, admitindo que os árbitros autorizados a julgar por eqüidade podem usar esse mesmo critério de julgamento relativo à própria competência:

Ainsi l'arrêt no. 11: On peut en revanche se demander si un amiable compositeur ne peut pas, en cette qualité, statuer sur sa compétence, c'est-à-dire en

464 Embora referindo-se especificamente à lex mercatoria, as opiniões são aplicáveis igualmente ao processo. Veja-se Berger, Klaus Peter. International Economic Arbitration, cit., p. 568. No mesmo sentido, Robert, Jean. Arbitrage... cit., p. 278. 
l'espèce interpréter la clause compromissoire et le protocole en équité uniquement, autant naturellement qu'il y ait une diférence à faire entre l'interprétation en équité et celle selon le principe de la confiance. Selon Brosset (FJS 464, p. 5), qui se réfèere à Capitant, l'amiable compositeur a le pouvoir de décider en équité quant au fond et sans égard aux rèlgres de procédure quant à la forme. (Dans le même sens, Concordat suisse sur l'arbitragem annoté, ad art. 31)... Sur le fond, l'amiable compositeur n'est pas lié par les règles du droit, quelles qu'elles soient, c'est-à-dire même s'il s'agit d'une disposition légale impérative (ch. rec. A.c.S., 28.10.75, arrêt no. 5). En revanche, pour ce qui est de la procédure, l'amiable compositeur ne peut être valablement liberé d'appliquer les règles impératives de la procédure, c'est-a-dire celles qui sont prescrites par le Concordat luit-même (voir art. 1er al. 3 du Concordat). On ne voit donc pas d'emblée ce qui empêcherait les parties de permettre aux arbitres de statuer en amiables compositeurs sur leur propre compétence, pour autant qui'ils ne se saisissent pas d'une cause ressortissant à la compétence exclusive d'une autorité étatique en vertu d'une disposition impérative de la loi. Il resterait alors la question de la validité de la clause compromissoire ou du compromis arbitral, question que ne peut être résule qu'en droit, mais qui, en la présente espèce, ne se pose pas, car cette validité n'est pas contestée. Faute de réserve quelconque ou de disposition impérative fondant une compétence exclusive d'une autorité étatique, il n'est pas exclu que les arbitres aient été fondés à statuer en amiable compositeurs sur toutes les questions; donc, même s'ils avaient réellement statué en cetter qualité, il n'y aurait pas motif à annuler leur sentence. ${ }^{465}$

Essa liberdade parece dirigida à interpretação da cláusula de arbitragem e do compromisso arbitral. Igualmente, envolve questões de "competência" que nenhuma disposição imperativa da lei coloque sob a égide dos tribunais estatais ou mesmo da legislação imperativa. De qualquer modo, reconhece a liberdade de julgamento por eqüidade da própria competência do tribunal arbitral. Trata-se de uma posição ainda pouco explorada na doutrina. Todavia, pode-se encontrar caso prático em que a decisão sobre a competência do tribunal é tomada por eqüidade.

No caso CCI n. 12.070, decidiu-se:

47. - The Tribunal notes, however, that Respondent's initial declaration to accept to submit the dispute to arbitration, as expressed in its letter of 7 May 2002, did not contain such a restriction, which therefore cannot be added unilaterally at a later stage. In reply to the question raised under the first item of the Terms of Reference, the Tribunal finds, therefore, that its power to decide ex aequo et bono does extend to the question whether the 1997 Order was validly transferred from [...] to Claimant. The issue raised by Respondent is, anyhow, not as controversial than it appears to be when referring to the

\footnotetext{
${ }^{465}$ PoudRET, Jean-François; ReYmond, Claude; Wurzburger, Alain. L'Application du Concordat Intercantonal sur l'Arbitrage par le Tribunal Cantonal Vaudois (dix ans de jurisprudence). Journal des Tribunaux, v. 3, p. 92, 1981.
} 
Partie's pleadings. As this will be developed below, the Parties agree upon the basic legal requirements in relation to such transfer (i.e. that some form of approval by Respondent either express or implied or through conduct is necessary), whereas they disagree when it comes to establish the pertinent factual elements that may, or may not, meet the legal conditions underlying such a transfer. ${ }^{466}$

A aplicação da eqüidade para decisão de questões relativas à organização da própria arbitragem, tal como o alcance da cláusula de arbitragem, parece ser uma possibilidade viável. Ao menos, não se encontram determinações legais que impeçam tal aplicação de modo peremptório ou determinem qual critério de julgamento (direito ou eqüidade) deva ser aplicado. Entretanto, tal aplicação encontra barreiras na ordem pública e na vontade das partes.

Imagine-se o exemplo de uma legislação que reconheça somente a cláusula arbitral quando simultaneamente assinada pelas partes. Poderiam árbitros decidindo por eqüidade reconhecer a validade de um acordo de arbitragem que tenha sido alcançado por meio de troca de correspondência? Uma desconsideração de tal natureza não parece ferir os princípios elementares da ordem jurídica internacional, porque mostra o atingimento da finalidade da forma, de modo distinto (comprovação indubitável da vontade das partes). Também porque privilegia a boa-fé. No entanto, caso algum dos países envolvidos na arbitragem venha a considerar a norma escrita como elemento da ordem pública internacional, a decisão poderá ser anulada.

A liberdade não é absoluta nem totalmente desvinculada dos direitos nacionais. Seja pela via de ação de nulidade, seja por oposição ao reconhecimento da sentença, os tribunais estatais dos diversos países envolvidos darão a palavra final sobre a validade da cláusula. Caso os árbitros tenham decidido de modo a violar a ordem pública do foro ou do local da execução da sentença, haverá nulidade (ou ausência de eficácia) da sentença arbitral.

Portanto, o fundamento central de que o Estado tem o controle sobre a validade da cláusula arbitral e sobre a arbitrabilidade continua operante. A lei aplicável para tal controle é matéria que concerne ao Estado em questão, que poderá ou não valer-se de outros ordenamentos ou regras transnacionais.

Assim, do ponto de vista formal, não se vê impossibilidade de que o julgamento por eqüidade seja feito igualmente quanto a questões não relacionadas ao mérito.

466 Citado de modo mais completo no capítulo relativo à jurisprudência arbitral. 
Todavia, existe outro aspecto de fundamental relevância: a vontade das partes. Podese inferir que a autorização para julgamento por eqüidade significa que as partes quiseram que tal critério fosse aplicado também às questões não relacionadas ao mérito? A questão deve ser vista com cautela.

Da mesma forma que a lei escolhida para o mérito não significa uma escolha de lei aplicável à cláusula, ${ }^{467}$ a escolha da arbitragem por eqüidade pode não significar escolha de critério de julgamento de questões preliminares. Caso seja possível identificar a vontade das partes, evidentemente o tribunal deve segui-la. Caso não seja possível, deve-se considerar a própria eqüidade como uma das opções (e certamente não a única).

A escolha de eqüidade pode significar, por um lado, o desejo de desvinculação da arbitragem das "amarras" de leis nacionais: as partes a escolhem para não ter de enfrentar particularismos legislativos, preferindo abandonar a lei positiva em favor do sentimento de justiça dos árbitros. Tal vontade pode servir tanto para o mérito da questão quanto para a parte procedimental e outros aspectos preliminares. Nesse sentido, a escolha de eqüidade ao mérito pode ser vista como uma indicação de aplicação a questões preliminares. Por outro lado, a aplicação de eqüidade à validade da cláusula e outras questões de constituição da arbitragem são a minoria dos casos e, até o momento, não parece dominante na doutrina. Essa circunstância milita contra a aplicação da eqüidade neste caso. Portanto, a escolha de eqüidade não deve ser vista como índice único para aferir a vontade das partes em relação à lei aplicável às questões preliminares. Contudo, caso essa solução pareça adequada aos árbitros, não vemos impedimento formal para que a apliquem.

\subsubsection{Decisão por eqüidade e costume}

A aplicação dos usos e costumes do comércio internacional é uma das características mais marcantes da arbitragem internacional. Diversas leis nacionais, sobretudo de inspiração na Lei Modelo da CNUDCI, e regras de arbitragem (como o caso da CCI) fazem menção expressa à observância de tais usos e costumes.

No caso da arbitragem por eqüidade, existe uma questão sobre a disposição espacial dessas provisões. No caso do regulamento da CCI, o art. 17 prescreve no item 2 que em todos

467 O que pode gerar complexos problemas de direito internacional privado, como se verifica em FOUCHARD, Gaillard e Goldman. Traité de l'Arbitrage Commercial International, cit., p. 227 e ss. Lew, Julian D. M. The Law Applicable... cit., p. 114 e ss.; e Blessing, Marc. The Law Applicable to the Arbitration Clause, cit., p. 168 e ss. 
os casos os usos serão "levados em consideração". Apenas o item 3 do mesmo artigo prevê a arbitragem por eqüidade. No caso da Lei Modelo, o art. 28 inverte essa ordem, prevendo em primeiro lugar a arbitragem por eqüidade e, em seguida, que o tribunal decidirá de acordo com o contrato e "levará em consideração" os usos do comércio pertinentes. Pode-se afirmar que essa distribuição espacial reflete alguma orientação diferenciada? Ou seja, no primeiro caso não haveria obrigação de respeitar os usos do comércio e no segundo haveria?

Em princípio, a distribuição da matéria não é decisiva para sua aplicação, salvo se o contexto indicar o contrário. No caso específico do regulamento da CCI, o próprio texto não autoriza entendimento pela exclusão (a disposição refere-se a "todos os casos"). No entanto, dada a imensa liberdade das partes em escolher os critérios e as leis aplicáveis ao mérito, parece evidente que tais disposições não são imperativas e comportam pacto em contrário. Se as partes podem pactuar a exclusão de certos dispositivos legais ou partes de um ordenamento, ${ }^{468}$ parece perfeitamente possível que as partes pactuem que determinados usos não se aplicam.

De qualquer modo, é improvável que, na prática, os tribunais deixem de considerar usos comerciais, que representam prática estabelecida e em boa medida subentendida pelas partes (salvo se o contrário resultar da vontade destas). A aplicação dos usos e costumes do comércio é amplamente aceita (Incoterms, por exemplo) e representa o núcleo duro das teorias que preconizam a existência de um direito supranacional dos mercadores internacionais.

Os usos representam a prática e podem ter força cogente, dependendo de sua reiteração e da vontade de cumpri-los como norma. No caso da teoria da lex mercatoria, os usos e costumes do comércio vão, por força de sua repetição, cristalizando princípios e um quase-ordenamento com força cogente, sempre que for aplicável ao caso. $\mathrm{O}$ árbitro em eqüidade certamente os levará em consideração porque representam um entendimento médio dos atores do comércio do que seja o mais adequado para as transações.

Embora o árbitro em eqüidade deva observar os usos e costumes, ele tem a faculdade de derrogar eventuais regras costumeiras que lhe pareçam injustas no caso concreto: "The arbitrator who acts as amiable compositeur may disregard an applicable trade usage if it contravenes his notion of equity and fairness, which, however, will rarely be the case". ${ }^{469}$

468 Como ocorre com a exclusão de determinados tratados integrantes do ordenamento, como a Convenção de Viena sobre compra e venda internacional, ou certos remédios jurídicos, como casos de equitable reliefs nos países de common law.

469 Berger, Klaus Peter. International Economic Arbitration, cit., p. 577. No mesmo sentido, Robert, Jean. Arbitrage... cit., p. 278. 
Tal posição parece evidente: se o árbitro de eqüidade tem o poder de derrogar o direito positivo, certamente poderá derrogar o costume que, em seu maior grau de reconhecimento, será equivalente a uma norma positiva. Os usos e costumes podem oscilar entre a eficácia de cumprimento voluntário (assemelhando-se a um contrato) e uma eficácia próxima à da lei positiva, dependendo da sua difusão, anterioridade e acatamento. Quer se aproxime do contrato, quer se aproxime da lei, o costume estará equiparado a disposições que podem ser derrogadas pelos árbitros em eqüidade. A única hipótese contrária seria o caso de certo costume ser considerado integrante da ordem pública. Todavia, ela parece de difícil configuração prática.

Essa conclusão não se altera por conta de disposições, legais ou de regulamentos, que determinem que os usos e costumes devem ser levados em consideração. Regras dessa natureza devem ser vistas com caráter supletivo, como visto, pois as partes não estão impedidas de pactuar em sentido contrário de um uso do comércio que não lhes pareça adequado à transação.

\subsection{Procedimento}

Embora os efeitos da arbitragem por eqüidade ocorram sobretudo na decisão de mérito, ela produz efeitos igualmente no procedimento.

O relacionamento da arbitragem por eqüidade com o procedimento propriamente dito ${ }^{470}$ dá-se em dois níveis principais: o primeiro, em relação ao procedimento previsto nas leis locais; o segundo, em relação aos regulamentos de arbitragem e outras escolhas contratuais de procedimento.

\subsubsection{Procedimento estatal ${ }^{471}$}

Alguns ordenamentos jurídicos prevêem procedimentos distintos para arbitragens de eqüidade e de direito. Isso ocorre principalmente em países cuja legislação prevê o procedimen-

470 Neste aspecto, utiliza-se o termo procedimento como uma “coordenação de atos que se sucedem" e não como um sinônimo do termo processo, como definido pelos processualistas. O sentido geral de procedimento usado neste capítulo é aproximadamente o mesmo adotado pela doutrina processualista. Trata-se sobretudo da concatenação dos atos que levam à decisão final. A esse respeito, veja-se, entre outros, CinTRA, Antonio Carlos Araújo; Grinover, Ada Pellegrini; Dinamarco, Cândido Rangel. Teoria geral do processo, cit., p. 247.

471 A desvinculação entre lei aplicável ao mérito e lei aplicável ao procedimento arbitral é estabelecida na arbitragem internacional (por todos, Fouchard, Gaillard e Goldman. Traité de l'Arbitrage Commercial International, cit., p. 650 e ss). Embora reconheça-se um papel algo limitado, essa lei tem importância direta sobre a validade da sentença: sua violação é causa de não-reconhecimento da sentença arbitral, nos termos da Convenção de Nova Iorque (art. V, 1, d). Além disso, a lei processual impõe certos limites importantes sobre 
to de modo mais detalhado. Contudo, trata-se de uma tendência em declínio. O movimento de reforma das legislações nacionais que ocorre desde a década de 1970 trouxe menor intervenção legislativa no procedimento arbitral. As legislações nacionais concedem ampla liberdade para que as partes e/ou o tribunal fixem o procedimento. A preocupação maior das legislações cinge-se ao "núcleo duro" do procedimento, como a igualdade das partes, devido processo, motivação, etc.

As regras legais para o procedimento em eqüidade, quando existentes, prevêem um procedimento mais simples que o de direito. Não raro, há autorização expressa para atuação "sem sujeição às formas da lei". Também a maioria dos casos mantém a liberdade das partes de fixar o procedimento, caso assim desejem.

Em casos como a Argentina, dispõe-se sobre a produção das provas: limitam-se os árbitros em eqüidade a receber os documentos das partes e solicitar os esclarecimentos que julgarem necessários. No caso chileno existe um procedimento legal para as arbitragens por eqüidade, no caso de silêncio das partes. Por ser um procedimento mais célere, as partes podem acordar que ele seja utilizado também em arbitragens de direito. Essa diferença de procedimento também pode ser encontrada no Líbano, onde existe dispensa de aplicação de regras de procedimento, sob reserva dos "princípios diretores" do processo.

A razão principal para essa diferenciação, sobretudo nos países latino-americanos, parece ser a existência de procedimentos detalhados para arbitragens de direito. Não obstante

o andamento da arbitragem. No entanto, na prática é muito comum que os árbitros apenas façam referência ao regulamento de arbitragem, sem referência a lei processual alguma.

Tanto quanto outros aspectos de direito internacional privado da arbitragem, existem diversos métodos para sua fixação. Podem-se utilizar leis nacionais escolhidas por elementos de conexão ou princípios internacionais apreendidos do exame de direito comparado ou da jurisprudência arbitral. É amplamente reconhecida a autonomia das partes para fixar a lei, embora ela não seja muito frequente na prática.

Na ausência de escolha das partes, a resposta mais intuitiva sobre a lei aplicável é a do local da arbitragem. Essa solução é prevista na Convenção de Nova Iorque. Além disso, o elemento de conexão mais evidente para regulamentar o procedimento é o do local da arbitragem (Kaufmann-Kohler, Gabrielle. Identifying and applying the law governing the arbitration procedure - the role of the law of the place of arbitration. ICCA Congress series, Boston: Kluwer Law International, n. 9, p. 338, 1999). Embora a arbitragem internacional guarde um grau importante de independência em relação aos ordenamentos nacionais, é certo que mantém alguma relação com os diferentes ordenamentos envolvidos. Ao menos com os ordenamentos dos locais de execução da sentença arbitral e com aquele onde ela é proferida.

Por maior "deslocalização" que se possa conferir à arbitragem internacional, a lei do foro poderá ter influência determinante, ainda que para impor alguns padrões essenciais para o desenvolvimento do procedimento. Caso haja violação destes, pode existir nulidade da sentença arbitral pelos tribunais daquele país, o que pode ser um motivo de não-reconhecimento em outros países. Entre as restrições das legislações locais, pode-se aventar uma proibição da arbitragem por eqüidade, como já ocorreu com maior freqüência no passado.

Assim, conquanto haja bastante liberdade para a determinação da lei aplicável ao procedimento, a lei do local da arbitragem poderá ter influência sobre o procedimento. 
tenha havido mudanças gerais, alguns ainda impõem consideráveis formalidades, como a existência de secretários juramentados.

Alguns países latino-americanos ainda prevêem que somente pessoas com formação jurídica podem atuar como árbitros de direito. Já nas arbitragens por eqüidade, qualquer pessoa pode exercer a função. No caso da Argentina as causas de impedimento e suspensão são diferentes entre árbitros de direito e eqüidade. Portanto, em alguns países a simples escolha de eqüidade tem efeito imediato sobre o procedimento, por força de lei.

Para além dos casos de mudança do procedimento existe um aspecto processual de relevância: a possibilidade de derrogação das normas de direito relativas ao procedimento.

Aqui se recoloca, em alguma extensão, a questão já examinada do julgamento por eqüidade em questões não relacionadas ao mérito. Como visto, é defensável a posição de que a eqüidade abrangeria somente as regras aplicáveis ao mérito: tratar-se-ia de um critério para a solução do litígio e não as "regras do jogo".

Existem argumentos válidos para afirmar que os efeitos da eqüidade deveriam circunscrever-se ao julgamento de mérito. Ou que a ampla liberdade dos árbitros concernente ao mérito recomendaria ainda mais uma observância estrita do procedimento. ${ }^{472}$ As normas procedimentais conformam a arbitragem e seu desenvolvimento. Em situação limite, a derrogação de normas processuais poderia conceder aos árbitros liberdade ainda maior do que aquela conferida no tocante ao mérito.

$\mathrm{Na}$ doutrina francesa anterior à reforma da legislação de arbitragem admitia-se a possibilidade de derrogação de certas normas processuais, dentro de certos limites. ${ }^{473}$ Em obras posteriores, essa orientação é mantida, ressalvados os princípios "diretores" do processo, com respaldo em jurisprudência. ${ }^{474}$

A possibilidade de aplicação da eqüidade sobre questões processuais é decorrência da liberdade das partes de pactuar sobre o procedimento. Se as partes são livres para escolher a lei aplicável, têm o poder de derrogar certas normas de procedimento (sob reserva de ordem pública). Portanto, não há qualquer empecilho para que as partes "deleguem" o poder de derrogação.

472 Bredin, Jean Denis. L'amiable composition et le contrat, cit., p. 263.

473 Para o conjunto da discussão veja-se LoQuin, Eric. L'Amiable composition... cit., p. 191 e ss.

474 Boisséson, Matthieu de. Le Droit Français de l'Arbitrage... cit., p. 310. 
Um julgamento com base apenas no critério de justiça pode requerer uma postura mais ou menos inquisitória por parte do tribunal, que conhece os critérios de justiça que pretende seguir. Uma maior liberdade de critérios de julgamento implica maior liberdade para condução do procedimento, de modo a adequá-lo aos critérios de julgamento. ${ }^{475}$ Assim, a congruência entre procedimento e critério de julgamento autoriza a possibilidade de derrogação de certas normas processuais. Como afirmado por C.M. De Marini, ${ }^{476}$ o juízo de eqüidade pode ir a fatos que seriam "juridicamente irrelevantes", como condições subjetivas. Tem, portanto, um conhecimento mais amplo. A nosso ver, essa posição diferenciada, inclusive quanto aos fatos a serem conhecidos, justifica igualmente algumas adaptações de procedimento. ${ }^{477}$

Como exemplo de regras que podem ser derrogadas por árbitros em eqüidade estão aquelas que prevêem formas de tomada de depoimentos (dispensa da forma de reperguntas, nos países que a prevêem, em favor das perguntas diretas ou cross examination), formas de comunicação dos atos (utilização de correio eletrônico), fixação da ordem da realização das provas (realizando-se, por exemplo, a audiência antes de outras provas), regras que determinam procedimentos estritos na produção de provas ou o valor probatório de certos tipos de documento (como documentos públicos e privados) ou determinada forma de prova (como o caso de prova escrita para certos contratos). ${ }^{478}$

Afirmada a faculdade de derrogação íncita à eqüidade, resta saber quais são as normas que podem ser derrogadas pelos árbitros. Alguns autores afirmam a existência de uma "ordem pública processual", equivalente a um núcleo duro de normas inderrogáveis e que devem ser respeitadas pelo árbitro de eqüidade. ${ }^{479}$ Outro autor não vê coincidência exata entre os chamados "princípios diretores do processo" referidos pela lei francesa e a ordem pública. ${ }^{480}$

475 Conforme Loquin, Eric. L'Amiable composition... cit., p. 216: "Pour les mêmes raisons, l'amiable compositeur peut s'écarter du schéma processuel mis en place par le législateur. Il peut en particulier donner à l'instance arbitrale une coloration plus ou moins accusatoire ou inquisitoire en fonction des necessites du litige. C'est la base contractuelle de l'arbitrage qui autorise cette liberté. Il appartient aux parties d'organiser l'instance, et celles-ci peuvent, par la clause d'amiable compostion, déléguer aux arbitres cette initiative".

476 Il giudizio di equità nel processo civile, cit., p. 219.

477 Essa condição justifica, a nosso ver, a diferença de poderes instrutórios do árbitro em eqüidade reconhecida em algumas legislações latino-americanas, embora em geral essas diposições dêem liberdade para suprimir provas (ou confiar em um rol menor delas). Ainda que o comportamento dos árbitros julgando em eqüidade seja diferente em razão do critério decisório (buscando, por exemplo, questões que não sejam tão relevantes do ponto de vista do direito estrito), ele deve sempre permitir a ampla possibilidade de as partes apresentarem seu caso.

478 Para um elenco de possibilidades, em direito interno francês: LoQuin, Eric. L'Amiable composition... cit., p. 218.

479 Boisséson, Matthieu de. Le Droit Français de l'Arbitrage... cit., p. 308 e ss.

480 Loquin, Eric. L’Amiable composition... cit., p. 193. Desta página colhe-se, em tradução livre: “Também o problema não é saber se tal disposição do Código de Processo Civil deve ser qualificada de ordem pública e a este título ser aplicada a arbitragem, mas de determinar as regras que, em vista do caráter jurisdicional da missão do árbitro, devem ser por eles respeitadas. A função jurisdicional confiada aos árbitros de eqüidade 
Existem limites para a derrogação. ${ }^{481}$ A despeito de diferenças de qualificação, o "núcleo duro" da ordem processual pode ser definido como os princípios centrais do sistema que atingem aspectos de interesse geral da sociedade. Por cuidarem de interesses gerais, transcendem o âmbito da relação individual das partes e não permitem convenção em contrário.

Fora das regras de observação obrigatória, existem outras regras, de caráter ordinatório do procedimento. Em geral, comportam disposição em contrário das partes, que podem substituí-las por disposições próprias ou por referência a regulamentos de arbitragem. Essas regras passíveis de derrogação pelas partes podem ser desconsideradas pelos árbitros.

A definição dos limites de derrogação é difícil em vista do caráter móvel da ordem pública. A importância das regras varia conforme o momento histórico em que são aplicadas, o que se aplica às regras cogentes de processo. Existem igualmente variações entre ordenamentos distintos, no mesmo momento histórico. Uma das mais claras diferenças entre ordenamentos jurídicos pode ser encontrada na necessidade de motivação da sentença: enquanto a maioria dos países exige que a sentença tenha forma escrita e seja motivada, o direito inglês tradicionalmente permite convenção em contrário. ${ }^{482}$

Não obstante, podem-se divisar alguns elementos comuns que têm aceitação plena no mundo como inderrogáveis. O primeiro deles, como já mencionado, é o respeito aos direitos de defesa. Nenhum outro elemento tem aceitação tão ampla: repugna à consciência jurídica mundial a idéia de uma jurisdição que não garanta igualdade entre as partes litigantes. Sendo a arbitragem também uma espécie de jurisdição, nada mais natural que essas garantias também lhes sejam aplicadas. Tanto que a própria Convenção de Nova Iorque coloca o desrespeito aos

os obriga a respeitar os princípios que são a ela inerentes. Por outro lado, a origem contratual da missão do árbitro explica que ele possa ser dispensado pela cláusula de eqüidade de observar as regras estabelecidas para os tribunais em função da missão pública que estes assumem, mesmo se perante eles tais regras são consideradas de ordem pública". Convém ressaltar, todavia, que esta passagem é destinada ao direito interno francês anterior à reforma, em que havia aplicação de regras de processo civil ao procedimento arbitral.

481 "Procedural Rules may be more freely modified by the arbitrator amiable compositeur than rules relating to the merits. However, there are also obvious limits here, such as the right to be heard, and other basic rules of defence." JARvin, Sigvard. The sources and limits... cit., p. 140-163.

482 Arbitration Act de 1996:

52

Form of award

(1) The parties are free to agree on the form of an award.

(2) If or to the extent that there is no such agreement, the following provisions apply.

(3) The award shall be in writing signed by all the arbitrators or all those assenting to the award.

(4) The award shall contain the reasons for the award unless it is an agreed award or the parties have agreed to dispense with reasons.

(5) The award shall state the seat of the arbitration and the date when the award is made. 
direitos de defesa como uma das causas para negativa de execução da sentença arbitral estrangeira. ${ }^{483}$

Outra matéria que parece inderrogável é a forma da sentença prevista em lei. Sendo a arbitragem por eqüidade uma espécie de arbitragem e não havendo exceção prevista na lei positiva, ela deve seguir a mesma prescrição para todas as sentenças arbitrais. ${ }^{484}$ Caso exista, como no caso brasileiro, expressa disposição sobre forma e conteúdo da sentença arbitral, ela deve ser observada pelos árbitros. Caso contrário, criar-se-ia um procedimento paralelo à própria arbitragem, desvinculado de seus requisitos fundamentais.

Outras regras que parecem ser insusceptíveis de derrogação por parte dos árbitros são aquelas que dizem respeito aos requisitos essenciais da instauração de arbitragem, pelas mesmas razões relativas à sentença arbitral. $\mathrm{O}$ mesmo pode ser dito relativo às qualificações e impedimentos dos árbitros, embora neste caso encontrem-se exceções nos direitos nacionais, como é o caso de dispensa de formação em direito para os árbitros de eqüidade ou um número menor de hipóteses de impedimento ou suspeição (Argentina).

Os casos de arbitrabilidade objetiva, igualmente, parecem estar fora da liberdade de disposição de regras por parte dos árbitros de eqüidade. Os limites do alcance da arbitragem são concedidos pelo ordenamento positivo. Trata-se de uma das principais reservas de legalidade da arbitragem internacional, reconhecida pela Convenção de Nova Iorque. ${ }^{485}$ No que diz

${ }^{483}$ Artigo V - 1. O reconhecimento e a execução da sentença poderão ser indeferidos, a pedido da parte contra a qual ela é invocada, unicamente se esta parte fornecer à autoridade competente onde se tenciona o reconhecimento e a execução, prova de que: [...] b) a parte contra a qual a sentença é invocada não recebeu notificação apropriada acerca da designação do árbitro ou do processo de arbitragem, ou lhe foi impossível, por outras razões, apresentar seus argumentos.

484 A arbitragem por eqüidade é uma espécie do gênero arbitragem. Portanto, as disposições de observação obrigatória aos árbitros em geral aplicam-se também aos árbitros de eqüidade.

485 Artigo I

1. A presente Convenção aplicar-se-á ao reconhecimento e à execução de sentenças arbitrais estrangeiras proferidas no território de um Estado que não o Estado em que se tencione o reconhecimento e a execução de tais sentenças, oriundas de divergências entre pessoas, sejam elas físicas ou jurídicas. A Convenção aplicar-se-á igualmente a sentenças arbitrais não consideradas como sentenças domésticas no Estado onde se tencione o seu reconhecimento e a sua execução. [...]

3. Quando da assinatura, ratificação ou adesão à presente Convenção, ou da notificação de extensão nos termos do Artigo X, qualquer Estado poderá, com base em reciprocidade, declarar que aplicará a Convenção ao reconhecimento e à execução de sentenças proferidas unicamente no território de outro Estado signatário. Poderá igualmente declarar que aplicará a Convenção somente a divergências oriundas de relacionamentos jurídicos, sejam eles contratuais ou não, que sejam considerados como comerciais nos termos da lei nacional do Estado que fizer tal declaração.

Artigo V - 1. O reconhecimento e a execução da sentença poderão ser indeferidos, a pedido da parte contra a qual ela é invocada, unicamente se esta parte fornecer à autoridade competente onde se tenciona o reconhecimento e a execução, prova de que: a) as partes do acordo a que se refere o Artigo II estavam, em conformidade com a lei a elas aplicável, de algum modo incapacitadas, ou que tal acordo não é válido nos termos da lei à qual 
respeito aos ordenamentos jurídicos nacionais, todos prevêem alguma espécie de limitação de questões que possam ser submetidas à arbitragem. Em geral, tais regras são imperativas e não admitem convenção em contrário: sua violação em regra implica nulidade da arbitragem. Todavia, essa questão parece possuir maiores nuanças, quando se coloca a questão na perspectiva da arbitragem internacional. Considerando-se a teoria pela qual a arbitragem internacional não possui foro e considerando-se que o primeiro "guardião" da arbitrabilidade é o árbitro, qual deve ser o critério a ser seguido pelos árbitros para definir a arbitrabilidade? A resposta, sugerem alguns, está na “ordem pública verdadeiramente internacional”. ${ }^{486}$ Se assim o for, haveria uma perda de importância da lei nacional, ao menos em um primeiro momento, para a questão da arbitrabilidade objetiva. Assim, poderia haver algum espaço para critérios não-positivos de decisão sobre a matéria, ao menos desde um ponto de vista prático. Todavia, o atual estágio do desenvolvimento da arbitragem internacional não permite maiores ilações sobre essa possibilidade, especialmente em vista do conteúdo da Convenção de Nova Iorque. De qualquer modo, é conveniente reafirmar que a extensão da arbitragem por eqüidade não pode ser maior do que a da própria arbitragem.

No tocante à arbitrabilidade subjetiva, pode haver algum espaço para discussões, maior que os casos de arbitrabilidade subjetiva. Em princípio, os árbitros em eqüidade não podem estender a convenção de arbitragem fora de seus limites pessoais. Não podem, por exemplo, afirmar que uma parte incapaz possa contratar arbitragem. Todavia, na arbitragem internacional, é particularmente recorrente a questão da capacidade de empresas estatais ou do próprio estado em se comprometer. ${ }^{487}$

Existem diversas disposições nacionais que proíbem empresas estatais de celebrar cláusula compromissória ou a sujeitam a autorizações prévias. Essas proibições ou autorizações têm sido objeto de reiteradas decisões em arbitragem internacional ${ }^{488}$ - ${ }^{489}$ Em geral, a jurisprudência considera que as regras nacionais impeditivas não são óbice para a validade da cláusula

as partes submeteram, ou na ausência de indicação sobre a matéria, nos termos da lei do país onde a sentença foi proferida; [...] 2. O reconhecimento e a execução de uma sentença arbitral também poderão ser recusados caso a autoridade competente do país em que se tenciona o reconhecimento e a execução constatar que: a) segundo a lei daquele país, o objeto da divergência não é passível de decisão mediante arbitragem; [...].

Fouchard, Gaillard e Goldman. Traité de l'Arbitrage Commercial International, cit., p. 363.

Embora exista neste caso um problema de qualificação: seria a matéria uma questão de capacidade, poderes ou autônoma de arbitrabilidade? (Fouchard, GaIllard e Goldman. Traité de l'Arbitrage Commercial International, cit., p. 331).

488 Foi, também, objeto de Resolução do Instituto de Direito Internacional a sessão de Santiago de Compostela, em 1989: "Article 5

A State, a state enterprise, or a state entity cannot invoke incapacity to arbitrate in order to resist arbitration to which it has agreed".

489 Para um apanhado da jurisprudência, veja-se Fouchard, GAILlaRd e GoldMAn. Traité de l'Arbitrage Commercial International, cit., p. 341 e ss. 
arbitral. De sua reiteração, tem-se invocado a existência de um princípio internacional da não oponibilidade de tais disposições nacionais às partes que de boa-fé contratam. Portanto, tais regras nacionais não encontram aplicação no âmbito da arbitragem internacional. Dessa forma, o princípio em questão parece fazer parte da chamada “ordem pública verdadeiramente internacional”, aquela que é inerente à comunidade internacional, transcendendo direito nacionais.

Alguns dos fundamentos encontrados na jurisprudência arbitral para afastar regras nacionais impeditivas guardam estreita relação com considerações de eqüidade, embora existam também no direito positivo. Entre eles, a impossibilidade de se contradizer ${ }^{490}$ e o respeito à boa-fé. ${ }^{491}$ Transportando-se a questão para o direito privado, um possível paralelo pode ser visto nos casos da chamada "teoria da aparência", em que o mandatário aparente vincula a parte, mesmo sem possuir poderes do ponto de vista do direito estrito. Assim, verifica-se no exame da arbitrabilidade subjetiva algum grau de superação da estrita aplicação de direitos nacionais positivos. Em alguns casos, em favor de princípios gerais do direito, de forte cunho equitativo (que, todavia, não são sinônimo de eqüidade).

Cumpre ainda verificar o efeito da arbitragem por eqüidade sobre duas regras processuais da mais alta importância: a distribuição do ônus da prova e o valor probante de certos fatos. Existem autores que sustentam que a eqüidade inverte o ônus da prova para determinados fatos. ${ }^{492}$ Para outros, os padrões de valoração da prova podem ser flexibilizados. ${ }^{493}$

Na pesquisa de campo realizada para esta obra ${ }^{494}$ perguntou-se aos participantes se a inversão do ônus da prova seria uma das hipóteses em que deixariam de aplicar o direito positivo em favor do sentimento de justiça. A maioria dos participantes (47\%) afirmou não ser uma das hipóteses em que derrogariam o direito positivo. Todavia, uma parte substancial $(38 \%)$ entendeu que esta seria uma hipótese plausível para atuação da eqüidade.

A despeito do entendimento da maioria, podem existir circunstâncias que autorizam uma flexibilização do ônus da prova. Um dos possíveis exemplos são casos em que a prova seja

\footnotetext{
490 Por exemplo, caso Benteler vs. Bélgica. Revue de l'Arbitrage, n. 2, p. 339.

491 Caso CCI n. 4.381, mencionado por Fouchard, GaIllard e Goldman. Traité de l'Arbitrage Commercial International, cit., p. 343.

492 Berger, Klaus Peter. International Economic Arbitration cit., p. 570-571, com citação de precedentes em arbitragem.

493 "In one case the arbitrators held that since they were not amiable compositeurs they could not dispense the party alleging certain facts from proving them if he wished to rely on them. Would this imply that an arbitrator acting as amiable compositeur was more free than one acting according to the rules of law to base his decision on non-proven arguments. Probably not, but the arbitrator might be empowered to evaluate the evidence by using less strict norms than those applicable under national procedural rules, eg, by applying a lower degree of conviction when accepting facts as proven." JARVIN, Sigvard. The sources and limits... cit., p. 140-163.

494 Veja-se capítulo específico.
} 
muito difícil ou apenas possível mediante atuação da parte contrária. Nesses casos, podem-se levar em consideração provas indiretas na formação do convencimento do árbitro de eqüidade. Não nos parece haver violação de ordem pública em tais hipóteses. Existem alguns exemplos de uma relativização do ônus da prova na jurisprudência arbitral. No caso CCI n.o 7.913, ${ }^{495} \mathrm{o}$ tribunal "tempera" a regra de distribuição do ônus da prova para permitir "medida de instrução" requerida:

Le Tribunal observe qu'en vertu de ses pouvoirs d'amiable compositeur, il a 'tempéré les rigueurs de la règle suivant laquelle 'actor incumbit probatio' en faisant droit à la mesure d'instruction sollicitée par [demandante], alors que [demandante] reconnaissait elle-même ne pas rapporter la preuve qui lui incombait. Le Tribunal a, en effet, couvert, par la mesure d'instruction, une période excédant très largement le terme de la convention, voulant, par là, s'assurer que [demandante] ne se voyait pas privée d'une juste rémunération sur des transactions qui auraient été, par hypothèse, conclues après l'expiration du terme mais dont la conclusion aurait été le résultat d'efforts déployés durant la période contractuelle.

No caso n. $2.605^{496}$ os árbitros decidiram como suficientes para a comprovação de danos certos documentos em que intervinham apenas uma das partes e um cliente desta. Para tanto, invocaram sua condição de amiables compositeurs. Neste caso, parece ter havido uso dos poderes de decidir em eqüidade sobre uma regra de apreciação da prova. Mas há posições jurisprudenciais em contrário. ${ }^{497}$

De qualquer modo, a despeito de possível flexibilização equitativa, existe um claro limite de ordem pública: não se pode derrogar o princípio geral da distribuição do ônus da prova, fazendo com que quem alega esteja dispensado de provar. ${ }^{498}$

Por fim, afirme-se o declínio do interesse prático na matéria de derrogação de disposições legais de procedimento. A onda de reforma das leis nacionais de arbitragem conferiu enorme liberdade procedimental às partes e ao tribunal arbitral. Hodiernamente, legislações que prescrevem um procedimento detalhado parecem ser a minoria no cenário mundial. A atual técnica legislativa prefere apenas resguardar os princípios gerais do procedimento em vez de prever um procedimento detalhado. Essa solução merece ser aprovada, por ser eficaz sem restringir a liberdade das partes.

495 ICC International Court of Arbitration Bulletin, v. 18, n. 1, 2007, p. 67 e ss.

496 Citado superficialmente nos comentários do caso n. 2.694, Collection of ICC Arbitral Awards, Recueil des Sentences Arbitrales de la CCI, Boston: Kluwer Law and Taxation Publishers, p. 325, 1990.

497 No caso CCI n. 3.344, o tribunal não verificou provas suficientes para um pedido reconvencional e afirmou que o princípio do actor incumbit probatio é de ordem pública e não pode ser afastado em eqüidade.

498 Sobre a impossibilidade de revogar a regra do actori incumbit probatio, veja-se BERGER, Klaus Peter. International Economic Arbitration, cit., p. 571. 
O caso brasileiro afigura-se exemplar nesse aspecto: existe ampla liberdade de fixação do procedimento, com obrigação de observância dos princípios do contraditório, da igualdade das partes, da imparcialidade dos árbitros e seu livre convencimento (art. 21 da Lei de Arbitragem). Na Lei de Arbitragem, a rigor, a única disposição propriamente ordinatória do procedimento é a que disciplina os depoimentos.

\subsubsection{Procedimento convencional}

Os efeitos da eqüidade sobre o procedimento colocam-se de modo distinto quanto às escolhas contratuais das partes. Essas escolhas podem se dar tanto pela referência a regulamentos de arbitragem como pelo detalhamento procedimental na convenção de arbitragem.

Nessa hipótese, eventual derrogação não envolve norma estatal genérica e preestabelecida, mas sim as escolhas das partes. As escolhas contratuais que regulam a arbitragem constituem, em larga medida, a fonte do poder de atuação do tribunal arbitral. São a origem do "mandato" conferido aos árbitros, e cujos termos estão adstritos: se não houve escolha de arbitragem, não há competência; se as partes convencionaram um regulamento de arbitragem, os árbitros não podem aplicar outro.

A doutrina internacional posiciona-se de modo contrário à possibilidade de derrogação das regras estabelecidas pelas partes. Eric Loquin ${ }^{499}$ e Mathieu de Boisseisson ${ }^{500}$ colocam-se francamente contrários à possibilidade de alteração das disposições das partes sobre o procedimento.

Tal oposição é compreensível, pois a permissão para modificar as regras impostas pelas partes implica, em algum grau, a possibilidade de atuar contra o próprio mandato.

Essa posição leva à conclusão de que, para efeitos de arbitragem de eqüidade, a regra contratual tem mais valor do que as regras de origem estatal. Entretanto, trata-se de um parado-

\footnotetext{
499 "En effet, l'interprétation conjointe de la clause d'amiable composition et des stipulations du compromis concernant la procédure ne peut conduire qu'à l'affimation que les parties ont renoncé à toutes les règles de procédure, sauf à qu'elles ont expressément adoptées dans le compromis. Ces dernières règles, soustraites au champ de la renonciation, s'imposent aux amiables compositeurs. En matière d'arbitrage, il n'est pas paradoxal d'admettre qu' une règle privée d'origine contractuelle ait plus de force obligatoire qu'une loi. [...] La conséquence est que toute violation des stipulations procédurales des parties dans le compromis devrait entraîner la nullité de la sentence." L'Amiable composition... cit., p. 211-212.

500 Le Droit Français de l'Arbitrage... cit., p. 371.
} 
xo apenas aparente: dado o aspecto contratual que integra a arbitragem, nenhuma surpresa pode haver que a vontade das partes tenha mais força do que uma regra estatal dispositiva. ${ }^{501}$

Por outro lado, a prática mostra que boa parte dos regulamentos de arbitragem confere poderes mais ou menos amplos aos árbitros para decidirem sobre o procedimento (ainda que com caráter subsidiário). ${ }^{502}$ Assim, no caso de escolha de arbitragem institucional, as partes já conferem aos árbitros um considerável grau de liberdade, o que de certo modo torna a questão da possibilidade de alteração das regras contratuais menos importante, na prática, do que possa parecer à primeira vista.

Todavia, a questão não é pacífica. A arbitragem por eqüidade implica maior poder discricionário, o que inclui adaptar ou derrogar disposições legais ou contratuais, sob reserva de ordem pública. Com base em tal liberdade, tem havido posições segundo as quais certas formalidades processuais podem ser deixadas de lado, inclusive aquelas fixadas pelas partes.

No caso CCI n. $3.327^{503}$ o tribunal desconsiderou atraso na entrega de memoriais, em razão de alegada instabilidade política. O tribunal entendeu que "não parece oportuno" aplicar princípios de preclusão em eqüidade, sobretudo porque a parte que invoca a extemporaneidade não demonstra prejuízo. Aplicou por analogia a regra do pas de nullité sans grief, reconhecida pelo direito processual escolhido pelas partes. ${ }^{504}$

Em interessante comentário publicado na mesma obra, ${ }^{505}$ afirma-se que a liberdade em relação ao regulamento depende da liberdade que se reconheça em relação ao contrato. Usase um fundamento contratual: da mesma forma que podem desconsiderar regras contratuais injustas, podem desconsiderar regras escolhidas pelas partes para o procedimento, pelo mesmo princípio. Se se autoriza descarte de cláusulas contratuais, deve-se admitir revisão de algumas regras procedimentais. De qualquer modo, o direito de defesa continua sendo o limite de qualquer derrogação. E conclui:

C'est pourquoi il ne nous paraît pas entièrement certain que l'arbitre amiable compositeur ne pourrait pas s'écarter des règles procédurales arrêtées par

\footnotetext{
501 A respeito, veja-se Eric Loquin, na nota precedente.

502 Vide, por exemplo, Regulamento da CCI, art. 15, e Regulamento CNUDCI, art. 15.

503 Collection of ICC Arbitral Awards, Recueil des Sentences Arbitrales de la CCI, Boston: Kluwer Law and Taxation Publishers, p. 433, 1990.

504 Para resultado contrário, veja-se o caso CCI n. 9671. Nele, o tribunal não conheceu de defesas de jurisdição, porque vieram fora do prazo.

505 Collection of ICC Arbitral Awards, cit., p. 438.
} 
les parties et dont les effets lui paraîtraient inéquitables, ce qui est interdit à l'arbitre statuant en droit.

Outros autores parecem admitir liberdade dos árbitros de eqüidade em relação a prazos processuais:

There may, however, be instances where the tribunal may use its powers as amiable compositeur for the flexible handling of deadlines set for the submission of written pleadings or evidence. ${ }^{506}$

Na pesquisa de campo realizada para este trabalho ${ }^{507}$ perguntou-se se, em eqüidade, os participantes desconsiderariam um prazo processual em favor de considerações de eqüidade. Uma expressiva minoria de participantes (31) afirmou que desconsideraria. A maioria (38) respondeu que não o faria.

Assim, ainda que de forma minoritária, existe uma linha de entendimento de que a eqüidade implica algum grau de liberdade relativamente ao procedimento escolhido pelas partes. Todavia, além do natural cuidado com os direitos de defesa, a liberdade deve ser considerada com as devidas cautelas. Ela abarca o próprio mandato pelo qual elas conferem essa liberdade?

Há três pontos a se considerar. Em primeiro lugar, a particularidade do juízo de eqüidade em relação ao juízo de direito. No juízo de eqüidade a formação da convicção é feita de modo livre. Certas questões podem ser reputadas irrelevantes, embora importantes em julgamento conforme o direito. Podem, portanto, ser dispensadas de maiores questionamentos. Caso o regulamento adotado contemple de modo mais ou menos incisivo essas questões, pode haver algum espaço para ajustes por parte dos árbitros. Em segundo lugar, certas circunstâncias que ocorram durante o procedimento podem fazer com que uma das partes enfrente dificuldade para a realização de certos atos (como obter documentos que não estejam sob sua guarda, exame de grandes quantidades de provas ou dificuldades de comunicação). Desse modo, pode ser necessária alguma flexibilidade para se garantir uma igualdade efetiva entre as partes. ${ }^{508} \mathrm{Neste}$ caso, a adaptação possibilita o contraditório efetivo. Em terceiro lugar, as escolhas processuais das partes integram o mandato dos árbitros. Assim, uma eventual flexibilização não pode ser uma desobediência frontal aos aspectos fundamentais de tal escolha, sob pena de violação do mandato recebido.

506 Berger, Klaus Peter. International Economic Arbitration, cit., p. 572. Nesta passagem há referência a Craig, William Laurence, Park, William; PAulsson, Jan. International Chamber of Commerce Arbitration, New York; Paris: Oceana; ICC Publishing, 1990, p. 275.

507 Veja-se capítulo específico desta obra.

508 Essa flexibilidade também pode ser necessária na arbitragem de direito. 
Da contraposição entre a liberdade do juízo de eqüidade e a necessidade de respeito à convenção de arbitragem, pode-se inferir uma liberdade restrita de modificar o procedimento, para melhor adaptá-lo ao tipo de decisão escolhida ou para, com base em um tratamento eqüitativo, beneficiar a igualdade material entre as partes.

Em qualquer hipótese, essa liberdade deve ser interpretada restritivamente. A uma, porque uma intervenção profunda pode significar falseamento da vontade das partes e excesso de mandato. A duas, porque os árbitros têm o dever de produzir uma sentença exeqüível no maior número possível de jurisdições envolvidas. Portanto, devem limitar os avanços sobre a convenção de arbitragem, sob pena de colocar em risco a sentença arbitral.

\subsubsection{Motivação}

A grande maioria dos direitos nacionais obriga que o árbitro motive sua sentença. Todavia, essa não é uma regra geral. Existem direitos nacionais, sobretudo de common law, ${ }^{509}$ que permitem sentenças não-motivadas. Representaria a sentença por eqüidade uma modificação no alcance de tais regras?

Como já visto, a arbitragem por eqüidade possui efeitos sobre o procedimento, principalmente no que diz respeito a formalidades e regras dispositivas. Por outro lado, existem opiniões que se assemelham, em efeitos práticos, às decisões não sujeitas a fundamentação e decisões por eqüidade. ${ }^{510}$

A função principal da exigência de motivação parece ser uma garantia de defesa das partes. No caso brasileiro essa obrigação parece surgir da tradição pátria de que o julgador deve apresentar seu livre convencimento motivado, que foi transposta para as sentenças arbitrais, em direito ou eqüidade. Em outros países o fundamento parece ser o mesmo: as partes têm o direito de saber as razões pelas quais foram julgadas. Além da afirmação do princípio, existem razões de ordem prática para tal exigência. Existe uma série de causas de nulidade da sentença arbitral, a ser decretada por tribunais arbitrais. Entre elas, o desrespeito ao contraditório e outros motivos que tocam os mais importantes elementos do devido processo. Caso não exista moti-

509 Como é o caso do atual direito inglês, no art. 52 do Arbitration Act de 1996.

510 Loquin, Eric. L'Amiable composition... cit., p. 109 e ss. Segundo este autor, a possibilidade de sentenças não motivadas retiraria a possibilidade de escrutínio das cortes inglesas sobre a sentença arbitral, em razão de erro na aplicação do direito. Não apenas pelo controle posterior, como também pela ausência de procedimento de special case (segundo o qual os tribunais podem intervir no curso de uma arbitragem para dirimir algum ponto de direito). Assim, por escapar de qualquer escrutínio dos tribunais e da aplicação da lei, guarda semelhanças com a arbitragem por eqüidade. 
vação, as partes estariam, na prática, privadas de uma série de recursos para corrigir eventuais violações de direito feitas na sentença arbitral.

Assim, dificilmente pode-se afirmar que a motivação da sentença é uma das formalidades que podem ser derrogadas por árbitros julgando em eqüidade. Ao contrário, certas exigências de forma, por tocarem diretamente aos direitos de defesa, devem ser consideradas de ordem pública e, portanto, insusceptíveis de derrogação por parte dos árbitros julgando em eqüidade. O direito de defesa é o núcleo duro da ordem pública nacional, internacional e "verdadeiramente internacional".

Além disso, deve-se considerar que a arbitragem por eqüidade é uma espécie do gênero arbitragem. As exigências de forma da sentença arbitral aplicam-se de modo geral a ambas as espécies, salvo disposição legal em contrário. Não existe razão para um entendimento diferente sem previsão legal expressa. A doutrina parece ser unânime nesse sentido ${ }^{511}-.^{512}$

\subsubsection{Recursos}

Nos sistemas jurídicos que permitem recurso contra sentenças arbitrais, normalmente existem regras especiais para a arbitragem por eqüidade. Esses países representam a minoria dos países pesquisados. O movimento de reforma das leis de arbitragem tem mostrado uma tendência de exclusão de recursos de mérito a tribunais estatais. Todavia, o exame da disciplina recursal existente para os julgamentos por eqüidade revela alguns aspectos do instituto.

No caso francês as partes podem tirar recurso contra sentença arbitral, salvo convenção em contrário. No caso da arbitragem por eqüidade a regra é invertida: somente poderá haver recurso caso as partes expressamente convencionem. ${ }^{513}$ Esta regra é encontrada em

511 "In ICC practice the arbitrator acting as amiable compositeur is not relieved from giving reasons for the award. This duty flows from the court's practice applicable to all awards to be approved by it whether arbitrators are deciding strictly according to the law or not, and is based on the principle that the parties have a right to be informed of the reasons for the award. This should increase their understanding of the decision and make it more readily acceptable, and therefore contribute to an early voluntary implementation". JARVIN, Sigvard. The sources... cit. Também LoQuin, Eric. L'Amiable composition... cit.

512 Sobre o caso francês, veja-se Clay, Thomas. L'Arbitre. Paris: Dalloz, 2001. p. 632. Na nota 5, há um apanhado da jurisprudência francesa sobre a necessidade de motivação da sentença em eqüidade. Encontram-se exemplos antigos em que se considerou que não havia necessidade de motivação da sentença por eqüidade. Todavia, a orientação posterior é maciça em sentido contrário. Na doutrina, encontra-se uma opinião dissonante sobre essa possibilidade, feita verbalmente por J.P. Ancel, em banca de defesa de tese.

513 Article 1.482.

La sentence arbitrale est susceptible d'appel à moins que les parties n'aient renoncé à l'appel dans la convention d'arbitrage. Toutefois, elle n'est pas susceptible d'appel lorsque l'arbitre a reçu mission de statuer comme 
alguns outros países. ${ }^{514}$ Quando houver recurso, o tribunal estatal deve decidir também por eqüidade. ${ }^{515-516}$

Existe uma variante desta regra, destinada aos recursos de anulação da sentença arbitral. Em alguns países o recurso para anulação da sentença arbitral pode conter um pedido de decisão do mérito pelo próprio tribunal estatal. Caso a sentença arbitral tenha sido dada por eqüidade, o tribunal estatal que anulá-la também julgará o mérito por eqüidade..$^{517}$

Em ambos os casos, a intenção do legislador é respeitar a vontade das partes de serem julgadas conforme a eqüidade. Dessa forma, o desejo de julgamento por eqüidade sobrevive a uma sentença nula. Essa solução deve ser aprovada, porque o desejo de julgamento por eqüidade é anterior à sentença, geralmente expresso na convenção de arbitragem. O fato de os árbitros não terem desempenhado sua função a contento não implica modificação na intenção das partes expressa anteriormente. Esse regime reconhece um efeito adicional da convenção de arbitragem no âmbito da jurisdição estatal.

Outra regra relativa a recursos é a da vedação a recursos de mérito em caso de arbitragem por eqüidade. ${ }^{518} \mathrm{~A}$ idéia que parece orientar essas disposições é a de que tribunais estatais agem como guardiões do direito, zelando por sua correta aplicação. Quando se tratar a sentença com base em eqüidade, essa função desaparece, deixando de existir, igualmente, interesse na supervisão das decisões. Na Inglaterra uma decisão por eqüidade exclui recursos para exame de questions of law ou o pedido para exame de preliminary point of law, existentes na atual lei de arbitragem. ${ }^{519}$

Portanto, a escolha de eqüidade tem efeitos também no regime recursal das arbitragens.

amiable compositeur, à moins que les parties n'aient expressément réservé cette faculté dans la convention d'arbitrage.

514 Líbano, Líbia, Mauritânia.

515 Article 1.483.

Lorsque, suivant les distinctions faites à l'article 1482, les parties n'ont pas renoncé à l'appel, ou qu'elles se sont réservées expressément cette faculté dans la convention d'arbitrage, la voie de l'appel est seule ouverte, qu'elle tende à la réformation de la sentence arbitrale ou à son annulation. Le juge d'appel statue comme amiable compositeur lorsque l'arbitre avait cette mission.

516 Esta regra é também encontrada no Chile, com algumas peculiaridades,

517 Madagascar, Mauritânia, Tunísia (que também veda o recurso de mérito contra sentença arbitral por eqüidade)

518 Caso da Argentina, Catar, Líbia, Peru, Síria, Tunísia. No caso dos Emirados Árabes Unidos, o uso da eqüidade modifica o regime recursal contra a sentença estatal que confirma ou anula o julgamento arbitral.

519 Mustill, Michael J.; Boyd, Stewart. Commercial Arbitration... cit., p. 328. 


\subsubsection{O devido processo}

A condução da arbitragem está condicionada à observância de determinados princípios gerais procedimentais. A escolha de quais princípios gerais são aplicáveis depende do legislador nacional ou dos tratados internacionais.

A doutrina de processo civil tem dividido as regras gerais do processo como princípios ou regras técnicas. ${ }^{520}$ Princípios podem ser considerados como os pilares do sistema processual, com índole político-constitucional. As regras gerais, em oposição, são internas ao sistema. De qualquer modo, ambos visam ao correto desenvolvimento do procedimento.

São considerados princípios, por exemplo, o devido processo legal, a igualdade das partes, o contraditório, a ampla defesa, o juiz natural e a publicidade dos atos processuais. São regras técnicas o chamado princípio da demanda, segundo o qual o juiz somente age mediante provocação, o princípio da correlação entre provimento e demanda e o princípio do livre convencimento. ${ }^{521}$

Dessas regras e princípios, pode-se dizer que boa parte converge para um núcleo comum que é o devido processo legal. ${ }^{522}$ Os legisladores nacionais têm buscado utilizar-se de alguns elementos mínimos que garantam o devido processo na arbitragem, colocando-os nas leis nacionais. ${ }^{523}$ No entanto, tal escolha não é uniforme. No caso brasileiro o legislador exigiu respeito ao contraditório, à igualdade das partes, a imparcialidade do árbitro e o livre convencimento. No caso português são a igualdade, ampla defesa e contraditório. No caso espanhol são o contraditório e a igualdade das partes. ${ }^{524}$

Todavia, quaisquer que sejam os elementos do devido processo que se escolham, ${ }^{525}$ todas as legislações possuem um elemento central obrigatório que determina a existência de um processo "justo", em que as partes tenham ampla possibilidade de participar em igualdade

520 Para a diferença entre princípios e regras técnicas, veja-se DinAmarco, Cândido Rangel. Instituições de direito processual civil, I, São Paulo, Malheiros, 2005, p. 214 e ss.

521 Idem, ibidem, p. 215.

522 Idem, p. 217.

523 Carmona, Carlos Alberto. Arbitragem e processo, cit., p. 251.

524 Idem, ibidem, p. 251-252.

525 Na prática, esses elementos se sobrepõem e é difícil traçar uma separação nítida entre eles (DiNAMARCO, Cândido Rangel. Instituições de direito processual civil, I, cit., p. 217). Daí por que a escolha de um ou de outro não significa que os demais não tenham aplicação ou não devam ser observados. Especialmente em um contexto de culturas jurídicas distintas, em que o alcance de cada um deles pode ter conteúdos diferentes conforme a tradição jurídica em que esteja inserido. 
de oportunidades para convencer os árbitros de seus pleitos. A esse procedimento justo chamaremos de "devido processo". Trata-se, a nosso ver, de um conceito finalístico, que é medido mais por seu atingimento do que pela observância estrita de regras procedimentais que visam garanti-lo. Ou seja, o devido processo é um fim, que pode ser alcançado pela aplicação das regras formais previstas em lei, mas também pela sua consideração em todos os momentos e situações não previstas pelas regras formais. Entendemos que esse enfoque "finalístico" deve ser a preocupação principal em uma obra de direito internacional, que abrange mais de um ordenamento jurídico em sua análise.

O princípio geral do devido processo, com seus elementos normativos, deve ser observado na condução da arbitragem por eqüidade, tanto quanto em qualquer outra arbitragem. Árbitros julgando em eqüidade não podem, a pretexto de sua liberdade de derrogação de normas, prejudicar o direito de defesa das partes, sua igualdade de oportunidades ou a independência de julgamento. Qualquer condução do processo tendente a tal resultado causará a nulidade da sentença arbitral.

O respeito ao devido processo constitui a matéria de ordem pública em qualquer de suas manifestações ou níveis. Todos os direitos nacionais apresentam disposições no sentido de garantir o devido processo. ${ }^{526}$ Portanto, conclui-se sem maiores dificuldades que se trata de um valor universal. Integra a chamada ordem pública "verdadeiramente internacional". A despeito de quais sejam as opções do legislador nacional ao contemplar os diferentes aspectos do devido processo, o conceito, em sua concepção "finalística", deve ser respeitado em sua integralidade no âmbito da arbitragem internacional. Entendemos que o árbitro internacional, se considerado como desvinculado de qualquer foro, deve respeitar o devido processo na totalidade de suas manifestações nacionais, depreendidas em exame de direito comparado e da jurisprudência arbitral.

A predominância de um critério finalístico pode ser traduzida na garantia de oportunidades razoáveis para que as partes apresentem o caso, com igualdade. Assim, embora em geral não haja regras sobre prazos de produção de prova, deve-se definir prazo razoável para que as partes possam produzir as suas, bem como examinar e comentar aquelas produzidas pelas contrapartes. As partes devem ser chamadas à arbitragem na forma correta e com tempo suficiente para se defender, respeitada a convenção. Não parece possível a derrogação de normas dessa natureza em virtude dos poderes para decidir em eqüidade, salvo casos excepcionalíssimos em que sua desconsideração, no caso concreto, não atinja os direitos de defesa. Embora raros, pode-se imaginar que em certos casos as oportunidades tenham sido oferecidas ou consumadas

526 Loquin, Eric. L'Amiable composition... cit., p. 195. Sobre o respeito ao contraditório na arbitragem (francesa) por eqüidade, veja-se também Clay, Thomaz. L'Arbitre, cit., p. 159. 
de modo distinto. Todavia, fora dos casos em que o objetivo das regras de proteção pode ser alcançado de modo distinto, não se vislumbra a faculdade de derrogar normas.

Mesmo reconhecendo-se poderes mais inquisitórios dos árbitros de eqüidade, as partes devem ter ampla oportunidade de comentar as provas colhidas. Devem ter a oportunidade de apresentar as provas necessárias para rebater provas novas. Mesmo que os conhecimentos pessoais prévios do árbitro possam ser levados em consideração, os elementos de prova devem ser trazidos ao debate, caso seja causa de decidir. ${ }^{527}$

Outro aspecto que toca ao devido processo é o fato de as partes não saberem de antemão o critério de julgamento. Assim, podem atuar de modo errôneo ou que não seja o mais adequado para a defesa de seus interesses.

Essa questão foi analisada por autores oriundos da prática processual. O professor italiano Edoardo Ricci, em artigo sobre a lei brasileira, mas de todo aplicável à arbitragem internacional, chega a um grau amplo: afirma que os árbitros julgando em eqüidade devem informar às partes, antes do julgamento, quais são os critérios de justiça que pretendem utilizar. Caso não o façam, deixam as partes às cegas e prejudicam sua atuação em contraditório. ${ }^{528}$

A postulação do ilustre mestre parece demasiado ampliativa do conceito de devido processo. O critério de julgamento dos árbitros de eqüidade é seu sentimento de justiça. A aplicação desse sentimento pode se dar de acordo com vários métodos, inclusive a estrita aplicação do direito positivo. Ao escolherem essa espécie de arbitragem, as partes sabem que existe algum grau de indeterminação, ínsita ao juízo de eqüidade e ao sentimento subjetivo de justiça. Como visto, o juízo de eqüidade pode manifestar-se como uma solução ex facto, sem recurso a qualquer critério prévio. Portanto, existe a possibilidade de que os árbitros nem mesmo saibam de antemão qual critério aplicarão. Além disso, essa incerteza quanto a critérios existe também no direito positivo. Imagine-se uma disputa acerca da interpretação de um determinado dispositivo legal. A solução pode variar consideravelmente conforme o critério de interpretação que o juiz utilizar. Ora, os diversos métodos existentes (histórico, semântico, teleológico, contextual, etc.) conduzem não raro a resultados distintos. Não é normal que os juízes informem de antemão qual critério seguirão, como não é comum que as leis positivas façam escolhas acerca deles. Ainda assim, não há violação ao devido processo na escolha de um dos métodos por parte do juiz. As partes acautelam-se quanto a essa possibilidade desenvolvendo suas razões em vista

527 Loquin, Eric. L'Amiable composition... cit., p. 200.

528 RICCI, Edoardo Flavio. O contraditório na arbitragem de eqüidade, cit., p. 149 e ss. Outras referências à questão encontram-se em Rubino-SAMmarTANo, Mauro. Il diritto dell'arbitrato, cit., p. 561. Nessa obra, o autor referese ao trabalho de Vaccarella no mesmo sentido de Ricci. 
dos diferentes métodos ou defendendo qual deles é mais adequado ao caso concreto. No caso da arbitragem por eqüidade, caso a incerteza pareça demasiada às partes, elas podem escolher arbitragem de direito, se entenderem que resulta em maior previsibilidade.

\subsubsection{Correlação entre pedido e provimento}

Ainda do devido processo decorre uma questão, quanto ao objeto do litígio. Aplica-se, também na decisão por eqüidade, o princípio da correlação? A resposta intuitiva é pela afirmativa. É difícil imaginar que os árbitros em eqüidade possam proceder a julgamentos fora do quanto pedido pelas partes. Todavia, é importante situar a origem dos poderes dos árbitros.

No procedimento judicial os limites de atuação dos juízes são dados pelas partes, ao formularem o pedido. Trata-se do princípio da correlação, segundo o qual o juiz não pode conceder mais do que lhe é pedido pela parte. No caso da arbitragem, há autores que sustentam que se trata de um fundamento distinto: é a convenção de arbitragem que coloca determinados fatos sob a jurisdição arbitral, retirando-os do conhecimento dos tribunais estatais. ${ }^{529}$ Portanto, os limites da arbitragem são dados pela convenção de arbitragem, que pode ter sua redação mais ou menos genérica. ${ }^{530}$ Dentro do objeto delimitado pela convenção de arbitragem, as partes fazem seus pedidos.

Parece impossível que os árbitros julguem fora do compromisso, pela simples razão de que não são competentes para conhecer questões que não lhe são submetidas. No entanto, podem os árbitros, dentro da matéria objeto do compromisso, conceder provimento distinto daquele diretamente pedido pelas partes? Existem autores que reconhecem certa liberdade dos árbitros que julgam por eqüidade em relação aos pedidos específicos das partes:

L'équité exige en effect que l'arbitre puisse aller au secours du plaideur en relevant un moyen de droit ou d'équité non invoqué par ce dernier et permettant de conduire à une solution opportune du litige. ${ }^{531}$

Assim, os árbitros em eqüidade teriam a possibilidade de conceder determinados provimentos não requeridos pelas partes, desde que entendam ser a melhor forma de realizar a eqüidade na solução da controvérsia. Contudo, entendemos que essa liberdade deve ser vista com o critério mais restritivo possível. O principal limite parece ser o devido processo: os árbi-

529 LoQuin, Eric. L'Amiable composition... cit., p. 208.

530 Sobre a possibilidade de redações genéricas de compromisso no direito brasileiro, veja-se CARMONA, Carlos Alberto. Arbitragem e processo, cit., p. 181.

531 LoQuin, Eric. L'Amiable composition... cit., p. 210. 
tros não podem conceder provimento sobre o qual a parte demandada não teve a oportunidade de se manifestar, salvo tratar-se de pedidos acessórios, tal como juros e ônus de sucumbência. Relativamente a esse tipo de pedido, existe liberdade em alguma medida mesmo nos julgamentos estatais. Quanto aos demais pedidos, a regra de comportamento do árbitro em eqüidade deve ser a de cautela e máxima limitação no exercício de sua liberdade.

Em qualquer hipótese, o julgamento deve respeitar o disposto na convenção de arbitragem, ${ }^{532}$ sob pena de nulidade. Não pode haver julgamento fora do objeto do litígio limitado pelas partes. Igualmente, caso as partes especifiquem, na convenção de arbitragem, os pedidos de modo claro, os árbitros não podem julgar fora deles.

Na jurisprudência arbitral encontram-se casos em que os árbitros autorizados a decidir por eqüidade afirmam seu dever de respeitar os pedidos. No caso CCI n. 3.540, laudo final, ${ }^{533}$ o tribunal afirma, obiter dicta, que tem dever de respeitar os princípios fundamentais do direito processual, como o princípio da correlação entre pedido e julgamento (vedação de julgamento extra petita). No caso CCI n.o $3.267^{534}$ o tribunal entendeu que certos pedidos mencionados por uma parte não estavam implícita ou explicitamente contidos na ata de missão e que seus poderes não chegam ao ponto de alterar os pedidos.

532 LoQuin, Eric. L'Amiable composition... cit.

533 Inédito, 1989.

534 Citado em seu inteiro teor no capítulo específico de jurisprudência arbitral. 


\section{CAPÍTULO 4}

\section{ARBITRAGEM POR EQÜIDADE E SEUS LIMITES}

Estudados os efeitos da arbitragem por eqüidade, cumpre analisar quais os limites dessa atuação. Eles têm três naturezas distintas: a ordem pública, o devido processo e a vontade das partes expressa no contrato. No tocante ao devido processo e ao procedimento de modo geral, a questão já foi explorada no capítulo imediatamente anterior. Julga-se desnecessário repetir a análise, embora também se trate de limites do instituto. Quanto ao contrato, embora também se trate de uma questão de efeitos da arbitragem por eqüidade, a análise foi deixada apenas para o presente capítulo, por se entender que o aspecto dominante da matéria é de cunho limitativo. De qualquer forma, trata-se de uma opção de divisão das matérias: em um caso, preferiu-se o estudo da matéria nos aspectos dos efeitos da eqüidade; em outro, nos aspectos da limitação. Não se desconhece que ambas são, de um lado, emanações dos efeitos da arbitragem por eqüidade e, de outro, refletem seus limites. Há apenas uma escolha para facilidade e simetria de exposição.

\subsection{Ordem pública}

A questão da ordem pública na arbitragem internacional é um tema prolífico e complexo. A despeito da extensa bibliografia, sua definição e seu alcance ainda estão longe de serem consensuais. Não é objeto deste trabalho discutir em profundidade as diferentes concepções de ordem pública. Em princípio, sua caracterização como um conjunto de valores fundamentais de uma sociedade, seus níveis nacional e internacional e sua função como "filtro estatal" para a aplicação do direito ou reconhecimento de atos estrangeiros parecem ser suficientes para os efeitos da tese.

Nessa exposição terão especial importância os efeitos da ordem pública para o árbitro internacional, dentro da perspectiva da "deslocalização" da arbitragem.

\subsubsection{Os níveis de atuação da ordem pública}

A ordem pública costuma ser dividida entre interna e internacional. Todavia, os autores de direito internacional privado parecem convergir na atualidade para a caracterização da ordem pública como uma emanação do direito estatal, com âmbitos distintos. Trata-se de um 
fenômeno único, com esferas de atuação em relação ao direito interno e em relação à aplicação de normas estrangeiras. No caso da ordem pública interna, trata-se das normas que não podem ser derrogadas por convenção das partes. Seu campo de atuação equivale ao que a doutrina se refere como normas imperativas, cogentes, inderrogáveis e outros sinônimos. ${ }^{535}$ No caso da ordem pública internacional, trata-se da vedação de efeitos de certas normas ou atos jurídicos estrangeiros, por conterem disposições não aceitáveis ao ordenamento jurídico. ${ }^{536}$

Para um exame dos níveis de atuação da ordem pública, cremos que a obra de Jacob Dolinger traz uma postulação particularmente feliz. ${ }^{537}$ Tais níveis representam a gradação da ingerência do direito positivo nacional sobre atos entre particulares ou normas estrangeiras.

O primeiro nível de atuação da ordem pública é local, vedando convenções particulares que derroguem certos valores jurídicos ou morais considerados inderrogáveis pelo ordenamento. São exemplos de tais casos a vedação de juros acima do máximo legal, de pacto sobre sucessão de pessoa viva, certas limitações de responsabilidade, proteção de menores, etc. Neste caso, a disposição contratual será tida como nula. Esse é o nível de maior ingerência estatal e se dá na jurisdição estatal quando do julgamento do mérito de questões internas.

O segundo nível, de ingerência mais restrita, se dá no impedimento de aplicação de determinadas disposições de direito estrangeiro que seriam aplicáveis ao caso por força do direito internacional privado. Seu âmbito de aplicação é igualmente a jurisdição estatal, quando chamada a aplicar o direito estrangeiro, por força dos elementos de conexão. Neste grau, não há coincidência entre o direito cogente e a ordem pública. Somente a regra estrangeira que se choque frontalmente e de forma grave com a ordem pública terá sua aplicação impedida. Alguns casos em que o direito cogente não permita pacto em contrário podem não afetar a aplicação de norma estrangeira. Pode-se, por exemplo, mencionar o caso de vedação de renúncia à prescrição antes de ser consumada. Embora não se possa pactuar em sentido contrário, não se vê maior óbice em aplicar uma norma estrangeira que o permita.

535 Nesse aspecto, conclui-se, com Jacob Dolinger, que não existem propriamente leis de ordem pública, mas sim um princípio geral de direito que veda certos pactos. As normas em si não devem ser classificadas como de ordem pública ou não. Eles podem conter, ou não, aspectos dos princípios jurídicos e morais do foro que não podem ser derrogados por pactos privados ou mesmo pela aplicação do direito estrangeiro (DoliNGER, Jacob. $A$ evolução da ordem pública no direito internacional privado. Rio de Janeiro, 1979, p. 9-10. Mimeografado).

536 Resumindo as diferentes posições doutrinárias, veja-se DoLINGER, Jacob. A evolução da ordem pública no direito internacional privado, cit., p. 1-49, e Direito internacional privado, cit.,, p. 323 e ss. Também Ramalho Almeida, Ricardo. Arbitragem comercial internacional e ordem pública. Rio de Janeiro: Renovar, 2005. p. 24 e ss.

537 Dolinger, Jacob. A evolução da ordem pública no direito internacional privado, cit., p. 40 e ss.; e Direito internacional privado, cit., p. 332 e ss. 
No terceiro nível tem-se o reconhecimento de efeitos de atos ocorridos no exterior. Este é o nível de menor ingerência estatal. Por ele podem-se reconhecer efeitos de atos jurídicos válidos no exterior, mesmo quando a norma estrangeira aplicada não possa ser empregada por tribunais nacionais. Um exemplo citado pela doutrina é o reconhecimento de efeitos patrimoniais do casamento poligâmico: embora não se reconheça uma família polígama, não se negam alguns efeitos de tal ato celebrado no exterior. É neste nível que se dá o exame das sentenças estrangeiras, estatais ou arbitrais. Este nível menor de ingerência nas sentenças estrangeiras é decorrente também da própria natureza do procedimento de homologação, que em regra não reexamina o mérito da questão, mas os efeitos da sentença no ordenamento nacional. Assim, interessam mais os efeitos "chocantes" da sentença (prisão por dívidas, morte civil, etc.) do que a norma que as inspira. Todavia, essa não é uma regra absoluta. Pode haver normas tão conflitantes com os princípios de direito nacional que se deva negar homologação mesmo a uma sentença cujos efeitos não ofendam a ordem pública. Seria o caso de sentença aplicando princípios de discriminação racial, mas cujos efeitos sejam meramente patrimoniais.

Ao lado desses três níveis de ordem pública existe a postulação doutrinária de uma ordem pública “verdadeiramente internacional”. Essa ordem pública, inspirada pelo princípio da comitas gentium no direito internacional privado, levaria os países a um grau mais alto de cooperação internacional. Tratar-se-ia de princípios internacionais, geralmente reconhecidos na comunidade das nações, aos quais os Estados dariam aplicação mesmo em prejuízo de sua ordem interna. ${ }^{538}$ Essa teoria tem particular interesse no caso da arbitragem comercial internacional, em vista das posições de "deslocalização" e autonomia em relação aos ordenamentos jurídicos nacionais. Essa ordem pública transnacional, em apertada síntese, equivaleria aos princípios geralmente aceitos pela comunidade internacional, e seu reconhecimento e aplicação decorreriam de uma pesquisa dos valores largamente aceitos. ${ }^{539}$

538 Dolinger, Jacob. A evolução da ordem pública no direito internacional privado, cit., p. 249.

539 Fouchard, Gaillard e Goldman. Traité de l'Arbitrage Commercial International, cit., p. 866. De modo geral, LALIVE, Pierre. Transnational (or Truly International) Public Policy and International Arbitration. ICCA Congress series, New York, n. 3, p. 258 e ss., 1986, do qual se extrai: "97. From the preceding presentation, which did not attempt to be exhaustive, one thing at least seems clear: in an increasing number of cases, a national judge, although a State organ having the function to state and apply the law of a particular State and to ensure the respect of its fundamental principles (in particular by means of the traditional concept of external public policy) has not hesitated to recognize and give effect to a wider notion, more international or perhaps supranational, of public policy, based on the vital interests not only of the national community to which the judge belongs but also of a broader, regional or universal, international community.

98. The question then naturally arises: if such is the situation for the judge of a State, should not the international arbitrator also, and so to speak a fortiori, take into account transnational public policy and enforce it?". Vejase também Ramalho Almeida, Ricardo. Arbitragem comercial internacional e ordem pública cit., p. 206 e ss. Nesta obra, o autor menciona a correlação entre a ordem pública verdadeiramente internacional e a doutrina da aplicação de normas não-estatais na arbitragem internacional. Esta ordem pública seria também a ordem pública desse "ordenamento" não-estatal. 
Por fim, mencione-se também o conceito das chamadas leis de aplicação imediata, também referidas como leis de polícia (lois de police). Por esse método, existem normas que devem ser aplicadas, independentemente de qual seja o direito aplicável. Trata-se aqui de uma inversão do método clássico de direito internacional privado, que busca nos elementos de conexão para a fixação de um direito. No caso das normas de aplicação imediata, eles se impõem ad hoc, por seu próprio texto, a determinadas relações. Portanto, não se ocupam da escolha de um direito aplicável, mas sim buscam sua aplicação a determinadas situações, qualquer que seja o direito aplicável. ${ }^{540}$

\subsubsection{Atuação da ordem pública na arbitragem por eqüidade}

$\mathrm{Na}$ arbitragem internacional há uma pluralidade de ordens públicas envolvidas: a ordem pública do local da arbitragem, a ordem pública da lei de regência do contrato, a ordem pública dos países em que será executada ou ainda a ordem pública verdadeiramente internacional. Em alguma medida, encontram-se opiniões doutrinárias a favor da aplicação de todas elas. ${ }^{541}$ Qual deve ser a posição do árbitro internacional que julga por eqüidade?

Se ao juiz estatal trata-se da ordem pública internacional de seu país, qual ordem pública deve respeitar o árbitro, que em princípio não está ligado a nenhum ordenamento estatal? $\mathrm{O}$ árbitro não é propriamente um guardião da ordem pública, mas sim de sua sentença, dentro do princípio de que ele deve zelar pela eficácia de sua decisão. Assim, deve levar em consideração as ordens públicas que podem intervir contra a eficácia da sentença.

Eric Loquin indaga se o árbitro estaria sujeito às regras de ordem pública que regem materialmente a relação litigiosa. Aqui, o autor refere-se, aparentemente, às chamadas leis de aplicação imediata ou de polícia. ${ }^{542}$ Elas não são exatamente as mesmas aplicáveis ao fundo e se aplicariam em razão de ligações próprias, independentemente da lei que rege a relação material. Caso se entenda que os limites do árbitro de eqüidade estejam dentro dessas leis, respeitam-se suas fronteiras. Todavia, tal conclusão é desprovida de sanção jurídica, na medida em que os juízes nacionais são guardiões de sua própria ordem pública e não das demais. Eles não verificam se houve violação de ordem pública dos demais ordenamentos envolvidos. ${ }^{543}$

\footnotetext{
540 Seraglini, Christophe. Lois de Police et Justice Arbitrale Internationale. Paris: Dalloz, 2001. p. 1 e ss.; FouCHARD, Gaillard e Goldman. Traité de l'Arbitrage Commercial International, cit., p. 859; Ramalho Almeida, Ricardo. Arbitragem comercial internacional e ordem pública cit., p. 50 e ss.; e DolingER, Jacob. A evolução da ordem pública no direito internacional privado, cit.

${ }^{541}$ Para um panorama das discussões, veja-se LoQuin, Eric. L'Amiable composition... cit., p. 262-263.

542 Loquin, Eric. L'Amiable composition... cit., p. 266.

543 Idem, ibidem, p. 267. Todavia, essa posição deve ser tomada com cautela. Existem certos casos de aplicação de ordem pública estrangeira pelo juiz do foro. Como aquele autor admite, existe na Convenção de Nova Iorque (Art. 5. , 1, “e”). Em seu viés estatal, a ordem pública verdadeiramente internacional pode significar o reconhecimento de ordem pública de outro país.
} 
Qual seria, então, a posição em relação à lex contractus? Seria essa a ordem pública a ser respeitada pelo árbitro internacional julgando por eqüidade? Se for, sua ordem pública seria interna ou externa? Há diferença relevante entre as situações de escolha expressa das partes e sua ausência?

Eric Loquin afirma que, no caso de escolha de lei aplicável, o dever dos árbitros é o de respeitar a ordem pública interna do direito escolhido, ou seja, devem aplicar o direito imperativo. Essa seria a interpretação razoável da vontade das partes que quiseram submeter-se a tais normas. ${ }^{544}$ No entanto, como já explicitado no capítulo anterior, não compartilhamos dessa opinião. $\mathrm{Na}$ arbitragem internacional as partes podem fazer inúmeras variações de escolhas de lei, podendo "congelar" as normas em uma determinada data, excluir determinadas disposições que anulariam o contrato ou parte dele e outras combinações. ${ }^{545}$ Como já visto nesta obra, na

544 Loquin, Eric. L'Amiable composition... cit., p. 268.

545 Conforme Yves Derains (Public policy... cit.), embora compartilhe da opinião de Loquin, apresenta fundamentos importantes sobre a liberdade das partes quanto à escolha de lei na arbitragem: "28. As we have seen, the parties' discretion is unrestricted so far as the choice of the applicable law is concerned (cf. Nos. 9 and 26). Not only do the parties have the absolute discretion to choose any law that they wish, but they may also exclude the application of any national law by referring to the general principles of law or the lex mercatoria, restrict the field of application of the national law selected by combining it with the general principles of law, freeze that law at a given date, etc. They may also very well exclude from the applicable law selected those provisions that would make certain contractual clauses void. However, if this is what they intend, they must specify the fact.

29. Thus, a conflict between the wording of the contract and the public policy of the law chosen by the parties must only be resolved by the international arbitrator in the light of the wording of the contractual clauses relating to the applicable law. For example, a clause providing that 'for all questions not covered by the contract, Dutch law shall be applicable' obliges the arbitrators to give effect to all the contractual stipulations, even if these would be void by virtue of Dutch public policy. On the other hand, a clause specifying: "this contract is governed by French law' means that there is a direct hierarchical link between French law and the contractual clauses; the parties have decided to have their will put into effect in accordance with French law. A clause that would be void under French public policy would therefore have to be set aside by the arbitrators. In the award rendered in 1980 in ICC Case No. 3380 the arbitrators considered that a clause phrased: this Agreement shall be subject to and constructed in accordance with the laws in Syria meant that 'the contract is governed by and should be interpreted in accordance with Syrian law in its entirety without restriction'.

Likewise, in 1978, arbitrators in ICC Case No. 2119 held that a clause indicating that a contract was to be 'performed and interpreted in accordance with French law' meant that 'the contractual provisions were directly applicable insofar as they were not in contravention of the mandatory provisions of French law'. Indeed, if a contract has to be performed 'in accordance' with a given law, this could not be done in the case of stipulations contrary to the public policy rules of that very law.

30. The actual implications of the wording of certain clauses stipulating the applicable law can be more difficult to determine. For example, faced with a clause whereby 'the arbitration shall take place at The Hague and the arbitrators shall apply Swedish law', can the arbitrators set aside a clause in the contract because it is in breach of Swedish public policy? It would seem that they can, because the apparent will of the parties is that any dispute is to be settled by Swedish law; and the validity of a contractual clause is a dispute like any other. However, there are other interpretations. It is up to the arbitrator, whose task is to interpret the contract, to decide. Likewise, the fact that arbitrators have been granted the powers of amiables compositeurs and this is combined with the choice of a particular national law should not be interpreted as authority for excluding the public policy of the lex contractus.

31. It is important to underline that so far as the arbitrator is concerned, there is no natural hierarchy between the contract and any particular national law. Quite the contrary, a law is only applied if the parties have cho- 
parte da mecânica de decisão por eqüidade, a escolha de lei pode simplesmente significar uma “mecânica de decisão" e não a sujeição às normas imperativas do direito escolhido.

Se não houver escolha, a questão se coloca de modo mais complexo. Se se entender que sempre deve haver uma lex contractus de submissão, implica afirmar que os árbitros têm sempre de percorrer o caminho de definição de uma lei aplicável. ${ }^{546}$ Mais ainda, que os poderes dos árbitros de eqüidade seria apenas o de derrogar normas supletivas da lex contractus, ${ }^{547} \mathrm{em}$ qualquer hipótese. Ou seja, a escolha de lei pelos árbitros tem o efeito de orientar a restrição, fixando o ordenamento jurídico de onde as normas podem ser derrogadas. Assim, as regras imperativas da lex contractus sempre seriam impostas ao árbitro.

Por outro lado, se se considerar possível a referência a critérios não estatais de julgamento, como a lex mercatoria ou princípios gerais, então a arbitragem por eqüidade pode ser considerada uma vontade de "desnacionalizar" a relação litigiosa, criando uma espécie de contrato sem lei estatal. ${ }^{548}$

Essa posição tem o inconveniente de derrogar a ordem pública por convenção das partes e, de certa forma, criar um "contrato sem lei" ${ }^{549}$ Contudo, o mesmo ocorre em relação a todas as sentenças que julgam conforme critérios não nacionais. Mesmo porque, se existe a fa-

sen it and within the bounds of that will. If the parties have expressly excluded certain rules of that law, the arbitrators may not enforce the application of those rules in the name of public policy of which they are not the guardians. By introducing appropriate clauses into their contract, it is possible that the parties intended to exclude the public provisions of a law which they intended to apply to the rest of the contract.

However, it cannot be held that this is the implied will of the parties on every occasion that a stipulation in the contract is contrary to the public policy of the law chosen by them. It is only by an analysis of the clause whereby the parties designated the applicable law that the arbitrator is able to determine the role that the parties intended to confer on that law and to resolve the conflict between that law and one contractual stipulation or another, or even an entire contract when its validity is in question. In this connection, it should be noted that in practice in concluding contracts preference is given to wording that involves a hierarchical link between the chosen law and the contract, with the chosen law in the dominant position. But the parties may very well alter that hierarchy subsequently by recognizing that a clause that is void by virtue of the public policy of the chosen law is to have effect, either expressly or impliedly by performing it voluntarily. There is nothing to prevent the parties from choosing the applicable law after the conclusion of the contract. Parallel to this, there is nothing to prevent them from restricting the field of application of that law".

546 LoQuin, Eric. L'Amiable composition... cit., p. 268.

547 Loquin afirma, como visto no parágrafo anterior, que a combinação de eqüidade e escolha de lei implica somente a possibilidade de derrogação do direito supletivo. Não concordamos com essa assertiva.

548 Loquin, Eric. L'Amiable composition... cit., p. 268.

549 De certa forma, o efeito é reconhecido pela doutrina. "Si juridiquement, il paraît impossible qu'un contrat puisse être détaché de toute législation positive, il demeure que la référence à des tribunaux arbitraux statuant comme amiables compositeurs conduit à des résultats pratiquement équivalents.” Bredin, Jean Denis; Loussouarn, Droit du Commerce Internacional. Paris: Sirey, 1969. p. 603, apud LoQuIN, Eric. L'Amiable composition... cit., p. 319. 
culdade de uma lex contractus não estatal, é forçoso reconhecer que pode haver desvinculação em princípio de qualquer ordem pública estatal.

Entretanto, conforme afirma Loquin, ${ }^{550}$ a questão é sobretudo teórica, porque o juiz do exequatur não zela pela aplicação do direito imperativo estrangeiro, mas apenas do seu próprio. Assim, eventual descumprimento de disposições imperativas de uma hipotética lex contractus (a lei que deveria ser aplicada, após a aplicação dos métodos de conflito) não será sancionada. ${ }^{551}$

De nossa parte, entendemos que não existe necessidade de utilização do critério de lex contractus em qualquer hipótese. Dada a natureza da arbitragem por eqüidade, parece-nos contraditória a busca de qualquer critério que se aproxime de uma lei que as partes quiseram abandonar. No âmbito internacional têm havido opiniões de que a ordem pública transnacional ou verdadeiramente internacional seria adequada à arbitragem por eqüidade. ${ }^{552}$ Em se admitindo o conceito de ordem pública transnacional, essa parece ser uma solução adequada.

Loquin, de sua parte, afirma que nem mesmo a chamada ordem pública verdadeiramente internacional deve ser observada obrigatoriamente pelo árbitro de eqüidade, porque ele não é guardião de nenhuma ordem pública. ${ }^{553}$ Assim, respeita-se apenas por uma questão moral. A importância em observá-la está menos na função de guardião de ordem pública do que na obrigação de produzir uma sentença exeqüível, na medida em que a ordem pública verdadeiramente internacional é uma expressão de todas as nacionais. Todavia, a afirmação deve ser vista com algumas reservas teóricas. Não obstante todas as questões que envolvem método de direito comparado na arbitragem internacional tenham forçosamente um caráter mais fluido e de difícil concretização, isso não significa sua total ausência de efeito prático. Pode-se imaginar uma situação em que uma determinada regra fira a ordem pública verdadeiramente internacional, mas não fira algumas ordens públicas nacionais. Um exemplo citado é o caso de discriminação étnica ou de gênero, que ocorreram no passado. Ou ainda, para os que consideram como ofensivas à ordem pública verdadeiramente internacional as restrições regionais ao poder do Estado de participar de arbitragens. Desse modo, caso o ordenamento de execução permita eventual discriminação ou restrições ao poder do Estado para contratar, ainda assim a ordem pública

\footnotetext{
550 LoQuin, Eric. L'Amiable composition... cit., p. 269.

551 Salvo se houver coincidência entre lex contractus hipotética e o foro da execução, o que será uma casualidade.

552 Pryles, Michael. Reflections on Transnational Public Policy. Journal of International Arbitration, 24(1), p. 1 e ss., 2007, com referências à opinião de Michael Reisman.

553 LoQuin, Eric. L'Amiable composition... cit., p. 269.
} 
verdadeiramente internacional pode derrogar essa disposição, ainda que fosse aceita nos locais de execução do contrato. No entanto, serão raríssimos os casos de sua ocorrência.

Loquin conclui ${ }^{554}$ que apenas a violação da ordem pública do local da execução é que tem efeitos práticos, pois arrisca a validade da sentença. Portanto, nos casos de ausência de escolha de lei pelas partes, a ordem pública internacional dos locais de execução deve ser respeitada, por uma questão de manutenção da validade da sentença. Esse método tem o inconveniente de certa dose de incerteza, porque pressupõe um exercício de previsão do local da execução. Todavia, confere um grau mais amplo de liberdade aos árbitros.

Essa solução parece ser a mais correta, pois busca a validade da sentença e evita um exercício desnecessário de direito internacional privado para a fixação da lex contractus, que as partes quiseram evitar ao escolher a arbitragem por eqüidade. Todavia, entendemos que ela deva ser feita em conjunto com a ordem pública verdadeira internacional ou transnacional. Esta, como expressão da comunidade internacional. Aquela, pelo dever dos árbitros de produzir uma sentença exeqüível.

\subsection{Contrato}

A questão dos poderes do árbitro que julga por eqüidade em relação ao contrato é matéria controvertida. Como outros, esse aspecto da arbitragem por eqüidade não é regulado pelo direito positivo. Assim, tem cabido à doutrina e à jurisprudência o papel de precisar a questão.

Existem duas posições básicas sobre a matéria: respeito pelo contrato em sua integralidade ou a possibilidade de modificação dentro de certos limites.

A primeira posição baseia-se na assunção de que a eqüidade é um critério de julgamento aplicável em relação ao direito positivo. Trata-se da faculdade de derrogação do direito, quando essa solução parecer justa aos árbitros. Essa liberdade em relação ao direito positivo não se estenderia à vontade das partes, à qual os árbitros encontram-se ligados por força da convenção de arbitragem. Como afirma Jean-Denis Bredin:

La clause d'amiable composition est sans doute une renonciation sans équivoque au droit. Est-elle une renonciation sans équivoque au respect strict du contrat? On ne voit pas comment on pourrait, sans forcer ou présumer la volonté des parties, prétendre que la clause compromissoire libérerait l'arbitre

554 Loquin, Eric. L'Amiable composition... cit., p. 269. 
de la volonté contractuelle. Je me permets même de présenter la même observation que celle faite tout à l'heure concernant la procédure: ne pourraiton pas se demander au contraire si l'amiable composition n'impliquerait pas, dans l'aventure du non-droit, un respect spécialement scrupuleux du contrat? D'abord, parce que l'amiable composition est probablement vécue comme une exaltation de la volonté, et de la bonne volonté contractuelle. Ensuite, parce que l'amiable compositeur, qui pourait s'égarer dans les champs incertains de l'équité, devrait, après tout, avoir le contrat pour seule lumière, éclairant la nuit du non-droit. ${ }^{555}$

Assim, a simples escolha de eqüidade não seria suficiente para demonstrar uma vontade inequívoca das partes de derrogar as normas contratuais. Ao contrário, a liberdade relativa ao direito recomendaria a aplicação estrita do contrato: a eqüidade é "vivida" como emanação da vontade. Na ausência de critérios objetivos no campo da eqüidade, o fio condutor da decisão deve ser justamente o contrato, escrupulosamente observado.

Outro argumento em favor do estrito respeito ao contrato é o caráter cogente do princípio do pacta sunt servanda no direito internacional. Por essa posição, o respeito ao contrato teria caráter de ordem pública. Portanto, não estaria ao alcance dos árbitros modificar o contrato, por força de uma norma jurídica imperativa. ${ }^{556}$ Particularmente no âmbito da arbitragem comercial internacional, o princípio da força vinculante dos contratos é reiteradamente aplicado e erigido a um dos fundamentos do comércio internacional. ${ }^{557}$

Outros autores também apresentam uma visão geral contrária à modificação do contrato pelos árbitros. ${ }^{558}$

A favor da possibilidade de derrogação de regras contratuais tem-se levantado o argumento de que as normas contratuais são de direito supletivo. Uma vez que o árbitro de eqüi-

555 Bredin, Jean Denis. L'amiable composition et le contrat, cit., p. 259.

556 Berger, Klaus Peter. International Economic Arbitration, cit., p. 573-574. Embora esse autor afirme que os árbitros não podem modificar o contrato, esclarece que a regra geral pode admitir poucas exceções, como no caso de autorização das partes para alteração/derrogação do contrato e hipóteses de abuso de direito.

557 Um caso emblemático em que tal entendimento ocorre em arbitragem por eqüidade é o CCI n. 6.141. Neste caso, o tribunal estima que os poderes de eqüidade não permitem revisão do contrato:

"Such powers do no give the arbitrators any right to disregard, in any way whatsoever, the will of the parties, and therefore they remain obligated to apply all provisions of the contract freely agreed to by the parties, unless it is demonstrated that such provisions are clearly contrary to the real intention of the both parties, or are contrary to a generally accepted principle of public order.

$[\ldots]$

The arbitrators, even acting as amiable compositeurs, remain bound by the general principle of law 'pacta sunt Servanda' and are therefore obliged to observe, respect and apply the contractual provisions, freely agreed to by the parties, without having any authority to disregard, amend org o beyond or against the contract or its provisions".

558 Essa parece ser a opinião pessoal de Mauro Rubino-Sammartano (Il Diritto... cit., p. 560). Todavia, aquele autor reconhece julgados que permitem a mitigação do contrato. 
dade tem poderes de derrogação do direito supletivo, também possuiria a mesma faculdade concernente ao contrato. Todavia, como apontado por Eric Loquin, ${ }^{559}$ esse argumento pode ser contraposto pela afirmação do princípio do pacta sunt servanda como parte integrante da ordem pública.

O principal argumento apontado em favor da derrogação do contrato é o de que a escolha da eqüidade implica renúncia da sanção estrita dos direitos adquiridos:

Si l'on admet que, par la clause d'amiable composition, les parties renoncent à la sanction stricte des droits qu'elles ont acquis au moment où naît le litige et dont elles ont la libre disposition, rien n'interdit aux amiables compositeurs de modérer au nom de l'équité les droits créés par le contrat. ${ }^{560}$

Entendendo-se a arbitragem por eqüidade como uma renúncia dos direitos dispositivos concedidos pela lei, segue-se a possibilidade de renúncia dos direitos conferidos pelo contrato. Isso porque a faculdade de renúncia abrange os direitos subjetivos em geral, pouco importando a fonte da norma que os concede: seja estatal, seja contratual, pode haver a derrogação do direito concedido, desde que esse seja disponível no momento em que opera a renúncia.

Não se trata de uma renúncia genérica ao contrato, o que seria um contra-senso, mas uma renúncia à prerrogativa da "sanção estrita dos direitos que ele dispõe". ${ }^{561}$ Logo, os direitos não contestados continuam sendo normalmente exigíveis. Igualmente o são os direitos que os árbitros confirmarem em sua sentença.

Para os fins deste argumento, não se verifica uma diferença substancial entre a caracterização da arbitragem por eqüidade como renúncia, sustentada por parte da doutrina, e a de critério de julgamento, como proposto nesta obra. O critério de julgamento da eqüidade contém, ou ao menos pode conter, um elemento de renúncia à sanção estrita de direitos.

Essa última posição é admitida pela maioria da doutrina e conta com precedentes em arbitragem e decisões estatais. ${ }^{562}$ No âmbito da jurisprudência de arbitragem, encontram-se di-

559 Loquin, Eric. Les Pouvoirs de l'Amiable Compositeur. A Propos de Trois Arrêts de la Cour d'Appel de Paris. Revue de l'Arbitrage, n. 2, p. 199 e ss., 1985.

560 Idem, ibidem, p. 199 e ss.

561 Idem. L'Amiable composition... cit., p. 283.

562 Corte de Cassação italiana, julgado de 31.05.2001, apud Rubino-SAmmartano, Mauro. Il Diritto... cit., p. 560. Eric Loquin refere-se a mais de 15 precedentes franceses no mesmo sentido. Veja-se Comentário ao julgado da Corte de Cassação francesa de 15.02.2001, publicado em Revue de l'Arbitrage, n. 1, p. 135 e ss., 2001. 
versos casos em que houve alterações do contrato. Em geral não para uma efetiva renegociação, mas para descartar certas conseqüências tidas como injustas. ${ }^{563}$

Essa tendência foi igualmente encontrada na pesquisa de campo realizada para o presente trabalho, na qual foram feitas duas questões aos participantes sobre o alcance da arbitragem por eqüidade em relação ao contrato. Na primeira, perguntava-se se o árbitro deveria aplicar integralmente as disposições do contrato ou desconsiderar as que lhe pareçam injustas. Em torno de 59\% dos participantes (54) respondeu que desconsideraria as disposições injustas e 33\% (30) respondeu que aplicariam o contrato integralmente. Desse modo, parece haver uma nítida preferência pela possibilidade de descartar disposições injustas.

Assim, tanto a doutrina quanto a prática vêm admitindo, de modo majoritário, o poder do árbitro de moderar certas conseqüências do contrato que lhe pareçam injustas. Essa moderação pode ser dar sobretudo pela negativa de efeito de disposições injustas ou mesmo a redução do alcance de certas disposições ou de valores previstos.

Uma vez afirmada a possibilidade de derrogação de disposições contratuais, deve-se indagar se os poderes dos árbitros podem chegar à revisão substancial do contrato. A maioria da doutrina sustenta que os poderes não chegam a ponto de renegociar o contrato.

Em geral, admite-se que o poder dos árbitros ocorre apenas para que sejam descartados certos efeitos injustos que cláusulas contratuais possam produzir. Parte-se, como já visto, da presunção de que a arbitragem por eqüidade implica algum grau de abdicação da sanção estrita dos contratos, em favor de uma decisão que pareça equitativa aos árbitros. São diversos os exemplos de casos em que esses poderes foram exercidos pelos árbitros, como já mencionado antes.

Eric Loquin ${ }^{564}$ propõe a distinção dos contratos entre "especulativos" e não-especulativos. Nos primeiros, as partes aceitam certo grau de risco na distribuição da álea contratual, suportando os riscos inerentes a tal escolha. Neste caso, não deve o árbitro, que decide em eqüidade, modificar as áleas do contrato, mesmo que conduzam a situações injustas. No segundo caso, entende-se que as partes quiseram repartir a álea e os riscos do contrato. Neste caso, o árbitro em eqüidade pode intervir de modo mais direto, para "temperar o rigor" das estipulações contratuais em favor da parte afetada unilateralmente. Embora essa definição de contratos não pareça ser dominante nos dias de hoje, a opinião expressa tem valor orientativo na atuação dos

563 Vejam-se casos CCI n. 3.327, 11.934/EC, 92.029, 6.763/BGD, 3.344, 4.972, 10.504, 6.503, 3.267 e 3.540, todos descritos no capítulo relativo à jurisprudência.

564 L'Amiable composition... cit., p. 283. 
árbitros por eqüidade. Deve-se atentar para a alocação de riscos no contrato original e verificar se os acontecimentos posteriores faziam parte das assunções originais das partes. Ainda quanto à álea dos contratos, é interessante a posição expressa por Mezger, segundo a qual, nos casos de contratos aleatórios com cláusula de decisão por eqüidade, deve-se presumir que as partes tentaram diminuir a álea, confiando na sabedoria do árbitro. ${ }^{565}$

Todavia, existem certos poderes de revisão por parte dos árbitros de eqüidade. O enquadramento legal da arbitragem por eqüidade pode ser considerado como um ambiente propício para a aplicação de revisões decorrentes da teoria de imprevisão, hardship e assemelhados. ${ }^{566}$ Entretanto, existem limites para essa operação. A primeira delas é a existência de pedidos das partes. No caso da moderação de cláusulas contratuais, encontram-se exemplos de atuação dos árbitros de ofício ao não aplicar certas disposições contratuais. ${ }^{567}$ Os árbitros por vezes decidem por moto próprio descartar disposições contratuais que lhes pareçam conduzir a um resultado iníquo. Essa moderação de cláusulas é feita da mesma forma que a não-aplicação de determinada lei. Ocorre dentro do dever do árbitro de dar uma solução justa ao caso, mesmo que contrariamente à lei ou ao contrato. Neste caso, não parece ser necessário qualquer pedido expresso. Os árbitros apenas julgam o conflito existente conforme as regras dadas, descartando aquelas que conduzam a resultados iníquos. Essa tarefa integra a natureza dessa forma de decidir.

Pode existir uma postura mais ativa na revisão do contrato? A resposta parece ser negativa. A revisão do contrato em geral busca a manutenção do equilíbrio original, modificado por circunstâncias supervenientes. Busca-se a restituição de uma situação inicial, modificada em desfavor de uma das partes. A necessidade de modificação é dada pela sensibilidade da parte que a sofre. Não se concebe que os árbitros, na ausência de pedido específico da parte interessada, procedam a uma revisão do contrato em nome de seu sentimento de justiça. ${ }^{568}$

De qualquer modo, havendo pedido específico das partes, nada impede que o árbitro que decide por eqüidade atue de modo a revisar o contrato para readequá-lo a uma nova situação de fato. No entanto, deve-se fazê-lo apenas a pedido das partes:

Les développements précédents nous permettent de conclure que rien ne s'oppose à donner à l'amiable compositeur le pouvoir général de réviser le

565 Mezger, E. Comentário ao julgado da Corte de Apelações de Paris, de 10 de março de 1981. Revue de l'Arbitrage, n. 2, p. 222, 1982.

566 Almeida Prado, Maurício. Le Hardship dans le Droit du Commerce International, cit., p. 223 e ss. MezGer, E. Comentário ao julgado da Corte de Apelações de Paris, cit., p. 222.

567 Por exemplo, caso CCI n. 12.099/JNK, citado no capítulo relativo à pesquisa de jurisprudência.

568 Essa parece ser a conclusão de Eric Loquin, ainda que não necessariamente nos mesmos termos (L'Amiable composition... cit., p. 297). 
contrat à la requête de l'une des parties. Ce pouvoir est fondé sur la renonciation qu'ont faite les contractants en stipulant la clause, de se retrancher derrière la défense stricte de leurs droits. Les résultats de l'octroi d'un tel pouvoir sont conformes à l'évolution de la pratique de la révision qui va dans le sens d'une révision générale des contrats. Ils n'excèdent pas le cadre de la mission jurisdictionnelle confiée à l'amiable compositeur. Mais, ce dernier, bien sûr, reste tenu par le principe de l'immutabilité du litige. Il ne peut donc, en l'absence d'une demande expresse de révision émanant de l'une des parties, résoudre le litige survenant lors de l'exécution du contrat, en le modifiant de sa proprie initiative. ${ }^{569}$

A revisão do contrato opera para o futuro. Assim, dependendo da forma que é colocada, pode desbordar do caráter jurisdicional da arbitragem. Parte da doutrina ${ }^{570}$ afirma que os árbitros devem se cingir às questões existentes e não renegociar obrigações futuras, na ausência de pedido expresso. Uma atuação tendente a modificar relações futuras poderia desnaturar o caráter de arbitragem e passaria ao campo do mandato comum. A atuação de um árbitro tem caráter jurisdicional, essencialmente ligado à função de dirimir um litígio existente, a partir da posição das partes. Por sua vez, a adaptação de um relacionamento para o futuro tem um caráter "criador": recria-se a relação contratual. O poder de negociar em nome das partes é tarefa essencialmente de um mandatário comum e não do árbitro que reconhece e dá efetividade a direitos existentes.

No entanto, a questão parece ser menos nítida do que se possa imaginar à primeira vista. Em primeiro lugar, a distinção entre lide existente e reajuste para o futuro tem fronteiras permeáveis. Imagine-se um litígio sobre a interpretação de uma cláusula contratual. Caso ela venha a ser considerada ineficaz, o futuro da relação das partes terá sido modificado em razão da solução de um litígio presente. Assim, os poderes "moderadores" do árbitro de eqüidade podem modificar substancialmente o futuro do contrato, moldando-o a novas realidades pelo simples fato de deixar de sancionar algum direito.

Em segundo lugar, tampouco é nítida a dicotomia entre arbitragem como forma de dirimir litígios existentes e mandato comum como âmbito do trabalho "criador". Existe uma tendência ao reconhecimento como arbitragem de formas de solução de controvérsia em que intervém um terceiro escolhido pelas partes. ${ }^{571}$

Em terceiro lugar, existem situações em que o próprio juiz estatal é chamado a dirimir questões modificando o conteúdo contratual. Caso a mesma questão seja referida à arbitragem,

\footnotetext{
569 LoQuin, Eric. L'Amiable composition... cit., p. 297 e ss.

570 Loquin, Eric. Les Pouvoirs de l'Amiable Compositeur... cit., p. 199 e ss.

571 Idem, ibidem, p. 212. DAVID, René. Arbitration... cit., p. 409 e ss.
} 
não há desnaturação desta em favor de um mandato comum, esteja decidindo em direito ou eqüidade. A única diferença entre a arbitragem e o mandato comum seria um pedido de revisão na arbitragem. Esse parece ser um critério excessivamente formal para criar uma distinção profunda.

Na pesquisa de campo para este trabalho, perguntou-se aos participantes se o árbitro pode modificar o conteúdo do contrato para manter a relação entre as partes. Há aqui um grau maior de intervenção em relação ao simples descarte de disposições. Esse rearranjo implica, em alguma medida, a modificação da economia do contrato, ainda que em decorrência de fatos supervenientes.

Neste caso, 49\% dos participantes responderam que não pode haver modificação, ao passo que $39 \%$ entenderam que se pode modificar o contrato.

Comparando-se os resultados, pode-se concluir que, para os participantes, o árbitro pode negar efeito a uma disposição contratual injusta. Entretanto, uma modificação do conteúdo do contrato não é aceita. Existe, de qualquer modo, um percentual alto de pessoas que admitem uma modificação mais profunda, de modo que sua ocorrência não pode ser descartada em casos reais.

Essa parece ser a posição majoritária da doutrina. ${ }^{572}$ Jean Robert ${ }^{573}$ afirma a possibilidade de moderação dos efeitos do contrato, devendo-se entretanto respeitar a economia deste. Segundo aquele autor, a modificação da economia do contrato equivale a uma desnaturação do contrato; contudo, entende que os tribunais franceses não a têm sancionado como tal. No mesmo sentido de permitir o descarte de disposições do contrato sem alterar-lhe a economia, Yves Derains e Eric Schwartz, ${ }^{574}$ Fouchard, Gaillard e Goldman ${ }^{575}$ e Matthieu Boisséson. ${ }^{576}$

Existe uma sólida tradição na jurisprudência arbitral em favor dessa opinião majoritária. No caso CCI n. $6.141^{577}$ o tribunal estima que os poderes de eqüidade não permitem revisão do contrato:

\footnotetext{
572 Loquin, Eric. Les Pouvoirs de l'Amiable Compositeur... cit., p. 199 e ss.

573 Arbitrage... cit., p. 277.

574 A Guide to ICC Arbitration... cit., p. 246.

575 Traité de l'Arbitrage Commercial International, cit. p. 29.

576 Le Droit Français de l'Arbitrage, cit., p. 320.

577 Inédito.
} 
Such powers do no give the arbitrators any right to disregard, in any way whatsoever, the will of the parties, and therefore they remain obligated to apply all provisions of the contract freely agreed to by the parties, unless it is demonstrated that such provisions are clearly contrary to the real intention of the both parties, or are contrary to a generally accepted principle of public order.

$[\ldots]$

The arbitrators, even acting as amiable compositeurs, remain bound by the general principle of law "pacta sunt servanda" and are therefore obliged to observe, respect and apply the contractual provisions, freely agreed to by the parties, without having any authority to disregard, amend org o beyond or against the contract or its provisions.

No caso CCI n. $7.913,{ }^{578}$ de 1996, o tribunal afirma que parte da doutrina e de textos legais coloca o pacta sunt servanda em proeminência. Entretanto, a maioria da doutrina permite a moderação de certas disposições específicas do contrato ou atenuar seu rigor, nos limites da ordem pública e sem "renegociá-lo" nem presumir que as partes renunciaram aos direitos dele nascidos. O tribunal tem de respeitar a economia do contrato. Por outro lado, pode deixar de aplicar alguma disposição que pareça abusiva em relação a uma das partes ou iníqua em relação à natureza do contrato ou às suas circunstâncias. Aceitando a diferenciação doutrinária entre os contratos "especulativos" e não-especulativos, afirma que, se o contrato possui uma álea considerável, trata-se de um risco assumido (portanto, "especulativo"), e a eqüidade não deve mudá-lo.

No caso CCI n. $2.694^{579}$ o tribunal, mesmo tendo sido chamado a rever o contrato, recusou-se a fazê-lo, por entender que os poderes de decidir por eqüidade não alcançam o de se substituir às partes. No caso CCI n. $3.938^{580}$ o tribunal entendeu que não pode negociar em nome das partes se elas não the deram poderes específicos. Entende que os poderes de eqüidade não chegam ao ponto de substituir um índice por outro. No caso CCI n. $3.267^{581}$ (laudo final) os árbitros afirmaram como princípio geralmente aceito da arbitragem internacional que o dever dos árbitros em direito ou eqüidade é aplicar o contrato, salvo se as cláusulas sejam manifestamente contrárias à verdadeira intenção das partes ou à ordem pública. No caso CCI n. 9.262,582 de 1997, o árbitro único entendeu que, mesmo investido de poderes para decidir por eqüidade, não poderia modificar os termos da transação que havia entre as partes, longamente negociada.

578 ICC International Court of Arbitration Bulletin, v. 18, n. 1, p. 67 e ss., 2007.

579 Collection of ICC Arbitral Awards... cit., p. 320. Paris/New York/Deventer/Boston, ICC Publishing S.A./ Kluwer Law and Taxation Publishers, 1990,pg.: 320.

580 Jarvin, Sigvard; Derains, Yves. Collection of ICC Arbitral Awards, cit., p. 502.

581 Jarvin, Sigvard; Derains, Yves; Arnaldez, Jean-Jacques. Collection of ICC Arbitral Awards, 1986-1990. Recueil des Sentences Arbitrales de la CCI, 1986-1990. Boston: Kluwer Law and Taxation Publishers, 1994. p. 43.

582 ICC International Court of Arbitration Bulletin, v. 18, n. 1, p. 79 e ss., 2007. 
No caso CCI n. $12.772^{583}$ o árbitro afirmou que somente em casos extremamente específicos, como os da cláusula rebus sic stantibus, poderá haver intervenção do árbitro no contrato. Fora desses casos, deve atender às disposições do contrato, "na medida em que forem claras", e não as alterar.

Reconhecidos os limites da atuação dos árbitros em relação ao contrato, qual é a sanção por seu desrespeito? Trata-se aqui de um ato em excesso do mandato outorgado pelas partes. Nesse aspecto, assemelha-se a outras violações de mandato por parte dos árbitros. Sua sanção deve ser a mesma: a nulidade da sentença arbitral.

No caso Coderre, julgado pela Corte de Apelação de Québec, há uma vigorosa condenação do desconhecimento dos termos do contrato por parte do árbitro. Neste caso, o árbitro havia descartado a aplicação de uma fórmula contratual de fixação de preço. O julgado, embora reconheça algum poder moderador relativamente ao contrato, condena a modificação de suas condições. ${ }^{584}$

583 ICC International Court of Arbitration Bulletin, v. 18, n. 1, p. 79 e ss., 2007, p. 112 e ss.

584 “'[104] En l'espèce, la solution retenue par l'arbitre, qui a retranché deux des dispositions de la transaction, va au delà de la 'modération contractuelle' apparemment inhérente à l'amiable composition et dépasse l'action supplétive qui pourrait lui être reconnue: il a plutôt écarté des dispositions contractuelles jugées inopportunes, défaisant ainsi 'l'équilibre initial du contrat', perturbant 'la proportionnalité des prestations prévues à l'origine' et, enfin, modifiant l'économie du contrat dans un contexte où, pourtant, les parties ont longuement mûri chacun des termes de leur entente. L'arbitre, tout en affirmant qu' '[il] ne s'agit pas ici de modifier la transaction mais de suppléer au défaut des parties d'anticiper l'effet des acquisitions'77, a en réalité fait plus que d'atténuer la rigueur des droits contractuels, choisissant plutôt, en l'absence d'une habilitation claire, de réformer le contrat en substance.

[105] L'amiable composition ne doit pas, il me semble, devenir l'occasion de permettre à une partie d'échapper aux conséquences d'un choix contractuel malavisé ou dont elle n'aurait pas considéré tous les effets futurs. Le professeur Antaki, partisan d'une vision large de l'amiable composition, écrit pourtant que:

191. Il arrive fréquemment que l'arbitrage d'amiable composition soit réclamé avec énergie par un entrepreneur malchanceux qui avait mal calculé ses coûts ou son risque commercial et qui souhaite que l'arbitre modifie les effets du contrat initial bien rédigé. C'est méconnaître la nature de l'institution. L'arbitre n'a pas pour fonction de transférer les risques du contrat ou de venir en aide aux personnes ayant mal préparé leur soumission.78

En ce sens, quoique dans un contexte légèrement différent, voir: Alain Prujiner, loc. cit., voir supra, note 24. L'auteur y écrit ce qui suit à la p. 435:

[...] L'amiable composition introduit l'équité dans le mode de résolution des conflits mais non dans le cœur de la relation contractuelle. En l'absence d'autres indications, il n'est pas possible d'inférer de sa seule présence dans la clause d'arbitrage une obligation générale, indéterminée, d'adaptation du contrat aux changements de circonstances. Or, l'absence de cette obligation enlève la possibilité juridique d'un litige, condition nécessaire à l'intervention de l'arbitre amiable compositeur, à moins que ce contrat ne soit soumis à un droit qui pratique la théorie de l'imprévision, mais en ce cas l'obligation provient de la loi et non de l'amiable composition. $[\ldots]$

[106] L'arbitre-amiable compositeur demeure en effet un arbitre, exerçant une fonction juridictionnelle et, comme le rappelle le professeur Antaki, ‘[i]l n'est pas un médiateur, un conciliateur ou un mandataire commun [...]'79.

[107] De ce point de vue, la situation de Groupe Roger au regard de la transaction n'en est pas une d'imprévision au sens propre, c'est-à-dire d'un '[c]hangement de circonstances que l'une des parties ne pouvait prévoir lors 
O problema que se coloca neste ponto é o de aferição do grau de intervenção do contrato. As cortes nacionais, ao se depararem com uma alegação de ingerência indevida no contrato pelos árbitros, deverão agir com cautela. Existe uma área cinzenta entre os casos de clara moderação (como a diminuição de taxa de juros, redução proporcional de multas) e uma revisão profunda do contrato (como a mudança de obrigações entre as partes). Um exemplo de situação limítrofe é a alteração de uma cláusula de não-concorrência, que se por um lado pode implicar simples moderação de um excesso, como nos casos de prazos muito longos, por outro pode modificar substancialmente a economia do contrato, em que se transferem conhecimentos com a premissa de que não serão utilizados pela concorrência.

$\mathrm{Na}$ opinião do autor, os tribunais devem adotar padrões mais rigorosos para aferir a existência de "renegociação" do contrato, sob pena de se abrir a possibilidade de revisão de mérito da sentença arbitral. Esses padrões devem levar em consideração a alocação original de riscos e responsabilidades do contrato.

Em resumo, pode-se afirmar que os poderes dos árbitros que decidem por eqüidade em relação ao contrato (i) existem segundo a maioria da doutrina e da jurisprudência; (ii) derivam da natureza da cláusula de arbitragem por eqüidade, que presume a intenção de não buscar a sanção estrita de todos os direitos; (iii) possibilitam a moderação de conseqüências injustas da estrita aplicação da cláusula, mesmo sem pedido expresso; (iv) a moderação não pode implicar renegociação do contrato; e (v) pode chegar a uma revisão do contrato, desde que haja pedido expresso das partes.

de la formation du contrat et qui a pour effet d'en rendre l'exécution plus onéreuse' 80 . Plutôt, Groupe Roger paraît avoir mal évalué, au moment de la conclusion du contrat, les effets potentiels (et logiquement prévisibles) des termes sur lesquels les parties se sont entendues." Disponível em: <http://www.mcgill.ca/files/ arbitration/CoderreCA.pdf>. Acesso em: 15 nov. 2008. 


\section{Parte II}

\section{DA PRESENÇA DA ARBITRAGEM POR EQÜIDADE NO DIREITO INTERNACIONAL}

Nesta parte, a existência da arbitragem por eqüidade no mundo será verificada em três aspectos: os direitos nacionais, os tratados e os regulamentos de arbitragem. Para melhor abordagem da matéria, dividiu-se-a em parte geral (i) e parte especial (ii). Cada uma corresponde a um capítulo desta parte. Na parte geral, são expostas as regras gerais dessumidas do exame de leis, regulamentos e tratados, de modo mais ou menos sistematizado. Na parte especial, são apresentados os resultados da pesquisa realizada em 98 ordenamentos jurídicos distintos, bem como dos principais tratados internacionais. Não foram incluídos os regulamentos de arbitragem na parte especial, porque eles são integralmente mencionados nas referências da partes geral, razão pela qual preferiu-se evitar a repetição. 


\section{CAPÍTULO 5}

\section{PARTE GERAL}

Pode-se definir a moldura jurídica da arbitragem no direito internacional pela conjunção de três elementos: (i) as legislações nacionais; (ii) os tratados; e (iii) os regulamentos de arbitragem. ${ }^{585}$

Toda e qualquer arbitragem internacional estará sujeita, em alguma medida, aos efeitos de cada um desses elementos. Em geral, de modo concorrente e sobreposto. ${ }^{586}$

Os direitos nacionais têm influência direta nas arbitragens que ocorrem nos respectivos territórios, sobretudo em relação a aspectos organizacionais (arbitrabilidade, princípios processuais a serem respeitados, etc.). Possuem igualmente influência determinante no reconhecimento de execução das sentenças arbitrais estrangeiras, na medida em que disciplinam a

585 Essa não é a única classificação possível. Há outras formas de classificação de "fontes" da arbitragem internacional, com acréscimo de alguns elementos ou subdivisões. Fouchard, Gaillard e Goldman (Traité de l'Arbitrage Commercial International, cit., p. 71 e ss.) propõem a divisão entre fontes de origem pública e privada, conforme a natureza das entidades que emanam as regras. As fontes de origem pública dividem-se em nacionais (essencialmente as legislações nacionais) e internacionais. Estas últimas incluem: (i) instrumentos facultativos, tais como regulamentos de arbitragem propostos por instituições de direito internacional público, como as Comissões das Nações Unidas e a Lei Modelo); (ii) acordos bilaterais, como tratados de assistência judiciária ou outros que incluam a arbitragem como modo de solução de controvérsias (entre os quais os que têm como objeto específico a arbitragem, como os Acordos de Argel); e (iii) convenções multilaterais, tal como a Convenção de Nova Iorque. As fontes de origem privada abrangem: (i) convenções-tipo, como cláusulas modelo de instituições e acordos entre instituições; (ii) regulamentos de arbitragem e outros regulamentos, tais como códigos deontológicos ou de assuntos específicos, como a administração de provas; e (iii) sentenças arbitrais. Embora esta seja uma forma mais elaborada de classificação, ela privilegia um aspecto, que é o da origem das fontes. Para os fins do estudo da presença da arbitragem por eqüidade no âmbito da arbitragem internacional, entendemos mais conveniente utilizar um critério que privilegie a natureza dos atos. Alguns dos itens mencionados na classificação dos tratadistas franceses são englobados nas três categorias adotadas neste capítulo e outras em capítulos distintos desta obra (como o caso das sentenças). Outras, como códigos deontológicos, não foram incluídas.

586 "2-42 Wherever the parties are from and whatever form and place of arbitration is selected, every arbitration will be situated within and subject to some legal and regulatory systems. In most international arbitrations, there will be an overlap between two or more of these systems, e.g. the law of the place of arbitration and the arbitration rules. The effectiveness of the arbitration and the enforceability of the arbitration award will depend on the relevant law and rules being respected.

2-43 As will be seen throughout this study, in every arbitration there is an underlying national law, normally that of the place of arbitration, which regulate and controls the arbitration. It will be tempered by international arbitration practice and the rules of arbitration, institutional or ad hoc, which the parties may have selected to govern their arbitration. An inevitable question is which shall prevail where the two are in conflict." LEw, Julian D.M.; Mistelıs, Loukas A.; KRöLl, Stefan M. Comparative international commercial arbitration. Deventer: Kluwer Law International, 2003. p. 17. 
forma e os limites de tal ato. ${ }^{587}$ Nesse aspecto, o reconhecimento da ou a vedação à arbitragem por eqüidade nos ordenamentos jurídicos nacionais é decisivo para a existência deste tipo de arbitragem. Existem regulamentos de arbitragem e tratados internacionais que fazem remissão expressa à lei aplicável ao procedimento como elemento para determinar a possibilidade de decisão por eqüidade. Ainda que se entenda que a arbitragem por eqüidade emana de um consenso supranacional gerador de regulação sobreposta às leis nacionais, uma vedação por parte dos ordenamentos locais poderá ser causa de nulidade da sentença arbitral ou de recusa à sua execução.

Os tratados internacionais criam uma regulamentação especial da matéria dentro de seu âmbito de aplicação. Criam disciplina comum para questões que envolvam dois ou mais territórios e moldam direitos nacionais, inserindo certos elementos "materiais". Sobretudo no que diz respeito aos tratados multilaterais, há a criação de disciplina própria com irradiação considerável na arbitragem internacional. Neste estudo, não foram incluídos os tratados bilaterais de arbitragem, preferindo-se os atos de vocação universal ou regional. ${ }^{588}$ Essa escolha se deve essencialmente a três razões: (i) o declínio da importância prática dos tratados bilaterais no âmbito da arbitragem comercial ${ }^{589}$ e (ii) sua pouca importância específica para o Brasil; e (iii) a necessidade de ampliação demasiada do escopo para obtenção de uma base abrangente. ${ }^{590}$

Apesar de existir considerável regulamentação por instrumentos legislativos, as partes gozam de ampla autonomia para delinear a arbitragem. Em todo espaço não regulamentado de forma cogente, as partes desfrutam de ampla liberdade. Em geral, tratados e legislações nacionais concedem às partes a primazia da regulamentação do procedimento, exceto por poucos pontos considerados inderrogáveis, normalmente ligados ao direito de defesa, à igualdade das partes e à arbitrabilidade.

Dentro de sua autonomia, é comum que as partes escolham instituições para administrar os procedimentos arbitrais ou submetê-la a regulamentos previamente editados. A utilização desses regulamentos tem caráter contratual: é fruto de uma convenção entre as partes. $\mathrm{Na}$

587 Como já visto nesta obra, existe uma corrente expressiva na arbitragem internacional que defende sua deslocalização. Todavia, essa corrente não exclui efeitos da lei nacional da sede da arbitragem ou do país em que se busque a execução da sentença arbitral. A violação da ordem pública de qualquer desses ordenamentos nacionais pode acarretar a nulidade da sentença ou a negativa de sua execução.

588 Com a importante exceção dos Acordos de Argel.

589 Fouchard, Gaillard e Goldman. Traité de l'Arbitrage Commercial International, cit., p. 121. Note-se, porém, que os chamados Tratados Bilaterais de Investimento foram um instrumento muito utilizado em determinadas épocas da segunda metade do século XX.

590 Pode-se estimar que a maioria dos tratados bilaterais em geral cuida de vários aspectos do relacionamento entre países, dos quais a arbitragem é apenas um deles. Contudo, uma afirmação de tal fato dependeria de um exame mais completo da base desses tratados. 
prática, salvo por circunstâncias específicas, o uso de tais regulamentos é preferível à elaboração de uma cláusula que regulamente todo o procedimento, como um pequeno código inserido em um contrato.

As principais instituições moldam suas regras de acordo com experiência considerável e com a ajuda de técnicos destacados. Isso confere aos regulamentos uma adequação nem sempre encontrada em cláusulas negociadas. Essa proeminência técnica das instituições de arbitragem as coloca em um patamar de referência prática importante. A ampla aceitação de tais regulamentos e a repetida convergência de determinadas soluções entre eles (forma da sentença, etc.) constituem usos e costumes geralmente aceitos na arbitragem internacional. ${ }^{591}$ São fatores importantes de coesão da arbitragem internacional.

A sobreposição desses níveis de regulação cria uma espécie de "rede regulatória" 592 que tem por pedra angular a autonomia da vontade das partes, formatada pelas (poucas) regras obrigatórias impostas pelas leis estatais. Cada um dos aspectos dessa rede regulatória atua de modo concorrente sobre as arbitragens internacionais.

591 Fouchard, Gaillard e Goldman. Traité de l'Arbitrage Commercial International, cit., pg. 196-197.

592 "The Regulatory Web

2-45 The agreement of the parties (1) will prevail over the provisions in the chosen arbitration rules (2) which in turn prevail over international arbitration practice (3) and the applicable law (4). In this hierarchy the norms of a lower stage are superseded by those of a higher stage and are only applicable where there is no regulation in any of the preceding stages. By corollary, in the absence of agreement as to specific rules or arbitration rules it is the applicable law (4) that will govern the arbitration.

2-46 International arbitration practice (3) comes into play at all stages, not only as a separate source but also to interpret the arbitration agreement, the chosen arbitration and the applicable national law. The international conventions (6) form part of the applicable law and aim to ensure that arbitration agreements and awards are enforced. In so doing, they uphold party autonomy as the backbone of the regulatory web. The shape of the web changes over time with the international arbitration practice influencing the contents of the applicable arbitration rules and the law.

2-47 The regulatory web is constrained at both sides by relevant mandatory rules. These impact, at the outset, on the types of issues that can be submitted to arbitration (5a) and ultimately the effectiveness and enforceability of the arbitration award (5b).

2-48 There are few mandatory requirements in national arbitration laws.(30) Most arbitration laws are permissive allowing the parties a wide degree of discretion in deciding how their arbitration should be organised and conducted. The selection, intentional or inadvertent, of a particular arbitration system will demonstrate the parties' intention and will generally be respected. Ultimately, just as the decision to submit disputes to arbitration is based on the parties' choice, so too the applicable rules will be determined according to the wishes of the parties.

2-49 Where there are complications and uncertainties, these should be resolved by national courts and arbitrators in accordance with international arbitration practice, as illustrated and recorded in the international arbitration instruments, including the New York Convention, the Uncitral Rules and the Model Law. The overriding factors must be the importance of the will of the parties and the absolute essential to achieve an effective and enforceable arbitration award. Hence the importance of the criteria set out as fundamental to the validity of an award in Article V of the New York Convention." Lew, Julian D.M.; Mistelis, Loukas A.; Kröll, Stefan M. Comparative international commercial arbitration, cit., p. 28 e ss. 
O objetivo do presente capítulo é verificar a presença da arbitragem por eqüidade em cada um dos elementos da moldura jurídica da arbitragem internacional.

\subsection{A presença da arbitragem por eqüidade nos sistemas jurídicos nacionais}

Para a elaboração de uma análise de direito internacional, entendeu-se necessário um estudo de direito comparado de base ampliada: apenas a verificação do maior número possível de sistemas normativos pode determinar o alcance territorial do instituto. Tão-somente o exame de legislações é capaz de fornecer dados para se concluir com segurança se a arbitragem por eqüidade é uma instituição genuinamente internacional ou restrita a alguns direitos nacionais.

Assim, procurou-se examinar o maior número possível de ordenamentos jurídicos. Foi obtido material relativo a 99 ordenamentos jurídicos diferentes, o que representa uma parcela substancial do total de países do mundo ${ }^{593}$ e certamente abrange os principais atores da arbitragem internacional.

A verificação de tal número de ordenamentos naturalmente torna a análise menos profunda do que em uma situação de comparação entre poucos países selecionados, que é mais comum em obras acadêmicas. Todavia, existe uma linha consistente de obras que adotam, ao menos em parte, uma perspectiva global de exame da arbitragem. ${ }^{594}$ Trata-se, portanto, de uma escolha de método já utilizado anteriormente em obras de relevo. Acredita o autor que os benefícios do aumento da base de países compensam eventual diminuição da abrangência ou mesmo do rigor metodológico de direito comparado.

O exame do direito comparado não é apenas o estudo de normas comparadas. Cada ordenamento jurídico nacional é um sistema e como tal deve ser analisado. ${ }^{595}$ Em todos os casos, os textos de lei foram consultados. Na maioria deles, recorreu-se ao menos a duas obras sobre o regime de direito interno. Para tanto, foram utilizados principalmente dois grandes compêndios de direito da arbitragem comparado. ${ }^{596}$ No entanto, nem sempre tais compêndios ofereceram

593 Em outubro de 2008, existiam 192 países-membros das Nações Unidas, conforme informação disponível em: $<$ www.un.org $>$.

594 Entre outras: Fouchard, Gaillard e Goldman. Traité de l'Arbitrage Commercial International, cit., p. 83 e ss.; SANDERs, Pieter. International Encyclopedia of Comparative Law... cit., passim; DAvid, René. Arbitration... cit., passim.

595 David, René. Le Droit Comparé: Droits d'Hier, Droits de Demain. Paris: Economica, 1982. p. 115.

596 International Handbook on Commercial Arbitration. Alphen aan den Rijn: Kluwer Law International, 2007. Editor atual: Paulsson, Jan. Smit, Hans; РеснотA, V. Smit's Guides to International Arbitration: National Arbitration Laws. Huntington: JurisNet, 2006. Ambas as obras têm a forma de fichários, aos quais são acrescentadas atualizações periódicas, por vezes com autores diferentes identificados. 
informações suficientes. Assim, foram adotadas outras fontes, como artigos, monografias específicas e sítios de internet. A existência de apenas uma fonte foi considerada suficiente para a demonstração da arbitragem por eqüidade, embora o emprego de ao menos duas tenha sido a regra geral. Em poucos casos, o único material disponível foi o próprio texto da lei, sem comentários.

Paralelamente à ampliação da base, selecionou-se um número de países mais significativos para aprofundar a pesquisa de doutrina e jurisprudência. Foram escolhidos países mais expressivos no âmbito da arbitragem internacional, bem como do ponto de vista do comércio exterior do Brasil.

Como resultado da pesquisa, verifica-se que a arbitragem por eqüidade tem ampla aceitação no cenário mundial, sendo raros os países que não a permitem. Existem essencialmente três sistemas gerais relativos à arbitragem por eqüidade: (i) um sistema de presunção da arbitragem de direito, com permissão de arbitragem por eqüidade caso as partes a autorizem; (ii) um sistema de presunção de arbitragem por eqüidade, com permissão de arbitragem de direito, caso as partes a autorizem; e (iii) um sistema que veda a arbitragem por eqüidade.

O primeiro sistema encontra ampla aceitação na maioria dos países pesquisados, com pequenas variações. O segundo sistema, encontrado em alguns países da América Espanhola, perece perder adeptos conforme são reformados os regimes de arbitragem. Esse sistema é referido nesta obra como "sistema hispano-americano" em razão de sua localização geográfica. O terceiro sistema, também pouco encontrado nos dias de hoje, veda a utilização da arbitragem por eqüidade. Não há, contudo, vedação expressa. Ela ocorre na dinâmica do sistema de direito interno e é fruto de dois sistemas do passado que tiveram considerável irradiação mundial. Entretanto, o silêncio sobre a arbitragem por eqüidade não significa necessariamente vedação. A ausência de menção pode significar também a permissão, conforme a tradição jurídica em que esteja inserida. Assim, os ordenamentos que silenciam sobre a arbitragem por eqüidade não formam por si um sistema próprio.

Qualquer exame de direito de arbitragem comparado necessariamente passa pela constatação de uma onda renovadora das leis nacionais de arbitragem ocorrida a partir da década de 1970. ${ }^{597}$ Essa renovação demonstra o reconhecimento da importância da arbitragem comercial como método de solução de controvérsias e a preocupação com uma legislação adequada ao seu desenvolvimento. Nesse movimento, há um claro protagonismo do trabalho da CNUDCI, que

597 Fouchard, Gaillard e Goldman. Traité de l'Arbitrage Commercial International, cit., p. 83. 
tem atuado como catalisador da modernização. A Lei Modelo tem sido inspiradora das reformas ocorridas, inclusive quanto à arbitragem por eqüidade.

\subsubsection{A obra da CNUDCI}

A arbitragem comercial internacional tem sido um dos principais eixos do trabalho da CNUDCI desde sua criação, constituindo objeto de grupo de trabalho específico.

Em 21 de junho de 1985, a CNUDCI adotou uma "Lei Modelo sobre Arbitragem Comercial Internacional”, objeto da Resolução 40/72 da Assembléia Geral das Nações Unidas, de 11 de dezembro de 1985. Naquela Resolução, a Assembléia Geral recomendou que os Estados considerassem "devidamente" a Lei Modelo, em vista do objetivo da uniformidade da regulação da arbitragem e das necessidades específicas da arbitragem internacional. Sua difusão é considerada um grande sucesso, ${ }^{598}$ utilizando-se de um método diferente da elaboração dos tratados. No entanto, seu resultado é tão eficaz quanto um ato internacional, justamente pela ampla flexibilidade que confere aos Estados em sua adoção: podem adaptá-la livremente em sua incorporação. 599

Baseada em grande parte no próprio regulamento de arbitragem da CNUDCI, editado em 1976, a Lei Modelo cobre todas as fases do procedimento arbitral.

O pano de fundo para sua a elaboração foi a constatação de que as leis domésticas apresentavam estágios variados de evolução, nem sempre favoráveis à arbitragem. Em muitos casos, a arbitragem era colocada em igualdade com o processo judicial, com as vicissitudes a ele inerentes. Mesmo as mais modernas legislações tratavam essencialmente da arbitragem interna, o que acarretava um aporte de particularidades internas no âmbito internacional, em prejuízo da previsibilidade e de um regime comum. ${ }^{600}$

598 "Uncitral's Model Law on Arbitration (ML) was a great success. In the 20 years that have elapsed since its recommendation by the General Assembly of the UN in its Resolution of 15 December 1985, some 50 states from all parts of the world have adopted the ML for their national arbitration legislation. The ML was conceived for international commercial arbitration, but a large number of states adopted the ML also for domestic arbitration." SANDERS, Pieter. Uncitral's Model Law on International and Commercial Arbitration: Present Situation. Arbitration International, v. 21, nov. 2005.

599 Fouchard, Gaillard e Goldman. Traité de l'Arbitrage Commercial International, cit., p. 119.

600 "3.3. The Uncitral Model Law and the Development of Modern Arbitration Laws in many Jurisdictions.

2-38 As a result of the successful operation of the New York Convention and the development of established arbitration practice, the differences between national arbitration laws became only too apparent. There were essentially three different situations.2-39 In some countries the courts still sought to control and supervise arbitrations taking place in their jurisdictions. Other countries sought rather to provide support for the arbitration process whilst refusing to intervene or interfere in the process itself, as opposed to strict supervision of 
Fruto de longa elaboração e herdeira de uma tradição que remonta às Comissões Econômicas das Nações Unidas para a Europa e para a Ásia, bem como das próprias regras de arbitragem da CNUDCI, ${ }^{601}$ pode-se dizer que ela representa um "consenso" global quanto a certos pontos centrais da arbitragem..$^{602}$

Após sua aprovação, a Lei Modelo foi rapidamente adotada por vários países, a começar pelo Canadá já no ano de 1986. Em outubro de 2007, a Lei Modelo contava com a adesão direta de mais de 48 países. ${ }^{603}$ Entretanto, para além desses 48 países, vários outros inspiraramse na Lei Modelo. ${ }^{604}$

the arbitration process. This can be called a minimalist approach to international commercial arbitration. This last development recognised the fundamental influence of party autonomy in international arbitration, which effectively required very limited interference with a party's will. The third group of countries had either old and out of date arbitration laws or no arbitration laws at all.

2-40 It became increasingly clear that some uniformity was needed to reflect the commonly accepted standards for international arbitration. The benchmark event in this respect was the introduction of the Uncitral Model Law of 1985. The concepts of party autonomy and the supportive role of courts to the arbitration process are the basis of the Model Law. The Model Law harmonised and modernized the issues it touches upon and represents a step forward along with the New York Convention and the Uncitral Rules. What is equally important is the jurisdictions where new legislation has been influenced by the Model Law.

2-41 The minimalist approach and the primacy of the principle of party autonomy, as embodied in the Model Law, have now been recognised in all modern arbitration laws. They reshape the scope of courts' powers in respect of assistance and supervision. The scope of court assistance is generally confined to the appointment and removal of arbitrators, the grant of provisional relief and the collection of evidence. The supervisory powers of a court are limited generally to the challenge to jurisdiction, removal of arbitrators, and appeal from, setting aside and enforcement of arbitration awards. In addition, no derogation is allowed from the due process requirements and there is a limit in each jurisdiction to matters which are arbitrable.” Lew, Julian D.M.; MisTELIS, Loukas A.; KRÖLl, Stefan M. Comparative international commercial arbitration, cit., p. 26-27.

601 SANDERS, Pieter. The work of Uncitral... cit., p. 2.

602 A despeito de haver uma "linguagem comum" da arbitragem internacional, que é fruto inegável do sucesso da Lei Modelo, existem divergências de monta sobre sua interpretação, como salienta Marc Blessing: "The successful discussion and agreement on the Uncitral Model Law may be viewed as an impressive success showing that, around the globe, there is indeed a common approach and perception of international commercial arbitration.

However, if a closer look is taken into the extensive discussions in respect of individual paragraphs of the Model Law, one will realize to what extent different views and different positions were expressed by scholars both from industrialized and from developing countries. The Model Law may, thus, create a wrong impression that there is full harmony of understanding in all respects which, in fact, is not the case, at least not in a way that we may wish to see it". Globalization (and harmonization?) of arbitration. Journal of International Arbitration, v. 9 , n. 1, p. 79 e ss., 1992.

603 Veja-se o sítio de internet oficial da CNUDCI: <www.uncitral.org>. Também SANDERS, Pieter. Uncitral's Model Law... cit., p. 443 e ss.

604 O inegável sucesso da Lei Modelo não ficou, todavia, isento de críticas:

"The procedural elements of the Model Law may be sound but here again, an effective demolition job has been done by some English lawyers and their objections, which are based on the inadequacy of judicial control provided in the Model Law, must be taken seriously. However, there are two more serious reasons against the adoption of the Model Law by Third World states. The first is the removal of a vast sphere of dispute settlement in which their interests may be heavily implicated by characterizing them as international business disputes through a wide definition of international commercial arbitration. The second lies in the elevation of party autonomy to such heights as to play down the significance of mandatory provisions of any applicable law and then make a supranational law of uncertain origins, into which norms inimical to developing states 
A Lei Modelo reconhece decididamente a arbitragem por eqüidade, ${ }^{605}$ contudo não a presume. Ela somente poderá ser utilizada quando houver expressa permissão das partes. Neste aspecto, o sistema da Lei Modelo reflete a prática estabelecida e consistente na arbitragem internacional, quer por regras de arbitragem, quer por leis nacionais.

O exame dos trabalhos preparatórios da Lei Modelo e mesmo do Regulamento de Arbitragem da CNUDCI não apresenta nenhum posicionamento diverso. ${ }^{606}$ Desde as primeiras versões dos documentos, a arbitragem por eqüidade sempre foi colocada como uma opção a critério das partes.

Não se poderá jamais subestimar o efeito da Lei Modelo na implementação da arbitragem por eqüidade pelo mundo. Sua edição encontrou em curso um amplo movimento de renovação das legislações nacionais de arbitragem. Nesse movimento, os legisladores nacionais ou adotaram a Lei Modelo ou ao menos levaram sua sistemática em consideração. Assim, a disciplina da arbitragem por eqüidade constante da Lei Modelo foi empregada (ou reafirmada) em muitas legislações nacionais. Pode-se afirmar que o sistema por ela adotado prevalece na imensa maioria dos países. ${ }^{607}$

Além de unificar a disciplina da arbitragem por eqüidade nos diversos países que já a reconheciam, ${ }^{608}$ a Lei Modelo foi o instrumento de introdução do instituto em dois sistemas jurídicos tradicionalmente refratários a ele: países de common law e os antigos países socialistas. ${ }^{609}$

A obra da CNUDCI alterou o panorama da arbitragem comercial no mundo ${ }^{610}$ Ao fazê-lo, criou uma espécie de sistema comum que, com poucas adaptações, pode ser encontrado em quase todos os países. Seus fundamentos, em boa medida, constituem uma "língua comum" da arbitragem internacional, também no que diz respeito à arbitragem por eqüidade.

could be introduced, apply to the dispute. Third World states which contemplate the adoption of the Model Law should carefully weigh the advantages of having a set of laws on international arbitration against the possible costs to their interests." Sornarajah, M. The Uncitral Model Law: a third world viewpoint. Journal of International Arbitration, v. 6, n. 4, p. 7 e ss., 1989.

605 Art. 28. Veja-se também, entre muitos outros, SANDERs, Pieter. The work of Uncitral... cit., p. 48.

606 Kavass, Igor; LiIVAK, Arno. Uncitral Model Law... cit.

607 Ainda que essa disciplina tivesse sido a orientação anterior, como de fato o era na maioria dos países.

608 Em alguns países, como era o caso da Alemanha, a arbitragem por eqüidade era permitida, embora não mencionada expressamente em lei. A adoção da Lei Modelo serviu para explicitar a opção.

609 SANDERs, Pieter. The work of Uncitral... cit., p. 48. A menção à common law refere-se sobretudo ao sistema inglês e suas irradiações a ex-colônias. Nos EUA, a arbitragem por eqüidade era permitida, embora com pouca utilização. No caso dos países socialistas, Rússia e Bulgária parecem continuar como exceções, mesmo tendo adotado a Lei Modelo (omitindo a disposição acerca da arbitragem por eqüidade).

610 O processo de adoção da Lei Modelo, embora avançado, continua em curso, como atestam as recentes adesões de Áustria e Dinamarca. 


\subsubsection{A presunção de arbitragem de direito}

Na pesquisa realizada, verifica-se que o sistema da permissão da arbitragem por eqüidade mediante convenção das partes é adotado pela ampla maioria dos países. Por esse sistema, a utilização da arbitragem por eqüidade depende de convenção expressa das partes, adicionalmente à escolha da arbitragem como método de solução de controvérsias. Portanto, embora permita esse tipo de arbitragem, não a presume como método padrão.

A influência da Lei Modelo na difusão desse sistema é evidente. Todavia, não é de sua criação. A Lei Modelo é fruto de debate ampliado, integrado por acadêmicos, instituições e representantes dos países-membros. Seu texto, conquanto possa trazer inovações, igualmente consolida entendimentos e soluções já existentes na prática internacional.

A arbitragem por eqüidade mediante convenção das partes constitui uma tradição sólida e duradoura nos direitos nacionais. Embora possa-se aventar que, em tempos mais antigos, a escolha de arbitragem implicasse, por si só, julgamento por eqüidade, essa assimilação perdeuse na transição para o século XIX em boa parte dos países.

Como já demonstrado nesta obra, o direito brasileiro adota consistentemente a atual orientação desde o século XIX. Essa é também a orientação do direito francês desde ao menos a edição do Código de Processo Civil de 1806. ${ }^{611}$

Essa orientação justifica-se pelo caráter excepcional da arbitragem por eqüidade em relação à de direito. ${ }^{612} \mathrm{~A}$ arbitragem desempenha um papel de substituto do procedimento estatal. Neste procedimento, a regra geral é a de que o juiz decide conforme a lei, salvo situações excepcionais. Assim, o efeito imediato da substituição do procedimento estatal é a utilização de um procedimento paralelo. Entretanto, a utilização de outro critério de julgamento não decorre imediatamente da substituição de procedimentos. ${ }^{613}$

A arbitragem afigura-se como uma forma alternativa de solução de controvérsias, fora do exercício da jurisdição estatal, porém com efeitos equivalentes. Trata-se de um "equivalente

611 Loquin, Eric. L'Amiable composition... cit., p. 17-18.

612 Sobre o conjunto da questão, com especial foco no direito francês, veja-se LoQuin, Eric. L'Amiable composition... cit., p. 32 e ss. Essencialmente, no caso francês, a presunção de arbitragem de direito vem de uma desconfiança do instituto da arbitragem, à época da codificação processual, bem como um desejo de alinhar a figura do árbitro com a do juiz.

613 Há autores que afirmam que a presunção de arbitragem de direito não advém de uma assimilação entre árbitro e juiz estatal, mas sim do fato de que o julgamento por eqüidade implica renúncia aos benefícios da lei, do direito positivo. Sendo a renúncia expcional, deve ser expressa de modo claro. Veja-se a respeito a nota de Eric Loquin sobre jurisprudência francesa publicada na Revue de l'Arbitrage, n. 3, p. 548, 1980. 
jurisdicional" ou de uma "jurisdição privada", ${ }^{614}$ em que, por escolha das partes (e permissão do Estado), o conflito é dirimido de modo final por pessoas escolhidas para tal fim, sem intervenção estatal direta.

Trata-se aqui, todavia, de questão de política legislativa. Existem exemplos, como será visto adiante, em que a mera escolha da arbitragem como forma de solução de controvérsias implica julgamento por eqüidade. Havendo duas orientações distintas em direito comparado, não se pode afirmar que qualquer uma delas seja "ontologicamente" correta ou necessária. Deve-se, portanto, indagar qual dos sistemas é mais conveniente. De qualquer modo, de um ponto de vista teórico, não existe correlação necessária entre arbitragem e aplicação do direito ou da eqüidade.

No entanto, parece mais natural que a presunção de aplicação do direito existente no processo civil seja seguida na arbitragem. Em primeiro lugar, porque essa interpretação acentua o caráter da arbitragem como veículo alternativo de solução de controvérsia, de uma "jurisdição privada" em que os mesmos efeitos de uma decisão estatal são alcançados. Eventual associação da arbitragem com a aplicação da eqüidade dilui o caráter de meio alternativo de solução de controvérsia para incluir um elemento adicional: passa a existir um critério diferente de decisão e não apenas uma "jurisdição alternativa". A escolha das partes deixa de abranger apenas a forma de solução da controvérsia para incluir um critério de decisão diferenciado. Essa situação milita contrariamente ao uso da arbitragem.

Em segundo lugar, porque o desejo de previsibilidade geralmente reconhecido a todas as partes deve ser respeitado. O direito positivo garante um grau maior de previsibilidade de resultados. A expectativa de um resultado influencia o comportamento das partes no relacionamento comercial. A assimilação de arbitragem e eqüidade conferiria um grau de insegurança maior do que o recurso ao Judiciário e poderia frustrar a legítima expectativa das partes. Estas estão inseridas em uma cultura jurídica cuja regra é a aplicação do direito estatal. É duvidoso que a mera opção por arbitragem sem outras qualificadoras seja percebida de modo automático como um abandono da aplicação do direito positivo. O afastamento do que pode ser considerado como o curso da vida quotidiana deve exigir uma manifestação de vontade inequívoca e não ser apenas uma conseqüência implícita de outro ato. Especialmente se o alcance da opção resultar claro apenas para os iniciados em certo conhecimento técnico específico.

614 Neste caso, deve-se entender o termo jurisdição em sentido mais amplo que o normalmente adotado no processo civil. Não apenas como uma função do Estado, mas como o modo de dirimir um conflito. 
Além de gozar de maior aceitação no direito comparado, o sistema de presunção de arbitragem de direito tem sido adotado por países que anteriormente utilizavam o sistema da presunção de arbitragem por eqüidade. As recentes experiências da Espanha e do Paraguai demonstram a "migração" de sistemas quando da renovação da legislação de arbitragem. Também o advento do Acordo sobre Arbitragem Internacional do Mercosul que, em seu âmbito de aplicação, modificou a orientação geral das legislações argentina e uruguaia.

Embora denomine-se a orientação prevalente de "sistema", ele é bastante lacônico: salvo exceções, as legislações nacionais limitam-se a afirmar que as partes podem convencionar que os árbitros decidam a questão por eqüidade, em geral de modo expresso. Todavia, além de tais breves menções, as lei nacionais normalmente silenciam sobre quase todos os demais aspectos, seja quanto a requisitos formais, seja quanto às conseqüências e aos limites de tal espécie de arbitragem.

Portanto, trata-se de um sistema em que a maioria dos aspectos do instituto depende de elaboração posterior, fora do nível legislativo. Jurisprudência e doutrina ganham, desse modo, importância redobrada na definição de seu regime.

A despeito de tal ausência de regulamentação, podem ser encontradas algumas tendências relativamente difundidas nas legislações nacionais.

Quanto à técnica legislativa, a maioria segue a Lei Modelo, dispondo que o tribunal decidirá por eqüidade apenas se as partes assim o autorizarem expressamente. Algumas leis nacionais optaram pela Lei Modelo do Conselho da Europa, dispondo que, "salvo disposição em contrário, o tribunal decidirá conforme o direito". Esse é o caso de Bélgica, Grécia (arbitragens internas) e, de modo um pouco distinto, Inglaterra. No caso brasileiro, optou-se por uma divisão clara de gêneros da arbitragem, dispondo que podem ser de direito ou eqüidade. Nos ordenamentos em que se exige o compromisso, costuma-se impor que dele conste eventual autorização para decisão por eqüidade.

Em geral, não há imposição de fórmulas de redação, embora exija-se o modo expresso, como já mencionado. No caso italiano, a lei expressamente afirma que as partes podem utilizar “qualquer expressão" para indicar sua vontade de que a decisão seja por eqüidade.

Em alguns países de direito consuetudinário, mesmo com a adoção da Lei Modelo, preferiu-se utilizar expressões perifrásticas ou expletivas para esclarecer a natureza de uma decisão por eqüidade, tais como "decisões conforme princípios de eqüidade e justiça”. Algumas 
legislações acrescentam a fórmula explicativa "sem estar limitado pela aplicação da lei” à menção da arbitragem por eqüidade. Esse é o caso da atual legislação egípcia e jordaniana. Também era o caso brasileiro antes da nova Lei de Arbitragem. Algumas leis nacionais mencionam ainda a necessidade de respeito à ordem pública.

Nos países em que as sentenças arbitrais estão sujeitas a recurso, a arbitragem por eqüidade em geral possui regras específicas. Uma regra encontrada com alguma freqüência é a de que os recursos tirados contra sentenças por eqüidade sejam julgados por eqüidade nos tribunais. No pólo oposto, existem legislações que vedam recursos contra sentenças dadas por eqüidade. No caso francês, reproduzido em algumas outras legislações, há inversão da regra de recurso: enquanto na arbitragem de direito haverá recurso salvo disposição em contrário, na arbitragem por eqüidade somente existirá recurso caso as partes convencionem expressamente. Se houver recurso contra a sentença dada em eqüidade, ele será julgado pelo mesmo critério.

Uma regra peculiar encontrada em alguns países árabes é de que a escolha da decisão por eqüidade somente seja válida se a seleção dos nomes dos árbitros for efetuada no mesmo ato. Essa regra, adotada por Catar, Emirados Árabes Unidos e Líbia, indica a exigência de cuidados maiores para a utilização da eqüidade. Como a arbitragem por eqüidade confere poderes amplos aos árbitros, somente pode ser devidamente sopesada já com a escolha dos nomes que exercerão tal poder. Essa regra possui um ponto de orientação comum com a antiga regra belga de que as partes somente poderiam contratar arbitragem por eqüidade após a existência do conflito concreto. Em ambos os casos, busca-se circunscrever outorga de poderes mais amplos a momentos em que haja elementos concretos (seja a controvérsia específica, sejam os árbitros).

Embora privilegie a prudência, essa orientação parece pecar pelo excesso. Em primeiro lugar, porque diminui a autonomia da vontade das partes, o que vem de encontro com a tendência geral da arbitragem. Ao escolher a arbitragem por eqüidade, que nestes casos depende de um ato positivo e expresso, as partes sabem ou devem saber dos riscos e vantagens inerentes a essa decisão. Cercear sua liberdade em nome de uma proteção adicional não parece boa política legislativa, especialmente porque as partes estão protegidas no que é fundamental pela ordem pública. Em segundo lugar, porque dificulta sobremaneira o uso da arbitragem por eqüidade na prática. No caso da antiga regra belga, porque, uma vez que as partes já conheçam o litígio, também terão avaliado as suas chances de êxito nos dois cenários (direito e eqüidade). É natural que a parte que se veja em uma posição mais forte em direito não consinta em arbitragem por eqüidade. No caso da regra árabe, a indicação de árbitros pelo nome pode causar uma série de inconvenientes de ordem prática que trazem riscos à escolha (como a possibilidade de impedimentos supervenientes, causando problemas de substituição, etc.). 
No caso de países que possuem o procedimento arbitral regulado em lei, normalmente com aplicação subsidiária dos respectivos códigos de processo civil, existem regras liberando os árbitros que decidem por eqüidade de seguir o procedimento padrão, ou ao menos liberandoos de certos aspectos deste.

\subsubsection{O sistema hispano-americano}

Uma forma mais radical do reconhecimento da arbitragem por eqüidade existe em um número limitado de países que não apenas a permitem, como ainda a presumem como a forma de arbitragem padrão. Por essa orientação, no caso de as partes silenciarem sobre a forma da arbitragem, ela será por eqüidade. Trata-se, assim, da inversão da regra encontrada na maioria dos países pesquisados: para que tenham uma arbitragem de direito, as partes devem acordar de modo expresso. Portanto, tal sistema cria uma espécie de sinonímia entre arbitragem e eqüidade, que somente é afastada por vontade das partes.

Trata-se de um sistema utilizado por poucos países, atualmente localizados apenas na América Latina. Atualmente, Argentina, Bolívia, Equador, El Salvador, Panamá, Peru e Uruguai empregam esse sistema. Todavia, até um passado recente, uma série de outros países LatinoAmericanos e a Espanha adotavam a mesma orientação.

Normalmente, esse sistema divide de forma marcada a arbitragem de direito e a arbitragem por eqüidade, embora ambos continuem a ser formas de arbitragem. ${ }^{615}$ Não raro, são utiliza-

615 “(A) 'Legal' and 'Equity' Arbitration.

Latin American countries, following the Continental Law tradition, distinguish between 'legal' arbitrators (or de iure arbitrators) and 'equity arbitrators' or 'amiable compositeurs' (ex aequo et bono arbitrators). Legal arbitrators' decisions are strictly grounded on the existing law. They are supposed to apply the private international law of the place where they are sitting if a choice-of-law problem arises. In principle, they also observe the procedural rules contemplated for normal court proceedings unless specific procedural provisions governing arbitration are applicable or the parties decide otherwise. Although the awards of legal arbitrators can be reviewed for the same reasons that a court decision may be reviewed, the parties are allowed to waive recourse to appeal at the moment of the submission ('compromiso') and it is debatable if this is also possible at the earlier stage of signing the arbitral agreement.

However, recourse to setting aside the award on the ground, for instance, that the arbitrator decided on points not submitted to arbitration, or because the award was made beyond the deadline agreed by the parties, or because the arbitrator made an essential procedural mistake, cannot be waived. Nonetheless, there are some differences between Latin American legislations in this regard.

Equity arbitrators are not bound to apply the strict rule of law and must decide the dispute in an equitable way on the basis of their notions of justice. They may disregard imperative norms, do not owe allegiance to abstract rules and are supposed to find a solution adapted to the specific case. However, they cannot ignore or fail to apply public policy principles or public policy norms rather protecting the interests of the community than the interests of the parties. Ex aequo et bono awards are not subject to any means of recourse. Nevertheless, ex aequo et bono awards may be set aside if the arbitrators have decided on points not submitted to arbitration or if the decision is made after expiration of the agreed deadline. Some countries, however, do not always maintain 
das expressões distintas para se referir aos árbitros de direito (em geral, chamados de árbitros) e os árbitros de eqüidade (chamados ora de arbitradores, ora de amigables componedores).

Esse sistema era encontrado em antigas legislações nacionais, não raro nos respectivos códigos de processo civil. ${ }^{616}$ Entretanto, conforme foram sendo reformadas as legislações, o sistema vem sendo abandonado progressivamente. Os exemplos da Espanha, do Paraguai e da Nicarágua demonstram o movimento de abandono do sistema. Todavia, esse sistema parece ter criado raízes na tradição jurídica de alguns países, que o mantiveram mesmo após recentes reformas, como é o caso da Bolívia, do Equador e do Panamá. Argentina e Uruguai abrandaram a regra de presunção de arbitragem por eqüidade para as arbitragens cobertas pelo Acordo sobre Arbitragem Comercial do Mercosul.

As principais razões para o abandono desse sistema parecem ser aquelas descritas na exposição de motivos da nova lei espanhola de arbitragem: (i) maior adesão ao sistema da presunção de arbitragem de direito, em direito comparado; e (ii) ser discutível que a mera referência à arbitragem signifique a vontade das partes em submeter a controvérsia a um critério diferente do que seria utilizado por um tribunal estatal. Como já exposto acima, a excepcionalidade da decisão por eqüidade recomenda que haja uma manifestação clara de vontade das partes ao adotá-la. Por outro lado, nos países que têm reafirmado a presunção de eqüidade após a reforma da legislação de arbitragem, o critério não parece criar maiores incômodos. Supõe-se que esteja já definitivamente enraizado nas respectivas culturas jurídicas de modo a não causar dúvidas relevantes nas partes ao escolherem a arbitragem.

No que diz respeito à técnica legislativa, ela não é unívoca. Por vezes, é utilizada a tradicional dicotomia entre arbitragens de direito e eqüidade (Argentina, El Salvador e Equador), por outras disposições atinentes às regras aplicáveis ao mérito (Bolívia) e ainda disposições relativas ao compromisso (Uruguai).

a clear borderline between the type of means for setting aside which can be raised in respect of 'legal' and of ex aequo et bono arbitration awards or simply establish that identical means to that end are available for both types of arbitrations.

In some Latin American countries, unless the parties have otherwise provided, it is presumed that arbitrators shall decide as 'amiable compositeurs'Chile accepts a third category of 'mixed' arbitrators, who are placed half-way between 'legal' and ex aequo et bono arbitration. Mixed arbitrators under Chilean law are not bound by the procedural rules applicable to court proceedings, but the substance of their award must abide by the strict rules of law. Mixed arbitrators are empowered - like ex aequo et bono arbitrators - to shape at their will the arbitral procedure; but they have to decide the dispute as legal arbitrators would do." Grigera NAÓN, Horácio. Arbitration in Latin America: Overcoming Traditional Hostility. Arbitration International, v. 5, n. 2, p. 137 e ss., 1989.

616 A adesão a tal sistema foi importante a ponto de ser a orientação de uma tentativa de lei uniforme para os países americanos, elaborada pela União Pan-Americana e a IACAC, ainda na década de 1950. A respeito dessa tentativa, veja-se: DAvid, René. Arbitration ... cit., p. 163. 
Por outro lado, ao disporem sobre a forma de decisão por eqüidade, existe recorrência às expressões consagradas nos direitos hispano-americanos (mesmo de presunção de arbitragem de direito), determinando que os árbitros devem julgar conforme seu "leal saber e entender", atendendo aos princípios da "crítica sã", "segundo ditar a consciência", atendendo "à verdade e à boa-fé".

Nos países em que o procedimento arbitral é previsto na legislação, as arbitragens de eqüidade possuem regras próprias mais simplificadas do que aquelas previstas para arbitragem de direito. Essa observação é válida igualmente para os países que presumem a arbitragem de direito como padrão. Trata-se de uma ocorrência bastante comum em direitos latino-americanos. Todavia, a tendência atual das legislações de arbitragem é deixar que o procedimento seja definido pelas partes ou pelos árbitros.

Por estarem inseridos na prática latino-americana, alguns países do sistema hispanoamericano exigem formação jurídica aos árbitros que decidem em direito. Todavia, não se trata de uma característica ligada à presunção de eqüidade. Mesmo porque alguns países do sistema hispano-americano não fazem tal exigência, como é o caso da Argentina. Por outro lado, diversos países que não presumem a arbitragem por eqüidade como regra padrão igualmente exigem formação jurídica para árbitros de direito. Assim, embora não caracterize o "sistema hispanoamericano", essa exigência é uma particularidade latino-americana.

\subsubsection{O sistema de vedação}

Embora atualmente conte com a adesão de poucos países, existe uma tradição consistente de vedação da arbitragem por eqüidade, que foi responsável por grandes debates no século XX.

A principal oposição à arbitragem por eqüidade historicamente concentrou-se na Inglaterra e em outros países de direito consuetudinário e foi amplamente estudada em direito comparado. ${ }^{617}$ A diferença de concepção entre a common law e do direito continental acerca da arbitragem por eqüidade foi apontada como um dos grandes obstáculos para a harmonização dos direitos da arbitragem no mundo. ${ }^{618}$

617 Entre vários outros, veja-se: SANDERs, Pieter. International Encyclopedia of Comparative Law... cit., p. 138. Loquin, Eric. L'Amiable composition... cit., p. 96 e ss. DAvID, René. Arbitration ... cit., p. 107 e 108. Note-se que os EUA são uma notável exceção na tradição de common law. Embora pouco conhecida, a arbitragem por eqüidade não foi proibida naquele país.

${ }^{618}$ SANDERs, Pieter. Quo vadis Arbitration? The Hague: Kluwer Law International, 1999. p. 35, entre outros. 
O principal obstáculo ao reconhecimento de uma arbitragem sem a aplicação do direito na Inglaterra decorria da natureza de sua organização judiciária. Sendo um país com um número tradicionalmente baixo de juízes e com uma justiça de primeira instância bastante fragmentada, a Inglaterra tradicionalmente incluiu a arbitragem nas formas de administração da justiça. Integrando o sistema de administração da justiça, a arbitragem estava sujeita a recursos a tribunais superiores. Essa configuração "estrutural" levou a que a Inglaterra virtualmente desconhecesse julgamentos que não fossem baseados em direito. ${ }^{619}$ Essa configuração incluía uma série de recursos, inclusive o conhecido statement of special case, que permitia a intervenção direta dos tribunais estatais para definir alguma questão de direito que se colocasse na arbitragem. Essa interpenetração entre arbitragem e procedimentos estatais fez com que o direito inglês vetasse a possibilidade de decisões que não aplicassem o direito estritamente, mesmo porque as cortes não poderiam aplicar outro critério de julgamento que não o direito inglês.

Todavia, desde pelo menos a década de 1980, parece ter havido maior tolerância à arbitragem por eqüidade no direito inglês, principalmente no que se refere à arbitragem internacional. ${ }^{620} \mathrm{Na}$ seqüência dessa aparente flexibilização, a edição da nova lei de arbitragem inglesa em 1996 deixou consignada a possibilidade de aplicação de outros critérios que não o direito positivo para julgamento. Entre tais outros critérios, sem dúvida está a arbitragem por eqüidade. ${ }^{621}$ Portanto, no que diz respeito à arbitragem por eqüidade, o direito inglês não mais apresenta restrições a seu uso.

O segundo sistema em geral refratário à arbitragem por eqüidade era encontrado nos denominados países socialistas ou de economia planificada. ${ }^{622}$ No tocante às arbitragens internacionais, a regra dos países do Bloco Socialista era a de que os árbitros deveriam decidir as demandas de acordo com o direito. Como já mencionado, o modelo daqueles países para arbitragens internacionais previa em geral a utilização de câmaras de arbitragens criadas com

619 David, René. Conception... cit., t. I, p. 765 e ss.; Arbitration... cit., p. 107-108. David, René. Le Concept d'Arbitrage Privé et Les Conventions Internationales. Études Juridiques Offets à Leon Julliot de la Morandière. Paris: Dalloz, 1964. p. 154-155.

620 Boyd, Stewart. Arbitrator not to be bound by the Law. Clauses in Arbitration International, v. 6, n. 2, p. 122 , 1990, com diversas referências jurisprudenciais.

621 Mustill, Michael J.; Boyd, Stewart. Commercial Arbitration... cit., p. 326.

ReDFern, Alan; Hunter, Martin. Law and practice... cit., p. 128

Shackleton, Stewart R. The Applicable Law in International Arbitration Under the New English Arbitration Act 1996. Arbitration International, v. 13, n. 4, p. 375 e ss., 1997.

622 "5.3. Neither in the FTAC nor in the MAC may the arbitrators act as 'amiable compositeurs', whose task is usually deemed to consist of finding a compromise solution of the dispute acceptable to both parties or of resolving it ex aequo et bono without being bound by rules of the law, contract provisions, etc.". Lebedev, Seguei N. Relatório URSS in International Handbook on Commercial Arbitration, Suplemento 17. Também LoQUIN, Eric. L'Amiable composition... cit., p. 128 e ss.

DAVID, René. Arbitration... cit., p. 124, com algumas nuanças. 
o propósito específico de resolver questões atinentes ao comércio internacional. Essas instituições eram órgãos estatais e seus regulamentos tinham enorme importância para a definição do regime de arbitragens. Adotavam o princípio da "legalidade socialista", com evidente supremacia do direito positivo. ${ }^{623}$ Várias razões podem ser apontadas para esse posicionamento. Entre elas, a concepção socialista de que o direito seria um instrumento para a criação da sociedade comunista e também para o cumprimento das metas econômicas fixadas pelo governo central. Outras, de cunho mais prático, falam do interesse dos países socialistas em mostrar imparcialidade de suas instituições arbitrais, objetivo melhor servido pela aplicação do direito positivo, seja local ou estrangeiro. ${ }^{624}$ Deve-se levar em consideração que alguns países socialistas aparentemente permitiam a arbitragem por eqüidade, como era o caso da Romênia.

Com o fim do socialismo real, na década de 1990, os países daquele bloco reformaram sua legislação de arbitragem, em grande medida conforme a Lei Modelo da CNUDCI. Alguns deles com integral adoção. Outros, com uma adaptação no texto do art. 28, que exclui a passagem pela qual a arbitragem por eqüidade é permitida desde que as partes a autorizem expressamente. Esse foi o caso da Bulgária, da Mongólia e da Rússia. ${ }^{625}$ Esses países vêm sendo considerados como resistentes ao conceito de arbitragem por eqüidade, devendo a ausência de menção em suas leis ser interpretada como proibição a esse tipo de arbitragem. ${ }^{626} \mathrm{~A}$ esses países de tradição socialista pode-se acrescentar o Vietnã, também egresso da tradição socialista, cuja lei local igualmente suprimiu o art. 28(3), quando da adoção da Lei Modelo.

Os demais países que não permitem a arbitragem por eqüidade são ex-colônias britânicas, que adotaram, em alguma medida, a disciplina inglesa do instituto da arbitragem. Os direitos internos de Malásia e Paquistão parecem ter uma orientação francamente contrária à arbitragem por eqüidade em quaisquer circunstâncias. Por outro lado, as Bermudas e Cingapura utilizaram a Lei Modelo em sua integralidade para os casos de arbitragens internacionais, criando uma dualidade de regimes arbitrais. No caso desses países, o regime internacional permite a arbitragem por eqüidade, ao passo que o local a proíbe.

No que concerne à técnica legislativa, não existe nenhuma disposição vedando o uso da arbitragem por eqüidade. Em sua totalidade, os países que a vedam deixam de mencioná-la em sua legislação, cabendo à doutrina e à jurisprudência interpretar o valor de tal ausência.

${ }^{623}$ LoQuin, Eric. L'Amiable composition... cit., p. 128

624 Idem, ibidem, p. 133.

625 A Bielo-Rússia igualmente suprimiu o art. 28(3) de sua lei local. Todavia, há indícios de que a arbitragem por eqüidade seja permitida, em razão de sua menção em regulamento de arbitragem.

626 Entre outros: SANDERs, Pieter. International Encyclopedia of Comparative Law... cit., p. 138. 
Portanto, das 99 legislações pesquisadas, apenas oito apresentam alguma restrição à arbitragem por eqüidade, e apenas seis possuem uma vedação genérica ao seu uso. Assim, cerca de $6 \%$ das legislações nacionais pesquisadas proíbem a arbitragem por eqüidade. Esse dado demonstra a ampla aceitação da instituição em todos os continentes do globo.

\subsection{Dos Tratados Internacionais}

Desde o início do século XX, tratados internacionais têm disciplinado a arbitragem comercial internacional. ${ }^{627}$ Nesse período, os operadores do comércio internacional têm defendido a adoção de instrumentos legais que facilitem a utilização da arbitragem como forma de solução de controvérsias.

Existem diversos tratados bilaterais que cuidam da arbitragem. Todavia, como já informado, eles não serão estudados nesta obra por três razões principais: (i) o declínio da importância prática no âmbito da arbitragem comercial; (ii) pouca importância específica para o Brasil; e (iii) ampliação demasiada do escopo de pesquisa. A esses três argumentos já considerados acima pode-se acrescentar o escasso âmbito de atuação dos tratados bilaterais (necessariamente apenas dois países) em relação aos tratados multilaterais, que efetivamente definem a disciplina da arbitragem internacional de modo mais amplo. Além disso, tratados bilaterais normalmente cuidam da arbitragem como uma matéria, entre outras, ${ }^{628}$ muitas vezes parte de menos importância, em vista do objeto "principal" do tratado. Ao contrário, diversos tratados multilaterais regulam a arbitragem de modo mais amplo ou dedicam-se exclusivamente a ela. Ou ao menos o fazem de modo mais detalhado. Assim, preferiu-se o exame dos tratados de base mais ampla.

Diversas convenções, de âmbito universal ou regional, têm sido adotadas com o objetivo de proteger ao menos dois aspectos da arbitragem internacional: a validade das cláusulas arbitrais e a execução das sentenças. Algumas vão além e regulam outros aspectos, entre eles, a decisão por eqüidade.

Analisado o aspecto da arbitragem por eqüidade, os primeiros tratados multilaterais não a prevêem. Tanto nos dois Protocolos de Genebra como na Convenção de Nova Iorque os Estados preferiram não regulamentar a matéria. A exceção foi o Código Bustamante, que apenas menciona sentenças arbitrais emanadas de "compositores amigáveis" como passíveis

\footnotetext{
${ }^{627}$ Alguns autores situam o início desses esforços já no final do século XIX, com a Convenção de Haia: Lew, Julian D. M.; Mistelis, Loukas A.; KRöLL, Stefan M. Comparative international commercial arbitration, cit., p. 17.

${ }^{628}$ Fouchard, Gaillard e Goldman. Traité de l'Arbitrage Commercial International, cit., p. 121 e 138.
} 
de execução. Posteriormente, já na década de 1960, a Convenção de Genebra e a Convenção de Washington, por preocuparem-se com a organização da arbitragem de modo mais detalhado que as precedentes (restritas ao reconhecimento das cláusulas e sentenças arbitrais), mencionam a possibilidade da arbitragem por eqüidade, sujeita à escolha das partes (e, no caso da Convenção de Genebra, à lei aplicável ao procedimento). Posteriormente, os tratados de âmbito regional passam a se ocupar da arbitragem por eqüidade, normalmente para possibilitá-la caso as partes assim convencionem. Todavia, no caso de alguns tratados de cooperação judicial, não há menção a sentenças arbitrais por eqüidade. Igualmente não há nenhuma referência a ela na Convenção de Moscou. Alguns tratados, ainda que não mencionem a arbitragem de modo direto, o fazem indiretamente. Como no caso da Convenção do Panamá, dos Acordos de Argel e do Tratado para Harmonização do Direito Empresarial na África. Nesses tratados, há remissão a certas regras que prevêem a arbitragem por eqüidade. Respectivamente, trata-se do Regulamento de Arbitragem da Comissão Interamericana de Arbitragem Comercial, o regulamento da CNUDCI e o regulamento da Corte da OHADA.

Em todos os casos em que os tratados internacionais a prevêem, a regra é a de que a arbitragem por eqüidade é uma faculdade, cuja utilização depende de convenção das partes nesse sentido. Portanto, os tratados criam uma regra material que permite a arbitragem por eqüidade, desde que haja autorização das partes. Nesse sentido, refletem a a orientação majoritária dos direitos nacionais sobre a matéria.

No capítulo $6 .^{\circ}$ desta obra, serão abordados cada um dos tratados individualmente.

\subsection{Regras de Arbitragem}

O exame dos regulamentos de arbitragem existentes no mundo revela, tanto quanto o exame das legislações nacionais, o amplo reconhecimento da arbitragem por eqüidade. Dos cerca de sessenta regulamentos pesquisados para a presente pesquisa, apenas cinco não a prevêem. Desses, apenas um em vigor atualmente apresenta uma redação claramente contrária ao uso dessa forma de arbitragem.

Do mesmo modo que nas legislações nacionais, encontram-se três sistemas principais de utilização da arbitragem por eqüidade. A imensa maioria das regras prevê o sistema optativo, pelo qual as partes podem escolher esse tipo de arbitragem. Em segundo lugar, o sistema da presunção de arbitragem por eqüidade. Neste caso, a simples referência à arbitragem implica que a decisão será feita por eqüidade. Esse sistema é encontrado em um número menor de regulamentos, em geral de instituições oriundas de países cujo direito também prevê a decisão por 
eqüidade como regra geral. Em terceiro lugar, encontra-se o sistema da vedação das decisões por eqüidade, operacionalizado pela determinação de que seja aplicado um direito nacional na decisão. Esse é o sistema de menor adesão.

A imensa maioria dos regulamentos de arbitragem conhece a existência da arbitragem por eqüidade. Desses, todos permitem a escolha das partes. Qualquer que seja a regra padrão (presunção de direito ou de eqüidade), todos eles permitem que as partes escolham o critério de decisão. As únicas aparentes exceções são de certos regulamentos de arbitragem expedita, que parecem determinar decisão apenas pela eqüidade. No entanto, as mesmas instituições permitem a escolha nos regulamentos padrão.

\subsubsection{Contornos da Arbitragem por Eqüidade nos Regulamentos}

O exame dos regulamentos de arbitragem, ademais, fornece alguns dados para a melhor definição de alguns contornos da arbitragem por eqüidade.

a) Denominação

No que diz respeito à denominação, as regras em geral (ou ao menos nas respectivas traduções ao inglês) mencionam a arbitragem por eqüidade pelas denominações mais conhecidas, como amiable composition ou ex aequo et bono, bem como pelos termos equivalentes à palavra eqüidade nos respectivos idiomas (Billigkeit, equidad, equità, etc.). Alguns países de língua espanhola utilizam ainda os termos "em consciência" ou a distinção entre árbitros (de direito) e arbitradores (de eqüidade), que são peculiares a seus direitos internos.

Formas perifrásticas que por vezes ocorrem em legislações nacionais são pouco encontradas nos regulamentos pesquisados. Entretanto, o regulamento da London Court of International Arbitration (LCIA) apresenta uma redação mais expletiva, mencionando "princípios derivados de 'ex aequo et bono' 'amiable composition' ou 'honourable engagement'”. ${ }^{29}$

629 Article 22. Additional powers of the Arbitral Tribunal.

22.1 Unless the parties at any time agree otherwise in writing, the Arbitral Tribunal shall have the power, on the application of any party or of its own motion, but in either case only after giving the parties a reasonable opportunity to state their views:

$[\ldots]$

22.3 The Arbitral Tribunal shall decide the parties' dispute in accordance with the law(s) or rules of law chosen by the parties as applicable to the merits of their dispute. If and to the extent that the Arbitral Tribunal determines that the parties have made no such choice, the Arbitral Tribunal shall apply the law(s) or rules of law which it considers appropriate. 
De maneira geral, o texto dos regulamentos indica de modo direto a diferença de significados entre os termos amiable composition e ex aequo et bono. Entretanto, no caso da Corte de Arbitragem da Câmara de Comércio e Indústria da Hungria, existe menção dos termos como figuras aparentemente distintas, na qual ex aequo et bono é uma decisão por eqüidade e amiable compositeur tem a função de intermediário "amigável”. ${ }^{630}$

\section{b) Localização}

Em geral, as regras pesquisadas inserem a permissão para decisão por eqüidade nas disposições relativas ao direito aplicável ao mérito da disputa ou ao tratar de modo geral da sentença.

No entanto, algumas instituições incluem as disposições na descrição dos poderes do tribunal arbitral. Esse é o caso da London Court of International Arbitration, ao tratar da matéria no âmbito dos "poderes adicionais" do tribunal arbitral. Também é o caso da Câmara Arbitral de Paris, que fala em outorga da "missão" de decidir por eqüidade na esfera dos poderes do tribunal, havendo regra específica para redução a termo no caso de autorização das partes no curso

22.4 The Arbitral Tribunal shall only apply to the merits of the dispute principles deriving from "ex aequo et bono" "amiable composition" or "honourable engagement" where the parties have so agreed expressly in writing.

Disponível em: <http://www.lcia-arbitration.com>. Acesso em: 20 ago. 2008. Também publicado no Yearbook Commercial Arbitration, v. 23, p. 369 e ss., 1998.

${ }_{630}$ Regras de 1993:

Article 13. The applicable Law.

(1) The arbitral tribunal and the sole arbitrator (hereinafter the "arbitral tribunal") shall apply the law stipulated by the parties. The stipulation of a given legal system is to be understood to be the stipulation that refers directly to the substantive law and not to the conflict of law norms of the given state.

(2) Failing stipulation by the parties, the arbitral tribunal shall apply the law which it considers to be applicable according to the rules of Hungarian private international law.

(3) The arbitral tribunal renders a decision on the basis of equity (ex aequo et bono) or as a friendly intermediator (amiable compositeur) only if it has been expressly authorized to do so by the parties. [...]

Fonte: Yearbook Commercial Arbitration, v. 20, p. 295 e ss., 1995.

Regras de 2008:

Art. 14. The Applicable Law.

(1) The arbitral tribunal and the sole arbitrator (hereinafter the "“"arbitral tribunal”) shall apply the law stipulated by the parties. The stipulation of a given legal system is to be understood as a stipulation that refers directly to the substantive law and not to the norms of the conflict of laws of the given state.

(2) Failing stipulation by the parties, the arbitral tribunal shall apply the law which it considers to be applicable according to international treaty or failing this, according to the rules of the Hungarian private international law.

(3) The arbitral tribunal may render a decision on the basis of equity (ex aequo et bono) or as a friendly intermediator (amiable compositeur) only, if it has been expressly authorized to do so by the parties.

$[\ldots]$

Disponível em: <http://www.mkik.hu/index.php?id=1407>. Acesso em: 21 ago. 2008. 
de processo. ${ }^{631}$ No tocante aos regulamentos anteriores da Câmara de Comércio Internacional, a arbitragem por eqüidade era mencionada nas disposições relativas à chamada ata de missão ou "terms of reference". ${ }^{632}$

c) Arbitragem por eqüidade e procedimento

De modo geral, os regulamentos nada dispõem sobre os poderes dos árbitros de eqüidade relativamente ao procedimento.

Uma exceção é o regulamento do Centro Belga de Arbitragem e Mediação (Cepani), que prevê que os árbitros decidindo por eqüidade devem, de qualquer modo, respeitar o regulamento ${ }^{633}$ Com essa disposição, o Cepani faz uma clara opção sobre por uma matéria ainda não definitivamente esclarecida em doutrina: a possibilidade de os árbitros em eqüidade derrogarem regras de procedimento.

Em sentido contrário, o regulamento da Corte Civil e Mercantil de Arbitragem, da Espanha, dispõe que o árbitro de eqüidade pode encurtar prazos, respeitando sugestões das partes que entender cabíveis. ${ }^{634}$

A existência de duas orientações distintas, incapazes de demonstrar qualquer tendência dentro do universo geral, parece indicar que a questão talvez tenha um caráter mais empírico do que de princípio geral.

631 Pouvoirs

Article 5:

La désignation de la Chambre Arbitrale de Paris pour organiser un arbitrage implique pour les parties renonciation au droit d'appel devant la juridiction d'appel de droit commun, les sentences étant rendues en dernier ressort et sans autre recours que celui en annulation. Elle implique également que les parties renoncent à ce que la juridiction d'appel de droit commun, saisie d'un recours en annulation, statue sur le fond si la sentence arbitrale en cause est annulée. [...]

Si au cours d'une instance déjà engagée devant un Tribunal Arbitral, les parties conviennent de transformer la mission d'arbitrage en mission d'amiable composition, un procès verbal établi en séance, signé par les parties et les arbitres, le constate, la sentence rendue à la majorité simple étant alors définitive.

Disponível em: <http://www.arbitrage.org/fr/procedures/reglement_fr_2005.pdf>. Acesso em: 21 ago. 2008.

632 Regras de 1975: Yearbook Commercial Arbitration, v. 1, p. 157 e ss., 1976. Regras de 1988: Yearbook Commercial Arbitration, v. 13, p. 185 e ss., 1988.

633 4. Le tribunal arbitral n'exerce les pouvoirs d'amiable compositeur que si les parties les lui confèrent. Le tribunal arbitral se conforme néanmoins, dans ce cas, aux dispositions du présent règlement. Disponível em: $<$ http://www.cepani.be/FR/default.aspx?PId=202>. Acesso em: 21 ago. 2008.

634 Artículo $26 .^{\circ}$

En los arbitrajes de equidad, el Árbitro podrá concentrar el procedimiento regulado en los artículos anteriores y acortar sus plazos, respetando a tal fin las sugerencias de las partes en cuanto las estime compatibles con el correcto desempeño de su cometido arbitral específico.

Disponível em: <http://www.cimaarbitraje.com/documentacion/reglamentos>. Acesso em: 21 ago. 2008. 


\section{d) Tempo para a escolha}

A maioria dos regulamentos não menciona o tempo para a escolha da arbitragem por eqüidade.

Todavia, o regulamento da Instituição Alemã para Arbitragem (DIS) dispõe que as partes podem autorizar o tribunal até o momento de ser proferida a sentença. ${ }^{635}$ A previsão do regulamento da Câmara de Arbitragem de Paris para redução a termo de autorização feita no curso do processo, já mencionada neste item, parece indicar solução idêntica.

A despeito de tais disposições, não se deve entender que a autorização para decisão por eqüidade no curso do procedimento não possa existir, mesmo no caso dos regulamentos que não contenham disposição semelhante. Tendo as partes liberdade de dispor sobre a arbitragem em geral, nada impede que façam tal opção no curso do procedimento.

e) Modo da escolha

Todos os regulamentos pressupõem algum ato de vontade das partes para a escolha do tipo de decisão. Como todos presumem um regime (seja de eqüidade ou de direito), a escolha de outro exige, em regra, convenção das partes sobre a matéria. Assim, todos os regulamentos requerem convenção das partes para a alteração do regime presumido.

Alguns deles ainda prevêem que a autorização seja feita "expressamente". Outros acrescentam que a autorização deve ser feita na forma escrita.

Como já visto nesta obra, não há sinonímia perfeita entre "expressamente" e "por escrito". Expresso contrapõe-se a implícito, ao passo que forma escrita opõe-se a outras formas de expressão da vontade (mormente a verbal). Embora a questão seja de escassa importância prática, pode-se concluir que a exigência de convenção expressa abarca formas de expressão

${ }^{635}$ Section 23. Applicable Law.

23.1. The arbitral tribunal shall decide the dispute in accordance with such rules of law as are chosen by the parties as applicable to the substance of the dispute. Any designation of the law or legal system of a given State shall be construed, unless otherwise expressed, as directly referring to the substantive law of that State and not to its conflict of laws rules.

23.2. Failing any designation by the parties, the arbitral tribunal shall apply the law of the State with which the subject-matter of the proceedings is most closely connected.

23.3. The arbitral tribunal shall decide ex aequo et bono or as amiable compositeur only if the parties have expressly authorized it to do so. The parties may so authorize the arbitral tribunal up to the time of its decision.

$[\ldots]$

Fonte: Yearbook Commercial Arbitration, v. 23, p. 288 e ss., 1998. 
não apenas escritas (como acordo verbal, expressão por sinais, etc.). No que concerne aos regulamentos que não exigem manifestação "expressa" sobre a matéria, há espaço para que acordos tácitos de vontade igualmente conduzam a um ou outro tipo de arbitragem.

Ainda quanto à escolha do tipo de arbitragem, houve um sistema bastante peculiar adotado no regulamento de 1989 do Tribunal Arbitral de Barcelona da Associació Catalana per a l'Arbitratge. Ele dispunha que, à falta de acordo entre as partes, o tribunal decidiria qual o tipo de arbitragem de acordo com as circunstâncias do caso. ${ }^{636}$ Todavia, tal sistema foi modificado em 2004, com a edição de um novo regulamento. ${ }^{637}$ Essa disposição parece ser fruto do regime anterior do direito espanhol, que previa a arbitragem por eqüidade como a regra padrão das arbitragens, salvo disposição em contrário das partes. Nesse contexto, a disposição deve ser vista como uma forma de mitigar a presunção legal de eqüidade.

De qualquer modo, a atuação da própria instituição como definidora do tipo de arbitragem no caso de silêncio das partes foi a única exceção ao regime de presunções normalmente adotado por regulamentos.

\section{f) Direito aplicável}

Alguns regulamentos de arbitragem condicionam a possibilidade de arbitragem por eqüidade à autorização do direito aplicável. Embora tenham caráter mais pedagógico do que funcional, tais disposições tocam na delicada questão de qual lei deve reger a cláusula de arbitragem por eqüidade: a lei aplicável à cláusula de arbitragem, a lei aplicável ao procedimento arbitral ou a lei aplicável ao mérito da disputa.

A maioria das instituições que mencionam a questão refere-se à lei aplicável ao procedimento. Essa é a orientação do regulamento da CNUDCI, ${ }^{638}$ da Comissão Interameri-

636 Artículo 8

A falta de acuerdo entre las partes y de no estar previsto en el convenio arbitral, el TAB decidirá en atención a las circunstancias del caso, sobre si el arbitraje será de derecho o de equidad, el número de árbitros, el lugar de la celebración del arbitraje y de la emisión del laudo, el nombramiento del árbitro o árbitros y, en su caso, del presidente del colegio arbitral.

Disponível em: <www.kluwerlaw.com>. Acesso em: 21 ago. 2008.

Disponível em: <http://www.tab.es/castellano/2_reglamento.htm>. Acesso em: 21 ago. 2008.

638 CNUDCI:

Applicable Law, Amiable Compositeur.

Article 33.

1. The arbitral tribunal shall apply the law designated by the parties as applicable to the substance of the dispute. Failing such designation by the parties, the arbitral tribunal shall apply the law determined by the conflict of laws rules which it considers applicable.

2. The arbitral tribunal shall decide as amiable compositeur or ex aequo et bono only if the parties have expressly authorized the arbitral tribunal to do so and if the law applicable to the arbitral procedure permits such arbitration. 
cana de Arbitragem Comercial, ${ }^{639}$ do Centro Regional do Cairo para Arbitragem Comercial Internacional, ${ }^{640}$ do Centro Australiano para Arbitragem Comercial Internacional (Acica) ${ }^{641} \mathrm{e}$ da Câmara de Comércio Nacional da Cidade do México. ${ }^{642}$ Essa é igualmente a orientação de

Disponível em: <http://www.uncitral.org/pdf/english/texts/arbitration/arb-rules/arb-rules.pdf>. Acesso em: 20 set. 2008.

Essa orientação da CNUDCI é a mesma contida nos regulamentos das Comissões Econômicas das Nações Unidas para a Europa e para a Ásia. Ambas editaram regulamentos de arbitragem ainda na década de 1960, tendo sido precursoras do trabalho da CNUDCI em relação à arbitragem (LoQuin, Eric. L'Amiable composition... cit., p. 135-136).

${ }^{639}$ Comissão Interamericana de Arbitragem Comercial:

Applicable Law, Amiable Compositeur.

Article 30.

1. The arbitral tribunal shall apply the law designated by the parties as applicable to the substance of the dispute. Failing such designation by the parties, the arbitral tribunal shall apply the law determined by the conflict of laws rules that it considers applicable.

2. The arbitral tribunal shall decide as amiable compositeur or ex aequo et bono only if the parties have expressly authorized the arbitral tribunal to do so and if the law applicable to the arbitral procedure permits such arbitration.

3. In all cases, the arbitral tribunal shall decide in accordance with the terms of the contract and shall take into account the usages of the trade applicable to the transaction.

Fonte: International Handbook on Commercial Arbitration, suplemento 36, nov. 2002. Também disponível em: <http://www.adr.org/sp.asp?id=22093>. Acesso em: 21 ago. 2008.

640 Applicable Law, Amiable Compositeur.

Article 33.

1. The arbitral tribunal shall apply the law designated by the parties as applicable to the substance of the dispute. Failing such designation by the parties, the arbitral tribunal shall apply the law determined by the conflict of laws rules, which it considers applicable.

2. The arbitral tribunal shall decide as amiable compositeur or ex aequo et bono only if the parties have expressly authorized the arbitral tribunal to do so and if the law applicable to the arbitral procedure permits such arbitration.

3. In all cases, the arbitral tribunal shall decide in accordance with the terms of the contract and shall take into account the usages of the trade applicable to the transaction.

Disponível em: <http://crcica.org.eg/arbitration_rules.html>. Acesso em: 15 set. 2008.

641 34. Applicable Law, Amiable Compositeur.

34.1 The Arbitral Tribunal shall apply the law designated by the parties as applicable to the substance of the dispute. Failing such designation by the parties, the Arbitral Tribunal shall apply the rules of law which it considers applicable.

34.2 The Arbitral Tribunal shall decide as amiable compositeur or ex aequo et bono only if the parties have, in writing, expressly authorized the Arbitral Tribunal to do so and if the law applicable to the arbitral procedure permits such arbitration.

34.3 In all cases, the Arbitral Tribunal shall decide in accordance with the terms of the contract and shall take into account the usages of the trade applicable to the transaction.

Disponível em: <http://www.acica.org.au/arbitration_rules.html>. Acesso em: 21 ago. 2008.

642 Artículo 40

Ley aplicable, Amigable Componedor.

1. El tribunal arbitral aplicará al fondo de la controversia, las normas de derecho que las partes hayan acordado.

A falta de acuerdo de las partes, el tribunal arbitral aplicará las normas de derecho que considere apropiadas.

2. El tribunal arbitral decidirá como amigable componedor (ex aequo et bono) sólo si las partes lo han autorizado expresamente para ello y si la ley aplicable al procedimiento arbitral permite este tipo de arbitraje.

3. En todos los casos, el tribunal arbitral decidirá con arreglo a las estipulaciones del contrato y tendrá en cuenta los usos mercantiles aplicables al caso.

Disponível em: <http://arbitrajecanaco.com.mx/index.php?option=com_content\&task=blogcategory\&id=8\& Itemid=8>. Acesso em: 22 set. 2008. 
algumas regras específicas da Corte Permanente de Arbitragem. ${ }^{643}$ No regulamento relativo à “additional facility" do CIRDI/ICSID, ${ }^{644}$ menciona-se apenas a lei aplicável à arbitragem, sem referência à lei do procedimento. Todavia, por "aplicável à arbitragem” em geral considera-se a lei aplicável ao procedimento.

\subsubsection{Presunção de arbitragem de direito}

Da mesma forma que as legislações nacionais, a imensa maioria dos regulamentos de arbitragem permitem a utilização da arbitragem por eqüidade, desde que as partes a autorizem. Assim, presumem que as arbitragens serão de direito e autorizam que as partes convencionem a aplicação da eqüidade.

Essa é a regra de todas as principais instituições de arbitragem de vocação internacional, tais como a CNUDCI, a CCI, o ICDR/AAA e a LCIA. ${ }^{645}$

643 A Corte Permanente de Arbitragem possui uma série de regras para diferentes situações. Ao menos duas delas referem-se a disputas entre entes privados e Estados e Organizações Internacionais. Transcreve-se abaixo a regra relativa a entes privados e Estados:

Applicable Law, Amiable Compositeur.

Article 33.

1. The arbitral tribunal shall apply the law designated by the parties as applicable to the substance of the dispute. Failing such designation by the parties, the arbitral tribunal shall apply the law determined by the conflict of laws rules which it considers applicable.

2. The arbitral tribunal shall decide as amiable compositeur or ex aequo et bono only if the parties have expressly authorized the arbitral tribunal to do so and if the law applicable to the arbitral procedure permits such arbitration. [...]

Fonte: Yearbook of Commercial Arbitration, v. 19, p. 338 e ss., 1994. Também disponível em: <http://www. pca-cpa.org/showpage.asp?pag_id=1188>. Acesso em: 21 ago. 2008.

644 O CIRDI/ICSID publicou documento com cerca de 19 modelos de cláusulas para arbitragem, contemplando diversos aspectos da solução de disputas. Entre elas, existe um modelo para decisão por eqüidade: E. Ex Aequo et Bono Adjudication.

\section{Clause XVIII}

"Any Arbitral Tribunal constituted pursuant to this Agreement shall decide any dispute ex aequo et bono." Fonte: Yearbook Commercial Arbitration, v. 9, p. 170 e ss., 1984.

Além do disposto na Convenção de Washington, o Centro elaborou regras de arbitragem para certos casos não abrangidos pelo escopo daquela Convenção (também chamadas de "Additional Facility Rules"). Essencialmente, para casos em que ao menos uma das partes não seja Estado-membro ou nacional de Estado-membro da Convenção. Nestas regras, há previsão de arbitragem por eqüidade:

Article 54.

Applicable Law.

1. The Tribunal shall apply the rules of law designated by the parties as applicable to the substance of the dispute. Failing such designation by the parties, the Tribunal shall apply (a) the law determined by the conflict of laws rules which it considers applicable and (b) such rules of international law as the Tribunal considers applicable.

2. The Tribunal may decide ex aequo et bono if the parties have expressly authorized it to do so and if the law applicable to the arbitration so permits.

Disponível em: <http://icsid.worldbank.org/ICSID/ICSID/AdditionalFacilityRules.jsp>. Acesso em: 20 set. 2008.

645 CCI:

Article 17. Applicable Rules of Law. 
A mesma regra também pode ser encontrada em instituições internacionais especializadas, como é o caso do Tribunal Arbitral do Esporte, ${ }^{646}$ dos procedimentos arbitrais sob a égide da Organização Mundial da Propriedade Intelectual ${ }^{647}$ e das regras do Fundo Europeu de Desenvolvimento. ${ }^{648}$

1.The parties shall be free to agree upon the rules of law to be applied by the Arbitral Tribunal to the merits of the dispute. In the absence of any such agreement, the Arbitral Tribunal shall apply the rules of law which it determines to be appropriate.

2. In all cases the Arbitral Tribunal shall take account of the provisions of the contract and the relevant trade usages.

3. The Arbitral Tribunal shall assume the powers of an amiable compositeur or decide ex aequo et bono only if the parties have agreed to give it such powers.

Disponível em: <http://www.iccwbo.org/court/arbitration/id4093/index.html>. Acesso em: 20 ago. 2008.

Centro Internacional para Solução de Controvérsias da American Arbitration Association (ICDR):

Applicable Laws and Remedies

Article 28.

1. The tribunal shall apply the substantive law(s) or rules of law designated by the parties as applicable to the dispute. Failing such a designation by the parties, the tribunal shall apply such law(s) or rules of law as it determines to be appropriate.

2. In arbitrations involving the application of contracts, the tribunal shall decide in accordance with the terms of the contract and shall take into account usages of the trade applicable to the contract.

3. The tribunal shall not decide as amiable compositeur or ex aequo et bono unless the parties have expressly authorized it to do so. [...]

Disponível em: <http://www.adr.org/sp.asp?id=33994>. Acesso em: 20 set. 2008.

646 B. Special Provisions Applicable to the Ordinary Arbitration Procedure.

$[\ldots]$

R45.

Law Applicable to the Merits

The Panel shall decide the dispute according to the rules of law chosen by the parties or, in the absence of such a choice, according to Swiss law. The parties may authorize the Panel to decide ex aequo et bono.

Disponível em: <http://www.tas-cas.org/en/arbitrage_reglement.asp/4-0-1030-4-1-1/5-0-1089-7-1-1>. Acesso em: 21 ago. 2008.

647 Article 59.

(a) The Tribunal shall decide the substance of the dispute in accordance with the law or rules of law chosen by the parties. Any designation of the law of a given State shall be construed, unless otherwise expressed, as directly referring to the substantive law of that State and not to its conflict of laws rules. Failing a choice by the parties, the Tribunal shall apply the law or rules of law that it determines to be appropriate. In all cases, the Tribunal shall decide having due regard to the terms of any relevant contract and taking into account applicable trade usages. The Tribunal may decide as amiable compositeur or ex aequo et bono only if the parties have expressly authorized it to do so.

Fonte: Arbitration International, v. 13, n. 2, p. 207 e ss., 1997. Também disponível em: <www.wipo.int>. Acesso em: 21 ago. 2008.

648 Article 14. Applicable Law and Procedural Rules.

14.1 The Tribunal shall apply the law of the State of the Contracting Authority to the matters in dispute, unless otherwise specified in the Contract, in which case the Tribunal shall apply the law so specified. In all cases, the Tribunal shall decide in accordance with the terms of the Contract, and may take into account the usages of the trade applicable to the transaction.

14.2 Where the applicable law is silent on any specific point, the Tribunal shall apply the conflict of laws rules resulting from the law applicable to the Contract. The Tribunal may not decline to make an award on the ground that the law is silent or obscure on the point.

14.3 Notwithstanding the provisions of Articles 5.1 and 14.1, if the Parties expressly so authorise the Tribunal in the course of the arbitration proceedings, it shall decide as Amicable Compositor or ex aequo et bono. [...]

Fonte: Yearbook Commercial Arbitration, v. 17, p. 325 e ss., 1992. 
Idêntica orientação encontra-se nas regras de diversas instituições de cunho nacional ou regional em todos os continentes.

Nas Américas, está presente nas regras do Centro de Arbitragem do México ${ }^{649}$ da Câmara de Comércio Nacional da Cidade do México, do Centro de Arbitragem Comercial Internacional da Colúmbia Britânica ${ }^{650}$ e do Centro de Arbitragem Comercial e Mediação para as Américas. ${ }^{651}$

\section{$\mathrm{Na}$ Ásia, nas regras do Conselho de Arbitragem Comercial da Coréia (Korean Commer- cial Arbitration Board), ${ }^{652}$ do Centro de Arbitragem Internacional de Hong Kong (HKIAC), ${ }^{653}$}

649 Artículo 23. Derecho aplicable.

Las partes pueden elegir libremente el derecho que el Tribunal Arbitral deberá aplicar al fondo de litigio. A falta de elección, el Tribunal Arbitral aplicará las reglas de derecho que juzgue apropiadas.

En cualquier caso, el Tribunal Arbitral tomará en consideración las estipulaciones del contrato y los usos del comercio.

El Tribunal Arbitral tendrá los poderes de amigable componedor cuando las partes así lo determinen expresamente.

Disponível em: <http://www.camex.com.mx/r4.htm\#b23>. Acesso em: 21 ago. 2008.

650 Article 30. Rules applicable to substance of dispute.

1. The arbitral tribunal shall decide the dispute in accordance with the rules of law designated by the parties as applicable to the substance of the dispute.

2. Any designation by the parties of the law or legal system of a given state shall be construed, unless otherwise expressed, as directly referring to the substantive law of that state and not to its conflict of laws rules.

3. Failing any designation of the law under (1) by the parties, the arbitral tribunal shall apply the rules of law it considers to be appropriate given all the circumstances surrounding the dispute.

4. The arbitral tribunal shall decide ex aequo et bono or as amiable compositeur if the parties have expressly authorized it to do so. [...]

Disponível em: <http://www.bcicac.com/bcicac_ica_rules.php>. Acesso em: 21 ago. 2008.

651 Article 30. Applicable Laws.

1. The tribunal shall apply the laws or rules of law designated by the parties as applicable to the dispute. Failing such a designation by the parties, the tribunal shall apply such law or laws as it determines to be appropriate.

2. In arbitrations involving the application of contracts, the tribunal shall decide in accordance with the terms of the contract and shall take into account usages of the trade applicable to the contract.

3. The tribunal shall not decide as amiable compositeur or ex aequo et bono unless the parties have expressly authorized it to do so.

Fonte: Yearbook Commercial Arbitration, v. 22, p. 329 e ss., 1997. Também disponível em: <http://www.adr. org/sp.asp?id=22092>. Acesso em: 24 set. 2008.

652 Article 25. Applicable Law.

1. The parties shall be free to agree upon the substantive laws or rules of law to be applied by the Arbitral Tribunal to the merits of the dispute. In the absence of any such agreement, the Arbitral Tribunal shall apply the substantive laws or rules of law which it determines to be appropriate.

2. In all cases the Arbitral Tribunal shall take account of the provisions of the contract and the relevant trade usages.

3. The Arbitral Tribunal shall assume the powers of an amiable compositeur or decide ex aequo et bono only if the parties have agreed to give it such powers

Fonte: International Handbook on Commercial Arbitration, suplemento 52, jun. 2008.

653 Article 31. Applicable Law, Amiable Compositeur.

31.1 The arbitral tribunal shall decide the case in accordance with the rules of law agreed upon by the parties or, in the absence of a choice of law, by applying the rules of law with which the dispute has the closest connection. 
da Associação Japonesa de Arbitragem Comercial, ${ }^{654}$ do Centro Regional de Kuala Lumpur para a Arbitragem, ${ }^{655}$ do Conselho Nacional de Arbitragem da Indonésia (Bani). ${ }^{656}$ No caso da Comissão Chinesa para Arbitragem Comercial e Econômica Internacionais (CIETAC), não há propriamente menção à arbitragem por eqüidade nos moldes tradicionais. Todavia, a determinação para que o tribunal decida "com referência às práticas internacionais e de acordo com princípios de justiça e razoabilidade" ${ }^{957}$ vem sendo entendida por alguns como uma autorização para decisão por eqüidade. ${ }^{658}$ Entretanto, se assim pode ser entendido, sua disciplina parece bastante lacunosa, não sendo claros as circunstâncias e o modo pelo qual tal autorização pode operar. A simples leitura do texto parece indicar mais uma regra de interpretação do que uma decisão por eqüidade propriamente dita.

31.2 The arbitral tribunal shall decide as amiable compositeur or ex aequo et bono only if the parties have expressly authorised the arbitral tribunal to do so.

31.3 In all cases, the arbitral tribunal shall decide the case in accordance with the terms of the contract and shall take into account the usages of the trade applicable to the transaction.

Disponível em: <http://www.hkiac.org/HKIAC/pdf/Rules/AA\%20Rules.pdf>. Acesso em: 21 ago. 2008.

${ }_{654}$ Rule 41. Rules Applicable to Substance of Dispute.

1. The arbitral tribunal shall decide the dispute in accordance with such rules of law as are agreed by the parties as applicable to the substance of the dispute.

2. Failing agreement provided for in the preceding paragraph, the arbitral tribunal shall apply the law of the country or state to which the dispute in the arbitral proceedings is most closely connected.

3. Notwithstanding the provisions contained in the preceding two paragraphs, the arbitral tribunal shall decide ex aequo et bono only if the parties have expressly requested it to do so.

Fonte: Yearbook Commercial Arbitration, v. 29, p. 378, 2004.

${ }_{655}$ Adota as regras da CNUDCI, com pequenas alterações que, todavia, não modificam as disposições relativas à arbitragem por eqüidade. Disponível em: <http://www.rcakl.org.my/rules.html>. Acesso em: 25 set. 2008.

656 Article 15. Applicable Law.

1. Governing Law

The law that shall govern the substance of the dispute shall be the law that has been designated so to govern in the underlying commercial agreement between or among the parties in connection with which the dispute has arisen. In the absence of any such prior agreement by the parties as to the law that shall govern, the parties shall be free to designate the governing law on their mutual agreement. In the absence of any such agreement, the Tribunal shall have the authority to apply such rules of law as it deems appropriate, considering the circumstances of the matter.

\section{Contract Stipulations}

In applying the governing law, the Tribunal shall take into account the provisions of the underlying agreement as well as relevant trade practices and usage.

3. Ex Aequo et Bono

The Tribunal may assume the powers of an amiable compositeur and or decide ex aequo et bono where, and to the extent that, the parties have so agreed.

Fonte: Yearbook Commercial Arbitration, v. 28, p. 331 e ss., 2003.

657 Article 43. Making Award.

1. The arbitral tribunal shall independently and impartially make its arbitral award on the basis of the facts, in accordance with the law and the terms of the contracts, with reference to international practices and in compliance with the principle of fairness and reasonableness. [...]

Disponível em: <http://www.cietac.org.cn/english/rules/rules.htm>. Acesso em: 25 ago. 2008.

${ }^{658} \mathrm{Li}$, Hu. Arbitration ex aequo et bono in China, in Arbitration International, v. 66, n. 3, p. 188 e ss., 2000. 
$\mathrm{Na}$ África, nas regras do Centro Regional do Cairo para Arbitragem Comercial Internacional, bem como no regulamento da OHADA, reproduzido no item relativo a Convenções Internacionais.

$\mathrm{Na}$ Europa, nos regulamentos de arbitragens nacionais e internacionais da Associação Italiana para a Arbitragem (AIA) ${ }^{659}$ nas regras do Centro de Arbitragem da Câmara de Comércio de Estocolmo, ${ }^{660}$ nas regras das Câmaras de Comércio da Suíça,${ }^{661}$ no regulamento da Câmara Federal Econômica da Áustria (Austrian Federal Economic Chamber), ${ }^{662}$ nas da Associação

659 Internacional:

Art. 22. Norme per la pronuncia.

1. Ove le parti non abbiano pattuito le norme applicabili al merito né abbiano concordato che l'arbitro pronunci secondo equità, l'arbitro applica la legge con la quale il rapporto è più strettamente collegato.

2. L'arbitro decide secondo equità solo su concorde volontà delle parti.

Disponível em: <http://www.arbitratoaia.org/regolamento_internaz.pdf>. Acesso em: 20 ago. 2008.

Nacional:

Art. 21. Norme per la pronuncia.

1. L'arbitro decide secondo diritto salvo che le parti abbiano Concordemente pattuito ch'egli decida secondo equità.

Disponível em: <http://www.arbitratoaia.org/regolamento_nazionale.pdf>. Acesso em: 20 ago. 2008.

660 Instituto de Arbitragem da Câmara de Comércio de Estocolmo:

Article 22. Applicable Law.

(1) The Arbitral Tribunal shall decide the merits of the dispute on the basis of the law or rules of law agreed upon by the parties. In the absence of such agreement, the Arbitral Tribunal shall apply the law or rules of law which it considers to be most appropriate.

(2) Any designation made by the parties of the law of a given state shall be deemed to refer to the substantive law of that state and not to its conflict of laws rules.

(3) The Arbitral Tribunal shall decide the dispute ex aequo et bono or as amiable compositeur only if the parties have expressly authorised it to do so.

Dsiponível em: <http://www.sccinstitute.com/_upload/shared_files/regler/2007_Arbitration_Rules_eng.pdf>. Acesso em: 21 set. 2008.

661 Regras para Arbitragem Internacional das Câmaras de Comércio Suíças (Regras Suíças). Essas regras estão em vigor desde janeiro de 2004 e são utilizadas pelas diversas Câmaras de Comércio e Indústria da Suíça, inclusive as de Genebra e Zurique:

Applicable Law, Amiable Compositeur.

Article 33.

1. The arbitral tribunal shall decide the case in accordance with the rules of law agreed upon by the parties or, in the absence of a choice of law, by applying the rules of law with which the dispute has the closest connection.

2. The arbitral tribunal shall decide as amiable compositeur or ex aequo et bono only if the parties have expressly authorised the arbitral tribunal to do so. [...]

Fonte: Boletim da Associação Suiça de Arbitragem, v. 22, n. 1, 2004.

662 Applicable Law, Equity

Article 24.

1. The sole arbitrator (arbitral tribunal) shall decide the dispute in accordance with such legislation or rules of law as are chosen by the parties as applicable. Any choice of law or legal system of a given state shall be construed, unless otherwise expressed by the parties, as directly referring to the substantive law of that state and not to its conflict of law rules. 
Francesa de Arbitragem, ${ }^{663}$ da Corte de Arbitragem Internacional da Câmara de Comércio e Indústria da Ucrânia. ${ }^{664}$

As entidades brasileiras permitem a arbitragem por eqüidade quando as partes a autorizarem, seguindo a orientação legislativa nacional. Em geral, a opção é mencionada nas disposições relativas ao compromisso arbitral (chamado de termo em algumas regras), orientação que também se encontra na Lei de Arbitragem (art. 11). Algumas delas ainda determinam de modo expresso que os árbitros mencionem se a sentença foi proferida por eqüidade, tal como a Lei de Arbitragem obriga (art. 26). ${ }^{665}$

2. Failing any designation by the parties, the sole arbitrator (arbitral tribunal) shall apply the rules of law considered by him (it) as appropriate.

3. The sole arbitrator (arbitral tribunal) may decide on equity only if the parties have expressly authorized him (it) to do so.

663 Article 12.

I - Le Tribunal arbitral est juge de sa compétence et de la validité de sa saisine.

Il est dispensé d'observer dans la procédure les délais et les formes établis pour les tribunaux, à l'exception des formes propres à la matière de l'arbitrage.

Le Tribunal arbitral statue en qualité d'amiable compositeur si les parties lui en ont donné le pouvoir. [....]

Disponível em: <http://www.afa-arbitrage.com/reglement.php>. Acesso em: 24 set. 2008.

664 Article 14. Applicable Law.

1. The Arbitral Tribunal shall settle disputes in accordance with the rules of law, which the parties have chosen to apply to the subject matter of the dispute. Any reference to the law or the legal system of a country shall be interpreted as direct reference to the substantive law of such country, rather than to the conflict of laws rules thereof.

2. Failing such reference by the parties, the Arbitral Tribunal shall apply a law determined by the conflict of laws rules, which it deems appropriate.

3. The Arbitral Tribunal shall decide ex aequo et bono or as amiable compositeur only if the parties have expressly authorized it to do so. [...]

Disponível em: <http://www.ucci.org.ua/arb/icac/en/rules.html>. Acesso em: 20 ago. 2008.

${ }^{665}$ Centro de Mediação e Arbitragem da Câmara de Comércio Brasil-Canadá:

5.8. Escolhidos os árbitros, o Centro elaborará Termo de Arbitragem com a assistência das partes, contendo $[\ldots]$ autorização ou não para que os árbitros julguem por eqüidade, $[\ldots]$.

10.5. A sentença arbitral conterá, necessariamente: [...]

(b) os fundamentos da decisão, que disporá quanto às questões de fato e de direito, com declaração expressa, quando for o caso, de ter sido proferida por eqüidade; [...]

Disponível em: <http://www.ccbc.org.br/arbitragem.asp?subcategoria=regulamento\%20portugues $>$. Acesso em: 21 set. 2008.

Câmara de Mediação e Arbitragem de São Paulo (vinculada à Federação das Indústrias do Estado de São Paulo):

3. Do Termo de Arbitragem

3.1 - As partes e árbitros elaborarão Termo de Arbitragem podendo contar com a assistência da Câmara. O Termo de Arbitragem conterá [...], autorização ou não para que os árbitros julguem por eqüidade [...].

3.6 - A sentença arbitral conterá, necessariamente: a) relatório, com o nome das partes e um resumo do litígio; b) os fundamentos da decisão, que disporá quanto às questões de fato e de direito, com esclarecimento expresso, quando for o caso, de ter sido proferida por equiidade; c) o dispositivo, com todas as suas especificações e prazo para cumprimento da decisão, se for o caso; e d) o dia, mês, ano e lugar em que foi proferida.

Disponível em: <http://www.camaradearbitragemsp.org.br>. Acesso em: 21 set. 2008.

Câmara de Mediação e Arbitragem Empresarial - CAMARB: 


\subsubsection{Presunção de arbitragem por eqüidade}

Na pesquisa realizada, encontra-se uma clara tendência de correlação entre as regras que presumem a arbitragem por eqüidade com as legislações que adotam a mesma orientação. Os regulamentos que presumem a arbitragem por eqüidade são geralmente encontrados nos países em cuja legislação nacional existe idêntica presunção.

No entanto, essa tendência não é geral. Há exceções, como no caso do Instituto Holandês para a Arbitragem, ${ }^{666}$ que prevê a arbitragem por eqüidade como regra geral nas arbitragens nacionais, embora não seja essa a orientação do direito holandês.

A correlação entre direito nacional e regime dos regulamentos de arbitragem parece ser comprovada pelo exemplo das instituições espanholas. No direito espanhol, até a reforma de 2003, as arbitragens seriam decididas por eqüidade salvo convenção das partes. Posteriormente, a legislação foi alterada para inverter a regra, de modo que a decisão por eqüidade somente ocorresse quando as partes assim convencionassem.

Os regulamentos elaborados anteriormente à reforma do regime espanhol presumiam a eqüidade; após a reforma, passaram a presumir a decisão conforme direito, salvo convenção em contrário. Esse é o caso da Corte Espanhola de Arbitragem, ${ }^{667}$ do Tribunal

2.6 No prazo de 7 (sete) dias da nomeação do(s) árbitro(s), a Secretaria Geral da CAMARB elaborará o compromisso arbitral, se for o caso, o qual conterá: [...]

e) a autorização para que o(s) árbitro(s) julgue(m) por eqüidade, fora das regras de direito, se assim for convencionado pelas partes; $[\ldots]$

5.18 A sentença arbitral conterá: [...]

b) os fundamentos da decisão, onde serão analisadas as questões de fato e de direito, com menção expressa, quando for o caso, de ter sido proferida por eqüidade; [...]

Disponível em: <http://www.camarb.com.br/areas/subareas_conteudo.aspx?subareano=259>. Acesso em: 21 ago. 2008.

Igualmente o Regulamento Centro de Arbitragem da Câmara Americana de Comércio de São Paulo AmCham, referindo-se à arbitragem por eqüidade nas disposições relativas ao compromisso. Disponível em: <http:// www.amcham.com.br/servicos/arbitragem/regulamento_port.pdf>. Acesso em: 21 ago. 2008.

666 Article 45. Decision According to Rules of Law or as Amiable Compositeur.

1. The arbitral tribunal shall decide as amiable compositeur unless the parties agreed to authorise it to make its award in accordance with the rules of law.

2. In an international arbitration, the arbitral tribunal shall make its award in accordance with the rules of law unless the parties agreed to authorise it to decide as amiable compositeur.

Disponível em: <http://www.nai-nl.org/english/info2.html>.

${ }^{667}$ Artículo 3. Arbitraje de Equidad.

El arbitraje siempre será de equidad, salvo que las partes hayan optado expresamente por el arbitraje de derecho.

Disponível em: <www.kluwearbitration.com>. Acesso em: 22 set. 2008. 
Arbitral do Comércio de Bilbao e, em extensão menor, da Associação Catalã para a Arbitragem. ${ }^{668}$

Algumas das instituições espanholas apresentavam regras peculiares quanto ao regime de arbitragem por eqüidade. No caso do Tribunal Arbitral do Comércio de Bilbao, havia presunção de arbitragem por eqüidade, com dispensa para motivação da sentença que a utilizasse como critério de decisão (as regras apenas recomendavam a motivação, mas não a obrigavam). ${ }^{669} \mathrm{~A}$ liberdade para não motivar a sentença em eqüidade afasta-se da orientação mundial majoritária nos países em que a motivação das sentenças é obrigatória. O regulamento foi reformado para modificar a presunção de arbitragem, mas não para alterar o status de recomendação de motivação da sentença por eqüidade. ${ }^{670}$

O regulamento do Centro de Arbitragem e Mediação do Paraguai foi elaborado antes da reforma do regime de arbitragem e pelo visto não foi modificado posteriormente. Assim, tal como no regime paraguaio anterior, o regulamento presume a arbitragem por eqüidade. Tal regulamento ainda prevê que a sentença arbitral em eqüidade está dispensada dos requisitos legais e apresenta uma série de critérios os quais os árbitros de eqüidade devem seguir, por ordem: a eqüidade, a "verdade sabida" e a "boa fé guardada", bem como os costumes aplicáveis à solução de controvérsias. ${ }^{671} \mathrm{Em}$ grande medida, esses critérios "materiais" de decisão por

Tal orientação foi modificada na reforma posterior do regulamento, conforme se verifica em: <https://www. camaras.org/publicado/arbitraje/disposiciones_gral_1221.html>. Acesso em: 22 set. 2008.

${ }^{668}$ Como já mencionado, a regra anterior dessa Associação deixava a cargo da própria instituição a definição do tipo de arbitragem.

669 Artículo 2. ${ }^{\circ}$

El arbitraje lo será siempre de equidad, salvo en el caso de que las partes hayan optado expresamente por el arbitraje de derecho. [...]

Artículo 37. ${ }^{\circ}$

1. El Laudo se dictará por escrito y expresará, al menos, las circunstancias personales de los árbitros y de las partes en el lugar en que se dicta la cuestión sometida a arbitraje, una sucinta relación de las pruebas practicadas, las alegaciones de las partes y la decisión arbitral.

2. En el caso de los arbitrajes de derecho, el Laudo tendrá que ser, además, motivado. En los arbitrajes de equidad, se recomienda también su motivación. [...]

Disponível em: <www.kluwearbitration.com>. Acesso em: 22 set. 2008.

670 Disponível em: <http://www.camarabilbao.com/ccb/contenidos.item.action?id=2158929\&type=2158929\&m enuId=2158929>. Acesso em: 22 set. 2008.

${ }_{671}$ Artículo 14. El tribunal arbitral podrá estar integrado por árbitros o arbitradores. Los árbitros deben fallar conforme a derecho y los arbitradores conforme a equidad. En ausencia de acuerdo, se entenderá que la controversia ha sido sometida arbitradores.

$[\ldots]$

Artículo 53. Requisitos del laudo de equidad

Los arbitradores no tendrán que laudar sometiéndose a formas legales, lo harán de acuerdo a su conciencia en la forma que estimen justo y equitativo.

Para laudar en equidad, los arbitradores tendrán en consideración los siguientes elementos, en el orden de prioridad que determine su leal saber y entender sobre la cuestión controvertida: 
eqüidade fazem remissão a fórmulas utilizadas na legislação de alguns países integrantes do sistema hispano-americano ao dispor sobre a arbitragem por eqüidade.

Na Argentina, o Tribunal Arbitral da Bolsa de Comércio de Buenos Aires, a exemplo da legislação local, presume a arbitragem de eqüidade, salvo disposição em contrário. Neste regulamento, há uma descrição detalhada do procedimento para arbitragens por eqüidade, inclusive quanto a recursos contra a sentença. ${ }^{672}$

No caso do Peru, o Centro de Conciliação e Arbitragem Nacional e Internacional da Câmara de Comércio de Lima apresentava uma divisão de regimes sobre a arbitragem por eqüidade: se fosse interna, a arbitragem seria por eqüidade no caso de silêncio das partes; caso a arbitragem fosse internacional e as partes nada dispusessem, seria de direito. Esse regime espelhava o da Lei Geral de Arbitragem do Peru, editada em 1995. Em 2007, o regulamento foi alterado para que o silêncio das partes fosse considerado uma escolha de arbitragem de direito, em ambos os casos. Ambos os regulamentos prevêem requisitos diferenciados para a sentença por eqüidade. No caso desta, os árbitros estão dispensados de apresentar motivação sobre a valoração das provas e sobre fundamentos de fato e de direito para a decisão. ${ }^{673}$

1. La equidad.

2. La verdad sabida y buena fe guardada.

3. Los usos y costumbres aplicables a la solución de la controversia.

Disponível em: <http://www.camparaguay.com/v3/index.php\#>. Acesso em: 25 set. 2008.

672 Carácter de su actuación.

Art. 2. El Tribunal en su conjunto, así como sus miembros particularmente, tiene el carácter de árbitros de derecho o de árbitros arbitradores amigables componedores, conforme a la modalidad que las partes hayan asignado al arbitraje. Si nada se hubiese estipulado, se entiende que debe proceder y decidir como amigable componedor. [...]

Veredicto y laudo.

Art. 61. Dentro de tercero día de concluida la vista de la causa, el Tribunal pronunciará su veredicto expidiéndose sobre los hechos controvertidos. Dentro del plazo fijado conforme al art. 45 inc. c), se dictará el laudo sobre los puntos de com- promiso, por mayoría de los votos de los miembros del Tribunal. La decisión se fundará equitativamente según el leal saber y entender de los árbitros; contendrá pronunciamiento expreso sobre la imposición de las costas y plazos para su cumplimiento, salvo expresa disposición en contrario contenida en el compromiso arbitral. [...]

Irrecurribilidad: laudo de amigables componedores.

Art. 64. No es recurrible el laudo de amigables componedores.

Acción de nulidad en el arbitraje de derecho y en el de amigables componedores.

Art. 65. Podrá demandarse la nulidad del laudo de amigables componedores y de árbitros de derecho, aun cuando hubiesen sido renunciados los recursos, si se pronuncia fuera del plazo previsto en el compromiso o hubiese recaído sobre puntos no comprometidos.

Disponível em: <http://www.bcba.sba.com.ar/BCBA/doc/Régimen_Arbitral.pdf>. Acesso em: 26 sset. 2008.

673 Artículo12. ${ }^{\circ}$

Arbitraje de derecho o de conciencia.

El arbitraje puede ser de derecho o de conciencia. Es de derecho cuando los árbitros resuelven la cuestión controvertida con arreglo al derecho aplicable. Es de conciencia cuando resuelven conforme a sus conocimientos y leal saber y entender. En ambos casos, los árbitros tendrán en cuenta, de tratarse de asuntos de carácter comercial, los usos mercantiles aplicables al caso. 
Na França, pode-se encontrar um exemplo de presunção de eqüidade em caso de silêncio das partes nas regras da Câmara Arbitral Internacional de Frutas e Legumes de Estrasburgo. ${ }^{674}$ Essa instituição, bem como suas sentenças, já foram pesquisadas por Eric Loquin em sua clássica obra sobre arbitragem por eqüidade. ${ }^{675}$ No caso da Câmara de Arbitragem de Paris, existe presunção de eqüidade em um tipo de procedimento célere. ${ }^{676}$

No tocante a instituições de vocação internacional, existe presunção de arbitragem por eqüidade em apenas um caso, de especialização temática: o Tribunal Arbitral da Federação Internacional de Basquetebol ${ }^{677}$ presume arbitragem por eqüidade em caso de silêncio das partes.

El arbitraje será de derecho cuando las partes lo hubiesen acordado expresamente. En caso de duda o en defecto de pacto, el arbitraje será de conciencia.

Artículo 61.

Contenido del laudo arbitral.

El laudo arbitral de derecho debe contener:

a) Lugar y fecha de expedición.

b) Nombres de las partes y de los árbitros.

c) La cuestión sometida a arbitraje y una sumaria referencia a las alegaciones y conclusiones de las partes.

d) Valoración de las pruebas en que se sustenta la decisión.

e) Fundamentos de hecho y de derecho para admitir o rechazar las respectivas pretensiones y defensas.

f) La decisión.

g) La condena en costos a que se refiere el artículo 62..

El laudo arbitral de conciencia debe contener lo dispuesto en los incisos a), b), c), f) y g) del presente artículo. Este laudo requiere además de una motivación razonada.

Arbitragem internacional:

Artículo 75.

Arbitraje de derecho o de conciencia.

El arbitraje será de derecho, salvo que las partes hubiesen pactado expresamente que será de conciencia.

Disponíveis em: <http://www.camaralima.org.pe/arbitraje/reglamento.htm>. Acesso em: 25 ago. 2009.

674 c) Les Tribunaux arbitraux

La mission juridictionnelle relève des pouvoirs des Tribunaux arbitraux constitués comme il est dit ci-dessus et qui statuent en leur nom propre. Les Tribunaux arbitraux sont dispensés de suivre, au cours de leur mission d'arbitrage, les règles établies pour les Tribunaux de droit commun. Toutefois, les principes directeurs du procès énoncés aux articles 4 à 10, 11 (1er aliéna), et 13 à 21 du Nouveau Code de procédure civile français sont applicables à l'instance arbitrale.

Sauf convention écrite contraire, le Tribunal arbitral a les pouvoirs d'amiable compositeur.

Le Tribunal arbitral constitué est, dans chaque espèce dont il est saisi, juge de sa compétence.

Disponível em: <http://www.interfel.com/medias/commext/chambre-arbitrale.pdf>. Acesso em: 25 set. 2008.

675 LoQuin, Eric. L'Amiable composition... cit., p. 321.

676 Article 3.E Sentence.

Le Tribunal Arbitral statue en qualité d'amiable compositeur et définitivement sur le litige par une sentence qui est notifiée aux parties.

Disponível em: <http://www.arbitrage.org/fr/procedures/reglement_fr_2005.pdf>. Acesso em: 21 ago. 2008.

677 15. Law Applicable to the Merits

15.1. Unless the parties have agreed otherwise the Arbitrator shall decide the dispute ex aequo et bono, applying general considerations of justice and fairness without reference to any particular national or international law. 
Em todos os casos, a presunção de arbitragem por eqüidade opera apenas como uma regra dispositiva: tal como nos direitos nacionais, as partes podem convencionar que a arbitragem seja decidida conforme o direito. As duas únicas hipóteses em que parece haver uma aplicação obrigatória da eqüidade são regras relativas a procedimentos simplificados para disputas de valores mais baixos, encontradas no antigo regulamento do Tribunal Arbitral do Comércio de Bilbao, no chamado procedimento oral ${ }^{678}$ e no procedimento de arbitragem rápida da Câmara de Arbitragem de Paris, já mencionado.

\subsubsection{Proibição}

Tanto quanto a presente pesquisa pode alcançar, não existem regras que vedem expressamente a utilização da arbitragem por eqüidade. Todavia, existem formulações de regras que parecem impedir a escolha da decisão por eqüidade pelas partes. Constatação idêntica ocorre no exame das legislações nacionais. Mesmo direitos refratários à arbitragem por eqüidade não a proíbem de modo expresso.

A formulação mais incisiva encontrada é a do Tribunal de Arbitragem Comercial Internacional da Câmara de Comércio e Indústria da Federação Russa, que dispõe que as controvérsias serão decididas conforme o direito substantivo escolhido pelas partes e, em caso de ausência de escolha, pela lei determinada pelas regras de direito internacional privado escolhidas pelo tribunal ${ }^{679}$ Ao determinar que as controvérsias sejam dirimidas pela aplicação de uma lei substantiva, parece haver pouco ou nenhum espaço para uma decisão por eqüidade. Embora essa interpretação possa ser mitigada na prática, nada indica que ocorra no caso concreto. Em verdade, a origem dessa instituição parece corroborar a interpretação. Como visto, a disciplina de arbitragem na Rússia é refratária à utilização da eqüidade.

15.2. If according to the arbitraiton clause the Arbitrator is not authorised to decide ex aequo et bono, he/she shall decide the dispute according to the rules of law chosen by the parties or, in the absence of such a choice, according to the rules of law he/she deems apropriate.

Disponível em: <http://www.fiba.com/downloads/v3_expe/fat/FAT_Arbitration_Rules.pdf?v1>. Acesso em: 25 set. 2008.

678 Artículo 43. ${ }^{\circ}$

Los arbitrajes que se sigan conforme al procedimiento regulado en el presente Título serán siempre de equidad, y su resolución será encomendada, en todo caso, a un árbitro único.

Disponível em: <www.kluwearbitration.com>. Acesso em: 22 set. 2008.

679 1. The ICAC shall settle disputes on the basis of the applicable rules of substantive law determined by an agreement of the parties. Failing any designation by the parties, the arbitral tribunal shall apply the law determined by the conflict of laws rules which it considers applicable. In all cases, the arbitral tribunal shall decide in accordance with the terms of the contract and shall take into account the usages of the trade applicable to the transaction.

Disponível em: <http://eng.tpprf.ru/ru/main/icac/>. Acesso em: 20 set. 2008. Também publicado no Yearbook Commercial Arbitration, v. 31, p. 462 e ss., 2006. 
Como se verifica do regulamento da Corte de Arbitragem da Câmara de Comércio e Indústria da União Soviética, ${ }^{60}$ da qual a homóloga russa é sucessora, e do Regulamento Uniforme das Cortes de Arbitragem das Câmaras de Comércio dos Países do Comecon, ${ }^{681}$ existe uma tradição consistente de aplicação de direito nacional material ao mérito das arbitragens.

Existem ainda dois regulamentos pesquisados que não dispõem sobre a arbitragem por eqüidade. No caso do Conselho Indiano de Arbitragem, existe menção à falta de acordo sobre a lei substantiva a ser aplicada. Nessa hipótese, ela será determinada pelo tribunal arbitral. ${ }^{682}$ Trata-se de uma redação menos incisiva do que o caso da instituição russa sobre a obrigatoriedade de decisão conforme direito positivo. Além disso, o fato de que o direito indiano prevê a arbitragem por eqüidade não permite afirmar que haja vedação.

No caso do Centro de Arbitragem Internacional de Cingapura, igualmente não há menção à arbitragem por eqüidade no regulamento atual, editado em 2007, nem no anterior, editado em 1997. ${ }^{683}$ Embora ambos se refiram em diversas passagens à lei aplicável, não há elementos para inferir qualquer posição acerca da arbitragem por eqüidade. O direito de Cingapura apresenta soluções distintas: permite a arbitragem por eqüidade no caso de arbitragem internacional, sendo incerta a possibilidade em arbitragens internas. Dado o alcance internacional que o Centro pretende e a permissão da legislação local quanto a arbitragens internacionais, é mais razoável entender que as partes possam escolher a arbitragem por eqüidade.

680 Article 13. Applicable Law.

1. The Arbitration Court shall settle disputes on the basis of the applicable rules of substantive law, being guided, if the dispute has arisen from contractual relations, by the provisions of the contract and having regard to trade usages.

Fonte: Yearbook Commercial Arbitration, v. 14, p. 293 e ss., 1989.

$681 \S 12$.

The Arbitration Court shall settle disputes on the basis of the applicable rules of substantive law, guided by the provisions of the contract and having regard to trade customs.

Fonte: Yearbook Commercial Arbitration, v.1, p. 147 e ss., 1976.

682 Rule 6.

If one or both of the parties to a dispute which is referred to arbitration by the Council belong to a country or countries other than India, in the absence of an agreement by the parties on the substantive law to be applied, it will be determined by the arbitral tribunal. The procedural law shall be the laws of India and parties shall be deemed to have submitted to the jurisdiction of the Courts in India.

Fonte: Yearbook Commercial Arbitration, v. 23, p. 310 e ss., 1998.

Também disponível em: <http://www.ficci.com/icanet/rules/commercialarbitration/arbitration\&conciliation/ clause.htm\#1>. Acesso em: 25 set. 2008.

683 Regulamento de 1997 publicado em Yearbook Commercial Arbitration, Vol. XXIII, 1998, pg. 424 e ss. Regulamento de 2007: sítio de internet http://www.siac.org.sg/rules-siac01.htm\#rule32, consultado em 28.9.2008. 


\section{CAPÍTULO 6}

\section{PARTE ESPECIAL}

Nesta parte especial, serão vistos os tratados internacionais (1) e as legislações nacionais (2) em espécie. Eles apresentam os dados discutidos no capítulo anterior. Sempre que conveniente, buscou-se uma pequena discussão acerca dos regimes trazidos pelos tratados e pelas leis nacionais.

\subsection{Tratados Internacionais}

\subsubsection{Da Convenção de Nova Iorque}

A Convenção das Nações Unidas sobre Reconhecimento e Execução de Sentenças Arbitrais Estrangeiras, de 10.06.1958, chamada Convenção de Nova Iorque (“CNI"), ${ }^{684}$ é o instrumento internacional mais importante sobre arbitragem comercial internacional, contando com a adesão de mais de 142 países. ${ }^{685}$

A CNI trata do reconhecimento e execução de sentenças arbitrais estrangeiras, bem como do reconhecimento de convenções de arbitragem celebradas no exterior.

A CNI não dispõe diretamente sobre a arbitragem por eqüidade. Entretanto, em seu art. II constam disposições relativas ao reconhecimento das cláusulas de arbitragem, salvo nulidade, inoperância ou inexeqüibilidade. ${ }^{66}$ Neste artigo, a CNI afirma o princípio de reconhecimento da cláusula de arbitragem, fixando um critério material para sua validade. Mais ainda,

684 Nome original: United Nations Convention on Recognition and Enforcement of Foreign Arbitral Awards. Publicada em United Nations, Treaty Series, v. 330, n. 4.739, p. 38, 1959. No Brasil, a Convenção entrou em vigor por meio do Decreto 4.311, de 23.07.2002.

685 Disponível no site da Comissão das Nações Unidas para o Direito do Comércio Internacional (CNUDCI/Uncitral): <http://www.uncitral.org/uncitral/en/uncitral_texts/arbitration/NYConvention_status.html >. Acesso em: 28 dez. 2008.

686 Artigo II.

1. Cada Estado signatário deverá reconhecer o acordo escrito pelo qual as partes se comprometem a submeter à arbitragem todas as divergências que tenham surgido ou que possam vir a surgir entre si no que diz respeito a um relacionamento jurídico definido, seja ele contratual ou não, com relação a uma matéria passível de solução mediante arbitragem.

2. Entender-se-á por "acordo escrito" uma cláusula arbitral inserida em contrato ou acordo de arbitragem, firmado pelas partes ou contido em troca de cartas ou telegramas. 
em combinação com o art. V, 1, “d”, reconhece a autonomia das partes para a celebração da cláusula e definição do procedimento, colocando-se a lei do local da arbitragem como critério subsidiário. ${ }^{687} \mathrm{O}$ principal efeito do reconhecimento da cláusula de arbitragem é a vedação ao acesso das partes aos tribunais estatais do país: existindo uma cláusula válida, as partes serão remetidas à arbitragem.

Nos arts. III a V, a CNI dispõe sobre o reconhecimento e execução das sentenças arbitrais, seu procedimento e as causas para negativa por parte dos tribunais do país onde se buscam tais reconhecimento e execução. ${ }^{68}$ Entre eles, a invalidade da convenção de arbitragem de acordo com a lei a que as partes a submeteram ou, à falta deste, de acordo com a lei do local onde a sentença foi proferida, e a violação da ordem pública do país onde se busca a execução, por parte da sentença.

Tais disposições podem ser consideradas o núcleo duro do sistema de arbitragem comercial internacional: representam os aspectos mais amplamente aceitos no mundo atual. Tal núcleo duro é por vezes complementado por acordos regionais (e legislações nacionais), como previsto pela própria CNI.

3. O tribunal de um Estado signatário, quando de posse de ação sobre matéria com relação à qual as partes tenham estabelecido acordo nos termos do presente artigo, a pedido de uma delas, encaminhará as partes à arbitragem, a menos que constate que tal acordo é nulo e sem efeitos, inoperante ou inexeqüível.

687 Fouchard, Gaillard e Goldman. Traité de l'Arbitrage Commercial International, cit., p. 144-145.

688 Artigo III - Cada Estado signatário reconhecerá as sentenças como obrigatórias e as executará em conformidade com as regras de procedimento do território no qual a sentença é invocada, de acordo com as condições estabelecidas nos artigos que se seguem. Para fins de reconhecimento ou de execução das sentenças arbitrais às quais a presente Convenção se aplica, não serão impostas condições substancialmente mais onerosas ou taxas ou cobranças mais altas do que as impostas para o reconhecimento ou a execução de sentenças arbitrais domésticas. [...]

Artigo V - 1. O reconhecimento e a execução da sentença poderão ser indeferidos, a pedido da parte contra a qual ela é invocada, unicamente se esta parte fornecer à autoridade competente onde se tenciona o reconhecimento e a execução, prova de que: a) as partes do acordo a que se refere o Artigo II estavam, em conformidade com a lei a elas aplicável, de algum modo incapacitadas, ou que tal acordo não é válido nos termos da lei à qual as partes submeteram, ou na ausência de indicação sobre a matéria, nos termos da lei do país onde a sentença foi proferida; ou b) a parte contra a qual a sentença é invocada não recebeu notificação apropriada acerca da designação do árbitro ou do processo de arbitragem, ou lhe foi impossível, por outras razões, apresentar seus argumentos; ou c) a sentença se refere a uma divergência que não está prevista ou que não se enquadra nos termos da cláusula de submissão à arbitragem, ou contém decisões acerca de matérias que transcendem o alcance da cláusula de submissão, contanto que, se as decisões sobre matérias suscetíveis de arbitragem puderem ser separadas daquelas não suscetíveis, a parte da sentença que contém decisões sobre matérias suscetíveis possa ser reconhecida e executada; ou d) a composição da autoridade arbitral ou procedimento arbitral não se deu em conformidade com o acordado pelas partes, ou, na ausência de tal acordo, não se deu em conformidade com a lei do país em que a arbitragem ocorreu; ou e) a sentença ainda não se tornou obrigatória para as partes ou foi anulada ou suspensa por autoridade competente do país em que, ou conforme a lei do qual, a sentença tenha sido proferida.

2. O reconhecimento e a execução de uma sentença arbitral também poderão ser recusados caso a autoridade competente do país em que se tenciona o reconhecimento e a execução constatar que: a) segundo a lei daquele país, o objeto da divergência não é passível de decisão mediante arbitragem; ou b) no reconhecimento ou execução da sentença seria contrário à ordem pública daquele país. 
As disposições da CNI não podem ser interpretadas como permissivas ou proibitivas da arbitragem por eqüidade. Em sua elaboração, houve a opção de não tratar da matéria, que foi deixada para regulamentação de atos regionais e legislações nacionais. A existência de uma cláusula de arbitragem por eqüidade ou de uma sentença passada com esse critério de julgamento submetem-se ao regime geral da CNI.

Caso uma cláusula que preveja arbitragem por eqüidade seja considerada inválida pela lei a ela aplicável, poder-se-á negar execução à sentença que dela resulte, nos termos do art. V, 1, "d". Portanto, um sistema nacional pode afetar a escolha da arbitragem por eqüidade, desde que sua lei seja aplicável à cláusula arbitral. Do mesmo modo, uma sentença passada em eqüidade pode não ser reconhecida e executada caso o país em que se busca a execução considere esse tipo de arbitragem como uma violação à ordem pública.

Deve-se reconhecer, para todos os fins, que violação à ordem pública é um grau maior que a simples proibição em direito interno. A mera vedação de uma prática no direito interno não significa que tal prática viole a ordem pública (internacional) de tal país. Portanto, não se trata de aplicar os mesmos critérios: é necessário que a decisão por eqüidade seja considerada uma violação aos princípios fundamentais do ordenamento jurídico daquele país. O mesmo pode ser afirmado sobre o simples desconhecimento da arbitragem por eqüidade como instituto.

Da pesquisa de legislações nacionais realizada, é pouco encontrada a hipótese de a arbitragem por eqüidade ser proibida.

Os antecedentes diretos da CNI como instrumentos de arbitragem comercial de vocação internacional são o Protocolo de Genebra de 1923, sobre reconhecimento de cláusulas arbitrais, e a Convenção de Genebra de 1927, sobre reconhecimento e execução de sentenças arbitrais, ambos elaborados sob os auspícios da Liga das Nações. Nenhum deles mencionava a arbitragem por eqüidade.

\subsubsection{Código Bustamante}

A Convenção de Direito Internacional Privado de Havana, mais conhecida como o Código Bustamante (adotado pelo Brasil por intermédio do Decreto 18.871, de 13.08.1929), ao tratar sobre a execução de sentenças estrangeiras, estende os dispositivos relativos às sentenças estatais em matéria cível às sentenças emitidas por árbitros e "compositores amigáveis", nos termos da lei do país do local da execução: 
Art. 432. O processo e os efeitos regulados nos artigos anteriores serão aplicados nos Estados contratantes às sentenças proferidas em qualquer deles por árbitros ou compositores amigáveis, sempre que o assunto que as motiva possa ser objeto de compromisso, nos termos da legislação do país em que a execução ser solicite.

O Código não disciplina a matéria de arbitragem por eqüidade. Apenas menciona a existência dos "compositores amigáveis" ao lado dos árbitros. Essa distinção, considerando a origem e o âmbito de aplicação do Código Bustamante, é fruto da divisão encontrada em alguns sistemas de direito hispano-americanos entre árbitros, que decidem em direito, e arbitradores ou "compositores amigáveis", que decidem conforme eqüidade ou "em consciência". Todavia, essa menção a esses árbitros é possivelmente a primeira menção às arbitragens por eqüidade em tratados multilaterais no século XX. Mostra a aceitação desse tipo de arbitragem no âmbito da América Latina.

\subsubsection{Convenção de Genebra}

A Convenção Européia sobre Arbitragem Comercial Internacional de 21.4.1961 foi elaborada em Genebra ${ }^{689}$ e conta com cerca de 32 Estados contratantes. Seu âmbito de aplicação é essencialmente europeu. ${ }^{690}$

Ao contrário da Convenção de Nova Iorque, a Convenção de Genebra possui disposição específica sobre lei aplicável ao mérito da controvérsia, em seu art. VII. Nesse artigo, há permissão para que a decisão seja feita por eqüidade, desde que as partes assim convencionem e que a lei aplicável à arbitragem assim o permita:

\section{Article VII - APPLICABLE LAW}

1. The parties shall be free to determine, by agreement, the law to be applied by the arbitrators to the substance of the dispute. Failing any indication by the parties as to the applicable law, the arbitrators shall apply the proper law under the rule of conflict that the arbitrators deem applicable. In both cases the arbitrators shall take account of the terms of the contract and trade usages.

2. The arbitrators shall act as amiables compositeurs if the parties so decide and if they may do so under the law applicable to the arbitration.

689 Referida internacionalmente como European Convention on International Commercial Arbitration of 1961. United Nations, Treaty Series, v. 484, n. 7.041, p. 364, 1963-1964

690 Disponível em: <http://www.kluwerarbitration.com/arbitration/CStates.aspx?ipn=cstates;legis:eur>. Acesso em: 28 dez. 2007. 
A Convenção de Genebra adota (i) a autonomia da vontade das partes para a escolha de lei aplicável ao mérito; (ii) posição de cunho "conflitualista" para a determinação da lei aplicável na ausência de escolha (embora outorgue liberdade de critério aos árbitros); e (iii) condiciona o uso da eqüidade à lei aplicável à arbitragem, embora não determine qual seja ela.

A decisão de condicionar a arbitragem por eqüidade à lei aplicável à arbitragem devese (i) à intenção de adesão da Inglaterra, cujo direito, à época, não permitia a arbitragem por eqüidade; e (ii) um compromisso entre as delegações dos países ocidentais e socialistas, estes em geral refratários à decisão por eqüidade. ${ }^{691}$

A referência à lei aplicável à arbitragem, sem referência direta à lei do local da arbitragem, deixa aberta a possibilidade de que outra lei venha a ser aplicável. Por exemplo, em razão de escolha das partes. Essa posição representa modificação em relação a uma posição em geral territorialista vigente à época. Como exemplo, veja-se que, em 1957, o Instituto de Direito Internacional editou resolução segundo a qual as partes poderiam autorizar a decisão por eqüidade na arbitragem, desde que o direito da sede do tribunal arbitral assim permitisse. ${ }^{692}$ Ao utilizar o critério do direito aplicável à arbitragem sem referência necessária à lei do local da arbitram, a Convenção de Genebra permitiu interpretações tendentes à autonomia territorial da arbitragem internacional.

A Convenção de Genebra, tanto quanto esta pesquisa conseguiu apurar, foi o primeiro ato internacional em que o princípio da presunção da arbitragem de direito foi afirmado. Este princípio, também contemplado pela grande maioria das legislações nacionais, seria seguido em outros atos internacionais.

691 Loquin, Eric. L'Amiable composition... cit., p. 173-174.

692 "F. Droit applicable au fond du litige

Article 11

Les règles de rattachement en vigueur dans 1'Etat du siège du tribunal arbitral doivent être suivies pour déterminer la loi applicable au fond du litige.

Dans les limites de cette loi, les arbitres appliquent la loi choisie par les parties ou, à défaut d'indication expresse de celles-ci, déterminent quelle est la volonté des parties à cet égard en considérant toutes les circonstances de la cause.

Si la loi du lieu du siège du tribunal arbitral les y autorise, les parties peuvent donner aux arbitres le pouvoir de juger en équité ou d'après les règlements des associations professionnelles."

Dispníve no site oficial do Instituto de Direito Internacional: <http://www.idi-iil.org/idiF/resolutionsF/1957_ amst_03_fr.pdf>. Acesso em: 28 dez. 2007. 


\subsubsection{Convenção de Washington}

A Convenção sobre a Resolução de Disputas de Investimento entre Estados e Nacionais de Outros Estados, chamada Convenção de Washington, foi concluída em 18.03.1965. ${ }^{693}$ Trata-se de uma das mais abrangentes convenções relativas a investimento. ${ }^{694}$

Entre outras matérias, criou o Centro Internacional para Resolução de Disputas relativas a Investimento (CIRDI ou ICSID, como é mais comumente referido). Esse Centro, sediado em Washington, tem por função primordial administrar arbitragens e conciliações oriundas de disputas de investimento estrangeiro.

O art. 42 da Convenção de Washington dispõe sobre o direito aplicável pelos tribunais arbitrais. Em seu inciso 3, prevê expressamente a possibilidade de decisão por eqüidade, caso as partes assim escolham:

\section{Article 42}

(1) The Tribunal shall decide a dispute in accordance with such rules of law as may be agreed by the parties. In the absence of such agreement, the Tribunal shall apply the law of the Contracting State party to the dispute (including its rules on the conflict of laws) and such rules of international law as may be applicable.

(2) The Tribunal may not bring in a finding of non liquet on the ground of silence or obscurity of the law.

(3) The provisions of paragraphs (1) and (2) shall not prejudice the power of the Tribunal to decide ex aequo et bono if the parties so agree.

A despeito de tal autorização e do uso cada vez maior do ICSID nos últimos anos, ${ }^{695}$ somente um caso decidido por eqüidade foi encontrado nos arquivos daquela instituição. Trata-se do caso Benvenuti e Bonfant srl. vs. República do Congo, decidido no início dos anos 1980.696

Note-se que essa Convenção não menciona a lei aplicável à arbitragem como limite para decisão em eqüidade. Essa orientação é diversa das regras relativas à "Additonal Facility" da mesma instituição, que faz referência à lei aplicável à arbitragem. A razão para tal distinção é a de que a Convenção de Washington, sendo ato de direito internacional público, constitui a

693 Em inglês: Convention on the Settlement of Investment Disputes Between States and Nationals of Other States.

694 Esta Convenção possui mais de 140 membros, conforme informação do site do ICSID: <http://icsid.worldbank.org/ICSID/Index.jsp>. Acesso em: 28 dez. 2007. Até o presente momento, o Brasil não aderiu.

695 Havia mais de 120 casos pendentes de julgamento em 28.12.2007, conforme o site oficial do ICSID: <http:// icsid.worldbank.org/ICSID/FrontServlet?requestType=CasesRH\&actionVal=ListPending >.

696 Yearbook Commercial Arbitration, v. 8, p. 144 e ss., 1983. 
própria regulação da arbitragem, sem que seja necessário o recurso a qualquer lei nacional. ${ }^{697}$ Já as regras da "Additional Facility", que funcionam sobretudo para partes privadas, estará sujeita a leis nacionais (e eventualmente regras transnacionais, dependendo da orientação que se adote).

\subsubsection{Acordo sobre Arbitragem Comercial Internacional do Mercosul}

Como forma de harmonizar a legislação de seus integrantes e visando à promoção de meios alternativos de solução de controvérsias privadas no marco legal do Mercado Comum do Cone Sul ("Mercosul"), os países-membros editaram em 1998 o Acordo sobre Arbitragem Comercial do Mercosul (“Acordo"). ${ }^{698}$

O Acordo inovou consideravelmente o regime da arbitragem internacional dos paísesmembros. Embora se possa questionar sobre a conveniência de mais um ato normativo sobre matéria já bastante regulada, o Acordo é extenso e dispõe sobre vários aspectos do procedimento arbitral.

Entre tais disposições, consta expressamente a possibilidade de arbitragem por eqüidade, desde que haja acordo expresso entre as partes:

Artigo 9

Arbitragem de direito ou de eqüidade

Por disposição das partes, a arbitragem poderá ser de direito ou de eqüidade.

Na ausência de disposição, será de direito.

Tal disposição, embora não traga nenhuma novidade no tocante ao direito de arbitragem brasileiro ou o novo direito de arbitragem paraguaio, inova quanto ao direito de arbitragem argentino e uruguaio. Dentro de seu âmbito de aplicação, o Acordo inverte a tradicional presunção de arbitragem por eqüidade constante do direito daqueles dois países.

697 "An international arbitration is governed not only by the rules adopted (or adapted) by the parties and the arbitral tribunal, but also by the lex arbitri. It may well be that the lex arbitri will govern with a very free rein, but it will govern nonetheless. The only exception is the particular case of arbitration between investors and states under the ICSID Convention, which is almost entirely insulated from the place of arbitration. Interim measures may only be sought from the tribunal itself (unless there is an express agreement otherwise) and any review of the award is the exclusive domain of an ad hoc committee appointed by the institution itself rather than the courts of the place of arbitration." ReDFern, Alan; HunTer, Martin. Law and practice... cit., p. 6.

${ }^{698} \mathrm{O}$ ato foi ratificado pelo Brasil em 2003, com a edição do Decreto 4.719, de 04.06.2003. 
Em princípio, atos internacionais aplicam-se a arbitragens oriundas dos demais paísesmembros. Todavia, o art. 3. ${ }^{\circ}$ do Acordo apresenta uma série de critérios que excedem o simples âmbito territorial dos países do Mercosul. Os critérios de domicílio das partes, sede do tribunal arbitral, "contato objetivo" do contrato e intenção das partes podem ser aplicados por si ou cumulativamente. ${ }^{699}$ Assim, os efeitos do Acordo podem estender-se além do território de seus Estados-membros.

Além da permissão para a arbitragem por eqüidade desde que as partes assim escolham, o Acordo ainda determina que a sentença arbitral seja fundamentada, ainda que proferida por eqüidade. ${ }^{700}$ Assim, ao contrário de outros atos internacionais, normalmente econômicos no tratamento sobre a arbitragem por eqüidade, o Acordo a prevê e determina que a respectiva sentença seja motivada.

No âmbito do Mercosul, porém fora da arbitragem comercial, existem ainda duas disposições sobre decisões por eqüidade em controvérsias entre seus membros. Tanto o Protocolo

699 Artigo 3.

Âmbito material e espacial de aplicação.

O presente Acordo se aplicará à arbitragem, sua organização e procedimentos e às sentenças ou laudos arbitrais, se ocorrer alguma das seguintes circunstâncias:

a) a convenção arbitral for celebrada entre pessoas físicas ou jurídicas que, no momento de sua celebração, tenham sua residência habitual ou o centro principal dos negócios, ou a sede, ou sucursais, ou estabelecimentos ou agências, em mais de uma Parte Signatária;

b) o contrato-base tiver algum contato objetivo - jurídico ou econômico - com mais de uma Parte Signatária;

c) se as partes não expressarem sua vontade em contrário e o contrato-base tiver algum contato objetivo - jurídico ou econômico - com uma Parte Signatária, sempre que o tribunal tenha a sua sede em uma das Partes Signatárias;

d) o contrato-base tiver algum contato objetivo - jurídico ou econômico - com uma Parte Signatária e o tribunal arbitral não tiver sua sede em nenhuma Parte Signatária, sempre que as partes declararem expressamente sua intenção de submeter-se ao presente Acordo;

e) o contrato-base não tiver nenhum contato objetivo - jurídico ou econômico - com uma Parte Signatária e as partes tenham elegido um tribunal arbitral com sede em uma Parte Signatária, sempre que as partes declararem expressamente sua intenção de submeter-se ao pressente Acordo.

700 Artigo 20.

Laudo ou sentença arbitral

1 - O laudo ou sentença arbitral será escrito, fundamentado e decidirá completamente o litígio. O laudo ou sentença será definitivo e obrigatório para as partes e não admitirá recursos, exceto os estabelecidos nos arts. 21 e 22.

2 - Quando houver diversos árbitros, a decisão será tomada por maioria. Caso não se obtenha maioria, a questão será decidida pelo voto do presidente.

3 - O árbitro que discorde da maioria poderá declarar e fundamentar seu voto em separado.

4 - O laudo ou sentença será assinado pelos árbitros e conterá:

a) a data e lugar em que foi proferido;

b) os fundamentos em que se baseia, ainda que seja por eqüidade;

c) a decisão acerca da totalidade das questões submetidas à arbitragem;

d) as despesas da arbitragem. [...] 
de Brasília ${ }^{701}$ quanto seu sucessor, o Protocolo de Olivos, ${ }^{702}$ prevêem a possibilidade de decisões por eqüidade em tribunais arbitrais instituídos para dirimir disputas entre os Estados-membros.

\subsubsection{Convenção de Amã sobre Arbitragem Comercial}

Em 1987, 15 países árabes celebraram a Convenção de Amã sobre Arbitragem Comercial com o objetivo de criar um regime comum sobre a matéria em seu território. Em seu preâmbulo, a Convenção informa que os países são desejosos de encontrar soluções eqüitativas para as disputas comerciais, ${ }^{703}$ embora o sentido dessa expressão deva ser entendido como um desejo geral de justiça e não como uma referência a um tipo de arbitragem. Não obstante, a Convenção dispõe sobre as regras de direito aplicáveis ao mérito em seu art. 21, no qual prevê que o tribunal arbitral "deve" julgar conforme as "regras de eqüidade" caso as partes convencionem expressamente. ${ }^{704}$

$701 \quad$ Artigo 19

1. O Tribunal Arbitral decidirá a controvérsia com base nas disposições do Tratado de Assunção, dos acordos celebrados no âmbito do mesmo, das decisões do Conselho do Mercado Comum, bem como nos princípios e disposições do direito internacional aplicáveis à matéria.

2. A presente disposição não restringe a faculdade do Tribunal Arbitral de decidir uma controvérsia ex aequo et bono, se as partes assim convierem. (Decreto n. 922, de 10 de setembro de 1993.)

702 Artigo 17.

Recurso de Revisão

1. Qualquer das partes na controvérsia poderá apresentar um recurso de revisão do laudo do Tribunal Arbitral Ad Hoc ao Tribunal Permanente de Revisão, em prazo não superior a quinze (15) dias a partir da notificação do mesmo.

2. O recurso estará limitado a questões de direito tratadas na controvérsia e às interpretações jurídicas desenvolvidas no laudo do Tribunal Arbitral Ad Hoc.

3.Os laudos dos Tribunais Ad Hoc emitidos com base nos princípios ex aequo et bono não serão suscetíveis de recurso de revisão.

4. A Secretaria Administrativa do Mercosul estará encarregada das gestões administrativas que lhe sejam encomendadas para o trâmite dos procedimentos e manterá informados os Estados partes na controvérsia e o Grupo Mercado Comum. [...]

Artigo 34 .

Direito Aplicável

1. Os Tribunais Arbitrais Ad Hoc e o Tribunal Permanente de Revisão decidirão a controvérsia com base no Tratado de Assunção, no Protocolo de Ouro Preto, nos protocolos e acordos celebrados no marco do Tratado de Assunção, nas Decisões do Conselho do Mercado Comum, nas Resoluções do Grupo Mercado Comum e nas Diretrizes da Comissão de Comércio do Mercosul, bem como nos princípios e disposições de Direito Internacional aplicáveis à matéria.

2. A presente disposição não restringe a faculdade dos Tribunais Arbitrais Ad Hoc ou a do Tribunal Permanente de Revisão, quando atue como instância direta e única conforme o disposto no artigo 23, de decidir a controvérsia ex aequo et bono, se as partes assim acordarem. (Decreto n.o 4.982, de 9 de fevereiro de 2004.)

703 Soucieux de réaliser un juste équilibre en matière de résolution des différends susceptibles de naître des contrats commerciaux internationaux, de même que de trouver des solutions équitables à ces différends.

704 Article 21.

1. Le tribunal arbitral statue sur le différend conformément aux termes du contrat conclu entre les parties et aux dispositions de la loi dont elles sont convenues expressément ou tacitement, sinon de la loi la plus en 


\subsubsection{Organização para Harmonização do Direito Empresarial na África (OHADA)}

Em 1993, diversos países africanos celebraram um Tratado relativo à Harmonização do Direito Empresarial na África, pelo qual foi instituída a Organização para Harmonização do Direito Empresarial na África (“OHADA”). Entre outras matérias, as partes criaram uma Corte Comum de Justiça e Arbitragem da OHADA, que tem por atribuição administrar arbitragens, inclusive as de natureza privada entre partes oriundas dos paísesmembros.

O regulamento de arbitragem da Corte determina que, quando o árbitro receber o procedimento, deverá convocar as partes para uma primeira reunião, na qual serão decididos diversos aspectos procedimentais preliminares da arbitragem. O regulamento prescreve que, "em caso de necessidade, o árbitro deve inquirir as partes para saber se elas pretendem atribuir-lhe o poder de julgar por eqüidade". ${ }^{705}$ Trata-se de uma disposição original, cuja intenção subjacente parece ser a de garantir que as partes sejam explícitas acerca de sua intenção quanto ao critério de julgamento. A norma da OHADA é dirigida ao comportamento do árbitro, embora conceda alguma discricionariedade, evidenciada pela expressão “caso necessário". Presume-se que tal necessidade apareça quando houver dúvida sobre a intenção das partes.

Ao dispor sobre o direito aplicável ao mérito da controvérsia, o regulamento prevê que o julgamento será por eqüidade caso as partes tenham-se colocado de acordo sobre esse

rapport avec l'objet du différend sauf à respecter les règles bien établies en matière d'usage commercial international.

Le tribunal arbitral doit statuer selon les règles de l'équité si les parties en conviennent expressément.

705 Article 15.

15.1 Après réception du dossier par l'arbitre, celui-ci convoque les parties ou leurs représentants dûment habilités et leurs conseils, à une réunion qui doit se tenir aussi rapidement qu'il est possible, et au plus tard dans les soixante (60) jours de cette réception du dossier.

Cette réunion a pour objet:

a) de constater la saisine de l'arbitre et les demandes sur lesquelles il doit se prononcer. Il est procédé à une énumération de ces demandes telles qu'elles résultent des mémoires respectivement produits par les parties à cette date, avec une indication sommaire des motifs de ces demandes et des moyens invoqués pour qu'il y soit fait droit;

b) de constater s'il existe ou non un accord des parties sur les points énumérés aux articles 5.e) et 6.b) et d) ci-dessus.

En l'absence d'un tel accord, l'arbitre constate que la sentence aura à se prononcer à ce sujet.

La langue de l'arbitrage fait, au cours de la réunion, l'objet d'une décision immédiate de l'arbitre au vu des dires des parties sur ce point, en tenant compte des circonstances.

En cas de besoin l'arbitre interroge les parties pour savoir si celles-ci entendent lui attribuer les pouvoirs d'amiable compositeur. Il est fait mention de la réponse des parties. [...] 
aspecto na convenção de arbitragem ou posteriormente. ${ }^{706}$ Assim, o regulamento adere à regra tradicional de condicionar a decisão por eqüidade a acordo das partes, acrescentando disposição acerca do tempo para a escolha.

\subsubsection{Convenção do Panamá}

Em 30.01.1975, diversos Estados-membros da Organização dos Estados Americanos (OEA) concluíram uma Convenção Interamericana sobre Arbitragem Comercial Internacional, também chamada de Convenção do Panamá. Seu objeto é o reconhecimento de cláusulas e sentenças arbitrais entre os países que a ela aderirem.

Em larga medida, a Convenção do Panamá reafirma os princípios da CNI, com alguns acréscimos. A elaboração de um ato em termos próximos aos da CNI pode ser explicada pelo momento histórico de sua elaboração: na década de 1970, boa parte dos países latino-americanos ainda não havia aderido à CNI, panorama que só veio a ser modificado a partir da década de 1980 .

A Convenção do Panamá não trata diretamente da arbitragem por eqüidade, a exemplo da CNI. No entanto, possui uma regra segundo a qual, caso as partes não escolham o regulamento de arbitragem, aplicam-se as regras da Comissão Interamericana de arbitragem comercial. ${ }^{707}$ Tais regras, por sua vez, prevêem a arbitragem por eqüidade, no caso de acordo expresso entre as partes e se a lei aplicável ao procedimento permitir. ${ }^{708}$ Assim, ainda que de modo indireto, a Convenção do Panamá remete à possibilidade de arbitragem por eqüidade,

706 Article 17.

Les parties sont libres de déterminer le droit que l'arbitre devra appliquer au fond du litige. A défaut d'indication par les parties du droit applicable, l'arbitre appliquera la loi désignée par la règle de conflit qu'il jugera appropriée en l'espèce.

Dans tous les cas, l'arbitre tiendra compte des stipulations du contrat et des usages du commerce.

L'arbitre reçoit les pouvoirs d'amiable compositeur si les parties ont donné leur accord sur ce point dans la convention d'arbitrage, ou postérieurement.

707 Artigo 3. Na falta de acordo expresso entre as partes, a arbitragem será efetuada de acordo com as normas de procedimento da Comissão Interamericana de Arbitragem Comercial.

708 Lei Aplicável e Eqüidade

Artigo 30.

1. O tribunal arbitral aplicará a lei designada pelas partes como aplicável ao mérito do litígio. Se as partes deixarem de fazer essa designação, o tribunal arbitral aplicará a lei determinada pelas regras de conflito que considerar aplicada.

2. O tribunal arbitral somente decidirá por eqüidade ou ex aequo et bono somente se as partes autorizarem-no expressamente e a lei aplicável ao procedimento arbitral assim permitir.

3. Em todos os casos, o tribunal arbitral decidirá de acordo com os termos do contrato e levará em consideração os usos e costumes do comércio aplicáveis ao contrato. Disponível no site oficial do CIAC: <http://www. ciac-iacac.org/documentos/2006_5_8_15_7_21_Regulamento\%20CIAC.pdf>. Acesso em: 30 set. 2008. 


\subsubsection{Agência Multilateral de Garantia de Investimentos (MIGA)}

Em 1985, sob os auspícios do Banco Mundial, foi celebrada a Convenção criadora da Agência Multilateral de Garantia de Investimentos (MIGA). ${ }^{709}$ Embora funcione como entidade independente, a MIGA tem vínculos funcionais com o Banco Mundial.

Na Convenção, foram previstas algumas formas de solução de controvérsias. Entre elas, a arbitragem de disputas oriundas de contratos de garantia ou resseguros. Neste caso, a Convenção remete as partes para arbitragem conforme as regras acordadas no contrato. Nas disputas entre a Agência e seus membros, a Convenção estabelece um procedimento arbitral específico em seu Anexo II. Neste anexo, além de referências ao procedimento do CIRDI/ ICSID, existe previsão expressa de que as partes podem escolher que a decisão seja feita por eqüidade. ${ }^{710}$

\subsubsection{Acordos de Argel}

Os Acordos de Argel foram elaborados pelos governos dos EUA e do Irã, para a solução de controvérsias decorrentes de atos subseqüentes à revolução iraniana de 1979. Os acordos criaram um tribunal arbitral chamado Tribunal para Disputas Irã-Estados Unidos (Iran-United States Claims Tribunal), sediado na Haia, e que teria por competência conhecer de pedidos de cidadãos de ambos os países. Embora tenha origem no direito internacional público e caráter institucional, o Tribunal conheceu de pedidos de partes privadas sobre matérias civis e comerciais.

O Tribunal aplicava o regulamento da CNUDCI, sujeito a algumas alterações. ${ }^{711}$ No que diz respeito à arbitragem por eqüidade, houve uma pequena modificação para acrescentar que a autorização das partes deve ser feita por escrito e retirar a menção à autorização da lei

709 Nome em inglês: Convention Establishing the Multilateral Investment Guarantee Agency.
710 Article 4. Arbitration.

$[\ldots]$

(g) The Tribunal shall, in any dispute within the scope of this Annex, apply the provisions of this Convention, any relevant agreement between the parties to the dispute, the Agency's by-laws and regulations, the applicable rules of international law, the domestic law of the member concerned as well as the applicable provisions of the investment contract, if any. Without prejudice to the provisions of this Convention, the Tribunal may decide a dispute ex aequo et bono if the Agency and the member concerned so agree. The Tribunal may not bring a finding of non liquet on the ground of silence or obscurity of the law.

Fonte: Yearbook Commercial Arbitration, v. 12, p. 219 e ss., 1987.

711 2. Members of the Tribunal shall be appointed and the Tribunal shall conduct its business in accordance with the arbitration rules of the United Nations Commission on International Trade Law (Uncitral) except to the extent modified by the parties or by the Tribunal to ensure that this agreement can be carried out. The Uncitral 
aplicável ao procedimento. ${ }^{712}$ Assim, era possível a escolha de tal forma de decisão, embora não tenham sido encontrados casos julgados por eqüidade. De qualquer modo, trata-se de um reconhecimento indireto da arbitragem por eqüidade em tratado internacional, tal como no caso da Convenção do Panamá.

\subsubsection{Convenção de Estrasburgo}

Em 1966, um grupo de especialistas em arbitragem reunido no âmbito do Conselho Europeu elaborou uma Convenção Européia criando uma Lei Uniforme sobre Arbitragem. Essa Convenção foi assinada por dois países e ratificada por apenas um. Em seu art. 21, aquela lei uniforme prevê que, salvo disposição em contrário, o tribunal arbitral decide a questão de acordo com o direito. ${ }^{713}$ Essa é a técnica legislativa adotada pela Bélgica, o único país que ratificou a Convenção.

A mesma Convenção, em seu Anexo II, dispõe sobre diversas reservas possíveis quando da adesão pelos Estados. Entre elas, encontra-se a faculdade de dispor que a liberação dos árbitros de decidir conforme a lei somente pode ser outorgada quando já houver uma disputa concreta. ${ }^{714}$ Essa disposição era encontrada, não por acaso, no direito belga até a década de 1990. A razão de tal regra é a de que somente após a verificação da disputa real as partes podem escolher o regime excepcional de não-aplicação do direito.

rules for appointing members of three-member Tribunals shall apply mutatis mutandis to the appointment of the Tribunal. [...]

Fonte: Yearbook Commercial Arbitration, v. 7, p. 257 e ss., 1982.

712 Applicable Law

Article 33.

Text of Uncitral Rule

$[\ldots]$

Modification of the Uncitral Rule

Article 33 of the Uncitral is modified to read as follows:

1. The arbitral tribunal shall decide all cases on the basis of respect for law, applying such choice of law rules and principles of commercial and international law as the arbitral tribunal determines to be applicable, taking into account relevant usages of the trade, contract provisions and changed circumstances.

2. The arbitral tribunal shall decide ex aequo et bono only if the arbitrating parties have expressly and in writing authorized it to do so.

Disponível em: <http://www.iusct.org/tribunal-rules.pdf>. Acesso em: 29 set. 2008.

713 Article 21.

Except where otherwise stipulated, arbitrators shall make their awards in accordance with the rules of law.

Disponível em: <http://conventions.coe.int/treaty/en/Treaties/Html/056.htm:. Acesso em: 20 set. 2008.

$714 \mathrm{~g})$ to provide that it is only after a dispute has arisen that the parties may, in pursuance of Article 21 of the uniform law, exempt the arbitrators from deciding in accordance with the rules of Law. 


\subsubsection{Convenção Estabelecendo a Sociedade Inter-Árabe para Garantia de Investimentos}

Em 1971, foi elaborada uma Convenção Estabelecendo a Sociedade Inter-Árabe para Garantia de Investimentos, sob os auspícios de órgãos ligados à Liga Árabe. A Convenção previu que, para algumas espécies de conflitos envolvendo países-membros e a sociedade, seriam aplicadas as regras de arbitragem previstas no Anexo I da Convenção. Essas regras prevêem que as partes podem determinar que a disputa seja dirimida por eqüidade. ${ }^{715}$

\subsubsection{Convenção de Moscou}

A Convenção sobre a Resolução por Arbitragem de Disputas Civis Oriundas de Relações de Cooperação Econômica e Técnico-Científicas de 1972, chamada de Convenção de Moscou, foi o mais importante ato internacional relativo à arbitragem nos países do bloco socialista, produzida no âmbito do Conselho para Ajuda Econômica Mútua (Comecon).

A Convenção estabelecia a competência das Cortes de Arbitragem adjuntas às Câmaras de Comércio dos países-membros para dirimir divergências oriundas de acordos de cooperação econômica e técnico-científicas entre "organizações econômicas" de seus países. Também previa a forma de execução das respectivas sentenças. A Convenção de Moscou não se ocupou de regulamentar o direito aplicável, ${ }^{716}$ tampouco menciona a arbitragem por eqüidade. ${ }^{717}$

\subsubsection{Outros Tratados}

Outros tratados sobre arbitragem ou reconhecimento de sentenças arbitrais também não fazem nenhuma menção à arbitragem por eqüidade. Entre os pesquisados, podem-se mencio-

715 Article 4. Arbitration.

$[\ldots]$

2. Substantive Law in the application of the provisions of this Convention, the regulations of the Corporation, decisions of the Shareholders' Council or the Board of Directors and other contractual rules relied upon by the parties to the dispute, the Arbitration Tribunal shall abide by the legal sources set out in Article 6 of this Convention.

Subject to the agreement of the parties to the dispute, the Tribunal may decide on the dispute in accordance with principles of justice and equity.

In no event shall the Tribunal refrain from giving judgment in the dispute on the ground of deficiency or uncertainty of the applicable law.

Disponível em: <www.kluwerarbitration.com>. Acesso em: 20 set. 2008.

716 Embora, em alguns casos, a escolha de uma Corte de Arbitragem implicava igualmente a escolha de um direito aplicável.

717 Fonte: International Handbook on Commercial Arbitration, suplemento 5, maio 1986. 
nar a Convenção da Liga Árabe sobre Execução de Julgados e Sentenças Arbitrais, de 1952; $;^{718}$ a Convenção Interamericana sobre Eficácia Extraterritorial das Sentenças e Laudos Arbitrais Estrangeiros, de 1979, também conhecida como Convenção de Montevidéu; ${ }^{719}$ o Acordo para Promoção, Proteção e Garantia de Investimentos entre os países da Organização da Conferência Islâmica, que prevê procedimento específico para arbitragem; ${ }^{720}$ e a Convenção Árabe sobre Cooperação Judicial, de 1983, também chamada de Convenção de Riad. ${ }^{721}$

\subsection{Legislações Nacionais}

\subsection{1 África do Sul}

A África do Sul ainda não passou pela reforma da legislação de arbitragem que tem ocorrido no restante do mundo. Sua lei de arbitragem é o Arbitration Act 42 de 1965, que parece seguir os moldes da common law anterior ao movimento de renovação.

O Arbitration Act não possui provisão específica sobre arbitragem por eqüidade. Entretanto, a doutrina sul-africana apresentada nas coletâneas de arbitragem internacional indica que nada proíbe o uso desse tipo de arbitragem. ${ }^{722}$ Assim, a ausência de menção não deve ser entendida como proibição ao uso da arbitragem por eqüidade. Todavia, é lícito inferir que a ausência de disposição específica aliada a um sistema de common law indica pouca utilização deste tipo de arbitragem.

\subsubsection{Alemanha}

Tradicionalmente, o direito da República Federal da Alemanha era silente sobre a possibilidade de arbitragens por eqüidade. Entretanto, sua prática era de que, caso as partes decidissem conferir o poder de decidir por eqüidade aos árbitros, o acordo seria respeitado.

\footnotetext{
718 Fonte: International Handbook on Commercial Arbitration, suplemento 17, jan. 1994.

719 Decreto 2.411, de 02.12.1997.

720 Disponível em: <www.kluwerarbitration.com>. Acesso em: 20 set. 2008.

721 Fonte: International Handbook on Commercial Arbitration, suplemento 11, jan. 1990.

722 Relatório sobre África do Sul elaborado por Lane, Patrick M.M. In: PAULSson, Jan. International Handbook on Commercial Arbitration. Alphen aan den Rijn: Kluwer Law International, 2007 (data do suplemento: 1995): "An arbitrator is not empowered by the Act to decide as amiable compositeur or ex aequo et bono but there is nothing to prevent the parties agreeing that he should act accordingly."

Para uma visão histórica do direito da arbitragem na África do Sul, entretanto sem maiores efeitos para o estudo do direito atual, veja-se Pyemont, L.O.P. Arbitration in South Africa. Johannesburg: The Transvaal Leader, 1914.
} 
Em 1998, a Alemanha promoveu uma reforma de seu direito de arbitragem, adotando em larga medida a Lei Modelo da CNUDCI. Assim, com a edição da nova lei, publicada em 22.12.1997, o art. 1.051 do Código de Processo Civil passou a prever expressamente a possibilidade de arbitragem por eqüidade, nos moldes da Lei Modelo. Assim, pode-se usar a eqüidade caso as partes expressamente autorizem. À falta de disposição específica, presume-se que a arbitragem seja de direito.

$\mathrm{Na}$ língua original, o referido artigo apenas menciona a palavra "Billigkeit", traduzida normalmente como eqüidade. ${ }^{723}$ Não faz alusão às variantes ex aequo et bono e amiable composition previstas no texto original da Lei Modelo. ${ }^{724}$

723 Vide Smit, Hans; Реснота, V. Smit's Guides to International Arbitration: National Arbitration Laws. Huntington: JurisNet, 2006. p. GER B(1)-11.

$\S 1.051$. Anwendbares Recht

(1) Das Schiedsgericht hat die Streitigkeit in Übereinstimmung mit den Rechtsvorschriften zu entscheiden, die von den Parteien als auf den Inhalt des Rechtsstreits anwendbar bezeichnet worden sind. Die Bezeichnung des Rechts oder der Rechtsordnung eines bestimmten Staates ist, sofern die Parteien nicht ausdrücklich etwas anderes vereinbart haben, als unmittelbare Verweisung auf die Sachvorschriften dieses Staates und nicht auf sein Kollisionsrecht zu verstehen.

(2) Haben die Parteien die anzuwendenden Rechtsvorschriften nicht bestimmt, so hat das Schiedsgericht das Recht des Staates anzuwenden, mit dem der Gegenstand des Verfahrens die engsten Verbindungen aufweist.

(3) Das Schiedsgericht hat nur dann nach Billigkeit zu entscheiden, wenn die Parteien es ausdrücklich dazu ermächtigt haben. Die Ermächtigung kann bis zur Entscheidung des Schiedsgerichts erteilt werden.

(4) In allen Fällen hat das Schiedsgericht in Übereinstimmung mit den Bestimmungen des Vertrages zu entscheiden und dabei bestehende Handelsbräuche zu berücksichtigen.

Tambem o sitio de internet da Deutsche Institution fuer Schiedsgerichtbarkeit ("DIS").

Disponível em: <http://www.dis-arb.de/>. Acesso em: 9 out. 2007.

724 Contudo, as versões inglesas publicadas no International Handbook on Commercial Arbitration (suplemento 34, p. Germany: Annex I- 9, dez. 2001,) e no livro de H. Smit e V. Pechota utilizam a terminologia dupla da Lei Modelo:

"Section 1.051. Rules Applicable to Substance of Dispute

(1) The arbitral tribunal shall decide the dispute in accordance with such rules of law as are chosen by the parties as applicable to the substance of the dispute. Any designation of the law or legal system of a given State shall be construed, unless otherwise expressed, as directly referring to the substantive law of that State and not to its conflict of laws rules.

(2) Failing any designation by the parties, the arbitral tribunal shall apply the law of the State with which the subject-matter of the proceedings is most closely connected.

(3) The arbitral tribunal shall decide ex aequo et bono or as amiable compositeur only if the parties have expressly authorized it to do so. The parties may so authorize the arbitral tribunal up to the time of its decision.

(4) In all cases, the arbitral tribunal shall decide in accordance with the terms of the contract and shall take into account the usages of the trade applicable to the transaction" (texto utilizado do International Handbook).

As traduções feitas pela própria DIS (seguramente uma das mais respeitáveis instituições de arbitragem naquele país) para outras línguas não mantêm consistência no uso dos termos. A tradução para o francês usa apenas o termo "equite" e a tradução para o espanhol adota os termos da Lei Modelo, tal como no original (amiable composition e ex aequo et bono). A versão inglesa naquele site também emprega as duas expressões da Lei Modelo (Disponível em: <http://www.dis-arb.de/>. Acesso em: 9 out. 2007). 


\subsubsection{Arábia Saudita}

A principal lei da Arábia Saudita sobre arbitragem é o Decreto Real M/46, de 25.04.1983, que foi seguida das regras de implementação editadas pelo Conselho de Ministros em 27.05.1985. A legislação saudita, segundo as fontes consultadas, ${ }^{725}$ não possui uma provisão exata sobre o julgamento por eqüidade. Entretanto, o art. 16 do decreto real é apontado como permissão para este tipo de decisão. ${ }^{726}$ No entanto, a tradução do referido artigo em inglês utiliza a palavra "compromise", a partir do original árabe "sulh". ${ }^{727}$

Na lei muçulmana, também conhecida como shari'a, sulh aparece como uma forma de conciliação oriunda da escola sunita hanafi, cujos ensinamentos foram em parte reunidos no Império Otomano, em um código conhecido como Majalla. Embora tenha um caráter mais próximo da conciliação, ela é apontada como um possível equivalente da arbitragem por eqüidade ocidental ${ }^{728}$ e que resulta em uma decisão irrecorrível. ${ }^{729}$ Portanto, possivelmente a utilização da sulh tem efeitos bastante próximos de uma decisão por eqüidade.

Outros autores apontam que, a despeito da ausência de uma previsão específica sobre arbitragem por eqüidade, a prática demonstra que tal espécie de arbitragem seria aceita desde que as partes assim consintam. ${ }^{730}$

\subsubsection{Argélia}

A Argélia editou sua atual legislação sobre arbitragem em 1993, por meio do Decreto Legislativo 93-09, de 25.04.1993, que alterou disposições do Código de Processo Civil (originalmente editado em 1966). No art. 458 bis 15, há previsão de que o tribunal arbitral apenas

725 Turck, Nancy B. Relatório sobre Arábia Saudita. In: PAulsson, Jan (Ed.). International Handbook on Commercial Arbitration, cit. (data do suplemento: jan. 2004) e SMIT, H. e Pechota. Smit's Guides to International Arbitration, cit.

726 Smit, H. e Pechota. Smit's Guides to International Arbitration, cit., p. SAU C-8.

727 Paulsson, Jan (Ed.). International Handbook on Commercial Arbitration, cit., p. Saudi Arábia Annex I-2.: "Article 16: The decision of the arbitrators shall be taken by a majority vote and if they authorized to reach a compromise solution (Arabic: sulh), their decision shall be by unanimity".

Em termos similares Smit, H. e Pechota. Smit’s Guides to International Arbitration, cit., p. SAU B-3.

728 SAleh, Samir. Commercial Arbitration in the Arab Middle East: Shari'a, Lebanon, Syria and Egypt. 2. ed. Oxford: Hart Publishing, 2006. p. 45.

729 Idem, ibidem, p. 73.

730 Turck, Nancy B. Relatório sobre Arábia Saudita, cit., p. Saudi Arábia 24:

"Neither the Regulation nor the Rules address the question whether arbitrators can be authorized to decide as amiables compositeurs. However, from our experience, arbitrators are entitled to do so, if parties so stipulate". 
decidirá por eqüidade se as partes expressamente o autorizarem: "Le tribunal arbitral statue comme amiable compositeur si la convention des parties lui a conféré ce pouvoir". ${ }^{731}$

Portanto, a Argélia permite a arbitragem por eqüidade e filia-se à orientação de presunção da arbitragem de direito.

\subsubsection{Argentina}

A Argentina prevê a arbitragem por eqüidade em seu Código de Processo Civil, nos arts. 766 e seguintes. No direito argentino, há uma divisão dos tipos de arbitragem entre arbitragem de direito e arbitragem de eqüidade. No Livro VI de seu Código de Processo Civil, denominado juicio arbitral, há divisão entre o juicio arbitral, que se desenvolve conforme o direito, e o juicio de amigables componedores.

Uma particularidade da legislação argentina (comum a outros países hispano-americanos) é a presunção de arbitragem por eqüidade. Com efeito, conforme previsto no art. 766 do Código de Processo Civil local:

\section{OBJETO. CLASE DE ARBITRAJE}

Art. 766. Podrán someterse a la decisión de arbitradores o amigables componedores, las cuestiones que pueden ser objeto del juicio de árbitros.

Si nada se hubiese estipulado en el compromiso acerca de si el arbitraje ha de ser de derecho o de amigables componedores, o si se hubiese autorizado a los árbitros a decidir la controversia según equidad, se entenderá que es de amigables componedores.

Também em comum com outros direitos hispano-americanos, o direito argentino distingue procedimentalmente a arbitragem de direito e de eqüidade. A arbitragem de direito possui alguns requisitos bastante formais, tais como a obrigatoriedade de um secretário juramentado (art. 749) e a aplicação do procedimento judicial caso as partes não o tenham estipulado na cláusula ou no compromisso. Já a escolha de arbitragem por eqüidade tem o efeito de liberalizar o procedimento, eis que os amigables componedores procederão "sem sujeição a formas legais", limitando-se a receber documentos e a solicitar das partes as explicações que julgarem neces-

731 Disponível em: <www.kluwerarbitration.com>. Acesso em: 25 set. 2007. Também citado em Revue de l'Arbitrage, n. 3, p. 478 e ss.; e Sмiт, H.; Реснота, V. Smit's Guides to International Arbitration: National Arbitration Laws. Huntington: JurisNet, 2006. p: ALG B-8 (data do suplemento: 1999). 
sárias para julgar conforme "seu saber e entender". ${ }^{732}$ A doutrina argentina consultada não diferencia o juízo de amigables componedores de uma decisão por eqüidade. ${ }^{733}$ Portanto, pode-se assumir que os termos são utilizados como sinônimos. Mesmo que a legislação argentina tenha seguido a fórmula encontrada em alguns países hispano-americanos de julgamento conforme “saber e entender", é geralmente aceito que tal fórmula contempla um juízo de eqüidade.

Portanto, embora a legislação argentina tenha sido reformada nos primórdios da década de 1980, ${ }^{734}$ a Argentina ainda filia-se à corrente hispano-americana "clássica", com a divisão inclusive procedimental entre os dois tipos de arbitragem, em geral com presunção do uso de eqüidade no silêncio das partes. Embora alguns autores apontem que o uso dos termos amigable composición é derivado do equivalente francês amiable composition, ${ }^{735}$ é possível observar maiores similaridades com o direito de outros países hispano-americanos, que também utilizam a expressão amigable composicion e/ou amigable componedores, bem como com o direito espanhol anterior à década de 1950, do que com o regime francês da arbitragem por eqüidade. Especialmente a presunção de eqüidade parece ser um elemento essencialmente hispano-americano (embora tenha sido abandonada em alguns países em decorrência de reformas legislativas mais recentes, como foi o caso do Paraguai e da própria Espanha), jamais adotado na legislação francesa.

Aparte da questão processual e do direito aplicável ao mérito, os dois tipos de arbitragem possuem uma disciplina comum no que diz respeito à capacidade de contratar arbitragem, aos requisitos do compromisso, à forma de indicação dos árbitros, sua qualificação e forma do laudo. ${ }^{736}$ No tocante à qualificação dos árbitros, o direito argentino afasta-se de alguns direitos

732 Procedimiento. Carácter de la actuacion

Art. 769. Los amigables componedores procederán sin sujeción a formas legales, limitándose a recibir los antecedentes o documentos que las partes les presentasen, a pedirles las explicaciones que creyeren convenientes, y a dictar sentencia según su saber y entender.

733 Para uma visão mais geral das divisões da arbitragem na Argentina, veja-se: CAIvano, Roque J. Arbitraje. Buenos Aires: Ad Hoc Villela Editor, 2000. p. 71 e ss. Fernandez, Raymundo L.; Gomez Leo, Osvaldo R. El Arbitraje en el Código de Comercio in LA LEY 1981-D, p. 1.308; ANAYA, Jaime. Equidad y amigable composición. El derecho, 181, p. 548. Colombo, Carlos J.; KIPER, Claudio M. Código Procesal Comercial y Civil de la Nación anotado y comentado. Buenos Aires: La Ley, 2006, t. VI, p. 673 e ss.; Pucci, Adriana Noemi. El arbitraje... cit., p. 135 e ss.

734 Lei 22.434, de 16.03.1981. Fonte: Smit, Hans; Реснота, V. Smit's Guides to International Arbitration, cit., p: ARG A-1. Relativamente aos demais textos de lei, p: ARG B(1)-2 e ss.

735 Caivano, Roque J. Arbitraje, cit., p. 73.

736 Normas Comunes

Art. 767. Se aplicará al juicio de amigables componedores lo prescripto para los árbitros respecto de:

1) La capacidad de los contrayentes.

2) El contenido y forma del compromiso.

3) Calidad que deban tener los arbitradores y forma de nombramiento.

4) La aceptación del cargo y responsabilidad de los arbitradores.

5) El modo de reemplazarlos. 
hispano-americanos, que exigem formação em direito para árbitros de direito, dispensando tal qualificação em arbitragens de eqüidade. No direito argentino, não há necessidade de formação profissional específica.

Por outro lado, o regime de impedimento dos árbitros de eqüidade é diferente do de árbitros de direito. Segundo o art. 768 do Código de Processo Civil, somente poderá haver recusa de árbitros de eqüidade por causas posteriores a sua indicação. Além disso, há um número fechado de causas de recusa, ao passo que na arbitragem de direito os motivos de impedimento são os mesmos dos juízes estatais. ${ }^{737} \mathrm{O}$ prazo para finalização do laudo em regra pode ser fixado pelas partes. Entretanto, se estas não tiverem fixado, no caso de arbitragem de direito, o prazo será fixado pelo juiz (art. 755) e no caso de arbitragem de eqüidade o prazo será de três meses (art. 770). ${ }^{738}$

O regime recursal também é diferente em ambos os casos. Enquanto na arbitragem de direito as partes podem recorrer como fariam em relação a uma sentença, salvo convenção em contrário das partes (art. 758), no caso de arbitragem de eqüidade não é permitido recurso, salvo demanda de anulação da sentença, com base em desrespeito aos prazos ou decisão fora do compromisso. ${ }^{739}$ Essa demanda não tem caráter de recurso. ${ }^{740}$

As disposições relativas ao reconhecimento e execução das sentenças estrangeiras nada dispõem sobre arbitragem por eqüidade.

6) La forma de acordar y pronunciar el laudo.

737 Recusaciones

Art. 768. Los amigables componedores podrán ser recusados únicamente por causas posteriores al nombramiento.

Sólo serán causas legales de recusación:

1) Interés directo o indirecto en el asunto.

2) Parentesco dentro del cuarto grado de consanguinidad, o segundo de afinidad con alguna de las partes.

3) Enemistad manifiesta con aquéllas, por hechos determinados.

En el incidente de recusación se procederá según lo prescripto para la de los árbitros.

738 Plazo

Art. 770. Si las partes no hubiesen fijado plazo, los amigables componedores deberán pronunciar el laudo dentro de los TRES (3) meses de la última aceptación.

739 Nulidad

Art. 771. El laudo de los amigables componedores no será recurrible, pero si se hubiese pronunciado fuera del plazo o sobre puntos no comprometidos, las partes podrán demandar su nulidad dentro de CINCO (5) días de notificado.

Presentada la demanda, el juez dará traslado a la otra parte por CINCO (5) días. Vencido este plazo, contestado o no el traslado, el juez resolverá acerca de la validez o nulidad del laudo, sin recurso alguno.

740 Colombo, Carlos J.; Kiper, Claudio M. Código Procesal Comercial y Civil..., cit., p. 755. 
Todavia, o regime de presunção de arbitragem por eqüidade na Argentina pode alterarse no âmbito do Acordo sobre Arbitragem Comercial Internacional do Mercosul, que dispõe em seu art. 9 que as partes poderão escolher arbitragem de direito ou de eqüidade e que, na ausência de disposição, a arbitragem será de direito. ${ }^{741}$

Portanto, tratando-se de arbitragem internacional em que uma das partes seja ou tenha sido domiciliada em algum dos países partes, ou o contrato seja relacionado com tais países ${ }^{742}$ a presunção de arbitragem por eqüidade não deve se aplicar. O autor desconhece, até a presente data, qualquer aplicação dessa regra por parte de tribunais argentinos.

\subsubsection{Austrália}

A Austrália tem editado novas disposições sobre arbitragem comercial internacional desde 1974 até o final dos anos 1980. Sendo um Estado federal, a Austrália possui legislação federal e estadual sobre a matéria. O International Arbitration Act é composto de quatro capítulos, que contêm disposições preliminares, a Convenção de Nova Iorque, a Lei Modelo da CNUDCI e a Convenção de Washington. Seguindo um modelo legislativo relativamente comum em países de common law, a Lei Modelo é colocada como um anexo da lei, sujeita às alte-

741 Artigo 9.

Arbitragem de direito ou de eqüidade

Por disposição das partes, a arbitragem poderá ser de direito ou de eqüidade. Na ausência de disposição, será de direito.

742 O âmbito de aplicação do acordo, conforme seu artigo 3 e complexo e envolve critérios pessoais, territoriais e em razão da matéria:

Artigo 3.

Ámbito material e espacial de aplicação

O presente Acordo se aplicará à arbitragem, sua organização e procedimentos e às sentenças ou laudos arbitrais, se ocorrer alguma das seguintes circunstâncias:

a) a convenção arbitral for celebrada entre pessoas físicas ou jurídicas que, no momento de sua celebração, tenham sua residência habitual ou o centro principal dos negócios, ou a sede, ou sucursais, ou estabelecimentos ou agências, em mais de uma Parte Signatária;

b) o contrato-base tiver algum contato objetivo - jurídico ou econômico - com mais de uma Parte Signatária;

c) se as partes não expressarem sua vontade em contrário e o contrato-base tiver algum contato objetivo - jurídico ou econômico - com uma Parte Signatária, sempre que o tribunal tenha a sua sede em uma das Partes Signatárias;

d) o contrato-base tiver algum contato objetivo - jurídico ou econômico - com uma Parte Signatária e o tribunal arbitral não tiver sua sede em nenhuma Parte Signatária, sempre que as partes declararem expressamente sua intenção de submeter-se ao presente Acordo;

e) o contrato-base não tiver nenhum contato objetivo - jurídico ou econômico - com uma Parte Signatária e as partes tenham elegido um tribunal arbitral com sede em uma Parte Signatária, sempre que as partes declararem expressamente sua intenção de submeter-se ao pressente Acordo. 
rações previstas no corpo desta. ${ }^{743}$ As partes podem optar pela não-aplicação da Lei Modelo. ${ }^{744}$ Paralelamente, todos os Estados e Territórios da Austrália adotaram o Commercial Arbitration Act, para reger arbitragens domésticas, de modo a unificar e modernizar o direito interno, anteriormente baseado na legislação inglesa anterior a 1950.

No que diz respeito à arbitragem por eqüidade, não houve alterações das disposições da Lei Modelo, razão pela qual seu regime aplica-se, ao menos quanto a arbitragens internacionais, na Austrália. Portanto, as partes podem autorizar o uso de arbitragem por eqüidade. Entretanto, se não o fizerem, a arbitragem será de direito. ${ }^{745}$

\subsection{7 Áustria}

A Áustria modificou recentemente sua legislação sobre arbitragem. A lei de arbitragem editada em 13.01.2006 reformou as disposições de arbitragem contidas no Código de Processo Civil austríaco, adaptando-o e adotando boa parte das disposições da Lei Modelo CNUDCI.

$\mathrm{O}$ art. 603 do referido Código expressamente permite a arbitragem por eqüidade, nos moldes da Lei Modelo: somente com expressa autorização das partes. ${ }^{746}$

Ao adotar a Lei Modelo, a Áustria preferiu utilizar apenas a palavra Billigkeit, normalmente traduzida como eqüidade, para denominar aquele tipo de arbitragem. Não utilizou

743 Smit, Hans; Реснота, V. Smit's Guides to International Arbitration, cit., p. AUS B-1 e ss.

744 Idem, ibidem, p. AUS A-1.

745 Sobre a autorização para decisão por eqüidade, vide também PAulsson, Jan (editor). PAulsson, Jan (Ed.). International Handbook on Commercial Arbitration, cit., p. Austrália 10.

746 Texto original: "§ 603. (1) Das Schiedsgericht hat die Streitigkeit in Übereinstimmung mit den Rechtsvorschriften oder Rechtsregeln zu entscheiden, die von den Parteien vereinbart worden sind. Die Vereinbarung des Rechts oder der Rechtsordnung eines bestimmten Staates ist, sofern die Parteien nicht ausdrücklich etwas anderes vereinbart haben, als unmittelbare Verweisung auf das materielle Recht dieses Staates und nicht auf sein Kollisionsrecht zu verstehen.

(2) Haben die Parteien die anzuwendenden Rechtsvorschriften oder Rechtsregeln nicht bestimmt, so hat das Schiedsgericht jene Rechtsvorschriften anzuwenden, die es für angemessen erachtet.

(3) Das Schiedsgericht hat nur dann nach Billigkeit zu entscheiden, wenn die Parteien es ausdrücklich dazu ermächtigt haben".

Tradução livre do item relevante: “(3) O árbitro decidirá por eqüidade apenas quando as partes autorizarem expressamente".

Texto original dsiponível no site da Câmara Federal de Economia, possivelmente a mais prestigiosa instituição austríaca de arbitragem: <http://portal.wko.at/wk/dok_detail_html.wk?AngID=1\&DocID=680199\&StID=32 5466>. Acesso em: 9 set. 2007. O mesmo sítio apresenta uma tradução para o inglês. Uma tradução para o francês foi publicada na Revue de l'Arbitrage, Paris, n. 2, p. 518 e ss., 2006. 
nenhuma das expressões previstas na Lei Modelo, tampouco utilizou mais de uma expressão para descrever tal arbitragem.

\subsubsection{Bahrain}

O Bahrain editou uma nova legislação sobre arbitragem comercial internacional em 1994. Trata-se do Decreto-lei 9 de 1994, que se baseia na Lei Modelo da CNUDCI.

Entretanto, há uma divergência relevante de fontes quanto ao conteúdo do referido Decreto-lei. Ao passo que o International Handbook on Commercial Arbitration publicado pelo International Council for Commercial Arbitration ${ }^{747}$ afirma textualmente que o Decreto apenas coloca a Lei Modelo como anexo, seguindo uma técnica relativamente comum em países de common law, o livro de Smit e Pechota transcreve a lei de arbitragem, que segue a Lei Modelo, porém com algumas alterações. Uma dessas autorizações é justamente o art. 28, sobre escolha de lei, em que é retirada a menção à possibilidade de arbitragem de eqüidade.

Nem sempre a ausência de referência à arbitragem por eqüidade significa uma limitação ao uso deste tipo de arbitragem. Por vezes, legislações que não tratam da matéria são interpretadas como uma autorização para seu uso, como é o caso da Suécia e o regime alemão anterior à reforma. Em outros casos, como Rússia e Bulgária, a ausência de menção é vista como proibição. No caso do Bahrain, não há elementos para tomar posição. Entretanto, no âmbito de uma reforma legislativa baseada na Lei Modelo, a retirada proposital de um elemento constante do texto original parece indicar uma atitude de não-aceitação por parte da ordem jurídica local.

Entretanto, não há elementos para uma posição final sobre o assunto.

\subsubsection{Bangladesh}

Bangladesh reformou sua legislação de arbitragem em 2001, ao editar uma nova lei que entrou em efeito em 10 de abril do mesmo ano. Anteriormente à tal lei, a legislação era datada da década de 1940.

747 Paulsson, Jan (Ed.). International Handbook on Commercial Arbitration (suplemento ago. 1995), p. Bahrain - I e Bahrain Annex I - i. 
Embora siga a Lei Modelo em quase sua totalidade, a lei de Bangladesh, ao tratar da lei aplicável ao mérito da disputa, não menciona a possibilidade de autorização para julgamento em eqüidade, suprimindo a alínea "c" do art. 28 da Lei Modelo no equivalente ao art. 36 da lei de arbitragem. ${ }^{748}$

Como já discutido nesta obra, a omissão por si só não pode ser considerada uma proibição, embora seja um indicativo de posição negativa do legislador nacional, no caso da implementação da Lei Modelo. Entretanto, há obra que sustenta que a omissão da lei de arbitragem de Bangladesh não proíbe o uso da arbitragem por eqüidade, desde que as regras aplicáveis à arbitragem assim permitam. ${ }^{749}$

\subsubsection{Bélgica}

A Bélgica tem uma longa tradição de arbitragem. A arbitragem está regulada em seu Código de Processo (Code Judiciaire) e segue as tendências mais modernas da arbitragem. Em seu art. 1.700, o referido Código permite o uso de arbitragem por eqüidade, nos seguintes termos:

Sauf convention contraire des parties, les arbitres statuent selon les règles du droit.

Lorsqu'une personne morale de droit public est partie à la convention d'arbitrage, les arbitres statuent toujours selon les règles de droit, sans préjudice des lois particulières.

Assim, embora não mencione a arbitragem por eqüidade, o Código faculta às partes a escolha de regras que não sejam o direito positivo. A doutrina belga em geral aceita que tal autorização abarca a decisão por eqüidade. ${ }^{750}$ Assim, ainda que com uma redação particular, o direito belga permite a arbitragem por eqüidade.

Uma disposição interessante da legislação belga é a definição de que, caso a convenção de arbitragem tenha como parte uma pessoa jurídica de direito público, somente regras de

748 Paulsson, Jan (Ed.). International Handbook on Commercial Arbitration (suplemento jan. 2006), p. Bangladesh Annex I - 13; e Sмit, Hans; Реснота, V. Smit's Guides to International Arbitration, cit., p. BAN B-17.

749 Smit, Hans; Pechota, V. Smit's Guides to International Arbitration, cit., p. BAN C-4.

750 Vide Keutgen, Guy; Dal, Georges Albert. Relatório sobre a Bélgica. In: PAulsson, Jan (Ed.). International Handbook on Commercial Arbitration, cit. (suplemento abr. 2007), p: Belgium 29. Também a versão anterior deste relatório, datado de outubro de 1995, de Matray, Lambert; LefeVre, Françoise; Lemaitre, Henri-Paul; VeRBIST, Herman. Questionário sobre a arbitragem por eqüidade submetido a Força Tarefa da CCI sobre Arbitragem por Eqüidade, 2006. Mimeografado. Disponível em: <www.iccwbo.org >. (entrada permitida apenas a membros da Força Tarefa). 
direito podem ser aplicadas. A exceção a tal princípio somente pode ser dada por lei específica. ${ }^{751}$ Trata-se aqui de uma vedação ao uso da arbitragem de eqüidade para entidades estatais. Esta disposição legislativa é única no mundo. Todavia, uma tal posição não parece encontrar acolhida na arbitragem comercial internacional, em que os contratos com o Estado, de modo geral, são considerados contratos civis, ao menos quando tratarem de atos de gestão.

Anteriormente à reforma legislativa de 1998, o art. 1.700 do Código de Processo belga dispunha que qualquer autorização para os árbitros decidirem fora das regras de direito somente seria válida após a notificação para início da arbitragem. ${ }^{752}$ Em outras palavras, a autorização para julgamento em eqüidade somente poderia ser conferida após o surgimento do litígio. Esta disposição é original e aparentemente não encontra paralelo nas legislações pesquisadas. Ela parte do pressuposto de que as partes somente podem realmente considerar a autorização para julgamento excepcional como o de eqüidade depois de terem a clara idéia de qual é o litígio. Como a cláusula arbitral é estipulada antes do surgimento de qualquer divergência e se refere genericamente a um contrato, do qual podem surgir diversos tipos de disputa, reputa-se que uma tal autorização seria excessivamente ampla. Além disso, considerando-se a cláusula de arbitragem por eqüidade como uma renúncia (ou como contendo um elemento de renúncia), há direitos aos quais não se pode renunciar de antemão. Assim, uma renúncia feita quando da celebração do contrato e antes do surgimento de um litígio pode ser considerada uma renúncia antecipada. Essa antiga disposição belga parece inspirar-se em tal raciocínio. Tal opção legislativa não é isenta de críticas e foi objeto de muitos debates internos. ${ }^{753}$

751 Matray, Lambert; Lefevre, Françoise; Lemaitre, Henri-Paul; Verbist, Herman. Questionário sobre a arbitragem por eqüidade..., cit.

752 "1.700 - Sauf estipulation contraire, qui ne peut valablement intervenir qu'apres la notification prevue a l'article 1683, les arbitres statuent selon les regles de droit."

753 Veja-se a opinião de Lambert Matray:

The usual practice is for arbitrators to decide according to the rules of law. The parties may agree that the arbitrators shall decide as amiables compositeurs, but only after a dispute has arisen (Art. 1700). This provision is not contained in the European Uniform Law of 1966 according to which the parties could agree on amiable composition before and after the dispute has arisen (Art. 21). The Belgian legislative intent was to prevent amiable composition from being agreed upon before the parties have had a chance to realize the nature and significance of their dispute.

This legal provision - which is an innovation - has been widely commented upon. It is generally criticised by those who favour arbitration and who see it as an obstacle to the development of arbitration. The restrictive standpoint of the Judicial Code could, perhaps, have been avoided if the usually vague structure of amiable composition were capable of being more clearly defined. Arbitrators who have been given the power to act as amiables compositeurs do not depart from the law unless they deem it necessary. The possibility which is left open to them is not an obligation. Furthermore, they are only allowed to ignore non-stringent legal rules (règles légales supplétives). They are always bound by mandatory provisions and by public order. Finally, like arbitrators deciding according to the rules of law, they are allowed to interpret, but not change, clauses or contracts brought before them in a dispute." In: PAulsson, Jan (Editor). International Handbook on Commercial Arbitration, cit., relatório de outubro de 1995. 
Entretanto, tal orientação era minoritária em direito comparado e terminou sendo abandonada pela Bélgica, que fez a opção legislativa de seguir a posição dominante.

\subsubsection{Bermudas}

Bermudas igualmente seguiu a tendência mundial de modernização de legislação de arbitragem e editou, em 1993, a Lei de Arbitragem e Conciliação Internacionais (The Bermuda International Conciliation and Arbitration Act 1993), que está em vigor desde 29.06.1993. Seguindo a técnica usada por países de common law, a Lei Modelo da Uncitral é um anexo da lei nacional, com expressa remissão. Portanto, o sistema da Lei Modelo está implantado. Entretanto, a permissão para arbitragem de eqüidade somente serve para arbitragens internacionais. A doutrina considera que nas arbitragens internas a decisão deve ser feita com base em princípios de direito. ${ }^{754}$ Neste aspecto, segue a antiga orientação inglesa no tocante à arbitragem de eqüidade.

\subsubsection{Bielo-Rússia}

A legislação bielo-russa ${ }^{755}$ sobre arbitragem comercial parece um híbrido entre o antigo sistema dos países socialistas e o sistema ocidental. Dos tempos socialistas, há a criação por lei de um órgão dedicado ao julgamento de arbitragens comerciais internacionais, a Corte Permanente de Arbitragem Internacional, definida na lei como uma instituição "não estatal e não comercial”. Entretanto, há permissão para arbitragens não institucionais.

De um modo geral, pode-se dizer que a legislação da Bielo-Rússia inspirou-se na Lei Modelo. No entanto, há variações significativas. No tocante ao direito aplicável, há liberdade de escolha das partes. Todavia, não há repetição do art. 28(3) da Lei Modelo.

Nas fontes disponíveis para consulta sobre o direito de arbitragem na Bielo-Rússia, ${ }^{756}$ não há menção expressa à possibilidade ou proibição de arbitragem por eqüidade. Contudo, as regras de arbitragem da Corte de Arbitragem Internacional da Câmara de Comércio e Indústria da

${ }^{754}$ Conforme o relatório de Hargun, Narinder K.; Elkinson, Jeffrey P. contido em Paulsson, Jan (Editor). International Handbook on Commercial Arbitration, cit., suplemento 18, set. 1994:

"An arbitral tribunal is not entitled to ignore legal principles and determine the claim on the basis of their private notions of what is fair and equitable in the circumstances. "Equity clauses" do provide a limited latitude to the arbitral tribunal particularly in relation to construction of contractual documents. However, equity clauses do not allow the arbitral tribunal to depart from the applicable legal principles".

755 Fonte: Smit, Hans; РеснотA, V. Smit's Guides to International Arbitration, cit., p: BLR B-1 e ss.

756 Smit, Hans; Pеснота, V. Smit's Guides to International Arbitration, cit., p: BLR A-1 e ss., e Ruck, Segei I. Arbitration in Belarus. Croatian Arbitration Yearbook, v. 4, p. 73 (fonte lexisnexis). 
Bielo-Rússia expressamente permitem este tipo de arbitragem, desde que haja consentimento das partes. ${ }^{757}$ Portanto, pode-se concluir que existe a possibilidade de tal arbitragem naquele país.

\subsubsection{Bolivia}

A Bolívia editou uma nova lei de arbitragem em 1997, com a edição da Ley de Arbitraje y Conciliación 1.770, de 10 de março daquele ano. Anteriormente, a legislação boliviana de arbitragem era contida no Código de Processo Civil de 1975.

A nova lei de arbitragem, em seu art. 54, expressamente prevê que, salvo convenção em contrário, a arbitragem será decidida por eqüidade:

Artículo 54.- (Normas aplicables al fondo)

I. - El Tribunal Arbitral decidirá en el fondo de la controversia con arreglo a las estipulaciones del contrato principal. Tratándose de un asunto de naturaleza comercial, tendrá además en cuenta los usos mercantiles aplicables al caso.

II. - Salvo pacto en contrario, el Tribunal Arbitral decidirá según la equidad y conforme a sus conocimientos y leal saber y entender. ${ }^{758}$

Assim, a Bolívia filia-se ao sistema hipano-americano de presunção de arbitragem por eqüidade. Seu direito anterior utilizava-se da expressão amigable componedor e previa dois procedimentos distintos, caso fosse de direito ou de eqüidade. Igualmente, havia presunção de eqüidade na falta de acordo. Portanto, verifica-se no caso boliviano que o sistema de presunção de arbitragem por eqüidade pode subsistir mesmo à modernização de legislação. Aparentemen-

757 Article 38.

1. The IAC composition shall settle a dispute in accordance with such rules of law as are chosen by the parties as applicable to the substance of the dispute. Any designation to the law or legal system of a given State shall be construed as a direct reference to the substantive law of that State and not to its conflict of laws rules.

2. The parties should submit evidences confirming the content of rules of foreign law on which they rely for substantiation of their claims or defences to the claims as well as in another way may assist the IAC composition to ascertain the content of such rules of foreign law.

3. Failing any designation to the applicable law by the parties, the IAC composition shall make an award on the basis of law determined by the conflict of laws rules which it considers applicable.

4. Having applied the substantive law the IAC composition shall base on the terms of the contract binding upon the parties or other legal relationship between the parties and also shall take into account existing commercial and legal practice.

5. Settlement of a dispute ex aequo et bono (on the basis of general accepted moral rules) is allowed, only if the parties have expressly agreed to it and provided that it does not contradict the imperative rules of law.

6. The IAC composition which settles the dispute may request the IAC Presidium to give an interpretation of the applicable law and the existing practice.

Disponível em: <http://www.cci.by/en/PageE1.html>. Acesso em: 15 nov. 2007.

758 Fontes: Sмiт, Hans; Реснота, V. Smit's Guides to International Arbitration, cit., p. BOL B(1)11. Igualmente dsiponível em: <www.cbar.org.br>. Acesso em: 14 nov. 2007. 
te, trata-se de uma tradição bastante arraigada na cultura jurídica local, que sobreviveu à edição de novas normas, ao contrário do que ocorreu, por exemplo, com a Espanha e o Paraguai, que inverteram a presunção de eqüidade.

A forma da redação do art. 54 da lei boliviana parece indicar que os árbitros devem respeitar as regras do contrato, mesmo quando autorizados a decidir em eqüidade.

\subsubsection{Bulgária}

A Bulgária editou uma lei de arbitragem internacional em 1988, ainda durante o período socialista, e a reformou em 1993, com a edição de uma nova lei emendando a primeira (publicada no Diário Oficial de 02.11.1993). Esta lei, embora tenha se inspirado na Lei Modelo, não seguiu seu modelo no que diz respeito à arbitragem por eqüidade. $\mathrm{O}$ art. 38 da lei búlgara baseia-se no art. 28(3) da Lei Modelo. Entretanto, não repete o inciso (3), que faculta o uso da arbitragem por eqüidade. ${ }^{759}$ Neste sentido, a Bulgária repete outras legislações de países anteriormente socialistas, como a Rússia, a Bielo-Rússia e a Mongólia.

No entanto, no caso da Bulgária, a doutrina considera este silêncio como uma proibição do uso da arbitragem por eqüidade. ${ }^{760}$

759 Smit, Hans; Pechota, V. Smit's Guides to International Arbitration, cit., p. BUL B-7, e Paulsson, Jan (Ed.). International Handbook on Commercial Arbitration, cit., p. Bulgária: Annex I - 6 (suplemento jan. 1994).

760 Relatório sobre a Bulgária feito por Stalev Zhivko, In: PAulsson, Jan (Ed.). International Handbook on Commercial Arbitration, cit., suplemento 19 ago. 1995:

"It should be noted that Art. 38(1) of the LICA differs from Art. 28(1) of the UML, substituting the words 'rules of law' used by the Model Law, by the word 'law'. The intent is to clarify that the law of a specific State is to be applied. Unlike the UML, the LICA does not allow the parties to empower the arbitrators to decide ex aequo et bono as amiables compositeurs. Therefore, arbitrators cannot be validly conferred with this power and consequently to do so would affect the validity of the arbitration agreement (Art. 47(1) LICA)". 


\subsubsection{Camboja}

O Camboja editou uma recente lei de arbitragem comercial com base na Lei Modelo da Uncitral. Trata-se da Lei de Arbitragem datada de 06.03.2006. Conforme o art. 26, a arbitragem por eqüidade é permitida no sistema de autorização expressa da Lei Modelo. ${ }^{761}$

\subsubsection{Camarões}

O Código de Processo Civil e Comercial de Camarões, datado de 1956, ainda parece ser a legislação aplicável à arbitragem comercial naquele país. ${ }^{762} \mathrm{O}$ art. 592 daquele Código autoriza a decisão por eqüidade desde que as partes assim convencionem no compromisso arbitral. ${ }^{763}$ Interessante notar que a legislação local é expressa ao mencionar o compromisso como local para autorização deste tipo de arbitragem. A expressão utilizada na língua original é a amiable composition.

\subsubsection{Canadá}

Em 1986, o Canadá foi o primeiro país do mundo a adotar a Lei Modelo da Uncitral. Seguindo o modelo legislativo de diversos países de common law, a Lei Modelo foi anexada integralmente ao texto da lei, de modo que o art. 28(3) foi transcrito ipsis litteris. ${ }^{764}$

Todavia, tratando-se de um Estado federativo, há também diversas leis provinciais sobre a mesma matéria. Excederia aos limites desta obra, cujo objetivo é apenas verificar a existência da arbitragem por eqüidade em direito comparado, proceder a um exame detalhado da legislação das diversas províncias canadenses. Deve-se afirmar, de qualquer forma, que de um modo geral as províncias possuem legislações tanto para arbitragem interna como internacional e a maioria delas segue o modelo da CNUDCI no que diz respeito às internacionais. ${ }^{765}$

761 Fonte: Paulsson, Jan (Ed.). International Handbook on Commercial Arbitration, cit., suplemento 47, p. Cambodia: Annex I-9, nov. 2006.

762 Sмiт, Hans; РеснотA, V. Smit's Guides to International Arbitration, cit., p. CAM A-1.

763 Art. 592 - Leas arbitres et tiers arbitre decideront d'apres les regles du droit, a moins que lê compromis ne leur donne pouvoir de prononcer comme amiables compositeurs. Fonte: Smit, Hans; PeснотA, V. Smit’s Guides to International Arbitration, cit., p. CAM B(1)-2.

764 Smit, Hans; Реснота, V. Smit's Guides to International Arbitration, cit., p. CAN B-14.

765 Idem, ibidem, p. CAN C-15. 
A doutrina reconhece a permissão de arbitragens por eqüidade nas diversas províncias. ${ }^{766}$

\subsubsection{Catar}

O Catar renovou sua legislação sobre arbitragem em 1992, em seu Código de Processo Civil e Comercial. Este código permite expressamente a arbitragem por eqüidade, mediante autorização por escrito das partes e desde que os árbitros sejam indicados por nome. ${ }^{767}$

$\overline{766 \text { "b. Domestic Arbitration }}$

In Common Law provinces, arbitrators decide according to the rules of law including equity. The arbitral tribunal may also take into account any applicable usages of trade.

The Quebec CCP states that the arbitrators shall settle the dispute according to the rules of law which they consider appropriate and shall take account of applicable usages of trade (art. 944.10 CCP).

In Quebec and for the Federal Government, the arbitral tribunal shall decide ex aequo et bono or as amiable compositeur only if the parties have expressly authorized it to do so (Art. 944.10 CCP and Sect. 28(3) of Canada Commercial Arbitration Act). In British Columbia, an arbitrator must adjudicate the matter by reference to law unless the parties, as a term of an agreement agree that the matter in dispute may be decided on equitable grounds, grounds of conscience or some other basis (Sect. 23 Commercial Arbitration Act). This formulation includes amiable composition.

Although Arbitration Acts in other Common Law provinces do not expressly provide for amiable compositeur or ex aequo et bono clauses, nothing prevents parties from adopting similar clauses given the fact that the tribunal shall decide the dispute in accordance with the arbitration agreement and the contract under which the dispute arose (see, e.g., Sect. 33 of Ontario Arbitration Act, 1991).

Should the parties decide to use amiable compositeur and ex aequo et bono clauses in an arbitration agreement, this will allow the arbitrators to decide the dispute according to the legal principles they believe to be just, without being limited to any particular national law. They can disregard legal technicalities and strict constructions which they would be required to apply in their decisions if the arbitration agreement contained no such clause. Lalonde, Marc. Relatório sobre Canadá. In Paulsson, Jan (Ed.). International Handbook on Commercial Arbitration, cit., suplemento nov. 2004;

767 Article 190.

In an arbitration agreement (Special Arbitration Deed), one may agree to arbitrate in a determined dispute. Likewise, one may agree to arbitrate all disputes arising out of performance of a determined contract.

An agreement to arbitrate may only be made in writing.

The subject-matter of the dispute must be determined in the agreement to arbitrate or during the proceedings, even if the arbitrators may settle the case as amiables compositeurs, else the arbitration may be set aside. There can be no arbitration in matters which the parties cannot settle amicably.

Arbitration is only valid if those persons who resort to it have the capacity to dispose of their rights.

Article 191.

If arbitrators are to receive the mission to settle the case amicably between the parties, or to act as amiables compositeurs, they must be appointed by name in the agreement to arbitrate, or in a separate agreement.

Fonte: Journal of International Arbitration, v. 10, n. 2, p. 156 e ss., 1993; 
O Código ainda prevê que os árbitros decidindo por eqüidade devem obedecer a ordem pública e os bons costumes ${ }^{768}$ (como também o devem os árbitros de direito). As sentenças emitidas em eqüidade não estão sujeitas a recurso. ${ }^{769}$

\subsubsection{Chile}

O Chile possui duas disciplinas distintas de arbitragem, quer esta seja nacional ou internacional. A arbitragem internacional é regulada pela Lei 19.971, de 30.09.2004, que segue a Lei Modelo de perto. Em seu art. 28, há previsão idêntica à da Lei Modelo. O legislador chileno preferiu referir-se a arbitragem de eqüidade por amigable componedor..$^{770}$

No tocante à arbitragem interna, a legislação local é bastante antiga e tem seus primórdios ainda no século XIX. ${ }^{771} \mathrm{O}$ Chile segue o modelo hispano-americano tradicional e separa o procedimento da arbitragem de direito da amigable composición. Entre outras particularidades, existem casos de arbitragem obrigatória no Chile. A matéria encontra-se regulada tanto no Código Orgânico dos Tribunais como no Código de Procedimento Civil. No caso da arbitragem de

\section{Article 198.}

Arbitrators make their award without being bound by the procedures foreseen in this Code, except those foreseen in the present Chapter. The award must comply with the rules of law, unless the arbitrators are empowered to act as amiables compositeurs, and provided they do not violate the rules of public order and good morals.

If the agreement to arbitrate was made in Qatar, Qatari law is necessarily applicable to the element of the dispute, unless the parties agreed otherwise.

769 Article 205.

Arbitral awards are subject to appeal according to the rules foreseen for appeal against judgments made by the Court originally having jurisdiction over the dispute. Such an appeal must be made within fifteen days following the date of the filing of the original of the award with the clerk of the Court, and it must be made before the competent Court of Appeal.

However, the award is not subject to appeal if it was made by arbitrators acting as amiables compositeurs or arbitrators in appeal or if the parties explicitly waived their right to appeal.

770 Artículo 28. Normas aplicables al fondo del

litigio.

1) El tribunal arbitral decidirá el litigio de conformidad con las normas de derecho elegidas por las partes como aplicables al fondo del litigio. Se entenderá que toda indicación del derecho u ordenamiento jurídico de un Estado determinado se refiere, a menos que se exprese lo contrario, al derecho sustantivo de ese Estado y no a sus normas de conflicto de leyes.

2) Si las partes no indican la ley aplicable, el tribunal arbitral aplicará la ley que determinen las normas de conflicto de leyes que estime aplicables.

3) El tribunal arbitral decidirá ex aequo et bono o como amigable componedor sólo si las partes le han autorizado expresamente a hacerlo así. [...]

Disponível no site da Biblioteca do Congresso do Chile: <http://www.bcn.cl>. Acesso em: 15 nov. 2007. Também Smit, Hans; РеснотA, V. Smit's Guides to International Arbitration, cit., p. CHI B(2) 1 e ss.

771 Vide Jorquiera, Carlos Eugenio; Helmuinger, Karin. Chile. In: Blackby, Nigel; Lindsey, David M.; Spinillo, Alessandro (Ed.). International Arbitration in Latin América. The Hague: Kluwer Law International, 2002. p. 90 e ss. 
direito, somente advogados podem funcionar como árbitros. ${ }^{772} \mathrm{O}$ árbitro de eqüidade, chamado de "arbitrador", julgará "obedecendo o que sua prudência e a eqüidade ditarem". Ele não está obrigado a seguir o procedimento previsto para arbitragens de direito, que envolve, entre outras regulações, a obrigatoriedade de um secretário e a observação do procedimento judicial civil. Ao contrário, os árbitros de eqüidade devem seguir o disposto pelas partes ou, caso estas nada tenham convencionado, seguem um procedimento mais célere, ${ }^{773}$ em que há amplos poderes instrutórios ao árbitro. ${ }^{774}$

Entretanto, em casos permitidos por lei, os poderes de árbitro de eqüidade podem ser concedidos aos árbitros de direito, apenas no relativamente ao procedimento, deixando-se a aplicação da lei apenas para o mérito. ${ }^{775}$ Assim, no direito chileno, a escolha da arbitragem de

772 Código Orgânico de Tribunais:

Art. 225. Puede ser nombrado árbitro toda persona mayor de edad, con tal que tenga la libre disposición de sus bienes y sepa leer y escribir. Los abogados habilitados para ejercer la profesión pueden ser árbitros aunque sean menores de edad. El nombramiento de árbitros de derecho sólo puede recaer en un abogado. $[\ldots]$

773 Código de Procedimento Civil:

Art. 636. (793). El arbitrador no está obligado a guardar en sus procedimientos y en su fallo otras reglas que las que las partes hayan expresado en el acto constitutivo del compromiso.

Si las partes nada han dicho a este respecto, se observarán las reglas establecidas en los artículos que siguen.

774 Código de Procedimento Civil:

Art. 637. (794). El arbitrador oirá a los interesados; recibirá y agregará al proceso los instrumentos que le presenten; practicará las diligencias que estime necesarias para el conocimiento de los hechos, y dará su fallo en el sentido que la prudencia y la equidad le dicten.

Podrá oír a los interesados por separado, si no le es posible reunirlos.

775 Código de Procedimento Civil:

Art. 628. (785). Los árbitros de derecho se someterán, tanto en la tramitación como en el pronunciamiento de la sentencia definitiva, a las reglas que la ley establece para los jueces ordinarios, según la naturaleza de la acción deducida.

Sin embargo, en los casos en que la ley lo permita, podrán concederse al árbitro de derecho las facultades de arbitrador, en cuanto al procedimiento, y limitarse al pronunciamiento de la sentencia definitiva la aplicación estricta de la ley. La tramitación se ajustará en tal caso a las reglas del párrafo

siguiente:

Por motivos de manifiesta conveniencia podrá los tribunales autorizar la concesión al árbitro de derecho de las facultades de que trata el inciso anterior, aun cuando uno o más de los interesados en el juicio sean incapaces.

Código Orgânico de Tribunais:

Art. 223. El árbitro puede ser nombrado, o con la calidad de árbitro de derecho, o con la de árbitro arbitrador o amigable componedor.

El árbitro de derecho fallará con arreglo a la ley y se someterá, tanto en la tramitación como en el pronunciamiento de la sentencia definitiva, a las reglas establecidas para los jueces ordinarios, según la naturaleza de la acción deducida.

El arbitrador fallará obedeciendo a lo que su prudencia y la equidad le dictaren, y no estará obligado a guardar en sus procedimientos y en su fallo otras reglas que las que las partes hayan expresado en el acto constitutivo del compromiso, y si éstas nada hubieren expresado, a las que se establecen para este caso en el Código de Procedimiento Civil. 
eqüidade tem um impacto direto no procedimento, além do próprio mérito. Tanto que pode existir uma espécie de arbitragem híbrida em que há uma espécie de "procedimento em eqüidade" com aplicação de direito ao fundo. Todavia, esta solução parece ser mais ligada ao excessivo rigor procedimental da arbitragem de direito. Tal preocupação procedimental na arbitragem de direito talvez tenha por fundamento o fato de existir no direito chileno a arbitragem compulsória, o que, a exemplo do procedimento jurisdicional estatal, torna mais premente a necessidade de garantias às partes, pelo que se adotam normalmente procedimentos mais rígidos. A despeito disso, parece a este autor que tal duplicidade demonstra uma das funções da arbitragem por eqüidade, que é justamente a de simplificar as decisões, quer do ponto de vista formal, quer do ponto de vista material.

Por outro lado e contrariando alguns países do sistema hispano-americano, em caso de silêncio das partes, presume-se que a arbitragem seja de direito. ${ }^{776}$

Caso as partes assim convencionem, poderá haver recurso contra as sentenças arbitrais internas em eqüidade. Entretanto, tal recurso será julgado por um outro tribunal arbitral nomeado pelas partes. ${ }^{777}$ Portanto, o recurso é feito dentro da instância arbitral e não perante tribunais estatais. Esta parece ser uma disposição particular da legislação chilena. Entretanto, ao dispor sobre a matéria de recursos em arbitragem, o Código de Organização dos Tribunais dispõe que, caso haja recurso disponível, o tribunal poderá decidir em eqüidade, conforme seja o caso. ${ }^{778}$

Sin embargo, en los casos en que la ley lo permita, podrán concederse al árbitro de derecho facultades de arbitrador, en cuanto al procedimiento, y limitarse al pronunciamiento de la sentencia definitiva la aplicación estricta de la ley.

776 Código Orgânico de Tribunais:

Art. 235. Si las partes no expresaren con qué calidad es nombrado el árbitro, se entiende que lo es con la de árbitro de derecho.

Si faltare la expresión del lugar en que deba seguirse el juicio, se entenderá que lo es aquel en que se ha celebrado el compromiso.

Si faltare la designación del tiempo, se entenderá que el árbitro debe evacuar su encargo en el término de dos años contados desde su aceptación.

777 Código de Procedimento Civil:

Art. 642. (799). Sólo habrá lugar a la apelación de la sentencia del arbitrador cuando las partes, en el instrumento en que constituyen el compromiso, expresen que se reservan dicho recurso para ante otros árbitros del mismo carácter y designen las personas que han de desempeñar este cargo.

778 Art. 238. En caso de no resultar mayoría en el pronunciamiento de la sentencia definitiva o de otra clase de resoluciones, siempre que ellas no sean apelables, quedará sin efecto el compromiso, si éste es

voluntario. Si es forzoso, se procederá a nombrar nuevos árbitros.

Cuando pueda deducirse el recurso, se elevarán los antecedentes al tribunal de alzada para que resuelva la cuestión que motiva el desacuerdo conforme a derecho o equidad, según corresponda. 


\subsubsection{Chipre}

O Chipre tem dois regimes de arbitragem, quer esta seja interna ou internacional. No caso da arbitragem internacional, o Chipre adotou a Lei Modelo por intermédio da Lei 101, de 29.05.1987. O Chipre foi o segundo país do mundo a adotar a Lei Modelo, apos o Canadá. ${ }^{779}$ Assim, o art. 28(3) é reproduzido na íntegra. ${ }^{780}$

$\mathrm{Na}$ arbitragem interna a legislação cipriota data de 1944 e é baseada no direito inglês anterior às reformas de $1996 \mathrm{e} 1979.781$

\subsubsection{China}

A arbitragem na China ainda segue, em muitos aspectos, o mesmo sistema adotado pelos países então socialistas da Europa ocidental. O principal deles é o virtual monopólio de órgãos oficiais para os assuntos relativos à arbitragem comercial internacional.

Embora tenha promovido reformas recentes na lei de arbitragem, com a edição de uma nova lei de arbitragem em 1994, a China manteve a visão "institucionalista" da arbitragem, outorgando poderes à Câmara Chinesa de Comércio Internacional (também mencionada como Conselho Chinês para a Promoção do Comércio Internacional), o poder de criar e organizar entidades arbitrais que lidem com arbitragens relativas ao comércio internacional. Esta instituição já havia criado tanto a Comissão Chinesa para Arbitragem Internacional (conhecida pela sigla CIETAC em inglês, a partir de China International Economic and Trade Arbitration Comission) como a Comissão Chinesa para Arbitragem Marítima (conhecida pela sigla CMAC em inglês, a partir de China Maritime Arbitration Comission). Assim, tem-se entendido que esses órgãos foram criados a partir da competência específica atribuída. ${ }^{782}$

A nova lei chinesa de arbitragem trata apenas das arbitragens institucionais, nada mencionando sobre arbitragens ad hoc. Portanto, essa possibilidade ainda é duvidosa. ${ }^{783}$ Assim, o

\footnotetext{
779 Smit, Hans; Реснота, V. Smit's Guides to International Arbitration, cit., p: CYP A-1.

780 Idem, ibidem, p. CYP B-10. Vide também Paulsson, Jan (Ed.). International Handbook on Commercial Arbitration, cit., p. Cyprus - i., suplemento jan. 2004.

781 Sмiт, Hans; Реснота, V. Smit’s Guides to International Arbitration, cit., p: CYP A-1.

782 Houzhi, Tang; Shengchang, Wang. Relatório constante do suplemento 25. In: Paulsson, Jan (Ed.). International Handbook on Commercial Arbitration, cit., suplemento jan. 1998, p. PR China -4. Vide também SMIT, Hans; Реснот, V. Smit's Guides to International Arbitration, cit., p. CHA A-1 e ss.

783 HouzhI, Tang; Shengchang, Wang. Ibidem, p. PR China -4
} 
sistema de órgãos criados pelo Estado com monopólio das arbitragens relativas ao comércio internacional parece continuar na China. Dessa circunstância advém a relevância das próprias regras institucionais para a verificação do direito vigente no país, na medida em que serão aplicadas a quase todos os casos.

A lei de arbitragem foi promulgada em 31.08.1994, com efeito a partir de 1. ${ }^{\circ} .09 .1995$. Embora ela não indique a possibilidade de arbitragem por eqüidade, seu art. 7 menciona que as disputas em arbitragem devem ser resolvidas com base nos fatos, em observância da lei e de modo equitativo e razoável. ${ }^{784}$

Essa disposição é interpretada por vários autores como uma espécie de autorização implícita para a decisão por eqüidade:

Accordingly, in domestic arbitration as well as in international (foreign-related) commercial arbitration, the arbitral tribunal (arbitrator/arbitrators) is bound to decide cases according to rules of law in the first place; in cases where the parties so authorize or the rules of law that are relevant to the specific disputes do not exist, the arbitral tribunal (arbitrator/arbitrators) may act as amiables compositeurs and decide the disputes ex aequo et bono, by virtue of applying the principle of fairness and reasonableness. ${ }^{785}$

Também outros autores apontam a possibilidade de arbitragem por eqüidade com base na referida norma, especialmente em vista do regulamento de arbitragem da CIETAC. ${ }^{786} \mathrm{O}$ atual regulamento, em vigor desde 2005, possui a seguinte disposição em seu art. 43:

\section{Article 43. Making Award}

1. The arbitral tribunal shall independently and impartially make its arbitral award on the basis of the facts, in accordance with the law and the terms of the contracts, with reference to international practices and in compliance with the principle of fairness and reasonableness.

Outros autores subscrevem a possibilidade de arbitragem por eqüidade na China. ${ }^{787}$

\footnotetext{
784 Article 7

In arbitration, disputes shall be resolved on the basis of facts, in compliance with law and in an equitable and reasonable.

Fonte: Paulsson, Jan (Ed.). International Handbook on Commercial Arbitration, cit., suplemento 18, set. 1994, e suplemento 25, jan. 1998.

785 Houzhi, Tang; Shengchang, Wang. Relatório constante do suplemento 25, cit.

786 Li, Hu. Arbitration ex aequo et bono in China. Arbitration International, v. 66, n. 3, p. 188 e ss., 2000. Note-se que este autor refere-se ao regulamento de arbitragem anterior ao atual.

787 Shang, Wang Sheng. Resolving Disputes in People's Republic of China, apud Smit, Hans; Pechota, V. Smit's Guides to International Arbitration, cit., p. CHA C-2.
} 


\subsubsection{Cingapura}

Cingapura possui dois regimes de arbitragem, quer se trate de arbitragem interna ou internacional. A arbitragem internacional é regulada pela Lei de Arbitragem Internacional de 1994, revisada em 2002, ${ }^{788}$ que adotou a Lei Modelo, com algumas modificações.

O regime de arbitragem interno é previsto pela Lei de Arbitragem de 1953, revisada em 1980, que segue o modelo do Arbitration Act inglês de $1950,{ }^{789}$ hostil à arbitragem por eqüidade.

Dessa divergência de regimes, tem-se que, no regime interno, a possibilidade de decisão de eqüidade é duvidosa. No regime internacional, é reconhecida. ${ }^{790}$

\subsubsection{Colômbia}

A Colômbia possui diversas disposições legais sobre a arbitragem. Houve uma tentativa de unificação do direito da arbitragem com a edição do Decreto 1.818 , de $1998 .{ }^{791}$

A Colômbia conhece três tipos de arbitragem: a arbitragem de direito, a arbitragem por eqüidade e a arbitragem técnica. A arbitragem por eqüidade é definida como aquela em que os árbitros decidem "segundo o sentido comum e a eqüidade". A arbitragem técnica é aquela segundo os árbitros julgam conforme seus conhecimentos específicos de uma ciência, arte ou

788 Vide Smit, Hans; Реснота, V. Smit's Guides to International Arbitration, cit., p. SIN A-1, e Hwang, Michael; Boo, Lawrence G.S.; LaI, Amy. Relatório de Cingapura. In: PAulsson, Jan (Ed.). International Handbook on Commercial Arbitration, cit., suplemento 41, jul. 2004.

789 Vide Smit, Hans; РеснотA, V. Smit's Guides to International Arbitration, cit., p. SIN A-1

790 Vide Hwang, Michael; Boo, Lawrence G.S.; LAI, Amy. Relatório de Cingapura. In: Paulsson, Jan (Ed.). International Handbook on Commercial Arbitration, cit., suplemento 41, p. Singapore 40-41, jul. 2004:

“a. Domestic Arbitration

[...] While contracts may give arbitrators the power to act as amiable compositeur or make awards ex aequo et bono, it is uncertain whether the courts would uphold awards made in this manner.

[...] However, some degree of liberty may be expected where the arbitration agreement permits the tribunal to decide on 'equitable rather than a strictly legal interpretation' of the contract. Such "equity" clauses have been upheld and interpreted by English court to mean that the tribunal will be free from procedural technicalities and strict construction of the contract.

b. International Arbitration

[...] The law also permits arbitrators to act as amiable compositeur or make awards ex aequo et bono if the parties so agree. The terms 'amiable compositeur' or making awards 'ex aequo et bono' are not defined or illustrated in the IAA."

791 Para uma visão da complexidade da edição de normas sobre arbitragem na Colômbia, veja-se Mantilla-Serrano, Fernando. Capítulo sobre Colômbia. In: Blackby, Nigel et. al. International Arbitration in Latin América, cit, p. 113. 
ofício. Caso as partes não indiquem o tipo de arbitragem, presume-se que seja de direito. Neste caso, os árbitros devem ser advogados inscritos. ${ }^{792}$

Além desses tipos de arbitragem, a Colômbia ainda prevê a figura do amigable componedor, que é um terceiro que decide as questões relativas ao "estado, às partes, e à forma de cumprimento de um negócio jurídico particular", com caráter vinculante. ${ }^{793}$ Sua decisão tem efeito de uma transação entre as partes. Quer parecer que o legislador colombiano inspirou-se no arbitrato irrituale ou nos bindend advies da Holanda, ambas figuras de natureza contratual. De qualquer forma, a amigable composicion colombiana é uma figura próxima da arbitragem, embora suas decisões não se executem como sentenças arbitrais. De qualquer modo, verificase que não há previsão legal sobre quais devem ser os fundamentos da decisão do amigable componedor.

Ao contrário do amigable componedor, a decisão do árbitro de eqüidade é exeqüível como uma sentença arbitral normal. ${ }^{794}$

792 Artículo $115 .^{\circ}$ Definición y modalidades. El arbitraje es un mecanismo por medio del cual las partes involucradas en un conflicto de carácter transigible, defieren su solución a un tribunal arbitral, el cual queda transitoriamente investido de la facultad de administrar justicia, profiriendo una decisión denominada laudo arbitral. El arbitraje puede ser en derecho, en equidad o técnico. El arbitraje en derecho es aquel en el cual los árbitros fundamentan su decisión en el derecho positivo vigente.

En este evento el árbitro deberá ser abogado inscrito. El arbitraje en equidad es aquel en que los árbitros deciden según el sentido común y la equidad. Cuando los árbitros pronuncian su fallo en razón de sus específicos conocimientos en una determinada ciencia, arte u oficio, el arbitraje es técnico.

Parágrafo. En la cláusula compromisoria o en el compromiso, las partes indicarán el tipo de arbitraje. Si nada se estipula, el fallo será en derecho.

793 Artículo 223. ${ }^{\circ}$ Definición. La amigable composición es un mecanismo de solución de conflictos, por medio del cual dos o más particulares delegan en un tercero, denominado amigable componedor, la facultad de precisar, con fuerza vinculante para ellas, el estado, las partes y la forma de cumplimiento de un negocio jurídico particular. El amigable componedor podrá ser singular o plural (artículo 130 Ley 446 de 1998).

Artículo $224 .^{\circ}$ Efectos. La decisión del amigable componedor producirá los efectos legales relativos a la transacción (artículo 131 Ley 446 de 1998).

Artículo $225 .^{\circ}$ Designación. Las partes podrán nombrar al amigable componedor directamente o delegar en un tercero la designación. El tercero delegado por las partes para nombrar al amigable componedor puede ser una persona natural o jurídica (artículo 132 Ley 446 de 1998).

Disponível em: <http://www.ftaa-alca.org/busfac/comarb/Colombia/D1818I_s.asp>. Acesso em: 15 nov. 2007.

794 Segundo o relatório de Marco Gerardo Monroy Cabra:

"The general rule is that arbitrators must decide according to law. Nevertheless, the parties may give the arbitrators the power to decide in equity, or according to technical principles. If the award is to be decided according to equity, the parties may confer the power on the arbitrators to mediate the claims of the parties.

The parties can, by common agreement, appoint amiables compositeurs, or delegate the appointment to a third person (Art. 51 of the Decree). The decision of the amiable compositeurs is enforceable as a contract between the parties, but it is not an arbitral award. On the other hand, arbitration in equity does lead to an enforceable award like the awards according to the rules of law.

b. International Commercial Arbitration 
Nas contratações com a administração pública, todavia, há vedação ao uso de eqüidade caso o contrato se execute na Colômbia. Ou melhor, há obrigatoriedade para o uso de arbitragem de direito. ${ }^{795}$

\subsubsection{Coréia do Sul}

A Coréia do Sul editou uma nova lei de arbitragem em 1999, que se aplica tanto às arbitragens internas como internacionais. Trata-se da Lei 6.083, de 1999, que segue o modelo da CNUDCI. O equivalente ao art. 28(3) da Lei Modelo encontra-se no art. 29.3 da lei coreana. ${ }^{796}$

\subsubsection{Costa do Marfim}

A Costa do Marfim adotou uma nova lei sobre arbitragem em 1993. Trata-se da Lei $93-$ 671, de 09.08.1993. A lei é fortemente inspirada no direito francês ${ }^{797}$ de arbitragem e permite a arbitragem por eqüidade tanto no regime de arbitragem interna quanto internacional. ${ }^{798}$

The applicable law in international commercial arbitration is determined in accordance with the treaties ratified and in force in Colombia. If there is no treaty, the arbitrators must decide which law must be applied to the substance of the dispute. There is no prevalent opinion or criteria in this matter in the Colombian doctrine or jurisprudence.

Fonte: Paulsson, Jan (Ed.). International Handbook on Commercial Arbitration, cit., suplemento 18, set. 1994.

795 Lei 80, de 1993:

Artículo 70. De La Cláusula Compromisoria.

En los contratos estatales podrá incluirse la cláusula compromisoria a fin de someter a la decisión de árbitros las distintas diferencias que puedan surgir por razón de la celebración del contrato y de su ejecución, desarrollo, terminación o liquidación.

El arbitramento será en derecho. Los árbitros serán tres (3), a menos que las partes decidan acudir a un árbitro único. En las controversias de menor cuantía habrá un sólo arbitro.

Disponível em: <http://www.mineducacion.gov.co/1621/articles-85593_archivo_pdf4.pdf>. Acesso em: 15 nov. 2007.

Vide também Mantilla-Serrano, Fernando. Capítulo sobre Colômbia, cit., p. 115.

798 Article 32.

L'arbitre tranche le litige conformément aux règles de droit, à moins que, dans la convention d'arbitrage, les parties ne lui aient confié mission de statuer comme amiable compositeur.

Article 54.

L'arbitre tranche le litige conformément aux règles de droit que les parties ont choisies ; à défaut d'un tel choix, conformément à celles qu'il estime appropriées.

Il tient compte, dans tous les cas, des usages de commerce.

Article 55.

L'arbitre statue comme amiable compositeur si la convention des parties lui a conféré cette mission. 


\subsubsection{Costa Rica}

A Costa Rica adotou sua nova legislação de arbitragem em 1997, com a edição da Lei 7.727 sobre meios alternativos de solução de controvérsias e promoção da paz social. O art. 19 daquela divide a arbitragem em arbitragens de direito e arbitragens de eqüidade, presumindose, na ausência de disposição, que seja de direito. ${ }^{799}$ No caso de arbitragens de direito, somente advogados podem ser árbitros. $\mathrm{Na}$ arbitragem de eqüidade, qualquer pessoa pode funcionar como árbitro. ${ }^{800}$

\subsubsection{Croácia}

A Croácia adotou uma nova lei de arbitragem em 2001, publicada no Diário Oficial de 11.10.2001. A lei baseia-se na Lei Modelo e permite a arbitragem por eqüidade se as partes assim decidirem. ${ }^{801}$

Disponível em: <http://droit.francophonie.org/df-web/publication.do?publicationId=2108>. Acesso em: 15 nov. 2007.

799 Artículo 19. Arbitraje de derecho

El arbitraje podrá ser de derecho o de equidad. Cuando no exista acuerdo expreso al respecto, se presumirá que el arbitraje pactado por las partes es de derecho.

800 Artículo 20. Composición de tribunal

Para los arbitrajes de derecho, el tribunal estará compuesto, exclusivamente, por abogados y resolverá las controversias con estricto apego a la ley aplicable. Si se tratare de un arbitraje de equidad, cualquier persona podrá integrar el tribunal sin requerimiento alguno de oficio o profesión, excepto los que las partes dispongan para este efecto. El tribunal resolverá las controversias en conciencia "ex-aequo et bono", según los conocimientos sobre la materia objeto del arbitraje y el sentido de la equidad y la justicia de sus integrantes.

Fonte do texto em espanhol: Sмiт, Hans; Реснота, V. Smit's Guides to International Arbitration, cit., p. COS B(1)-9, e disponível em:<http://www.ftaa-alca.org/busfac/comarb/Costa_Rica/L7727A_s.asp>

Para uma versão em inglês do texto, veja-se: PAulsson, Jan (Ed.). International Handbook on Commercial Arbitration, cit., suplemento 30, jan. 2000.

801 Article 27

1. The arbitral tribunal shall decide the dispute in accordance with such rules of law as are chosen by the parties as applicable to the substance of the dispute. Any designation of the law or legal system of a given state shall be construed, unless otherwise expressed, as directly referring to the substantive law of that State and not to its conflict of laws rules.

2. Failing any designation by the parties under paragraph 1 of this article, the arbitral tribunal shall apply the law which it considers to be most closely connected with the dispute.

3. The arbitral tribunal shall decide ex aequo et bono or en qualité d'amiable compositeur only if the parties have expressly authorized it to do so.

4. In all cases, the arbitral tribunal shall decide in accordance with the terms of the contract and shall take into account the applicable usages.

Fonte: Sмit, Hans; Реснота, V. Smit's Guides to International Arbitration, cit., p. CRO B-15, e Paulsson, Jan (Ed.). International Handbook on Commercial Arbitration, cit., suplemento 39, out. 2003. 


\subsubsection{Dinamarca}

A nova lei de arbitragem da Dinamarca, editada em 24.06.2005, segue a Lei Modelo e prevê, em seu art. 28(3), a possibilidade de arbitragem por eqüidade desde que as partes autorizem. ${ }^{802}$

\subsubsection{Djibuti}

Após sua independência em 1977, o Dijibuti editou um longo Código de Arbitragem Internacional, que possui disposições bastante originais, como é o caso da criação de uma Comissão de Recursos Arbitrais. No que diz respeito à arbitragem interna, o direito do Djibuti utiliza o Código de Processo Civil francês. ${ }^{803} \mathrm{Na}$ arbitragem internacional, o art. 13 expressamente prevê a arbitragem por eqüidade (amiable composition), desde que haja autorização das partes. Uma peculiaridade da lei do Djibuti é o fato de ela descrever os poderes do árbitro de eqüidade em relação à escolha de lei:

\section{Article 13.}

Les arbitres statueront comme amiable compositeurs si les parties leur ont donné le pouvoir.

Les pouvoirs d'amiables compositeurs donnent aux arbitres la faculté d'écarter les solutions du droit applicable selon l'article 12 s'ils estiment leurs conséquences inéquitables. Dans tous les cas, es arbitres amiables compositeurs doivent respecter l'ordre public international. ${ }^{804}$

Dessa forma, apenas pela leitura do texto legal, há uma dispensa de aplicação da lei, sob reserva de ordem pública internacional. Todavia, da forma em que redigido, parece indicar que, mesmo que as partes tenham permitido a decisão por eqüidade, ainda assim deveria haver uma prévia escolha de lei para depois serem descartadas as disposições que pareçam injustas aos árbitros. Haveria, portanto, a adoção de uma forma de produção do juízo de eqüidade, que sempre seria efetuada a partir da análise do direito positivo.

\footnotetext{
802 Disponível no site da Faculdade de Direito de Copenhagen: <http://www.jur.ku.dk/comparativecommerciallawii/Appendix/Act2005.pdf>. Acesso em: 10 out. 2007, e na revista International Arbitration, disponível em: $<$ www.kluwerlaw.com>.

803 Smit, Hans; Pechota, V. Smit's Guides to International Arbitration, cit., p. DJI A-1

804 Idem, ibidem, p. DJI B(1)-4.
} 
Todavia, há comentário ${ }^{805}$ mencionando apenas a faculdade de dispensar a aplicação estrita das regras de direito, sob reserva de ordem pública, sem se referir a qualquer obrigação prévia de escolher um direito para descartar apenas as soluções injustas.

\subsubsection{Equador}

O Equador editou sua lei de arbitragem e medição em 04.09.1997. Em seu art. 3, a lei prevê as duas espécies de arbitragem, e, na ausência de convenção das partes, a presunção é que seja de eqüidade. Caso a arbitragem seja por eqüidade, os árbitros devem atuar "conforme seu leal saber e entender e "atendiendo a los principios de la sana critica". Caso sejam de direito, os árbitros devem ser advogados. Caso seja de eqüidade, não há tal necessidade:

Arbitraje de equidad o derecho

Art. 3.- Las partes indicarán si los árbitros deben decidir en equidad o en derecho, a falta de convenio, el fallo será en equidad.

Si el laudo debe expedirse fundado en la equidad, los árbitros actuarán conforme a su leal saber y entender y atendiendo a los principios de la sana crítica. En este caso, los árbitros no tienen que ser necesariamente abogados.

Si el laudo debe expedirse fundado en derecho, los árbitros deberán atenerse a la ley, a los principios universales del derecho, a la jurisprudencia y a la doctrina. En este caso, los árbitros deberán ser abogados. ${ }^{806}$

\subsubsection{Egito}

O Egito editou sua nova legislação de arbitragem em 1994, com a Lei 27, de 21.04.1994. O país permite a arbitragem de eqüidade, desde que haja previsão expressa, conforme o art. 33 . Conforme as traduções disponíveis do referido artigo, a menção à decisão por eqüidade (também referida como "com base na justiça e na eqüidade" - "justice and fairness") vem acompanhada da expressão "sem estar limitado pelas disposições legais, nos moldes das disposições do Código Civil brasileiro de $1916 .{ }^{807}$

805 Smit, Hans; Pеснота, V. Smit's Guides to International Arbitration, cit., p. DJI C-3.

Idem, ibidem, p. ECU B(1)-3, no site da Câmara de Comercio Americana (AmCham) de Quito: <http://www. ecamcham.com/documentos_pdf/ley_arbitraje_mediacion.pdf $>$. Acesso em: 10 out. 2007.

807 Tradução francesa contida na Revue de l'Arbitrage, Paris, n. 4, p. 763 e ss., 1994: Article 39.

(1) Le tribunal arbitral applique au fond du litige les règles sur lesquelles les deux parties se sont mises d'accord. Si elles se sont mises d'accord sur l'application de la loi d'un Etat déterminé, application sera faite des règles de fond de cette loi à l'exclusion des règles de conflit de lois, à moins que les parties n'en soient convenues autrement.

(2) Si les deux parties ne se sont pas mises d'accord sur les règles de droit applicables au fond du litige, le tribunal arbitral applique les règles de fond de la loi qui lui paraît avoir les liens les plus étroits avec le litige. 


\subsubsection{El Salvador}

O direito da arbitragem de El Salvador está previsto no Código Comercial, de 1970, no Código de Procedimentos Civis, de 1882, e no Decreto 360, de 14.06.1973 ${ }^{808}$ Seguindo-se o modelo hispano-americano, há divisão entre árbitros de direito e de eqüidade, que são chamados de árbitros arbitradores ou amigables componedores. Estes, segundo definição do Código de Procedimentos Civis, procedem e sentenciam segundo ditames da consciência, "sem atender mais que a verdade e a boa-fé". ${ }^{809}$ Embora se utilize uma perífrase, a lei salvadorenha coloca uma indicação do que entende por eqüidade: atender aos ditames da boa-fé. Embora não seja conhecida no mundo qualquer legislação que não preveja a prevalência da boa-fé, é de notar que houve uma tentativa de colocar algum conteúdo material neste tipo de decisão.

Segundo o Código Comercial de El Salvador, os árbitros decidem em eqüidade salvo disposição em contrário. ${ }^{810}$

\subsubsection{Emirados Árabes Unidos}

Os Emirados Árabes Unidos possuem disposições sobre a arbitragem na chamada Lei de Processo Civil, conforme redação de 08.03.1992. Também naquele país permite-se a arbitra-

(3) Le tribunal arbitral doit, lorsqu'il tranche le fond du litige, prendre en considération les stipulations du contrat objet du litige ainsi que les usages du commerce dans ce type d'opération.

(4) Le tribunal arbitral peut, si les deux parties l'ont autorisé expressément à statuer en amiable composition, trancher le fond du litige en appliquant les règles de la justice et de l'équité, sans être lié par les dispositions d'une loi.

Nas traduções inglesas publicadas em Smit e Pechota (Smit's Guides to International Arbitration, cit., p. EGY B-13) e em Jan Paulsson (International Handbook on Commercial Arbitration, cit., p. Egypt Annex I-11), o referido artigo é traduzido como: "4. - The arbitral panel may, if it has been expressly empowered [authorized] to act as 'amiable compositeur' by agreement between the two parties to the arbitration, adjudicate the merits of the dispute in conformity with the rules of justice and fairness (ex aequo et bono), without being restricted by the legal provisions".

808 Sмiт, Hans; Реснота, V. Smit's Guides to International Arbitration, cit., p. E.S. A-1.

809 Código de Procedimentos Civis

Art. 57 - Los Jueces arbitros pueden ser de una o de dos clases, a saber: arbitros de derecho o arbitros arbitradores, que tambien se llaman amigables componedores.

Art. 58 - Los árbitros de derecho proceden como los Jueces ordinários y arreglaran sus procedimientos, como sus decisiones, a las leyes vigentes en la matéria. Los arbitros arbitradores procederan y sentenciaran, segun les dictar su consciência, sin atender mas que a la verdad y a la buena fe.

Fonte: Sмiт, Hans; Реснота, V. Smit's Guides to International Arbitration, cit., p. E.S. B(1)-1.

810 Art. 1.010 - Los árbitros decidiran la controversia como amigables componedores, salvo en que la cláusula compromisoria se les designe como arbitros de derecho.

Fonte: Smit, Hans; РеснотA, V. Smit's Guides to International Arbitration, cit., p. E.S. B(1)-5. 
gem por eqüidade, desde que haja disposição expressa autorizando. ${ }^{811} \mathrm{O}$ legislador daquele país foi particularmente cuidadoso ao tratar da arbitragem por eqüidade, ressalvando no texto da lei o respeito à ordem pública e ao objeto do litígio. ${ }^{812}$

De modo semelhante ao direito líbio, os árbitros devem ser investidos dos poderes de decisão por eqüidade quando houver indicação pessoal expressa. ${ }^{813}$ Portanto, uma cláusula de arbitragem por eqüidade não basta por si só para a atribuição dessa faculdade aos árbitros, salvo se o nome destes estiver nela contido (o que é uma prática em geral desaconselhável, em vista dos possíveis impedimentos que podem surgir antes de qualquer litígio). Caso não haja a designação dos árbitros, a missão destes de decidir por eqüidade deverá ser confirmada em acordo posterior.

O uso da arbitragem por eqüidade também retira certas faculdades de recurso das partes. $^{814}$

\subsubsection{Escócia}

A Escócia, ao contrário da Inglaterra, adotou a Lei Modelo da Uncitral em 1990, com o Law Reform Act. Seguindo-se uma técnica relativamente comum, a Lei Modelo foi anexada

811 Article 203.

1. Les contractants peuvent, à titre général, stipuler dans le contrat ou dans un accord ultérieur que tout différend qui naîtrait entre eux à l'occasion de l'exécution d'un contrat sera soumis à un ou plusieurs arbitres. Ils peuvent également convenir de l'arbitrage pour un différend déterminé, à des conditions particulières.

2. La preuve de la convention d'arbitrage ne peut être établie que par écrit.

3. L'objet du différend doit être précisé dans la convention d'arbitrage ou au cours de l'examen de l'affaire, même dans le cas où les arbitres sont désignés en qualité d'amiables compositeurs. A défaut, l'arbitrage est nul.

Fonte: Revue de l'arbitrage, n. 2, p. 343 e ss., 1993.

812 Article 212.

1. L'arbitre statue sans être tenu de suivre la procédure judiciaire, à l'exception de celle prévue dans le présent titre et celle particulière à la convocation des parties et à l'audition de leurs moyens de défense, ainsi que celle leur permettant de produire leurs documents. Les parties peuvent, néanmoins, convenir d'une procédure déterminée qui devra être suivie par l'arbitre.

2. La sentence arbitrale doit être conforme aux règles de droit à moins que l'arbitre n'ait reçu mission de statuer en amiable composition, auquel cas il ne sera tenu de respecter que les seules règles se rapportant à l'ordre public.

813 Article 205.

Les arbitres ne peuvent être investis de la mission d'amiables compositeurs que s'ils sont désignés par leur nom dans la convention d'arbitrage ou dans un acte ultérieur.

814 Article 217.

1. Les sentences arbitrales ne sont susceptibles d'aucun recours.

2. Le jugement confirmant ou annulant la sentence arbitrale peut être attaqué par toute voie de recours.

3. Par exception aux dispositions du paragraphe précédent, le jugement ne sera pas susceptible d'appel si les arbitres ont reçu mission de statuer en amiable composition, si les parties ont renoncé expressément au droit de faire appel ou si la contestation porte sur un montant n'excédant pas les dix mille dirhams. 
à referida lei ${ }^{815}$ Portanto, também a Escócia permite a arbitragem por eqüidade, nos moldes da Lei Modelo. ${ }^{816}$

\subsubsection{Espanha}

A arbitragem por eqüidade é tradicional no direito espanhol. Até a reforma ocorrida com a edição da Lei 60, de 23.12.2003, havia presunção de eqüidade, salvo convenção em contrário das partes. ${ }^{817}$ Entretanto, por razões discutidas na própria exposição de motivos da atual lei, a presunção foi invertida, procedendo-se à arbitragem por eqüidade apenas quando houver autorização expressa das partes. ${ }^{818}$ As razões apontadas para tal modificação da presunção no direito anterior são a busca de uma maior consistência com a prática internacional, que adota majoritariamente o regime de presunção de arbitragem de direito, bem como a busca de maior respeito pela vontade das partes, que nem sempre associam a pura contratação de arbitragem com a utilização de eqüidade na decisão. ${ }^{819}$

815 Paulsson, Jan (Ed.). International Handbook on Commercial Arbitration, cit., suplemento 19, p. Scotland Annex III, ago. 1995.

816 O que é confirmado por doutrina, cf. Dervaird:

"Arbiters must decide according to rules of law unless the parties agree that they shall decide as amiables compositeurs, either at common law or under Art. 28(3) of the Uncitral Model Law" (PAulsson, Jan (Ed.). International Handbook on Commercial Arbitration, cit., suplemento ago. 1995, p. Scotland - 22.

817 Entre muitos outros, vide Sмiт, Hans; Реснот,, V. Smit's Guides to International Arbitration, cit., p. SPA C-14.

818 Artículo 34.

Normas aplicables al fondo de la controversia.

1. Los árbitros sólo decidirán en equidad si las partes les han autorizado expresamente para ello.

2. Sin perjuicio de lo dispuesto en el apartado anterior, cuando el arbitraje sea internacional, los árbitros decidirán la controversia de conformidad con las normas jurídicas elegidas por las partes. Se entenderá que toda indicación del derecho u ordenamiento jurídico de un Estado determinado se refiere, a menos que se exprese lo contrario, al derecho sustantivo de ese Estado y no a sus normas de conflicto de leyes.

Si las partes no indican las normas jurídicas aplicables, los árbitros aplicarán las que estimen apropiadas.

3. En todo caso, los árbitros decidirán con arreglo a las estipulaciones del contrato y tendrán en cuenta los usos aplicables.

Disponível em: <http://www.boe.es/boe/dias/2003/12/26/pdfs/A46097-46109.pdf>. Acesso em: 16 nov. 2007.

819 El título VI se dedica al laudo y a otras posibles formas de terminación del procedimiento arbitral. El artículo 34 regula la importante cuestión de qué normas han de aplicarse a la resolución del fondo de la controversia, sobre la base de los siguientes criterios: $1^{\circ}{ }^{\circ}$ La premisa es, una vez más, como en la Ley de 1988, la libertad de las partes. $2^{\circ}{ }^{\circ}$ ) Se invierte la regla que la ley de 1988 contenía a favor del arbitraje de equidad. La preferencia por el arbitraje de derecho en defecto de acuerdo delas partes es la orientación más generalizada en el panorama comparado. Resulta, además, muy discutible que la voluntad de las partes de someterse a arbitraje, sin más especificaciones, pueda presumirse que incluya la de que la controversia sea resuelta en equidad y no sobre la base de los mismos criterios jurídicos que si hubiere de resolver un tribunal. El arbitraje de equidad queda limitado a los casos en que las partes lo hayan pactado expresamente, ya sea a través de una remission literal a la "equidad", o a términos similares como decisión "en conciencia", "ex aequo et bono", o que el árbitro actuará como "amigable componedor". No obstante, si las partes autorizan la decisión en equidad y al tiempo señalan normas jurídicas aplicables, los árbitros no pueden ignorar esta última indicación. 


\subsubsection{Estados Unidos da América}

A arbitragem nos Estados Unidos sujeita-se a uma série de leis. Em matérias de jurisdição federal, a arbitragem é regulada pelo Federal Arbitration Act, cujos capítulos prevêem matérias internas e convenções internacionais. No que diz respeito ao direito interno, o Capítulo 1 do Federal Arbitration Act, que foi editado pela primeira vez em 1925, com sucessivas revisões. Além disso, os Estados podem legislar sobre arbitragem. Mais da metade dos Estados adota o Uniform Arbitration Act que também tem a intenção de ser uma espécie de lei modelo para a unificação do direito da arbitragem (há outras leis-modelo para outras matérias). ${ }^{820}$ Vários Estados norte-americanos editaram legislação sobre arbitragem internacional com base na Lei Modelo. ${ }^{821}$

A legislação federal norte-americana não menciona a arbitragem por eqüidade. Tampouco o faz o Uniform Arbitration Act. Entretanto, é comumente aceito que os EUA permitem a arbitragem por eqüidade, embora seja um conceito atípico para sua cultura jurídica. ${ }^{82}$

Disponível em: <http://www.boe.es/boe/dias/2003/12/26/pdfs/A46097-46109.pdf>. Acesso em: 16 nov. 2007.

820 Sobre a regulação de arbitragem, ver Sмit, Hans; РеснотA, V. Smit's Guides to International Arbitration, cit., p. USA A-1 e ss.; Holtzmann, Howard M.; Donovan, Donald Francis. In: PAulsson, Jan (Ed.). International Handbook on Commercial Arbitration, cit., p. United States 1 e ss.

821 São eles: Califórnia, Connecticut, Illinois, Louisiana, Oregon e Texas, conforme o site da Uncitral: <http:// www.uncitral.org/uncitral/en/uncitral_texts/arbitration/1985Model_arbitration_status.html.> Acesso em: 16 nov. 2007.

822 Conforme Holtzmann, Howard M.; Donovan, Donald Francis. In: PAulsson, Jan (Ed.). International Handbook on Commercial Arbitration, cit., p. United States 53:

"The practice of arbitrators deciding as amiables compositeurs, which is permitted under the law of certain countries, is not typical in the United States. However, a similar concept is not unusual in American arbitration. As noted above, in those cases where neither the contract nor the rules call for application of law in deciding the substance of the dispute, the arbitrators may decide in accordance with their own sense of justice and equity - a concept not unlike deciding as amiables compositeurs". Também as opiniões de George Von Mehren, nas respostas ao questionário da Força Tarefa da Câmara de Comércio Internacional sobre Arbitragem por Eqüidade (disponível em: <http://intranet.iccwbo.org/view_topic.asp?topic=258\&forum=10>, com restrições de acesso. Vide também Sмiт, Hans; Реснота, V. Smit’s Guides to International Arbitration, cit., p. USA C-4):

"The concept of amiable compositeurs is unknown in American law because there is no expectation or statutory requirement binding arbitrators to follow rules of law. It is therefore not unusual for arbitrators to base their decision on general principles of fairness and equity. The AAA rules permit an arbitrator to grant any remedy or relief which he deems just and equitable and within the scope of the agreement of the parties (rule 43). In a landmark tudy of arbitral behavior conducted in the early 1960s, 80 percent of the arbitrators surveyed thought that they should make their decision within the framework of substantive law principles, but a full 90 percent thought that they were not required to do so if the application of rules of law would result in a less just decision. Since reasons for arbitral awards are neither required nor costumary under U.S. law, it is often difficult to determine the reasoning on which arbitral decisions are based. Furthermore, an incorrect application of the law is not a ground for setting aside an award". 


\subsubsection{Finlândia}

A Finlândia editou sua lei de arbitragem em 23.10.1992, substituindo a legislação anterior de 1928. Aquela lei segue a Lei Modelo, mas aplica-se às arbitragens internas e internacionais. $\mathrm{O}$ art. 31 da lei expressamente prevê a arbitragem por eqüidade. ${ }^{823}$

\subsubsection{França}

O direito francês é um dos principais pontos de irradiação da arbitragem por eqüidade no mundo. A literatura é suficientemente extensa e é bastante citada nesta obra, bem como sua jurisprudência. Portanto, limita-se a abordagem aqui a apenas transcrever os artigos do Código de Processo Civil francês que tratam da matéria, conforme a reforma efetuada em 1981 (Decreto 81-500):

Article 1.474

L'arbitre tranche le litige conformément aux règles de droit, à moins que, dans la convention d'arbitrage, les parties ne lui aient conféré mission de statuer comme amiable compositeur

Article 1.482

La sentence arbitrale est susceptible d'appel à moins que les parties n'aient renoncé à l'appel dans la convention d'arbitrage. Toutefois, elle n'est pas susceptible d'appel lorsque l'arbitre a reçu mission de statuer comme amiable compositeur, à moins que les parties n'aient expressément réservé cette faculté dans la convention d'arbitrage .

Article 1.483

Lorsque, suivant les distinctions faites à l'article 1482, les parties n'ont pas renoncé à l'appel, ou qu'elles se sont réservées expressément cette faculté dans la convention d'arbitrage, la voie de l'appel est seule ouverte, qu'elle tende à la réformation de la sentence arbitrale ou à son annulation. Le juge d'appel statue comme amiable compositeur lorsque l'arbitre avait cette mission.

Article 1.497

L'arbitre statue comme amiable compositeur si la convention des parties lui a conféré cette mission.

S23 Section 31

1. The arbitral tribunal shall decide the dispute in accordance with the rules of law applicable to the substance of the dispute.

2. If the parties have designated the law of a given State as applicable to the substance of the dispute, the arbitral tribunal shall apply that law.

3. The arbitral tribunal shall decide ex aequo et bono only if the parties have expressly authorised it to do so. Fontes: PAulsson, Jan (Ed.). International Handbook on Commercial Arbitration, cit., suplemento out. 1995, p. Finland Annex I-7. Vide também Smit, Hans; РеснотA, V. Smit's Guides to International Arbitration, cit., p. FIN B-9. 


\subsubsection{Grécia}

A Grécia possui uma lei de arbitragem comercial internacional, baseada na Lei Modelo (Lei 2.735/1999). Esta lei regula somente a arbitragem internacional. A arbitragem interna é regulada pelo Código de Processo Civil, ${ }^{824}$ de 1971. O art. 28 da lei de arbitragem internacional prevê a arbitragem por eqüidade nos termos da Lei Modelo. O Código de Processo Civil prevê, em seu art. 890, que, "salvo convenção em contrário, os árbitros aplicam a lei substantiva". Portanto, permite a arbitragem por eqüidade desde que as partes assim contratem. ${ }^{825}$

\subsubsection{Guatemala}

A Guatemala editou em 1995 uma nova lei de arbitragem, baseada na Lei Modelo. Esta lei aplica-se às arbitragens internas e internacionais. ${ }^{826}$ Em seu art. 37, a Lei prevê a arbitragem por eqüidade, a qual também se refere como ex aequo et bono. Ambas as arbitragens estão sujeitas às mesmas regras:

Artículo 37. Amigable composición (arbitraje "ex aequo et bono").

1) En el arbitraje de equidad ("ex aequo et bono"), también llamado amigable composición, los árbitros no se encuentran obligados a decidir en base a las normas de derecho, sino que pueden hacerlo "en conciencia" o "según su leal saber y entender".

2) Con excepción de lo dispuesto en el párrafo anterior, el arbitraje "de derecho" y el arbitraje "de equidad" (ex aequo et bono), se encuentran sujetos a la misma regulación contemplada en esta ley.

3) El tribunal arbitral compuesto de amigables componedores o árbitros arbitradores decidirá conforme a la equidad (ex aequo et bono) sólo si las partes lo han autorizado expresamente a hacerlo así. ${ }^{827}$

\subsubsection{Holanda}

A Holanda possui uma tradição de longa data de arbitragem. Seu regime de arbitragem não diferencia arbitragens nacionais e internacionais. Seu regime jurídico está previsto no Código de Processo Civil, tal como emendado em 1986.

824 Smit, Hans; Pechota, V. Smit's Guides to International Arbitration, cit., p. GRE A-1, e Foustoucos, Anghelos C.; Koussoulis, Stelios. In: Paulsson, Jan (Ed.). International Handbook on Commercial Arbitration, cit., p. Greece 1, suplemento dez. 2001.

825 Foustoucos, Anghelos C.; Koussoulis, Stelios. Ibidem, p. Greece 28.

826 Smit, Hans; PеснотA, V. Smit's Guides to International Arbitration, cit.,. pg. GUA A-1.

827 Idem, ibidem, p. GUA B91)-15. 
O art. 1.054 do Código expressamente prevê a possibilidade de arbitragem por eqüidade, desde que as partes assim acordem..$^{828}$

\subsubsection{Honduras}

Honduras renovou sua legislação sobre arbitragem em 2000, com a edição da Lei de Conciliação e Arbitragem (Decreto 161/2000). Esta lei admite a arbitragem por eqüidade, definindo-a como aquela em que os árbitros decidem "conforme o sentimento comum e a eqüidade". ${ }^{829}$ Aqui também se mostra algum esboço de um conteúdo material de eqüidade, que tem como elemento central o "sentimento comum" ou o senso comum.

Caso a arbitragem seja de direito, os árbitros devem ser profissionais do direito. ${ }^{830}$ Caso as partes não tenham especificado a natureza da arbitragem, presume-se que esta é de direito. ${ }^{831}$

828 Article 1.054. Rules Applicable to the Substance of The Dispute

1. The arbitral tribunal shall make its award in accordance with the rules of law.

2. If a choice of law is made by the parties, the arbitral tribunal shall make its award in accordance with the rules of law chosen by the parties. Failing such choice of law, the arbitral tribunal shall make its award in accordance with the rules of law which it considers appropriate.

3. The arbitral tribunal shall decide as amiable compositeur if the parties by agreement have authorised it to do so.

4. In all cases the arbitral tribunal shall take into account any applicable trade usages.

Fonte: Paulsson, Jan (Ed.). International Handbook on Commercial Arbitration, cit., p. The Netherlands Annex I-11, suplemento mar. 2005. Também Sмiт, Hans; РеснотA, V. Smit's Guides to International Arbitration, cit., p. NET B(2)-14.

829 34. Definiciones y Reglas de Interpretacion. Se adoptan las siguientes definiciones y reglas de interpretación comunes a la presente ley: 1) Tribunal arbitral: significa tanto un solo arbitro como una pluralidad de árbitros. 2) El arbitraje en cuanto a las reglas de procedimiento puede ser: a) Ad-hoc: Es aquel en el cual las partes acuerdan las reglas de procedimiento aplicables en la solución de su controversia. b) Institucional: Es aquel en el cual las partes se someten a un procedimiento establecido por un centro de arbitraje. 3) El arbitraje en cuanto a su naturaleza puede ser: a) En derecho: Es aquel en el cual los árbitros fundamentan su decisión en el derecho positivo vigente. b) En equidad: Es aquel en que los árbitros deciden según el sentimiento común y la equidad. c) Técnico: Es aquel en el cual los árbitros pronuncien su fallo en razón de sus específicos conocimientos en una determinada ciencia, arte u oficio. 4) Laudo: Sentencia o fallo dictado por un tribunal arbitral. 5) Las normas referidas a la integración del tribunal arbitral y al procedimiento arbitral son de carácter supletorio en relación a la voluntad de las partes.

Fonte: Smit, Hans; РеснотA, V. Smit’s Guides to International Arbitration, cit., p. HON B(1)-11.

830 Artículo 43. Requisitos para ser árbitro. Solo las personas naturales que se hallen en el pleno ejercicio de sus derechos civiles podrán ser designados como árbitros. Cuando el arbitraje haya de decidirse con sujeción a derecho, los árbitros deberán ser profesionales del derecho. Cuando el arbitraje se deba resolver conforme a normas o principios técnicos, los árbitros deberán ser expertos en el arte, profesión u oficio respectivo. Las partes podrán establecer requisitos o condiciones adicionales para los árbitros en el convenio arbitral.

831 Capítulo V - Del Laudo Arbitral. Artículo 66. Forma de dirimir asuntos. El tribunal arbitral decidirá la cuestión sometida a su consideración con sujeción a derecho, en equidad o conforme a normas y principios técnicos, de conformidad a lo estipulado en el convenio arbitral. En caso de que las partes no hayan pactado al respecto, el tribunal deberá resolver conforme a derecho. 


\subsubsection{Hong Kong}

Hong Kong é uma região administrativa especial da República Popular da China que tem ordenamento jurídico próprio. A transferência de soberania do Reino Unido para a China popular ocorreu em 1997. A arbitragem em Hong Kong é regulada pela Arbitration Ordinance, emendada pela última vez em 2000. Esta lei distingue entre arbitragens internas e internacionais. As internacionais são reguladas pela Lei Modelo, adotada com pequenas alterações, que não atingem o art. 28(3). Portanto, Hong Kong reconhece a arbitragem por eqüidade nos moldes da Lei Modelo. ${ }^{832}$ No tocante à arbitragem interna, a lei é silente.

\subsubsection{Hungria}

A Hungria reformou sua legislação de arbitragem em 1994, com a edição de Lei LXXI. Esta lei aplica-se a arbitragens internas e internacionais e é baseada na Lei Modelo. A autorização para decisão por eqüidade encontra-se no art. 49 da referida Lei. ${ }^{833}$

\subsubsection{Iemem}

O Iemem editou sua atual legislação sobre arbitragem por meio do Decreto Presidencial 22/1992. A lei iemenita define a arbitragem por eqüidade em seu art. 2 como o acordo pelo qual as partes indicam um ou vários árbitros para decidir de acordo com princípios de justiça e eqüidade (justice and fairness), sem utilização dos tribunais competentes. ${ }^{834}$ Esta definição possui a peculiaridade de mencionar o efeito negativo da convenção de arbitragem relativamente aos tribunais.

832 Fonte: Smit, Hans; Pechota, V. Smit's Guides to International Arbitration, cit., p. HKG B(1)-41 e ss.

833 Section 49

(1) The arbitral tribunal shall decide the dispute in accordance with such rules of law as are chosen by the parties as applicable to the substance of the dispute. Any designation of the law or legal system of a given state shall be construed - unless the parties have agreed otherwise - as one referring to the rules in the given state's law, relating directly to the points in issue.

(2) Failing any designation of law by the parties, the applicable law shall be determined by the arbitral tribunal.

(3) The arbitral tribunal may only decide ex aequo et bono, instead of the application of a law, if it was expressly authorized to do so by the parties.

Fonte: Smit, Hans; Pechota, V. Smit's Guides to International Arbitration, cit., p. B(2)-16, e Paulsson, Jan (Ed.). International Handbook on Commercial Arbitration, cit., p. Hungary: Annex I-13.

834 Article 2.

The terms and expressions mentioned below shall, for the purposes of this Act, have the meaning indicated hereafter, unless otherwise dictated by context.

Arbitration: is the choice by which the parties agree to appoint one or several third parties in order to arbitrate the disputes or conflicts which might arise between them, without resorting to the competent court.

Commercial arbitration: means any arbitration where the parties are natural or juristic persons undertaking commercial, economic or investment operations, whether they are Yemeni, Arab or foreign. 


\subsubsection{6 Índia}

A Índia editou sua nova lei de arbitragem em 1996, chamada Arbitration and Conciliation Act (Lei 26, de 16.08.1996). Esta lei, que se aplica à arbitragem doméstica e internacional, é baseada na Lei Modelo. Em seu art. 28, prevê a arbitragem por eqüidade desde que as partes assim autorizem. ${ }^{835}$

\subsubsection{Indonésia}

A Indonésia editou sua nova legislação sobre arbitragem em 1999, com a Lei 30, sobre arbitragem e meios alternativos de solução de controvérsias. Nesta lei, a Indonésia não seguiu a Lei Modelo. ${ }^{836} \mathrm{O}$ art. 56 daquela lei prevê:

National arbitration: means an arbitration where the parties to the dispute are nationals of the Yemeni Republic.

International arbitration: means an arbitration where the parties are of different nationality or whose domicile or main establishment is located in different countries, or an arbitration taking place within an international arbitration centre.

The agreement to arbitrate: means the acceptance by the parties to resort to arbitration and can be an arbitration agreement (a separate contract) or an arbitration clause (a clause contained in a contract).

The arbitral tribunal: The arbitral tribunal is composed of a sole arbitrator or several arbitrators in compliance with the agreement to arbitrate, or the provisions of this Act.

The competent court: is the court normally having jurisdiction over the dispute or to which this Act refers for any question which is not under the jurisdiction of the arbitral tribunal.

"Amiable composition": The agreement by the parties to appoint one or several arbitrators to arbitrate between them in compliance with the principles of fairness and justice, without resorting to the competent court.

Fonte: Journal of International Arbitration, v. 11, n. 2, p. 70-76, 1994.

835 28. Rules Applicable to Substance of Dispute

(1) Where the place of arbitration is situate in India, -

(a) in an arbitration other than an international commercial arbitration, the arbitral tribunal shall decide the dispute submitted to arbitration in accordance with the substantive law for the time being in force in India;

(b) in international commercial arbitration, -

(i) the arbitral tribunal shall decide the dispute in accordance with the rules of law designated by the parties as applicable to the substance of the dispute;

(ii) any designation by the parties of the law or legal system of a given country shall be construed, unless otherwise expressed, as directly referring to the substantive law of that country and not to its conflict of laws rules;

(iii) failing any designation of the law under sub-clause (ii) by the parties, the arbitral tribunal shall apply the rules of law it considers to be appropriate given all the circumstances surrounding the dispute.

(2) The arbitral tribunal shall decide ex aequo et bono or as amiable compositeur only if the parties have expressly authorised it to do so.

(3) In all cases, the arbitral tribunal shall decide in accordance with the terms of the contract and shall take into account the usages of the trade applicable to the transaction.

Fonte: PAulsson, Jan (Ed.). International Handbook on Commercial Arbitration, cit., p. India: Annex I-12, suplemento set. 2006. Também Smit, Hans; РеснотA, V. Smit's Guides to International Arbitration, cit., p. IND B-14.

836 Smit, Hans; Pechota, V. Smit's Guides to International Arbitration, cit., p. INS A-1. Também Mills, Karen. Relatório Indonésia. In: PAulsson, Jan (Ed.). International Handbook on Commercial Arbitration, cit., p. Indonésia - 2, suplemento nov. 2006. 
Article 56

(1) The arbitrator or arbitration tribunal shall render its decision based upon the relevant provisions of law, or based upon justice and fairness.

(2) The parties are entitled to designate the choice of law to be applied to the resolution of disputes which may arise, or which have arisen, between or among them. ${ }^{837}$

Duas observações nascem do exame deste artigo. Em primeiro lugar, a ausência de previsão expressa sobre qual critério (lei ou justiça e eqüidade) deve prevalecer. Há pronunciamento da doutrina mencionando que, embora este art. ainda não tenha sido testado, é quase certo que a possibilidade de critérios de justiça e eqüidade sobreporem-se à lei depende de convenção expressa das partes. ${ }^{838}$ Essa era a orientação no direito anterior, quando ainda havia a divisão entre arbitragem interna e internacional (art. 631 do Código Civil). ${ }^{839}$

\subsubsection{Irã}

O Irã adotou uma nova legislação sobre arbitragem comercial internacional em 1998, baseada na Lei Modelo. Em seu art. 27(3), a lei iraniana reproduz as disposições do art. 28(3) da Lei Modelo, permitindo a arbitragem por eqüidade caso as partes autorizem. ${ }^{840}$

\subsubsection{Irlanda}

A Irlanda reformou sua legislação sobre arbitragem em 1998, com a edição do International (International Commercial) Act. Anteriormente, sua legislação era baseada nas leis inglesas de 1950 e 1979. A nova lei (n. 14 de 1998) expressamente adota a Lei Modelo, cujo texto é colocado como anexo. No que diz respeito à arbitragem doméstica, a Irlanda manteve as leis anteriores, com modernizações. Portanto, há dois regimes de arbitragem na Irlanda. ${ }^{841}$

837 Fonte: Paulsson, Jan (Ed.). International Handbook on Commercial Arbitration, cit., p. Indonésia Annex I-10, suplemento nov. 2006. Smit, Hans; РеснотA, V. Smit’s Guides to International Arbitration, cit., p. INS B-20.

838 Também MiLls, Karen. Relatório Indonésia, cit., p. Indonésia - 28, suplemento nov. 2006.

839 Gautama, Sudargo. Relatório de 1998. Paulsson, Jan (Ed.). International Handbook on Commercial Arbitration, cit. (este relatório foi substituído pelo de Karen Mills, citado na nota anterior).

840 Fonte: Journal of International Arbitration, v. 15, n. 3, p. 42-52, 1998.

841 Smit, Hans; PeсhотA, V. Smit's Guides to International Arbitration, cit., p. IRE A-1., e BunNi, Nael. Ireland. In: Paulsson, Jan (Ed.). International Handbook on Commercial Arbitration, cit., p. Ireland 2, suplemento abr. 2001. 
Considera-se que em ambos os regimes a arbitragem por eqüidade é permitida desde que haja autorização expressa das partes, embora estes casos sejam raros em arbitragem doméstica. ${ }^{842}$

\subsubsection{Israel}

A arbitragem em Israel é regulada basicamente pela Lei 5.728, de 1968, emendada pela Lei 5.734, de 1974. Embora não haja uma permissão expressa na legislação de Israel consultada para esta pesquisa, a doutrina converge em afirmar que a arbitragem por eqüidade é permitida naquele país. ${ }^{843} \mathrm{~A}$ não-aplicação pelo árbitro do direito escolhido pelas partes é causa de nulidade da sentença arbitral. ${ }^{844}$

842 BunN, Nael. Ibidem, p. Ireland 31.

${ }^{843}$ Ottolenghi, Smadar. Relatório sobre Israel. In: Paulsson, Jan (Ed.). International Handbook on Commercial Arbitration, cit., suplemento ago. 1984.

"5. Applicable Law

A. Domestic Arbitration

$[\ldots]$

b. The arbitrator may also decide as an amiable compositeur, if the parties have expressly authorized him to do so. When this decision is given in the form of an award, there is no difference between this decision and the one based on his best judgment or on the rules of law. When this decision is given in the form of a contractual compromise by the parties, however, it would be deprived of all the advantages of the Arbitration Act in regard to confirmation and execution.

Where no applicable law has been chosen by the parties, the Schedule provides that the arbitrator is not bound by substantive law (Sect. N). In such a case the arbitrator has to make his award to the best of his judgement in accordance with the material before him. The arbitrator may decide as amiable compositeur if the parties have expressly authorized him to do so." Sмiт, Hans; Реснота, V. Smit's Guides to International Arbitration, cit., p. ISR C-4.

844 24. Setting Aside Arbitral Award

The court may, on the application of a party (in this Law referred to as an "application to set aside"), set aside an arbitral award, wholly or in part, or supplement or amend it, or remit it to the arbitrator, for one of the following reasons:

(1) the arbitration agreement was not valid

(2) the award was made by an arbitrator not properly appointed

(3) the arbitrator acted without authority or exceeded the authority vested in him by the arbitration agreement

(4) a party was not given a suitable opportunity to state his case or to produce his evidence

(5) the arbitrator did not determine one of the matters referred to him for determination

(6) the arbitrator did not assign reasons for the award though the arbitration agreement required him to do so

(7) the arbitrator did not make the award in accordance with law though the arbitration agreement required him to do so

(8) the award was made after the period for making it had expired

(9) the contents of the award are contrary to public policy

(10) a ground exists on which a court would have set aside a final, non-appealable judgment.

Paulsson, Jan (Ed.). International Handbook on Commercial Arbitration, cit., p. Israel Annex I -5, suplemento ago. 1984. Também Smit, Hans; PеснотA, V. Smit’s Guides to International Arbitration, cit., p. ISR B-6. 
Uma disposição interessante da lei de Israel é a letra $\mathrm{N}$ do anexo da Lei 5.728, que prevê que, caso as partes não tenham escolhido uma lei aplicável, o árbitro deve usar seu "melhor julgamento" de acordo com o material apresentado. ${ }^{845}$ Embora esta disposição pareça conviver paralelamente à arbitragem por eqüidade, ${ }^{846}$ há uma interessante sugestão de julgamento de fato.

\subsubsection{Itália}

Como já visto nesta obra, a Itália possui um sistema "duplo" de arbitragem, dividido entre arbitrato rituale e arbitrato irrituale ou libero. $\mathrm{O}$ primeiro assemelha-se à arbitragem conhecida no restante do mundo. É regulado pelo Código de Processo Civil e suas sentenças são exeqüíveis judicialmente e têm força de coisa julgada. O arbitrato irrituale era até pouco tempo atrás uma criação essencialmente de doutrina e jurisprudência, com base na autonomia contratual das partes, funcionando como uma espécie de "arbitragem contratual": os árbitros são chamados a decidir uma questão contratual, como mandatários das partes em uma transação. O resultado de sua decisão tem força de contrato e como tal pode ser anulado. ${ }^{847}$ Além desses dois tipos de arbitragem, a Itália ainda conhece o chamado arbitraggio, que é uma forma de arbitramento contratual. Em uma apertada síntese, podese dizer que a diferença entre o arbitrato irrituale e o arbitraggio é que o primeiro efetivamente decide uma controvérsia existente e o segundo completa o conteúdo negocial de um contrato. Pode-se dizer que o primeiro assemelha-se a uma transação por mandato (parte da doutrina italiana defende que se trata de um negócio de jurídico "di accertamento" "448) e o segundo a uma estipulação por terceiro.

Em geral, os poderes do árbitro irrituale são negociais. Ele chega a uma solução como mandatário das partes. Assim, sua função é mais negocial do que propriamente jurídica. Podese afirmar, com apoio na doutrina local, que o árbitro irrituale decide sempre em eqüidade com uma visão mais negocial do que jurídico-positiva. ${ }^{849} \mathrm{Ou}$, em outras palavras, "il mandato a tran-

845 N. The arbitrator shall act in such manner as appears to him most conducive to a just and speedy determination of the dispute, and shall make the award to the best of his judgment in accordance with the material before him. The arbitrator shall not be bound by the substantive law, the rules of evidence or the rules of procedure obtaining in the courts.

Fonte: Paulsson, Jan (Ed.). International Handbook on Commercial Arbitration, cit., p. Israel annex I-9, e Sмit, Hans; Реснота, V. Smit's Guides to International Arbitration, cit., p. ISR B-12. tion, cit., p. Italy - 3, suplemento abr. 2007.

848 Rubino-Sammartano, Mauro. Il diritto dell'arbitrato, cit., p. 89 e ss.

849 Biamonti, Luigi. Verbete “Arbitrato”. Enciclopedia del diritto. Milano: Giuffrè, 1958. p. 944. 
sigere ha sempre implicito un potere discrezionale equitativo". ${ }^{850}$ Seguramente, trata-se de um juízo de oportunidade econômica, que atende mais ao negócio do que ao direito.

Havia na doutrina e jurisprudência italianas divergência quanto ao modo de interpretar a cláusula arbitral, de modo a definir se as partes pretendiam arbitrato rituale ou irrituale. Todavia, com a nova reforma da lei italiana sobre arbitragem, ocorrida em 2006, a questão parece ser resolvida com a tipificação deste tipo de arbitragem. ${ }^{851}$

No que diz respeito ao arbitrato rituale, a permissão para decisão em eqüidade consta da nova versão do art. 822 do Código de Processo Civil daquele país. ${ }^{852}$ A nova redação praticamente repete a redação anterior à reforma de $2006 .{ }^{853}$ No entanto, a reforma de 2006 retirou o art. 834 do $C P C,{ }^{854}$ que tratava da autorização para decisão por eqüidade na arbitragem internacional. Essa modificação reflete a nova orientação do direito italiano relativamente à regulação específica da arbitragem internacional e não a retirada da autorização para a decisão por eqüidade.

Uma das características interessantes da legislação italiana é que esta deixa clara a ausência de formas "sacramentais" para a autorização para arbitragem por eqüidade. Não é necessária a menção expressa ao nome de eqüidade, bastando que a vontade das partes seja suficientemente clara. Essa possibilidade naturalmente pode gerar algumas dúvidas.

850 Rubino-Sammartano, Mauro. Il diritto dell'arbitrato, cit., Pg. 153. Aquele autor, porém, entende que há limites para tais poderes, especialmente se a decisão tem premissas que advém do sistema normativo.

851 808-ter. (Arbitrato irrituale)

Le parti possono, con disposizione espressa per iscritto, stabilire che, in deroga a quanto disposto dall'articolo 824-bis, la controversia sia definita dagli arbitri mediante determinazione contrattuale. Altrimenti si applicano le disposizioni del presente titolo. Il lodo contrattuale e' annullabile dal giudice competente secondo le disposizioni del libro I: 1) se la convenzione dell'arbitrato e' invalida, o gli arbitri hanno pronunciato su conclusioni che esorbitano dai suoi limiti e la relativa eccezione e' stata sollevata nel procedimento arbitrale; 2) se gli arbitri non sono stati nominati con le forme e nei modi stabiliti dalla convenzione arbitrale; 3) se il lodo e' stato pronunciato da chi non poteva essere nominato arbitro a norma dell' articolo 812; 4) se gli arbitri non si sono attenuti alle regole imposte dalle parti come condizione di validita' del lodo; 5) se non e' stato osservato nel procedimento arbitrale il principio del contraddittorio. Al lodo contrattuale non si applica l'articolo 825.

852 Art. 822. (Norme per la deliberazione)

Gli arbitri decidono secondo le norme di diritto, salvo che le parti abbiano disposto con qualsiasi espressione che gli arbitri pronunciano secondo equita'.

853 Art. 822. (Norme per la deliberazione) Gli arbitri decidono secondo le norme di diritto, salvo che le parti li abbiano autorizzati con qualsiasi espressione a pronunciare secondo equita.

854 Art. 834. (Norme applicabili al merito)

Le parti hanno facolta' di stabilire d'accordo tra loro le norme che gli arbitri debbono applicare al merito della controversia oppure di disporre che gli arbitri pronuncino secondo equita'. Se le parti non provvedono, si applica la legge con la quale il rapporto e' piu' strettamente collegato. In entrambi i casi gli arbitri tengono conto delle indicazioni del contratto e degli usi del commercio. 
Uma delas é o uso da expressão amichevole compositore. Até a edição da nova disciplina para o arbitrato irrituale, pairava a dúvida se a expressão referia-se à escolha de uma arbitragem rituale por eqüidade ou a conferência do mandato para transigir ínsito ao arbitrato irrituale. A doutrina italiana encontrava-se bastante dividida, ${ }^{855}$ embora a jurisprudência tenha entendido ser cabível a referência a amichevole componimento e arbitragem rituale, caso isso resultasse do texto do contrato. Neste caso, entendia-se que a arbitragem seria rituale, por eqüidade..$^{856}$

\subsubsection{Japão}

O Japão editou sua nova lei de arbitragem em 2003 (Lei 138 de 2003), baseando-se largamente na Lei Modelo. A lei aplica-se a arbitragens internas e internacionais e não se limita a matérias comerciais. O art. 36(3) da lei japonesa reproduz o art. 28(3) da Lei Modelo, possibilitando aos árbitros decidir por eqüidade, quando as partes expressamente os autorizarem. ${ }^{857}$

\subsubsection{Jordânia}

A Jordânia adotou uma lei de arbitragem em 2001 (Lei 31/2001, de 14.06.2001). Em seu art. 36, há permissão para decisão por eqüidade, desde que haja autorização expressa das partes para tanto. Embora as disposições da lei jordaniana sejam similares as da Lei Modelo, há diferença na redação, contendo a alínea "d" da referida lei uma parte explicativa, asseverando que tribunal arbitral pode julgar o mérito do litígio aplicando "regras de justiça e eqüidade, sem estar ligado às disposições de uma lei”. ${ }^{858}$ Esta parte explicativa dos poderes afirma que a eqüi-

855 Para um exame mais detalhado das posições doutrinárias, vide Rubino-Sammartano, Mauro. Il diritto dell'arbitrato, cit., p. 110 e ss.

856 Rubino-Sammartano, Mauro. Il diritto dell'arbitrato, cit., p. 112.

857 Fonte: PAulsson, Jan (Ed.). International Handbook on Commercial Arbitration, cit., p. Japan : Annex I - 11, suplemento mar. 2005.

Também Smit, Hans; PеснотA, V. Smit's Guides to International Arbitration, cit., p. JAP B-16.

858 Article 36

a) Le tribunal arbitral applique au fond du litige les règles sur lesquelles les deux parties se sont mises d'accord. Si elles se sont mises d'accord sur l'application de la loi d'un Etat déterminé, application sera faite des règles de fond de cette loi à l'exclusion des règles de conflit des lois.

b) Si les deux parties ne se sont pas mises d'accord sur les règles de droit applicables au fond du litige, le tribunal arbitral applique les règles de fond de la loi qui lui paraît avoir les liens les plus étroits avec le litige.

c) Dans tous les cas, le tribunal arbitral doit, lorsqu'il tranche le fond du litige, prendre en considération les stipulations du contrat, objet du litige, ainsi que les usages courants dans ce type d'opération, de même que les habitudes suivies et la manière dont les parties avaient coutume de traiter entre elles.

d) Le tribunal arbitral peut, si les deux parties l'ont autorisé expressément à statuer en amiable composition, trancher le fond du litige en appliquant les règles de la justice et de l'équité sans être lié par les dispositions d'une loi.

Fonte: Revue de l'Arbitrage, n. 2, p. 493-509, 2002. 
dade deve ser utilizada apenas para as questões de mérito e deixa claro que não é necessária a referência a uma lei estatal para a decisão.

\subsubsection{Kwait}

O Kwait, tanto quanto foi possível obter informações, tem a arbitragem regulada no Código de Processo Civil e Comercial. Em seu capítulo 182, há previsão de que os árbitros decidem conforme a lei, salvo se forem autorizados a conciliar (to compromise, na tradução para o inglês) ${ }^{859}$ Possivelmente, trata-se da mesma forma de decisão de sulh, tal como prevista na legislação saudita, acima referida. A doutrina encontrada, anterior à edição deste código, refere-se à decisão por compromisso em oposição à aplicação da lei estrita ${ }^{860}$ Ela parece estar de acordo com o texto de lei acima citado.

\subsubsection{Libano}

O Líbano regula a arbitragem em seu Código de Processo Civil de 1983. Há uma regulação bem detalhada sobre a arbitragem por eqüidade, que é prevista e regulada em diversos artigos. Nos arts. 775 e seguintes, há autorização para que as partes convencionem a arbitragem por eqüidade tanto na cláusula compromissória como no compromisso, ou ainda em documento apartado. Em caso de silêncio das partes, presume-se que a arbitragem será de direito. ${ }^{861}$

859 Art. 182.

The arbitrator shall issue his award without being bound by the procedure laid down by law, except those laid down in this chapter. Nevertheless, the adversaries may agree on certain procedures which the arbitrator shall follow.

The award of the arbitrator shall be issued in accordance with the basic rules of law, unless he has been authorized to compromise, in which case he shall not be bound by these rules except those relating to public policy.

The rules relating to expedited execution of judgment shall apply to the awards of arbitrators. The award of the arbitrator must be issued in Kuwait, otherwise it shall be subject to the basic rules governing awards issued by arbitrators in a foreign country.

Fonte: Journal of International Arbitration, v. 6, n. 3, p. 86-96, 1989.

860 "5. Applicable Law

A. Domestic Arbitration

In making the award, the arbitrators shall comply with rules of law, unless they are authorized to settle the dispute by compromise." Zayyad, Fuad S. Abu. Relatório sobre o Kwait. In SAnders, Pieter (Ed.). Yearbook Commercial Arbitration, Deventer, Kluwer, v. 4, p. 144, 1970.

861 Art. 775.

Les parties peuvent convenir dans la clause compromissoire ou dans le compromis, ou dans un contrat séparé, que l'arbitrage sera un arbitrage en droit ou en amiable composition; l'arbitre ou les arbitres peuvent également être chargés de concilier les parties.

Art. 776. 
Já o art. 777 daquele Código traz uma alentada explicação sobre os efeitos da arbitragem por eqüidade: os árbitros são dispensados da aplicação das regras de direito (material) e das regras de procedimento, julgando apenas em eqüidade. A dispensa de observação das leis não se aplica às regras de ordem pública e aos princípios fundamentais do processo, especialmente aquelas relativas ao direito de defesa, a motivação das sentenças e as regras "particulares a arbitragem":
Art. 777.
Dans l'arbitrage en amiable composition, l'arbitre ou les arbitres sont dispen- sés de l'application des règles de droit et des règles normales de procédure et ils jugent en équité.
Sont exclues de cette dispense les règles de droit intéressant l'ordre public, et les principes fondamentaux de procédure, notamment ceux relatifs aux droits de la défense, à la motivation des décisions ainsi que les règles particulières à l'arbitrage.
L'arbitrage en amiable composition ne peut être établi qu'en vertu d'une clau- se expresse insérée dans la convention d'arbitrage ou dans une convention séparée.

Com esta regra didática, a legislação libanesa esclarece os limites da arbitragem por eqüidade no tocante ao processo, reconhecendo efeitos processuais a este tipo de arbitragem, mas reservando aqueles princípios essenciais à manutenção do devido processo legal. Também parece haver uma opção concernente a regras particulares à arbitragem. Parece indicar que certas matérias relativas à competência e arbitrabilidade estão fora do âmbito da eqüidade.

Além disso, há previsão de que a autorização para julgamento em eqüidade somente pode ser feita por escrito, por cláusula inserida na convenção de arbitragem ou em documento separado.

Lorsqu'un doute apparait quant à la qualification de l'arbitrage, celui-ci sera considéré comme un arbitrage en droit.

Dans l'arbitrage en droit, l'arbitre ou les arbitres appliquent les règles de droit et les règles normales de procédure, à l'exclusion de celles qui sont incompatibles avec les principes de l'arbitrage, et notamment celles posées dans le présent titre.

Les parties peuvent dispenser l'arbitre ou les arbitres de l'application des règles normales de procédure ou de certaines d'entre elles, à l'exclusion de celles intéressant l'ordre public, et à condition qu'elles soient compatibles avec les règles et les principes de l'arbitrage. Cette dispense ne peut, en particulier, porter sur les principes prévus aux articles 365 à 368 et 371 à 374 .

Cette dispense ne peut être établie que par une clause expresse insérée dans la convention d'arbitrage ou dans une convention séparée.

Art. 789.

Les arbitres tranchent le litige conformément aux règles prévues à l'article 776, à moins que les parties ne leur aient conféré, dans le compromis d'arbitrage, le pouvoir de le trancher en tant qu'amiables compositeurs, auquel cas ils appliqueront les règles prévues par l'articles 777.

Fonte: Smit, Hans; РеснотA, V. Smit's Guides to International Arbitration, cit., p. LEB B-4 . 
No tocante aos recursos, a legislação libanesa segue a orientação francesa, colocando uma inversão da presunção: na arbitragem de direito, é permitido recurso salvo disposição em contrário; na arbitragem por eqüidade, não há recurso, salvo se as partes dispuserem em contrário. Caso as partes tenham permitido recurso, o tribunal competente também julgará por eqüidade. $^{862}$

Ha permissão de arbitragem por eqüidade também nas disposições relativas à arbitragem internacional. ${ }^{863}$

\subsubsection{Líbia}

A arbitragem é regulada na Líbia pelo Código de Processo Civil de 1953, e a arbitragem internacional relativa a contratos com o Estado é prevista no regulamento de contratos administrativos, de 1980.

O Código de Processo Civil da Líbia prevê a possibilidade de arbitragem por eqüidade em seus arts. $745^{864}$ e 761, ${ }^{865}$ com um grau de detalhamento significativo em outros dispositivos vistos a seguir. $\mathrm{O}$ art. 745 possui a particularidade de exigir que, para haja decisão por eqüidade, esta determinação deve ser acompanhada da indicação nominal dos árbitros, quer no "acordo para arbitragem", quer em outro acordo anterior. Ou seja, a arbitragem por eqüidade somente é possível quando houver nomeação direta dos árbitros. Uma simples indicação de "arbitragem

862 Art. 799.

La sentence arbitrale est susceptible d'appel, à moins que les parties n'aient renoncé à l'appel dans la convention d'arbitrage.

La sentence arbitrale rendue par un arbitre amiable compositeur n'est pas susceptible d'appel, à moins que les parties ne se soient expressément réservé dans la convention d'arbitrage le droit d'exercer ce recours, et dans ce cas, la Cour d'appel statue comme arbitre amiable compositeur.

863 Art. 813.

L'arbitre tranche le litige conformément aux règles de droit choisies par les parties et à défaut d'un tel choix, conformément à celles qu'il estime appropriées. Il tient compte, dans tous ces cas, des usages commerciaux.

L'arbitre tranche le litige comme amiable compositeur si la convention des parties a précisé sa mission dans ce sens.

864 Article 745. "Amiable Composition"

The arbitrators may only be empowered to act as "amiables compositeurs" or settle a dispute as such if they were appointed by their name either in the agreement to arbitrate or in a prior agreement.

Fonte: Fonte: PAulsson, Jan (Ed.). International Handbook on Commercial Arbitration, cit., p. Libya: Annex I-1, suplemento ago. 1993.

865 Article 761. Place of Making the Award

The arbitral award must be made within Libyan territory otherwise it will be govemed by the rules applicable to judgments made abroad. The arbitrators must settle the case in law unless the parties authorize them to settle the case "ex aequo et bono" and in compliance with custom. 
por eqüidade" sem indicação de árbitros depende de uma reafirmação posterior, com indicação nominal dos árbitros. A razão para tal regra, segundo autores líbios, é a de que o grau de confiança depositado em um árbitro decidindo por eqüidade é tamanho que somente pode ser conferido a pessoas efetivamente conhecidas de antemão. ${ }^{866}$

$\mathrm{O}$ art. 755 do mesmo Código prevê a extensão dos limites dos árbitros em eqüidade: "estão liberados de qualquer dever de observância da lei ou de procedimentos legais" ${ }^{867}$ Portanto, a decisão por eqüidade tem efeitos igualmente sobre o procedimento, de modo a liberar os árbitros de seu seguimento. Os termos da tradução inglesa são bastante amplos "are freed from any duty". Entretanto, não há elementos para supor que tal liberação implica a possibilidade de não respeitar os elementos fundamentais de ordem pública em relação ao processo.

A arbitragem em eqüidade igualmente exclui a possibilidade de recurso. ${ }^{868}$

866 5. Applicable Law

a. Domestic Arbitration

Arbitrators must decide according to rules of law, i.e., the substantive law applicable to the dispute. The parties may empower the arbitrators to decide according to principles of equity and custom (Art. $761 \mathrm{CCP}$ ).

Arbitrators may be given power to decide as amiables compositeurs by the parties but only if they are named in the submission or in a prior agreement (Art. $745 \mathrm{CCP}$ ). The law does not allow for conferring such power upon arbitrators who are not yet known at the time the arbitration agreement is concluded. The reason for this is that the arbitrators deciding as amiables compositeurs are ipso jure freed from following substantive and procedural rules (Art. 755 CCP). Their award is not subject to appeal (Art. 767(2) CCP). Hence, the sole protection of the parties in this type of arbitration is the confidence they have in the person of the arbitrator; clearly, one cannot have confidence in unknown persons.

Kadiki, Khaled. Relatório sobre a Líbia. In: PAulsson, Jan (Ed.). International Handbook on Commercial Arbitration, cit., suplemento ago. 1993.

867 Article 755. Procedure for "Amiable Composition"

Arbitrators acting as "amiables compositeurs" are freed from any duty relating to the respect of the law or legal procedures.

Fonte: Fonte: Paulsson, Jan (Ed.). International Handbook on Commercial Arbitration, cit., p. Libya: Annex I-3.

868 Article 767. Appeal Against Arbitral Awards

Arbitral awards may be subject to appeal after they have been approved in compliance with the provisions of Article 763. The appeal must be made in compliance with the rules applicable for appeal against court judgments.

However, arbitral awards are not appealable if the arbitrators acted as "amiables compositeurs", if it was made in a case pending in appeal, if the parties have expressly waived their right to appeal or if the value of the claim settled by the award was such that no appeal is normally possible.

Appeal is made before the court which would have had jurisdiction over the case.

Fonte: PAulsson, Jan (Ed.). International Handbook on Commercial Arbitration, cit., p. Libya: Annex I-5. 


\subsubsection{Lituânia}

A Lituânia criou sua legislação de arbitragem em 1996, com a edição da Lei I-274, de 02.04.2006. Esta lei baseia-se na Lei Modelo e aplica-se a arbitragens internas e internacionais. Em seu art. 31, a arbitragem por eqüidade é prevista nos termos da Lei Modelo: ${ }^{869}$ somente com autorização expressa das partes.

\subsubsection{Luxemburgo}

Luxemburgo regula a arbitragem em seu Código de Processo Civil. Em seu art. 1.019, há previsão expressa de arbitragem por eqüidade, permitida desde que tal seja estipulado pelas partes no compromisso. ${ }^{870} \mathrm{O}$ Código utiliza a expressão amiable composition para defini-la. A opinião doutrinária prevalente é a de que a arbitragem por eqüidade libera os árbitros da aplicação das leis no mérito quanto no procedimento, desde que respeitada a ordem pública. ${ }^{871}$

\subsubsection{Madagascar}

Madagascar editou uma nova lei de arbitragem em 1998 (Lei 98-019), reformando os dispositivos de seu Código de Processo Civil. A arbitragem por eqüidade, ali referida como amiable composition, é prevista nos arts. $449^{872}$ e $461,{ }^{873}$ este utilizando os moldes da Lei Mo-

869 Smit, Hans; Реснота, V. Smit's Guides to International Arbitration, cit., p. LIT B(2)-11.

870 1019. Les arbitres et tiers-arbitres decideront d'apres les regles du droit, au moins que le compromis ne leur donne pouvoir de pronnoncer comme amiables compositeurs.

Disponível no site do governo de Luxemburgo: <http://www.legilux.public.lu/leg/textescoordonnes/codes/ index.html\#nouveau_code_procedure_civile>. Tradução inglesa publicada em: PAulsson, Jan (Ed.). International Handbook on Commercial Arbitration, cit., p. Luxembourg Annex I-3, suplemento set. 1994.

871 Arendt, Ernest; Harles-Walch, Thea. Relatório sobre Luxemburgo. In: PAulsson, Jan (Ed.). International Handbook on Commercial Arbitration, cit., p. Luxembourg 13, suplemento set. 1994.

872 Article 449.

L'arbitre tranche le litige conformément aux règles de droit, à moins que, dans la convention d'arbitrage, les parties ne lui aient conféré mission de statuer en amiable compositeur, c'est-à-dire selon les règles de l'équité.

Fonte: Revue de L'Arbitragem, n. 2, 1993.

873 Article 461.

1. Le tribunal arbitral tranche le litige conformément aux règles de droit choisies par les parties comme étant applicables au fond du litige. Toute désignation de la loi ou du système juridique d'un Etat donné est considérée, sauf indication contraire expresse, comme désignant directement les règles juridiques de fond de cet Etat et non ses règles de conflit de lois.

2. A défaut d'une telle désignation par les parties, le tribunal arbitral applique la loi désignée par la règle de conflit de lois qu'il juge applicable en l'espèce. 
delo da Uncitral. A lei malgaxe prevê recurso para anulação da sentença arbitral cumulada com um pedido de julgamento de mérito. Caso a sentença anulada tenha sido proferida por eqüidade, o tribunal igualmente julgará por eqüidade. ${ }^{874}$

\subsubsection{Malásia}

A Malásia adotou sua nova lei de arbitragem em 2005, baseando-se na Lei Modelo (Lei 646). Sua legislação anterior era baseada sobretudo no Arbitration Act inglês de 1950. Esta lei aplica-se a arbitragens internas e internacionais. Embora tenha sido inspirada na Lei Modelo, a lei malaia não seguiu o art. 28 no que diz respeito à arbitragem por eqüidade. $\mathrm{O}$ inciso 3 do art. 28 não foi repetido no seu equivalente da lei malaia ${ }^{875}$ Esta omissão não foi acidental. Há opiniões de juristas locais afirmando que uma decisão apenas em eqüidade, sem aplicação de uma lei, seria uma violação da ordem pública malaia. Portanto, deve-se entender que ela não é possível, ao menos no cenário interno. Quanto à homologação de uma sentença estrangeira dada em eqüidade, não há menção sobre os eventuais efeitos sobre a ordem pública. ${ }^{876}$

3. Le tribunal arbitral statue en amiable compositeur, c'est-à-dire selon les règles de l'équité, uniquement si les parties l'y ont expressément autorisé.

4. Dans tous les cas, le tribunal arbitral décide conformément aux stipulations du contrat et tient compte des usages du commerce applicables à la transaction.

874 Article 462.

$[\ldots]$

5. Lorsque la Cour, saisie de la demande en annulation, annule tout ou partie de la sentence arbitrale, elle peut à la demande de toutes les parties, statuer au fond. Elle agira en qualité d'amiable compositeur si le tribunal arbitral avait cette qualité.

875 Law applicable to substance of dispute

30. (1) In respect of a domestic arbitration where the seat of arbitration is in Malaysia, the arbitral tribunal shall decide the dispute in accordance with the substantive law of Malaysia.

(2) In respect of an international arbitration, the arbitral tribunal shall decide the dispute in accordance with the law as agreed upon by the parties as applicable to the substance of the dispute.

(3) Any designation by the parties of the law of a given State shall be construed, unless otherwise expressed, as directly referring to the substantive law of that State and not to its conflict of laws rules.

(4) Failing any agreement under subsection (2), the arbitral tribunal shall apply the law determined by the conflict of laws rules.

(5) The arbitral tribunal shall, in all cases, decide in accordance with the terms of the agreement and shall take into account the usages of the trade applicable to the transaction.

Fonte: PAulsson, Jan (Ed.). International Handbook on Commercial Arbitration, cit., p. Malaysia Annex I-11, suplemento nov. 2006.

Também Sмiт, Hans; Реснота, V. Smit's Guides to International Arbitration, cit., p. MAL B-18.

876 5. Applicable Law

a. Domestic Arbitration

In a domestic arbitration where the seat of arbitration is in Malaysia, the arbitral tribunal shall decide the dispute in accordance with the substantive law of Malaysia (Sect. 30(1)).

The arbitrators have not been given power to decide as amiables compositeurs or ex aequo et bono under the Act. A term which entitles the arbitrator to decide otherwise than in accordance with the substantive law governing the underlying contract as for example that which requires or empowers him to decide ex aequo et bono is 


\subsubsection{Malta}

Malta editou sua nova lei de arbitragem em 1996. Ela adota a Lei Modelo no que diz respeito à arbitragem internacional, que é colocada como anexo da lei. No tocante à arbitragem interna, a lei maltesa segue também a orientação da Lei Modelo. ${ }^{877}$ Portanto, em ambos os casos é possível a utilização de arbitragem por eqüidade, nos moldes da Lei Modelo.

\subsubsection{Marrocos}

A arbitragem em Marrocos é regulada pelo Código de Processo Civil. A legislação marroquina não diferencia arbitragens internas e internacionais. A arbitragem por eqüidade é prevista no art. 317 do Código de Processo Civil daquele país. ${ }^{878}$

\subsubsection{Mauritânia}

A Mauritânia adotou uma nova legislação sobre arbitragem em 2000 (Lei 2000-06), um Código de Arbitragem. Trata-se de uma lei bastante didática no que diz respeito à arbi-

contrary to public policy. This view may also apply to clauses which empower the arbitrator to act as amiable compositeurs.

Such equity clauses are not found in contracts in Malaysia. It is the view that the application of these clauses may prejudice the right of appeal on a question of law, which is taken away when an arbitrator is at liberty whether or not to apply the law. Deliberately to decide otherwise than in accordance with the law is not a permissible activity for a judge.

Lim, P.G. Relatório sobre Malásia. In: PAulsson, Jan (Ed.). International Handbook on Commercial Arbitration, cit., p. Malaysia-21, suplemento nov. 2006. A obra de Smit e Pechota nada menciona sobre este tipo de arbitragem.

877 Arbitration Act 1996, n. II of 1996. Assented to 13 February 1996

45. Applicable Law, Amiable Compositeur

(1) The arbitral tribunal shall apply, subject to the provisions of this Act, the law designated by the parties as applicable to the substance of the dispute. Failing such designation by the parties, the arbitral tribunal shall apply Maltese law including the rules of Maltese law relative to the conflict of laws.

(2) The arbitral tribunal shall decide as amiable compositeur or ex aequo et bono only if the parties have expressly authorised the arbitral tribunal to do so.

(3) In all cases, the arbitral tribunal shall decide in accordance with the terms of the contract and shall, if relevant, take into account the usages of the trade applicable to the transaction.

(4) Unless otherwise agreed to by the parties or otherwise provided for in or under this Act, the arbitral tribunal may conduct the arbitration in such manner it considers appropriate. The power conferred upon the arbitral tribunal includes the power to determine the admissibility, relevance, materiality and weight of any evidence. Fonte: Paulsson, Jan (Ed.). International Handbook on Commercial Arbitration, cit., p. Malta Annex I-15, suplemento out. 1997).

878 El Mernissi, Mohamed. Arbitration in Morocco. Reality and perspectives. Journal of International Arbitration, 19 (2), p. 179 e ss., 2002. 
tragem por eqüidade. Utilizando-se da denominação francesa amiable composition e amiable compositeur para os árbitros que decidem em eqüidade, a lei define estes últimos como "os árbitros aos quais a convenção de arbitragem lhes determina decidir o litígio segundo os princípios de justiça e eqüidade e não segundo as regras de direito". ${ }^{879}$

No art. 14, há nova menção aos poderes dos árbitros decidindo em eqüidade, com ligeira variação sobre a primeira definição: "neste caso, não são obrigados a aplicar regras de direito e decidem por eqüidade". ${ }^{880}$

No que concerne a recursos, a lei segue a orientação francesa: nas arbitragens de direito, o recurso é permitido salvo previsão em contrário das partes; nas arbitragens por eqüidade, o recurso é vedado salvo previsão em contrário. ${ }^{881}$ No caso de recurso tirado contra decisão de arbitragem por eqüidade, o tribunal decide também por eqüidade. ${ }^{882} \mathrm{O}$ mesmo acontece em caso de anulação da sentença arbitral, caso as partes tenham feito pedido para julgamento concomitante do mérito. ${ }^{883}$

879 Article 2.

On entend par:

$[\ldots]$

“Amiable compositeur": l'arbitre auquel la convention d'arbitrage lui confère de statuer sur le litige suivant les principes de justice et d'équité et non pas selon les règles de droit.

Fonte: Revue de l'Arbitrage, n. 4, p. 935 e ss., 2001.

880 Article 14.

Les arbitres doivent appliquer le droit, à moins que les parties ne leur confèrent, dans la convention d'arbitrage, la qualité d'amiables compositeurs. Ils ne sont pas, dans ce cas, tenus d'appliquer les règles de droit, et statuent en équité.

881 Article 37.

La sentence est susceptible d'appel à moins que les parties n'aient renoncé à l'appel dans la convention d'arbitrage. Toutefois, elle n'est pas susceptible d'appel lorsque l'arbitre a reçu mission de statuer comme amiable compositeur, à moins que les parties n'aient expressément réservé cette faculté dans la convention d'arbitrage.

L'appel de la sentence arbitrale est instruit et jugé selon les règles relatives à la procédure prévue par les dispositions du Code de procédure civile, commerciale et administrative concernant les jugements judiciaires.

Si la Cour confirme la sentence arbitrale attaquée, elle en donne l'exequatur. Si elle l'infirme, elle statue au fond et rend une nouvelle décision.

882 Article 39.

Si la juridiction compétente admet le bien-fondé du recours, elle annule la sentence ou la procédure d'arbitrage, en tout ou partie, selon les cas.

Elle doit statuer au fond à la requête des parties. Elle agira comme arbitre amiable compositeur si le tribunal arbitral en remplit lui-même les conditions requises.

La juridiction peut surseoir à statuer en cas de connexité avec une autre affaire pendante devant une autre juridiction judiciaire.

Si elle décide le rejet du recours, l'arrêt de rejet confère l'exequatur à la sentence arbitrale incriminée.

883 Article 59.

1. La sentence arbitrale rendue conformément aux dispositions de la présente loi n'est susceptible que du recours en annulation. Dans ce cas, la procédure à suivre sera celle prévue aux alinéas 2 et 3 du présent article. 


\subsubsection{México}

A disciplina da arbitragem comercial no México encontra-se no Código Comercial e nos diversos códigos de processo estaduais. ${ }^{884}$ Em 1993, aquele país efetuou uma ampla modificação da disciplina da arbitragem, com base na Lei Modelo, com variações. No que diz respeito à arbitragem por eqüidade, o atual art. 1.445 a prevê expressamente, nos moldes da Lei Mode10. ${ }^{885}$ Portanto, o México aceita a arbitragem por eqüidade, desde que as partes assim tenham convencionado expressamente. Na prática há indicação de que este tipo de arbitragem não é incomum, quer por vontade das partes, quer por disposição legal (como em matéria de seguros ou proteção ao consumidor). ${ }^{886} \mathrm{O}$ texto original da lei mexicana utiliza-se das expressões amigable componedor ou en conciencia, para se referir à arbitragem por eqüidade.

\subsubsection{Mongólia}

Quase não há fontes para a verificação do direito de arbitragem vigente na Mongólia. Entretanto, o sítio de internet da Câmara Nacional de Comércio e Indústria da Mongólia, conjunta à Câmara Nacional de Arbitragem da Mongólia, apresenta uma tradução da nova lei de arbitragem daquele país, bem como algum material de consulta. Ambas as instituições foram criadas na década de 1960, aparentemente dentro dos moldes das câmaras de comércio e arbitragem dos países socialistas de então.

2. La Cour d'appel ne peut annuler une sentence arbitrale que dans les deux cas suivants :

$[\ldots]$

a Lorsque la Cour saisie de la demande en annulation, annule partiellement ou totalement la sentence, elle peut, le cas échéant et à la demande de toutes les parties, statuer au fond; elle agira en qualité d'amiable compositeur prévue à l'article 14 du présent Code, si le tribunal arbitral en remplit lui-même les conditions requises.

884 Smit, Hans; Реснота, V. Smit's Guides to International Arbitration, cit., p. MEX A-1. Também Siqueiros, José Luis; Hoagland, Alexander C. Relatório sobre México. In: PAulsson, Jan (Ed.). International Handbook on Commercial Arbitration, cit., p. México - 1, suplemento ago. 1995. Segundo estes autores, o México diferencia a arbitragem comercial da arbitragem civil. Entretanto, tendo em vista que o escopo desta obra é a arbitragem comercial, será privilegiado o exame deste tipo de arbitragem.

885 Art. 1445.

El tribunal arbitral decidirá el litigio de conformidad con las normas de derecho elegidas por las partes. Se entenderá que toda indicación del derecho u ordenamiento jurídico de un país determinado se refiere, a menos que se exprese lo contrario, al derecho sustantivo de ese país y no a sus normas de conflicto de leyes.

Si las partes no indicaren la ley que debe regir fondo de litigio, el tribunal arbitral, tomando en cuenta las características y conexiones del caso, determinará el derecho aplicable.

El tribunal arbitral decidirá como amigable componedor o en conciencia, sólo si las partes le han autorizado expresamente a hacerlo.

En todos los casos, el tribunal arbitral decidirá con arreglo a las estipulaciones del convenio y tendrá en cuenta los usos mercantiles aplicables al caso.

Fonte: Sмiт, Hans; Реснота, V. Smit's Guides to International Arbitration, cit., p. MEX B(1)-5.

886 Siqueiros, José Luis; Hoagland, Alexander C. Relatório sobre México, cit., p. México 18. 
A Mongólia editou uma nova lei sobre arbitragens em 2003, seguindo a Lei Modelo. Entretanto, ao dispor sobre a lei aplicável à arbitragem, em seu art. 34, o legislador daquele país não repetiu a disposição do art. 28(3) da Lei Modelo. Portanto, não há menção expressa à arbitragem por eqüidade. ${ }^{887}$ Igualmente, as regras de arbitragem da Câmara Nacional de Arbitragem não prevêem expressamente a arbitragem por eqüidade. ${ }^{888}$ As fontes disponíveis não mencionam a arbitragem por eqüidade.

\subsubsection{Nepal}

O Nepal adotou uma nova lei de arbitragem em 24.06.1999. Em seu art. 17, aquela lei prevê a arbitragem por eqüidade, nos moldes da Lei Modelo da Uncitral. ${ }^{889}$

\subsubsection{Nicarágua}

Até 2005, a arbitragem na Nicarágua era regida pelo Código de Procedimento Civil de 1905. Este Código, seguindo um modelo clássico hispano-americano, dividia as arbitragens

887 Article 34. Rules applicable to substance of dispute

34.1. The arbitral tribunal shall decide the dispute in accordance with such rules

of law as are chosen by the parties as applicable to the substance of the

dispute.

34.2. Any designation of the law or legal system of a given State shall be

construed, unless otherwise expressed, as directly referring to the

substantive law of that State and not to its conflict of laws rules.

34.3. Failing any designation by the parties, the arbitral tribunal shall apply the law determined by the conflict of laws rules which it considers applicable.

34.4. In all cases, the arbitral tribunal shall decide in accordance with the terms

of the contract and shall take into account the usages of the trade applicable

to the transaction.

Disponível em:

<http://www.mongolchamber.mn/documents/law_on_arbitration1.pdf>. Acesso em: 20 nov. 2007.

888 Disponível em:

$<$ http://www.mongolchamber.mn/documents/arbitration_rules1.pdf>. Acesso em: 20 nov. 2007

889 17. Substantive Law to be applied by Arbitrators

(1) The Nepal Law shall be the substantive law to be applied by the arbitrator, except when otherwise provided for in the agreement.

(2) The arbitrator may settle the dispute according to the principle of ex act a et bono or amiable compositor only when explicitly authorised by the parties to do so.

(3) Notwithstanding anything contained elsewhere in this act, the arbitrator shall settle the dispute according to the conditions stipulated in the concerned contract. While doing so, he shall also pay attention to the commercial usages applicable to the concerned transaction.

Fonte: site da Universidade de Leuven: <http://www.law.kuleuven.be/ipr/eng/arbitration/legal\%20texts/nepalarbitrationact.html>. Acesso em: 20 nov. 2007. 
em direito e eqüidade. Nas arbitragens de direito, somente advogados poderiam ser árbitros e, nas de eqüidade, quaisquer maiores de 21 anos na livre disposição de seus bens. Este Código continha uma interessante norma sobre a presunção de eqüidade: caso as partes nomeassem advogados, seria presumida de direito; caso indicassem não-advogados, presumia-se-lhe em eqüidade (art. 968). ${ }^{890}$

Todavia, em 1995, a Nicarágua adotou a Lei de Mediação e Arbitragem (Lei 540). Esta lei aplica-se tanto às arbitragens nacionais quanto às internacionais e tem como inspiração parcial a Lei Modelo.

Em seu art. 24, a lei define a arbitragem de eqüidade como aquela em que se dá quando o tribunal arbitral resolve conforme conhecimentos profissionais e técnicos:

e) "Arbitraje de Equidad" ("ex aequo et bono"): Se da cuando el Tribunal Arbitral resuelve conforme a sus conocimientos profesionales y técnicos. ${ }^{891}$

No entanto, em seu art. 30, a lei fala que as controvérsias decididas em eqüidade o serão "segundo os conhecimentos sobre a matéria objeto da arbitragem e o sentido de eqüidade e de justiça de seus integrantes". ${ }^{892}$ Portanto, há dois componentes na definição legal da tarefa do tribunal decidindo por eqüidade: uma técnica e outra de justiça. Este mesmo artigo mantém a obrigatoriedade de advogados para atuação como árbitros de direito.

Ao mencionar as normas aplicáveis ao mérito da controvérsia, o art. 54 da lei repete a Lei Modelo. Entretanto, ao se referir à arbitragem por eqüidade não usa este termo, mas sim "como amigable componedor", embora utilize também a expressão ex aequo et bono. ${ }^{893}$

890 Sмiт, Hans; Реснота, V. Smit's Guides to International Arbitration, cit., p. NIC B(1)-3.

891 Site da Assembléia Nacional da Nicarágua: <http://legislacion.asamblea.gob.ni/Normaweb.nsf/164aa15ba01 2e567062568a2005b564b/d0489e6135592d16062570a10058541b?OpenDocument\&Highlight=2, arbitraje>. Acesso em: 20 nov. 2007.

892 Artículo 30. Composición del Tribunal

En el caso de los arbitrajes de derecho, el tribunal deberá estar compuesto exclusivamente por abogados y resolverá las controversias con estricto apego a la ley aplicable.

Si se tratar de un arbitraje de equidad, el tribunal podrá estar integrado por profesionales expertos en la materia objeto de arbitraje, excepto lo que las partes dispongan para ese efecto. En este caso, el tribunal resolverá las controversias "ex aequo et Bono" según los conocimientos sobre la materia objeto del arbitraje y el sentido de la equidad y la justicia de sus integrantes.

893 Artículo 54. Normas Aplicables al Fondo del Litigio

El tribunal arbitral decidirá el litigio de conformidad con las normas de derecho elegidas por las partes como aplicables al fondo del litigio. Se entenderá que toda indicación del derecho u ordenamiento jurídico de un Estado determinado se refiere, a menos que se exprese lo contrario, al derecho sustantivo de ese Estado.

Si las partes no indican la ley aplicable al fondo del litigio, el tribunal arbitral tomando en cuenta las características y naturaleza del caso, determinará la ley aplicable. 


\subsubsection{Nigéria}

A Nigéria adotou uma nova legislação sobre arbitragem em 1988, por meio do Decreto 11 sobre arbitragem e conciliação. Boa parte das disposições sobre arbitragem segue de perto a Lei Modelo. Há diferença de regime entre arbitragens nacionais e internacionais. Entretanto, ambas permitem expressamente a arbitragem por eqüidade, conforme se verifica nos arts. $22^{894}$ (interna) e $47^{895}$ (internacional). Como particularidade, a lei da Nigéria prevê um regulamento de arbitragem internacional como anexo, que se aplica caso as partes não tenham escolhido outras regras. Eles são uma versão ligeiramente modificada do regulamento da CNUDCI, que também permite arbitragem por eqüidade em seu art. 33, desde que a lei aplicável ao procedimento arbitral o permita. ${ }^{896}$

El tribunal arbitral decidirá ex aequo et bono o como amigable componedor sólo si las partes le han autorizados expresamente a hacerlo así.

En todos los casos, el tribunal arbitral decidirá con arreglo a las estipulaciones del contrato y tendrá en cuenta los usos y costumbres aplicables al caso.

894 22. Power of Arbitral Tribunal to Appoint Expert

(1) Unless otherwise agreed by the parties, the arbitral tribunal may-

(a) appoint one or more experts to report to it on specific issue to be determined by the arbitral tribunal;

(b) require a party to give to the expert any relevant information or to produce or provide access to, any documents, goods or other property for inspection.

(2) Unless otherwise agreed by the parties, if a party so requests or if the arbitral tribunal considers it necessary, any expert appointed under subsection (1) of this section shall, after delivering his written or oral report, participate in a hearing where the parties shall have the opportunity of putting questions to him and presenting expert witnesses to testify on their behalf on the points at issue.

(3) The arbitral tribunal shall not decide ex aequo et bono or as amiable compositeur unless the parties have expressly authorised it to do so.

(4) The arbitral tribunal shall decide in accordance with the terms of the contract and shall take account of the usages of the trade applicable to the transaction.

Fonte: Paulsson, Jan (Ed.). International Handbook on Commercial Arbitration, cit.,

p. Fed. Rep. of Nigéria: Annex I -7.

895 47. Rules Applicable to Substance of Dispute

(1) The arbitral tribunal shall decide the dispute in accordance with the rules in force in the country whose laws the parties have chosen as applicable to the substance of the dispute.

(2) Any designation of the law or legal system of a country shall, unless otherwise expressed, be construed as directly referring to the substantive law of that country and not to its conflict of laws rules.

(3) Where the laws of the country to be applied is not determined by the parties, the arbitral tribunal shall apply the law determined by the conflict of laws rules which it considers applicable.

(4) The arbitral tribunal shall not decide ex aequo et bono or as amiable compositeur unless the parties have expressly authorised it to do so.

(5) In all cases, the arbitral tribunal shall decide in accordance with the terms of the contract and shall take account of the usages of the trade applicable to the transaction.

(6) If the arbitration law of the country where the award is made requires that the award be filed or registered by the arbitral tribunal, the arbitral tribunal shall comply with this requirement within the period of time required by law.

Fonte: Paulsson, Jan (Ed.). International Handbook on Commercial Arbitration, cit., p. Annex I -14, suplemento jan. 1990.

896 Oyekunle, Tinuade. Relatório da Nigéria. In: PAulsson, Jan (Ed.). International Handbook on Commercial Arbitration, cit., p. Fed. Rep. of Nigeria 1, 16-17. 


\subsubsection{Noruega}

A arbitragem na Noruega é regulada pelo Código de Processo Civil de 1915, emendado posteriormente. Tal código não possui previsão expressa de arbitragem por eqüidade. Entretanto, a doutrina local entende possível a arbitragem por eqüidade, desde que as partes assim convencionem. ${ }^{897}$

\subsubsection{Nova Zelândia}

A Nova Zelândia editou sua nova lei de arbitragem em 1996, com o Arbitration Act 1996 099. A Lei é baseada na Lei Modelo, colocada como anexo. Embora distinga entre arbitragem interna e internacional, a previsão de arbitragem por eqüidade aplica-se às duas. ${ }^{898}$ Uma curiosidade a respeito do art. 28(3) é que, em duas fontes diferentes, ele aparece com uma frase entre parênteses para explicar o conceito de eqüidade. Menciona-se ali expressamente "conforme considerações de justiça geral e eqüidade" (according to considerations of general justice and fairness):

(3) The arbitral tribunal shall decide ex aequo et bono or as amiable compositeur (according to considerations of general justice and fairness) only if the parties have expressly authorised it to do so. ${ }^{899}$

Todavia, em uma outra citação deste mesmo artigo, ele é transcrito sem a frase explicativa..$^{900}$

\subsubsection{Omã}

O Sultanato de Omã editou sua nova lei de arbitragem em 1997, pelo Decreto do sultão ("sultani decree") 47/97, inspirado na Lei Modelo e aplicável às arbitragens nacionais e internacionais. Pelo art. 39(4), as partes podem conceder o poder de "efetuar um compromisso" (effect

897 5. Applicable Law

A. Domestic Commercial Arbitration

The tribunal must decide according to rules of law just as a court of law would do. This can be altered by an express agreement of the parties entitling the arbitrators to act as amiables compositeurs. If the arbitrators have obviously decided contrary to rules of law, the parties may have the award set aside according to Art. 468, no. 3, CPC (see Chap. VI.3).

Haug, Bjørn. Relatório sobre a Noruega. In: Paulsson, Jan (Ed.). International Handbook on Commercial Arbitration, cit., p. Norway- 13, suplemento jun. 1989.

898 Kennedy-Grant, Thomas. Relatório Nova Zelândia. In: Paulsson, Jan (Ed.). International Handbook on Commercial Arbitration, cit., p. New Zealand - 23, suplemento jan. 1998.

899 Sмгт, Hans; Реснота, V. Smit's Guides to International Arbitration, cit., p. NZ B-18, e PAulsson, Jan (Ed.). International Handbook on Commercial Arbitration, cit., p. New Zealand: Annex I -14, suplemento out. 1997.

900 Kennedy-Grant, Thomas. Relatório Nova Zelândia, cit., p. 23. 
a compromise, na tradução inglesa), hipótese em que a decisão será tomada de acordo com as regras de justiça e eqüidade, sem estarem os árbitros vinculados à lei ${ }^{901}$ Pelo que se infere da tradução, parece a lei referir-se ao sulh, tal como na Arábia Saudita.

\subsubsection{Panamá}

O Panamá editou sua nova norma de arbitragem em 1999, com o Decreto-lei 5, de 8 de julho, inspirado pela Lei Modelo. Em seu art. 3, o referido decreto-lei define a arbitragem por eqüidade como aquela em que os árbitros decidem conforme seu "leal saber y entender", sem sujeição às regras de direito. O mesmo artigo ainda prevê que os árbitros de direito devem ser advogados e, afastando-se ainda mais da disciplina da Lei Modelo, aplica a presunção de arbitragem por eqüidade, salvo convenção em contrário. ${ }^{902}$ No art. 26, o Decreto-lei dispõe que, nos casos de arbitragem por eqüidade, os árbitros aplicam "seu livre critério". 903

901 Article 39.

1. The arbitral tribunal shall apply to the subject-matter of the dispute the rules which the two parties agree upon. If they agree upon the application of the law of a given State, the substantive rules thereof shall be followed, and not the rules as to conflict of laws, unless otherwise agreed.

2. If the two parties do not agree on the legal rules to be applied to the subject-matter of the dispute, the arbitral tribunal shall apply the substantive rules of the law which it considers the most closely connected with the dispute.

3. In deciding the subject-matter of the dispute the arbitral tribunal shall observe the stipulations of the contract in dispute, and current custom.

4. It shall be permissible for the arbitral tribunal, if the two parties to the arbitration have expressly agreed to empower it to effect a compromise, to decide upon the subject-matter of the dispute in accordance with the rules of justice and equity, without being bound by the provisions of the law.

Fonte: PAulsson, Jan (Ed.). International Handbook on Commercial Arbitration, cit., p. Oman: Annex I-11 e I-12, suplemento dez. 1998.

902 Artículo 3. El arbitraje será de derecho o en equidad. Será de Derecho cuando el poder conferido por las partes a los árbitros sea para resolver la cuestión conforme a las reglas de Derecho. Será en equidad si los árbitros hubieren de resolver conforme a su leal saber y entender, sin sujeción a las reglas de Derecho. Las partes podrán determinar en el convenio, o con posterioridad. Si no fuera así, la clase de arbitraje será la que resulte del reglamento aplicable y, en su defecto, se entenderá que el arbitraje es de equidad.

Cuando el arbitraje sea de Derecho, el o los árbitros deberán ser abogados en ejercicio. Salvo que sea otra la voluntad de las partes, podrán nombrarse árbitros extranjeros para las distintas clases. En todo caso, para los arbitrajes de Derecho, el árbitro extranjero deberá cumplir con la condición de ser licenciado o doctor en Derecho.

Fonte: Sмiт, Hans; Реснота, V. Smit's Guides to International Arbitration, cit., p. PAN B-1.

903 Artículo 26. El tribunal arbitral aplicará las reglas de Derecho si el arbitraje es de Derecho y su libre criterio si el arbitraje es de equidad.

En el caso de ser el arbitraje comercial internacional, se procederán en la forma prevista en el Artículo 43 del presente Decreto Ley.

En todo caso, se tendrán en cuenta las estipulaciones del contrato y los usos mercantiles que se consideren de aplicación. 


\subsubsection{Paquistão}

A arbitragem é regulada no Paquistão pela Lei de Arbitragem de 1940 e suas sucessivas modificações. Tanto quanto se pode apurar para esta pesquisa, o Paquistão, dentro da antiga tradição inglesa, não aceita arbitragem por eqüidade. ${ }^{904}$ Embora a fonte desta opinião seja antiga, nenhuma modificação legal posterior que mudasse tal panorama foi detectada nesta pesquisa.

\subsubsection{Paraguai}

O Paraguai reformou sua legislação de arbitragem 2002, com a edição da Lei $1.879 / 2002$, baseada na Lei Modelo e regulando arbitragens tanto internas como externas. Entre outras inovações, esta lei inverteu a presunção de eqüidade existente na disciplina anterior da arbitragem no Paraguai. Na vigência do regime antigo de arbitragem, como disposto no Código de Processo Civil, no silêncio das partes, presumia-se que a arbitragem seria decidida por eqüidade. ${ }^{905}$ Após a edição da nova lei, o regime passou a ser o da presunção de direito. Diferentemente da Lei Modelo, o art. 32 da lei paraguaia preocupa-se em afirmar a sinonímia entre arbitragem de eqüidade e amigable composicion, bem como explicar o alcance dos poderes dos árbitros: facultados a não decidir conforme as leis, podendo fazê-lo "em consciência" ou "segundo leal saber y entender". 906

904 5. Applicable Law

A. Domestic Arbitration

Arbitrators must decide the dispute in accordance with the rules of law and principles of natural justice. Where this is not adhered to, the award may become defective. The arbitrators cannot decide as "amiables compositeurs". They have, however, power to dispense with the strict technicalities of the procedural law while conducting the proceedings.

An arbitrator has the power to state a special case for the opinion of the court on any question of law involved. Either party can request the arbitrator to state the special case. He may also do so on his own motion. However, the arbitrator is not obliged to state a special case. In Pakistan, the parties are permitted to exclude by agreement the arbitrator's power to state a special case. The exclusion can be agreed to both before and after the dispute has arisen (Sect. 13 under $b$ ). It is very rare for parties to contract out of the arbitrator's power to state a special case to the court.

JAFFER, Mahomed J. Relatorio sobre Paquistão. In: SAnders, Pieter (Ed.). Yearbook Commercial Arbitration, Deventer, Kluwer, v. 5, p. 114 e ss., 1980.

905 Pucci, Adriana Noemi. El arbitraje en los países del Mercosur. Buenos Aires: Ad Hoc, 1997.

906 Artículo 32. Normas aplicables al fondo del litigio. El tribunal arbitral decidirá el litigio de conformidad con las normas de derecho elegidas por las partes como aplicables al fondo del litigio. Se entenderá que toda indicación del derecho u ordenamiento jurídico de un estado determinado se refiere, a menos que se exprese lo contrario, al derecho sustantivo de ese estado y no a sus normas de conflicto de leyes.

Si las partes no indicaran la ley aplicable, el tribunal arbitral aplicará la ley que determinen las normas de conflicto de leyes que estime aplicables. 


\subsubsection{Peru}

O Peru renovou sua legislação sobre arbitragem com a edição da Lei Geral de Arbitragem em 1995 (Lei 26.572). Esta lei contém disposições originais sobre a regulação da arbitragem por eqüidade. Em seu regime para arbitragens nacionais, existe presunção de arbitragem por eqüidade; no regime de arbitragens internacionais, há presunção de arbitragem de direito. ${ }^{907}$

A previsão de direito interno está no art. $3 .^{\circ}$ da Lei, que se utiliza da denominação "arbitragem de consciência" para se referir àquela em que os árbitros decidem conforme seus conhecimentos e seu "leal saber y entender". Também neste artigo encontra-se a presunção de arbitragem por eqüidade..$^{908}$

El tribunal arbitral decidirá en equidad sólo si las partes le han autorizado expresamente a hacerlo así. En el arbitraje de equidad, o de amigable composición, los árbitros no se encuentran obligados a

resolver en base a las normas de derecho, sino que pueden hacerlo "en conciencia" o "según su leal saber y entender".

En todos los casos, el tribunal decidirá con arreglo a las estipulaciones del contrato y tendrá en cuenta los usos mercantiles aplicables al caso.

Fonte: Smit, Hans; Реснота, V. Smit's Guides to International Arbitration, cit., p. PAR B-13.

907 Osterling Parodi, Felipe. Peru. In: Blackby et. al (Ed.). International Arbitration in Latin America, cit., p. 211. Também Montoya Alberti, Ulises. Relatório sobre o Peru. In: PAulsson, Jan (Ed.). International Handbook on Commercial Arbitration, cit., Peru - 16-17, suplemento dez. 1998:

5. Applicable Law

The GAL regulates both domestic and international arbitration.

a. International Commercial Arbitration

For international arbitration, Art. 117 closely follows Art. 28 of the UNCITRAL Model Law concerning the rules applicable to the substance of the dispute. The difference is that according to the Peruvian law, failing any designation by the parties of the applicable law, the arbitral tribunal shall apply the law it deems proper (see Annex I).

The arbitral tribunal shall decide ex aequo et bono only if the parties have expressly authorized it to do so.

b. Domestic Arbitration

According to the GAL, arbitration may be de jure or ex aequo et bono (in equity).

Arbitrators must be expressly authorized to decide de jure. In the absence of such choice, it is presumed that the arbitration will be ex aequo et bono (Art. 3).

In case of arbitration de jure, the arbitrators shall decide according to the rules of law. For the law applicable in international arbitration, see Art. $117 \mathrm{GAL}$ and $a$, above. Arbitrators de jure must be a lawyers.

In case of arbitration ex aequo et bono the award must comply with the provisions under 1, 2, 3, and 6 of Art. $50 \mathrm{GAL}$. It shall also require a reasoned opinion.

The arbitrators decide to the best of their knowledge taking into consideration applicable usages and practices (Art. 3).

908 Artículo $3 .^{\circ}$ Arbitraje de derecho o de conciencia.

$\mathrm{El}$ arbitraje puede ser de derecho o de conciencia.

Es de derecho cuando los árbitros resuelven la cuestión controvertida con arreglo al derecho aplicable. Es de conciencia cuando resuelven conforme a sus conocimientos y leal saber y entender.

Salvo que las partes hayan pactado expresamente que el arbitraje será de derecho, el arbitraje se entenderá de conciencia. 
No tocante aos árbitros, caso a arbitragem seja de direito, estes devem ser advogados (art. 25). O conteúdo do laudo "em consciência" deve cumprir as exigências formais dos laudos de direito e apresentar fundamentação. ${ }^{909}$ Ao contrário das arbitragens de direito, as arbitragens de consciência não podem ser objeto de recurso de apelação. ${ }^{910}$

No caso das arbitragens internacionais, como dito, somente quando houver autorização expressa das partes poderá haver decisão por "consciência e eqüidade", conforme o art. 117. Apenas este artigo menciona a palavra eqüidade, como sinônimo de consciência. ${ }^{911}$

\subsubsection{Polônia}

A Polônia renovou sua legislação de arbitragem em 2005, com as emendas feitas ao Código de Processo Civil vigente. Em seu art. 1.194, há expressa previsão à decisão “conforme os princípios gerais de direito ou os princípios de eqüidade" (conforme tradução inglesa: in accordance with the general principles of law or the principles of equity). Entretanto, esta decisão

Los árbitros tendrán en cuenta, de tratarse de asuntos de carácter comercial, los usos mercantiles aplicables al caso.

Fonte: Sмit, Hans; РеснотA, V. Smit's Guides to International Arbitration, cit., p. PER B(1)-2.

909 Artículo $51 .^{\circ}$ Contenido del laudo de conciencia.

El laudo de conciencia necesariamente debe cumplir con lo dispuesto en los incisos 1), 2), 3) y 6) del

Artículo $50 .^{\circ}$ Requiere además de una motivación razonada.

910 Artículo 60. ${ }^{\circ}$ Recurso de Apelación.

Procede la interposición del recurso de apelación ante el Poder Judicial o ante una segunda instancia arbitral, cuando se hubiere pactado su admisibilidad en el convenio arbitral o si está previsto en el reglamento arbitral de la institución arbitral a la que las partes hubieran sometido su controversia. A falta de acuerdo expreso o en caso de duda, se entiende que las partes han pactado el recurso de apelación ante una segunda instancia arbitral.

El recurso de apelación tiene por objeto la revisión del laudo respecto de la apreciación de los fundamentos de las partes, de la prueba y, en su caso, aplicación e interpretación del derecho, y se resuelve confirmando o revocando total o parcialmente el laudo.

Contra los laudo de conciencia no procede recurso de apelación.

911 Artículo 117. ${ }^{\circ}$ Normas aplicables al fondo del litigio.

El tribunal arbitral decidirá el litigio de conformidad con las nonnas de derecho elegidas por las partes como aplicables al fondo del litigio. Se entenderá que toda indicación del derecho u ordenamiento jurídico de un Estado determinado, se refiere, a menos que se exprese lo contrario, al derecho sustantivo de ese Estado y no a sus normas de conflicto de leves.

Si las partes no indican la ley aplicable, el tribunal arbitral aplicará la ley que estime conveniente. El tribunal arbitral decidirá en conciencia y equidad sólo si las partes le han autorizado expresamente hacerlo así. En todos los casos, el tribunal arbitral decidirá con arreglo a las estipulaciones del contrato y tendrá en cuenta, de tratarse de un asunto de carácter comercial, los usos mercantiles aplicables al caso. 
somente pode ser feita com expressa autorização das partes. ${ }^{912}$ Embora princípios gerais de direito não sejam exatamente um sinônimo de decisão por eqüidade, autores poloneses assimilam ao menos os princípios de eqüidade a uma arbitragem por eqüidade, ex aequo et bono. ${ }^{913}$

\subsubsection{Portugal}

O principal marco regulatório da arbitragem em Portugal é a Lei 31/1986, embora outras fontes também existam, como o Código de Processo Civil e outros. Para os fins deste capítulo, limita-se a abordagem à Lei 31/1986. Esta lei baseia-se na disciplina francesa da arbitragem e adota algumas soluções da Lei Modelo. A lei cria dois regimes de arbitragens distintos (interna e internacional) e dispõe sobre a eqüidade em ambos.

No âmbito interno, o art. 22 daquela lei prevê que os árbitros julgam conforme o direito, salvo se as partes houverem autorizado o julgamento "segundo a eqüidade" em documento escrito, até a aceitação do primeiro árbitro. ${ }^{914}$ Portanto, há presunção de arbitragem de direito e exigência de autorização expressa por escrito, a ser elaborada até a aceitação do primeiro árbitro.

No que concerne à arbitragem internacional, a lei portuguesa contém duas previsões. Em seu art. 33, dispõe que as partes escolhem o direito aplicável, se não tiverem autorizado os árbitros a decidir por eqüidade. ${ }^{915}$

912 Art. 1194.

$\S 1$. The arbitral tribunal shall settle the dispute in accordance with the law applicable to the relationship in question, or if explicitly so authorized by the parties, in accordance with the general principles of law or the principles of equity.

$\S 2$. In all cases, however, the arbitral tribunal shall take into account the provisions of the agreement and the established customs applicable to the legal relationship in question.

Fonte: PAulsson, Jan (Ed.). International Handbook on Commercial Arbitration, cit., p. Poland: Annex I-11,. suplemento ago. 2006.

913 Szurski, Tadeusz; Wisniewski, Andrzej W. Relatório Polônia. In: PAuLsson, Jan (Ed.). International Handbook on Commercial Arbitration, cit., p: Poland -32, suplemento ago. 2006.

914 Artigo 22. ${ }^{\circ}$

(Direito aplicável; recurso à eqüidade)

Os árbitros julgam segundo o direito constituído, a menos que as partes, na convenção de arbitragem ou em documento subscrito até à aceitação do primeiro árbitro, os autorizem a julgar segundo a eqüidade.

915 Artigo 33. ${ }^{\circ}$

(Direito aplicável)

1 - As partes podem escolher o direito a aplicar pelos árbitros, se os não tiverem autorizado a julgar segundo a equidade.

2 - Na falta de escolha, o tribunal aplica o direito mais apropriado ao litígio. 
No entanto, o art. 35 expressamente prevê a "composição amigável”, nos seguintes termos:

\section{Artigo 35. \\ (Composição amigável)}

Se as partes lhe tiverem confiado essa função, o tribunal poderá decidir o litígio por apelo à composição das partes na base do equilíbrio dos interesses em jogo.

A natureza da composição amigável e o alcance deste tipo de decisão são controversos na doutrina portuguesa. ${ }^{916}$ Pode-se tanto defender a sinonímia entre eqüidade e composição amigável como verificar uma função efetivamente diferente entre as duas figuras.

$\mathrm{O}$ art. 35 da lei portuguesa parece ser, inclusive, pela escolha de vocabulário (“confiar a função") inspirado na legislação francesa. Contudo, a exposição dos poderes conferidos aos árbitros ("decidir por apelo a composição das partes na base do equilíbrio dos interesses em jogo") afigura-se uma idéia original portuguesa.

Em uma primeira leitura, o artigo parece sugerir um julgamento com base em razão econômica (equilíbrio dos interesses). Também a referência à composição das partes evoca uma espécie de decisão de caráter transacional, em que se pode alterar o conteúdo do negócio ou ao menos buscar um ponto médio. Nesse aspecto, a composição amigável portuguesa poderia se aproximar do arbitrato irrituale italiano ou outras espécies de "arbitragens contratuais", como binded advies holandês. $\mathrm{O}$ "decidir por apelo à composição das partes", por outro lado, parece evocar o amicabilis compositor medieval, quando passou a assumir funções efetivamente jurisdicionais.

Todavia, como referido nesta obra, uma composição econômica pode ser uma das funções de eqüidade. A decisão "na base do equilíbrio dos interesses" certamente é uma decisão fora dos critérios legais. Por outro lado, a decisão do compositor amigável, ao contrário do árbitro irrituale, é exeqüível como sentença. Assim, a amigável composição está muito próxima de uma arbitragem por eqüidade (senão no exato mesmo lugar).

Seguindo o texto da lei portuguesa, o único elemento que eventualmente poderia diferenciar amigável composição e eqüidade seria uma indicação de caráter transativo e de poderes de efetivamente modificar o conteúdo econômico do contrato. No entanto, este sentido da dife-

916 Para um apanhado desta discussão, veja-se RAPOso, Mario. Eqüidade, composição amigável e lex mercatoria. apud Lemes, Selma F. A Arbitragem e a Decisão por Eqüidade no Direito Brasileiro e Comparado in Arbitragem: estudos em homenagem ao Prof. Guido Fernando Silva Soares. São Paulo, Atlas, 2007, p. 189. 
renciação não é unânime na doutrina portuguesa. E tanto quanto este autor pode apurar, não há jurisprudência em Portugal sobre a matéria.

Ao prever duas expressões distintas em uma mesma seção, é muito possível que o legislador português tenha efetivamente querido criar duas instituições distintas. Entretanto, são instituições muito próximas, cuja diferenciação não encontra paralelos em direito comparado.

\subsubsection{Quênia}

O Quênia editou uma nova lei de arbitragem em 1995 (Lei 4 de 1995), largamente baseada na Lei Modelo. Em seu art. 29 da lei queniana segue a Lei Modelo. Contudo, em vez de mencionar as palavras amiable composition ou ex aequo et bono, o legislador daquele país preferiu uma forma explicativa, dizendo autorização para julgar "de acordo com considerações de justiça e eqüidade sem estar vinculado pelas regras de direito". 917

\subsubsection{Reino Unido (Inglaterra, Gales e Irlanda do Norte)}

A Inglaterra sempre foi um foco de resistência à arbitragem por eqüidade, tradicionalmente. Embora a possibilidade de execução de laudos estrangeiros decididos por eqüidade tenha se tornado possível nas últimas décadas, a modificação de posição definitiva veio com o Arbitration Act de 1996. ${ }^{918}$

917 29. Rules Applicable to Substance of Dispute

(1) The arbitral tribunal shall decide the dispute in accordance with the rules of law chosen by the parties as applicable to the substance of the dispute.

(2) The choice of the law or legal system of any designated state shall be construed, unless otherwise agreed by the parties, as directly referring to the substantive law of that state and not to its conflict of laws rules.

(3) Failing a choice of the law under subsection (1) by the parties, the arbitral tribunal shall apply the rules of law it considers to be appropriate given all the circumstances of the dispute.

(4) The arbitral tribunal shall decide on the substance of the dispute according to considerations of justice and fairness without being bound by the rules of law, only if the parties have expressly authorized it to do so.

(5) In all cases, the arbitral tribunal shall decide in accordance with the terms of the particular contract and shall take into account the usages of the trade applicable to the particular transaction.

Fonte: PAulsson, Jan (Ed.). International Handbook on Commercial Arbitration, cit., p. Kenya: Annex I -10, suplemento set. 1996.

918 A doutrina sobre a posição inglesa quanto à arbitragem por eqüidade é copiosa e foi citada nesta obra em mais de uma oportunidade. Por todos, pode-se verificar DAvid, René. Conception... cit.; e Mustill; Boyd, Stewart. Commercial Arbitration - 2001 Companion. cit. The law and practice of commercial arbitration in England. cit. RedFern, Alan; Hunter, Martin. Law and practice of international commercial arbitration. cit. 
Em seu art. 46, o Arbitration Act prevê que o tribunal arbitral decidirá de acordo com as regras de direito escolhidas pelas partes ou, "se as partes assim acordarem, de acordo com outras considerações", a escolha destas ou determinadas pelo tribunal:

46. Rules Applicable to Substance of Dispute

(1) The arbitral tribunal shall decide the dispute-

(a) in accordance with the law chosen by the parties as applicable to the substance of the dispute, or

(b) if the parties so agree, in accordance with such other considerations as are agreed by them or determined by the tribunal.

(2) For this purpose the choice of the laws of a country shall be understood to refer to the substantive laws of that country and not its conflict of laws rules.

(3) If or to the extent that there is no such choice or agreement, the tribunal shall apply the law determined by the conflict of laws rules which it considers applicable. ${ }^{919}$

É amplamente considerado pela doutrina inglesa que estas “outras considerações" incluem decisão por eqüidade, bem como regras transnacionais ou costume..$^{920}$

\subsubsection{República Dominicana}

A República Dominicana regulamenta sua arbitragem no Código de Processo Civil, como emendado em 1978. Em seu art. 1.019, há previsão de arbitragem por eqüidade ("fallar como amigables componedores"), desde que partes atribuam esse poder no compromisso. ${ }^{921}$

\subsubsection{República Tcheca}

A República Tcheca (ainda então Tchecoslováquia) editou sua nova legislação sobre arbitragem em 1994 (Lei 216/1994). Em seu art. 25, há previsão expressa de arbitragem por eqüidade, desde que as partes expressamente o autorizem. ${ }^{922}$

\footnotetext{
919 Fonte: Smit, Hans; РеснотA, V. Smit's Guides to International Arbitration, cit., p. UK B-23.

920 RedFern, Alan; Hunter, Martin. Law and practice of international commercial arbitration. cit., p. 128.

921 Art. 1.019.

Los árbitros y el tercero en discordia, decidirán, conforme a las reglas de derecho, a menos que el compromiso no les acuerde el poder de fallar como amigables componedores.

Fonte: Smit, Hans; Pеснота, V. Smit's Guides to International Arbitration, cit., p. DOM B(1)-3.

922 Article 25.
}

(1) An arbitral award shall be adopted by a majority of arbitrators, reduced in writing and signed by at least a majority of arbitrators. The operative part of the award shall not be ambiguous. 


\subsubsection{Romênia}

A Romênia modificou seu Código de Processo Civil em 1993 (Lei 53, de 23.07.1999), para renovar sua lei de arbitragem. Em seu art. 360, há expressa permissão para decisão por eqüidade, desde que as partes assim autorizem. ${ }^{923} \mathrm{O}$ mesmo código prevê que as decisões por eqüidade sejam motivadas, apresentando "as razões subjacentes à solução" do ponto de vista da eqüidade (da tradução inglesa: the reasons underlying the solution from this point of view). ${ }^{924-925}$

(2) An opinion, giving reasons for the decision (award) shall be attached to the award, unless the parties agree that no opinion need be attached to such award. The same shall apply to an arbitral award made under Article 24 paragraph (2) hereof.

(3) When taking their decision, the arbitrators shall base it on material law applicable to the case. They shall, however, be free to base their award on considerations ex aequo et bono provided the parties authorize them expressly to do so.

Fonte: Paulsson, Jan (Ed.). International Handbook on Commercial Arbitration, cit., suplemento ago. 1995. Também Sмiт, Hans; РеснотA, V. Smit's Guides to International Arbitration, cit., p. CZE B(2)-8, com uma tradução ligeiramente diferente:

"(3) The arbitrators shall decide the dispute in accordance with the rules of law applicable to the substance of the dispute; they may decide the dispute ex aequo et bono only if the parties have expressly authorized them to do so". Aparentemente, esta última tradução é mais fiel. O autor agradece a Tomas Dumbrov pelo auxílio com o idioma tcheco.

923 Article 360.

The arbitral tribunal shall decide the dispute on the basis of the principal contract and the applicable rules of law, taking into account trade usages, as the case may be.

On the basis of the express agreement of the parties, the arbitral tribunal may settle the dispute in equity.

Fonte: PAulsson, Jan (Ed.). International Handbook on Commercial Arbitration, cit., p. Romania Annex I-10, suplemento ago. 1996.

924 Article 361.

The arbitration award shall be in writing and it shall include:

(a) the nominal composition of the arbitral tribunal, the place and date of the making of the award;

(b) the name of the parties, their domicile or residence, or name and seat, name of the representatives of the parties as well as of the other persons having participated in the proceedings, as the case may be;

(c) mention of the arbitration agreement on the ground of which the arbitration was instituted;

(d) the object of the dispute and a brief account of the parties arguments;

(e)the reasons in fact and in law for the award, or in case of an arbitration in equity, the reasons underlying the solution from this point of view;

(f) the decisional part of the award;

(g) the signatures of all the arbitrators, under reserve of Article 3602.

925 Todavia, o artigo do Prof. Otavian Carpatina, que acompanha a mesma obra, diz textualmente que a legislação romena permite a decisão por equiidade, embora não a preveja expressamente. Portanto, este artigo não altera a conclusão principal quanto à possibilidade de arbitragem por eqüidade no direito romeno.

Vide: Paulsson, Jan (Ed.). International Handbook on Commercial Arbitration, cit., p. Romania-36:

\section{Applicable Law}

According to Art. 360, the arbitral tribunal shall decide the dispute on the basis of the main contract and the rules of law applicable to the contract, and shall take account, as the case may be, of commercial usages. Similar provisions are contained in Art. 52 of the Rules of the Rom CCI and Art. 56 of the Rules of the Arbitration Commissions.

Although the law and the Rules referred to are silent on this point, it is submitted that the arbitrators may also be entitled to decide ex aequo et bono or as amiables compositeurs, as provided, for example, in Art. 13(4) of 


\subsubsection{Rússia}

A Rússia editou sua lei de arbitragem em 07.07.1993. Em grande medida, adotou a Lei Modelo e é destinada a arbitragens internacionais. A Rússia ainda mantém alguns elementos do regime jurídico do período socialista, como o fato de estabelecer, anexos, a lei de arbitragem, os estatutos da Corte de Arbitragem Comercial Internacional da Câmara de Comércio e Indústria da Federação Russa, bem como da Comissão de Arbitragem Marítima da mesma Câmara. Ambas são sucessoras de seus equivalentes soviéticos. Todavia, ao contrário do que normalmente ocorria no período soviético, não há monopólio (ou quase-monopólio) dessas instituições no que diz respeito à arbitragem local.

Embora tenha adotado o modelo da CNUDCI, a lei russa não repetiu a provisão sobre eqüidade contida na Lei Modelo. Ao contrário, utilizou o art. 28 da Lei Modelo, mas omitiu o inciso 3:

Article 28. Rules Applicable to Substance of Dispute

1. The arbitral tribunal shall decide the dispute in accordance with such rules of law as are chosen by the parties as applicable to the substance of the dispute. Any designation of the law or legal system of a given State shall be construed as directly referring to the substantive law of that State and not to its conflict of laws rules.

2. Failing any designation by the parties, the arbitral tribunal shall apply the law determined by the conflict of laws rules which it considers applicable.

3. In all cases, the arbitral tribunal shall decide in accordance with the terms of the contract and shall take into account the usages of the trade applicable to the transaction..$^{926}$

Na Rússia, tem-se entendido que a ausência de tal permissão significa a impossibilidade de decisão por eqüidade. ${ }^{927}$

the "36" Rules of the International Chamber of Commerce (Paris). This allows the arbitrators more freedom in arriving at an equitable solution although it does not dispense arbitrators from the application of compulsory rules of the applicable law. Art. 42(2) of the Rules of the Rom CCI entitles parties to expressly agree that the arbitral tribunal shall render its award in equity (en équité).

926 Fonte: PAulsson, Jan (Ed.). International Handbook on Commercial Arbitration, cit., p. Russian Fed.: annex I-7, suplemento jan. 2004. Também Smit, Hans; РеснотA, V. Smit's Guides to International Arbitration, cit., p. RUS B(2)10.

927 Soderlund, Christer. A comparative overview of arbitration laws. Arbitration International, v. 20, n. 1, p. 83, 2004. SANDERs, Pieter. International Encyclopedia of Comparative Law. Capítulo “Arbitration”. cit. 


\subsubsection{Síria}

Embora uma mudança na legislação síria de arbitragem pareça estar a caminho, ${ }^{928}$ a arbitragem naquele país é regulada pelo Código de Processo Civil. Este, em seu art. 522, expressamente reconhece a arbitragem por eqüidade, ${ }^{929}$ liberando os árbitros de aplicarem as regras de direito material e processual. A arbitragem por eqüidade impede o acesso aos recursos ordinários com sentenças arbitrais. ${ }^{930}$ Há previsão expressa de que o objeto do litígio deve ser especificado na arbitragem, mesmo que se trate de arbitragem por eqüidade, sob pena de nulidade. ${ }^{931}$

A doutrina síria reconhece a arbitragem por eqüidade, com grandes poderes relativamente ao contrato, ao procedimento e mesmo a matérias probatórias,porém sempre dentro dos limites da ordem pública:

Arbitrators must decide according to the rules of substantive law (Art. 521, 2) unless they received the power of amiables compositeurs authorizing them to settle the case ex aequo et bono (Art. 522).

The substantive law is not necessarily local law; it is up to the parties, even in domestic arbitration, to decide on the law applicable to their relations, provided it does not violate national public policy (Art. 148, 1 Civil Code - see for the definition of public policy under II.3, a above).

928 Nota no relatório do Institute for Transnational Arbitration publicado em <http://www.kluwerarbitration.com/ arbitration/Newsletter.aspx\#Syria>. Acesso em: 23 nov. 2007.

929 Article 522.

Arbitrators acting as "amiables compositeurs" shall be exonerated from applying judicial procedures and rules the provisions of law.

Fonte: Kassis, Antoine. Syria. In: Saleh, Samir. Commercial Arbitration... cit., p. 168. Também com uma tradução ligeiramente diferente disponível em: <http://www.syrianlaws.com/brandguardians/english-law/Decree $\% 20$ No\%2084\%20of\%201953.htm>.

Acesso em: 20 nov. 2007.

930 Article 532.

1. Arbitral awards can be subjects of an appeal according to the rules and periods set for appealing decisions of courts of law. The recourse of appeal is not allowed when the arbitrators are acting as "amiables compositeurs", or as arbitrators in appeal, or if the parties expressly waived the right to lodge an appeal, or if an appeal is not permissible due to the subject matter of the dispute or the amount of the claim.

2. The appeal must be filed with the Court of Appeal which would have had jurisdiction over such an appeal if the dispute had been decided by the Court of First Instance originally having jurisdiction.

3. The decision made by the Court of Appeal can not be subject to "cassation".

Disponível em: <http://www.syrianlaws.com/brandguardians/english-law/Decree\%20No\%2084\%20of\%20 1953.htm>.

Acesso em: 20 nov. 2007. Também Kassis, Antoine. Théorie Generale cit., p. 169.

931 Article 510.

The subject matter of the dispute must be specified in the agreement to arbitrate or during the [arbitral] proceedings, even if the arbitrators act as amiable compositeurs, failing which, the arbitration will be void.

Fonte: Kassis, Antoine. Théorie Generale cit., p. 167. 
When empowered to decide as amiables compositeurs, arbitrators cannot deviate from the rules of public policy. But they can deviate from any other legal provision, as well as from the contract clauses, and they can decide on the basis of what seems to them just and equitable, even without due evidence. ${ }^{932}$

\subsubsection{Sri Lanka}

O Sri Lanka adotou sua lei de arbitragem em 1995 (Arbitration Act 11 of 1995). A lei aplica-se a arbitragens internas e internacionais e baseia-se na Lei Modelo. Em seu art. 28, a lei permite a arbitragem por eqüidade, embora com uma redação distinta da contida na lei modelo. ${ }^{933}$ A dicção da lei do Sri Lanka prefere a utilização da expressão "considerações gerais de justiça geral ou eqüidade", em vez das expressões amiable composition e ex aequo et bono da Lei Modelo. Também é relevante notar que a decisão com base em costumes comerciais encontra-se na mesma disposição legal, o que de certo modo implica uma certa visão comum do fenômeno do julgamento por regras que não sejam de direito positivo, mesmo que suas fontes sejam distintas. Em todos os casos, há necessidade de autorização expressa.

\subsubsection{Suécia}

A Suécia editou sua nova lei de arbitragem em 1999. Trata-se de uma lei importante, em virtude da tradição sueca de arbitragem. A nova lei sueca aplica-se tanto a arbitragens internas como a internacionais. Embora não tenha seguido a Lei Modelo da Uncitral na forma, sua disciplina em termos gerais não se diferencia muito.

932 El-Hakim, Jacques. Relatório nacional sobre a Síria. In: SANDERs, Pieter. Yearbook Commercial Arbitration, Deventen, Kluwer, v. 7, p. 35 e ss., 1982.

933 24. Law Applicable to Substance of Dispute

(1) An arbitral tribunal shall decide the dispute in accordance with such rules of law as are chosen by the parties as applicable to the substance of the dispute. Any designation of the law or legal system of a given State shall be construed, unless otherwise expressed, as referring to the substantive law of that State and not to its conflict of laws rules.

(2) Failing any designation by the parties to an arbitration agreement, the arbitral tribunal shall apply the law determined by the conflict of laws rules which it considers applicable.

(3) The provisions of subsections (1) and (2) shall apply only to the extent agreed to by the parties.

(4) The arbitral tribunal shall decide according to considerations of general justice and fairness or trade usages only if the parties have expressly authorised it to do so.

Site oficial do Governo do Sri Lanka: <http://www.lawnet.lk/sec_process.php?chapterid=1995Y0V0C11A\&s ectionno=24\&title=Arbitration \&path=2>. Acesso em: 17 nov. 2007.

Também Paulsson, Jan (Ed.). International Handbook on Commercial Arbitration, cit., p. Sri Lanka: Annex I -7, suplemento out. 2007. 
A nova lei sueca, seguindo a tradição do direito anterior, não prevê expressamente a arbitragem por eqüidade. Entretanto, como também ocorria no direito anterior, é geralmente aceito que pode haver arbitragem por eqüidade, desde que as partes assim contratem:

\section{Applicable Law}

There are no provisions on the rules applicable to the substance of the dispute in the Act. It is, however, the prevailing view in Sweden that the arbitral tribunal shall base its decision on rules of law, unless the parties have otherwise agreed.

The main rule in Sweden is that the tribunal shall decide the dispute in accordance with the law chosen by the parties as applicable to the substance of the dispute. If the parties have not chosen an applicable substantive law, the arbitrators will make the choice, when necessary. If the parties have not given any indication of which conflict of laws rules they wish to have applied, arbitrators in an arbitration taking place in Sweden would generally apply Swedish rules in this respect, even if they are not bound to do so. The basic choice of law principle in Sweden is that the law with which the case has the closest connection applies.

A direction to the arbitrators to decide the matter ex aequo et bono is also valid. However, an agreement to that effect must be expressly stated. ${ }^{934}$

\subsubsection{Suiça}

A Suíça seguramente é um dos países mais populares como sede de tribunais arbitrais. Além de seu histórico de neutralidade e localização central na Europa, a Suíça possui uma disciplina de arbitragem que é geralmente considerada favorável a sua utilização. O direito suíço já foi objeto de várias considerações nesta obra. Julga-se desnecessário repeti-las também neste capítulo, cujo objeto é apenas a demonstração da possibilidade de arbitragem por eqüidade.

A Suíça possui duas regras básicas acerca da arbitragem. No plano interno, a Concordata Intercantonal sobre Arbitragem de 1969 dispõe sobre a matéria. No plano internacional, a Lei de Direito Internacional Privado regula a matéria, embora esta lei permita que as partes optem pela disciplina da Concordata. Em ambos os textos, há previsão expressa sobre arbitragem por eqüidade. Na Concordata, o art. 31(3) dispõe sobre a matéria. ${ }^{935} \mathrm{Na}$ Lei de Direito

934 Franke, Ulf. Relatório sobre Suécia. PAuLsson, Jan (Ed.). International Handbook on Commercial Arbitration, cit., p. Sweden 16, suplemento dez. 2004.

$93531[\ldots]$

3 Le tribunal arbitral statue selon les règles du droit applicable, a moins que les parties ne l'aient autorise dans la convention d'arbitrage a statuer selon l'équité.

Fonte: Lalive, Pierre; Poudret, Jean-François; Reymond, Claude. Le Droit de l'Arbitrage Interne... cit., p. 167. 
Internacional Privado, o art. 187(2) a prevê. ${ }^{936}$ Em ambos os casos, esta espécie de arbitragem somente poderá ocorrer por convenção das partes.

\subsubsection{Tailândia}

A Tailândia editou uma nova lei de arbitragem em 2002 (Lei BE 2545), que regula as arbitragens internas e internacionais. Em boa medida, a lei se inspira na Lei Modelo. Em seu art. 34, a lei tailandesa repete o disposto no art. 28(3) da Lei Modelo, com pequena modificação da redação, mas não de sentido. ${ }^{937}$

\subsubsection{Taiwan (Formosa)}

Taiwan editou sua lei de arbitragem em 1998. Em seu art. 31, há previsão expressa à arbitragem por eqüidade, nos exatos termos da Lei Modelo. ${ }^{938}$

\subsubsection{Tunísia}

A Tunísia editou em 1993 um Código de Arbitragem, que regula a matéria de um modo geral. Ele possui um capítulo para arbitragem interna e outro para internacional. Em seu art. 14 (na parte geral), o Código prevê a arbitragem por eqüidade, que deve ser prevista pelas partes na

936 Art. 187 (1) Le tribunal arbitral statue selon les règles de droit choisies par les parties ou, a default de choix, selon les règles de droit avec lesquelles la cause présente les liens plus étroits.

(2) Les parties peuvent autoriser le tribunal a statuer en équité.

Fonte: Lalive, Pierre; Poudret, Jean-François; Reymond, Claude. Le Droit de l'Arbitrage Interne... cit., p. 387.

937 Section 34.

$[\ldots]$

The parties may expressly authorize the arbitral tribunal to decide ex aequo et bono or as amiable compositeur.

The decision of the arbitral tribunal shall be in accordance with the terms of the contract, and in the case of a commercial dispute, it shall take into account the usage of the trade applicable to the transaction.

Fonte: PAulsson, Jan (Ed.). International Handbook on Commercial Arbitration, cit.,

p. Thailand: Annex I-9.

Também Sмiт, Hans; РеснотA, V. Smit's Guides to International Arbitration, cit., p. THA B-14 (com uma tradução ligeiramente distinta: "The parties may expressly stipulate that the arbitral tribunal shall determine the disputes ex aequo et bono".

938 The arbitral tribunal shall decide ex aequo et bono or as amiable compositeur only if the parties have expressly authorised it to do so.

Journal of International Arbitration, v. 15, n. 4, p. 116 e ss., 1998. 
convenção de arbitragem. Neste caso, o artigo explica, os árbitros não estão obrigados a aplicar as regras de direito e julgam por eqüidade. ${ }^{939}$ Este artigo apresenta uma exceção para algumas exigências da sentença arbitral. ${ }^{940} \mathrm{~A}$ arbitragem por eqüidade igualmente impede recursos contra a sentença arbitral. ${ }^{941}$ No entanto, caso haja anulação da sentença arbitral, o tribunal estatal poderá julgar o mérito em eqüidade, caso esse tenha sido o caso da arbitragem. ${ }^{942} \mathrm{O}$ art. 73 do Código repete, para a arbitragem internacional, o disposto no art. 28(3) da Lei Modelo.

939 Article 14.

Les arbitres doivent appliquer le droit, à moins que les parties ne leur confèrent, dans la convention d'arbitrage, la qualité d'amiables compositeurs. Ils ne sont pas, dans ce cas, tenus d'appliquer les règles de droit, et statuent en équité.

Fonte: Revue de l'Arbitragem, 1993.

Também: Paulsson, Jan (Ed.). International Handbook on Commercial Arbitration, cit., p. Tunísia Annex I-3.

940 Article 30.

Le tribunal arbitral, après délibération, rend sa sentence à la majorité des voix.-La sentence doit comporter toutes les indications exigées par l'article 123 du Code de procédure civile et commerciale, sous réserve des dispositions de l'article 14 du Code d'arbitrage, relatives aux arbitres amiables compositeurs.

Elle doit en outre être signée par les arbitres.

En cas de refus ou d'incapacité de signer, par un ou plusieurs d'entre eux, mention en est faite à la sentence. La sentence est valable si elle est signée par la majorité des arbitres.

A défaut de majorité, le président du tribunal arbitral en fait mention et rend seul la sentence. Dans ce cas la signature du président suffit.

941 Article 39.

Ne peuvent faire l'objet d'un recours en appel:

1. Les sentences des arbitres amiables compositeurs;

2. Les sentences arbitrales, sauf stipulation contraire et expresse de la convention d'arbitrage.

Dans ce cas, l'appel est régi, au même titre que les jugements judiciaires, par les dispositions du Code de procédure civile et commerciale.

Si la cour confirme la sentence arbitrale attaquée, elle en ordonne l'exequatur.

Si elle l'infirme, elle statue au fond et rend une décision judiciaire.

942 Article 44.

Si la juridiction compétente admet le bien-fondé du recours, elle annule la sentence ou la procédure d'arbitrage, en tout ou en partie, selon les cas.

Elle doit statuer au fond, à la requête des parties. Elle agira comme arbitre amiable compositeur si le tribunal arbitral en remplit lui-même les conditions requises.

Elle peut surseoir à statuer en cas de connexité avec une autre affaire pendante devant une autre juridiction judiciaire.

Mais si elle décide le rejet du recours, l'arrêt de rejet confère l'exequatur à la sentence arbitrale incriminée.

Para a arbitragem internacional:

Article 78.

$[\ldots]$

5. Lorsque la cour, saisie de la demande en annulation, annule totalement ou partiellement la sentence, elle peut le cas échéant et à la demande de toutes les parties, statuer au fond, elle agira en qualité d'amiable compositeur prévue à l'article 14 du présent code, si le tribunal arbitral en remplit lui-même les conditions requises.

Le rejet du recours en annulation confère l'exequatur à la sentence arbitrale incriminée. [...] 


\subsubsection{Turquia}

A Turquia adotou sua lei de arbitragem internacional em 2001 (Lei 4.686, de 21.06.2001). Esta lei segue as principais linhas da Lei Modelo. Em seus arts. 10 e 12 (principalmente) há previsão expressa sobre arbitragem por eqüidade, que pode ocorrer mediante autorização expressa de ambas as partes. ${ }^{943}$

\subsubsection{Ucrânia}

A Ucrânia editou uma nova lei de arbitragem internacional em 24.02.1994. Esta lei seguiu em larga medida a Lei Modelo, reservando, porém, algumas alterações. No que diz respeito à arbitragem por eqüidade, a lei ucraniana repetiu o art. 28 da Lei Modelo. Portanto, a Ucrânia aceita a arbitragem por eqüidade, desde que as partes expressamente convencionem. ${ }^{944}$

943 Article 10.

$[\ldots]$

E) Unless otherwise agreed by the parties, the arbitral tribunal, following the submissions as to the claim and defence shall draw up its terms of reference.

The terms of reference may contain such particulars as the parties' names and titles, their addresses for notification during the arbitration, a summary of their claims or defences, their requests, explanations on the dispute in question, the names, surnames, titles, and addresses of the arbitrators, the place of arbitration, the term of arbitration, the commencement of the term, explanations as to the procedural law or rules applicable to the dispute, and whether or not the arbitrators are competent to act as amiable compositeur.

The terms of reference shall be signed by the arbitral tribunal and the parties.

$[\ldots]$

Article 12.

Expert appointment by arbitral tribunal, taking evidence, rules applicable to substance of dispute and settlement

A) The arbitral tribunal may [...]

C) The arbitral tribunal shall decide the dispute in accordance with such rules of law as are chosen by the parties as applicable to the substance of the dispute. The applicable trade usages under the law shall be taken into account in construing the provisions of the underlying contract and for filling gaps. Any designation of the law or legal system of a given State shall be construed, unless otherwise expressed, as directly referring to the substantive law of that State and not to its conflict of laws rules or its rules of procedure. Failing any designation by the parties of the applicable substantive law, the arbitral tribunal shall apply the substantive law of a State, which has the closest connection with the dispute. The arbitral tribunal shall decide ex aequo et bono or as amiable compositeur only if the parties have expressly authorized it to do so. [...]

Fonte: Paulsson, Jan (Ed.). International Handbook on Commercial Arbitration, cit., p. Turkey: Annex I-6 e ss., suplemento mar. 2005. Também Sмiт, Hans; Реснота, V. Smit’s Guides to International Arbitration, cit., p. TUR B-8 e ss. Obervação: nesta obra, a referência à arbitragem por eqüidade do art. 10 é subsituída por "whether or not the arbitrators are permitted to facilitate settlement negotiations". Portanto, dependendo da obra que se consulte, a autorização pode estar contida apenas no art. 12. A doutrina consultada menciona a possibilidade de aribtragem por eqüidade como prevista no art. 12C (vide Birsel, Mahmut T., Yesilirmak, Ali; CAvusoglu, Erdinc. Relatório sobre Turquia. In: PAulsson, Jan (Ed.). International Handbook on Commercial Arbitration, cit., p. Turkey 22.

944 Smit, Hans; PеснотA, V. Smit’s Guides to International Arbitration, cit., p. UKR B(2)-10. Também Paulsson, Jan (Ed.). International Handbook on Commercial Arbitration, cit., p. Ukraine: Annex I -8, suplemento out. 
Interessante notar que a Lei da Ucrânia, a exemplo de outros países oriundos do socialismo, cria duas câmaras de arbitragem: a Corte de Arbitragem Internacional da Câmara Ucraniana de Comércio e Indústria e a Comissão de Arbitragem Marítima, vinculada à mesma Câmara.

\subsubsection{Uganda}

Uganda renovou sua legislação sobre arbitragem em 2000, com a edição do Arbitration and Conciliation Act de 2000. Ele segue em larga medida a Lei Modelo e aplica-se às arbitragens internas e internacionais. Em seu art. 29, permite a arbitragem por eqüidade. ${ }^{945}$ Também neste caso, a lei evitou o uso das expressões ex aequo et bono ou amiable composition, preferindo utilizar "considerations of fairness and equity" e explicando seu alcance: "sem estar sujeito às regras da lei".

\subsubsection{Uruguai}

A disciplina da arbitragem no Uruguai está prevista no Código de Processo Civil daquele país, conforme alterações de 1988. O art. 477, inciso 5, daquele Código permite a arbitragem por eqüidade. Em caso de silêncio, seguindo o sistema hispano-americano clássico, presume que a arbitragem será por eqüidade. ${ }^{946} \mathrm{O}$ mesmo Código ainda prevê a chamada "arbitragem

1995. Também Pobirchenko, Igor. Relatório Ucrânia. In: PAulsson, Jan (Ed.). International Handbook on Commercial Arbitration, cit., p. Ukraine 13, suplemento out. 1995.

945 Rules applicable to substance of dispute

29. (1) The arbitral tribunal shall decide the dispute in accordance with the rules of law chosen by the parties as applicable to the substance of the dispute.

(2) The choice of the law or legal system of any designated state shall be construed, unless otherwise agreed by the parties, as directly referring to the substantive law of that state and not to its conflict of laws rules.

(3) If there is no choice of the law under subsection (1) by the parties, the arbitral tribunal shall apply the rules of law it considers to be appropriate given all the circumstances of the dispute.

(4) The arbitral tribunal shall decide on the substance of the dispute according to considerations of justice and fairness without being bound by the rules of law, only if the parties have expressly authorised it to do so.

(5) In all cases, the arbitral tribunal shall decide in accordance with the terms of the particular contract and shall take into account the usages of the trade applicable to the particular transaction.

Fonte: PAulsson, Jan (Ed.). International Handbook on Commercial Arbitration, cit., p. Uganda: Annex I-9, suplemento jan. 2006.

946 Artículo 477. Compromiso.

El compromiso deberá consignarse, bajo pena de nulidad en acta o escrito judicial o en escritura pública. La aceptación de los árbitros se recabará por el tribunal o por el escribano que autorizó la escritura.

El compromiso deberá contener:

1) Fecha de otorgamiento y nombre de los otorgantes.

2) Nombre de los árbitros, sin perjuicio d lo establecido en el artículo 480.4 . 
singular, que é uma espécie de arbitragem mais célere e menos formal, conduzida por árbitro único. Também esta arbitragem presume-se decidida por eqüidade. ${ }^{947}$

\subsubsection{Venezuela}

A Venezuela reformulou sua legislação sobre arbitragem em 1998, com a adoção da Lei sobre Arbitragem Comercial, de 07.04.1998. Esta lei aplica-se a arbitragens comerciais, tanto nacionais como internacionais. ${ }^{948}$ Esta lei contempla, em seu art. 8, a arbitragem por eqüidade, definida como aquela em que os árbitros "procedem com inteira liberdade, segundo seja mais conveniente ao interesse das partes, atendendo principalmente a eqüidade". Em caso de silêncio das partes, presume-se que a arbitragem seja de direito. ${ }^{949}$

Além da lei de arbitragem, o Código de Processo Civil da Venezuela também se aplica a arbitragens de caráter não comercial. Neste código, há, outrossim, previsões sobre arbitragem por eqüidade (cujos árbitros são denominados arbitradores) em termos muito parecidos com os da Lei de Arbitragem. Uma possível variação do regime de arbitragem do Código de Processo Civil é que este prevê que, caso as partes nada disponham sobre a natureza dos árbitros no compromisso, presume-se que sejam arbitradores (ou seja, decidem em eqüidade). ${ }^{950}$ Todavia, um artigo precedente afirma textualmente que, se não houver acordo entre as partes sobre o caráter dos árbitros e as regras a serem seguidas, entender-se-á que os árbitros decidirão conforme o

3) Puntos sobre los cuales debe recaer el laudo. Si no hubiera acuerdo de partes sobre este particular, cada una de ellas propondrá sus puntos y todos ellos serán objeto de arbitraje.

4) Procedimiento del arbitraje, si nada se dijera sobre este particular, se estará a lo dispuesto en el artículo 490.

5) La mención de si el arbitraje es de derecho o de equidad; si nada se dijere, los árbitros fallarán por equidad.

6) Plazo para laudar.

Fonte: Smit, Hans; Peснот, V. Smit's Guides to International Arbitration, cit., p. URU B(1)-2.

Smit, Hans; РеснотA, V. Smit's Guides to International Arbitration, cit., p. URU A-1.

948 Idem, ibidem, p. VEN A-1. Também Weininger, Bernardo; LindsAy, David M. Venezuela. In: Blackby et al. International Arbitration in Latin América, cit. p. 223.

949 Artículo 8. ${ }^{\circ}$

Los árbitros pueden ser de derecho o de equidad. Los primeros deberán observar las disposiciones de derecho en la fundamentación de los laudos. Los segundos procederán con entera libertad, según sea más conveniente al interés de las partes, atendiendo principalmente a la equidad. Si no hubiere indicación de las partes sobre al carácter de los árbitros se entenderá que decidirán como árbitros de derecho.

Los árbitros tendrán siempre en cuenta las estipulaciones del contrato y los usos y costumbres mercantiles.

Fonte: Sмit, Hans; Pechota, V. Smit's Guides to International Arbitration, cit., p. VEN B(1)-19.

950 Artigo 618, parágrafo terceiro:

"Si en el compromiso no se indica de alguna manera el caracter de los arbitros, se entiende que son arbitradores” (Smit, Hans; Реснота, V. Smit's Guides to International Arbitration, cit., p. VEN B(1)-7). 
direito e que a sentença será inapelável ${ }^{951}$ A doutrina consultada não aponta a forma de resolver esta aparente contradição. Contudo, informa que existe discordância na doutrina local sobre a aplicação subsidiária do Código de Processo Civil às arbitragens comerciais, especialmente no que diz respeito à qualificação dos árbitros, que, no regime do Código, devem ser advogados quando a arbitragem for de direito. ${ }^{952}$

\subsubsection{Vietnã}

O Vietnã adotou sua nova legislação sobre arbitragem em 25.02.2003. O art. 7 da referida lei, ao dispor sobre os princípios de aplicação de legislação ao mérito, apenas e tãosomente menciona leis nacionais. No caso de ausência de escolha, esta incumbe ao tribunal arbitral. Não há elementos que sugiram a possibilidade de decisão por eqüidade. ${ }^{953}$

\subsubsection{Zâmbia}

Em 29.12.2000, a Zâmbia aprovou uma nova lei de arbitragem (Lei 19 de 2000, o Arbitration Act). A lei segue a Lei Modelo, que é anexa à lei da Zâmbia, sem que haja modificação no que diz respeito à possibilidade de arbitragem por eqüidade. ${ }^{954}$

951 Artigo 614, parágrafo segundo:

Si no hubiere acuerdo entre las partes con respecto al caracter de los arbitros y a las reglas de procedimiento que deban seguir, se entendera que decidiran como arbitros de derecho y la sentencia que se dicte será inapelable."

Fonte: Smit, Hans; Pechota, V. Smit's Guides to International Arbitration, cit., p. VEN B(1)-5

952 Weininger, Bernardo; Lindsay, David M. Venezuela, cit., p. 245.

953 7. Principles in applying legislation for dispute resolution

1. For a dispute between Vietnamese parties, the arbitral panel shall apply the law of Vietnam do resolve the dispute.

2. For a dispute with foreign elements, the arbitral panel shall apply the law selected by the involved parties. The selection and application of foreign law must not be inconsistent with the basic principles of the law of Vietnam.

If the involved parties fail to select the law applicable to their dispute, the arbitral panel shall make that decision.

Fonte: Smit, Hans; Pechota, V. Smit's Guides to International Arbitration, cit., p. VIE B-3.

954 Paulsson, Jan (Ed.). International Handbook on Commercial Arbitration, cit., p. Zâmbia Annex I-1 e ss., suplemento jul. 2004. 


\subsubsection{Zimbábue}

O Zimbábue adotou sua lei de arbitragem em 1996 (Arbitration Act, Lei 6 de 1966). Aquele país adotou a Lei Modelo, com poucas variações. Seguindo uma técnica legislativa de common law, a Lei Modelo encontra-se como anexo do Arbitration Act. O art. 28(3) foi mantido integralmente, permitindo-se, portanto, a arbitragem por eqüidade desde que expressamente convencionada pelas partes. ${ }^{955}$

955 Paulsson, Jan (Ed.). International Handbook on Commercial Arbitration, cit., p. Zimbabwe: Annex I-11, suplemento out. 1997. 


\section{Parte III \\ ELEMENTOS DE EQÜIDADE NO COMÉRCIO INTERNACIONAL}

Esta parte dedica-se à pesquisa empírica de elementos de eqüidade na arbitragem comercial internacional. Em seu primeiro capítulo, apresenta os elementos de eqüidade encontrados na jurisprudência arbitral. No segundo, apresenta os resultados da pesquisa de campo realizada para esta obra. 


\section{CAPÍTULO 7}

\section{ELEMENTOS DE EQÜIDADE NA JURISPRUDÊNCIA ARBITRAL}

A utilização da jurisprudência como "fonte" de um direito da arbitragem é matéria distante da pacificação. A inexistência de um órgão superior de revisão, ao contrário do que ocorre em tribunais nacionais, representa uma barreira importante para tal reconhecimento. Além disso, a ausência de publicação da imensa maioria das sentenças arbitrais impede a verificação mais precisa de um corpus de decisões. Embora exista um movimento crescente de publicação de decisões arbitrais, seja em livros específicos, seja em periódicos, apenas a minoria dos casos chega a conhecimento público.

De qualquer modo, esse movimento de publicação de sentenças arbitrais é relevante e abrange sentenças da CCI, CIRDI/ICSID, CRCICA, arbitragens marítimas, antigas câmaras de comércio dos países socialistas e de alguns órgãos de arbitragem especializados. ${ }^{956}$ Além dos esforços institucionais, a criação de novos periódicos dedicados à arbitragem tem disseminado a publicação de sentenças arbitrais. Desde os pioneiros Journal du Droit International e Revue de l'Arbitrage à jovem Revista Brasileira de Arbitragem, existe uma gama extensa de publicações que dedicam parte considerável de seu espaço para a publicação de sentenças arbitrais e seus comentários.

Como resultado desse movimento de publicação de sentenças arbitrais, constatou-se o fenômeno de que as sentenças mais recentes tendem a buscar respaldo nas sentenças anteriores, havendo alguma espécie de coordenação de soluções. ${ }^{957}$ A despeito de tal importante constatação, não se pode afirmar que exista uma autoridade propriamente dita das sentenças arbitrais em relação umas às outras. O papel da jurisprudência como fonte do direito é problema ainda objeto de discussões em direitos nacionais. No campo da arbitragem internacional não existem órgãos revisores ou unificadores de sentido. Nele vigora um largo pluralismo de fontes. Portanto, a questão da autoridade das sentenças tende a ser mais complexa. Conquanto não se possa vislumbrar nada similar aos precedentes vinculantes da common law, a jurisprudência arbitral revela "um conjunto de decisões", revelando "um hábito de julgar em um determinado sentido" que certamente possui influência no âmbito da prática da arbitragem comercial internacional. ${ }^{958}$

\footnotetext{
956 Fouchard, Gaillard e Goldman. Traité de l'Arbitrage Commercial International, cit., p. 206.

957 Idem. ibidem.

958 Idem, p. 200 e ss.
} 
No caso específico desta obra, procura-se aferir a existência de algum conteúdo material na noção de eqüidade, reiteradamente considerada vaga e despida de conteúdo. Evidentemente, não se pretende chegar a uma definição de tal conteúdo, que necessariamente depende de um juízo pessoal de justiça e de uma variação infinita de fatos. A decisão por eqüidade, mais que a arbitragem de direito, depende dos fatos do caso concreto, que podem gerar uma regra específica somente aplicável ao caso.

Na elaboração da regra específica, não é necessário aplicar critérios de subsunção dos fatos à norma. Estando os árbitros desobrigados de seguirem a operação de subsunção, perde-se um elemento possibilitador de comparações, que é a norma genérica. Perdendo-se o elemento "unificador de sentido" da norma.

Nesta obra, busca-se verificar se, no corpo de decisões arbitrais decididas por eqüidade, podem-se encontrar elementos que caracterizem, ao menos em parte, "hábitos" de julgar em um determinado sentido. Indaga-se se a existência de casos comparáveis permite depreender elementos que caracterizem um entendimento acerca do que seja equitativo, na comunidade da arbitragem internacional.

Caso o esforço visasse à delimitação precisa do que seja eqüidade, seria uma tarefa destinada ao fracasso antes de seu início: a dependência dos fatos traz necessariamente algum grau de incerteza e qualquer elemento unificador tenderia a uma amplitude exagerada a ponto de não conferir nenhum conteúdo material relevante (possivelmente, a reedição de brocardos como o suum cuique tribuere). Todavia, a busca de elementos depreensíveis dos casos concretos pode representar um primeiro passo para a identificação de tendências. Assim, pode ter valor prático para os que estudam a matéria.

Além das pesquisas de sentenças publicadas em periódicos e livros, o autor obteve autorização da CCI para pesquisar seus arquivos de sentenças não publicadas, mediante compromisso de confidencialidade de dados. Essa autorização ofereceu uma oportunidade única: sendo a CCI uma das instituições mais importantes no mundo da arbitragem internacional, o acesso a seu acervo possibilitou ampliação considerável da base pesquisada. $\mathrm{O}$ acesso a uma quantidade considerável de sentenças por eqüidade trouxe uma vantagem importante: a comparação entre casos mais ou menos semelhantes.

Em geral, os casos escolhidos para publicação são aqueles que apresentam questões complexas ou de interesse mais geral, versando sobre aspectos fundamentais da arbitragem. No caso da arbitragem por eqüidade, em geral publicam-se as sentenças que definem os poderes dos árbitros, os efeitos no tocante ao contrato ou questões de ordem pública. Entretanto, os casos 
mais quotidianos, cuja importância em geral não transcende o debate entre as partes, têm grande interesse para o exame da "prática" da eqüidade. Eles dão perspectiva às sentenças amplamente conhecidas: um leading case sobre um ponto específico tem sua importância revista em face de vários outros casos em sentido contrário. Além disso, o acesso a um número considerável de casos oferece uma massa crítica a partir da qual tendências mais nítidas podem ser divisadas.

O autor agradece penhoradamente à CCI, pela gentileza de autorização, sem a qual esta obra teria um alcance muito mais reduzido.

Na pesquisa, o autor buscou sempre que possível o exame integral das sentenças arbitrais e o fez na maioria dos casos. Entretanto, em alguns casos, seja por razões técnicas, seja por limitações de tempo, não pôde ter acesso ao texto integral. Nesses casos, valeu-se de relatórios internos da CCI, em geral completos. A pesquisa tomou como base inicial busca por termos que incluíam arbitragem por eqüidade e seus sinônimos. Embora seguramente abranja a maioria das sentenças por eqüidade, não se pode descartar a possibilidade de que alguma sentença tenha escapado dessa busca. Portanto, não pode afirmar com certeza que tenha pesquisado todas as sentenças por eqüidade da CCI. Todavia, pode-se asseverar que a pesquisa abrange um número substancial e representativo do universo de sentenças por eqüidade naquele âmbito.

\subsection{Estatísticas da arbitragem por eqüidade}

Existem poucas fontes estatísticas sobre a arbitragem em geral. Dentro desse universo limitado de fontes, há ainda menos dados sobre decisões por eqüidade e direito aplicável em geral.

O sigilo que normalmente envolve a arbitragem afeta não apenas o conteúdo das decisões, mas também dados estatísticos. As razões inerentes a essa realidade são bastante conhecidas: o sigilo, a não-publicação de todas as sentenças, a existência de arbitragens ad hoc, etc. No caso das estatísticas, parece haver ainda mais barreiras: em geral, dependem de alguns dados gerais, como o número total de casos julgados em determinado período, nem sempre divulgados ou mesmo passíveis de obtenção no caso de arbitragens ad hoc. No entanto, existem alguns esforços de divulgação de dados por algumas entidades.

A CCI passou a publicar seu Boletim na década de 1990, com estatísticas relativas ao direito escolhido pelas partes. Em seu primeiro número, divulgou dados referentes à década de 
1980.959 Contudo, não foram divulgados dados concernentes à escolha de lei aplicável pelas partes. ${ }^{960}$

Ainda assim, no segundo volume do boletim, um artigo do então secretário-geral da Corte de Arbitragem da CCI, Stephen R. Bond, trouxe alguns dados estatísticos sobre arbitragem por eqüidade. ${ }^{961}$ Nele, afirmava-se a existência de poucas "clauses which authorize the arbitral tribunal to resolve the dispute on the basis of equity, amiable composition, ex aequo et bono, or with the arbitrators acting as mediators". Segundo aquele autor, houve apenas nove casos em 1987 (3\% do total) e 8 em 1989 (4\% do total). ${ }^{962}$

Em 1992, o Boletim informou o número de casos em que havia escolha expressa de critério de decisão. ${ }^{963}$ Segundo publicado, em mais de $83,7 \%$ dos casos, houve escolha de critério de decisão aplicável ao mérito. ${ }^{964}$ Todavia, embora afirmasse que leis nacionais eram o maior percentual computado, não informava o percentual dos outros critérios. ${ }^{965}$

O número de arbitragens por eqüidade passou a ser informado no boletim da CCI a partir dos dados do ano 2000. Nesse ano, de 541 casos novos, houve escolha do critério de julgamento em $77 \%$ deles, dos quais $75 \%$ uma lei nacional. Nos $2 \%$ restantes, houve escolha da Convenção de Viena, sete casos de referências aos princípios gerais do direito e do comércio internacional e apenas um caso de eqüidade. ${ }^{966}$

959 The ICC International Court of Arbitration Bulletin, Paris, ICC International Court of Arbitration, v. 1, n. 1, p. 8-9, jun. 1990.

960 Neste boletim verifica-se que a arbitragem da CCI foi uma atividade essencialmente européia-ocidental nos anos 1980. No início da década, cerca de 64\% das partes envolvidas em arbitragens eram européias, proporção que decaiu por volta de 50\% ao final do decênio. Também a nacionalidade dos árbitros foi por um longo período dominada pela Europa, países mediterrâneos e América do Norte, embora aumentando sua diversidade com o passar do tempo.

961 Bond, Stephen R. How to Draft an Arbitration Clause (revisited). The ICC International Court of Arbitration Bulletin, v. 1, n. 2, especialmente p. 19, dez. 1990.

$962 \mathrm{O}$ autor ainda informa que em alguns casos outras cláusulas especificamente proibiam decisão por eqüidade. Em outros, havia escolha concomitante de eqüidade e um direito nacional.

963 The ICC International Court of Arbitration Bulletin, v. 3, n. 1, p. 7, maio 1992.

964 Usa-se aqui a expressão "critério de decisão", embora o original utilize o termo "law", normalmente traduzido por "direito" ou "lei". Faz-se a escolha porque, como visto em publicações subseqüentes da CCI, o termo "law" engloba também decisões por eqüidade e outros critérios fora do direito positivo estrito (como princípios do comércio internacional e outros). A utilização do termo "direito" em português poderia criar falsas percepções, ao passo que "critério de julgamento" engloba todas as categorias, ainda que seja inferior do ponto de vista estilístico.

965 No ano seguinte, foram publicadas estatísticas dos dez anos anteriores. Todavia, não se informou o percentual de arbitragens de direito ou de eqüidade (The ICC International Court of Arbitration Bulletin, v. 4, n. 1, maio 1993).

966 The ICC International Court of Arbitration Bulletin, v. 12, n. 1, p. 5 e 11, 2001. 
Em 2001, de 566 casos novos, houve escolha de critério de julgamento em 78\% dos casos, dos quais $77 \%$ leis nacionais. De $1 \%$ restante, as partes referiram-se a "equity, international public law, amiable composition and ex aequo et bono". Houve ainda duas escolhas da Convenção de Viena. ${ }^{967}$

Em 2002, de 593 casos novos, houve escolha de eqüidade em 1,6\% deles: "In 2.3\% of contracts, the parties chose rules or principles other than national laws for the determination of their dispute, notably equity (1.6\% of contracts)". 968

Em 2003, de 580 casos novos, houve escolha de "princípios gerais de eqüidade" em apenas dois casos (“general principles of equity"). ${ }^{969}$

Em 2004, não existiu menção à eqüidade. ${ }^{970} \mathrm{Em} 2005$, houve escolha de eqüidade em um caso. ${ }^{971}$ Em 2006, de 593 casos novos, em 2\% ocorreu escolha de critérios distintos de leis nacionais. Destes, em 1\% foi escolhida a Convenção de Viena. Do restante, foram escolhidos lei da "Comunidade Econômica Européia, direito internacional, direito do comércio internacional, direito da arbitragem internacional (“international arbitration law") e eqüidade. ${ }^{972}$

Portanto, embora encontrem-se opiniões sobre a freqüência da arbitragem por eqüidade, o fato comprovado pelas estatísticas da CCI é que a utilização da arbitragem por eqüidade é bastante reduzida no total de arbitragens. Pelos dados obtidos, o percentual máximo de arbitragens por eqüidade foi de $4 \%$, e sua média tem se mantido abaixo de $1 \%$ dos casos desde o ano 2000 (exceto em 2002, quando teve 1,6\%).

Um dado estatístico francês sobre revisão estatal de sentenças arbitrais mostra um percentual de $23,8 \%$ de casos de arbitragem por eqüidade no total de arbitragens. ${ }^{973}$

967 V. 13, n. 1, p. 12, 2002.

968 The ICC International Court of Arbitration Bulletin, v. 14, n. 1, p. 14, 2003.

969 Ibidem, v. 15, n. 1, p. 13, 2004. Ao lado da eqüidade, foram feitas referências a: direito internacional (um caso); direito comercial internacional (um caso) e à Convenção de Viena (três casos).

970 The ICC International Court of Arbitration Bulletin, v 16, n. 1, p. 11, 2005. Neste ano, os critérios distintos das leis nacionais foram: Convenção de Viena (quatro casos); direito comercial internacional (dois casos); princípios gerais do direito (um caso); e "normas internacionais de interpretação de termos comerciais" (international rules for the interpretation of trade terms) (um caso). Total de casos novos no ano: 561 (p. 5).

971 The ICC International Court of Arbitration Bulletin, v. 17, n. 1, p. 11, 2006. Neste ano, os critérios distintos das leis nacionais foram: Convenção de Viena (cinco casos); direito internacional (um caso); direito do comércio internacional (um caso); e Convenção da Haia sobre Lei Aplicável ao Contrato de Agência (um caso). Total de casos novos: 521 (p. 5).

972 The ICC International Court of Arbitration Bulletin, v. 18, n. 1, p. 11, 2007.

973 Albiges, Christophe. De l'Équité en Droit Privé. Paris, LGDJ, 2000, p. 259. 


\subsection{O caso dos contratos de publicidade}

Como já mencionado, uma característica da arbitragem por eqüidade é sua estreita vinculação aos fatos do caso. Por sua natureza, permite a adequação da decisão aos fatos, sem necessariamente utilizar a "mediação" da lei. Como os fatos são infinitamente variáveis, há dificuldade em verificar sentidos unificadores nas decisões por eqüidade.

Na pesquisa realizada, verificou-se uma interessante recorrência de um tipo de disputa, abrangendo contratos e fatos parecidos. Em cerca de oito anos, foram conduzidos 27 casos relativos a contratos celebrados entre empresas de diversos países para a publicação de anúncios em periódicos de grande circulação da Europa e dos EUA. Em geral, as empresas contratantes do serviço advinham dos chamados "países emergentes" e empresas especializadas em publicidade, em geral situadas na América Central e Europa Ocidental.

A recorrência de casos é uma boa oportunidade para verificar como diferentes árbitros em eqüidade decidem uma questão semelhante. Em todos os casos, era pedido o pagamento do valor principal do contrato e juros. Em parte deles, há menção a uma taxa de juros superior a $1 \%$ ao mês. Em outra parte relevante, houve pedido de reembolso das despesas incorridas para a cobrança do débito, antes da arbitragem.

Embora os dados colhidos não permitam afirmar com certeza que os contratos fossem absolutamente idênticos, existem sinais de que o eram. Ao menos os contratos objeto das arbitragens possuem disposições muito semelhantes. No que diz respeito à situação de fato, há considerável semelhança: não houve pagamento dos valores contratuais e na maioria dos casos não existiu defesa dos demandados na arbitragem. Em todos os casos, o pedido de pagamento do valor do serviço foi julgado procedente, uma vez que não houve prova do pagamento por parte dos demandados.

Quanto aos juros, em dez casos (37\% do total), houve alguma forma de redução da taxa contratual. Embora se trate de um percentual alto de intervenção dos árbitros, o contrato foi aplicado na maioria deles (63\%), sem redução da taxa. O exame dos casos em que houve intervenção dos árbitros na taxa de juros oferece um interessante material sobre a atuação dos árbitros de eqüidade. 
Em três casos foram fixados juros de acordo com taxas internacionais de referência, como Prime Rate ${ }^{974}$ ou Libor. ${ }^{975}$ No caso n. 8.874976 (1996), o árbitro determinou a redução para da taxa de juros para Prime Rate, fazendo referência aos princípios do Unidroit. No caso n. 11.636, ${ }^{977} \mathrm{o}$ árbitro considerou a taxa de $1,8 \%$ ao mês (em dólares) usurária e a fixou em "Libor +2 ", com referência à eqüidade e à ordem pública. No caso n. $11.435,{ }^{978} \mathrm{o}$ árbitro altera, por eqüidade, a taxa original para uma de mercado, fazendo menção à lex mercatoria. No caso $9.483,{ }^{979}$ o árbitro reduziu a taxa de juros contratual (de 21,6\% ao ano) também para "Libor + 2 ". Dessa sentença destaca-se uma interessante fundamentação:

The Arbitrator considers that the parties have the freedom to decide on the rateof such contractual interest, subject to public order os the applicable law. The arbitrator considers that the purpose of a contractual clause providing for an interest rate applicalbe for late payment is to compensate the creditor's monetary damage during the period for which the Contract debt remains unsettled.

In the present case, the Arbitrator - who has the powers of an amiable compositeur and is to decide the case according to the principles of equity without needing to fully apply legal or procedural rules - is entitled to review the cosnequences of contractual provisions and to depart from a strict enforcement of such Contract provisions within the limits of the Contract's global balance.

It is obvious that the intent of the parties was to ensure protection against devaluation that would make the payment of interest unrealistic. It cannot have been the intention of the parties to replace interest by usury. What would have been understandable if the payment was foreseen in a weak currency is not applicable to a payment in US dollars. Article 13 of the Rules compels the arbitrator to apply the stipulations of the Contract, but also trade usages. No one would accept, as a trade usage, a yearly interest of $21.6 \%$ as applied to the US dollar. Indeed, such interest applied to a contract price made is US dollars, is too high, in view of equity and trade circumstances. Indeed, such rate would (1) not serve the sole purpose of serving as interest rate without a massive depreciation of the US dollar and (2) would too hardly damage the Defendant, especially in view of the fluctuation of the exchange rates between US dollar and the [moeda local do demandado].

\footnotetext{
974 Ou Prime Lending Rate, fixada por bancos norte-americanos.

975 London Interbank Offered Rate.

976 Inédito, de 1996.

977 Inédito, de 2002.

978 Inédito, de 2002.

979 ICC International Court of Arbitration Bulletin, v. 18, n. 1, p. 82 e ss., 2007.
} 
Em outros casos, os árbitros reduzem as taxas a percentuais por eles fixados. No caso n. $9.655,{ }^{980}$ houve fixação da taxa em $12 \%$ ao ano. No caso n. $9.704,{ }^{981}$ o árbitro fixa a taxa em $10 \%$. No caso n. $9.403,{ }^{982}$ houve redução da taxa de juros e fixação de um prazo razoável após a publicação do anúncio para que os juros passassem a incidir. Situação idêntica ocorreu no caso n. 9.616 .983

No caso n. 9.476, ${ }^{984}$ o árbitro invocou a lei de usura da França (local da arbitragem) para reduzir a taxa de juros. Portanto, o fez com base no argumento de ordem pública.

No caso, 12099, ${ }^{985}$ de 2003, tribunal determina que a diposição contratual que prevê juros de $1,8 \%$ ao mês seja interpretada como se referindo à taxa mensal aplicável por ano (ou seja, a taxa fixada em determinado mês para o período de um ano). Para tanto, invoca a prática dos mercados financeiros internacionais, especialmente o de Londres, onde as taxas de LIBOR são apresentadas (ainda que por mês) para o período de um ano. O tribunal ainda decide que o fato de a parte demandada ter confessado dever o valor mensal de juros deve ser tido em pouca importância, especialmente por não ter sido representada por advogados e por não ter tido a oportunidade de negociar o contrato, que é um formulário impresso. Além disso, afirma que a investidura em eqüidade confere poderes para mudar o contrato permite que, caso haja mais de uma interpretação possível, escolha-se a mais justa. Dessa decisão extrai-se:

Thus, the Arbitral Tribunal is of the view that the powers of amiable compositeur allow it to reduce the amount due under a contractual default interest formula if this amount would be inequitable, or to interpret or apply a contractual default interest formula in a manner yelding equitable results. Particularly so in circumstances where, as in the present case, the party owing the interest does not appear have negotiated, or had an opportunity to negotiate the details

980 ICC International Court of Arbitration Bulletin, v. 18, n. 1, p. 83 e ss., 2007, do qual se extrai:

"An interest for late-payment at a rate of $1.4 \%$ per month means $16.8 \%$ per year; Given the evolution of the general trends of interest rates since 1994, an interest for late payment at the rate of $16.8 \%$ is extremely high, and using his powers to decide the case according to the principles of equity, the Arbitral Tribunal hereby reduces the interest for late-payment to $1 \%$ per month i.e. $12 \%$ per year as of August 15, 1994".

981 ICC International Court of Arbitration Bulletin, v. 18, n. 1, p. 87 e ss., 2007, em que:

"It has been confirmed in prior cases and by legal commentators that an arbitrator 'amiable compositeur' may decide to reduce penalties payable under a contract or the interest rate by virtue of his/her powers of 'amiable compositeur' (see BREDIN, Jean Denis. L'amiable composition et le contrat, cit., p. 259-268).

Using such powers and applying the principles of equity pursuant to which this dispute must be decided according to Clause 5.2 Contract, the sole Arbitrator considers it equitable and fair under the circumstances to reduce the applicable interest to $10 \%$ per annum". Inédito, de 1998.

983 Inédito, de 1998.

984 Inédito.

985 ICC International Court of Arbitration Bulletin, v. 18, n. 1, p. 111 e ss., 2007. 
of the contractual terms, but instead to have simply signed off a standard order form presented by the other side.

The fact that Claimant produced evidence showing that Respondent agreed to the computation of interest made by claimant does not deprive the right of an Arbitral Tribunal as amiable compositeur to use such powers when considering the evidence. [o demandado], having not been represented by counsel in the present arbitration proceedings, may not have fully realised the implications of the amiable compositeur provisions in the Contract and may therefore have accepted the reading of the interest clause made by [demandante] without perceiving that this could be challenged. The Arbitral Tribunal is thus of the view that it is just and equitable, and within the powers of amiable compositeur, to give litlle weight to Respondeny's admission.

On February 25 2003, the one month US\$ Libor rate was 1.33750 and the one year rate was 1.38375 (see Financial Times edition of February 26). In the opinion of the Arbitral Tribunal, equity is best served by interpreting the contractual interest formula as saying that the rate of $1.8 \%$ per month referred to in the Contract is to be understood as one month rate in a manner consistent with the practice of international financial markets, namely as per annum rate computed monthly in a compounded basis."

No caso $9679,{ }^{986}$ o tribunal decide conceder juros, porém ressaltando que se trata de juros simples, uma vez que o texto do contrato não indica claramente que sejam compostos. ${ }^{987}$

Nos demais casos, os árbitros decidiram pela aplicação do contrato, inclusive no que diz respeito à cláusula de fixação dos juros. ${ }^{988}$ Em alguns casos, os árbitros afirmaram expressamente que nenhum elemento presente faz com que as disposições do contrato possam ser consideradas injustas. No caso n. 9.577, ${ }^{989}$ o tribunal determina apenas que os juros devem, por eqüidade, começar a correr a partir do último pagamento da parte demandada. No caso n. $96.045,{ }^{990}$ o tribunal afirma que os juros, embora altos, não parecem excessivos ou usurários. ${ }^{991}$

986 Inédito, de 1998.

987 Este caso também possui uma parte interessante a respeito da validade da cláusula de arbitragem, que era colocada no verso do contrato, sem assinatura específica. O tribunal decidiu que a validade é regida pelos princípios gerais do direito internacional e havia documento do demandado contrário à alegação de invalidade. A questão da validade foi decidida conforme os princípios gerais do direito internacional (com referência à lex mercatoria).

988 Casos 8.913, 9.019 9.462, 9.469 9.577, 9.597, 9.598, 9.654, 9.669, 9.671, 10.772, inéditos. Também o caso 9.669, publicado no ICC International Court of Arbitration Bulletin, v. 18, n. 1, p. 85, 2007.

989 Inédito, de 1998.

990 Inédito, de 1996.

991 Neste caso, há ainda a adoção da interpretação (hoje superada) de que a arbitragem por eqüidade tende a significar, ainda que implicitamente, a lex mercatoria. 
No caso, n. 9.653, ${ }^{992}$ o árbitro decidiu julgar apenas conforme o contrato, uma vez que este não ofende princípios de eqüidade. Assim, considerou equitativas as disposições do contrato, inclusive a taxa de juros. No caso n. $9.652,{ }^{993}$ foram aplicados juros de $1,4 \%$ ao mês, mesmo com a aplicação supletiva da lei francesa. Assim, contrapõe-se ao caso n. 9.476, acima citado, no qual a aplicação da lei de usura francesa, a título de ordem pública do foro, afasta a incidência de juros do mesmo patamar.

Com relação ao pedido de reembolso de despesas havidas com a cobrança prévia, eles foram concedidos nos casos n. 9.403, 9.462, 9.577, 9.597, 9.616 e 9.655. Em geral, as indenizações foram fixadas equitativamente. O mesmo pedido foi negado nos casos n. 9.469 e 96.045 .

\subsection{Elementos de Eqüidade na Jurisprudência}

\subsubsection{Prescrição}

Uma matéria recorrente em casos de arbitragem por eqüidade é a questão da prescrição. Ela oferece ao menos duas características importantes. Em geral, suas regras são precisas e deixam pouco espaço para interpretações. Salvo a caracterização do dies a quo ou qualificação (por exemplo, obrigação real ou pessoal), a precisão do texto não deixa muita margem para exegese. Assim, é um campo no qual a aplicação do direito é mais uniforme e pouco afeta a divergências e interpretações extensivas. Portanto, é um ponto em que a atuação da eqüidade aparece clara em sua função de derrogação do direito positivo.

Por outro lado, a prescrição é uma instituição que se situa nos confins da ordem pública (interna), tendendo a constituir normas imperativas, que não podem ser derrogadas pelas partes. Isso é demonstrado pela disposição, comum a certos direitos de origem romana, de que somente se pode renunciar à prescrição após sua ocorrência. Não por acaso, encontram-se interpretações distintas sobre a aplicação da eqüidade, tendendo-se a considerar a prescrição como matéria de ordem pública.

No caso 10.728, da CCI, ${ }^{994} \mathrm{o}$ árbitro único, seguindo a doutrina francesa, sustenta que, como a ata de missão prevendo arbitragem por eqüidade foi firmada após a existência da prescrição, pode-se reputar que as partes a ela renunciaram. Portanto, afirma a contrario, que antes

\footnotetext{
992 Inédito, de1998.

993 Inédito.

994 ICC International Court of Arbitration Bulletin, v. 18, n. 1, p. 98 e ss., 2007.
} 
da prescrição consumada não poderia haver "renúncia". No caso, afastou a prescrição consumada em razão de turbulências políticas relevantes no país do demandante, o que foi considerado como justa razão para a inércia continuada de 13 anos. A interpretação provavelmente seria outra, caso a assinatura da ata de missão ocorresse antes de consumada a prescrição.

No caso n. 4.265, ${ }^{995}$ de 1984, uma parte holandesa e uma egípcia discutiram um contrato de agência. Havia escolha de lei holandesa e eqüidade. Após o término do contrato, havia comissões a pagar, mas sobreveio desacordo entre as partes. Pelo direito holandês, o prazo de prescrição era de um ano. Como o pedido foi feito após esse prazo, o tribunal decretou a prescrição, por entender que não poderia revogar disposições de ordem pública.

No caso n. 114.09, ${ }^{996}$ de 2002, o tribunal afirma que as partes, ao escolherem eqüidade, delegam ao árbitro o poder de renunciar aos direitos que podem ser renunciados por contrato. Assim, pelo direito francês, pode descartar a prescrição adquirida. Como ao árbitro foi concedido o poder de julgar por eqüidade após a aquisição da prescrição, poderá descartá-la. ${ }^{997}$ Também neste caso, há o argumento a contrario que a prescrição não adquirida não poderia ser descartada.

No caso n. 10.900, ${ }^{998}$ de 2001, duas empresas européias discutiram contrato para realização de obra civil em país do Oriente Médio. O tribunal utilizou a lei francesa para afastar uma prescrição, que teria sido adquirida após o começo da arbitragem. Para tanto, houve referência a precedente francês de $2001 .{ }^{999}$

995 JARvin, Sigvard; Derains, Yves. Collection of ICC Arbitral Awards, cit., p. 499.

996 ICC International Court of Arbitration Bulletin, v. 18, n. 1, p. 100 e ss., 2007.

997 Pelo texto do julgado, o tribunal chega a afirmar que a Corte de Cassação francesa permitiu o descarte das consequências da prescrição. Todavia, a jurisprudência citada não se manifesta sobre ser a prescrição já adquirida ou não.

998 Inédito.

999 No caso específico, o precedente francês menciona prescrição e exceção de coisa julgada. Um comentador entende que houve o descarte da coisa julgada naquele caso, restando incerto se houve aquisição da prescrição antes da confirmação dos poderes para julgamento em equiidade. Assim, a matéria do descarte de prescrição não adquirida continua em aberto. Veja-se nota de Eric Loquin sobre julgado da Corte de Cassação frnacesa de 15.02.2001 e da Corte de Apelação de Grenoble de 15.12.1999 (Revue de l'Arbitrage, n. 1, p. 135, 2001): "L'arrêt rendu par la Cour de cassation reconnaît implicitement à l'amiable compositeur le pouvoir d'écarter, au nom de l'équité, les conséquences de la prescription et de l'autorité de la chose jugée. La clause d'amiable composition est une clause de renonciation par laquelle les parties abandonnent à l'arbitre la disposition des droits subjectifs dont elles peuvent elles-mêmes disposer (E. Loquin, L'amiable composition en droit comparé et international, Litec, 1980, n. 425 et s.). Il en résulte que l'amiable compositeur, si l'équité l'exige, peut écarter les droits dont les parties ont, une fois le litige né, la libre disposition. [...] La prescription extinctive est disponible pour les parties, mais, conformément à l'article 2220 du Code civil, à condition que la renonciation ne soit pas antérieure à son acquisition. Il en résulte que la clause d'amiable composition stipulée dans une clause compromissoire, avant l'écoulement du délai de prescription, c'est-à-dire avant l'acquisition du droit de renoncer à celle-ci, ne peut permettre aux arbitres de l'écarter. En revanche, confirmée une fois le litige né dans l'acte de mission ou prévue dans le compromis d'arbitrage, la clause d'amiable composition permet à 


\subsubsection{Aplicação do contrato}

A discussão acerca do relacionamento entre os árbitros de eqüidade e o contrato é um dos pontos nodais do estudo dessa espécie de arbitragem. A discussão justifica-se porque, embora os poderes dos árbitros de eqüidade sejam relativamente aceitos em relação ao direito positivo, não o são de forma definida em relação ao contrato. Sendo o contrato a expressão da vontade das partes, a escolha de eqüidade poderia ser considerada uma de autorização para rever essa mesma vontade, expressa no contrato? O posicionamento mais atual da doutrina encaminha-se para uma autorização limitada de descarte de soluções injustas e/ou abusivas do contrato, vedando-se sua renegociação.

Todavia, um aspecto aparentemente menos debatido nas obras que se dedicam à arbitragem por eqüidade é uma tendência de estrita aplicação dos contratos, tal como firmados pelas partes. Essa aplicação por vezes ocorre mediante invocação do contrato com expressão de eqüidade ou do princípio do pacta sunt servanda como expressão da ordem pública internacional. Entretanto, em muitos casos pesquisados, a solução se dá pela simples aplicação do contrato, mediante operação de subsunção dos fatos às hipóteses contratuais, sem maiores referência à eqüidade ou à lei.

\section{a) Aplicação do contrato}

Um alto grau de aplicação dos contratos pode ser verificado no caso dos contratos de publicação acima referidos. Essa tendência pode ser encontrada igualmente em diversos outros casos analisados na pesquisa realizada para esta obra.

No caso n. 9.867, ${ }^{1000}$ de 1999, houve a aplicação do contrato e da lei espanhola, escolhida pelas partes. $\mathrm{O}$ tribunal arbitral decidiu que, no caso concreto, não havia causa suficiente para a rescisão de um contrato atípico (mas ao qual foram aplicadas as regras de agência por analogia), determinando-se o pagamento de indenização. Neste caso, pode-se afirmar que a decisão seguiu a subsunção dos fatos ao contrato.

No caso n. $10.570,{ }^{1001}$ de 2000, duas empresas sul-americanas discutiam sobre pagamentos sob uma apólice de seguros que cobria a construção de rodovia. O tribunal decidiu que,

l'arbitre d'écarter la prescription. En l'espèce, l'arrêt ne précise pas à quel moment les parties avaient donné aux arbitres les pouvoirs d'amiable compositeur".

1000 Inédito.

1001 Inédito. 
embora os eventos fossem considerados acidentes, a culpa deles não era atribuível ao construtor e portanto a seguradora deveria pagar os valores conforme a apólice.

No caso n. 12.096, ${ }^{1002}$ de 2004, duas empresas européias discutiam sobre indenizações acerca de obras de construção de um porto. O tribunal decidiu que a ausência de pagamentos de fatura em decorrência de suspensão de obras configurava justa causa para rescisão do contrato e que as faturas aprovadas na forma do contrato deveriam ter sido pagas, além de indenizações. Neste caso, houve essencialmente subsunção dos fatos ao contrato.

No caso n. 6.141, ${ }^{1003}$ de 1993, uma parte européia e uma parte do Oriente Médio litigaram sobre um contrato de supervisão de construção de fábricas de fertilizante. Neste caso, houve escolha simultânea da lei do país do Oriente Médio e eqüidade, nos seguintes termos:

2 - With respect to the second preliminary issue, the Arbitral Tribunal will base its award on and be bound to give full effect to imperative and mandatory rules of [país do Oriente Médio] law, and shall be free to act as "amiable compositeur" with regard to any matter for which there is no mandatory or imperative rule of [país do Oriente Médio] law.

Com referência à doutrina ${ }^{1004}$ e precedentes da CCI, ${ }^{1005} \mathrm{o}$ tribunal estima que os poderes de eqüidade não permitem revisão do contrato, salvo excepcionalmente:

Such powers do no give the arbitrators any right to disregard, in any way
whatsoever, the will of the parties, and therefore they remain obligated to
apply all provisions of the contract freely agreed to by the parties, unless it
is demonstrated that such provisions are clearly contrary to the real intention
of the both parties, or are contrary to a generally accepted principle of public
order.
[...]
The arbitrators, even acting as amiable compositeurs, remain bound by the
general principle of law "pacta sunt servanda" and are therefore obliged to
observe, respect and apply the contractual provisions, freely agreed to by the
parties, without having any authority to disregard, amend or go beyond or
against the contract or its provisions.

O tribunal ainda invocou a lei do país do Oriente Médio, que reconhecia o pacta sunt servanda, além do regulamento da CCI, que determina que o contrato será observado em todos os casos.

\footnotetext{
1002 Inédito.

1003 Inédito.

1004 Craig, Park; Paulsson. International Chamber of Commerce Arbitration, cit.

1005 Casos 3.267, 3.327 e 3.398.
} 
Neste caso, o tribunal decidiu que determinada disposição contratual não poderia ser interpretada para estender garantias dadas pela parte européia sobre atos de terceiros, quando as garantias destes expirassem, caso contrário estaria imputando responsabilidade por trabalhos de terceiros. Para tanto, utilizou a eqüidade como argumento adicional à interpretação. No mesmo caso, o tribunal julgou válida uma cláusula de restrição de responsabilidade a $12,5 \%$ do valor total da obra, em razão do princípio do pacta sunt servanda.

No caso n. 11206, ${ }^{1006}$ de 2004, duas partes da América do Norte litigaram sobre contratos relacionados a uma joint venture entre as partes. O pleito maior era para obrigar a venda de ações de uma companhia à parte demandante. Neste caso, o tribunal arbitral aplicou o previsto no contrato, com algumas referências à lei de um Estado norte-americano.

O caso n. 7.913, ${ }^{1007}$ de 1996, trata de um litígio envolvendo partes européias, em contrato cujo objetivo era a prospecção de negócios para uma delas no território da segunda, mediante o pagamento de comissões. Este caso apresenta diversos aspectos importantes, que serão abordados no curso deste capítulo.

O tribunal discorre longamente sobre a questão da aplicação do contrato. Afirma que parte da doutrina e de textos legais colocam o pacta sunt servanda em proeminência. Entretanto, a maioria da doutrina permite a moderação de certas disposições específicas do contrato ou atenuar seu rigor, nos limites da ordem pública e sem "renegociá-lo" nem presumir que as partes renunciaram aos direitos dele nascidos. O tribunal declara ter a obrigação de respeitar a economia do contrato. Por outro lado, pode deixar de aplicar alguma disposição que pareça abusiva em relação a uma das partes ou iníqua em relação à natureza do contrato ou as suas circunstâncias.

Com apoio em Eric Loquin, ${ }^{1008} \mathrm{o}$ tribunal afirma que o árbitro em eqüidade deve distinguir entre os contratos "especulativos" e os que não o são. Segundo aquele autor, se o contrato possui uma álea considerável, trata-se de um risco assumido e a eqüidade não deve mudá-lo. $\mathrm{O}$ tribunal viu caráter especulativo no contrato analisado.

Não tendo havido prova de negócios feitos no país da parte demandante, nada haveria a pagar. Nesse aspecto, o tribunal foi bastante liberal ao mostrar-se disposto a "temperar" a regra do ônus da prova e admitir evidências de negócios concluídos após a vigência do contrato,

\footnotetext{
1006 Inédito.

1007 ICC International Court of Arbitration Bulletin, v. 18, n. 1, p. 67 e ss., 2007.

1008 L'Amiable composition... cit., p. 283.
} 
ainda que decorrentes de esforços da parte demandante. Entretanto, não houve prova de tais negócios. O tribunal, ademais, entendeu que não fere a eqüidade a estipulação de remuneração apenas com base nos eventuais negócios realizados. No tocante ao pleito subsidiário de pagamento das despesas incorridas pela parte demandante na busca de negócios, o tribunal entende que a cláusula que a vedava era da economia do contrato, não sendo abusiva ou iníqua.

No caso n. 12.772, ${ }^{1009}$ em que uma parte da América do Norte e outra da América Central litigaram sobre contrato no qual uma das partes deveria entregar à outra ações de determinada sociedade. $\mathrm{O}$ árbitro discorre sobre os poderes em eqüidade em relação ao contrato, afirmando que somente em casos extremamente específicos, como os da cláusula rebus sic stantibus, poderá haver intervenção do árbitro. Fora desses casos, o árbitro deve atender às disposições do contrato, "na medida em que essas forem claras", e não as alterar. A sentença assevera também que o fato de a disposição relativa à arbitragem por eqüidade aparecer posteriormente à determinação de observância do contrato no Regulamento da CCI não significa que esta última não lhe seja aplicável. No caso concreto, por entender que a redação do contrato é clara, decide aplicá-lo, independentemente de sua "autoridade" para julgar por eqüidade.

No caso n. 2.694, ${ }^{1010}$ de 1977, o tribunal constatou que o contrato entre as partes jamais havia sido cumprido. Mesmo tendo sido chamado por algumas das partes a rever o contrato, o tribunal recusou-se a fazê-lo, afirmando que os poderes de decidir por eqüidade não alcançam o de substituir às partes, renegociando o contrato litigioso.

O caso n. 3.938, ${ }^{1011}$ de 1982, um contrato de fornecimento de produtos químicos, previa a indexação do preço a um índice da indústria. O índice foi extinto sem substituto direto e as partes não chegaram a acordo quanto a um novo índice. $O$ tribunal entende que não pode negociar em nome das partes se elas não lhe deram poderes específicos. Entende que os poderes de eqüidade não chegam a ponto de substituir um índice arbitrariamente por outro e deu o contrato por terminado. ${ }^{1012}$

No caso n. $3.267^{1013}$ (laudo final), entre várias outras matérias, o tribunal decidiu que, à falta de abuso, aplicam-se os métodos do contrato para liquidação de créditos entre as partes. Neste caso, os árbitros sustentam que existe um princípio geralmente aceito da arbitragem in-

\footnotetext{
1009 ICC International Court of Arbitration Bulletin, v. 18, n. 1, p. 112 e ss., 2007.

${ }^{1010}$ Collection of ICC Arbitral Awards, cit., p. 320.

1011 Jarvin, Sigvard; Derains, Yves. Collection of ICC Arbitral Awards, cit., p. 502.

1012 Vejam-se também as observações de Sigvard Jarvin sobre as linhas de intervenção dos árbitros nos contratos nos comentários a esse caso, na p. 507 da mesma obra.

1013 Jarvin, Sigvard; Derains, Yves; Arnaldez, Jean-Jacques. Collection of ICC Arbitral Awards, cit., p. 43.
} 
ternacional de que o dever dos árbitros em direito ou eqüidade é aplicar o contrato, salvo se as cláusulas sejam manifestamente contrárias à verdadeira intenção das partes ou à ordem pública. Esse princípio foi considerado pelo tribunal como uma condição fundamental da segurança do comércio internacional.

No caso n. 5103, de 1988, ${ }^{1014}$ três partes européias de um mesmo grupo litigaram com quatro sociedade tunisinas sobre um relacionamento de fornecimento de determinadas matérias (fosfatados). Instado a especificar a lei aplicável por uma das partes, o tribunal afirma, lembrando seus poderes de eqüidade, que não necessita escolher uma lei. Todavia, explicita que decidirá primordialmente de acordo com o contrato, terá em conta os usos do comércio internacional e, conforme o caso, utilizará seus poderes de decidir em eqüidade.

No caso n. 9.262, ${ }^{1015}$ de 1997, três empresas africanas e duas empresas européias celebraram um contrato de joint venture. Esse contrato gerou uma primeira disputa, à qual as partes puseram fim por acordo. $\mathrm{O}$ acordo gerou uma segunda disputa entre duas empresas africanas e duas européias, sobre sua interpretação e cumprimento. As partes demandantes afirmavam terem concordado com uma redução de preço em troca de pesquisa e desenvolvimento que, entretanto, jamais foi providenciada. O árbitro único entendeu que, mesmo investido de poderes para decidir por eqüidade, não poderia modificar os termos da transação existente entre partes, longamente negociada. $\mathrm{O}$ árbitro único verificou que as demandadas não haviam subscrito nenhuma obrigação para entrega de pesquisas a um preço determinado, que era a única obrigação cujo descumprimento as demandantes alegaram. Evidentemente, prossegue o árbitro, não poderia haver descumprimento de obrigação inexistente. O árbitro constata, todavia, que uma das demandadas não agiu com o grau de cooperação que se espera de partes de uma joint venture. Como as demandantes não fundam sua pretensão na atitude "desenvolta" dos representantes das demandadas, o árbitro nega o pedido e termina por utilizá-la, aparentemente, na divisão dos custos de arbitragem, pela metade entre as partes.

No caso n. 9.653, mencionado no caso das publicações, o árbitro explicita seu entendimento sobre o julgamento conforme o contrato: por entender que este não viola a eqüidade, vai julgar apenas conforme seus termos.

No caso n. 11.409, já mencionado, o árbitro afirma expressamente que fará referência, em primeiro lugar, às normas objetivas e determinadas pelas próprias partes, contidas no contrato. Aos olhos do árbitro, elas são bastante claras e precisas a ponto de não ser necessário

\footnotetext{
1014 Jarvin, Sigvard; Derains, Yves; Arnaldez, Jean-Jacques. Collection of ICC Arbitral Awards, cit., p. 361. 1015 ICC International Court of Arbitration Bulletin, v. 18, n. 1, p. 79 e ss., 2007.
} 
substituí-las por interpretações jurisprudenciais "fortuitas" ou opiniões pessoais necessariamente subjetivas, sujeitas a serem taxadas de arbitrárias.

b) Alterações no contrato

Ao lado da tendência de aplicação do contrato, existe uma tendência, talvez mais conhecida, de intervenção. Todavia, em geral não se trata de uma intervenção "transacional" mais profunda, em que os árbitros substituem-se às partes para "renegociar" os termos do relacionamento. A tendência verificada nos julgamentos em relação ao contrato pertence mais ao âmbito do descarte de determinadas regras que pareçam injustas. Talvez pelo maior interesse que causem, os casos em que há efetiva intervenção no contrato aparecem com maior freqüência em comentários ou coletâneas. Esse maior interesse pode causar uma percepção de maior freqüência de casos de intervenção do contrato. No entanto, os dados colhidos para a presente pesquisa demonstram que a aplicação do contrato sem intervenções por parte dos árbitros é mais freqüente.

Um ponto interessante da tendência dominante de apenas descartar determinadas disposições é a medida que o "mero" descarte de disposições pode influenciar a economia do contrato como um todo. Em geral, as sentenças não apresentam fundamentação acerca da matéria e não parece existir nenhum critério recorrente.

O caso n. 3.327, ${ }^{1016}$ de 1981, envolveu uma empresa francesa e um Estado africano. Entre outras matérias importantes, o tribunal decidiu que eventual vício de consentimento de acordo com as estruturas estatais não é oponível à parte que contrata. Assim, concedeu os pedidos conforme o contrato; porém, invocando os poderes de eqüidade, decidiu conceder mais prazo para o pagamento. Assim, claramente alterou o contrato, nos termos de pagamento, em virtude da eqüidade.

No caso n. 11.934/, ${ }^{1017}$ de 2004, uma trading européia e uma distribuidora africana discutiram os termos de uma rescisão de contrato de distribuição. Essencialmente, o distribuidor afirmava que o término do contrato foi injustificado, ao passo que a trading sustentava várias violações sérias aos termos do contrato. No geral, os árbitros mencionam que há coincidência entre lei (francesa, no caso) e eqüidade, inclusive para os fins de fixação de juros. Todavia, alteraram o contrato, que previa o não-pagamento de indenização em caso de resilição.

1016 Jarvin, Sigvard; Derains, Yves. Collection of ICC Arbitral Awards, cit., p. 433.

1017 ICC International Court of Arbitration Bulletin, v. 18, n. 1, p. 104 e ss., 2007. 
O tribunal entendeu que a trading resiliu corretamente o contrato porque o distribuidor não aceitou receber mercadorias em um porto previsto. Além disso, afirmou que o distribuidor passara a produzir marca parecida com a anteriormente distribuída, fazendo-lhe concorrência ilícita. O tribunal considerou que as causas da resilição e a contrafação causaram dano, cuja ausência de indenização seria injusta. Assim, decidiu derrogar a disposição contratual sobre a não-indenização e determinou o pagamento de compensação. Entendeu também que havia uma ordem de produto não aceita pela trading contrariamente ao contrato. Portanto, determinaram que o distribuidor recebesse o valor que teria ganhado caso a ordem tivesse sido aceita.

No caso 920.290, ${ }^{1018}$ de 1992, um fornecedor litigou com o comprador e um banco acerca de um contrato de compra e venda e a respectiva garantia outorgada. Neste caso, o tribunal decidiu ajustar os termos do contrato havido entre as partes, para restaurar um equilíbrio contratual do negócio, ajustando a obrigação do comprador de pagar juros, proporcionalmente aos bens entregues e diminuição de capacidade (slippage).

No caso n. 6.763 , de 1992, ${ }^{1019}$ uma parte asiática e duas partes africanas litigaram sobre um contrato de fornecimento de uma fábrica em país africano. $\mathrm{O}$ tribunal decidiu que iria aplicar o contrato, porque a própria cláusula afirmava que a decisão deveria ser "according to contractual terms", além de reconhecer que o Regulamento da CCI assim determina e porque o princípio do pacta sunt servanda é uma regra geral de boa consciência e um uso relevante do comércio internacional. O tribunal sustentou ainda não possuir poderes para criar novas obrigações contratuais ou novos contratos entre as partes; entretanto, tem um poder maior do que apenas interpretar a vontade das partes eqüitativa e razoavelmente, uma vez que qualquer árbitro tem esse poder, mesmo sem estar investido dos poderes de eqüidade. Assim, o tribunal entendeu que a autorização para julgamento por eqüidade "empowers us to adjust the partie's contractual terms to restore the fair commercial balance intended by the parties' contractual bargain", embora reconheçam ser uma tarefa difícil na prática.

No caso concreto, asseveram que o contrato foi concebido para que os pagamentos da compradora fossem feitos a partir da venda de sua produção. As partes chegaram a acordo sobre diversos atrasos nas entregas, mas acabaram não mudando os prazos de pagamento. $\mathrm{O}$ tribunal diz que, na ausência de uma cláusula de eqüidade, nada poderia fazer. No entanto, utiliza seus poderes ex aequo et bono, para permitir um atraso no pagamento correspondente ao atraso (acordado) para a entrega. O tribunal entende que dessa forma recoloca o contrato no seu equilíbrio original: se as partes concordaram em atrasar a entrega, devem concordar com

\footnotetext{
1018 Inédito.

1019 Inédito.
} 
o correspondente atraso no pagamento, porque ambos devem compartilhar responsabilidade pelos arranjos pelos quais a produção iria gerar renda para o pagamento.

No caso 3.344, de 1981, ${ }^{1020}$ havia uma disputa sobre um contrato de fornecimento de petróleo entre duas entidades do mundo árabe. No contrato, continha uma forma de cálculo trimestral do valor do barril. A vendedora havia informado o preço novo e a compradora havia feito encomendas após essa data. Entretanto, houve desacordo sobre o preço e a vendedora faturou a USD13,95 o barril e a compradora pagou a USD12,50. O tribunal entendeu que, em princípio, a vendedora estaria correta. Entretanto, decidiu "temperar" a solução por eqüidade, considerando que houve uma mudança brusca do petróleo em 1974. Considerou também que as partes haviam estipulado um preço trimestral provisório de USD12,50, enquanto esperavam algumas definições das autoridades fiscais do país vendedor. Esse fato deixou a compradora em uma situação desfavorável. Além disso, se as negociações tivessem sido feitas antes, haveria um clima de concórdia que refletiria o tratamento privilegiado e preferencial que a compradora sempre recebeu da vendedora. Sendo assim, o tribunal resolve fixar, por eqüidade, o valor do barril em USD13,50 para o primeiro trimestre de 1974. No tocante à fixação posterior, o tribunal afasta a alegação de que haveria condição meramente potestativa.

No caso n. 4.972, de 1989, ${ }^{1021}$ foi discutido um contrato de distribuição exclusiva de produtos em um país em que ocorreu rescisão. $\mathrm{O}$ tribunal entendeu que não pode modificar o contrato, mas pode descartar determinadas disposições injustas - no caso concreto, a faculdade de rescisão do contrato. $\mathrm{O}$ Tribunal entendeu que a cláusula que permitia a rescisão não deveria ser aplicada, tendo em vista que o comportamento da concedente foi totalmente diverso nos três anos anteriores e que a violação do contrato foi de pequena monta. Assim, desconsiderou a faculdade da rescisão e determinou pagamento de indenização.

No caso n. 7.986, ${ }^{1022}$ de 1999, três partes (duas demandantes e uma demandada) discutiram um memorando de entendimento relativo a uma transferência de ações que tornaria uma das demandantes a líder de seu setor em um determinado país, por meio da compra de ações de uma sociedade, razão pela qual foram feitas declarações e garantias.

No tocante ao direito aplicável, o tribunal afirmou que, autorizado a decidir por eqüidade, está dispensado de aplicar uma lei nacional ou mesmo regras transnacionais. Sustenta ainda que o tribunal pode descartar disposições contratuais injustas, preservando a economia

\footnotetext{
1020 Jarvin, Sigvard; Derains, Yves. Collection of ICC Arbitral Awards, cit., p. 440.

1021 Jarvin, Sigvard; Derains, Yves; Arnaldez, Jean-Jacques. Collection of ICC Arbitral Awards, cit., p. 380.

1022 ICC International Court of Arbitration Bulletin, v. 18, n. 1, p. 72 e ss., 2007.
} 
do contrato, seu espírito e a intenção das partes quando o celebraram. Todavia, deve respeitar princípios de ordem pública, como o pacta sunt servanda.

A demandada alegou que as demandantes fizeram uma gestão ineficiente de certos ativos que deveriam ser por ela readquiridos (por não serem ligados à atividade principal que a companhia veículo do investimento passaria a desenvolver). O tribunal afirma que os preços foram devidamente fixados no contrato e que não existe qualquer ambigüidade sobre o funcionamento da operação. Assevera que, mesmo julgando por eqüidade, deve-se ater à vontade das partes expressa no contrato. Sustenta ainda que a demandada deveria readquirir os ativos, o que não fez quando devidamente convidada a tanto. A eventual gestão ineficiente não pode ser invocada, porque as demandantes, que não possuíam maior experiência naquela atividade, não tinham nenhuma obrigação de tal natureza, uma vez que o contrato previa que o grupo da demandada deveria readquirir os bens. Assim, entendem que as teses da demandada implicam reescrever o contrato, o que o tribunal não pode conceder, mesmo autorizado a julgar por eqüidade.

A demandada também alegou que, para que fosse determinada a reaquisição dos bens (não ligados ao objeto principal da empresa adquirida), o tribunal deve determinar que uma das demandantes faça o correspondente empréstimo do valor, conforme previsto no contrato, para reembolso sem juros em até três anos. O tribunal condena a demandada à reaquisição dos bens. Todavia, determina que a demandante em questão faça o correspondente empréstimo. Como a situação das partes foi modificada no prazo decorrido, seja pela atitude de descumprimento da demandada, seja porque seu grupo não mais possui a mesma situação financeira, o tribunal entende que a garantia oferecida pela demandada não é mais suficiente. Assim, estabelece que a demandada apresente uma garantia bancária de banco de seu país dentro de um prazo fixado na sentença. Caso não o faça, a recompra passa a ser incondicional (ou seja, sem a concessão do empréstimo por uma das demandantes). Com o objetivo de manter o equilíbrio original do contrato, o tribunal determina que uma das demandantes suporte o valor da garantia bancária, até um teto de $2 \%$. O tribunal declara que a decisão coloca as partes na situação que ocorreria se o contrato houvesse sido cumprido. Ainda que modifique a literalidade do contrato, que conduziria a um resultado injusto, respeita seu espírito.

Em conseqüência da decisão anterior, rejeita os pedidos de indenização das demandantes, no que diz respeito ao descumprimento do contrato pela demandada (dando conta de que uma das demandantes poderia ter obtido reequilíbrio financeiro se a demandada houvesse readquirido os bens tempestivamente). Como o tribunal determinou o cumprimento da obrigação, as indenizações configurariam bis in idem. 
Relativamente a um pedido de indenização por garantia de passivo (feito aparentemente nas declarações e garantias do contrato), o tribunal verifica que ele beneficia a parte da demandante, e não a sociedade adquirida. Assim, qualquer valor que seja encontrado será na proporção do capital que foi adquirido pela referida demandante. Embora a cláusula contratual preveja responsabilidade da demandada de $100 \%$ do valor da garantia, o tribunal utiliza seu poder de decidir em eqüidade para limitar a responsabilidade ao percentual adquirido pela demandante $(79,31 \%)$. O tribunal ainda decide tomar em conta o relatório de auditoria realizado na empresa adquirida antes de fechado o negócio. Se se tratar de informações que a demandante poderia obter "a partir" do primeiro relatório, será iníquo condenar a demandada a qualquer pagamento, porque a demandante teve a oportunidade de renegociar cláusulas após a ciência dos fatos. O tribunal afirma que, embora as disposições sobre garantias de passivo e valores sejam de interpretação estrita, pode temperar seu rigor em eqüidade.

No caso n. $10.504,{ }^{1023}$ de 2000, duas partes de países da Europa oriental discutiram um contrato pelo qual a parte demandada compensaria a demandante por perdas decorrentes de desaparecimento fraudulento de bens sob custódia da demandada. Apenas parte do valor foi pago e a parte demandante iniciou arbitragem para obter o restante dos valores. A cláusula arbitral, redigida em francês, previa que o árbitro decidiria em "arbitrage équitable". O árbitro entendeu que essa redação significava decisão por eqüidade.

O árbitro entendeu que havia contrato determinando o pagamento e, portanto, uma obrigação clara de pagar os danos. O árbitro não viu razão para moderar os danos contratados em eqüidade. Todavia, o árbitro julgou que houve pressão política indevida sobre a demandada para assinar o contrato. Uma testemunha confirmou diversos contatos políticos que, segundo o árbitro, poderiam ser considerados chantagem. O árbitro invoca os princípios do Unidroit para justificar que ameaças são um argumento válido para a nulidade dos contratos. Levando em conta todas as circunstâncias do caso, o árbitro decide reduzir por eqüidade o valor dos danos à metade.

c) Eqüidade e cláusulas de limitação de responsabilidade

Cláusulas de restrição de responsabilidade são bastante comuns em contratos internacionais e servem para preestabelecer o quantum de eventuais indenizações a ser pagas. Sua predeterminação possui uma álea ínsita: por serem pré-estimados, podem não corresponder ao dano efetivamente ocorrido. As diferenças entre o valor pré-estimado e o valor efetivo estive-

${ }^{1023}$ ICC International Court of Arbitration Bulletin, v. 18, n. 1, p. 95 e ss., 2007. 
ram sujeitas ao crivo de árbitros investidos de poderes por eqüidade, que tomaram posições distintas em face dos casos concretos.

No caso n. $6.503,{ }^{1024}$ de 1990, uma parte francesa e uma parte espanhola discutiram a rescisão de um contrato de licença para importação e fabricação de produtos de beleza.

Em primeiro lugar, a parte francesa pediu, contrariamente a sua posição anterior, a nulidade do contrato e o não-pagamento dos danos pré-estipulados, em razão de o direito da comunidade européia proibir a renovação contratual automática e a concessão de direitos exclusivos sobre o território espanhol. O tribunal, além de entender que tal pedido não estava abrangido pela ata de missão, afirma que o acolhimento de tal pretensão conduziria a um resultado "profundamente iníquo e chocante, considerando que a mesma demandante executou o contrato sem reserva, reconheceu sua validade em data posterior à entrada da Espanha na Comunidade Econômica Européia", além de admitir em carta que poderia pôr fim ao negócio mediante o pagamento de indenização prevista no contrato. O tribunal, situado na Suíça, reconheceu a tradição do direito daquele país de que os árbitros, decidindo por eqüidade, podem descartar mesmo disposições de direito imperativo (embora ressalvando a ordem pública). Todavia, como a lei aplicável ao mérito era suíça, deixou de decidir sobre as conseqüências do direito comunitário sobre o contrato.

No que diz respeito ao pagamento de indenização pré-estipulada (valor do lucro de 12 meses anteriores à resilição) e os prazos de renovação do contrato, o tribunal entendeu que havia um prazo inicial de dez anos no qual não poderia haver resilição e, posteriormente, havia esse direito mediante pagamento da multa. No caso específico, entenderam que o valor era eqüitativo e decidiram não diminuí-lo. Decidiram, também, colmatar uma lacuna do contrato, relativa ao aviso prévio para resilição, fixando data específica, por eqüidade.

No caso n. 3.267, já mencionado, havia cláusula de cálculo para um valor máximo de indenização. Embora os elementos da fórmula pudessem ser aplicados também para correção dos valores para a baixa, isso não ocorreu no caso concreto: o contrato somente previa a utilização para correção na alta dos valores. À falta de elementos que pudessem mostrar que outra era a intenção das partes, o tribunal manteve o limite somente para a alta. Uma das partes alegou que a indenização prefixada no caso concreto era injusta. O tribunal decidiu que, embora as multas possam ser diminuídas na maioria dos sistemas jurídicos, o mesmo não ocorre com indenizações prefixadas. A decisão reconhece que em certos casos o tribunal, decidindo por

1024 Arnaldez, Jean-Jacques; Derains, Yves; Hascher, Dominique. Collection of ICC Arbitral Awards, 1991-1995. Recueil des Sentences Arbitrales de la CCI, 1991-1995. Boston: Kluwer Law International, 1997. p. 613. 
eqüidade, pode não autorizar o exercício de certos direitos contratuais que sejam abusivos. No entanto, reconhece que não houve abuso no caso concreto.

No caso n. 3540, ${ }^{1025}$ duas partes européias discutiram sobre contrato para construção de obra civil em um terceiro país europeu. Na sentença final, o tribunal afirma que, em eqüidade, tem o poder de temperar a lei, que neste caso era a lex mercatoria. Também pode temperar o contrato, aplicando princípios de eqüidade se as conseqüências da lei ou do contrato forem demasiado rigorosas. Também sustenta que, de qualquer modo, deve respeitar ao menos os princípios fundamentais do direito processual (por exemplo, correlação entre pedido e provimento, contraditório, etc.). Quanto ao fundo, devem respeitar a ordem pública.

Neste caso, havia uma cláusula que limitava a indenização por atrasos a 3\% do valor total do negócio. Os atrasos verificados eram maiores que esse limite (em verdade, eram atribuíveis a ambas as partes, e, de um total de dez meses, sete cabiam à parte iugoslava e três, à francesa).

O tribunal decidiu que seria iníquo limitar a indenização a 3\% quando o valor real chegasse a quase $9 \%$. Embora tenha feito sua fundamentação por eqüidade, afirma que sua solução é a de inúmeros ordenamentos positivos, como o francês, o belga e o dos países socialistas (que têm a reparação integral do dano como princípio de ordem pública). Cita também o desfavor dos países de common law a essas limitações. O tribunal ainda sustenta que, embora seja uma limitação de multa, sua verdadeira natureza é de danos preestabelecidos. O tribunal também arbitrou por eqüidade diversas indenizações, de modo a proporcionalizar a culpa.

No caso n. 6.141, ${ }^{1026}$ de 1993, uma parte européia e uma parte do Oriente Médio litigaram sobre um contrato de supervisão de construção de fábricas de fertilizante. Neste caso, o tribunal estima que os poderes de eqüidade não permitem revisão do contrato:

Such powers do no give the arbitrators any right to disregard, in any way whatsoever, the will of the parties, and therefore they remain obligated to apply all provisions of the contract freely agreed to by the parties, unless it is demonstrated that such provisions are clearly contrary to the real intention of the both parties, or are contrary to a generally accepted principle of public order.

$[\ldots]$

1025 Collection of ICC Arbitral Awards, cit., p. 399.

1026 Inédito. 
The arbitrators, even acting as amiable compositeurs, remain bound by the general principle of law "pacta sunt servanda" and are therefore obliged to observe, respect and apply the contractual provisions, freely agreed to by the parties, without having any authority to disregard, amend or go beyond or against the contract or its provisions.

Em vista de tal posicionamento, julgou válida uma cláusula de restrição de responsabilidade a $12,5 \%$ do valor total da obra.

\subsubsection{Diferença entre amiable compositeur e decisão por eqüidade}

A diferença entre arbitragem por eqüidade (ex aequo et bono) e amiable composition, preconizada por parte da doutrina, pode ser encontrada em algumas sentenças arbitrais, relativamente recentes. As diferenças apontadas, contudo, parecem refletir as visões suíça e francesa do que seja arbitragem por eqüidade. Como visto nesta obra, parte da doutrina suíça (especialmente de língua francesa) entende que os árbitros autorizados a decidir por eqüidade podem derrogar disposições legais de ordem pública. Na doutrina francesa, geralmente entende-se que o amiable compositeur não pode derrogar disposições de ordem pública (interna). ${ }^{1027}$ No tocante à diferenciação aventada por alguns doutrinadores, segundo a qual a amiable composition poderia um caráter "transacional" mais acentuado, a pesquisa não encontrou nenhuma sentença arbitral que a adote.

A sentença do caso n. $12.772,{ }^{1028}$ de 2004, feito em Zurique, refere-se a uma vasta maioria de autores (suíços) que afirmam que na amiable composition os árbitros devem aplicar a lei e corrigir o resultado de modo equitativo, ao passo que na arbitragem por eqüidade os árbitros possuem uma "área mais ampla de discricionariedade", limitados apenas pelos princípios de ordem pública. Todavia, a sentença também reconhece a existência de autores, no âmbito internacional, que não vêem diferenças substanciais entre os institutos.

Essa diferenciação parece ter ocorrido também no caso n. 940.220, de $1994 .{ }^{1029}$ Neste caso, como houve escolha simultânea de eqüidade e uma lei nacional, o tribunal decidiu que não haveria decisão pura em eqüidade, mas sim da "eqüidade legal": aquela permitida pela lei, como no caso do famoso art. 4.o do Código das Obrigações suíço. Para chegar a essa conclusão, o tribunal utilizou a diferenciação da doutrina suíça entre decisão por eqüidade e amiable

\footnotetext{
1027 Alguns autores referem-se ainda ao fato de que os amiable compositeurs devem aplicar a lei e descartar apenas as soluções injustas, ao passo que os árbitros em eqüidade não precisariam partir da aplicação da lei.

1028 ICC International Court of Arbitration Bulletin, v. 18, n. 1, p. 112 e ss., 2007.

1029 Inédito.
} 
composition, concluindo que a escolha de lei juntamente com eqüidade tem efeitos diferentes da simples escolha da eqüidade. Neste caso, ambas as partes concordaram com a diferença entre eqüidade e amiable composition em suas manifestações.

Já no caso n. $11.409,{ }^{1030}$ de 2002, o tribunal afirma a identidade entre arbitragem por eqüidade e amiable composition:

Il est unanimement admis que statuer ex aequo et bono, c'est statuer en équité. La doctrine dominante considère que lorsque l'Arbitre a les pouvoirs de statuer en équité, il statue en amiable compositeur [...] La jurisprudence arbitrale n'établit pas des distinction entre les pouvoirs d'amiable compositeur et le pouvoir de juger ex aequo et bono [...].

No caso n. 7.913, ${ }^{1031}$ de 1996, o tribunal é claro ao assimilar a noção de eqüidade e amiable composition. Nesse caso, as partes haviam, em partes distintas do contrato, se referido aos dois termos. Entretanto, parte da argumentação é devida ao fato de que o regulamento da CCI então vigente somente mencionava apenas a expressão amiable composition para se referir a julgamentos sem recurso a lei.

No caso 7.986, ${ }^{1032}$ de 1999, o tribunal reconhece que, embora tenha havido controvérsia sobre a diferença entre arbitragem por eqüidade e amiable composition, ela não mais existe na doutrina mais moderna.

\subsubsection{Aplicação da lei}

Além da estrita aplicação do contrato, existem diversas decisões que, mesmo tomadas por eqüidade, aplicaram estritamente o direito positivo. Tal aplicação é perfeitamente possível, na medida em que as leis podem ser consideradas justas no caso concreto. Leis são elaboradas como emanação de uma vontade geral da sociedade, mediada pelo parlamento. Embora em sua generalidade possam deixar de atender certos casos concretos, buscam estipular uma regra que sirva à maioria. A seguir, encontram-se vários exemplos de decisões por eqüidade em que os árbitros aplicam apenas o direito positivo ou afirmam seu poder para tanto. Em alguns casos, existe a escolha simultânea de eqüidade e aplicação de um direito positivo. Nestas hipóteses, como visto, há uma indicação mais clara de aplicação da lei positiva, ficando facultado aos

\footnotetext{
$\overline{1030}$ ICC International Court of Arbitration Bulletin, v. 18, n. 1, p. 100 e ss., 2007.

1031 ICC International Court of Arbitration Bulletin, v. 18, n. 1, p. 67 e ss., 2007.

${ }^{1032}$ ICC International Court of Arbitration Bulletin, v. 18, n. 1, p. 72 e ss., 2007.
} 
árbitros descartar as soluções que pareçam injustas (respeitada a ordem pública). Seguem-se alguns exemplos, entre vários.

No caso n. 6.955, 1993, ${ }^{1033}$ uma empresa européia e uma empresa americana resolveram um litígio relativo à compra e venda de mercadorias. Além da eqüidade, as partes haviam escolhido a lei de um Estado norte-americano, que foi integralmente aplicada pelo tribunal arbitral.

No caso n. 4.467, de 1984, ${ }^{1034}$ envolvendo duas partes italianas, o árbitro único faz algumas considerações sobre sua tarefa de decidir por eqüidade. Diz que deve mitigar o rigor do summum ius com elementos e circunstâncias dos casos, que não influenciariam em direito. De qualquer modo, o árbitro afirma que pode aplicar o direito, quando coincide este com a eqüidade. Esta é um campo maior, que contém também o direito positivo.

No caso n. 11.206, já citado, duas partes norte-americanas discutiram direitos de venda de ações de uma determinada sociedade, em virtude de contrato de joint venture e outros contratos adicionais celebrados entre elas. O tribunal decide a questão com base nos contratos e com referência ao direito de um Estado norte-americano.

No caso n. 1.795 da Associação Italiana para a Arbitragem, ${ }^{1035}$ de 1996, o tribunal afirma expressamente que suas conclusões, com a aplicação da lei, atendem também à eqüidade:

These conclusions, which are reached in law, are not to be modified or mitigated in equity, the application of which the parties wished to moderate possible excesses of the law. The application of the law appears to lead to a satisfying balance of interests, so that the conclusions reached in law do not need to be mitigated in equity, also taking into account the agent's alternative work opportunities.

No caso n. $13.214,{ }^{1036}$ de 2005, uma parte européia e uma parte asiática discutiram contrato de distribuição no país asiático. O tribunal aplicou majoritariamente a lei do país europeu, seguida de uma observação de que entendia a solução encontrada equitativa. Neste caso, o tribunal entendeu que contínuos atrasos configuravam justa causa para rescisão.

\footnotetext{
1033 Inédito.

1034 Jarvin, Sigvard; Derains, Yves. Collection of ICC Arbitral Awards, cit., p. 501.

1035 Yearbook Commercial Arbitration, v. 24a, p. 196 e ss., 1999.

1036 Inédito.
} 
Em dois casos decididos por eqüidade perante o CRCICA, os tribunais aplicaram a lei egípcia (que havia sido escolhida pelas partes), sem sinais de modificação por eqüidade, inclusive relativamente a juros. ${ }^{1037}$

\subsubsection{Aplicação da lex mercatoria e princípios do comércio}

Como já visto na presente obra, a arbitragem por eqüidade foi um dos vetores da criação da chamada lex mercatoria. A dispensa da aplicação das leis nacionais, em um contexto territorialista ainda forte, serviu como abertura para aplicação de critérios não-estatais, como princípios e usos do comércio. Chegou-se mesmo à postulação segundo a qual a autorização para decisão por eqüidade significaria uma indicação implícita do desejo de aplicação da lex mercatoria.

Posteriormente, com o maior reconhecimento do conceito da lex mercatoria como um conjunto de regras dotadas de algum caráter positivo, houve afastamento do conceito de arbitragem por eqüidade. Chega-se, assim, à conclusão de que os árbitros decidindo por eqüidade podem derrogar regras da lex mercatoria, caso assim thes pareça equitativo. Nos casos abaixo, verificam-se as tendências de aproximação e algum afastamento. Note-se que a tarefa dos árbitros em eqüidade é chegar a uma decisão justa e ela pode ser buscada nos princípios gerais e nos usos do comércio internacional. Assim, nada impede que os apliquem diretamente, como expressão de seu sentimento de justiça.

No caso n. 5.616, ${ }^{1038}$ em sentença parcial de 1988, partes européias e de um país do Oriente Médio litigaram sobre um contrato versando sobre obras em refinaria situada no Oriente Médio. $\mathrm{Na}$ ata de missão (terms of reference), as partes escolheram arbitragem por eqüidade; todavia, incluíram tarefa do tribunal a determinação da lei aplicável. O tribunal, embora considerando que não seria estritamente necessário decidir a lei no caso concreto, faz um exercício de método "conflitualista", concluindo que as soluções são insatisfatórias. Assim adota os princípios geralmente aceitos do direito das relações contratuais. A essa escolha segue-se a seguinte passagem: "In the opinion of the Tribunal, this leads to the same result as the application of equitable principles as amiable compositeur under Swiss law".

No caso n. 3.540, já citado,em decisão sobre a lei aplicável ao mérito da questão, o tribunal, autorizado a decidir por eqüidade, resolve aplicar a lex mercatoria, após longa consideração

\footnotetext{
${ }^{1037}$ Casos n. 53/1994 e 66/1995, publicados no livro Arbitral Awards of the Cairo Regional Centre for International Commercial Arbitration, editado por Alam Eldin (Boston: Kluwer Law International, 2000, p. 87 e 181). 1038 Inédito.
} 
sobre os ordenamentos nacionais envolvidos no litígio. Embora não afirme expressamente que haja correlação necessária entre decisão por eqüidade e lex mercatoria, o tribunal expressamente utiliza a eqüidade como indicativo "implícito" da vontade de submeter o litígio aos princípios do comércio internacional, citando proposição no mesmo sentido de Goldman. Nos comentários a essa sentença publicados na mesma obra, há crítica a esse entendimento, que não serviria para dirimir a então recorrente ambigüidade entre decisão por eqüidade e lex mercatoria.

No laudo final, ${ }^{1039}$ o tribunal afirma expressamente que, decidindo em eqüidade, tem o poder de temperar a lei, neste caso a lex mercatoria, bem como o contrato, podendo aplicar princípios de eqüidade se as conseqüências da lei ou do contrato são demasiado rigorosas.

No caso n. 5.587, ${ }^{1040}$ de 1992, as partes debatem um contrato para criação de uma joint venture para participação de concorrência em país do Oriente Médio. O tribunal decide aplicar a lex mercatoria e esclarece que ela não se confunde com eqüidade.

Na sentença parcial do caso n. 3.267, ${ }^{1041}$ de 1979, o tribunal sustenta que, uma vez investido do poder de decidir por eqüidade, não precisa decidir direito aplicável. De qualquer modo, afirma que "the Arbitral Tribunal will apply the widely accepted general principle governing commercial international law with no specific reference to a particular system of law".

No caso n. 9.679, já referido no caso dos contratos de publicação, o tribunal assevera que, como o contrato é internacional, sua validade é regida pelos princípios gerais do direito internacional.

No caso n. 10.504, já mencionado, o árbitro único recorreu aos princípios do Unidroit para qualificar os efeitos de ameaça e pressão sobre os contratos, inclusive quando vinda de terceiros, afirmando também que esse é um princípio conhecido em todos os sistemas de direito.

\subsubsection{Juros}

Os casos já mencionados dos contratos de publicação mostram que juros são uma matéria recorrente em decisões por eqüidade. Naquele caso específico, para modificar ou confirmar uma taxa estabelecida contratualmente. Em outros casos, verifica-se que os árbitros, decidindo

\footnotetext{
1039 Inédito, 1989.

1040 Inédito.

${ }^{1041}$ Collection ICC Arbitral Awards, cit., p. 76.
} 
por eqüidade, utilizam seus poderes para fixar taxas de juros, em caso de não-fixação por contrato, ou para adequar taxas nacionais a patamares diferentes. Em outros casos, ainda, o tribunal fixa equitativamente o dies a quo dos juros. Portanto, atua de pelo menos três modos distintos.

O montante dos juros merece interesse: existe uma variação relevante entre as diferentes taxas consideradas equitativas pelos árbitros. Especialmente quando não existe remissão a taxas geralmente usadas (Libor, prime rate, etc.), há uma variação muito grande de valores e referenciais. Todos são menores dos que os juros praticados pelos bancos do Brasil no ano de 2008.

No caso n. $6.749,{ }^{1042}$ de 1992, uma parte francesa e uma parte turca discutiram um contrato de gerenciamento (management agreement). Neste caso, as partes escolheram arbitragem por eqüidade conjuntamente com o direito turco. Após entender que a parte demandada deveria pagar indenização, o tribunal decide que, como esta foi fixada em francos franceses, deixaria de determinar os juros em 30\% ao ano, como permite o direito turco, e os estabeleceria em 10\% ao ano, que "corresponde melhor ao prejuízo sofrido pela demandante".

No caso n. 7.986, já mencionado, o tribunal aplica a taxa legal da França, por ser a lei com maiores vínculos com o contrato e em virtude de ser o local da assinatura do protocolo e nacionalidade de uma das partes.

No caso n. 8.792, de 1998, ${ }^{1043}$ relativo à entrega de bem com alguns vícios, o tribunal determinou uma redução proporcional do preço, fixando os juros em 5\% ao ano, equitativamente.

No caso CIRDI/ICSID, ${ }^{1044}$ envolvendo Benvenuti \& Bonfant e a República do Congo, a parte demandante pediu a aplicação de uma taxa de $15 \%$ ao ano de juros, que foi considerada claramente superior àquela prevista na lei aplicável, do Congo. Todavia, como a parte demandada havia requerido a aplicação de uma taxa de $10 \%$ ao ano em sua reconvenção, o tribunal fixou a taxa de juros para o pedido principal, por eqüidade, em 10\%:

On account of the provisional agreement reached by and between the parties - not confirmed by the Government - Claimant has claimed interest at the rate of $15 \%$ annually on the total amount that would be awarded it. The Tribunal does not believe that it can accept this petition since the applicable law, that is to say, that of the Congo, provides for a legal rate of interest that is clearly

\footnotetext{
${ }_{1042}$ ICC International Court of Arbitration Bulletin, v. 18, n. 1, p. 63 e ss., 2007.

1043 Inédito.

${ }^{1044}$ Yearbook Commercial Arbitration, v. 8, p. 144, 1983.
} 
lower. But the Tribunal notes that the Government, in its Defense Memorial, has proposed an interest rate of $10 \%$ for its counterclaim. In view of its power to decide ex aequo et bono, the Tribunal deems it equitable to accept this rate for the compensation awarded to Claimant.

No caso n. $7.490,{ }^{1045}$ de 1994, em que uma parte européia e uma parte africana discutiram um contrato para fornecimento de matéria-prima, o tribunal entendeu justa a aplicação de uma taxa de $8 \%$ ao ano, porque ambas as partes haviam-na pedido em suas petições.

No caso n. $10.900,{ }^{1046}$ de 2001, em que duas partes européias discutiram um projeto de construção em um país árabe, o tribunal entendeu que houve culpa recíproca entre as partes, restando ainda um saldo em favor da parte demandante. Como considerou que ela tardou em iniciar a arbitragem, decide que os juros incidiriam apenas após o início da arbitragem.

No caso n. 940.220, ${ }^{1047}$ de 1994, uma empresa africana e uma empresa européia discutiram um contrato de fornecimento de equipamentos. O tribunal determinou um percentual de redução do preço por problemas no equipamento e utilizou a "eqüidade legal" para fixar os juros à taxa Libor. Neste caso, como já afirmado, o tribunal entendeu que não estava investido de poderes para uma decisão por eqüidade "pura", mas sim da "eqüidade legal”, ou seja, aquela permitida pela lei aplicável.

No caso n. 12.070, ${ }^{1048}$ de 2004, houve uma complexa disputa entre duas partes européias no tocante à venda de equipamentos, cessão de contratos e suspensão de fornecimento. O Tribunal decidiu favoravelmente a um pleito subsidiário de indenização, cujo montante foi reduzido equitativamente. Sobre esse montante fixou, também equitativamente, juros de $5 \%$ ao ano.

No caso n. 57/94, ${ }^{1049}$ da Associação Italiana de Arbitragem, o tribunal, após reconhecer culpa recíproca entre as partes, fixou juros sobre a indenização equitativamente de $13 \%$ ao ano.

\subsubsection{Fixação de danos}

Uma das práticas mais recorrentes em arbitragens por eqüidade é a da fixação equitativa de indenizações. Não se trata, porém, de uma exclusividade de arbitragens dessa natureza.

\footnotetext{
1045 Inédito.

1046 Inédito.

1047 Inédito.

1048 ICC International Court of Arbitration Bulletin, v. 18, n. 1, p. 108, 2007.

1049 Yearbook Commercial Arbitration, v. 22, p. 182, 1997.
} 
Diversos direitos nacionais permitem a fixação equitativa de danos em determinadas circunstâncias. Portanto, não é uma característica particular da arbitragem por eqüidade, embora seja um elemento recorrente. Explica-se tal recorrência porque a estimativa de danos constitui um dos principais vetores da proporção entre regras estabelecidas e casos concretos. Na teoria clássica da responsabilidade civil, a reparação deve corresponder ao dano causado. Todavia, nem sempre tal determinação pode ser feita de modo preciso, seja pela natureza dos danos, seja por dificuldades em sua mensuração, seja por proporcionalidade de culpas concorrentes. A fixação equitativa é um instrumento muito útil para superar tal sorte de adversidades.

\section{a) Fixação em geral}

O caso n. 8.544, ${ }^{1050}$ de 1998, envolveu duas empresas européias em uma joint venture para realização de empreendimentos imobiliários. Valendo-se dos princípios da vedação ao enriquecimento sem causa e do "prudente arbítrio", entenderam que houve desinteresse de ambas as partes na joint venture. Entretanto, a parte demandada teria descumprido seus deveres em uma extensão maior e acabou provocando a resilição de fato. Desse modo, acabou enriquecendo sem causa às expensas da autora, que adiantou dinheiro. Embora entendessem ser muito difícil estimar qual seria o lucro advindo da joint venture, estimaram-no por eqüidade, além de determinarem o reembolso de despesas havidas com o projeto.

No caso n. 12.070, já mencionado, importa afirmar, para os efeitos deste item, que o tribunal decidiu conceder um pleito subsidiário de que fossem pagas parcelas não honradas pelo comprador original dos equipamentos (a parte demandada era uma financiadora que havia adquirido os equipamentos do comprador original, para uma espécie de lease back). O tribunal entendeu que é princípio de direito internacional a necessidade de uma parte informar à outra quando deixará de cumprir o contrato. Entretanto, como a demandada aceitou os pagamentos vindos da demandante (financiadora), por uma questão de boa-fé e fair dealing, deveria ter informado sua intenção de descumprimento. Se a financiadora soubesse que o fornecedor não mais entregaria equipamentos, certamente não teria efetuado certos pagamentos. Portanto, há dever de indenizar. Todavia, a financiadora tinha meios próprios de obter a informação. Como não teve a diligência necessária, o tribunal reduziu o valor da indenização, equitativamente, em 1/3.

No caso n. 6.061, ${ }^{1051}$ de 1992, houve um contrato de compra e venda de máquinas. O tribunal decidiu que o maquinário havia sido entregue com vícios. Assim, aplicou multa,

\footnotetext{
1050 Inédito.

1051 Inédito.
} 
determinou a entrega de peças e fixou indenização por taxas de importação e outras verbas. A indenização, assim como os juros, foi fixada por eqüidade.

No caso n. $6.517,{ }^{1052}$ de 1992, duas partes européias discutiram indenização relativa a obras realizadas em país do Oriente Médio. A parte demandante era subempreiteira da parte demandada nas obras realizadas.

Após revolução no país local dos trabalhos, houve interrupção das obras e dos pagamentos. Quando do relançamento das relações entre o país do Oriente Médio e o da parte demandada, esta efetuou acordo pelo qual recebeu cerca de $10 \%$ do valor total dos pedidos. A demandante alega não ter sido informada ou consultada acerca da decisão de fechar acordo. Se soubesse, teria tomado outras providências para se resguardar, como negociar diretamente.

O tribunal julgou que o acordo foi fechado por instâncias políticas e não necessariamente comerciais. Entende que faltou um dever fiduciário de informação e consulta que deveria existir entre as partes. Assim, decide que há responsabilidade.

Ao estimar os danos, o tribunal considera que não se pode dizer que a demandante ganharia tudo o que pede. Por outro lado, considera que a demandante havia demonstrado certo desinteresse ou demora relativamente a esses créditos no passado. Assim, estima equitativamente um valor global, levando em conta também critérios que não seriam reputados em direito estrito. Determinam o pagamento de valor que havia sido calculado por um funcionário da demandada.

A estimativa da indenização é feita em eqüidade; porém, a fundamenta também na possibilidade, em direito italiano, de o juiz estimar indenizações equitativamente, o que ocorre também em direito suíço (sede da arbitragem).

No caso n. 5.996, ${ }^{1053}$ de 1991, uma parte africana e uma parte européia discutiram um contrato de compra e venda de uma fábrica. O árbitro único decidiu que havia obrigação de colocar em funcionamento certos modos especificados da fábrica e determinou o pagamento de indenização. A indenização foi estimada em eqüidade, levando em conta que a fábrica esteve inoperante também por questões financeiras da demandante, não atribuíveis à demandada. Estimou parte dos prejuízos no valor da contratação de nova empresa para assistência técnica.

\footnotetext{
1052 Inédito.
}

1053 Inédito. 
No caso n. 9.125, ${ }^{1054}$ de 1999, duas partes européias e uma parte africana discutiram o fornecimento de uma fábrica no país africano. Neste caso, houve debate sobre uma eventual "entrega de fato" da fábrica, uma vez que as partes demandantes alegavam que os testes de recepção não foram feitos em razão da insegurança, alegando a parte demandada descumprimento. Os árbitros viram na jurisprudência arbitral e de tribunais a existência de entrega de fato, afirmando que não precisavam recorrer à eqüidade para essa decisão. Todavia, o tribunal utilizou a eqüidade para estabelecer um valor para a entrega da fábrica, em razão de certos superfaturamentos encontrados por perito. Utilizou os mesmos poderes para determinar a redução à metade do preço de certos equipamentos cuja entrega não era devidamente comprovada.

No caso CIRDI/ICSID, ${ }^{1055}$ envolvendo Benvenuti \& Bonfant e a República do Congo, a parte demandante pediu diversas indenizações decorrentes de desapropriação de sociedade constituída no Congo e fixação de preço por decretos durante o funcionamento da empresa. As indenizações foram concedidas para fixação em eqüidade. Houve ainda pedido de danos morais, em vista do alegado impacto na imagem comercial da demandante de atos da parte da demandada. O tribunal não aceita tais alegações, mas, em vista de outros atos da parte demandada contra a demandante (ocupação militar e procedimentos criminais), decide fixar equitativamente um valor para compensação de danos morais:

The Tribunal has reasons for doubting the mere assertion by Claimant that it has lost its credit with its suppliers or bankers or that it would not be able to obtain the necessary personnel. However, in view of the measures to which Claimant has been subject and the suit that was the consequence thereof, which have certainly disturbed the activities of Claimant, the Tribunal deems it equitable to award it the amount of CFA 5,000,000 for moral damages.

No caso n. $10.900,{ }^{1056}$ de 2001, duas partes européias discutiram um projeto de construção em um país árabe. O tribunal entendeu que houve culpa recíproca das partes, restando ainda um saldo em favor da parte demandante. O tribunal determina que haja um abatimento de $20 \%$ pela responsabilidade da parte demandante. Determina que essa diferença seja abatida das quantias ainda devidas pelo contrato.

No caso n. 2.216, de 1974, ${ }^{1057}$ uma parte africana e uma parte européia discutiram um contrato de compra e venda de petróleo. Embora o tribunal entenda que a parte demandada não cumprira sua obrigação de adquirir o produto contratado, considera que a mudança posterior

\footnotetext{
1054 Inédito

1055 Yearbook Commercial Arbitration, v. 8, p. 144, 1983.

1056 Inédito.

${ }^{1057}$ Publicado em parte no Collection of ICC Arbitral Awards, cit., p. 224.
} 
nos preços do produto favoreceu a vendedora. Assim, em vez de conceder compensação integral, a reduziu a um percentual do contrato.

No caso n. 940.220, já mencionado, o tribunal entendeu não estar investido de autorização para julgamento por eqüidade puro, mas apenas para aplicar a "eqüidade legal”. Ao aplicar a "eqüidade legal", o tribunal fixou em 15\% do valor total da venda o montante de reparação por desconformidade dos produtos vendidos.

Por outro lado, no caso n. 2.502, ${ }^{1058} \mathrm{o}$ árbitro deixou de fixar danos por eqüidade, porque não havia recebido poderes para julgar por eqüidade e a parte não havia provado os danos alegados.

A sentença de 1975, oriunda da Corte de Arbitragem da Indústria a Construção, ${ }^{1059}$ da Holanda, trata sobre a responsabilidade por vedação de janelas em uma obra. O árbitro decidiu que a escolha dos perfis errôneos das janelas não era de responsabilidade do empreiteiro; todavia, a aplicação de vedação o era. Como o tribunal entendeu ser muito difícil separar com nitidez as responsabilidades, decidiu fixar por eqüidade uma soma geral de indenização.

No caso n. $7.770,{ }^{1060}$ de 1994, duas partes européias discutiram um contrato de distribuição exclusiva de produtos em determinado território. $O$ tribunal reconhece que a demandante (distribuidora) teve diversos problemas na execução do contrato, em decorrência de certos problemas previsíveis, mas insuperáveis do país de onde distribuía o produto. No entanto, sempre agiu de boa-fé. A alta especialização dos produtos distribuídos exigiu-lhe esforços consideráveis, demonstrados por várias ações tomadas para a promoção e o bom atendimento do mercado. Isso é demonstrado pela substituição da demandante por outra distribuidora em determinado mercado sem maiores traumas. O novo distribuidor e a demandada beneficiaram-se da penetração conseguida pela demandante, após um longo trabalho de prospecção e promoção. Assim, foi privada de receber o fruto de seu trabalho. Sua boa-fé foi reconhecida, ademais, pela demandada, que lhe ofereceu um novo campo de atividade e um novo contrato, o que não teria feito se a demandante fosse incompetente e infiel. Dessa forma, determina o pagamento de uma soma fixada equitativamente, para reparação de danos materiais e morais.

Como contraponto ao poder de fixação de danos equitativamente em qualquer circunstância, veja-se a posição tomada no caso n. $9.771,{ }^{1061}$ de 2001. Neste caso, o tribunal decidiu

\footnotetext{
${ }^{1058}$ Citado de passagem nos comentários do caso 2.694 em Collection of ICC Arbitral Awards, cit., p. 325.

1059 Yearbook Commercial Arbitration, v. 1, p. 137, 1976.

${ }^{1060}$ ICC International Court of Arbitration Bulletin, v. 18, n. 1, p. 64 e ss., 2007.

1061 Yearbook Commercial Arbitration, v. 29, p. 46, 2004.
} 
que, sem autorização expressa para julgar por eqüidade, o tribunal não poderia estimar danos equitativamente. ${ }^{1062}$

No caso n. 6.749, já mencionado, uma parte francesa e uma parte turca discutiram um contrato de gerenciamento (management agreement). A demandante pediu indenização por prejuízos ao crédito comercial. O tribunal entendeu que, levando em conta a notoriedade mundial da demandante, as dificuldades encontradas não terão impacto sobre o conjunto de suas atividades. Mesmo que ela venha a ter problemas para se instalar na Turquia, o conjunto do mercado mundial é grande o suficiente para que não haja uma perda nas atividades globais. Além disso, "considerações de eqüidade justificam que [a demandante] suporte ela mesma os eventuais inconvenientes econômicos" do fracasso do projeto.

A demandante ainda fez um pedido para que a parte demandada fosse condenada a garantir todas as somas que a demandante viesse a ser obrigada a pagar a terceiros, por força de descumprimentos da demandada. O tribunal considera prematura a pretensão de uma manifestação sobre eventuais condenações de terceiros. Entretanto, declara que a demandante poderá fazer uso de outros procedimentos de arbitragem, caso tenha novas pretensões cobertas pela cláusula arbitral. Neste caso, há uma rejeição de condenação eventual, tal como ocorre no direito civil estatal.

Na sentença do caso n. 57/94, ${ }^{1063}$ da Associação Italiana de Arbitragem, duas partes européias discutiram um contrato de distribuição. Entre outras matérias, as partes discutiram a não-implementação de um contrato de cessão de licença de manufatura e know-how para os produtos distribuídos. Embora as partes tenham trocado minutas, jamais o celebraram. $\mathrm{O}$ tribunal entende que ambas as partes agiram de modo culposo, causando a não-celebração do contrato. Assim, julgou extinta a obrigação de fazer a cessão, provocada pelo comportamento das duas partes.

b) Danos punitivos

Em pelo menos dois casos, houve enfrentamento da questão dos chamados danos punitivos (punitive damages). Essa espécie de dano, que se afigura como uma espécie de pena

1062 "Finally, the claimant has claimed 'other damages' for the loss of reputation to be determined in these proceedings. The claimant has requested the sole arbitrator to resolve this issue on the basis of ex aequo et bono.

According to the ICC Rules an arbitrator may not base any decision on the principle of ex aequo et bono unless expressly authorized. This is furthermore repeated in the Terms of Reference agreed and signed between the parties in these proceedings. No such agreement has been made. In addition, no other damages or the loss of reputation have been presented or evidenced in these proceedings either to the amount or otherwise. In any arbitration it is a fundamental principle that each party shall have the possibility to present its case and to respond to any claim made against it. Should the sole arbitrator award other damages then the defendant would clearly not have been given such opportunity. The sole arbitrator therefore has no basis on which to determine, or even less award, any damages under this heading. The claim for 'other damages' is therefore denied."

1063 Yearbook Commercial Arbitration, v. 22, p. 182, 1997. 
civil, embora popular no sistema jurídico dos EUA, não é difundida por todos os sistemas, especialmente naqueles de origem romano-germânica.

No caso n. $11.206,{ }^{1064}$ de 2004, duas partes norte-americanas discutiram contratos relativos a investimentos em diversas empresas. O tribunal utilizou seu poder de decidir em eqüidade para aplicar danos punitivos à parte demandada, por não cumprir com todas as determinações do tribunal e valer-se de expedientes dilatórios. Todavia, havia previsão expressa para aplicação de tais danos na cláusula arbitral. Nesse caso, a aplicação dos danos punitivos teve caráter eminentemente processual e mediante autorização expressa na cláusula de arbitragem.

No caso n. 5.616, ${ }^{1065}$ partes européias e de um país do Oriente Médio litigaram sobre um contrato versando a respeito da elaboração de um serviço em refinaria situada no Oriente Médio. O tribunal decidiu que é costume comercial que, antes de haver rescisão por falta de performance, exista um aviso claro, o que não houve no caso concreto.

Na sentença final, o tribunal sustenta que seria iníquo não conceder à parte que teve o contrato abruptamente encerrado alguma compensação, mesmo que ela não fosse ter lucro na obra: pelo menos algumas despesas têm de reembolsar.

Quanto ao pedido de danos punitivos, entendeu que sua aceitação não é geral. Assim, a aplicação de princípios gerais não acarreta necessariamente sua concessão. Como na lei do local da arbitragem (Suíça) esses danos não são permitidos e isso pode impactar a exeqüibilidade do laudo, o tribunal não concede tais danos. Para tanto, faz referência ao regulamento da CCI e ao dever geral de produzir uma sentença exeqüível.

c) Danos prefixados

Como já mencionado no item relativo ao contrato, existem posições divergentes acerca das cláusulas de prefixação de indenização. Remete-se o leitor aos casos lá mencionados.

d) Causalidade

Como parte da adaptação ao caso concreto, a atribuição de causalidade ao dano aparece como uma das formas de expressão da eqüidade na arbitragem internacional. Em dois casos en-

1064 Inédito.

1065 Inédito. 
contrados na pesquisa, houve consideração de fatores externos à relação contratual que atuaram sobre o dano. Portanto, embora tenha havido descumprimento de deveres contratuais, os tribunais consideraram efeitos de outras circunstâncias sobre o resultado efetivo. Conforme o caso, a indenização foi diminuída ou excluída. Verifica-se neste caso um exame de causalidade.

No caso n. 2.216, já mencionado, uma parte africana e uma parte européia discutiram contrato de fornecimento de petróleo. Embora a parte européia não tenha cumprido o contrato na forma devida, houve uma mudança dos preços do petróleo muito favorável à parte africana. O tribunal, em vez de conceder compensação integral, reduziu-a a um percentual do contrato.

No caso n. 7.490, ${ }^{1066}$ uma parte africana e uma parte européia discutiram um contrato de fornecimento de matérias-primas. Neste caso, houve aplicação da Convenção de Viena e eqüidade, de modo subsidiário. Depois de alguns descumprimentos da parte européia, posteriormente sanados, a parte africana deixou de realizar uma entrega de mercadoria, após o saneamento das falhas. O tribunal entendeu que o dano causado pela parte africana ocorreria de qualquer modo, porque o preço do produto final caíra muito à época do descumprimento. Assim, com ou sem entrega, o resultado final seria essencialmente o mesmo. O tribunal afirmou que o inadimplemento deve ser causa única do dano; se outra circunstância resultaria no mesmo resultado, não se reconhece o dever de indenizar. O tribunal ainda reconheceu que ambas as partes descuidaram de seus deveres contratuais em determinados períodos.

\subsubsection{Boa-fé}

Uma das principais vertentes que se encontra na aplicação da eqüidade como critério de julgamento é a proteção à boa-fé contratual. Ela se revela de vários modos: seja pelo dever de informação mais amplo à contraparte dos contratos, seja por abuso de direito, seja por obrigações ínsitas de não-concorrência, seja por reconhecer certos deveres de lealdade, para além das obrigações escritas no contrato ou decorrentes de lei. Reuniu-se essa gama variada de manifestações sob o nome genérico de boa-fé.

No caso n. 5.891, ${ }^{1067}$ de 1988, duas partes do mesmo país europeu discutiram uma sociedade para a realização de operações em país africano. Parte demandada associou-se à demandante que detinha know-how do mercado. Posteriormente, abandonou a sociedade e instalou-se sozinha no país.

\footnotetext{
1066 Inédito.

1067 Inédito.
} 
O árbitro único entendeu que a demandada, empresa muito maior que a demandante, utilizou-se da desta para ingressar no país depois de dispensá-la, quando havia adquirido a experiência necessária, chegando mesmo a contratar pessoal desta. O árbitro afirma que a demandada sempre possuiu segundas intenções e que a demandante foi ingênua.

O árbitro determinou o pagamento de indenização por perdas e todos os prejuízos morais à imagem da demandante. Sua principal argumentação é baseada na boa-fé. Reitera que seria iníquo que a demandante não receba indenização por certas situações, especialmente pelas dificuldades que ela enfrentou depois da associação, da qual teria saído em situação prejudicial. Mesmo que o contrato não possua cláusula de não-concorrência, deveria ter havido maior boafé por parte da demandada. Assim, determinou o pagamento de várias verbas indenizatórias, inclusive por dispensa de pessoal e perda de mercado.

No caso 11.934, já mencionado, o tribunal desconsiderou uma cláusula de não-indenização existente em um contrato porque a distribuidora havia feito concorrência desleal com a vendedora, fazendo-lhe perder mercado local. Assim, estimaram uma indenização pela perda de mercado. Trata-se aqui, sem dúvida, do reconhecimento de um dever geral de boa-fé, mesmo após o término da relação contratual, que se sobrepõe mesmo à letra do contrato mantido entre as partes.

No caso n. 6.517, já referido, o tribunal decidiu que a falta de informação à subempreiteira, da intenção de celebrar acordo com o proprietário da obra por um valor substancialmente inferior aos pleitos já efetuados, tolheu a liberdade de ação desta de tentar recuperar os créditos que entendia devidos. O tribunal julgou que o acordo foi fechado por instâncias políticas e não necessariamente comerciais. Entende que faltou um dever fiduciário de informação e consulta que deveria haver entre as partes.

No caso n. 10.049, ${ }^{1068}$ duas partes européias discutiram sobre um contrato de joint venture para obras em país do Oriente Médio. A joint venture estendia-se às duas fases iniciais de um projeto. A demandada, após o cumprimento das primeiras fases em conjunto, obteve apenas para si as duas fases subseqüentes, em cooperação com um ex-funcionário da demandante, especialista na área. O tribunal decidiu que as partes (em especial a demandada) tinham o dever de informar seu interesse e a possibilidade de continuação para as fases seguintes dos contratos. Por não informar a intenção de continuar no projeto e as oportunidades existentes, a demandada deve compensar a demandante pelo que esta teria ganho se participasse das fases seguintes. $\mathrm{O}$ tribunal entendeu que a joint venture original estava muito bem posicionada para obter os con-

${ }^{1068}$ ICC International Court of Arbitration Bulletin, v. 18, n. 1, p. 89 e ss., 2007. 
tratos das fases subseqüentes. Considerou, além disso, que na instrução ficou demonstrado que a demandada escondeu informações da demandante, mesmo tendo sido especificamente perguntada. O tribunal decidiu que havia um dever de dar a conhecer as intenções e de não pleitear outras obras no mesmo projeto, sem informar a outra parte. Considerou a falta de informação como uma quebra dos deveres dos contratuais.

Em caso ad hoc de 1971, ${ }^{1069}$ um tribunal arbitral anulou um contrato pelo qual a totalidade do capital social de uma empresa foi adquirido por preço superior a cinco vezes seu valor contábil. O preço havia sido baseado na intenção de administrar um cassino existente nas instalações da empresa que, depois de alguns meses, teve de ser fechado. Segundo os árbitros, os riscos de tal fato foram suficientemente esclarecidos pelos vendedores e o preço excessivo, em desproporção com o valor das ações, justificou a anulação do contrato. Ao ser confrontado com disposição legal de que o negócio não pode ser rescindido por desproporção de preço, o tribunal decidiu que, por estar autorizado a decidir por eqüidade, pode descartar a lei. As conseqüências da rescisão também foram determinadas equitativamente.

No caso n. 8.201, de 1997, uma parte européia e duas partes africanas discutiram contrato de empréstimo para compra de equipamentos. As partes demandadas alegaram vícios nos equipamentos. O tribunal faz remissão a princípios gerais do direito, tal como boa-fé e proibição de contradição. Segundo o tribunal, o comprador não pode alegar vício de equipamentos que vem utilizando há muito, se não reclamou quando recebeu. Se os está usando, tem o dever de pagar. Invoca como regras do comércio internacional a exceptio non adimpleti contractus e a proibição de contradição em desfavor de terceiro, que aplica a título de eqüidade.

No já mencionado caso n. 12.070, de 2004, duas partes européias discutiram os efeitos de contrato de fornecimento de equipamentos industriais, posteriormente transferidos à parte demandante, que os financiou. A demandante e a compradora original escreveram à demandada "confirmando" a transferência da ordem e que o demandante passaria a arrendar o bem à compradora original. Embora a demandada não tenha apresentado aceitação formal, passou a enviar as faturas para a demandada.

O tribunal afirma que a aceitação tácita de uma transferência de contrato é princípio do direito internacional. Todavia, não aceitou a existência de transferência no caso concreto. Também rejeitou o pedido subsidiário de indenização pelo valor total do equipamento. Entretanto, aceitou o segundo pleito subsidiário, de que fossem devolvidas duas parcelas pagas pela demandante à demandada, título de pagamento do equipamento, porque a demandada reteve a

1069 Yearbook Commercial Arbitration, v. 1, p. 135, 1976. 
entrega de um terceiro equipamento por conta de débitos do primeiro e do segundo, e as parcelas pagas pela demandante seriam devidas apenas após a entrega do equipamento.

O tribunal entende que a necessidade de uma parte informar à contraparte quando irá parar de cumprir o contrato é princípio de direito internacional e reconhecido pela Convenção de Viena sobre compra e venda de internacional. De forma geral, deveria ser exercido com a compradora inicial. Entretanto, como a demandada aceitou os pagamentos vindos da demandante, por uma questão de boa-fé e fair dealing, deveria ter informado a ela também, pois, se esta soubesse, não pagaria. Portanto, deve indenizar.

No caso n. $7.770,{ }^{1070}$ de 1994, duas partes européias discutiram um contrato de distribuição exclusiva de produtos em determinado território. O tribunal reconhece que a demandante (distribuidora) teve diversos problemas na execução do contrato, mas que no entanto sempre agiu de boa-fé. Sua boa-fé teria sido reconhecida pela própria demandada, que lhe ofereceu um novo campo de atividade e um novo contrato. Portanto, o tribunal determinou o pagamento de uma soma fixada equitativamente, para reparação de danos materiais e morais, pelo fim da distribuição.

No caso n. 3.267, já referido, o tribunal afirma que a decisão por eqüidade tem bastante serventia em casos de abuso de direito, especialmente quando envolver direitos nacionais nos quais o conceito de abuso não é suficientemente desenvolvido. No caso concreto, por entender que não houve abuso, aplicou o contrato.

\subsubsection{Temas processuais}

Como já visto nesta obra, a escolha de eqüidade tem alguns efeitos no tocante ao procedimento. Na pesquisa realizada, algumas questões procedimentais foram decididas com recurso a eqüidade, embora em menor freqüência que questões relativas ao mérito.

a) Prazos processuais

O caso n. 3.327, de 1981, ${ }^{1071}$ envolveu uma empresa francesa e um Estado africano. O tribunal desconsiderou o fato de que um dos memoriais do Estado africano chegou fora do prazo, em razão de alegada instabilidade política, aceitando-o. O tribunal afirma que, embo-

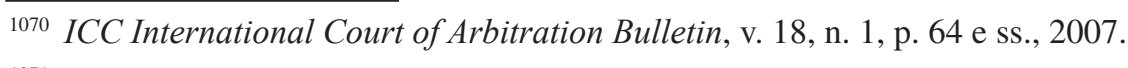

1071 Collection of ICC Arbitral Awards, cit., p. 433. 
ra o pedido de desconsideração do memorial tenha respaldo no direito positivo, "não parece oportuno" aplicar os mesmos princípios em eqüidade, sobretudo porque a parte que invoca a extemporaneidade não demonstra ter sofrido nenhum prejuízo. Como no direito processual de Genebra, aplicável ao caso por escolha na ata de missão, vigora a regra de pas de nullité sans grief, os árbitros autorizados a decidir por eqüidade aplicam-na também ao caso por analogia.

Este caso afirma a possibilidade de derrogação do regulamento de arbitragem pelos árbitros decidindo em eqüidade. Em interessante comentário a este caso, publicado na mesma obra, Yves Derains sustenta que essa liberdade em relação ao regulamento depende da liberdade que se reconheça aos árbitros de eqüidade em relação ao contrato.

Em contraposição, o caso n. 9.671, já mencionado relativamente aos contratos de publicação, o tribunal não conheceu de defesas de jurisdição porque vieram fora do prazo.

b) Ônus da prova

No caso n. 7.913, já citado, o tribunal "tempera" a regra de distribuição do ônus da prova, para permitir "medida de instrução" pedida pela demandante:

Le Tribunal observe qu'en vertu de ses pouvoirs d'amiable compositeur, il a 'tempéré les rigueurs de la règle suivant laquelle 'actor incumbit probatio' en faisant droit à la mesure d'instruction sollicitée par [demandante], alors que [demandante] reconnaissait elle-même ne pas rapporter la preuve qui lui incombait. Le Tribunal a, en effet, couvert, par la mesure d'instruction, une période excédant très largement le terme de la convention, voulant, par là, s'assurer que [demandante] ne se voyait pas privée d'une juste rémunération sur des transactions qui auraient été, par hypothèse, conclues après l'expiration du terme mais dont la conclusion aurait été le résultat d'efforts déployés durant la période contractuelle.

No caso n. 2.605, ${ }^{1072}$ os árbitros decidiram como suficientes para a comprovação de danos determinados documentos em que intervinham apenas uma das partes e um cliente desta, sem intervenção da outra parte na arbitragem. Para tanto, invocaram sua condição de amiables compositeurs. Neste caso, mais do que o ônus da prova, o tribunal utilizou seus poderes de decidir em eqüidade sobre uma regra de apreciação da prova.

Em posição contrária, no caso n. 3.344, já mencionado, o tribunal apreciou pedido reconvencional de perdas e danos. Ao fazê-lo, não vislumbrou prova e considera que o princípio do actor incumbit probatio é de ordem pública e não pode ser afastado em eqüidade.

${ }^{1072}$ Citado superficialmente nos comentários do caso 2.694 em Collection of ICC Arbitral Awards, cit., p. 325. 
c) Extensão da cláusula arbitral

Uma questão ainda polêmica na arbitragem internacional em geral é a forma de extensão da cláusula de arbitragem a partes não-signatárias, seja por meio de cessão de contrato, seja por integração de partes pertencentes ao mesmo grupo econômico. Na pesquisa realizada, foram encontradas quatro decisões por eqüidade que decidiram questões relativas à cessão ou à extensão da cláusula de arbitragem a outras partes.

No caso n. 3.742, de 1983, ${ }^{1073}$ discutiu-se um contrato entre parte européia e entidade estatal de um país socialista do Oriente Médio, para construção de indústria de vidro. A parte do país receptor foi substituída por uma terceira parte, que por sua vez foi dividida e teve seus bens transferidos a duas outras entidades. Embora o país árabe fosse de economia planificada e todas as partes fossem estatais e criadas por atos do governo, o fato de as partes resultantes das cessões não serem partes da arbitragem impede o tribunal de qualquer decisão concernente a elas: "Le Tribunal considère qu'il est incompétent pour statuer à l'égard de ces deux sociétés, au motif qu'elles ne sont pas visées dans l'Acte de mission. Celui-ci limite la compétence du Tribunal". Como as cessões foram válidas, aquelas partes deveriam ser demandadas de forma independente.

No caso n. 5.103, de 1988, ${ }^{1074}$ três partes européias de um mesmo grupo litigaram com quatro sociedades tunisinas sobre um contrato de fornecimento de fosfatados. Tendo julgado pleitos das demandantes e das demandadas (em reconvenção) parcialmente procedentes e estabelecido a respectiva compensação, o tribunal ainda determinou solidariedade entre empresas que pertenciam ao mesmo grupo. Embora justifique o reconhecimento da realidade econômica de empresas sobre o mesmo comando como uma tendência da arbitragem internacional, afirmou também que tal entendimento atende a eqüidade e não viola a ordem pública. A despeito de tal reconhecimento, o tribunal o faz relativamente ao mérito da demanda e não exatamente à cláusula arbitral.

No caso n. 12.070, já mencionado, o tribunal enfrentou igualmente a questão da extensão da cláusula arbitral a partes não-signatárias. Neste caso, a parte demandada, embora não se considerasse parte da cláusula arbitral, decide aceitá-la por conveniência. Quanto à decisão por eqüidade, a mesma parte afirma que somente deve ser aplicada ao mérito e não à extensão da cláusula arbitral. Entretanto, o tribunal decidiu a questão por eqüidade, por entender que seus poderes chegavam a tanto:

1073 Collection of ICC Arbitral Awards, cit., p. 486.

1074 Jarvin, Sigvard; Derains, Yves; Arnaldez, Jean-Jacques. Collection of ICC Arbitral Awards, cit., p. 361. 
47. - The Tribunal notes, however, that Respondent's initial declaration to accept to submit the dispute to arbitration, as expressed in its letter of 7 May 2002, did not contain such a restriction, which therefore cannot be added unilaterally at a later stage. In reply to the question raised under the first item of the Terms of Reference, the Tribunal finds, therefore, that its power to decide ex aequo et bono does extend to the question whether the 1997 Order was validly transferred from [...] to Claimant. The issue raised by Respondent is, anyhow, not as controversial as it appears to be when referring to the Parties' pleadings. As this will be developed below, the Parties agree upon the basic legal requirements in relation to such transfer (i.e. that some form of approval by Respondent either expresses or implied or through conduct is necessary), whereas they disagree when it comes to establish the pertinent factual elements that may, or may not, meet the legal conditions underlying such a transfer.

No caso n. 5.891, já referido, parte considerável do trabalho contratado foi feito por uma subsidiária da demandante situada no continente americano. No tocante a esses pleitos, o árbitro afirmou expressamente que a autorização para julgar por eqüidade não chegava a ponto de modificar a convenção de arbitragem, que deveria ser interpretada restritivamente, sob pena de haver julgamento extra petita. Asseverou que o árbitro não tem poder para modificar as partes da arbitragem, mesmo se ele tiver poderes para julgar por eqüidade, sustentando que "l'amiable composition est sans influence sur l'objet du litige". Por mais que a filial situada na América fosse integralmente detida pela demandante e tenha participado dos negócios até mais que a matriz em certos momentos, não pode ser confundida porque tem personalidade jurídica distinta. Segundo o árbitro, a eqüidade não afasta questões de ordem pública, e o comparecimento de terceiros na arbitragem é uma delas. Apenas fez uma exceção relativamente a uma fatura da filial, uma vez que havia correspondência entre as partes na qual se afirmava que deveria ser emitida pela matriz européia.

d) Correlação entre pedido e provimento

No caso n. 3.540, em seu laudo final, ${ }^{1075}$ o tribunal afirma, obiter dicta, que tem o poder de temperar a lei e o contrato. Sustenta também que deve respeitar pelo menos os princípios fundamentais do direito processual, como o princípio da correlação entre pedido e julgamento (vedação de julgamento extra petita) e o respeito ao contraditório.

No caso n. 3.267, já citado, uma das partes invocou certos pedidos que o tribunal entendeu não estarem implícita ou explicitamente contidos na ata de missão. O tribunal afirmou que os poderes de eqüidade não chegam a ponto de alterar os pedidos.

1075 Inédito, 1989. 


\subsubsection{Corrupção}

Em um caso encontrado na pesquisa, o tribunal arbitral autorizado a julgar por eqüidade enfrentou a questão da corrupção. Embora seja apenas um caso e o tribunal não tenha utilizado os poderes de eqüidade de forma explícita no tocante ao fundo, transcreve-se a sentença por seu interesse intrínseco.

Trata-se do caso n. 8.891, de 1998, ${ }^{1076}$ em que duas empresas européias discutiram sobre um contrato de consultoria, que a demandante ajudaria a demandada a conseguir um contrato com o governo de um país do Oriente Médio.

O tribunal, após entender que não deveria escolher qualquer lei aplicável, chega ao ponto da corrupção. Menciona que os autores divergem sobre ser a corrupção algo necessariamente contra a ordem pública internacional, mas, a título de "superabundância", afirma ser ilícito nos países de ambas as partes. Entende que devem verificar o ônus da prova: embora incumba a quem alegue, reconhece ser muito difícil no caso de corrupção, porque o ilícito vem disfarçado em disposições contratuais anódinas. Assim, tem de se basear em indícios.

No caso concreto, entende que houve corrupção a partir de vários indícios concorrentes e declara o contrato nulo. O tribunal assevera que a corrupção é universalmente rejeitada e não pode de nenhuma forma ser confirmada por um tribunal, ainda que privado. $\mathrm{O}$ fato de a corrupção ser o meio mais fácil ou mesmo a única forma de obter algo em alguns países, não justifica seu uso.

O tribunal sustenta que o fato desagradável é que o beneficiário da corrupção acaba por se beneficiar duplamente: pelo obtido e sem necessidade de pagar pelos "serviços". Trata-se de uma situação desconfortável, mas representa o mal menor, porque a alternativa seria contestar o contrato.

\subsubsection{Determinação de lei aplicável}

Uma das questões enfrentadas pelas sentenças arbitrais em eqüidade é a necessidade de determinar uma lei aplicável ao fundo. Em princípio, a utilização da eqüidade basta para que haja um critério de julgamento suficiente para dirimir a questão de mérito. Todavia, encontram-

1076 Inédito. 
se diversos casos em que as partes escolhem a eqüidade como critério de julgamento simultaneamente a uma lei nacional. Em outros casos, mesmo sem tal escolha, o tribunal decide por uma lei aplicável fundo, em conjunto com a eqüidade. Em parte deles, o faz por determinação das partes, que colocam tal questão como ponto a ser dirimido pelo tribunal. Nas demais situações, o tribunal assim procede por entender mais adequado à solução da disputa, o que inegavelmente está entre os seus poderes: a liberdade conferida pela eqüidade permite a aplicação da lei, que pode ser escolhida pelo tribunal. ${ }^{1077}$

Nada obstante, existe uma corrente consolidada na arbitragem internacional afirmando a desnecessidade de referência a qualquer lei quando o tribunal está autorizado a decidir por eqüidade.

No caso n. 8.544, já mencionado, os árbitros decidiram uma lei aplicável, por determinação da ata de missão. Todavia, não a consideraram determinante porque decidiram por eqüidade.

No caso n. 5.616, citado anteriormente, as partes igualmente fizeram constar da ata de missão (terms of reference) a determinação da lei aplicável. O tribunal, embora considerando que não seria estritamente necessário decidir a lei no caso concreto, faz um exercício de método "conflitualista", concluindo que as soluções são insatisfatórias. Decide fixar em princípios geralmente aceitos do direito das relações contratuais.

No caso n. 9.653, antes mencionado, o árbitro entendeu que, autorizado a julgar por eqüidade, está dispensado de se referir a uma lei nacional ou transnacional. Neste caso, o árbitro estimou que o contrato bastaria para resolver a questão.

No caso n. 10.900, já mencionado, o árbitro sustenta que a ausência de escolha de lei combinada com autorização para julgar por eqüidade dispensavam-no de decidir por qualquer lei.

No caso n. 5.103, já referido, o tribunal afirma seus poderes de decidir por eqüidade e que não necessita escolher uma lei. No entanto, explicita que decidirá primordialmente de acordo com o contrato e terá em conta os usos do comércio internacional.

\footnotetext{
1077 Veja-se, como exemplo, o caso n. 3.742, já mencionado. O tribunal entendeu que a autorização a julgar por eqüidade o libera para a escolha do direito aplicável sem recurso a método de conflito de leis. Compreendeu ainda que, no caso concreto, utilizaria o direito civil do país mais próximo da relação das partes, "na medida da eqüidade".
} 
No caso n. 8.891, já mencionado, o tribunal sustenta que, embora haja diferenças de concepção sobre a decisão por eqüidade, entende que está livre de aplicar qualquer regra de direito e, sob certas reservas, mesmo as do contrato. Afirma ainda que deve "rechercher la solution la plus juste", respeitando a ordem pública.

No caso n. 57, da Associação Italiana para Arbitragem, o tribunal assevera que decidirá independentemente de disposições específicas de lei, de acordo com a interpretação atual das relações do comércio internacional, levando em consideração o contrato e os usos comerciais.

No caso n. 7.986, citado anteriormente, o tribunal afirmou que, autorizado a decidir por eqüidade, está dispensado de aplicar uma lei nacional ou mesmo regras transnacionais. Sustenta ainda que o tribunal pode descartar disposições contratuais injustas, preservando a economia do contrato, seu espírito e a intenção das partes quando o celebraram. Entretanto, deve respeitar princípios de ordem pública, como o pacta sunt servanda.

No caso n. 3.267, já mencionado, o tribunal afirma que, por estar a autorizado a decidir por eqüidade, não precisa decidir direito aplicável. Declara que aplicará os princípios gerais amplamente aceitos no direito do comércio internacional.

No caso n. 12.070, já citado, o tribunal expressamente afirma:

43. The tribunal accepts that the authorization to decide ex aequo et bono does not place the Tribunal in a legal vacuum, completely unrelated to the legal regime or particular national law to which each party to the 1996 and 1997 Orders must have referred when determining its conduct in concluding and performing its rights and obligations. In this respect, arbitrators, when deciding ex aequo et bono, may refer to the applicable substantive law, but they are not bound to apply it (see, inter alia, Fouchard/Gaillard/Goldman, Traité de l'arbitrage commercial international, No. 1506, 1653). Thus, equity and fairness may require that the Tribunal takes the pertinent provisions and solutions (ratio scripta) offered by such applicable law into consideration.

[...]

45. When taking a particular national law into consideration (as explained under paragraph 43 above), an Arbitral Tribunal invested with power to decide ex aequo et bono is not bound to apply each particular rule of such law (except for public policy reasons that are not relevant in this dispute). The Tribunal's decision has to be based on equity considerations which may lead to solutions different from those resulting from applicable law. Such an approach is important and useful when a transaction involves parties from different countries and legal cultures. In such a case, equity and fairness may require not to confront one party with legal solutions which are familiar to the other party only. 
Essa última frase parece indicar uma dimensão multicultural da eqüidade: não pode impor o equitativo de um a outro.

\subsection{Conclusões}

A pretexto de conclusão do presente capítulo, pode-se que afirmar que:

(i) embora não se possa falar da força vinculante de precedentes na arbitragem internacional, estes possuem inegável importância como orientação prática para julgamentos posteriores;

(ii) as estatísticas disponíveis demonstram que a arbitragem por eqüidade mantém-se em um patamar próximo de 1\% no universo total de arbitragens, tendo obtido como percentual máximo de participação de 4\%;

(iii) mesmo em casos recorrentes e semelhantes, como no exemplo dos contratos de publicidade, existem divergências concretas de opinião sobre qual a solução mais justa para o caso;

(iv) parte considerável dos julgados por eqüidade aplica o contrato e a lei, sem derrogá-los; todavia, os tribunais em geral reconhecem seus poderes para moderá-los;

(v) a maioria das sentenças não reconhece diferença entre arbitragem por eqüidade e amiable composition;

(vi) pode-se utilizar a arbitragem por eqüidade como permissão para referência aos princípios gerais do direito do comércio internacional;

(vii) a autorização para julgar por eqüidade é utilizada para fixação de juros, estimativa de danos e sua proporcionalidade às especificidades do caso;

(viii) a arbitragem por eqüidade é um instrumento particularmente adequado para a aplicação da doutrina da boa-fé em suas diversas manifestações, tais como dever de informação, vedação a abuso de direito e deveres de lealdade em geral; 
(ix) a autorização para julgamento por eqüidade pode ter efeitos processuais importantes;

(x) não há necessidade de fixação de lei aplicável quando houver autorização para decisão por eqüidade, embora os árbitros possam fazê-lo se assim entenderem conveniente ou quando as partes determinarem. 


\section{CAPÍTULO 8}

\section{PESQUISA DE CAMPO}

\subsection{Da necessidade de pesquisa empírica na arbitragem}

Existe uma tradição de pesquisa empírica no campo da arbitragem. Todavia, a despeito de sua longevidade, ainda parece gozar de pouca preferência dos estudiosos.

Como notado, ${ }^{1078}$ parte de dados sobre arbitragem advém de historietas contadas por eminentes operadores, que as dividem com a audiência de congressos ou em artigos. No entanto, embora tenham inegável valor, nem sempre representam com precisão o "estado da arte" da prática da arbitragem internacional. Ou ao menos não podem ser tomados como um retrato fiel sem demonstração empírica.

Estudos empíricos sobre arbitragem existem desde pelo menos a década de 1940. ${ }^{1079}$ Uma das mais conhecidas referências é o artigo de Soia Mentschikoff, publicado em 1961, sobre arbitragens realizadas na American Arbitration Association. ${ }^{1080}$ Posteriormente, encontram-se outras iniciativas. ${ }^{1081}$ Algumas instituições de arbitragem passaram a publicar dados estatísticos, o que facilita essa linha de pesquisa. No começo da presente década, houve a criação do Global Center for Dispute Resolution Research, sob os auspícios da American Arbitration Association, que teve entre seus objetivos a pesquisa empírica na arbitragem internacional. ${ }^{1082}$

A pesquisa empírica parece particularmente útil em campos do direito que fujam da estrita aplicação do direito positivo nacional, tais como a chamada lex mercatoria, ordenamentos

${ }^{1078}$ Coe JR., Jack J. From Anecdote to Data: Reflections on the Global Center's Barcelona Meeting (nota n. 1). Journal of International Arbitration, v. 20, n. 1, p. 11 e ss., fev. 2003.

1079 Idem, ibidem, p. 11.

1080 Mentschikoff, Soia. Commercial Arbitration. Columbia Law Review, n. 61, p. 846 e ss.

1081 Vejam-se as referências às pesquisas já realizadas feitas por CoE JR., Jack J. From Anecdote to Data... cit., p. 11 e ss.; e DraHOZAL, Cristopher R. Of Rabbits and Rhinoceri: a Survey of Empirical Research in International Commercial Arbitration. Journal of International Arbitration, v. 20, n. 1, p. 22 e ss., fev. 2003. O livro Dealing in virtue: international commercial arbitration and the construction of a transnational legal order, de Dezalay e Garth (Chicago: The University of Chicago Press, 1996) é outro admirável exemplo de pesquisa empírica na arbitragem internacional. O recente artigo de Laurence Kiffer (Amiable Composition and ICC Arbitration, ICC International Court of Arbitration Bulletin, v. 18, n. 1, p. 51 e ss., 2007) é um exemplo de pesquisa de precedentes, no campo da arbitragem por eqüidade.

1082 Segundo informações obtidas junto à American Arbitration Association, o referido centro não é mais operacional. 
não-estatais e outras expressões do pluralismo jurídico. ${ }^{1083} \mathrm{~A}$ arbitragem por eqüidade integra esses domínios.

De outra parte, existe uma percepção mais ou menos difundida de que a arbitragem por eqüidade é causa de excessiva incerteza. ${ }^{1084}$ Ela parte do pressuposto de que a referência a conceitos vagos como justiça e eqüidade retiram a previsibilidade dos resultados.

Para ajudar a desvendar a utilização prática da arbitragem por eqüidade e seus limites, o autor decidiu, de comum acordo com o orientador, pela realização de uma pesquisa de campo com membros da comunidade da arbitragem comercial internacional.

Tal pesquisa foi executada por meio de um questionário enviado a cerca de 300 profissionais ligados à arbitragem comercial internacional distribuídos pelo mundo. Tanto quanto pode apurar o autor, nenhuma outra iniciativa similar foi tentada anteriormente. ${ }^{1085}$

\subsection{Dos objetivos da pesquisa}

A pesquisa teve três objetivos: (i) aferir a utilização da arbitragem por eqüidade em três esferas; (ii) verificar limites e modos de atuação; e (iii) esboçar um conteúdo material do que seja eqüitativo no mundo da arbitragem internacional.

(i) Utilização da arbitragem por eqüidade

Neste aspecto, buscou-se a experiência pessoal de cada um dos participantes da pesquisa. Pesquisou-se a freqüência com que a eqüidade tem sido utilizada dentro do universo da arbitragem. A pesquisa levou em consideração as três principais formas de atuação de operado-

$\overline{1083}$ Utilizamos a expressão pluralismo jurídico de modo amplo, abarcando quaisquer fontes normativas fora do monopólio estatal de edição de normas. De modo geral, frutos da criação de focos alternativos de regulações jurídicas, que se colocam em posição de concorrência com o direito positivo ditado pelo estado. Segundo Faria, esse pluralismo se dá na "perspectiva da sobreposição, articulação, intersecção e interpenetração de vários espaços jurídicos misturados" (O direito na economia globalizada, cit., p. 155). A bibliografia sobre a matéria é extensa e seu estudo aprofundado foge ao escopo desta obra.

${ }^{1084}$ Embora em boa medida essa crítica seja igualmente dirigida à arbitragem internacional em si. Como já foi notado com certo humor, a decisão na arbitragem possivelmente depende mais do árbitro escolhido do que da lei positiva aplicável.

1085 A Força Tarefa sobre arbitragem por eqüidade da CCI, da qual o autor foi membro, enviou dois questionários a seus integrantes. Embora haja uma pequena coincidência com questões da parte "C" da pesquisa do autor, os objetos são em geral distintos. Além disso, os questionários da Força Tarefa destinaram-se apenas a seus membros. 
res do direito: (a) na elaboração das cláusulas de arbitragem; (b) na atuação como árbitro; e (c) na representação de partes na arbitragem.

Embora o alvo principal da pesquisa seja os árbitros, há sobreposição dessa função e o exercício da advocacia. Assim, decidiu-se pela inclusão dos demais aspectos. O principal dado buscado é a proporção da eqüidade dentro do total de arbitragens.

(ii) Limites e modos de atuação da arbitragem por eqüidade

Neste aspecto, buscaram-se opiniões sobre os temas mais controvertidos da arbitragem por eqüidade: seu alcance no tocante aos contratos, sua relação com a ordem pública e a "mecânica" da decisão por eqüidade. Além disso, buscou-se a opinião pessoal dos participantes acerca da conveniência da arbitragem por eqüidade em geral e relativamente a quais espécies de contratos.

(iii) Esboço de conteúdo material.

A idéia de realização de uma pesquisa de campo para estudo da arbitragem por eqüidade surgiu do interesse de investigar a existência de algumas tendências na comunidade da arbitragem internacional acerca do "justo". Em outras palavras, o que seria equitativo para uma comunidade espalhada por diversas tradições jurídicas.

Esse aspecto foi o inspirador da pesquisa e ao mesmo tempo uma tarefa de Sísifo: em vista das infinitas variações de fato e limitações de método, não se poderia buscar mais do que um recorte de um momento determinado.

A operacionalização desta parte mostrou-se a etapa mais complexa do trabalho. Entre as possibilidades, divisam-se dois extremos: uma pesquisa de conteúdo abstrato, em que seriam procurados elementos gerais do conceito de justiça de cada um dos participantes, ou uma pesquisa de viés casuístico, em que seriam fornecidos exemplos de situações fáticas. No primeiro caso, as perguntas tenderiam a formulações abertas como "quais os elementos de justiça que V.Sa. considera mais importante para solução de determinada questão?" ou "a proporcionalidade entre conduta e sanção deve sobrepor-se ao pactuado pelas partes?”. No segundo caso, as perguntas tenderiam a buscar hipóteses mais detalhadas, com formulações como "em caso de variação entre $10 \%$ e $15 \%$ no valor de insumos, deve haver correção nos valores contratuais?" ou "qual seria o prazo razoável de aviso prévio para a rescisão de um contrato de distribuição em curso há mais de cinco anos?”. 
$\mathrm{O}$ autor entende que ambos os extremos trariam respostas insatisfatórias. No primeiro, demasiado amplas para depreender algum sentido prático: respeito à boa-fé ou pacta sunt servanda traria poucos elementos de utilização prática e de previsibilidade. No segundo, muitos detalhes fáticos causariam dispersão das respostas e dificultariam a percepção de tendências. É virtualmente impossível apresentar todas as possíveis variações de fato. Mesmo que fosse possível, seriam tantas que tornariam os dados mais ou menos aleatórios.

Tendo sopesado as opções extremas, o autor decidiu por uma solução intermediária, com prevalência do elemento prático. De uma análise das sentenças arbitrais por eqüidade então disponíveis (anteriormente à pesquisa efetuada na CCI), foram verificadas 14 situações mais ou menos recorrentes em que houve derrogação de disposições legais ou contratuais em benefício de uma solução equitativa. A partir de tais situações, foram elaboradas hipóteses correspondentes. Os participantes foram convidados a responder em quais casos derrogariam a lei em favor de considerações de justiça. Além delas, os participantes poderiam indicar outras situações em que soluções de eqüidade deveriam prevalecer sobre a lei. Com isso, o autor entende ter chegado a um ponto intermediário entre as posições extremas, mantendo o contato com o substrato da prática.

\subsection{Do desenho do questionário}

No desenvolvimento do questionário, tentou-se encontrar o equilíbrio entre a completude de dados e a probabilidade de participação. Assumiu-se que, quanto maior e mais complexo fosse o questionário, menor seria a probabilidade de respostas.

Na busca de tal equilíbrio, o autor preferiu a utilização de respostas binárias combinadas com oportunidades para participação livre e sugestões dos participantes.

Com intuito de obter o maior número de participantes, optou-se pelo envio de questionários por correio eletrônico. Consideramos este método o atual sucessor do correio comum, que foi sido utilizado com sucesso em outras experiências de pesquisa de campo no direito internacional. ${ }^{1086}$ Outras alternativas de pesquisas, notadamente o telefone e as entrevistas pes-

\footnotetext{
1086 Vejam-se, como exemplo do uso de correio, as pesquisas realizadas pelo Central - Center for Transnational Law, da Universidade de Colônia, publicada em BERGER, Klaus Peter et. al. The Central Enquiry on the use of Transnational Law. In: - (Ed.). International Contract Law and Arbitration - Background, Procedure and Selected Results. The Practice of Transnational Law. The Hague: London Kluwer Law International, 2001. p. 91 e ss., bem como a pesquisa elaborada por Maurício de Almeida Prado Curvelo publicada em seu Le Hardship dans le Droit du Commerce International (Paris: FEC, 2003. p. 118 e ss).
} 
soais, apresentam desvantagens. A principal delas parece ser a necessária diminuição da base pesquisada, tendo em vista o tempo e o orçamento disponíveis.

Além das versões em arquivos de texto, o autor decidiu elaborar um sítio de internet para que os participantes pudessem responder diretamente ao questionário. O sítio encontrase em <www.arbitrationsurvey.com.br $>$. A escolha de tal meio eletrônico visou proporcionar maior facilidade para os participantes. Dos 92 participantes, 33 preferiram utilizar o questionário na internet.

Decidida a forma, optou-se pela utilização de três idiomas: português, inglês e francês. A escolha do português dispensa explicações. O inglês e o francês são idiomas amplamente difundidos no mundo da arbitragem. Em vista de tal difusão, o benefício de outros idiomas apresenta-se menor do que o risco de dispersão de conceitos em traduções. Não obstante, foram elaboradas mensagens de convite para participação em português, francês, inglês, espanhol e italiano. ${ }^{1087}$

O autor contou ainda com a ajuda de alguns profissionais do Center for Statistical Consultation and Research da Universidade de Michigan (Ann Arbor). Esse centro fornece consultoria gratuita aos alunos que necessitam de aconselhamento para questões estatísticas. Além disso, recebeu o auxílio de três estudantes do curso de pós-graduação de metodologia de pesquisa (survey methodology) do Instituto de Ciências Sociais da mesma Universidade, que se dispuseram a comentar as minutas do questionário. ${ }^{1088}$

Após a elaboração do conteúdo dos questionários, o autor contratou o artista gráfico Élcio Miazaki para a confecção do layout dos formulários, de modo a torná-los visualmente claros e de fácil leitura. O mesmo artista gráfico, em conjunto com Renato Viveiros, elaborou o sítio de internet que contém a pesquisa.

\subsection{Confidencialidade}

Todas as respostas individuais são mantidas confidenciais. Trata-se de prática utilizada em outras pesquisas de campo em direito internacional ${ }^{1089}$ e ainda mais relevante no presente caso:

\footnotetext{
${ }^{1087}$ O autor agradece a Michael Timmins, Sebastian Lovera e Christian Patelmo pela ajuda na elaboração dos textos nos respectivos idiomas.

${ }^{1088} \mathrm{O}$ autor agradece a Rachel Orlowski, Marie Komanecky e Erica Zawacki pelos comentários e sugestões feitos à minuta dos questionários.

1089 Por exemplo, as duas pesquisas referidas anteriormente nas pesquisas realizadas pelo Central - Center for Transnational Law e por Maurício de Almeida Prado Curvelo.
} 
nenhuma das respostas pode servir para antecipação de convencimento em um futuro caso concreto. Desse modo, as respostas individuais permanecerão na mais estrita confidencialidade.

\subsection{A base pesquisada}

O principal critério para a seleção dos destinatários foi o da atuação como árbitro. Todavia, pessoas com relevante produção acadêmica ou importante atuação como advogados foram incluídas.

Os destinatários foram selecionados a partir de curricula disponíveis em órgãos reconhecidos no mundo da arbitragem: associações como o International Arbitration Institute e a Associação Suíça de Arbitragem ou instituições como a CCI ou a Câmara de Comércio Brasil-Canadá. Também foram convidadas pessoas mencionadas em rankings profissionais, como o caso do Chambers and Partners. Esses rankings serviram tanto para sugerir nomes como segunda referência de outras fontes. ${ }^{1090}$ Adicionalmente, os participantes da força-tarefa de arbitragem por eqüidade da Câmara de Comércio Internacional foram convidados a fazer parte da pesquisa, por evidente afinidade.

O autor procurou tanto quanto possível evitar tendências regionalistas. Ao mesmo tempo, teve de respeitar a importância relativa dos países dentro do mundo da arbitragem. Por essa razão, há um número maior de destinatários dos países da Europa ocidental e Estados Unidos da América, que ainda são os países preponderantes nas estatísticas publicadas de arbitragem, ${ }^{1091}$ bem como a origem da maioria dos estudos acadêmicos de circulação internacional. De qualquer modo, o aluno procurou não negligenciar nenhuma área do globo, embora tenha tido maiores dificuldades em encontrar potenciais participantes na Ásia e na Europa Oriental.

A distribuição global dos participantes é a seguinte: Alemanha: 6; Argentina: 2; Austrália: 1; Áustria: 4; Bélgica: 7; Bolívia: 1; Brasil: 8; Canadá: 1; Espanha: 3; EUA: 10; França: 21; Guatemala: 1; Inglaterra: 7; Itália: 8; Líbano: 1; Polônia: 1; Suíça: 9; e Tunísia: 1, conforme o gráfico a seguir.

\footnotetext{
1090 Tais como Smit, Hans; Carbonneau, Thomas E.; Mistelis, Loukas. The roster of International arbitrators. 2. ed. Huntington: JurisNet, 1999 (fichário com atualizações).

${ }^{1091}$ Embora o Brasil tenha aumentado sua participação nas estatísticas da CCI, trata-se de um fenômeno ainda em processo de consolidação.
} 


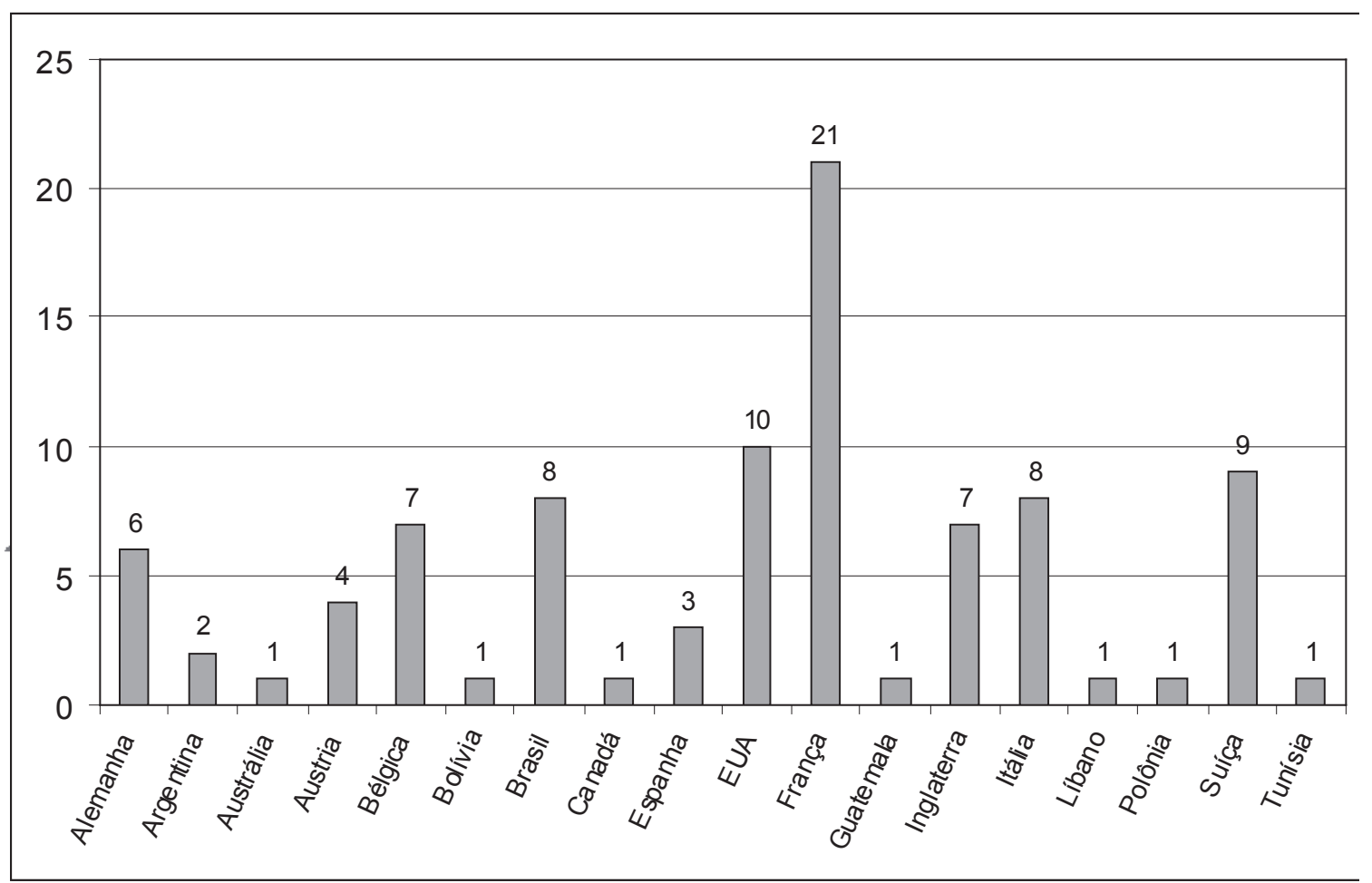

Dos cerca de 300 convites, a pesquisa recebeu 92 respostas, o que oferece um percentual aproximado de participação de $30 \%$. Esse percentual superou as expectativas iniciais do autor e tem sido próximo de outras pesquisas de campo, com bases maiores. ${ }^{1092}$ Causou particular satisfação o fato de grandes nomes da arbitragem internacional terem participado. Alguns ainda tiveram a imensa gentileza de enviar sugestões e críticas acerca do questionário. Esta qualidade de participação proporcionou ao autor conforto adicional sobre a condução da pesquisa de campo.

\subsection{Limitações da pesquisa}

Nenhuma pesquisa empírica em arbitragem internacional poderá refletir rigor estatístico absoluto: não há uma base geral de arbitragens no mundo. Sendo a arbitragem confidencial por natureza, apenas frações do total chegam a conhecimento público. Portanto, somente partes fracionárias dos dados podem ser estudadas. A natureza pulverizada e confidencial da arbitragem igualmente torna quase que impossível, em termos práticos, definir com precisão quem sejam os árbitros.

\footnotetext{
1092 Vejam-se dados do CENTRAL e do UNIDROIT mencionados por Berger, Klaus Peter et. al. The Central Enquiry on the use of Transnational Law. In: (Ed.). International Contract Law and Arbitration - Background, Procedure and Selected Results. The Practice of Transnational Law. The Hague: London Kluwer Law International, 2001
} 
Sendo a decisão por eqüidade aquela que melhor pode refletir o sentimento de justiça no caso concreto, é evidente que as decisões dos árbitros serão pautadas pelas circunstâncias de fato. Assim, a presente pesquisa jamais poderia reivindicar completude ou exatidão nas respostas que dependem do fato concreto. Antes, somente pode pretender refletir uma inclinação dos participantes no tocante a certas hipóteses levantadas.

As hipóteses selecionadas igualmente não esgotam as possibilidades de atuação do julgamento de eqüidade. Tanto quanto os fatos concretos, as hipóteses de litígio são infinitas. Entretanto, qualquer tentativa de abarcar uma gama infinita está fadada ao fracasso de antemão. O alargamento excessivo das situações de fato leva a resultados fragmentados.

O enfoque contrário igualmente não é isento de riscos: a busca de critérios teóricos pode levar a respostas demasiadamente vagas, que não possibilitam elaboração concreta.

A despeito de tais dificuldades, entende-se que a presente pesquisa pode representar uma contribuição concreta, mesmo que não possa reivindicar a representação da totalidade das arbitragens, dos árbitros, ou das hipóteses de fato.

Ela reflete um corte de um número considerável de profissionais que expressaram como tenderiam a julgar determinadas situações de fato, recorrentes na arbitragem. Expuseram outras hipóteses em que considerações de justiça e eqüidade sobrepor-se-iam à estrita aplicação do direito positivo. Embora dependam dos fatos, as respostas mostram algumas tendências de comportamento.

\subsection{Resultados}

\subsubsection{Utilização prática da arbitragem por eqüidade em relação à arbitragem de direito}

Nesta primeira parte, busca-se a experiência prévia dos participantes com arbitragens de eqüidade, em seus três aspectos: redação da cláusula de arbitragem, atuação como árbitro e representação de partes.

Apenas na atuação como árbitro há maioria de participantes com experiência prévia. Todavia, os percentuais superiores a $40 \%$ nos demais aspectos demonstram um grau considerável de atuação. 
Por outro lado, a imensa maioria dos participantes aponta um percentual inferior a $10 \%$ de utilização da arbitragem por eqüidade no total de arbitragens. Essa pequena participação expressa o caráter minoritário da arbitragem de eqüidade no total de arbitragens realizadas, o que encontra respaldo nas poucas estatísticas disponíveis sobre arbitragens por eqüidade. ${ }^{1093}$

No que diz respeito à divisão de intervalos, o autor preferiu não efetuar uma divisão por cinco segmentos idênticos de $20 \%$, porque as estatísticas disponíveis indicam tendência menor de utilização deste tipo de arbitragem, fazendo com que apenas uma das faixas pudesse concentrar $100 \%$ das respostas. Assim, preferiu-se reduzir a faixa inicial a $10 \%$. Os resultados da pesquisa confirmaram essa assunção.

Abaixo, o resultado das questões.

a) Em sua experiência profissional, o(a) Sr.(a) já redigiu uma cláusula de arbitragem por eqüidade?

\begin{tabular}{|c|c|c|c|}
\hline Respostas & Sim & Não & Não respondeu \\
\hline Freqüência & 38 & 54 & 0 \\
\hline Percentual & $41 \%$ & $59 \%$ & 0 \\
\hline
\end{tabular}

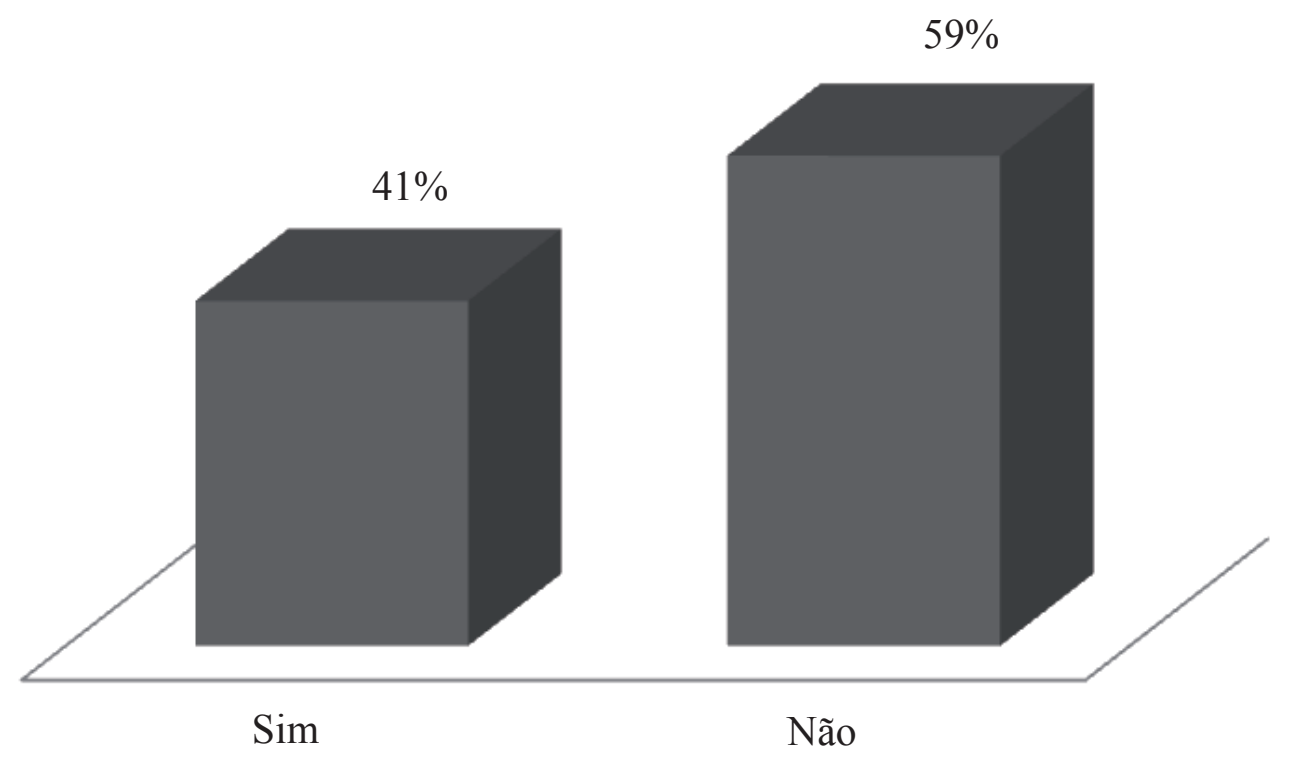

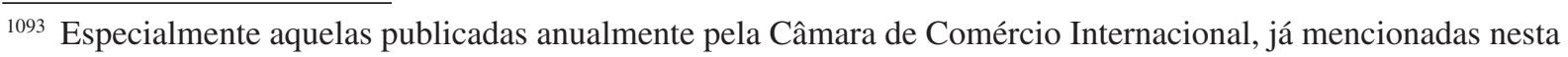
obra. Em nenhum dos anos o percentual de arbitragens por eqüidade sequer chegou próximo do patamar de $10 \%$. 
b) Caso tenha respondido "sim", por favor informe a proporção aproximada das cláusulas de arbitragem por eqüidade no total de cláusulas arbitrais que tenha redigido.

\begin{tabular}{|c|c|c|c|c|c|}
\hline Respostas & $\begin{array}{c}\text { Menos de } \\
\mathbf{1 0 \%}\end{array}$ & $\mathbf{1 0 \%} \mathbf{a} \mathbf{3 0} \%$ & $\mathbf{3 0 \%}$ a $\mathbf{5 0 \%}$ & $\mathbf{5 0 \%}$ a 70\% & $\mathbf{7 0 \%} \mathbf{a} \mathbf{9 0 \%}$ \\
\hline Freqüência & 29 & 6 & 2 & 1 & - \\
\hline Percentual & $76 \%$ & $16 \%$ & $5 \%$ & $3 \%$ & - \\
\hline
\end{tabular}

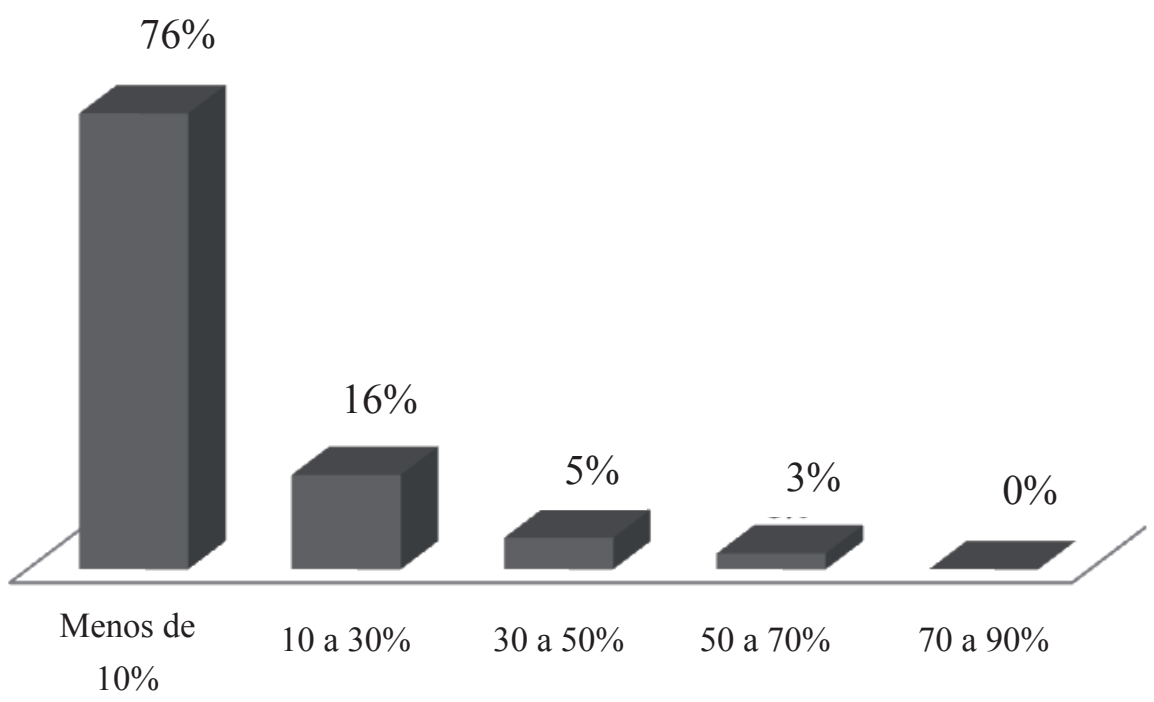

c) $O$ (a) Sr.(a) já atuou como árbitro em arbitragem por eqüidade?

\begin{tabular}{|c|c|c|c|}
\hline Respostas & Sim & Não & Não Respondeu \\
\hline Freqüência & 48 & 44 & 0 \\
\hline Percentual & $52 \%$ & $48 \%$ & 0 \\
\hline
\end{tabular}

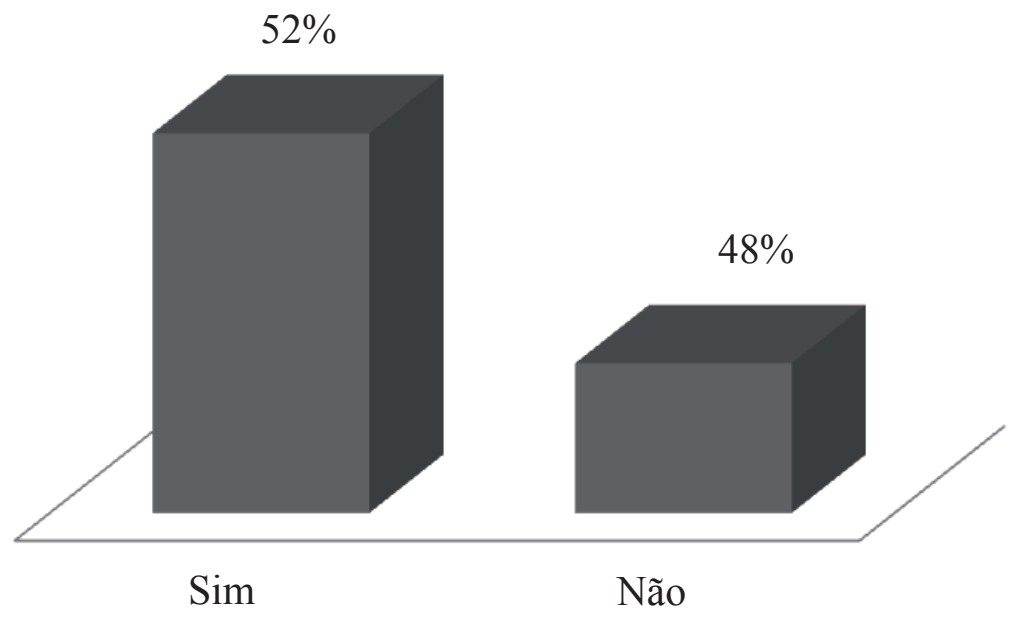


d) Caso tenha respondido "sim", por favor informe a proporção aproximada de arbitragens por eqüidade no total de arbitragens em que tenha atuado.

\begin{tabular}{|c|c|c|c|c|c|}
\hline Respostas & $\begin{array}{c}\text { Menos de } \\
\mathbf{1 0} \%\end{array}$ & $\mathbf{1 0 \%}$ a $\mathbf{3 0} \%$ & $\mathbf{3 0 \%}$ a $\mathbf{5 0 \%}$ & $\mathbf{5 0 \%}$ a $\mathbf{7 0} \%$ & $\mathbf{7 0 \%}$ a 90\% \\
\hline Freqüência & 35 & 7 & 4 & 2 & - \\
\hline Percentual & $73 \%$ & $15 \%$ & $8 \%$ & $4 \%$ & - \\
\hline
\end{tabular}

$73 \%$

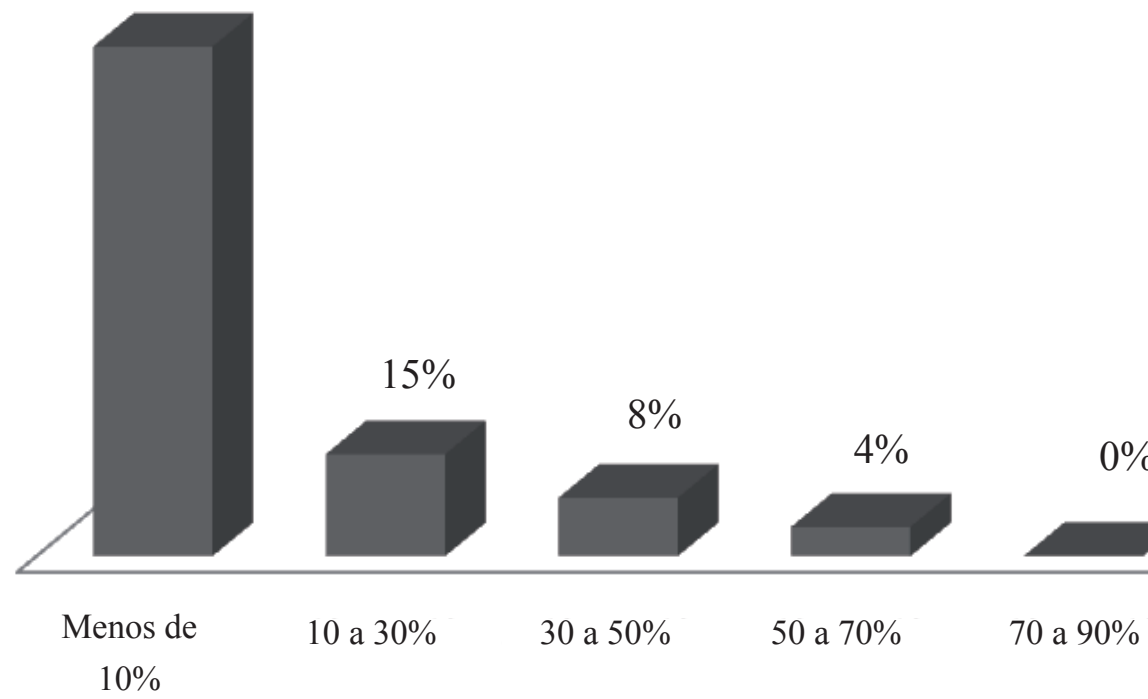

e) $O($ a) $\operatorname{Sr}($ a). já atuou como advogado em arbitragens por eqüidade?

\begin{tabular}{|c|c|c|c|}
\hline Respostas & Sim & Não & Não Respondeu \\
\hline Freqüência & 37 & 51 & 4 \\
\hline Percentual & $40 \%$ & $55 \%$ & $4 \%$ \\
\hline
\end{tabular}

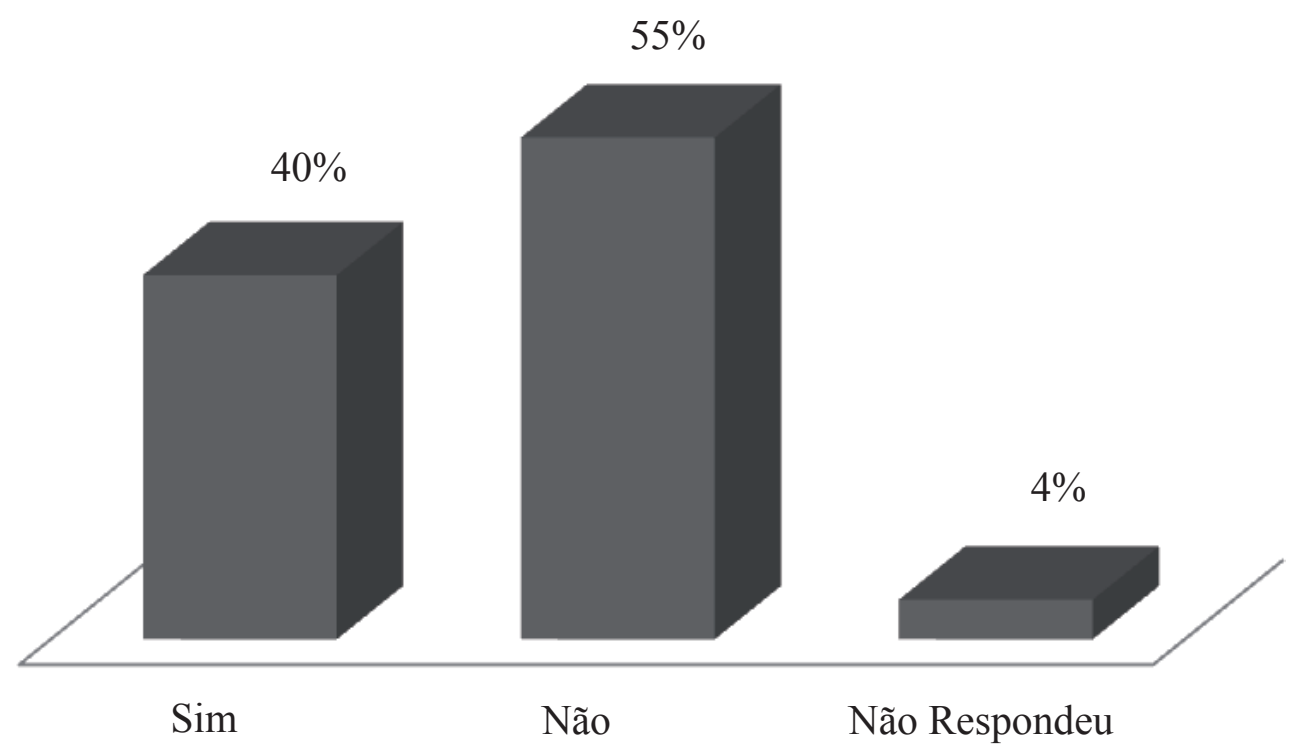


f) Caso tenha respondido "sim", por favor informe a proporção aproximada de arbitragens por eqüidade no total de arbitragens em que atuou.

\begin{tabular}{|c|c|c|c|c|c|}
\hline Respostas & $\begin{array}{c}\text { Menos de } \\
\mathbf{1 0} \%\end{array}$ & $\mathbf{1 0 \%}$ a $\mathbf{3 0 \%}$ & $\mathbf{3 0 \%}$ a $\mathbf{5 0} \%$ & $\mathbf{5 0 \%}$ a 70\% & $\mathbf{7 0 \%}$ a 90\% \\
\hline Freqüência & 29 & 4 & 3 & 1 & - \\
\hline Percentual & $78 \%$ & $11 \%$ & $8 \%$ & $3 \%$ & - \\
\hline
\end{tabular}

$78 \%$

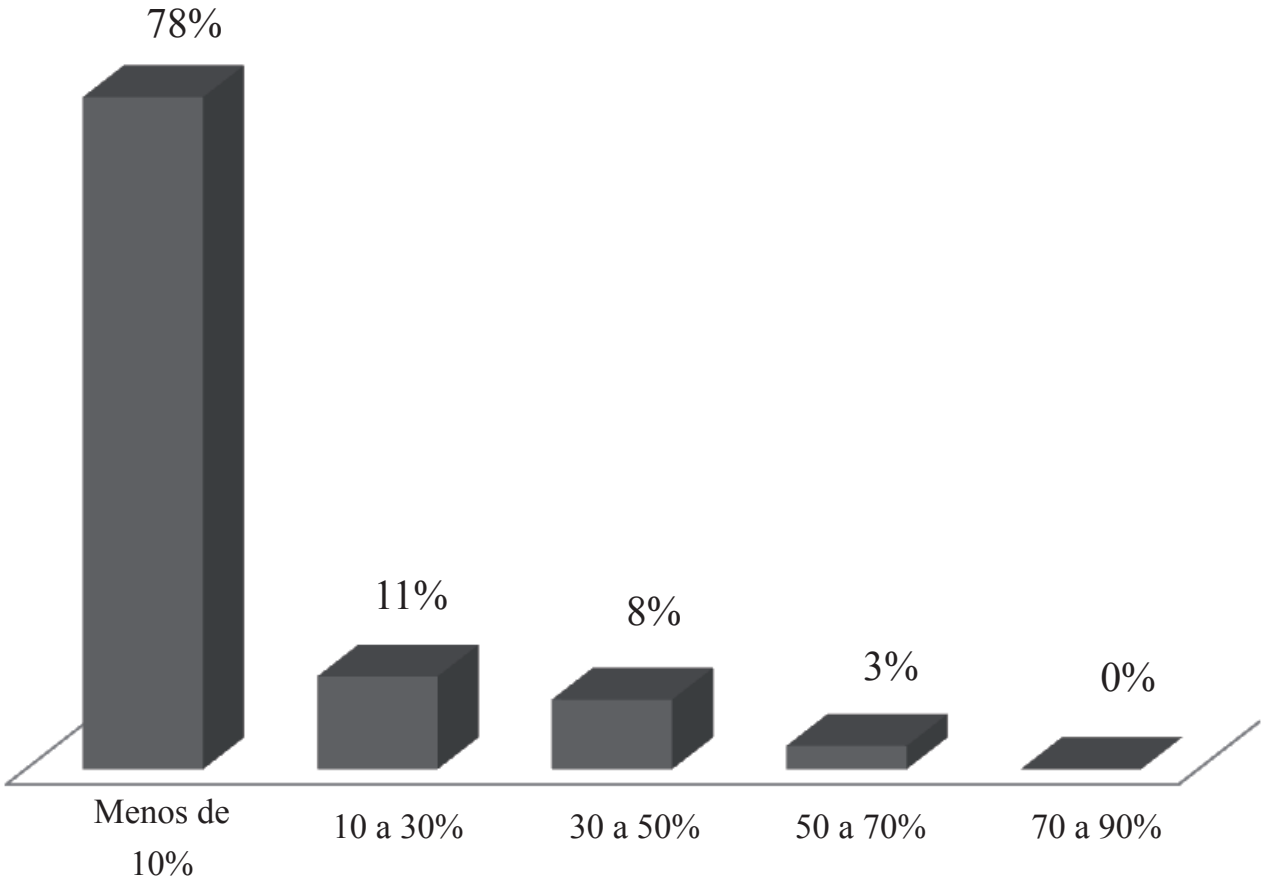

\subsubsection{Recomendação de utilização}

Nesta parte, a pesquisa busca saber se os participantes recomendariam a utilização da arbitragem por eqüidade e, em caso positivo, em quais circunstâncias.

No tocante às circunstâncias em que a arbitragem por eqüidade seria recomendada, preferiu-se a utilização de uma questão aberta, pois as alternativas são muitas e dificilmente redutíveis a itens comparáveis.

a) $O($ a) $\operatorname{Sr}(a)$. recomendaria o uso de arbitragem por eqüidade?

A resposta pode decepcionar alguns entusiastas da arbitragem por eqüidade. Todavia, deve-se considerar que a diferença entre as duas respostas é de cerca de $10 \%$, que não aparenta ser muito significativa dentro do grupo pesquisado. O fato de que $45 \%$ dos participantes pos- 
sam recomendar o uso da arbitragem por eqüidade representa um percentual bastante superior àquele que tem se mostrado como utilização efetiva nas estatísticas publicadas.

Alguns participantes mostraram-se fortemente opostos a esse tipo de arbitragem, reforçando tal fato nas mensagens de envio dos questionários. A principal razão apontada foi a imprevisibilidade. Por outro lado, o número de pessoas que não recomendam a arbitragem por eqüidade é ligeiramente superior ao número de pessoas que atuaram como árbitros neste tipo de arbitragem. Assim, existe um grupo que, embora tenha atuado diretamente neste tipo de arbitragem, não o recomenda.

\begin{tabular}{|c|c|c|c|}
\hline Respostas & Sim & Não & Não Respondeu \\
\hline Freqüência & 41 & 50 & 1 \\
\hline Percentual & $45 \%$ & $54 \%$ & $1 \%$ \\
\hline
\end{tabular}

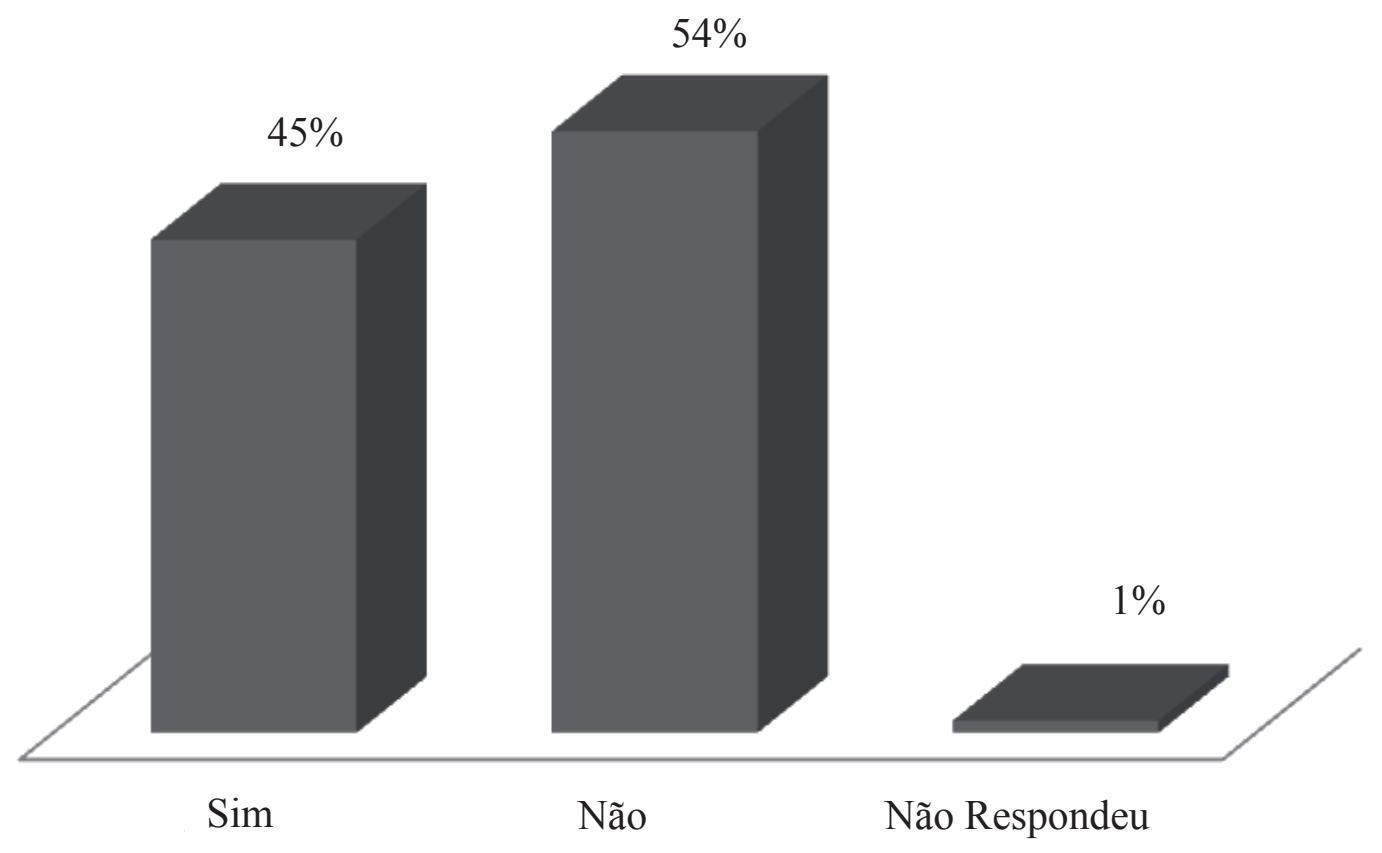

b) Caso tenha respondido "sim", em que tipo de contratos o(a) $\operatorname{Sr}($ a). entende que esta espécie de arbitragem seria mais adequada? (longo prazo ou curto prazo, alguma atividade econômica em particular, algum tipo especifico de contrato, etc.).

Neste quesito, houve um número reduzido de respostas. Embora tenha existido variação considerável no conteúdo, podem-se divisar alguns elementos mais recorrentes.

A maior parte das respostas indica os contratos de longo de prazo como o caso em que a arbitragem por eqüidade seria recomendável. Cerca de 12 respostas a indicaram 
como a hipótese mais adequada, ainda que algumas vezes em conjunto com outras das respostas. ${ }^{1094}$

Em segundo lugar, aparecem as respostas que recomendam a arbitragem por eqüidade em situações em que as partes não possam concordar sobre a lei aplicável, ou que esta se mostre desfavorável, insuficiente ou desconhecida das partes.

Em outra vertente, a terceira mais citada, alguns participantes (quatro) recomendariam a arbitragem por eqüidade a todos os tipos de contrato. Outros participantes responderam que a escolha depende mais da disputa em si (dois participantes) ou dos árbitros (dois participantes) do que do tipo de contrato.

A quarta circunstância mais citada, algumas vezes em conjunto com o longo prazo, refere-se ao contrato complexo, que envolva grandes prestações e diversos ordenamentos jurídicos.

No que concerne a tipos específicos de contratos citados, encontra-se o de construção, seguido do de sociedade.

Outras menções menos repetidas são o uso em casos de operações técnicas, prestações outras que não o pagamento do preço, casos em que seja necessária a revisão do preço (com uma menção específica a matérias-primas), casos em que seja difícil a apuração de montantes, casos de imposição de deveres muito altos às partes, casos em que as partes desejem uma decisão mais célere, casos em que as partes desejem evitar decisões de "tudo ou nada" e ainda hipóteses em que as partes estejam mais predispostas a uma atuação do tribunal com aspectos de mediação.

Assim, embora haja uma disparidade considerável de respostas, pode-se divisar uma função principal da arbitragem por eqüidade: a possibilidade de adaptação da decisão a circunstâncias de fato que não foram ou não poderiam ser objeto de deliberação prévia das partes. Tanto as respostas que mencionam os contratos de longo prazo (e portanto mais sujeitos a alterações dos fatos) quanto as de contratos complexos (e portanto com menor previsibilidade de todas as eventualidades), bem como aquelas relativas a mudanças de preço, parecem inequivocamente apontar para essa função.

1094 Essa recomendação encontra-se de acordo com opiniões da doutrina internacional. Entre outros, veja-se Mustill e Boyd. Commercial Arbitration - 2001 Companion, op. cit., p. 606. 
A segunda função da arbitragem por eqüidade, segundo os participantes, é o de servir como alternativa a legislações desfavoráveis, desconhecidas ou sem possibilidade de acordo. Aqui parece tratar-se de uma função negativa (para evitar uma alternativa pior) ou de técnica de negociação (ser um denominador comum aceitável entre duas posições antagônicas) do que propriamente do resultado que este tipo de arbitragem pode proporcionar. Todavia, convém lembrar que, na grande maioria das legislações, a arbitragem por eqüidade ocorre somente no caso de concordância de ambas as partes. Caso uma delas perceba maior proteção na lei aplicável no caso de não escolha da arbitragem por eqüidade, é pouco provável que consinta com esta.

A terceira função da arbitragem por eqüidade parece ser uma espécie de busca de moderação, que evite a imposição de julgamentos "tudo ou nada" ou ainda que imponham obrigações excessivas em nome da estrita observância da lei ou do contrato.

\subsubsection{Limites}

a) Com relação ao contrato, na sua opinião, o árbitro decidindo por eqüidade deve: aplicar integralmente as disposições do contrato [ou] desconsiderar disposições contratuais que lhe pareçam injustas.

Nesta questão, procura-se a resposta a uma das questões mais polêmicas da arbitragem por eqüidade: os limites de atuação do árbitro em relação ao contrato. Foram oferecidas duas opções aos participantes: os árbitros devem aplicar as disposições do contrato integralmente ou devem desconsiderar disposições contratuais que lhe pareçam injustas.

Embora a questão invoque um assunto de resposta nem sempre fácil, parece haver uma consolidação da opinião de que é possível descartar disposições injustas. ${ }^{1095}$ Há diferença de $26 \%$ pontos percentuais em favor da possibilidade:

\begin{tabular}{|c|c|c|c|}
\hline Resposta & $\begin{array}{c}\text { Aplicar integralmente as } \\
\text { disposições do contrato }\end{array}$ & $\begin{array}{c}\text { Desconsiderar dis- } \\
\text { posições injustas }\end{array}$ & Não Respondeu \\
\hline Freqüência & 30 & 54 & 8 \\
\hline Percentual & $33 \%$ & $59 \%$ & $9 \%$ \\
\hline
\end{tabular}

$1095 \mathrm{Ou}$, como alguns preferiram anotar à margem do questionário, de soluções injustas porventura criadas pelas disposições do contrato. 


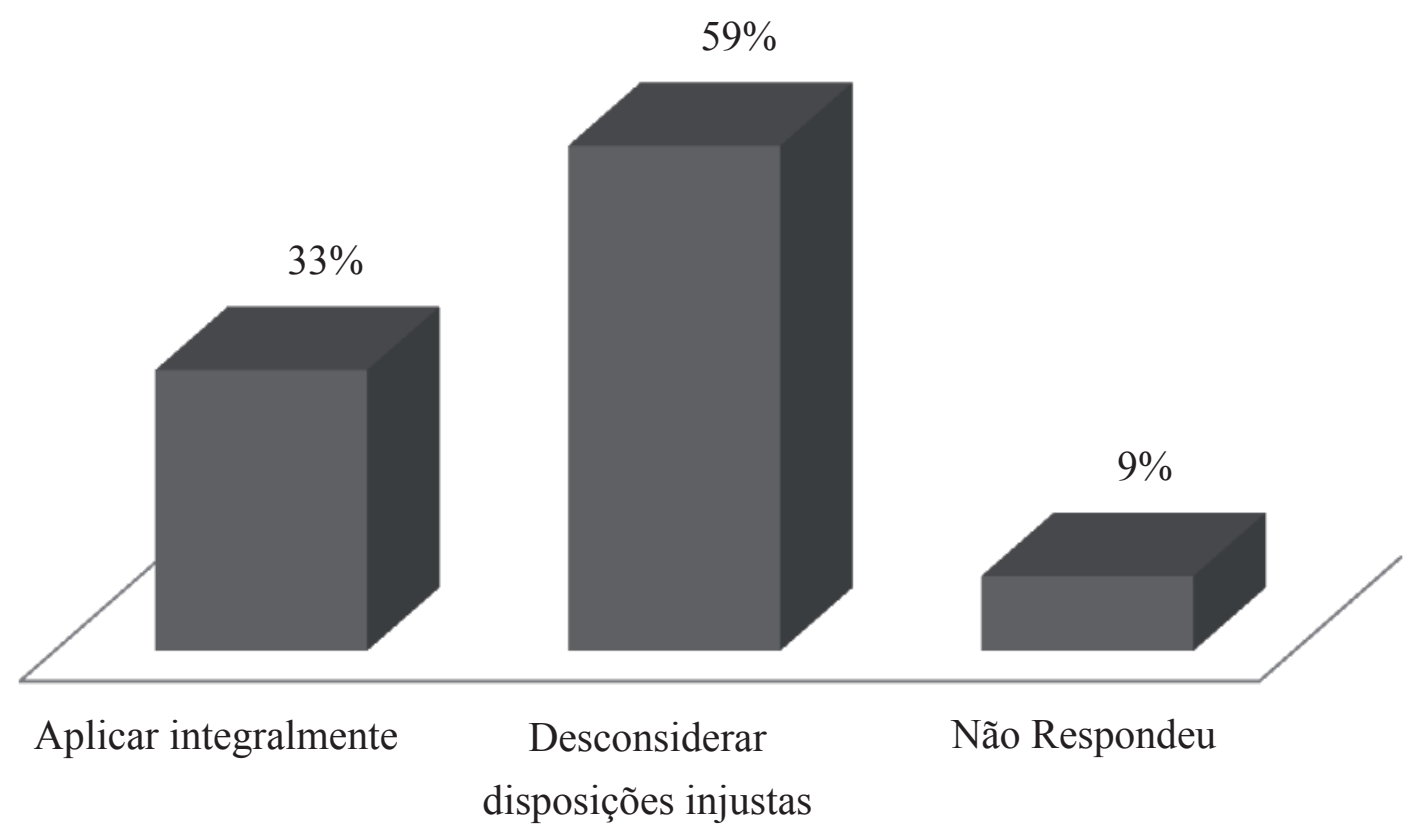

b) Na sua opinião pessoal, o árbitro decidindo por eqüidade pode modificar o conteúdo do contrato para manter a relação entre as partes? (Por favor, considere que nenhum poder foi conferido além da autorização para julgar por eqüidade.)

Nesta questão, buscou-se outro aspecto da relação entre árbitros e o contrato. Aqui se trata de saber se o árbitro pode rearranjar o conteúdo do contrato para manter a relação entre as partes. Nesta hipótese, há um grau maior de intervenção em relação ao simples descarte de disposições que levem a uma solução injusta.

Rearranjar implica, em alguma medida, a modificação da economia do contrato, ainda que em decorrência de fatos supervenientes. Essa modificação serve tanto para a adaptação a novas circunstâncias não previstas como para retornar à economia original, modificada por fatos supervenientes. São efeitos próximos aos de alguns tipos de cláusulas de hardship. Daí por que expressamente pediu-se que os participantes considerassem que não houvesse nenhuma outra cláusula permitindo tal modificação. Somente com essa qualificação podem-se isolar os eventuais efeitos da decisão por eqüidade, sem concorrência de fatores adicionais.

Evidentemente, a vida prática haverá de colocar uma infinidade de nuanças de fato que podem, em alguma medida, impactar a resposta dos participantes (o grau de modificação do contrato, a imprevisibilidade da circunstância superveniente, entre outros). No entanto, a questão pode demonstrar, tanto quanto possível, uma inclinação dos participantes no tocante a uma alteração mais profunda do conteúdo do contrato. 
Como se vê a seguir, e ao contrário da pergunta anterior, a maioria dos participantes entende que não pode haver tal modificação. Embora uma diferença de 10\% seja menos expressiva que a encontrada na questão anterior, mostra-se menor a aceitação de uma modificação mais ampla do contrato.

Comparando-se os resultados, pode-se concluir que, para os participantes, a liberdade do árbitro de eqüidade em relação ao contrato tem um aspecto negativo ou moderador: pode-se negar efeito a uma disposição contratual injusta. Todavia, uma postura mais ativa que envolva modificação do conteúdo do contrato não é tão bem aceita. De qualquer modo, deve-se considerar que há um percentual relativamente alto de participantes que permite a atuação mais ativa, de modo que sua ocorrência não pode ser descartada em casos reais, como apenas uma ocorrência marginal.

\begin{tabular}{|c|c|c|c|}
\hline Respostas & Sim & Não & Não Respondeu \\
\hline Freqüência & 36 & 45 & 11 \\
\hline Percentual & $39 \%$ & $49 \%$ & $12 \%$ \\
\hline
\end{tabular}

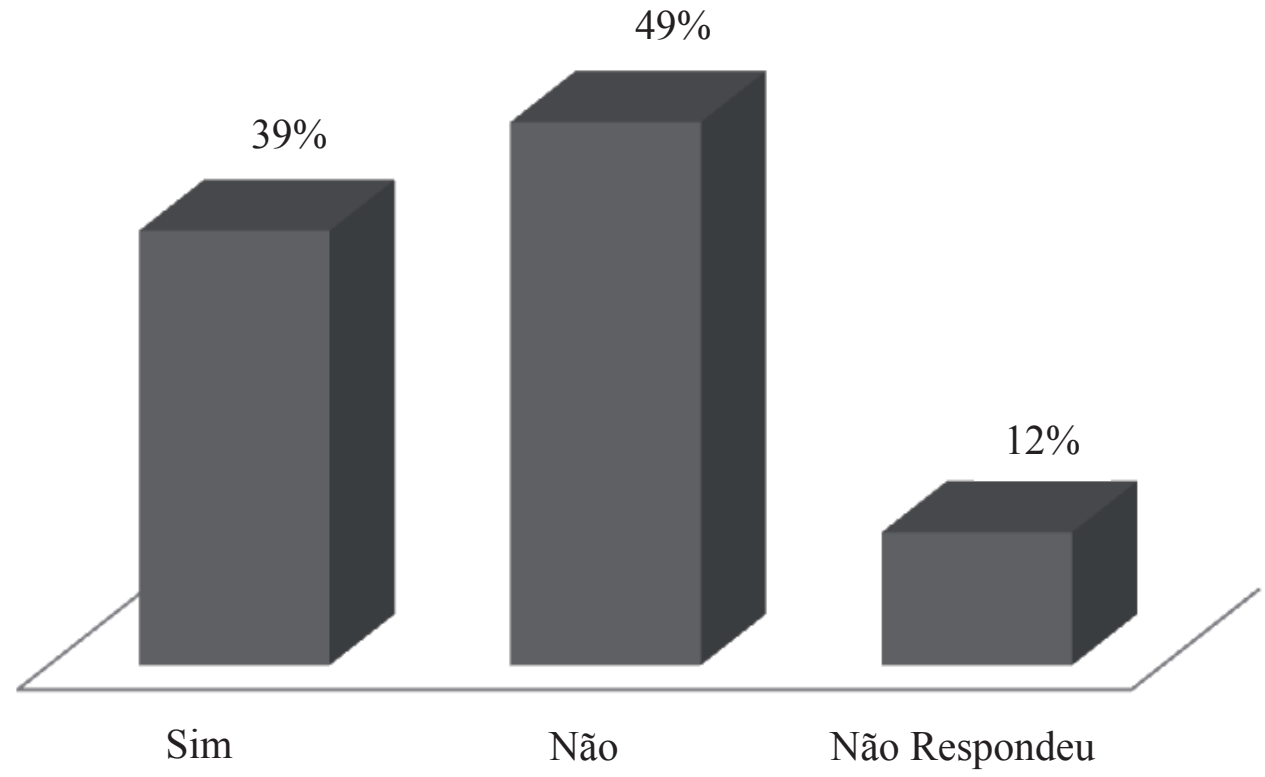

c) Na sua opinião pessoal, caso as partes não tenham escolhido a lei aplicável ao mérito, o árbitro decidindo por eqüidade deve: decidir somente conforme consciência sem determinar uma lei aplicável [ou] escolher lei aplicável e desconsiderar as disposições que lhe pareçam injustas?

Nesta pergunta, buscou-se verificar qual a posição dos participantes acerca da mecânica da decisão por eqüidade, especialmente em vista de uma corrente de opinião que preconiza 
que os árbitros devem escolher um direito nacional antes de aplicarem a eqüidade. Embora seja uma tendência relativamente recente, a maioria dos participantes entende que esse é o método correto para a formação da decisão por eqüidade.

O autor já apontou nesta obra as razões pelas quais entende que não há necessidade de escolha de uma lei quando se decidir por eqüidade. Não obstante mantenha sua opinião, não pode deixar de apontar a maioria expressiva do método de escolha de lei sobre a liberdade direta. O posicionamento dos participantes parece exprimir a busca por uma decisão mais previsível na arbitragem por eqüidade.

\begin{tabular}{|c|c|c|c|}
\hline Respostas & $\begin{array}{c}\text { Decidir somente } \\
\text { conforme consciência }\end{array}$ & Escolher lei aplicável & Não Respondeu \\
\hline Freqüência & 28 & 57 & 7 \\
\hline Percentual & $30 \%$ & $62 \%$ & $8 \%$ \\
\hline
\end{tabular}

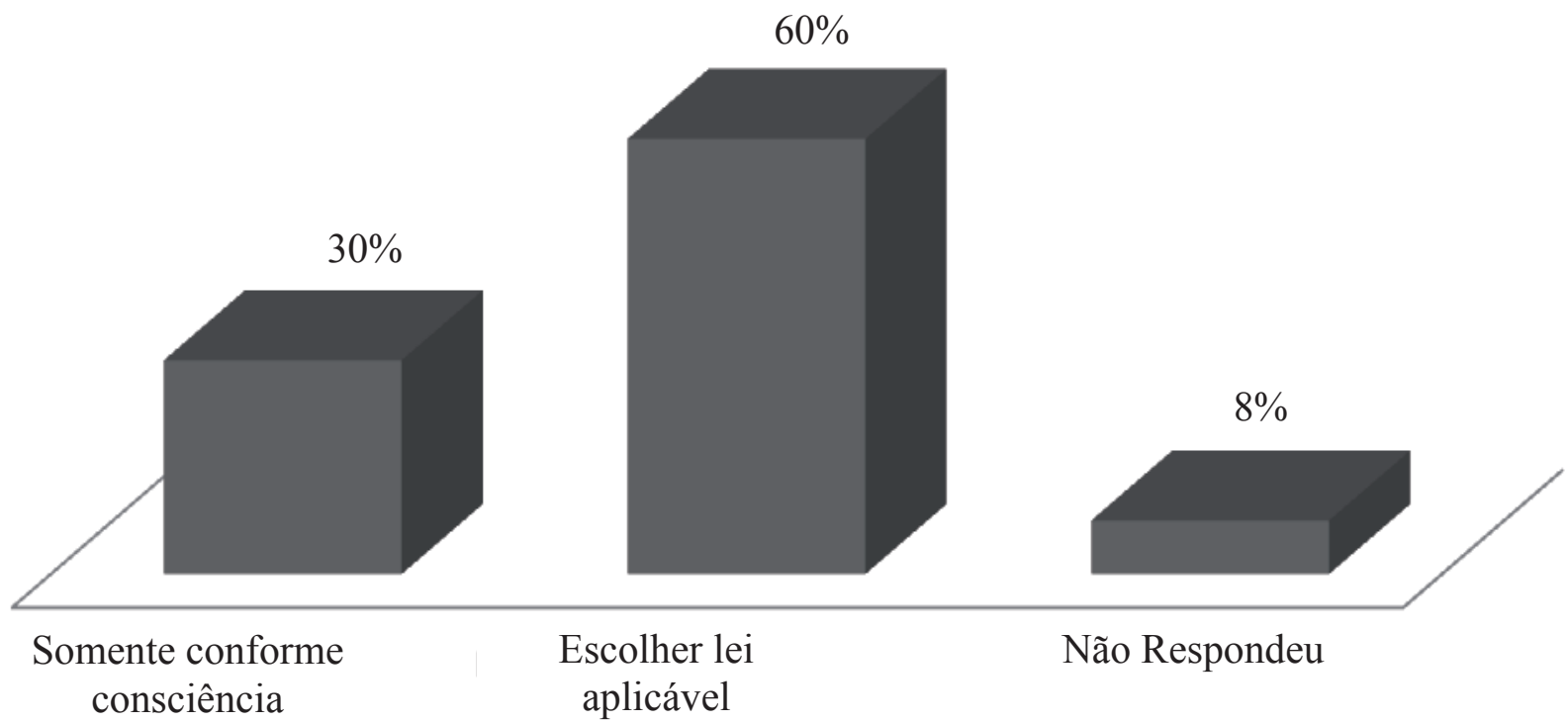

d) Na sua opinião pessoal, o árbitro decidindo por eqüidade está limitado pelas questões de ordem pública?

No caso da ordem pública, houve a única unanimidade encontrada na pesquisa: todos os participantes entendem que os árbitros decidindo por eqüidade estão limitados pela ordem pública. Ao menos uma resposta veio com o comentário adicional "evidentemente!" ao lado da questão, para que não houvesse dúvidas. Trata-se de um entendimento alinhado com a quase totalidade da doutrina sobre a matéria (ainda que exista divergência sobre qual ordem pública 
deva ser respeitada, se a interna ou a internacional). Pouco pode surpreender a resposta: todos os árbitros e todas as sentenças arbitrais estão sujeitas a limitações de ordem pública. A arbitragem por eqüidade não é exceção. Nesta pergunta evitou-se qualificar o tipo de ordem pública porque os conceitos que a envolvem são fugidios e nem sempre vistos do mesmo modo nos diferentes ordenamentos jurídicos, o que poderia gerar dúvidas desnecessárias nos participantes.

\begin{tabular}{|c|c|c|c|}
\hline Respostas & Sim & Não & Não Respondeu \\
\hline Freqüência & 80 & 0 & 12 \\
\hline Percentual & $87 \%$ & $0 \%$ & $13 \%$ \\
\hline
\end{tabular}

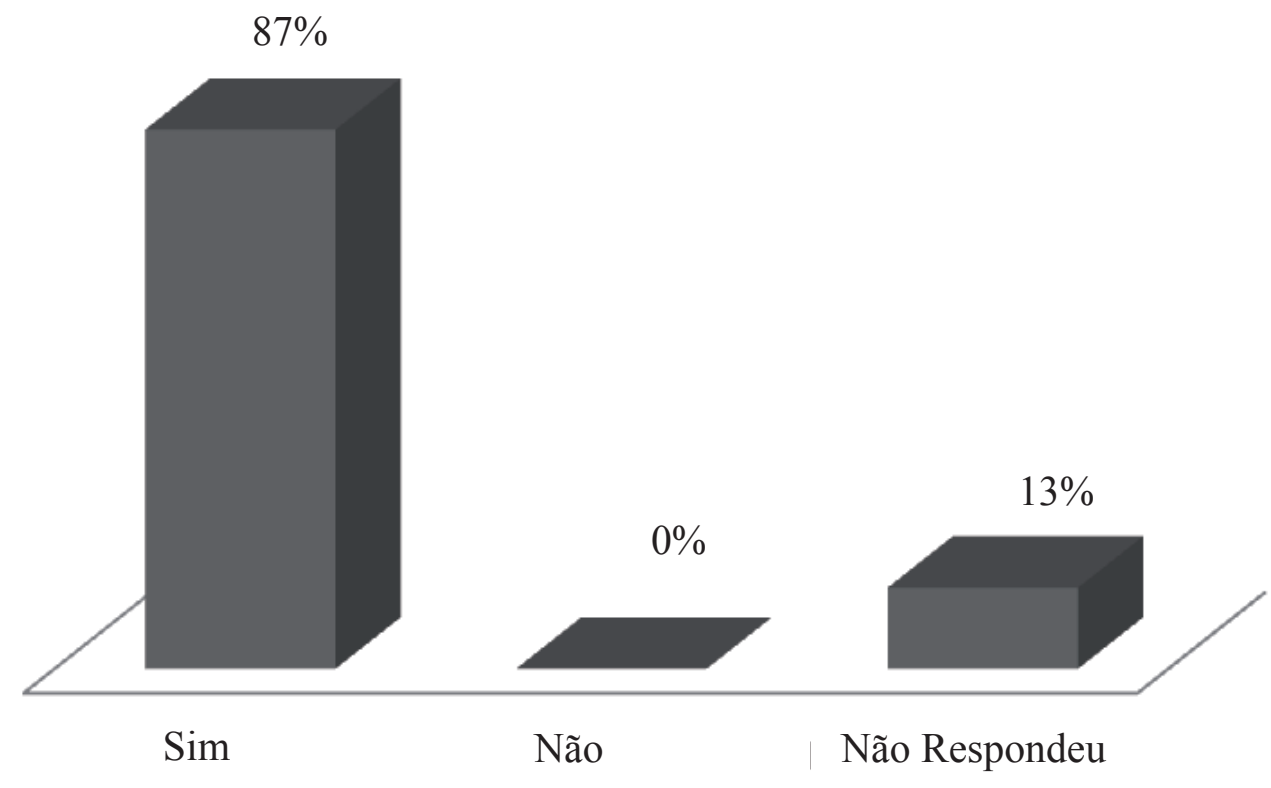

\subsubsection{Princípios de eqüidade na arbitragem comercial internacional}

Neste item, foi efetuada a seguinte questão: “Assumindo-se que os árbitros possam decidir por eqüidade, em quais das seguintes hipóteses o(a) $\operatorname{Sr}(a)$. entende que considerações de eqüidade ou justiça devem-se sobrepor a estrita aplicação da lei, caso haja discrepância entre elas? (Por favor, marque quantas alternativas desejar.)"

Os resultados foram os seguintes, para cada uma das 14 hipóteses apresentadas:

a) para alterar o preço ajustado quando houver modificação relevante do equilíbrio econômico do contrato

Neste caso, buscou-se uma situação bastante comum na arbitragem internacional: modificação superveniente no equilíbrio econômico do contrato. Trata-se aqui de hipóteses asse- 
melhadas à força maior ou ao hardship. Uma maioria expressiva entende que poderia modificar o preço (ou preços) previsto(s) no contrato, em reconhecimento de alteração do equilíbrio do contrato. Embora algumas legislações nacionais permitam essa modificação sem recurso à decisão por eqüidade, desde que certos patamares de desequilíbrio ocorram, é certo que nem todas o fazem. Portanto, a utilização da eqüidade como critério de decisão pode ser uma forma de garantir essa possibilidade de modificação, com critérios construídos para o caso concreto.

\begin{tabular}{|c|c|c|c|}
\hline Respostas & Sim & Não & Não Respondeu \\
\hline Freqüência & 61 & 20 & 11 \\
\hline Percentual & $66 \%$ & $22 \%$ & $12 \%$ \\
\hline
\end{tabular}

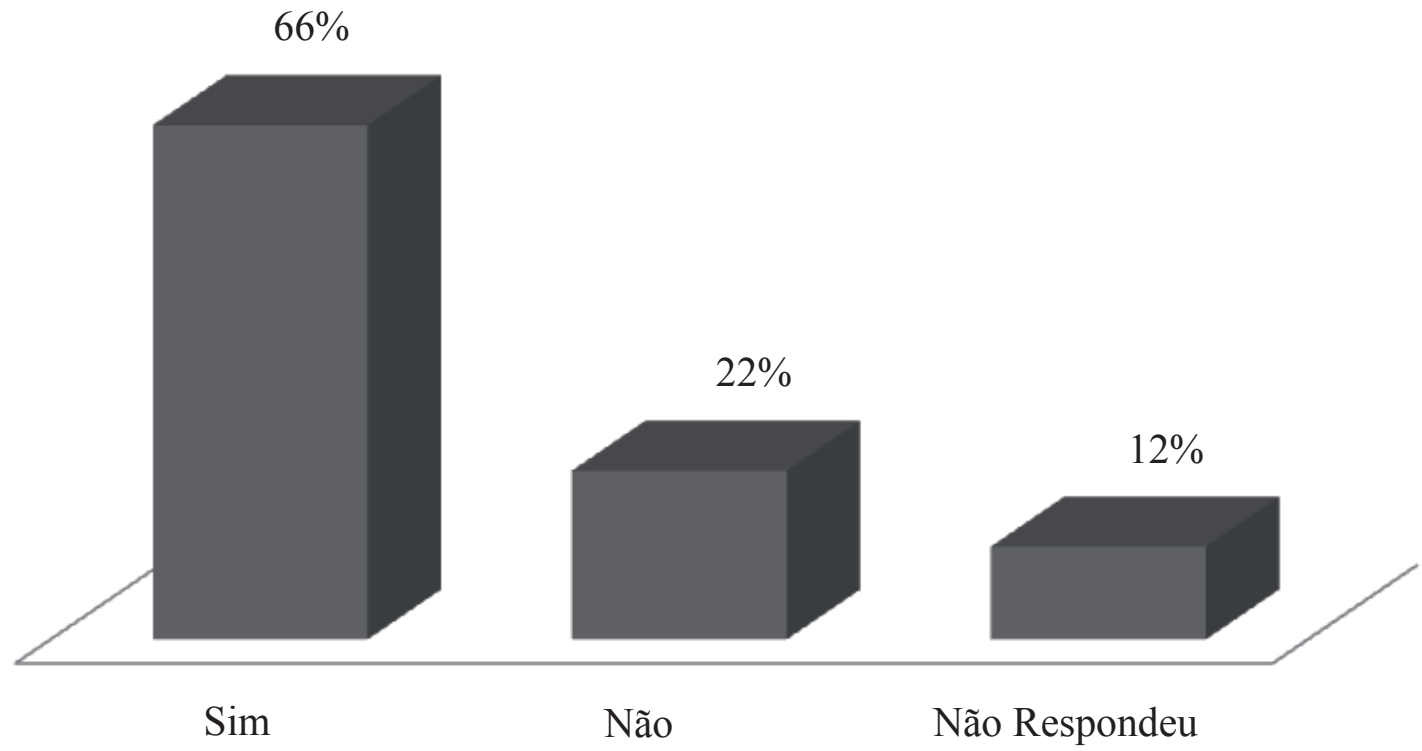

b) para alterar condições contratuais ajustadas quando houver modificação relevante do equilíbrio econômico do contrato

Essa questão tem objetivos semelhantes aos da anterior, porém com efeitos sobre outros aspectos do contrato que não o preço. Também neste caso houve uma maioria expressiva de participantes que se inclinam à adaptação do contrato em vista de modificações relevantes do equilíbrio econômico. Portanto, igualmente demonstra a utilidade da arbitragem por eqüidade como forma de garantir a adaptação do contrato, com critérios elaborados para o caso concreto.

\begin{tabular}{|c|c|c|c|}
\hline Respostas & Sim & Não & Não Respondeu \\
\hline Freqüência & 62 & 19 & 11 \\
\hline Percentual & $67 \%$ & $21 \%$ & $12 \%$ \\
\hline
\end{tabular}




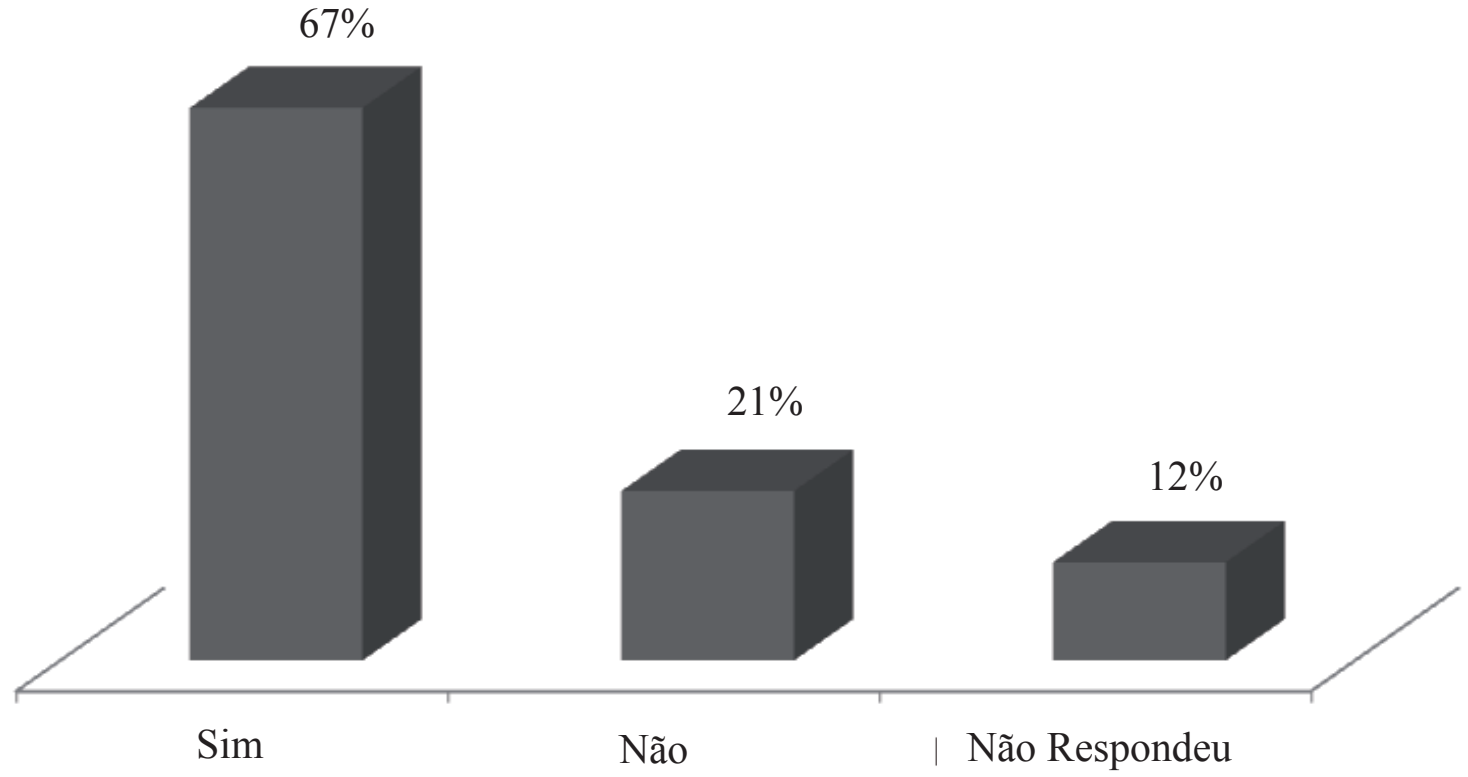

c) para reduzir proporcionalmente multas contratuais

Nesta questão, busca-se aferir a possibilidade de redução de multas contratuais em vista de circunstâncias de fato que possam atenuá-las, tal como o grau de culpa, a culpa concorrente, superveniência de fatos imprevisíveis, etc. Em alguma medida, a questão apresenta-se como uma forma qualificada das perguntas anteriores. No entanto, por se tratar de cláusula específica, merece tratamento à parte. Veja-se que os participantes têm maior inclinação em reduzir multas contratuais do que outros termos do contrato. Talvez essa maior inclinação justifique-se pelo fato de diversas legislações nacionais conferirem essa faculdade aos árbitros ou juízes.

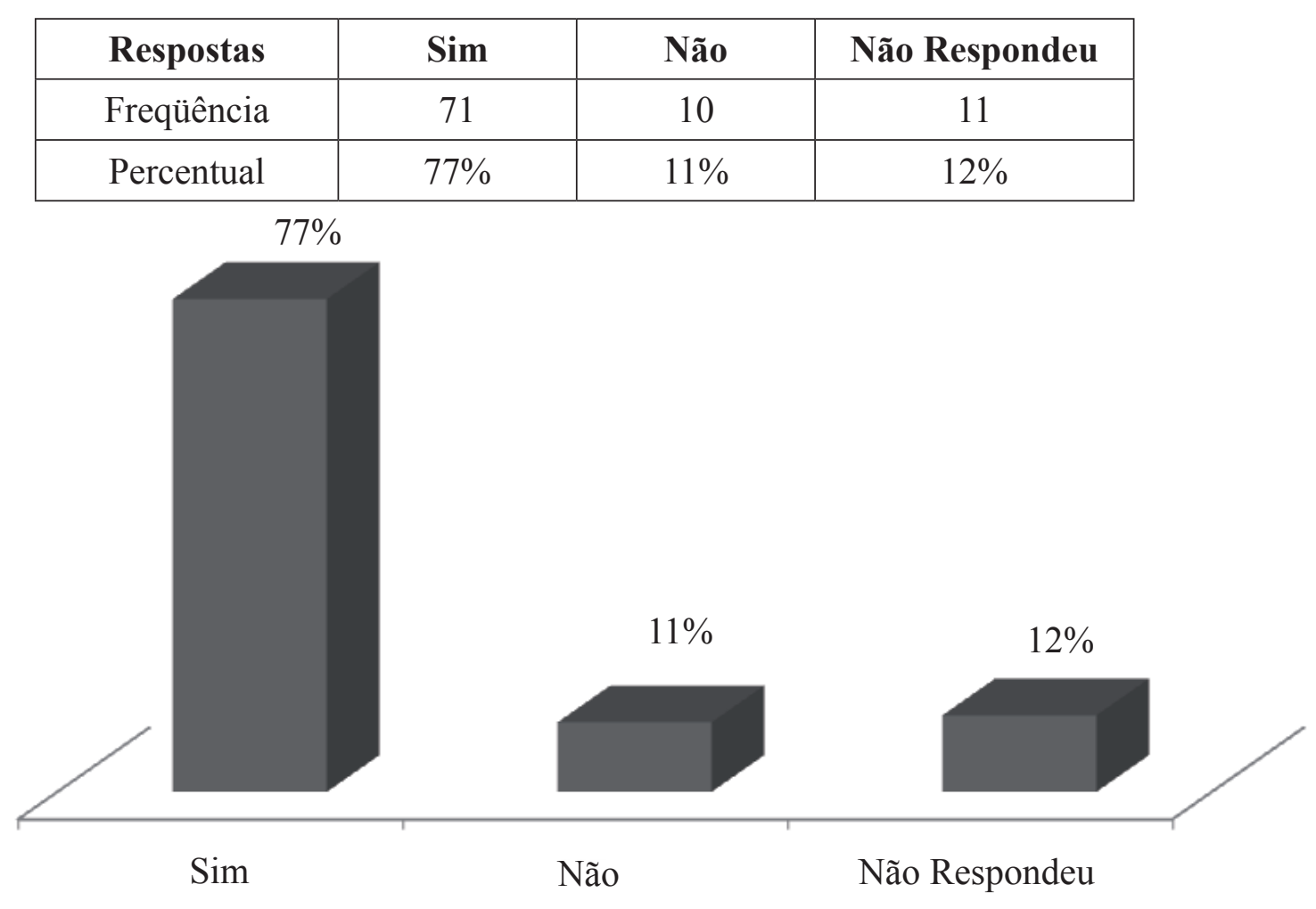


d) para reduzir proporcionalmente indenizações pré-estipuladas, tais como multas compensatórias ou liquidated damages

Esta questão relaciona-se diretamente com a anterior e, em conjunto com as três anteriores e a questão "f”, compõe o que poderia ser chamado de um bloco relativo à adaptação do contrato a circunstâncias supervenientes. Embora tenham esse elemento comum, cada uma delas representa aspectos diferentes, que aparecem de modo mais ou menos distinto na literatura e nos casos disponíveis para estudo.

Neste caso específico, busca-se verificar se os participantes consideram que a arbitragem por eqüidade autoriza a intervenção em cláusulas contratuais que predeterminam certas formas de compensação ou indenização livremente pactuadas pelas partes.

Nem todos os direitos nacionais permitem tal forma de intervenção, mesmo em casos em que exista desproporção entre os fatos ocorridos e a compensação prevista. Reconheça-se, porém, que existem certos princípios previstos no direito positivo que podem auxiliar em tal intervenção, como o da vedação ao enriquecimento sem causa. Todavia, tais princípios podem conflitar com o pacta sunt servanda e certas considerações sobre a economia e a álea do negócio.

Como demonstram os números abaixo, um percentual bastante elevado dos participantes entende que os árbitros que decidem por eqüidade podem ajustar proporcionalmente as compensações previamente estabelecidas pelas partes.

\begin{tabular}{|c|c|c|c|}
\hline Respostas & Sim & Não & Não Respondeu \\
\hline Freqüência & 68 & 8 & 13 \\
\hline Percentual & $74 \%$ & $9 \%$ & $14 \%$ \\
\hline
\end{tabular}

$74 \%$

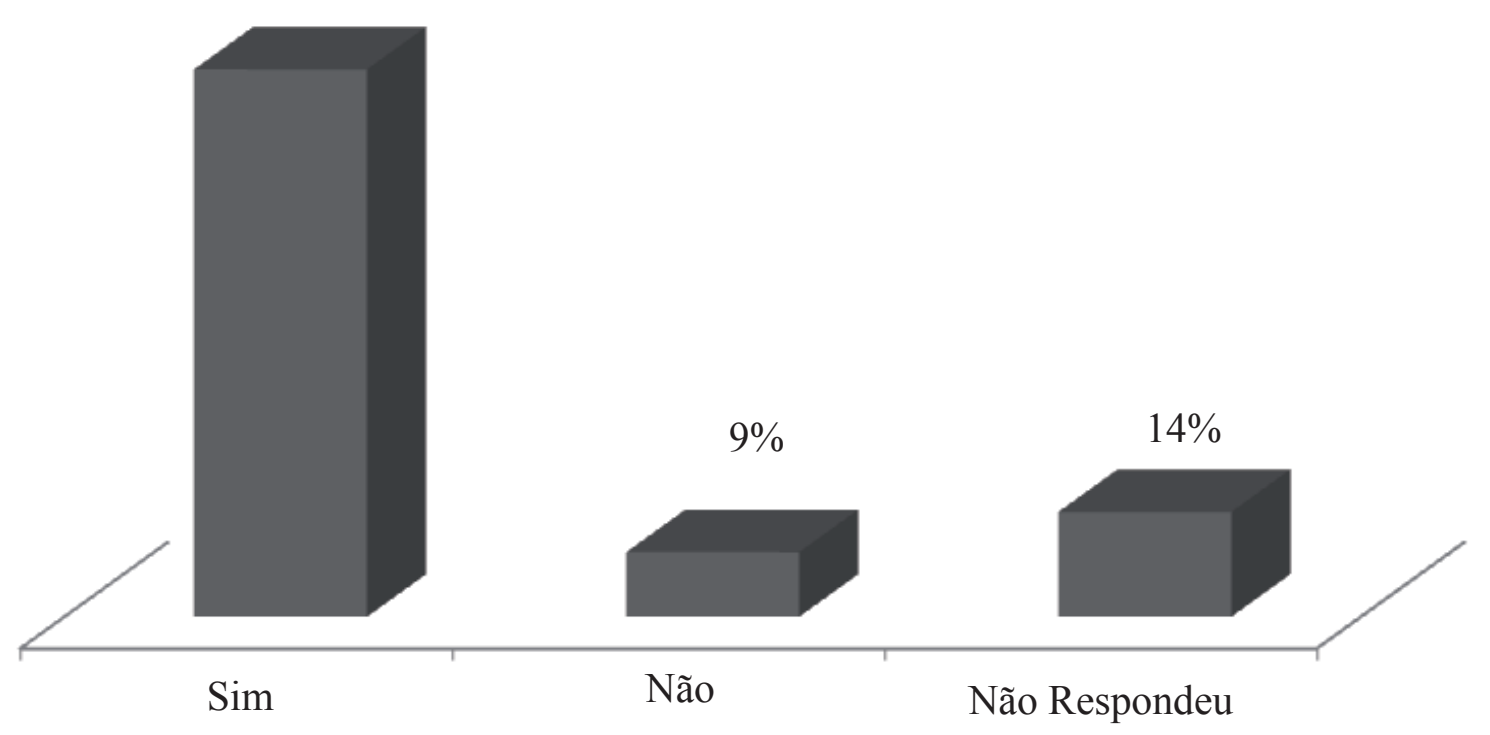


e) para estimar indenizações, quando não estipuladas no contrato

Esta questão busca a opinião dos participantes acerca da possibilidade de avaliação equitativa de indenizações, quando não previamente estipuladas. A regra geral para indenizações é que elas correspondam ao dano sofrido, tanto quanto possível. Entretanto, a avaliação exata nem sempre pode ser realizada, sendo por vezes necessária sua estimativa. Não é incomum que direitos positivos concedam aos juízes a faculdade de fixação equitativa de danos em certos casos, sobretudo nas hipóteses de difícil quantificação.

Aqui se verifica uma função importante da atuação da arbitragem por eqüidade: fixação de indenizações mesmo em hipóteses não expressamente autorizadas pela lei ou contrato. A grande maioria dos participantes (77\%), caso autorizados a decidir por eqüidade, admitiria estimar equitativamente uma indenização, mesmo que a lei positiva não determinasse este tipo de estimativa.

\begin{tabular}{|c|c|c|c|}
\hline Resposta & Sim & Não & Não Respondeu \\
\hline Freqüência & 71 & 8 & 13 \\
\hline Percentual & $77 \%$ & $9 \%$ & $14 \%$ \\
\hline
\end{tabular}

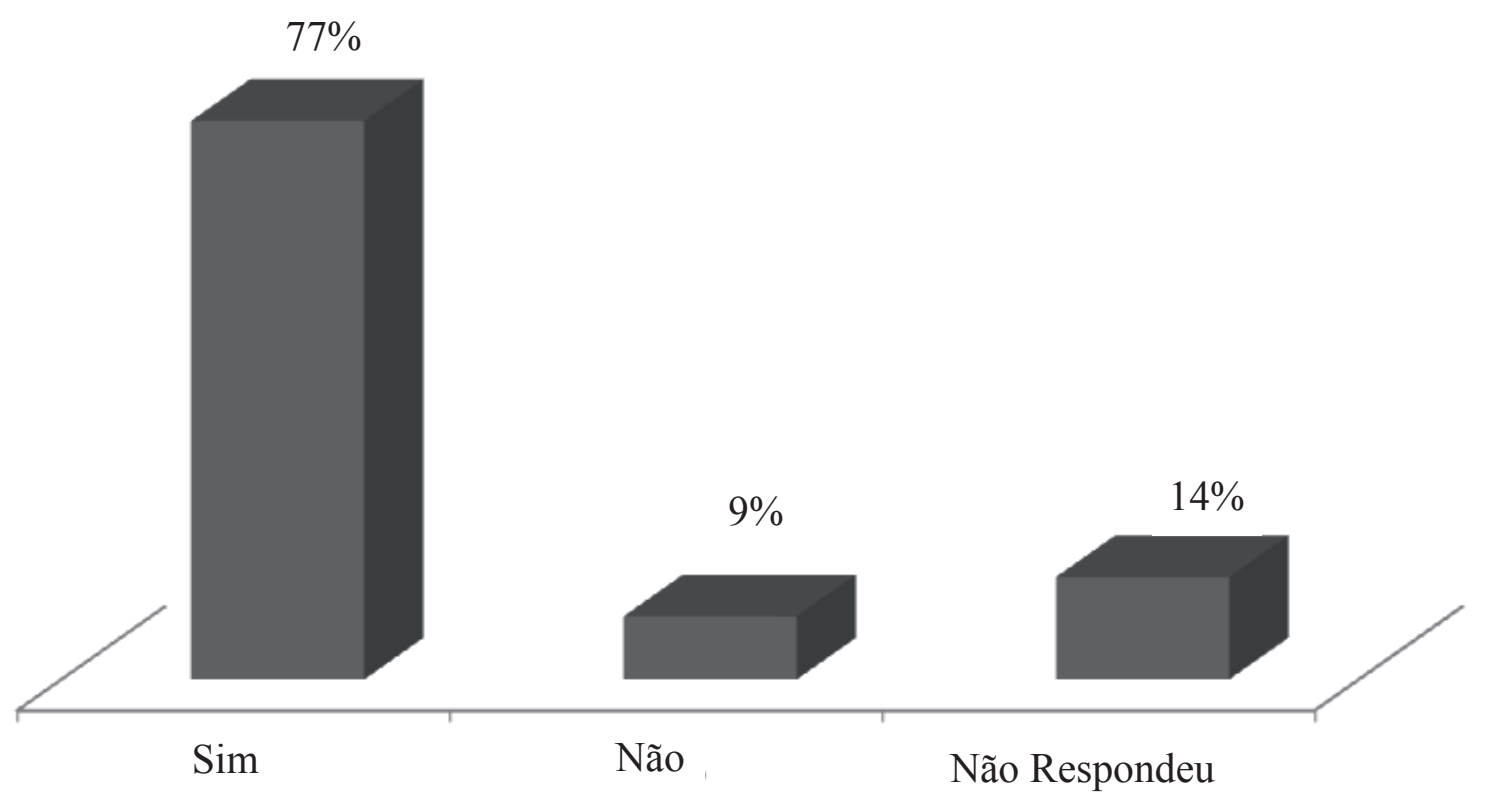

f) para alterar valores contratuais em razão de inflação ou desvalorização cambial

Nesta questão também se trata da modificação do contrato em razão de fatos supervenientes, sobretudo em relação a flutuações monetárias causadas por inflação ou câmbio. Esta questão apresenta-se como uma das mais suscetíveis de variação de acordo com os fatos da 
causa. Mesmo taxas de inflação encontradas em países estáveis podem causar algum tipo de variação substancial a longo prazo. $\mathrm{O}$ mesmo se pode dizer acerca de variações cambiais. $\mathrm{O}$ impacto de cada um desse elementos na economia do contrato é algo que somente pode ser verificado no caso concreto. Todavia, pode-se afirmar que, como uma inclinação geral, a maioria (64\%) dos participantes determinaria a alteração dos valores das prestações das partes, em caso de flutuações monetárias. Trata-se aqui de uma hipótese de alteração do contrato por fatos supervenientes em que houve uma menor (embora alta) taxa de probabilidade de desconsideração do pactuado.

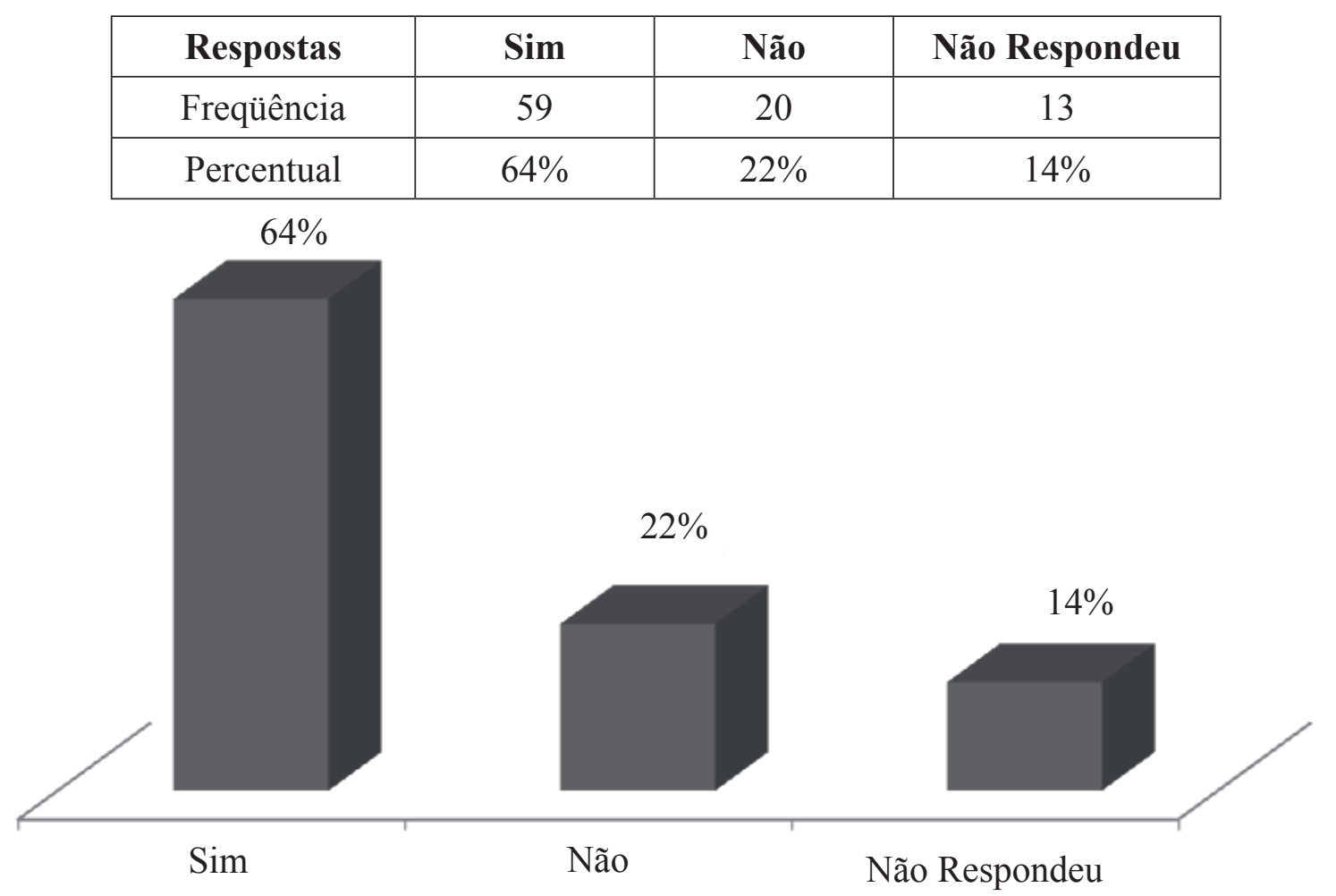

g) para fixar taxa de juros quando não prevista em lei ou no contrato (ou prevista de modo insatisfatório)

Nesta questão, procura-se aferir a atuação dos árbitros na fixação de juros. Embora fugindo da melhor técnica de metodologia de pesquisas de campo, o autor reuniu nesta pesquisa duas hipóteses: a fixação em caso de inexistência de convenção e a modificação em caso de inadequação. Neste último caso, ela pode determinar tanto o aumento, para casos de insuficiência dos juros, como a diminuição dos juros fixados. Essa escolha se deu pela relativa proximidade conceitual das duas situações, aliada à necessidade de não tornar o questionário muito extenso.

A imensa maioria dos participantes entende ser possível a alteração das taxas de juro por intermédio de uma decisão por eqüidade. 


\begin{tabular}{|c|c|c|c|}
\hline Respostas & Sim & Não & $\begin{array}{c}\text { Não Respon- } \\
\text { deu }\end{array}$ \\
\hline Freqüência & 70 & 8 & 14 \\
\hline Percentual & $76 \%$ & $9 \%$ & $15 \%$ \\
\hline
\end{tabular}

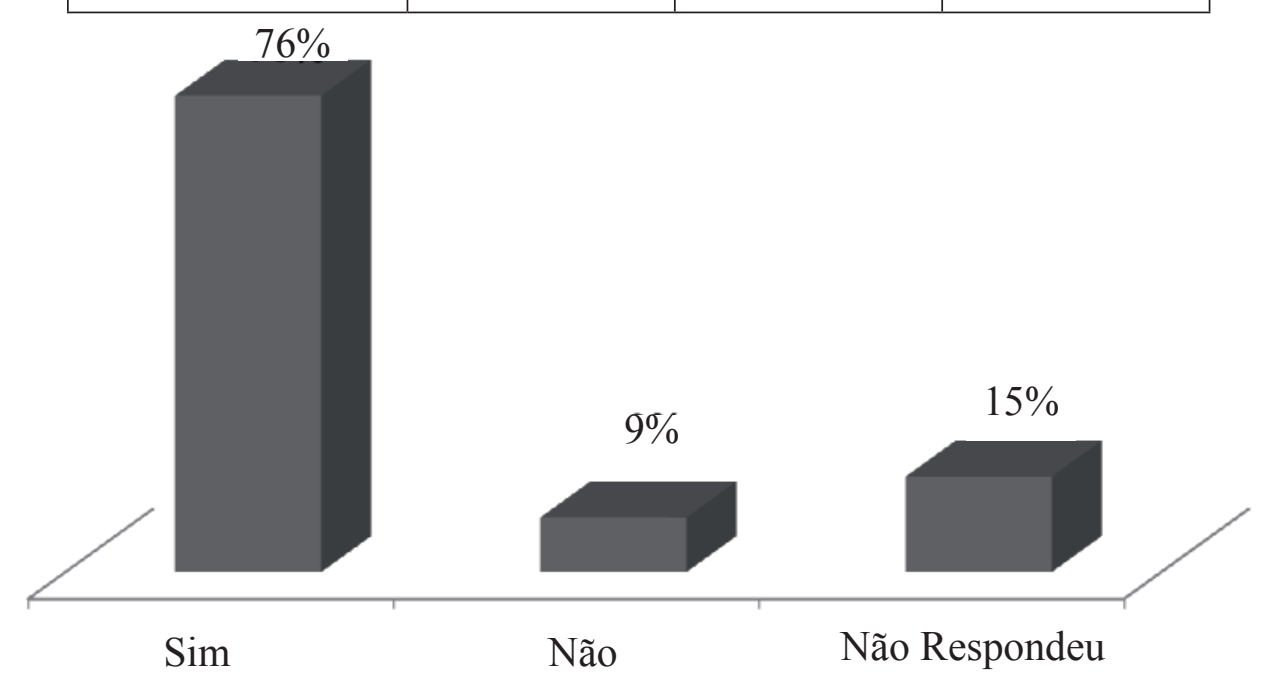

h) para autorizar compensação de valores entre as partes, sem formalidades

A compensação de valores serve para a regulação dos créditos entre as partes. Normalmente, ela é sujeita a certos requisitos e formalidades, por exemplo, ambos os créditos serem certos e vencidos. No entanto, sobretudo em relacionamentos complexos, pode haver créditos e débitos que não preencham todos os requisitos legais. Pergunta-se se, decidindo em eqüidade, os participantes tenderiam a permitir a compensação entre créditos que não preenchessem todos os requisitos. A maioria dos participantes (70\%) autorizaria a compensação sem a observância de formalidades.

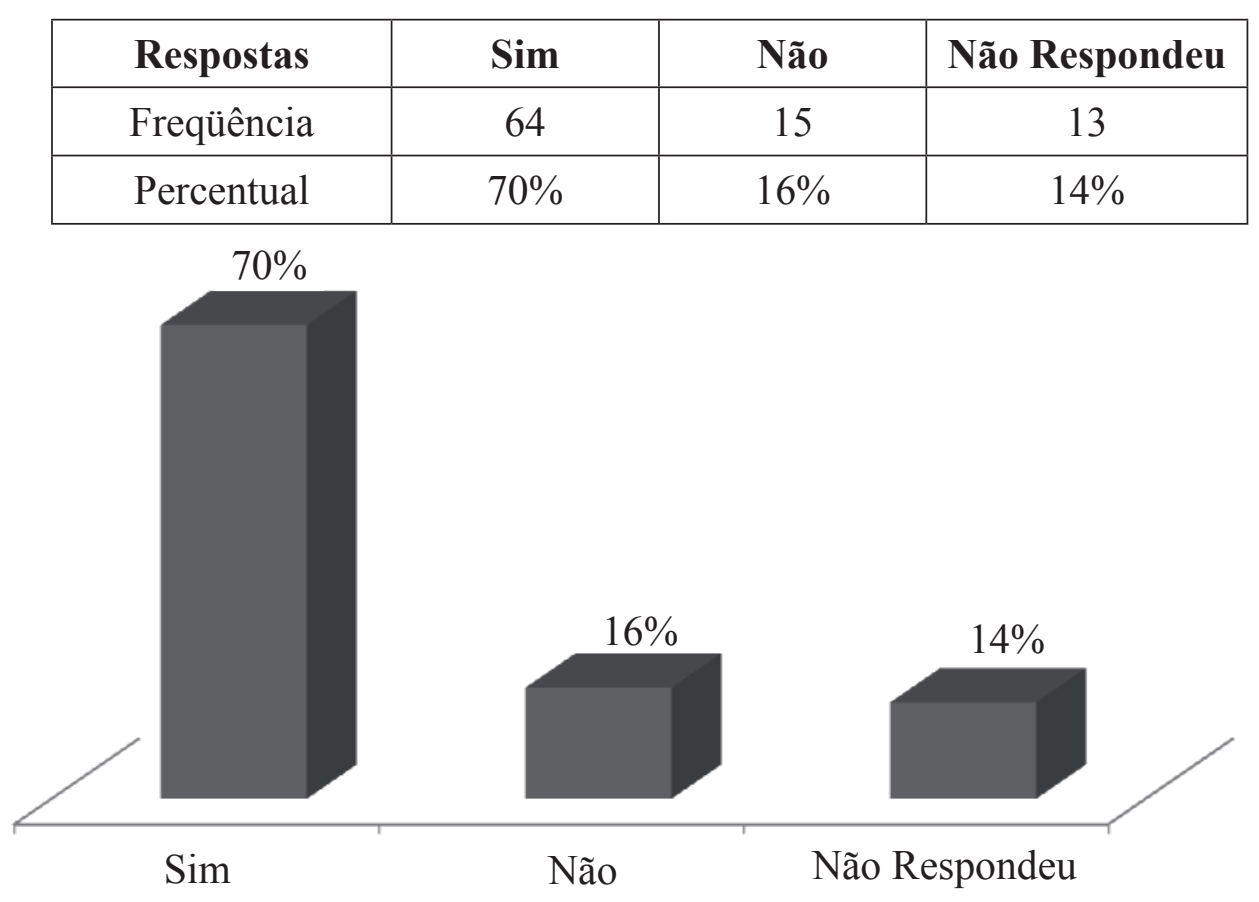


i) para aumentar prazos de prescrição para exercício de direitos

Nesta questão, busca-se saber se, na opinião dos participantes, os árbitros podem modificar ou desconsiderar prazos prescricionais para o exercício de direitos. Além de precedentes, a escolha deste tema levou em consideração um dos pontos que costumam causar problemas em certos contratos internacionais (sobretudo compra e venda): prazos prescricionais curtos em alguns ordenamentos, especialmente para vícios redibitórios.

Contudo, uma sólida maioria dos participantes entende que os árbitros decidindo em eqüidade não podem desconsiderar os prazos de prescrição. Parte de tal posicionamento pode ser explicado pelo fato de diversos ordenamentos levarem em conta disposições relativas a prescrição como de ordem pública o que impede, em certos casos, a renúncia à prescrição não adquirida.

\begin{tabular}{|c|c|c|c|}
\hline Respostas & Sim & Não & Não Respondeu \\
\hline Freqüência & 27 & 55 & 10 \\
\hline Percentual & $29 \%$ & $60 \%$ & $11 \%$ \\
\hline
\end{tabular}

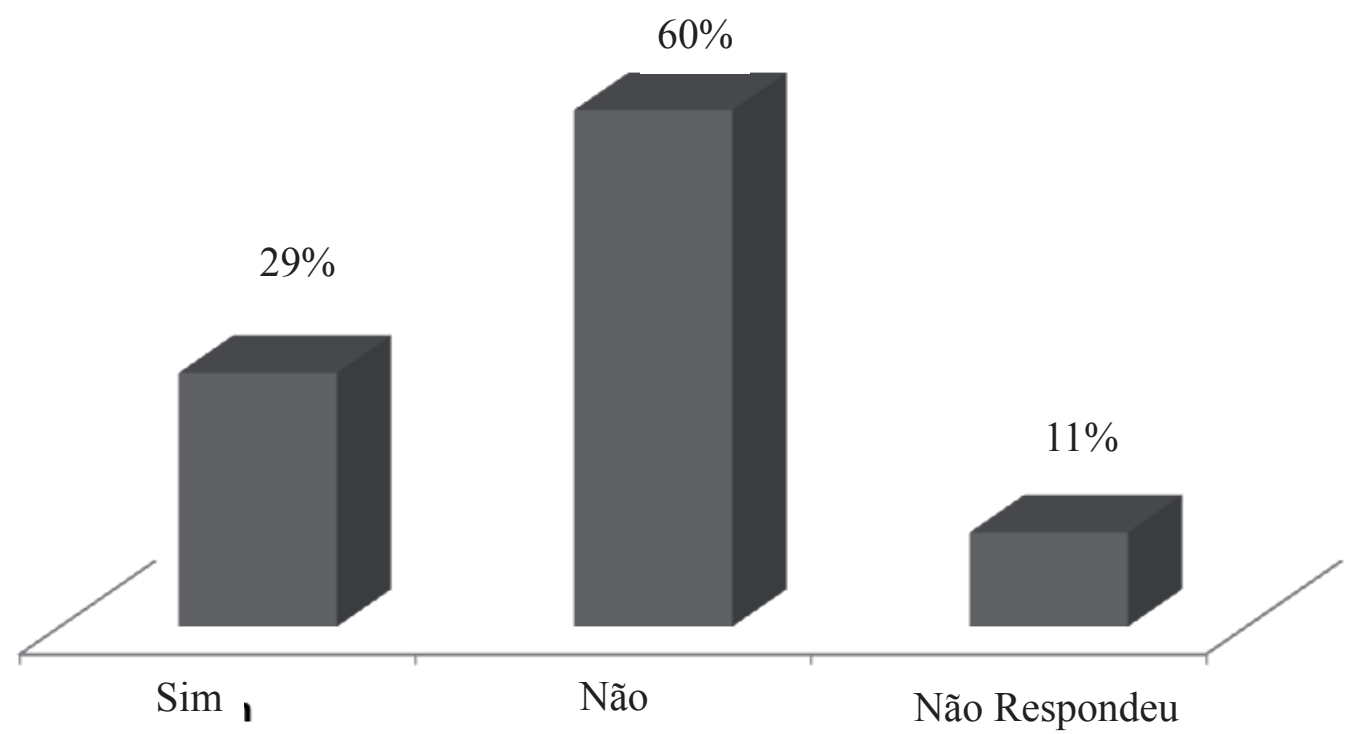

j) para aumentar prazos de pagamento previstos pelo contrato ou pela lei

A concessão de prazos adicionais para uma parte que porventura encontre dificuldades aparece como uma hipótese clássica de concessão equitativa, seja em decisões arbitrais, seja em negociações. Neste caso, pergunta-se se os participantes concederiam prazos adicionais para pagamentos, estendendo aqueles previstos no contrato ou na lei. Embora a maioria tenha opinado em favor da extensão quando a eqüidade o recomendar (64\%), note-se que este percentual é menor que o de outras hipóteses. 


\begin{tabular}{|c|c|c|c|}
\hline Respostas & Sim & Não & Não Respondeu \\
\hline Freqüência & 59 & 21 & 12 \\
\hline Percentual & $64 \%$ & $23 \%$ & $13 \%$ \\
\hline
\end{tabular}

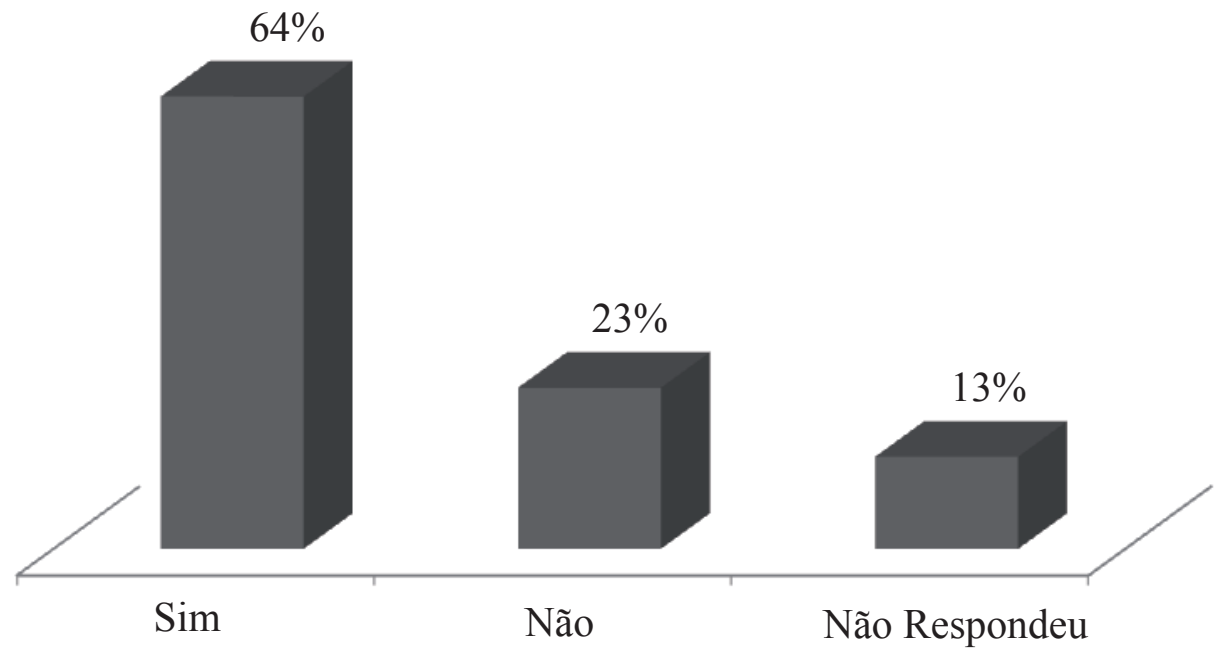

k) para desconsiderar um prazo processual da arbitragem

Nesta questão, procura-se aferir a possibilidade de atuação da eqüidade sobre o procedimento arbitral. Pergunta-se se, por eqüidade, pode-se desconsiderar um prazo processual, por exemplo, para que uma das partes apresente determinada manifestação a destempo. Tal como em outras questões procedimentais, a maioria dos participantes (49\%) afirma que não desconsideraria prazos processuais.

\begin{tabular}{|c|c|c|c|}
\hline Respostas & Sim & Não & Não Respondeu \\
\hline Freqüência & 36 & 45 & 11 \\
\hline Percentual & $39 \%$ & $49 \%$ & $12 \%$ \\
\hline
\end{tabular}

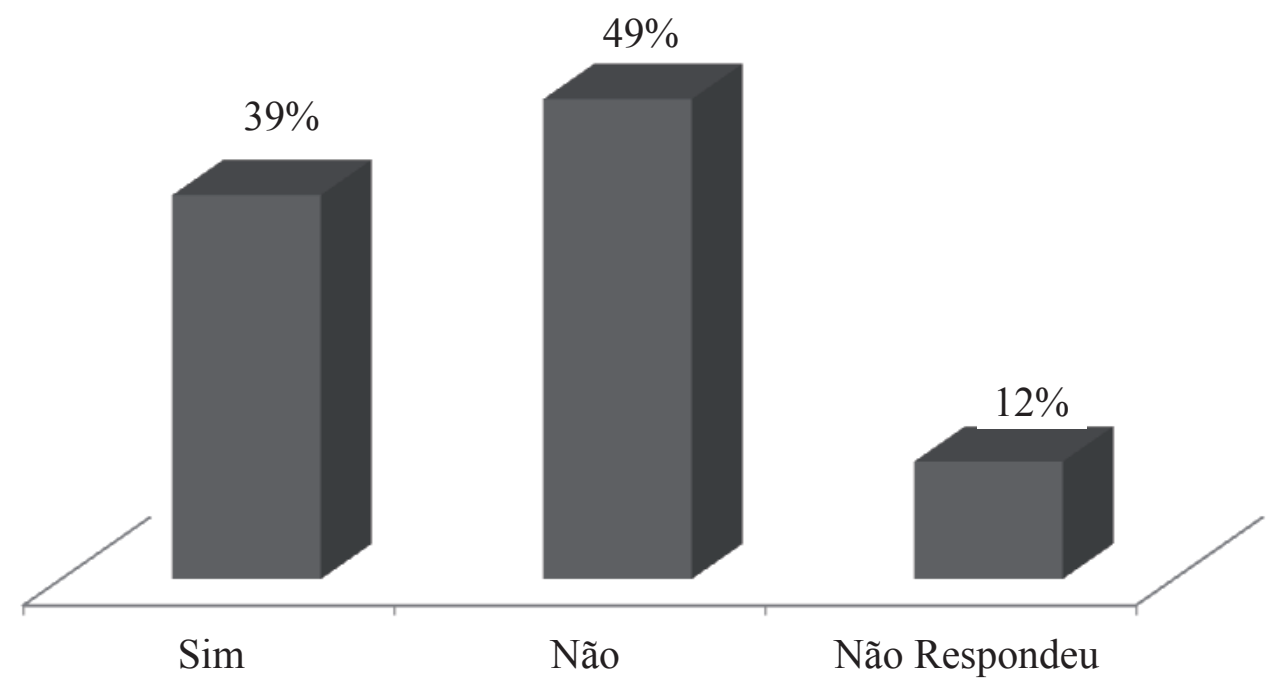




\section{l) para alterar o ônus da prova}

Nesta pergunta, que pode ser reputada como integrante do bloco de efeitos processuais da arbitragem por eqüidade, pergunta-se se os participantes considerariam a modificação do ônus da prova.

Como se sabe, a regra geral da distribuição do ônus da prova é a de que quem alega um fato em seu benefício deve prová-lo. Todavia, pode-se mitigar tal regra invertendo-se, para o fim específico de determinado fato, a presunção de veracidade, ou ainda considerando indícios em favor da parte que alega o fato.

Naturalmente, o limite de tal possibilidade é o do devido processo. Há exemplos de arbitragens por eqüidade em que os árbitros decidem mitigar a distribuição do ônus da prova, em prol de maior flexibilidade e tratamento equitativo entre as partes. Entretanto, a maioria dos participantes da pesquisa entende que não inverteriam a distribuição do ônus da prova normalmente prevista em decorrência de considerações de eqüidade. Embora exista um número substancial de participantes que inverteriam o ônus da prova (38\%), a maioria (47\%) não entende dessa forma.

\begin{tabular}{|c|c|c|c|}
\hline Respostas & Sim & Não & Não Respondeu \\
\hline Freqüência & 35 & 43 & 14 \\
\hline Percentual & $38 \%$ & $47 \%$ & $15 \%$ \\
\hline
\end{tabular}

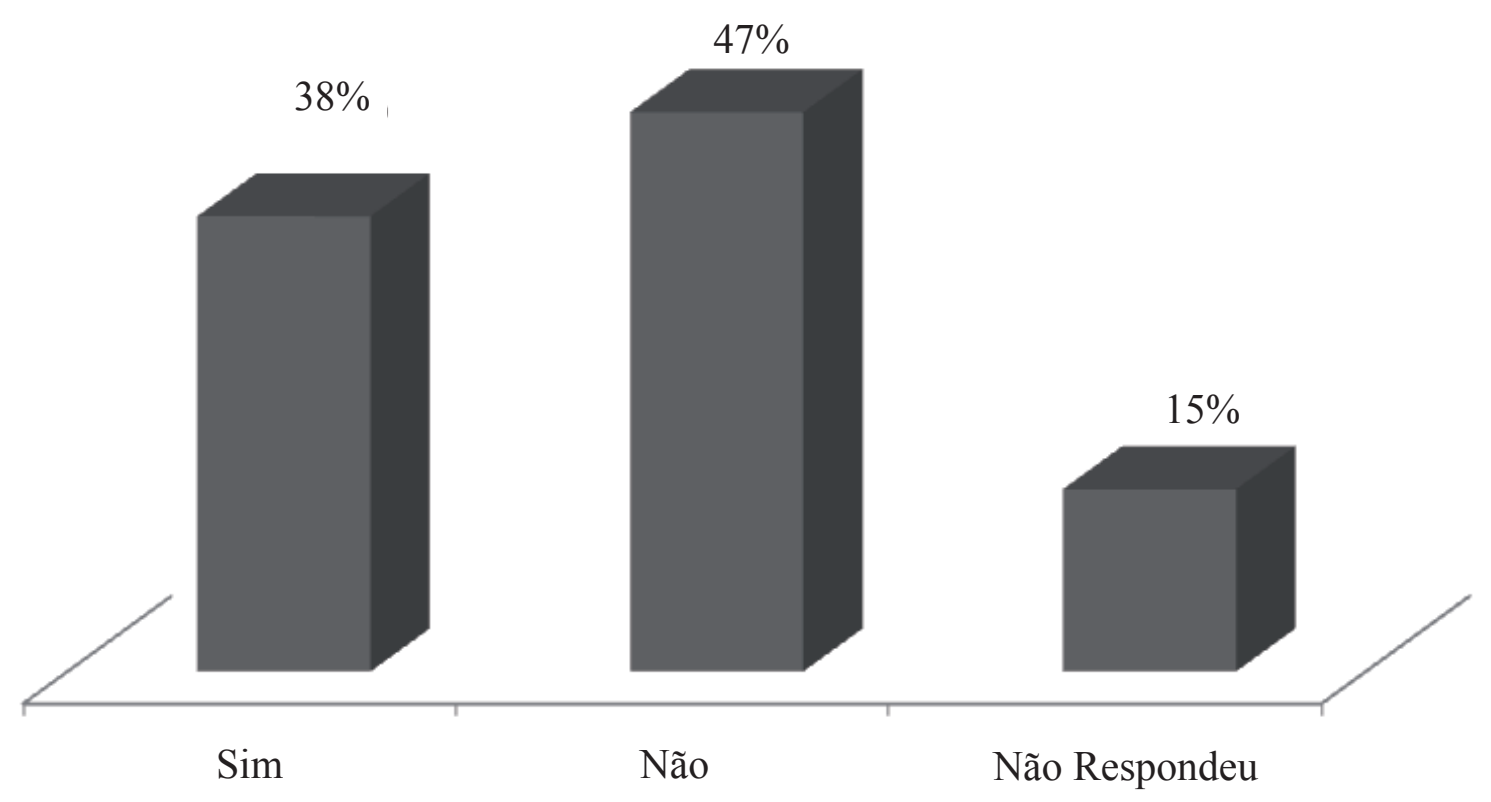


Nesta questão, busca-se verificar a opinião dos participantes quanto ao potencial tratamento diferenciado das partes, caso uma delas seja mais vulnerável economicamente. Naturalmente, a questão depende, em larga medida, do caso concreto e do que se venha a entender como maior vulnerabilidade econômica. Esta pode variar imensamente: tanto uma empresa de grande porte pode passar por dificuldades financeiras e apresentar-se de modo mais vulnerável na relação como partes economicamente menores podem apresentar ainda assim um grau de higidez econômica que não permita considerá-las vulneráveis. Para os efeitos desta questão, o autor considerou como "mais vulnerável economicamente" a parte que esteja em clara desvantagem em relação à outra em termos de cumprimento das obrigações.

Embora por uma diferença de 5\%, a maioria dos participantes entende que não derrogaria lei ou contrato para diminuir obrigações da parte mais vulnerável. Com todas as cautelas relativas ao método da pesquisa, pode-se afirmar que a vulnerabilidade econômica pode não ser razão suficiente para a intervenção da eqüidade.

\begin{tabular}{|c|c|c|c|}
\hline Respostas & Sim & Não & Não Respondeu \\
\hline Freqüência & 37 & 41 & 14 \\
\hline Percentual & $40 \%$ & $45 \%$ & $15 \%$ \\
\hline
\end{tabular}

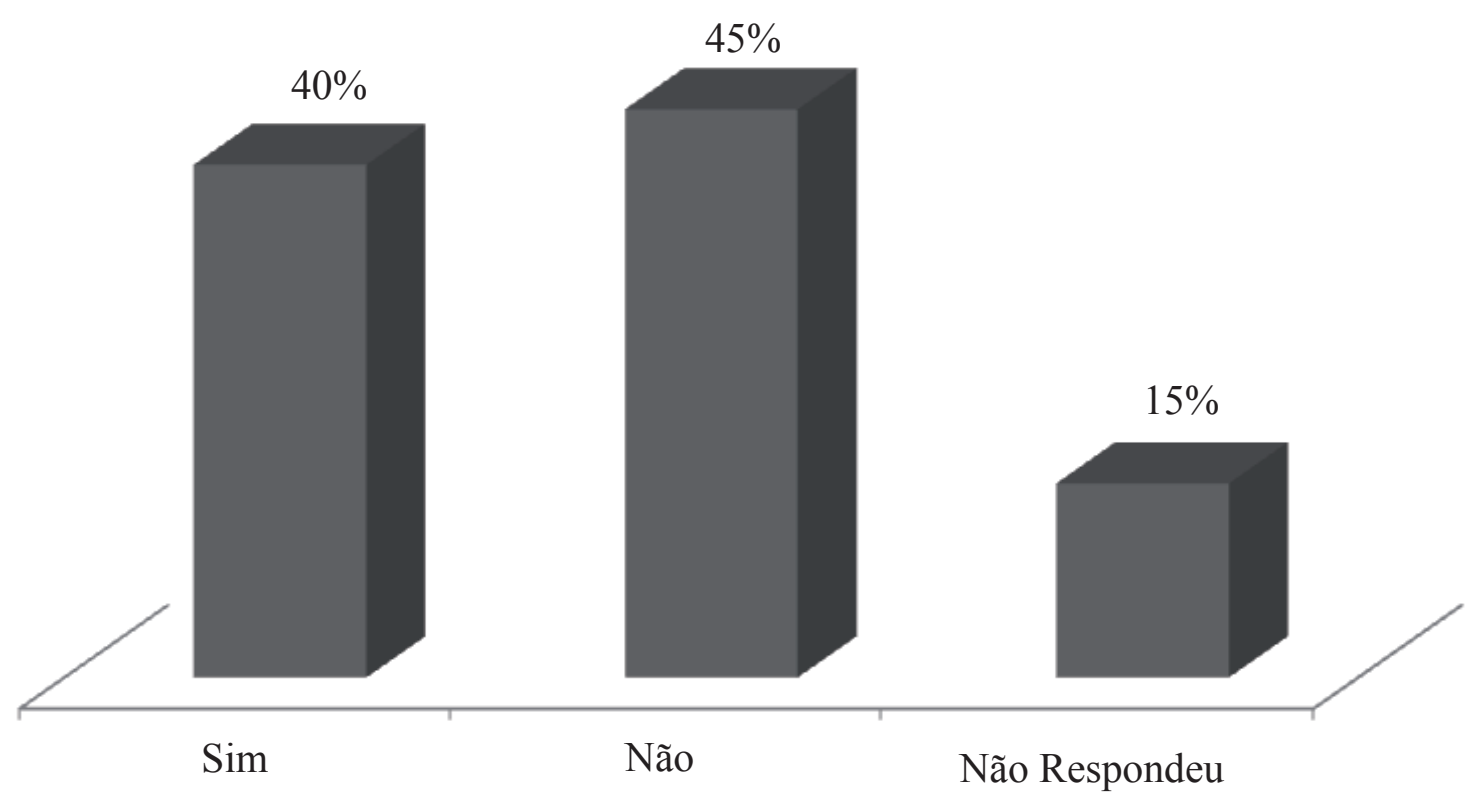


n) para aumentar o dever de informação entre as partes para niveis superiores aos requeridos por lei

Nesta questão, procura-se saber se a eqüidade pode operar um dever de informação entre as partes superior àquele previsto em lei. Esse dever de informação pode ocorrer tanto na fase contratual ou pré-contratual: espera-se boa-fé das partes em revelar suas intenções, todas as informações relevantes para que a outra parte tome suas decisões negociais.

Esse dever de informação tem sido coberto por direitos nacionais, o que se convencionou chamar de boa-fé objetiva. No entanto, nem sempre os ordenamentos jurídicos prevêem tais deveres de modo explícito, como era o caso do direito civil brasileiro até a edição do Código Civil de 2002.

De acordo com a resposta dos participantes, $51 \%$ deles entendem que a arbitragem por eqüidade deverá considerar, em grau relativamente maior que o previsto no direito positivo, o dever de informar as circunstâncias factuais relevantes que envolvam a relação jurídica.

Ainda que a função principal da pergunta seja relativa ao direito material, ela pode ter reflexos nos procedimentos: a demonstração de certos comportamentos pode requerer maior flexibilidade na administração da prova por parte do tribunal arbitral. ${ }^{1096}$

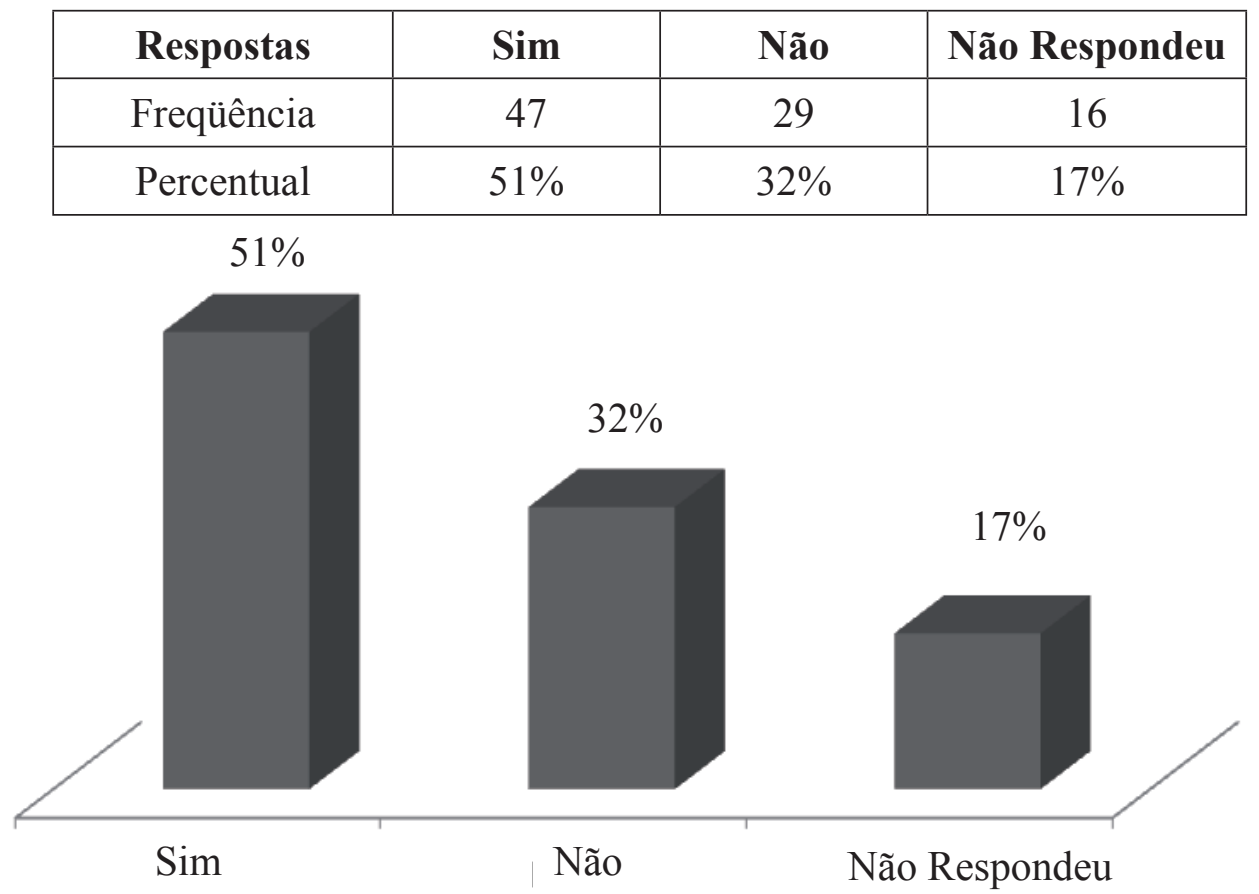

\footnotetext{
${ }^{1096}$ Um participante questionou se a presente questão referia-se ao comportamento processual das partes em uma arbitragem por eqüidade. Foi-lhe esclarecido que não. Admitindo-se que outros tenham respondido com base na mesma hipótese, a conclusão da pergunta altera-se para um comportamento processual. Por ele, verificarse-ia uma tendência maior, na arbitragem por eqüidade, de busca da verdade material, em relação à arbitragem comum. Haveria, assim, uma maior flexibilidade processual para a busca da verdade material.
} 


\section{o) Outros}

Nesta seção, os participantes puderam indicar outras hipóteses em que considerações de eqüidade poderiam sobrepor-se à estrita aplicação do direito positivo. Diversos utilizaram o espaço para considerações adicionais acerca da atuação por eqüidade.

Alguns participantes afirmam que os árbitros decidindo por eqüidade não devem afastar-se demasiadamente das grandes linhas do direito positivo ou contradizer a vontade das partes.

Um deles menciona que entende que os princípios do Unidroit refletem as grandes linhas de eqüidade que os árbitros devem aplicar nas disputas comerciais internacionais.

Outro participante afirma que, embora o árbitro decidindo em eqüidade tenha ampla autoridade para decidir o que entende ser justo, não deve utilizar esse poder em toda a sua extensão. Deve, antes, aplicar princípios equitativos reconhecidos (recognized equitable principles). Este participante é oriundo da tradição da common law, em que equitable principles podem ter um significado diferente do sentido comum dos países de direito de origem romanogermânica.

Outra hipótese apontada foi a possibilidade de trazer à arbitragem terceiros que possam vir a ser considerados responsáveis em última instância (evitando-se, assim, ações de regresso ou permitindo participação mais ativa destes).

Um participante estabelecido nos EUA informa que as cláusulas de arbitragem por eqüidade podem ingressar na arbitragem por meio do uso da palavra "justiça" na cláusula de arbitragem, sem referência direta à palavra eqüidade (ex aequo et bono).

Outro informa que os desvios do contrato devem ser muito excepcionais. Além disso, a arbitragem por eqüidade deve deixar a cargo das partes as adaptações contratuais e os árbitros devem se restringir à resilição. Na mesma linha, outro participante opina que o árbitro decidindo em eqüidade deve respeitar tanto a lei quanto o contrato. Ele pode apenas atuar os efeitos que lhe pareçam iníquos e desde que não se trate de regra de ordem pública.

No tocante à pesquisa, um participante afirma que suas respostas positivas devem ser entendidas no sentido de que é possível em certos casos chegar a esse efeito, mas não se trata de uma regra de princípio. 


\subsubsection{Principal área de atuação dos participantes}

Os participantes foram convidados a descrever quais suas ocupações principais. Como algumas delas se sobrepõem, foram convidados a marcar tantas opções quantas fossem necessárias. Por essa razão, a soma das respostas a este quesito é superior ao número de participantes.

A maioria dos participantes descreveu sua principal atividade como a de árbitro. Em segundo lugar, advogado atuando em escritório, seguida de atividades acadêmicas e, a uma considerável distância, advogado trabalhando em empresa.

\begin{tabular}{|c|c|c|c|c|}
\hline $\begin{array}{c}\text { advogado atuando } \\
\text { em escritório }\end{array}$ & $\begin{array}{c}\text { advogado atuando } \\
\text { em empresa }\end{array}$ & árbitro & acadêmico & outros \\
\hline $33 \%$ & $4 \%$ & $36 \%$ & $23 \%$ & $4 \%$ \\
\hline 52 & 7 & 58 & 37 & 6 \\
\hline
\end{tabular}

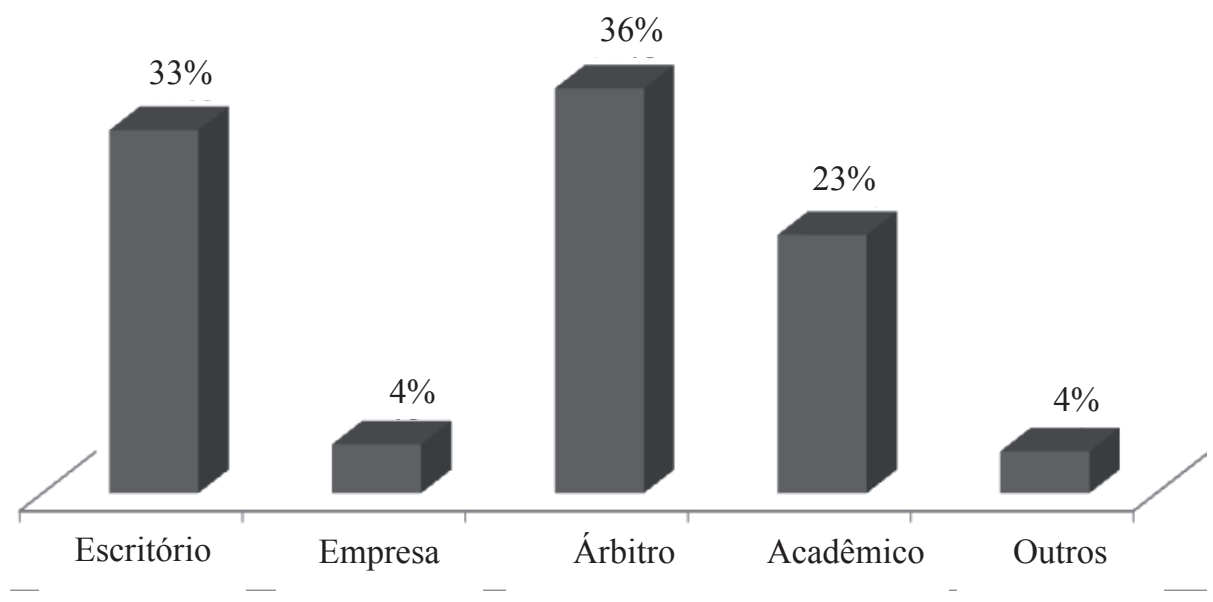

\subsection{Conclusões}

A título de conclusão deste capítulo, pode-se afirmar que:

(i) a arbitragem por eqüidade representa em geral menos de $10 \%$ do total de arbitragens em que os participantes tiveram contato;

(ii) o percentual de experiência efetiva com arbitragens por eqüidade dos participantes oscila entre 52\% (atuação como árbitros) e 40\% (representação de partes); 
(iii) a arbitragem por eqüidade é recomendada por $45 \%$ dos participantes, contra $55 \%$ que não a recomendam;

(iv) dos participantes que recomendam a arbitragem por eqüidade, a maior parte entende que ela é adequada, em primeiro lugar, a contratos de longa duração. Em segundo lugar, a casos em que haja problemas com a escolha da lei aplicável ou quando esta seja desfavorável, insuficiente ou desconhecida das partes. Em terceiro lugar, a relações contratuais complexas que envolvam grandes prestações e diversos ordenamentos jurídicos;

(v) quanto aos contratos em espécie, há maior referência aos de construção e de sociedade;

(vi) os participantes entendem que os árbitros podem descartar as disposições contratuais que lhes pareçam injustas; todavia, não podem modificar seu conteúdo econômico;

(vii) a maioria dos participantes entende que os árbitros devem escolher uma lei aplicável e desconsiderar as disposições injustas, em vez de decidir apenas conforme a consciência;

(viii) os árbitros devem respeitar a ordem pública, segundo opinião unânime dos participantes;

(ix) a maioria dos participantes entende que a eqüidade serve com maior propriedade à adequação da relação aos fatos supervenientes, para alterar preços ajustados, condições do contrato, reduzir proporcionalmente multas e indenizações prefixadas, alterar valores ou aumentar prazos de pagamento;

(x) a maioria dos participantes entende que a eqüidade serve também para estimar indenizações, autorizar compensação sem os requisitos legais, adequar taxa de juros e para estabelecer deveres de informação entre as partes maiores dos que os previstos em lei;

(xi) a maioria dos participantes entende que a arbitragem não se presta a aumentar prazos prescricionais, aumentar prazos procedimentais na arbitragem, autorizar a inversão do ônus da prova ou ainda para diminuir obrigações das partes economicamente mais fracas. 


\section{CONCLUSÕES GERAIS}

Ao fim deste trabalho, podem-se delinear algumas considerações gerais a pretexto de conclusão.

Sob um ponto de vista histórico, a arbitragem por eqüidade existe desde a Grécia antiga. O instituto foi conhecido em Roma, na forma da decisão do bonus vir e na arbitragem ex compromisso. Na Idade Média, ela foi desenvolvida sobretudo na obra dos glosadores. Ela foi reconhecida em muitas legislações nacionais criadas na esteira do movimento de codificação, inclusive na brasileira. Nos dias atuais, ela é amplamente reconhecida nos direitos nacionais. $\mathrm{O}$ movimento de renovação das legislações de arbitragem ocorrido desde as últimas décadas do século XX consolidou o reconhecimento no mundo. Este mesmo movimento tem forjado uma disciplina mais ou menos comum para o instituto, nos moldes propostos pela Lei Modelo da CNUDCI.

De um ponto de vista sincrônico, a arbitragem por eqüidade é admitida na ampla maioria dos países. O movimento de reforma das leis nacionais de arbitragem serviu para modificar posições legislativas anteriormente contrárias a este tipo de arbitragem.

A arbitragem por eqüidade é uma espécie do gênero arbitragem e não um instituto à parte. Propomos neste trabalho que ela, arbitragem por eqüidade, seja qualificada sobretudo como uma forma de arbitragem dotada de critério de decisão específico. Esse critério caracteriza-se pela liberdade de método e pela possibilidade de derrogação do direito positivo. Esse tipo de arbitragem igualmente contém um elemento abdicativo, porque implica o abandono de certos direitos pelas partes. Todavia, a caracterização tradicional da arbitragem por eqüidade como renúncia, embora explique um aspecto do instituto, deixa de abordar seu aspecto positivo: a forma de julgamento conforme a consciência. A renúncia não é seu único elemento caracterizador.

Não obstante a arbitragem por eqüidade tenha diversas denominações conforme o ordenamento ou o idioma que se examine, as divergências semânticas não indicam diferença substancial na natureza do instituto.

Para efeitos de qualificação, a cláusula de arbitragem integra o domínio da cláusula arbitral, em nossa opinião. Ela encontra-se sujeita à autonomia das partes para a escolha de lei aplicável. Entretanto, a lei do local da arbitragem pode apresentar uma barreira importante à 
existência da arbitragem por eqüidade. Essa ameaça à validade da cláusula de arbitragem por eqüidade foi maior no passado e hoje se encontra restrita a poucos países. Caso se admita a existência de regras materiais transancionais aplicáveis pelo árbitro internacional diretamente à cláusula, sem recurso a elementos de conexão, pode-se afirmar que existem algumas específicas à cláusula de arbitragem por eqüidade, retiradas do exame do direito comparado e da jurisprudência arbitral.

Quanto à mecânica decisória, não existe a primazia necessária de nenhum método para a decisão por eqüidade. Entre os diversos possíveis, nenhum é determinado por ordenamento estatal, regulamento arbitral ou reconhecido de forma dominante na jurisprudência. Portanto, o juízo de eqüidade caracteriza-se pela liberdade de escolha de método. Qualquer um dos existentes pode ser adotado pelos árbitros, desde que conduzam a uma decisão equitativa. $\mathrm{O}$ efeito principal de todos eles é a possibilidade de derrogação do direito positivo. Todavia, nada impede que os árbitros decidam de acordo com o direito positivo, caso este ofereça a solução justa para o caso. Embora a decisão por eqüidade se aplique sobretudo ao mérito, tem-se reconhecido a possibilidade de os árbitros decidirem questões prévias ao mérito por este método.

Quanto ao procedimento, a escolha da eqüidade também produz efeitos. No tocante ao procedimento previsto em lei, as modificações podem ocorrer por expressa previsão legal ou pela faculdade de derrogação de normas supletivas genericamente conferida aos árbitros. No que diz respeito ao procedimento convencional, existe desacordo na doutrina. No entanto, encontram-se precedentes de derrogação das normas convencionadas pelas partes. Em qualquer hipótese, os árbitros devem respeitar o devido processo, sob pena de nulidade.

Os limites para a decisão por eqüidade são fixados pela ordem pública, o devido processo e a vontade das partes. No caso da arbitragem internacional, submete-se nesta tese que, em conjugação de pontos de vista doutrinários e práticos, se deva respeitar a chamada ordem pública "verdadeiramente internacional" e a ordem pública do local de execução da sentença arbitral. Quanto ao contrato, a despeito de divergências doutrinárias, parece estar em curso a sedimentação do entendimento pelo qual os árbitros podem descartar disposições contratuais que conduzam a soluções injustas. Entretanto, não podem alterar de modo substancial a economia do contrato.

Nos ordenamentos nacionais, vislumbram-se três sistemas diferentes em relação à arbitragem por eqüidade. Na imensa maioria dos casos, permite-se-a desde que as partes assim convencionem. Presume-se, portanto, a arbitragem de direito, salvo convenção em contrário. Esse é o sistema predominante no mundo. Um segundo sistema, utilizado por alguns países 
hispano-americanos, presume que a arbitragem seja por eqüidade, salvo convenção das partes. Um terceiro sistema, adotado por poucos países, não permite a arbitragem por eqüidade.

Os tratados internacionais em geral não mencionam a arbitragem por eqüidade. Aqueles que o fazem, apresentam uma regra material: permitem-na, desde que as partes convencionem. Os regulamentos de arbitragem em geral seguem os mesmos sistemas acima expostos. Em termos de distribuição geográfica, as instituições tendem a seguir o regime do país em que estejam situadas. As instituições de vocação internacional seguem o sistema da presunção de arbitragem de direito.

$\mathrm{Na}$ pesquisa de campo realizada para esta obra, a maioria dos participantes não recomenda a arbitragem por eqüidade, embora parte considerável a recomende. A maioria dos participantes entende que a eqüidade serve com maior propriedade à adequação do contrato a situações supervenientes. Também opina que a eqüidade serve para efetuar estimativas de danos e para impor certos requisitos de boa-fé. Por outro lado, afirma que a eqüidade não se presta a aumentar prazos prescricionais, aumentar prazos procedimentais na arbitragem, autorizar a inversão do ônus da prova ou ainda para diminuir obrigações das partes economicamente mais fracas.

A arbitragem por eqüidade é excepcional no âmbito internacional. E talvez deva continuar da mesma forma. Seu caráter peculiar como método decisório recomenda um juízo prévio de conveniência, que nem sempre será feito caso a decisão por eqüidade seja presumida. Todavia, em um número considerável de casos, a arbitragem por eqüidade pode apresentar vantagens concretas sobre a arbitragem de direito.

O uso da eqüidade é a expressão de um justo anseio humano. Traz em si a busca de uma justiça mais intuitiva do que técnica, mais sentida do que elaborada: uma justiça voltada à boa-fé e à proporcionalidade. Seu amplo reconhecimento no mundo reflete a imanência desse anseio nas diversas culturas. Sua existência na arbitragem internacional demonstra que os operadores do comércio compartilham dessa aspiração.

Seu uso é excepcional e depende de vontade clara. É correto que assim o seja, porque causa maior incerteza e esta não deve ser presumida. Todavia, em sua excepcionalidade, seu espaço deve ser preservado como forma de atender a uma aspiração ancestral e moderna. Moderna como são todas as questões ancestrais. 


\section{REFERÊNCIAS BIBLIOGRÁFICAS}

Albiges, Christophe. De l'Équité en Droit Privé. Paris, LGDJ, 2000.

Alvim, Agostinho. Da eqüidade. Revista dos Tribunais, São Paulo, v. 82, p. 3 e ss., 1941.

Andrade, Mário de. A escrava que não é Isaura. Obra imatura. 3. ed. São Paulo: Martins; Belo Horizonte: Itatiaia, 1980. p. 201.

ARISTóteles. Arte retórica e arte poética. 16. ed. Rio de Janeiro: Ediouro, [s.d.].

—. Ética a Nicômaco. Bauru: Edipro, 2002.

Arnaldez, Jean-Jacques; Derains, Yves; Hascher, Dominique. Collection of ICC Arbitral Awards, 1991-1995. Recueil des Sentences Arbitrales de la CCI, 1991-1995. Boston: Kluwer Law International, 1997. p. 613.

AsCARelli, Tulio. Lezioni di diritto commerciale. Introduzione. 2. ed. Milano: Giuffrè, 1955.

Ascensão, José de Oliveira. Verbete "Eqüidade". Enciclopédia Saraiva do Direito. São Paulo: Saraiva, 1977.

BAPTISTA, Luiz Olavo. Arbitragem e contratos internacionais: a proteção da parte mais fraca. In: PuccI, Adriana (Coord.). Arbitragem comercial internacional. São Paulo: LTr, 1998. p. 77.

—. Contrato de risco. São Paulo: Bushatsky, 1976.

- Magalhães, José Carlos de. Arbitragem comercial. Rio de Janeiro: Freitas Bastos, 1986.

Berger, Klaus Peter. International Economic Arbitration. Boston: Kluwer Law and Taxation Publishers, 1993.

et. al. The Central Enquiry on the use of Transnational Law. In: (Ed.). International Contract Law and Arbitration - Background, Procedure and Selected Results. The Practice of Transnational Law. The Hague: Kluwer Law International, 2001. p. 91 e ss.

BetTi, Emilio. Diritto romano - parte generale. Padova: Cedam, 1935.

Beviláqua, Clóvis. Código Civil dos Estados Unidos do Brasil comentado. 6. ed. Rio de Janeiro: Livraria Francisco Alves, 1943.

—. Theoria geral do direito civil. Rio de Janeiro: Francisco Alves, 1929.

Biamonti, Luigi. Verbete “Arbitrato”. Enciclopedia del diritto. Milano: Giuffrè, 1958. p. 944. 
Biscardi, Arnaldo. On Aequitas and Epikeia in Aequitas and Equity: Equity in Civil Law and Mixed Jurisdictions. Anais da Second International Conference on Aequitas and Equity. Jerusalém: The Hebrew University of Jerusalém, 1997. p. 1-22.

Blessing, Marc. Globalization (and harmonization?) of arbitration. Journal of International Arbitration, v. 9, n. 1, p. 79 e ss., 1992.

- The Law Applicable to the Arbitration Clause. In: Van Den Berg, Albert Jan (Ed.). ICCA Congress Series. The Hague: Kluwer Law International, 1999. n. 9.

Boввіо, Norberto. Il positivismo giuridico. Torino: Cooperativa Libraria Universitária Torinese, 1961.

Borsséson, Matthieu de. Le Droit Français de l'Arbitrage: interne et international. Paris: GLN Joly, 1990.

- L ' Abitre International et le Problème de la Qualification in Liber Amicorum Claude Reymond. Paris: Litec Lexis Nexis, 2004.

Bond, Stephen R. How to Draft an Arbitration Clause (revisited). The ICC International Court of Arbitration Bulletin, v. 1, n. 2, p. 19, dez. 1990.

Bonfante, Pietro. Diritto romano. Milano: Giuffrè, 1976.

Bowers, Renzo D. A Treatise on the Law of Waiver. Denver: The W. H. Courtright Publishing Co., 1914.

Boyd, Stewart. Arbitrator not to be bound by the law clauses in Arbitration International, v. 6, n. 2, p. $122,1990$.

Bredin, Jean Denis. L'amiable composition et le contrat. Revue de L'Arbitrage, Paris, Comité Français de l'Arbitrage, n. 2, p. 271, 1984.

—. À la Recherche de l'Aequitas Mercatoria in L'Internationalisation du Droit. Mélanges en l'Honneur de Yvon Loussouarn. Paris, Dalloz, 1994, p. 109.

—. La Loi du Juge in Le Droit des Relations Économiques Internationales. Études Offertes à Berthold Goldman. Paris: Litec, 1982, p. 15.

Broggini, Gerardo. Aspetti Storici e Comparativisti in L'Equita. Atos da Convenção sobre Eqüidade realizada pelo Centro Nazionale di Prevenzione e Difesa Sociale. Milano: Giuffrè, 1975. p. 29.

- Réflexions sur l'Équité dans l'Arbitrage International. Bulletin de la Association Suisse de l'Arbitrage, n. 2, p. 95 e ss., jun. 1991. 
CAFFé Alves, Alaôr. Lógica: pensamento formal e argumentação. 3. ed. São Paulo: Quartier Latin, 2003.

Caivano, Roque J. Arbitraje. Buenos Aires: Ad Hoc Villela Editor, 2000.

Carbonnier, Jean. Les Renontiations au Bénéfice de la Loi en Droit Privé. Travaux de l'Association Henri Capitant. Paris: Dalloz, 1963. t. XIII (1959-1960).

Carmona, Carlos Alberto. Arbitragem e processo. 2. ed. São Paulo: Atlas, 2004.

Carreira Alvim, J. E. Direito Arbitral, 2. ed. Rio de Janeiro, Forense, 2004.

Carvalho Filho, Milton Paulo. Indenização por eqüidade no novo Código Civil. São Paulo: Atlas, 2003.

Carvalho Santos, J.M. Repertório enciclopédico do direito brasileiro. Rio de Janeiro: Borsoi, [s.d.]. v. 48.

Cavalcanti, José Paulo. Da renúncia no direito civil. Rio de Janeiro: Forense, 1958.

Cintra, Antonio Carlos Araújo; Grinover, Ada Pellegrini; Dinamarco, Cândido Rangel. Teoria geral do processo. 8. ed. São Paulo: RT, 1991.

Clay, Thomas. L'Arbitre. Paris, Dalloz, 2001.

CoE JR., Jack J. From Anecdote to Data: Reflections on the Global Center's Barcelona Meeting (nota n. 1). Journal of International Arbitration, v. 20, n. 1, p. 11 e ss., fev. 2003.

- International Commercial Arbitration: American principles and practice in a global context. Irvington-on-Hudson: Transnational Publishers, 1997.

Colombo, Carlos J.; KIPer, Claudio M. Código Procesal Comercial y Civil de la Nación anotado y comentado. Buenos Aires: La Ley, 2006. t. VI.

Craig, William Laurence, PARK, William; PAulsson, Jan. International Chamber of Commerce Arbitration, New York; Paris: Oceana; ICC Publishing, 1990, p. 275.

CRIFO, Giuliano. Enciclopedia del diritto. Verbete “arbitrato - diritto romano”. Milano: Giuffrè, 1958.

CuQ, Edouard. Les Institutions Juridiques des Romains. 2. ed. Paris: Librairie Plon, 1904. t. II.

Curvelo, Maurício de Almeida Prado. Le Hardship dans le Droit du Commerce International. Paris: FEC, 2003.

D’Agostino, Francesco. Dimensioni dell Equità. Torino: iapichelli, 1977.

—. Epikeia: Il tema dell'equità nell'antichità greca. Milano: Giuffrè, 1973. 
Dallari, Dalmo de Abreu. Elementos de teoria geral do Estado. 15. ed. São Paulo: Saraiva, 1991.

Dalloz, M.D. Repertoire de Legislation de Doctrine et de Jurisprudence. Verbete "Arbitrage". Paris: Bureau de la Jurisprudence Generale, 1846.

DAvID, René. Arbitration in international trade. Deventer: Kluwer Law International, 1985.

- Conception Française et Conception Anglaise de l'Arbitrage. Miscellanea W. J. Ganshof van der Meersch. Bruxelles: Etablissements Emile Bruylant, 1972. t. II.

—. Grandes sistemas de direito contemporâneo. 4. ed. São Paulo: Martins Fontes, 2002.

—. Le Concept d'Arbitrage Privé et Les Conventions Internationales. Études Juridiques Offets à Leon Julliot de la Morandière. Paris: Dalloz, 1964. p. 154-155.

—. Le Droit Comparé: Droits d'Hier, Droits de Demain. Paris: Economica, 1982.

—. O direito inglês. 2. ed. São Paulo: Martins Fontes, 2006.

Declareuil, Joseph. Du Compromis en Droit Romain et en Droit Français. Paris: Imprimerie Moquet, 1887.

Degan, V.D. L'Équité et le Droit International. La Haye (Den Haag): Martinus Nijhoff, 1970.

Della Valle, Martim. Considerações sobre pressupostos processuais em arbitragem. Revista Brasileira de Arbitragem, v. 12, p. 7 e ss., 2006.

De Marini, C. M. Il giudizio di equità nel processo civile (premesse teoriche). Padova: Cedam, 1957.

Derains, Yves. Public policy and the law applicable to the dispute in international arbitration. ICCA Congress series, Deventer, Kluwer, n. 3, p. 227-256, 1986.

- Schwartz, Eric. A Guide to the ICC Rules of Arbitration. 2. ed. The Hague: Kluwer Law International, 2005.

Dezalay; Garth. Dealing in virtue: international commercial arbitration and the construction of a transnational legal order. Chicago: The University of Chicago Press, 1996.

Dınız, Maria Helena. As lacunas no direito. 7. ed. São Paulo: Saraiva, 2006.

Dolinger, Jacob. A evolução da ordem pública no direito internacional privado. Rio de Janeiro, 1979, p. 9-10. Mimeografado.

—. Direito internacional privado (parte geral). 2. ed. Rio de Janeiro: Renovar, 1993. 
—- TiBúRCio, Carmen. Direito internacional privado: arbitragem comercial internacional. Rio de Janeiro: Renovar, 2003.

Drahozal, Cristopher R. Of Rabbits and Rhinoceri: a Survey of Empirical Research in International Commercial Arbitration. Journal of International Arbitration, v. 20, n. 1, p. 22 e ss., fev. 2003.

FARIA, José Eduardo. O direito na economia globalizada. São Paulo: Malheiros, 2002.

Ferraz JR., Tércio Sampaio. Estudos de filosofia do direito. São Paulo: Atlas, 2002.

—. Introdução ao estudo do direito. 4. ed. São Paulo: Atlas, 2003.

Fleischacker, Samuel. Uma breve história da justiça distributiva. São Paulo: Martins Fontes, 2006.

Fouchard, Philippe; Gaillard, Emmanuel; Goldman, Berthold. Traité de l'Arbitrage Commercial International. Paris: Litec, 1996.

—. L'Arbitrage Commercial International. Paris: Dalloz, 1965.

FRIEDMANN, Wolfgang. The contribution of English equity to the ideal of an international equity tribunal. London: Constable \& Co., 1935.

Frosini, Vittorio. Il Giudizio di Equità e il Giudice di Pace, Rivista di Diritto Civile, Padova, Cedam, ano XLII, parte primeira, p. 143 e ss., 1996.

—. La Struttura Giuridica del Giudizion di Equita. Teoremi e Problemi di Scienza Giuridica. Milano: Giuffrè, 1971. p. 197-212.

—. Teoremi e problemi di scienza giuridica. Milano: Giuffrè, 1971.

—. Verbete Equita (nozione). Enciclopédia del diritto. Milano: Giuffrè, 1966. v. 15.

Galgano, Francesco. Diritto ed Equità nel Giudizio Arbitrale. Contratto ed Impresa, Padova, Cedam, ano 7, v. 2, p. 461 e ss., 1991.

Garcia Del Corral, Ildefonso L. Cuerpo del derecho civil romano. Barcelona: Jaime Molinas Editor, 1889.

Goldman, Berthold. Frontières du droit et lex mercatoria. Archives de philosofie du droit, Paris, p. $177,1964$.

—. La lex mercatoria dans les contrats et l'arbitrage internationaux: réalité et perspectives. Journal du Droit International, p. 475, 1979. 
- Les Conflits de Loi dan l'Arbitrage International de Droit Privé. Recueil des Cours Academie de Droit International, Tomo 109. Leyde: A.W. Sijthoff, 1964.

Grigera Naón, Horácio. Arbitration in Latin America: Overcoming Traditional Hostility. Arbitration International, v. 5, n. 2, p. 137 e ss., 1989.

Huck, Hermes Marcelo. Contratos com o Estado: aspectos de direito internacional. São Paulo: Aquarela, 1989.

—. Sentença estrangeira e lex mercatoria. São Paulo: Saraiva, 1994.

JAKUBOWSKI, Jerzy. Reflections on the philosophy of international commercial arbitration and conciliation. The Art of Arbitration - Essays on International Arbitration. Liber Amicorum, Pieter Sanders, Deventer: Kluwer, p. 175, 1982.

Jarrosson, Charles. Comentário ao julgado da Cour de Cassation de 18.10.2001. Revue de l'Arbitrage, n. 2, p. 363, 2002.

—. La notion d'arbitrage. Paris: LGDJ, 1987.

JARVIN, Sigvard. The sources and limits of the arbitrator's powers. Arbitration International, v. 2, n. 2, p. 140 e ss., 1986.

_- BÜHLER, Michael. L'amiable compositeur: Peut-il laisser la quesiton du droit applicable au fond indeterminée? Mélanges en l honneur de François Knoepfler. Neuchatel: Helbing \& Lichenhan, 2002. p. 325 e ss.

; Derains, Yves. Collection of ICC Arbitral Awards. Recueil des Sentences Arbitrales de la CCI. Boston: Kluwer Law and Taxation Publishers, 1990.

- - cueil des Sentences Arbitrales de la CCI, 1986-1990. Boston: Kluwer Law and Taxation Publishers, 1994. p. 43.

Jolidon, Pierre. Commentaire du Concordat Suisse sur l'Arbitrage. Berne: Éditions Stæmpfli \& Cie., 1984.

—. La Sentence en Équité dans le Concordat Suisse sur l'Arbitrage. Recueil des Travaux Suisses sur l'Arbitrage International, Zürich, Schulthess Polygraphischer Verlag, p. 259 e ss., 1984.

Jorquiera, Carlos Eugenio; Helmlinger, Karin. Chile. In: Blackby, Nigel; Lindsey, David M.; Spinillo, Alessandro (Ed.). International Arbitration in Latin América. The Hague: Kluwer Law International, 2002. p. 90 e ss. 
KAssis, Antoine. L'Autonomie de l'Arbitrage Commercial International: le Droit Français en Question. Paris: L'Harmattan, 2005.

—. Théorie Generale des Usages du Commerce. Paris: LGDJ, 1984.

Kaufmann-Kohler, Gabrielle. Identifying and applying the law governing the arbitration procedure - the role of the law of the place of arbitration. ICCA Congress series, Boston: Kluwer Law International, n. 9, p. 338, 1999

KAVASS, Igor; LIIVAK, Arno (Compiladores). Uncitral Model Law of International Commercial Arbitration: a documentary history. Buffalo (NY), 1985. v. 1.

Kelsen, Hans. A justiça platônica. O que é Justiça? A justiça, o direito e a política no espelho da ciência. São Paulo: Martins Fontes, 2001.

Keutgen, Guy; Dal, Georges Albert. Relatório sobre a Bélgica. In: PAulsson, Jan (Ed.). International Handbook on Commercial Arbitration. Alphen aan den Rijn: Kluwer Law International, 2007.

KIfFER, Laurence. Amiable Composition and ICC Arbitration. ICC International Court of Arbitration Bulletin, v. 18, n. 1, p. 51 e ss., 2007.

Kolm, Serge-Christophe. Teorias modernas da justiça. São Paulo: Martins Fontes, 2000.

Lagarde, Paul. Approche Critique de la Lex Mercatoria. Mèlanges Goldman. Paris: Librairies Techniques, 1982.

LaLive, Pierre. Transnational (or Truly International) Public Policy and International Arbitration. ICCA Congress series, New York, n. 3, p. 258 e ss., 1986.

- ; Gaillard, Emmanuel. Le Nouveau Droit de l'Arbitrage International en Suisse. Journal du Droit International (Clunet), Paris, Editions Techniques SA ano 116, n. 4, p. 946 e ss., out.-nov.-dez. 1989.

—; Poudret, Jean-François; Reymond, Claude. Le Droit de l'Arbitrage Interne et International en Suisse. Lausanne: Payot, 1989.

LANDO, Ole. The Lex Mercatoria in International Commercial Arbitration. International Comparative Law Quarterly, n. 34, p. 754, 1985.

Larenz, Karl. Metodologia da ciência do direito. 3. ed. Lisboa: Fundação Calouste Gulbekian, 1997.

LATTES, Alessandro. Il diritto commerciale nella legislazione statutaria delle città italiane. Milano: Ulrico Hoepli, 1884. 
LeÃEs, Luiz Gastão Paes de Barros. Ensaio sobre arbitragens comerciais. São Paulo, [n.d], 1966.

Lebedev, Seguei N. Relatório URSS in International Handbook on Commercial Arbitration, Suplemento 17.

Lemes, Selma. Arbitragem na Administração Pública: fundamentos jurídicos e eficiência econômica. São Paulo: Quartier Latin, 2007.

. A Arbitragem e a Decisão por Eqüidade no Direito Brasileiro e Comparado in Arbitragem: estudos em homenagem ao Prof. Guido Fernando Silva Soares. São Paulo, Atlas, 2007, p. 189.

Le Robert Micro: Dictionnaire de la Langue Française. Paris: Dictionnaires Le Robert, 1998.

Lew, Julian D. M. Applicable Law in International Commercial Arbitration. Dobbs Ferry: Oceana Publications, 1978.

- The law Applicable to the Form and Substance of the Arbitration Clause. In: VAN DeN Berg, Albert Jan (Ed.). ICCA Congress Series. The Hague: Kluwer Law International, 1999. n. 9 , p. 114 e ss.

tration. Deventer: Kluwer Law International, 2003.

Li, Hu. Arbitration ex aequo et bono in China. Arbitration International, v. 66, n. 3, p. 188 e ss., 2000.

Limongi França. Formas e aplicação do direito positivo. São Paulo: RT, [s.d.].

- Manual de direito civil. São Paulo: RT, 1980 v. 1.

Long, George. The decline of the Roman Republic. London: Bell and Daldy, 1866. v. 2.

LoQuin, Eric. JurisClasseur de processo civil. Verbete Amiable Composition, fascículo 1038, item 91 e ss. Disponível em: <www.lexisnexis.com/fr/droit/frame.do?tokenKey=rsh-23>. Acesso em: 30 mar. 2008.

- L`Amiable composition en Droit Comparé et International. Paris: Librairies Techniques, 1980.

- Les Pouvoirs de l'Amiable Compositeur. À Propos de Trois Arrêts de la Cour d'Appel de Paris. Revue de l'Arbitrage, n. 2, p. 199 e ss., 1985.

Magalhães, José Carlos de. Direito econômico internacional. Curitiba: Juruá, 2005. 
—. Do Estado na arbitragem privada. São Paulo: Max Limonad, 1988.

Maniruzzaman, A. F. M. The arbitrator's prudence in lex mercatoria: amiable composition and ex aequo et bono in decision making. Separata de Mealey's International Arbitration Report, v. 18, n. 12 , dez. 2003.

Mantilla-Serrano, Fernando. Capítulo sobre Colômbia. In: Blackby, Nigel; Lindsey, David M.; Spinillo, Alessandro (Ed.). International Arbitration in Latin América. The Hague: Kluwer Law International, 2002.

Matray, Lambert; Lefevre, Françoise; Lemaitre, Henri-Paul; Verbist, Herman. Questionário sobre a arbitragem por eqüidade submetido a Força Tarefa da CCI sobre Arbitragem por Eqüidade, 2006. Mimeografado. Disponível em: <www.iccwbo.org>.

Maximiliano, Carlos. Hermenêutica e aplicação do direito. 19. ed. Rio de Janeiro: Forense, 2006.

Mentschikoff, Soia. Commercial Arbitration. Columbia Law Review, n. 61, p. 846 e ss.

Merriam-Webster’s Collegiate Dictionnaire. 10. ed. Springfield: Merriam-Webster. 1994.

Mezger, Ernst. Comentário ao julgado da Corte de Apelações de Paris, de 10 de março de 1981. Revue de l'Arbitrage, n. 2, p. 222, 1982.

—. La Distinction entre l'Arbitre Dispensé d'Observer la Règle de la Loi et l'Arbitre Statuant sans Appel. Liber Amicorum Martin Domke. The Hague: Martinus Nijhoff, 1967. p. 184.

Moreira Alves, José Carlos. Direito romano. 13. ed. Rio de Janeiro: Forense, 2005.

Mortari, Vincenzo Piano. Enciclopedia del diritto. Verbete "arbitrato - diritto intermedio". Milano: Giuffrè, 1958.

Mota de Souza, Carlos Aurélio. Evolução do conceito de eqüidade e sua influência na jurisprudência. 1989. Tese (Doutorado) - Faculdade de Direito da Universidade de São Paulo, São Paulo, mimeografado.

Motulsky, Henri. Écrits: études et notes sur l'arbitrage. Paris: Dalloz, 1974.

Mustill, Michael J. The new Lex Mercatoria: the first twenty-five years. Arbitration International, 4(2), p. 86 e ss., 1987

- - Boyd, Stewart. Commercial Arbitration - 2001 Companion. London: Butterworths, 2001 . 
- - - The law and practice of commercial arbitration in England. London: Butterworths, 1982.

Nestor, Ion. L 'Amiable Composition el'Arbitrage selon les Règles du Droit in Arbitrage Commercial/Commercial Arbitration: essays in memoriam Eugenio Minoli. Torino: UTET, 1974.

Newman, Ralph (Ed.). Equity in the World's Legal Systems: a Comparative Study. Brussels: Établissements Émile Bruylant, 1973.

OpPetit, Bruno. Théorie de l'Arbitrage. Paris: PUF, 1998.

PARK, William. Arbitration of International Business Disputes. New York; Oxford: Oxford University Press, 2006.

Pasukanis, Eugeny B. A teoria geral do direito e o marxismo. Rio de Janeiro: Renovar, 1989.

Paulsson, Jan (Ed.). International Handbook on Commercial Arbitration. Alphen aan den Rijn: Kluwer Law International, 2007.

Pereira, Caio Mário da Silva. Instituições de direito civil. Rio de Janeiro: Forense, 2004. v. 1.

Perelman, Chaïm. Ética e direito. São Paulo: Martins Fontes, 2005.

—. Lógica jurídica. São Paulo: Martins Fontes, 2004.

Pontes de Miranda, Francisco Cavalcanti. Tratado de direito privado. São Paulo: RT, 1983. t. III.

Poudret, Jean-François; Reymond, Claude; Wurzburger, Alain. L'Application du Concordat Intercantonal sur l'Arbitrage par le Tribunal Cantonal Vaudois (dix ans de jurisprudence). Journal des Tribunaux, v. 3, p. 92, 1981.

Prodi, Paolo. Uma história da justiça. Lisboa: Editorial Estampa, 2002.

Pryles, Michael. Reflections on Transnational Public Policy in Journal of International Arbitration, 24(1), 2007, p. 1 .

Pucci, Adriana Noemi. El arbitraje en los países del Mercosur. Buenos Aires: Ad Hoc, 1997.

Punzi, Carmine. Disegno sistematico dell'arbitrato. Padova: Cedam, 2000.

Pyemont, L.O.P. Arbitration in South Africa. Johannesburg: The Transvaal Leader, 1914.

Rabelo Mordechai, Alfredo. Aequitas and Equity: Equity in Civil Law and Mixed Jurisdictions. Jerusalém: The Hebrew University of Jerusalem, 1997.

Ramalho Almeida, Ricardo. Arbitragem comercial internacional e ordem pública. Rio de Janeiro: Renovar, 2005. 
RÁo, Vicente. O direito e a vida dos direitos. 5. ed. São Paulo: RT, 1997.

RAwls, John. Justiça como eqüidade: uma reformulação. São Paulo: Martins Fontes, 2003.

—. Uma teoria da justiça. São Paulo: Martins Fontes, 2002.

Reale, Miguel. A eqüidade no direito do trabalho. Estudos de filosofia e ciência do direito. São Paulo: Saraiva, 1978.

Recueil des Sentences Arbitrales de la CCI. ICC Arbitral Awards. Boston: Taxation Publishers, 1990, p. 399.

Redfern, Alan; Hunter, Martin. Law and practice of international commercial arbitration. 3. ed. London: Sweet \& Maxwell, 1999.

RICCI, Edoardo Flavio. O contraditório na arbitragem de eqüidade. Lei de Arbitragem brasileira. São Paulo: RT, 2004. p. 149 e ss.

Rigaux, François. Les Renontiations au Bénéfice de la Loi en Droit Civil Belge. Travaux de l'Association Henri Capitant. Paris: Dalloz, 1963. t. XIII (1959-1960).

RoBert, Jean. Arbitrage: droit interne, droit international privé. Paris: Dalloz, 1993.

Roebuck, Derek. Ancient Greek arbitration. Oxford: Holo Books, 2001.

— De Fumichon, Bruno L. Roman arbitration. Oxford: Holo Books, 2004.

Rubellin-Devichi, Jaqueline. L'arbitrage, nature juridique. Paris: LGDJ, 1965.

Rubino-Sammartano, Mauro. Amiable Compositeur (Joint Mandate to Settle) and Ex Bono et Aequo (Discretional Authority to Mitigate Strict Law): Apparent Synonyms Revisited. Journal of International Arbitration, Geneva, Kluwer, v. 9, n. 1, p. 5 e ss., 1992.

—. Il diritto dell'arbitrato. Padova: Cedam, 2005.

- International arbitration: law and practice. The Hague: Kluwer Law International, 2001.

Ruck, Segei I. Arbitration in Belarus. Croatian Arbitration Yearbook, v. 4, p. 73.

SAleh, Samir. Commercial Arbitration in the Arab Middle East: Shari'a, Lebanon, Syria and Egypt. 2. ed. Oxford: Hart Publishing, 2006. p. 45.

SANDERS, Pieter. International Encyclopedia of Comparative Law. Capítulo “Arbitration”. Tübigen: J. C. B. Mohr (Paul Siebeck), 1996.

. L'amiable Composition em Droit Comparé et International. Paris: Librairies Techniques, 1980. 
—. Quo vadis Arbitration? The Hague: Kluwer Law International, 1999.

- The Work of Uncitral on Arbitration and Conciliation. The Hague (Den Haag), Kluwer Law International, p. 22, 2001.

- Uncitral's Model Law on International and Commercial Arbitration: Present Situation. Arbitration International, v. 21, nov. 2005.

Savigny, Friedrich Karl von. Ciencia del derecho. Buenos Aires: Losada, 1949. v. 1: Sistema de direito romano.

Schmitthoff, Clive. Extrajudicial Dispute Settlement. Forum Internationale, Deventer, Kluwer Law and Taxation Publishers, n. 6, p. 14, 1985.

ShackLeton, Stewart R. The Applicable Law in International Arbitration Under the New English Arbitration Act 1996. Arbitration International, v. 13, n. 4, p. 375 e ss., 1997.

Seraglini, Christophe. Lois de Police et Justice Arbitrale Internationale. Paris: Dalloz, 2001.

Serpa Lopes, Miguel Maria de. Curso de direito civil. Rio de Janeiro: Freitas Bastos, 2000. v. 1.

Silveira, Alípio. Conceito e funções da eqüidade em face do direito positivo. [s.1.]: [s.n.], 1943.

—. Hermenêutica no direito brasileiro. São Paulo: RT, 1980.

Smit, Hans; CARbonneau, Thomas E.; Mistelis, Loukas. The roster of International arbitrators. 2. ed. Huntington: JurisNet, 1999.

- - Реснота, V. Smit's Guides to International Arbitration: National Arbitration Laws. Huntington: JurisNet, 2006.

SoAres, Guido Fernando da Silva. Common law: introdução ao direito dos EUA. São Paulo: RT, 2000.

—. Curso de direito internacional público. São Paulo: Atlas, 2002.

Soderlund, Christer. A comparative overview of arbitration laws. Arbitration International, v. 20, n. 1, p. 83, 2004.

SoHм, Rudolf. Historia e instituciones del derecho privado romano. Madrid: La España Moderna, 1898(?).

Sornarajah, M. The Uncitral Model Law: a third world viewpoint. Journal of International Arbitration, v. 6, n. 4, p. 7 e ss., 1989. 
Strenger, Irineu. Arbitragem comercial internacional. São Paulo: LTr, 1996.

SzURSKI, Tadeusz. Introducing Uncitral Model Law to Poland. Journal of International Arbitration, Deventer, Kluwer Law, 18(2), p. 232, 2001.

TAVAres Guerreiro, José Alexandre. Fundamentos da arbitragem do comércio internacional. São Paulo: Saraiva, 1993.

TeixeIra de Freitas, Augusto. Consolidação das Leis Civis. Edição fac-símile. Brasília: Senado Federal, 2003.

Turck, Nancy B. Relatório sobre Arábia Saudita. In: PAulsson, Jan (Ed.). International Handbook on Commercial Arbitration. Alphen aan den Rijn: Kluwer Law International, 2007.

Van Den Berg, A. J. (Ed.). Yearbook Commercial Arbitration. Deventen: Kluwer Law International, 1995.

VÁrady, Tibor; Barceló, John J.; Von Mehren, Arthur T. International commercial arbitration: a transnational perspective. Saint Paul: Thompson West, 2003.

VÁrios Autores. L 'Équité ou les Équités: Confrontation Occident et Monde Arabe. Paris: Societé de Législation Comparée, 2003.

Venosa, Silvio de Salvo. Direito civil. São Paulo: Atlas, 2006. v. 1.

Verde, Giovanni. Lineamenti del diritto dell'arbitrato. Torino: G. Giapichelli, 2004.

Vivante, Cesare. Trattato di diritto commerciale. 5. ed. Milano: Francesco Vallardi, 1922. v. 1.

Weber, Max. Economia e sociedade: fundamento da sociologia compreensiva. São Paulo: Editora UnB/Imprensa Oficial do Estado, 2004. v. 2

WeInBerg, Karyn. Equity in international arbitration: how fair is "fair"? A study of lex mercatoria and amiable composition. Boston University International Law Journal, 12, p. 227 e ss., primavera de 1994.

Wilken, Sean e Villiers. The Law of Waiver, Variation, and Estoppel. 2. ed. Oxford: Oxford University Press, 2002. 
ANEXO - QUESTIONÁRIOS 
A) PORTUGUÊS 


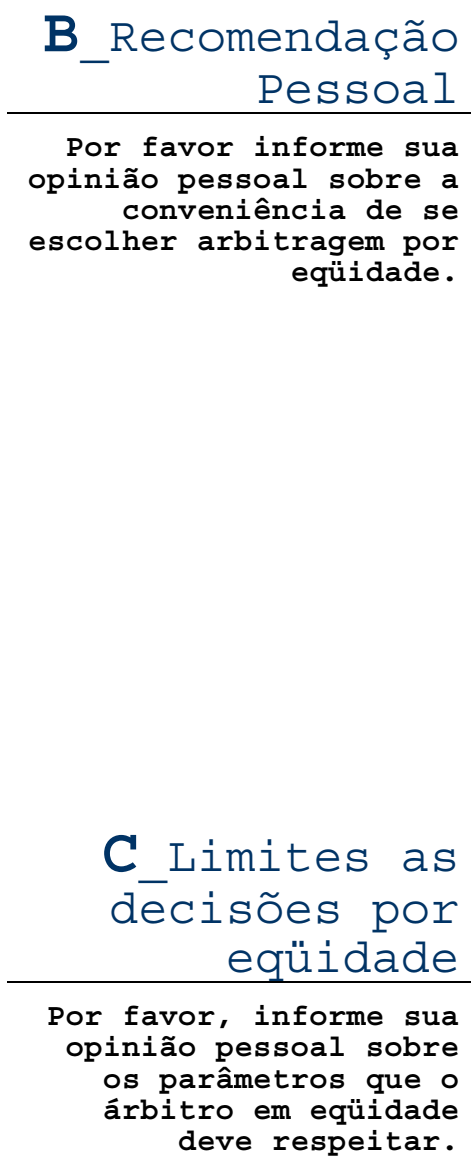


4.

Na sua opinião pessoal, o árbitro decidindo por eqüidade está limitado pelas questões de ordem pública?

sim

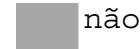

D Elementos de Eqüidade

Por favor, informe sua opinião sobre casos em que considerações de eqüidade ou justica devem-se sobrepor a aplicação estrita da lei, estando os árbitros autorizados a decidir por eqüidade. o objetivo desta questão e verificar se existem padrões comuns de justiça nos diferentes países.

1

Assumindo-se que os árbitros possam decidir por eqüidade, em quais das seguintes hipóteses o(a) $\operatorname{Sr}(a)$. entende que considerações de eqüidade ou justiça devem-se sobrepor a estrita aplicação da lei, caso haja discrepância entre elas: (Por favor, marque quantas alternativas desejar).

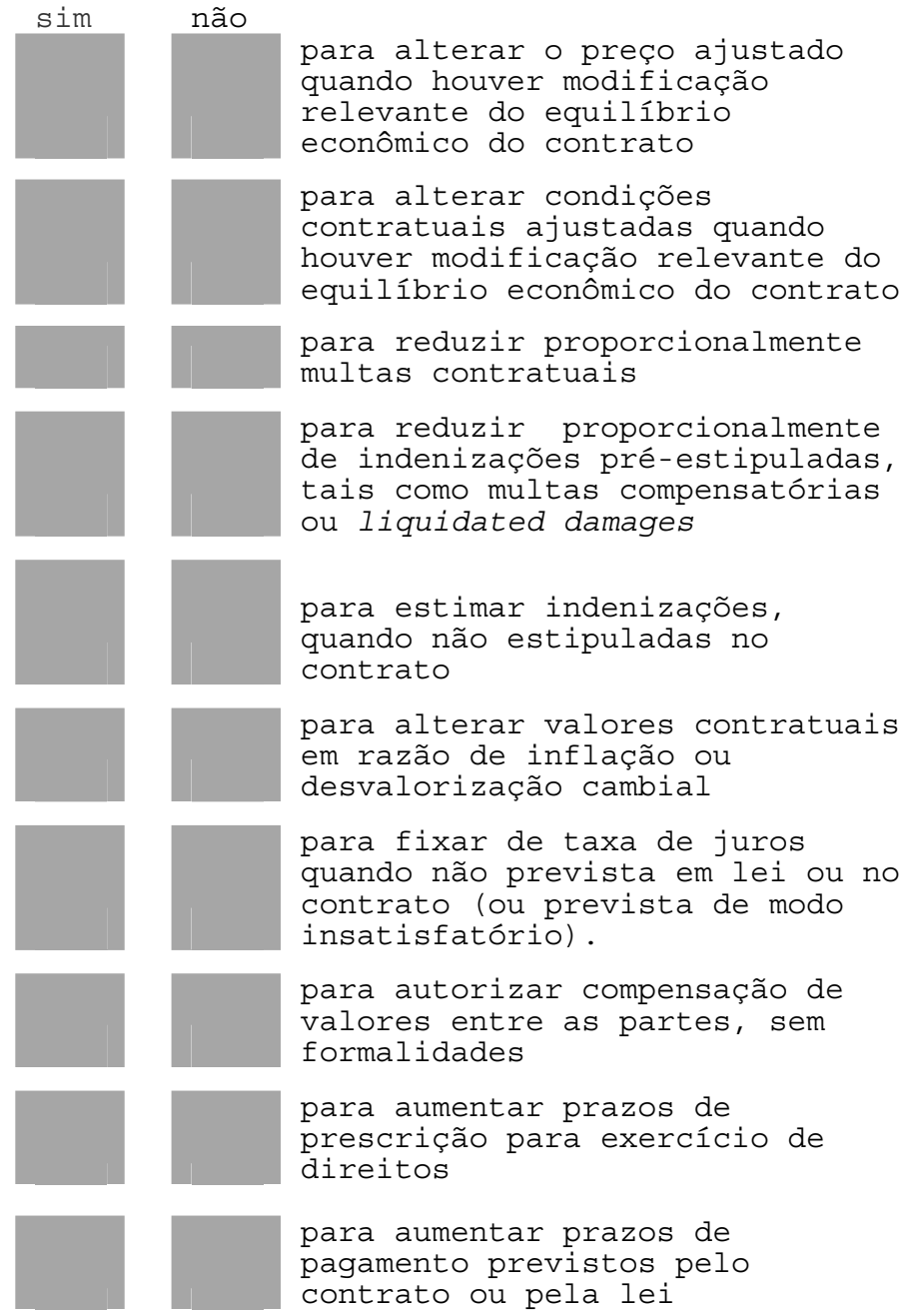




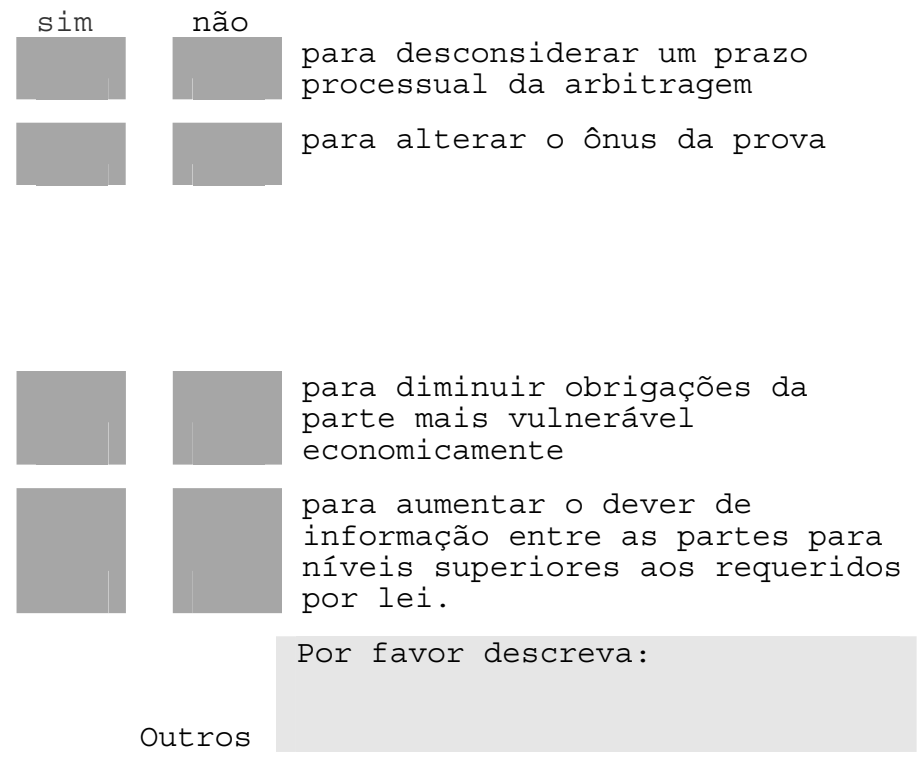

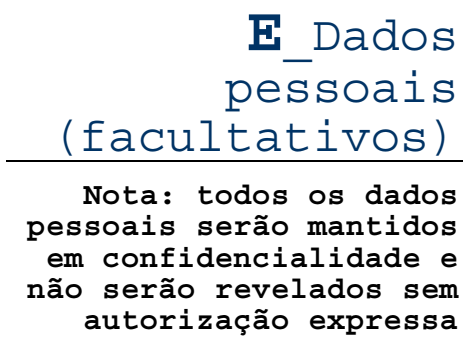

E_Dados facultativos) Nota: todos os dados
pessoais serão mantidos
em confidencialidade e
não serão revelados sem
autorização expressa 2

Principal atividade (marque quantas forem necessárias ):

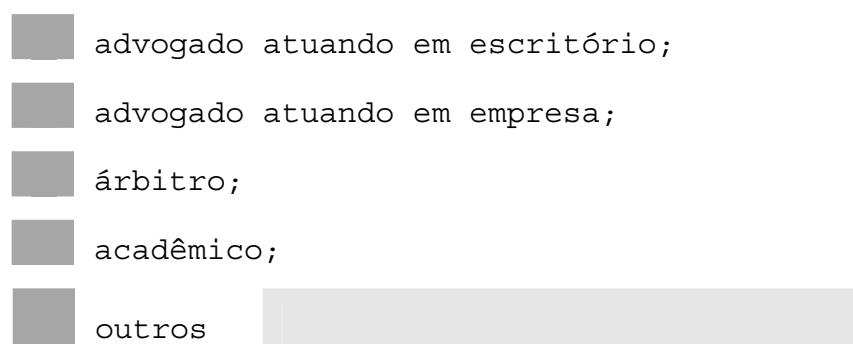

3.

O(a) $\operatorname{Sr}($ a). deseja receber uma copia dos resultados finais?
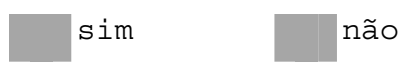

3. 1

Caso tenha respondido "sim", por favor informe seu endereço eletrônico 
4

Seu nome pode ser revelado para fins de agradecimento na tese?

sim não


B) INGLÊS 


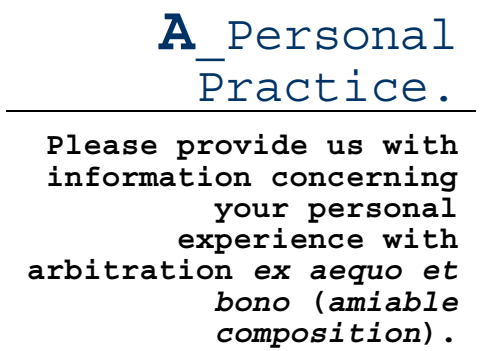

A Personal Practice.
In your professional practice, have you ever drafted any arbitration clause providing for arbitration ex aequo et bono (amiable composition)?

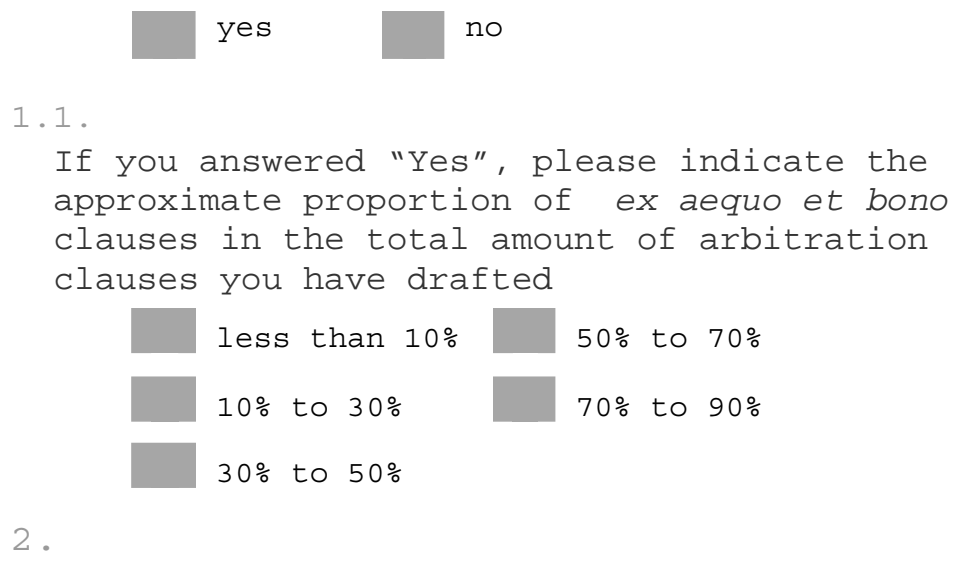
approximate proportion of ex aequo et bono arbitrations in the total amount of arbitrations you have acted as counsel

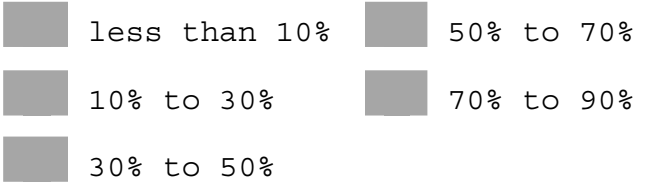




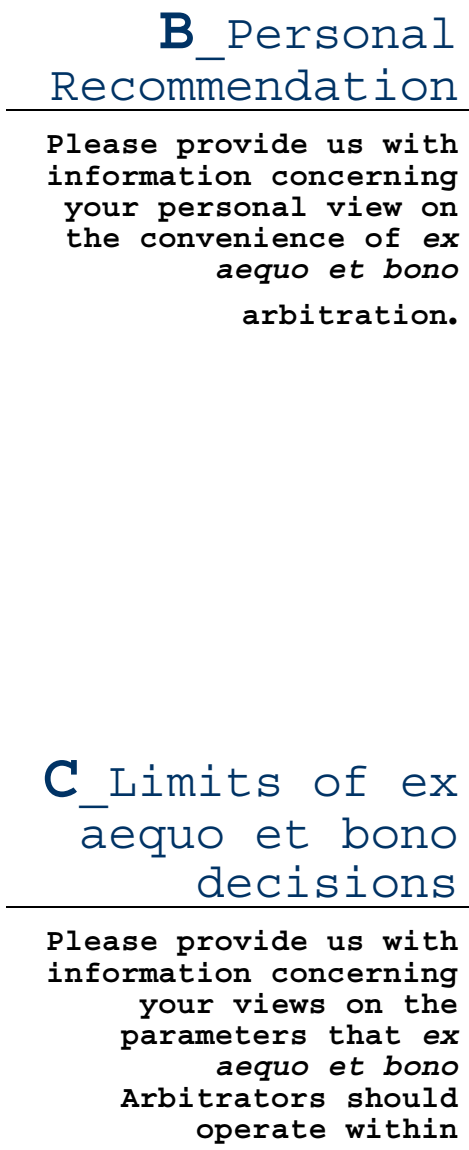

B_Personal Recommendation

provide us with your personal view on the convenience of ex aequo et bono arbitration.

1.1 .

If you answered "Yes", which type of contract would this be appropriate for? (long or short term, particular sector of industry/commerce, particular type of contract, etc)

Would you recommend the use of arbitration ex aequo et bono (amiable composition)?

1

In your personal opinion, the Arbitrator deciding ex aequo et bono (amiable compositeur) should:

apply all contract provisions strictly

not enforce contractual provisions that seem unfair

2.

In your personal opinion, can the Arbitrator deciding ex aequo et bono (amiable compositeur) alter unfair contractual provisions in order to maintain the relationship between the parties? (Please assume that no specific power has been given other than authorization to decide ex aequo et bono).

yes

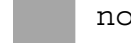

3

In your personal opinion, when the parties have not explicitly identified the proper law of the contract, the Arbitrator deciding ex aequo et bono (amiable compositeur) should:

decide according to his/her conscience without determining the proper law of the contract

determine the proper law of the contract and override the legal provisions deemed unfair. 
4.

In your personal opinion, is the Arbitrator deciding ex aequo et bono limited by issues of public policy/ordre public?

yes no

D_Fairness/

Equity issues

Please indicate your views on issues that may override the strict application of the law, when the Arbitrators are allowed to disregard it. The purpose of this section is to discover whether there are any common patterns applying justice over various jurisdictions.
1 .

Assuming the Arbitrators are allowed to decide ex aequo et bono (as amiable compositeurs), in which of the following cases do you believe that equitable/fairness considerations should override strict application of the law, in the event that there is a contradiction between them: (Please mark all options you consider appropriate) .

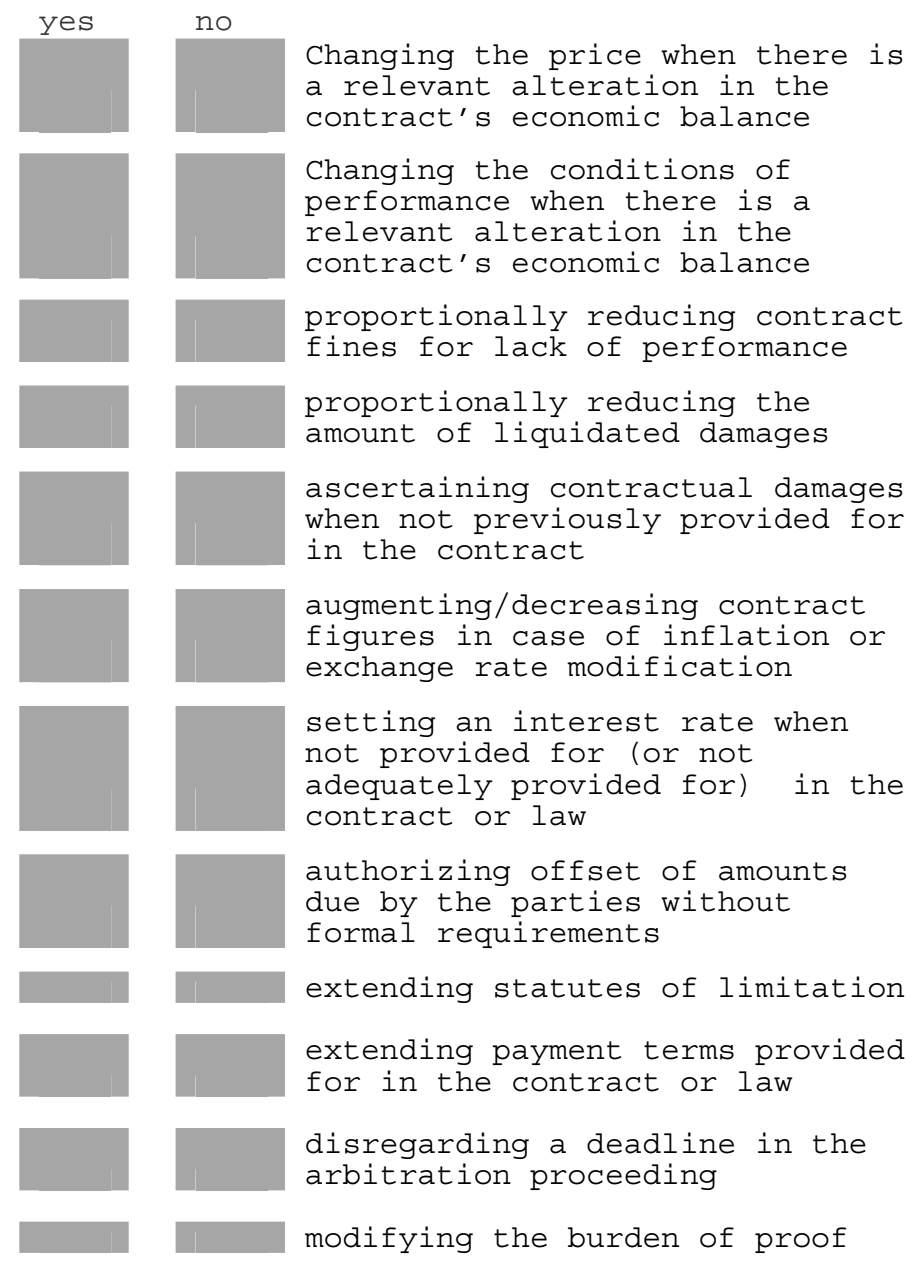




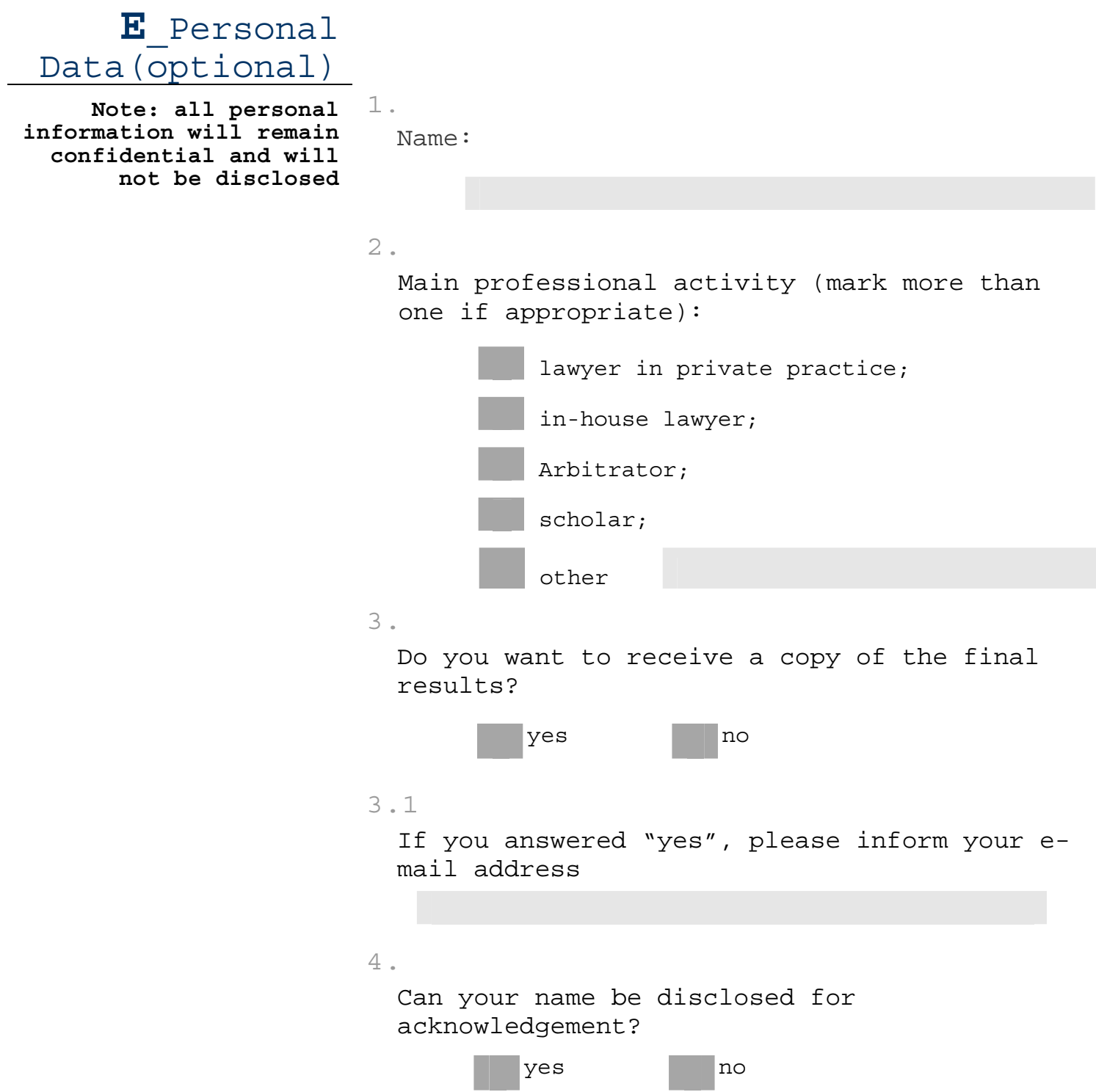


C) FRANCÊS 
A Expérience personnelle

Décrivez votre expérience personnelle dans le cadre de missions d'amiable composition
Dans votre expérience professionnelle, avezvous déjà rédigé une clause d'amiable composition?

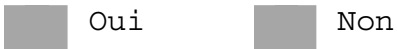

1. 1 .

Si vous avez répondu «oui », indiquez approximativement, $s^{\prime} i l$ vous plaît, la proportion que représentent les clauses d'amiable composition par rapport au total des clauses d'arbitrage que vous avez rédigées.

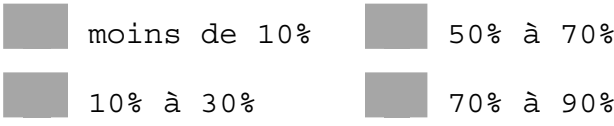

$30 \%$ à $50 \%$

2.

Avez-vous déjà statué en tant que amiable compositeur ?

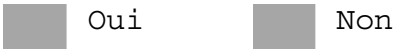

$2 \cdot 1$

Si vous avez répondu « oui », indiquez approximativement, $s^{\prime} i l$ vous plâ̂t, la proportion que représentent les amiables compositions par rapport au nombre total des arbitrages auxquels vous avez statué.

moins de $10 \% \quad 50 \%$ à $70 \%$

$10 \%$ à $30 \%$

$70 \%$ à $90 \%$

$30 \%$ à $50 \%$

Avez-vous déjà exercé comme avocat/conseil dans le cadre de procédures d'amiable composition?

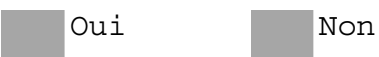

3. 1

Si vous avez répondu «oui », indiquez approximativement, $s^{\prime} i l$ vous plâ̂t, la proportion que représentent les amiables compositions par rapport au nombre total des arbitrages auxquels vous avez exercé.

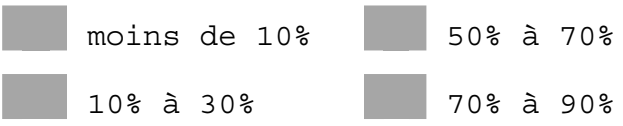

$30 \%$ à $50 \%$ 
B Recommandation personnelle

Donnez votre opinion
personnelle sur 1'intérêt
que comporte 1'amiable
composition.

C Limites des amiables compositions

Donnez votre opinion personnelle sur les paramètres que l'amiable compositeur doit respecter.
Recommanderiez-vous le recours à l'amiable composition?

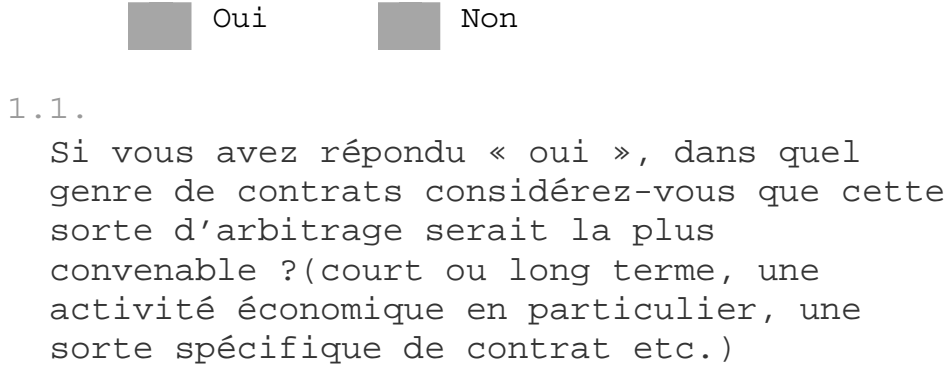

appliquer strictement les dispositions du contrat.

s'écarter des dispositions contractuelles qui lui sembleraient injustes.

2.

À votre avis, l'amiable compositeur peut-il modifier des dispositions du contrat pour maintenir les relations entre les parties ? (Aux fins de la présente question, considérez $q u^{\prime}$ aucun pouvoir $\mathrm{n}^{\prime} \mathrm{a}$ été conféré en sus de l'autorisation pour l'amiable composition).

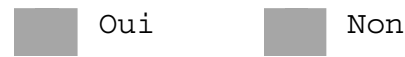
3

À votre avis personnel, si les parties n'ont pas choisi la législation applicable au fond, l'amiable compositeur doit :

statuer selon sa conscience sans déterminer une législation applicable.

choisir une loi applicable et s'écarter des dispositions contractuelles qui lui sembleraient injustes.

4

À votre avis, l'arbitre statuant en amiable compositeur est-il limité par les questions d'ordre public?

Oui Non 
D Éléments d'amiable composition

Donnez votre opinion
personnelle sur les
hypothèses dans
lesquelles il faut
privilégier des
considérations
d'équité ou de justice
au détriment de
l'application stricte
de la loi, lorsque
l'arbitre peut statuer
en amiable
compositeur.
L'objectif de cette
question est de
déceler l'existence
principes communs
desustice dans les
divers ordres

1 .

En supposant que les arbitres peuvent statuer en amiable compositeur, dans quelles hypothèses estimez-vous que les considérations d'équité ou de justice doivent l'emporter sur l'application stricte de la loi, en cas de divergence entre les deux? (Cochez autant d'options que vous souhaitez).

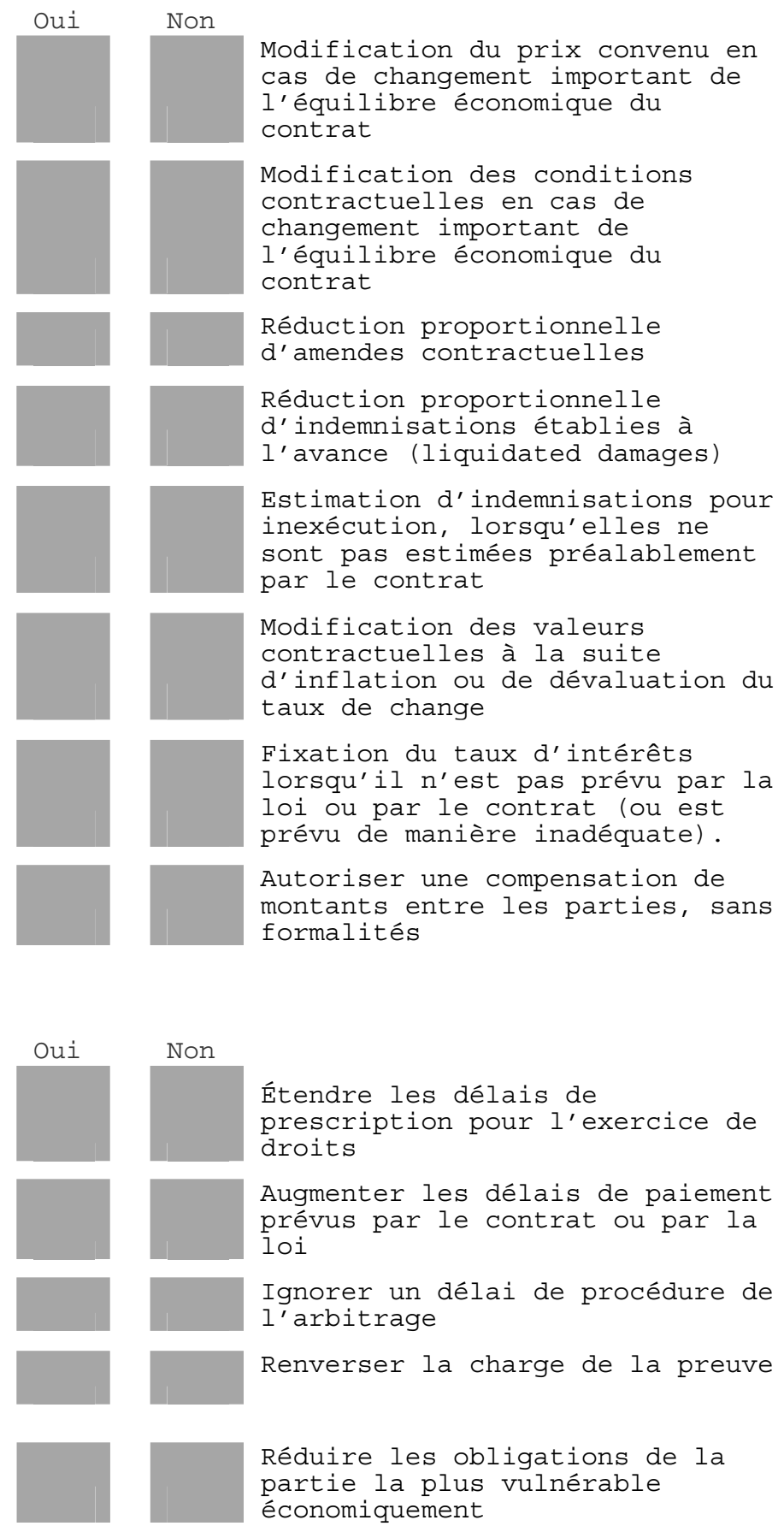


Porter le devoir d'information entre les parties à des niveaux supérieurs à ceux exigés par la $10 i$.

Décrivez s'il vous plait :

Autres

\section{E Informations personnelles (facultatives)

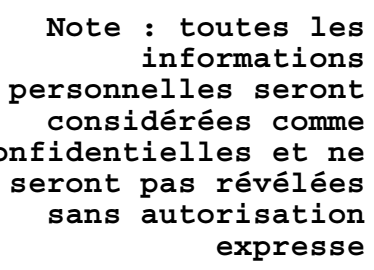

2

Activité principale (cochez autant de cases que nécessaire)

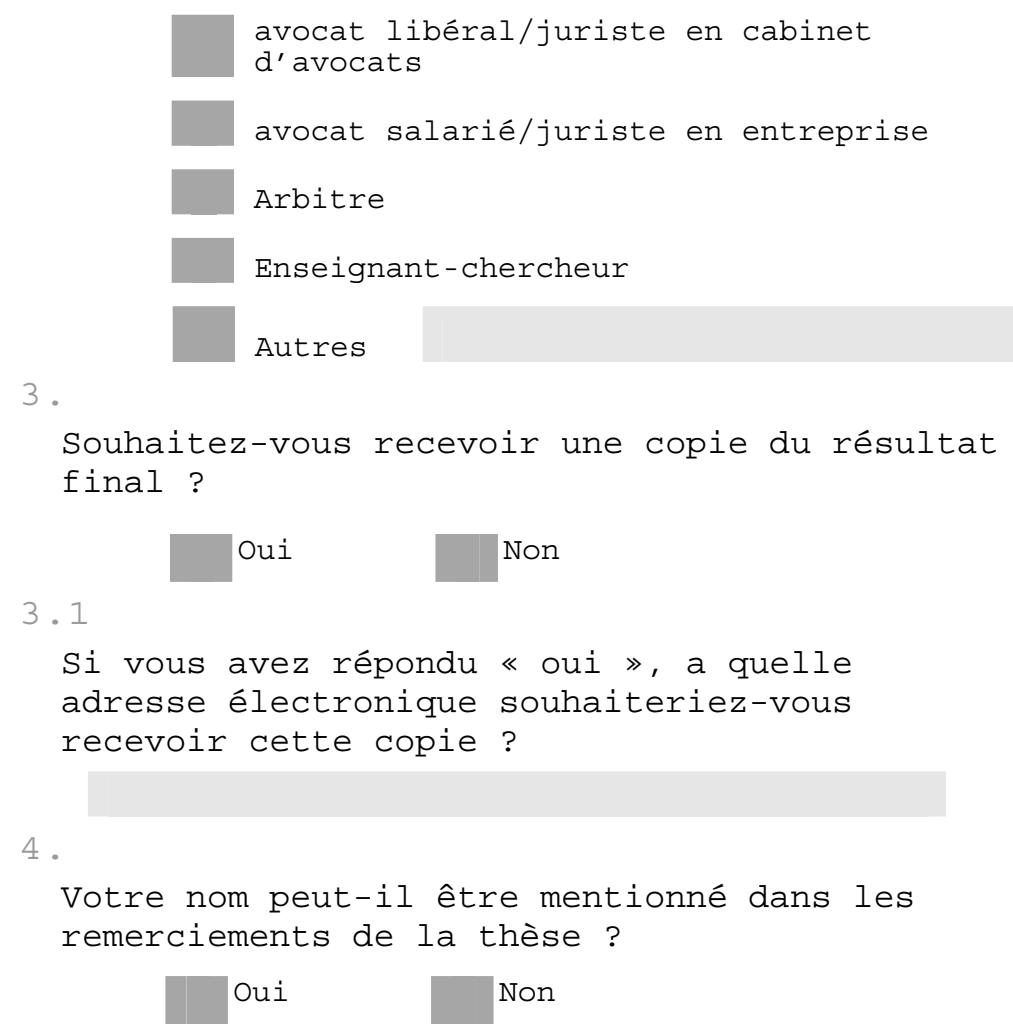




\section{RESUMO}

A eqüidade é um termo polissêmico e comporta diversas definições. Nesta obra, estudam-se as decisões por eqüidade na arbitragem comercial internacional e não a eqüidade em todos seus aspectos. Trata-se da função substitutiva da eqüidade.

A decisão por eqüidade na arbitragem apresenta-se como uma técnica: uma forma de decidir sem que haja remissão necessária ao direito positivo. Sua característica principal é a liberdade de método decisório. Seu principal efeito é a possibilidade de derrogar o direito positivo, dentro dos limites da ordem pública. Ela qualifica-se, do ponto de vista positivo, como uma técnica de decisão; do ponto de vista negativo, como uma abdicação do julgamento conforme regras de direito.

Em termos históricos, a decisão por eqüidade na arbitragem existe desde pelo menos a Grécia antiga. Desde então, ela sobrevive na tradição jurídica ocidental. Nos dias atuais, ela é encontrada na imensa maioria dos ordenamentos. Boa parte de sua disciplina atual no mundo decorre do movimento de reforma das legislações nacionais ocorrido nas últimas décadas, que teve na Lei Modelo da CNUDCI uma importante fonte de inspiração.

A arbitragem por eqüidade é uma espécie do gênero arbitragem. Embora possua diversas denominação no mundo, tais diferenças não encerram diversidade de conceitos. Em termos de qualificação da cláusula de arbitragem por eqüidade, existem divergências: pode-se relacioná-la à cláusula arbitral, ao procedimento ou ao mérito. Nesta obra, defendemos seu posicionamento nos domínios da cláusula arbitral, embora possua efeitos processuais. Nos dias de hoje, pode-se afirmar a existência de regras materiais transnacionais depreendidas do exame do direito comparado e jurisprudência arbitral, especificamente para a arbitragem por eqüidade.

A cláusula de arbitragem por eqüidade produz efeitos tanto no direito material quanto no procedimento. No direito material, possibilita-se a derrogação do direito positivo. No direito processual, tanto pode causar alterações automáticas do procedimento como conferir maior liberdade aos árbitros na condução da arbitragem. Resta dúvidas se autoriza modificações no procedimento convencionado pelas partes. Também é controversa a possibilidade de se decidir por eqüidade questões prévias ao mérito, como a validade da cláusula arbitral.

A decisão por eqüidade é limitada pela ordem pública e pelo princípio do devido processo. Com relação ao contrato, existem divergências sobre seu alcance. Todavia, pode-se verificar a sedimentação de um entendimento pelo qual os árbitros podem moderar certas disposições contratuais que produzam resultados injustos; todavia, não podem alterar substancialmente a economia do contrato.

Do exame de direito comparado, existem três sistemas de arbitragem por eqüidade. Na imensa maioria dos casos, permite-se-a desde que as partes assim convencionem. Presume-se, portanto, a arbitragem de direito. Um segundo sistema, utilizado por alguns países Latino-Americanos, presume que a arbitrgem seja por eqüidade, salvo convenção das partes. Um terceiro sistema, adotado por poucos países, não permite a arbitragem por eqüidade. Os tratatos internacionais em geral não tratam da arbitragem por eqüidade. Aqueles que o fazem, em geral apresentam uma regra material: permitem-na, desde que as partes convencionem.

Nesta obra, realizou-se um exame da jurisprudência arbitral e uma pesquisa empírica com 92 profissionais que atuam na arbitragem comercial internacional em diversos países. De seu exame, podem-se identificar alguns elementos recorrentes na prática da arbitragem por eqüidade no mundo. Esses elementos ajudam a desvendar as formas e limites da arbitragem do instituo, bem como o que tem sido compreendido como equitativo no domínio da arbitragem comercial.

Em outras palavras, o "justo no comércio internacional". 


\begin{abstract}
Equity is a polissemic term and comprises several definitions. This work focus on ex aequo et bono (sometimes referred to as in "equity") decisions rendered in international commercial arbitration, and not on the term "equity" as a whole. It is about the equity substitutive function.

The equity decision rendered in arbitration procedures presents itself as a technique: A way to decide without reference to positive law. Its main characteristic is the freedom of the decision method. Its main effect is the possibility to repeal the positive law, within the public order/ordre public limits. It is qualified, from a positive point of view, as a decision technique; from a negative point of view, as an abdication of judgment according to the rules of law.

In historical terms, ex aequo et bono decision in arbitration exists at least since Ancient Greece. Since then, it survives in the occidental legal tradition. Nowadays, it is found in most part of the legal systems. Good part of its current discipline in the World results from the national legislation reformulation movement occurring in the last decades, which was greatly inspired by the UNCITRAL Model Law.

Arbitration ex aequo et bono (amiable composition) is a type of arbitration. Although it has several different legal frameworks in the world, such differences do not imply a diversity of concept or nature. In terms of qualification of the amiable composition clause, there are divergences: It may be related to the arbitration clause, to proceeding or to merits. This work submits its positioning in the arbitration clause, in spite of its procedural effects. Nowadays, it may be affirmed the existence of transnational material rules applicable to arbitration ex aequo et bono (amiable composition) arising out of comparative law and case law analysis.
\end{abstract}

The ex aequo et bono (amiable composition) clause produces both substantive and procedural effects. In the substantive law, it is possible to repeal the positive law. In procedural law, it may cause automatic alterations in the proceeding, such as granting a greater freedom to the arbitrators in the conduction of the arbitration. It is still unclear if it authorizes modifications in the proceeding agreed by the parties. It is also controversial the possibility to render ex aequo et bono decisions in relation to those matters prior to the merit, such as the arbitration clause validity.

The decision ex aequo et bono is limited by the public order/ordre public and due process. There are divergences regarding its effects in relation to the contracts (and parties' will more generally). However, there seems to be an understanding according to which the arbitrators may mitigate certain contractual provisions producing unfair results; nevertheless, they may not substantially modify the contractual economy.

According to a comparative law analysis, there are three "systems" for ex aequo et bono clauses. In most of the cases, such kind of arbitration is permitted, provided that the parties so agree. It is therefore presumed the arbitration at law. A second system, used by some Latin-American countries, provides for ex aequo et bono decision as the default rule for arbitration, except as otherwise agreed by the parties. A third system, adopted by a few countries, does not allow this kind of arbitration. International treaties, in general, do not deal with arbitrations ex aequo et bono. Those which so deal with it, in general, present a material rule: decisions ex aequo et bono are permitted, if the parties so agree.

This work analyzes the case law related to ex aequo e bono arbitration and performs a field research with 92 professionals acting in the international commercial arbitration field in several countries. From such analysis, it can be identified some common features in the worldwide arbitration practice. Such elements help clarify the ways and limits of this kind of arbitration, as well as what has been understood as equitable within the commercial arbitration context. In other words, what is "fair" in international trade. 


\section{RÉSUMÉ}

L'équité est un terme polysémique et a plusieurs définitions. Dans cet ouvrage, sont étudiées les décisions par équité dans l'arbitrage commercial international et non l'équité dans tous ses aspects. Il s'agit de la fonction substitutive de l'équité.

L'amiable composition se présente comme une technique: une forme de décider sans qu'il y ait de rémission nécessaire au droit positif. Sa caractéristique principale est la liberté de méthode décisoire. Son principal effet est la possibilité de déroger le droit positif, dans les limites de l'ordre public. Elle se présente, du point de vue positif, comme une technique de décision; du point de vue négatif, comme une abdication du jugement en conformité avec les règles de droit.

En termes historiques, l'amiable composition (décision selon par équité) existe, pour le moins, depuis la Grèce antique. Depuis lors, elle survit dans la tradition juridique occidentale. De nos jours, on la retrouve dans l'immense majorité des ordres juridiques. Une bonne partie de sa discipline actuelle dans le monde découle du mouvement de réforme des législations nationales survenu ces dernières décennies, qui eut dans la Loi Modèle de la CNUDCI une importante source d'inspiration.

L'amiable composition est une espèce du genre arbitrage. Bien qu'elle possède plusieurs dénominations dans le monde, de telles différences ne limitent pas la diversité de concepts. En termes de qualification de la clause d'amiable composition, il existe des divergences: on peut la lier à la clause arbitrale, à la procédure ou au mérite. Dans cet ouvrage, nous défendons son positionnement dans les domaines de la clause arbitrale, bien qu'elle possède des effets processuels. De nos jours, on peut affirmer l'existence de règles matérielles transnationales déduites de l'examen du droit comparé et de la jurisprudence arbitrale, spécifiquement pour l'amiable composition.

La clause d'amiable composition produit des effets aussi bien dans le droit matériel que dans la procédure. Dans le droit matériel, elle permet la dérogation du droit positif. Dans le droit de procédure, elle peut aussi bien causer des altérations automatiques de la procédure que conférer une plus grande liberté aux arbitres dans la conduite de l'arbitrage. Il y a encore des doutes si elle permet des modifications de la procédure convenue entre les parties. De plus la possibilité de décider par équité des questions préalables au mérite, telle que la validité de la clause d'arbitrage, crée une controverse.

L'amiable composition est limitée par l'ordre public et par le principe du contradictoire. En ce qui concerne le contrat, il existe des divergences sur sa portée. Cependant, il est possible de vérifier la sédimentation d'une entente grâce à laquelle les arbitres peuvent modérer certaines dispositions contractuelles qui produisent des résultats injustes; cependant, ils ne peuvent pas altérer substantiellement l'économie du contrat.

À l'examen de droit comparé, on y découvre trois systèmes d'amiable composition. Dans l'immense majorité des cas, il est permis, à condition que les parties soient d'accord. On présume, donc, l'arbitrage de droit. Un deuxième système, utilisé par certains pays Latino-américains, présume que l'arbitrage est par équité, sauf convention des parties. Un troisième système, adopté par peu de pays, ne permet pas l'amiable composition. Les traités internationaux, en général, ne traitent pas de l'amiable composition. Ceux qui le font, en général, présentent une règle matérielle: ils le permettent, à condition que les parties en conviennent entre-elles.

Dans cet ouvrage, nous avons réalisé un examen de la jurisprudence arbitrale et une recherche empirique auprès de 92 professionnels qui travaillent dans l'arbitrage commercial international dans plusieurs pays. De son examen, nous pouvons identifier certains éléments récurrents dans la pratique de l'amiable compostition dans le monde. Ces éléments aident à découvrir les formes et les limites de l'amiable composition, ainsi que ce qui a été compris comme équitatif dans le domaine de l'arbitrage commercial. En d'autres mots, le "juste dans le commerce international". 